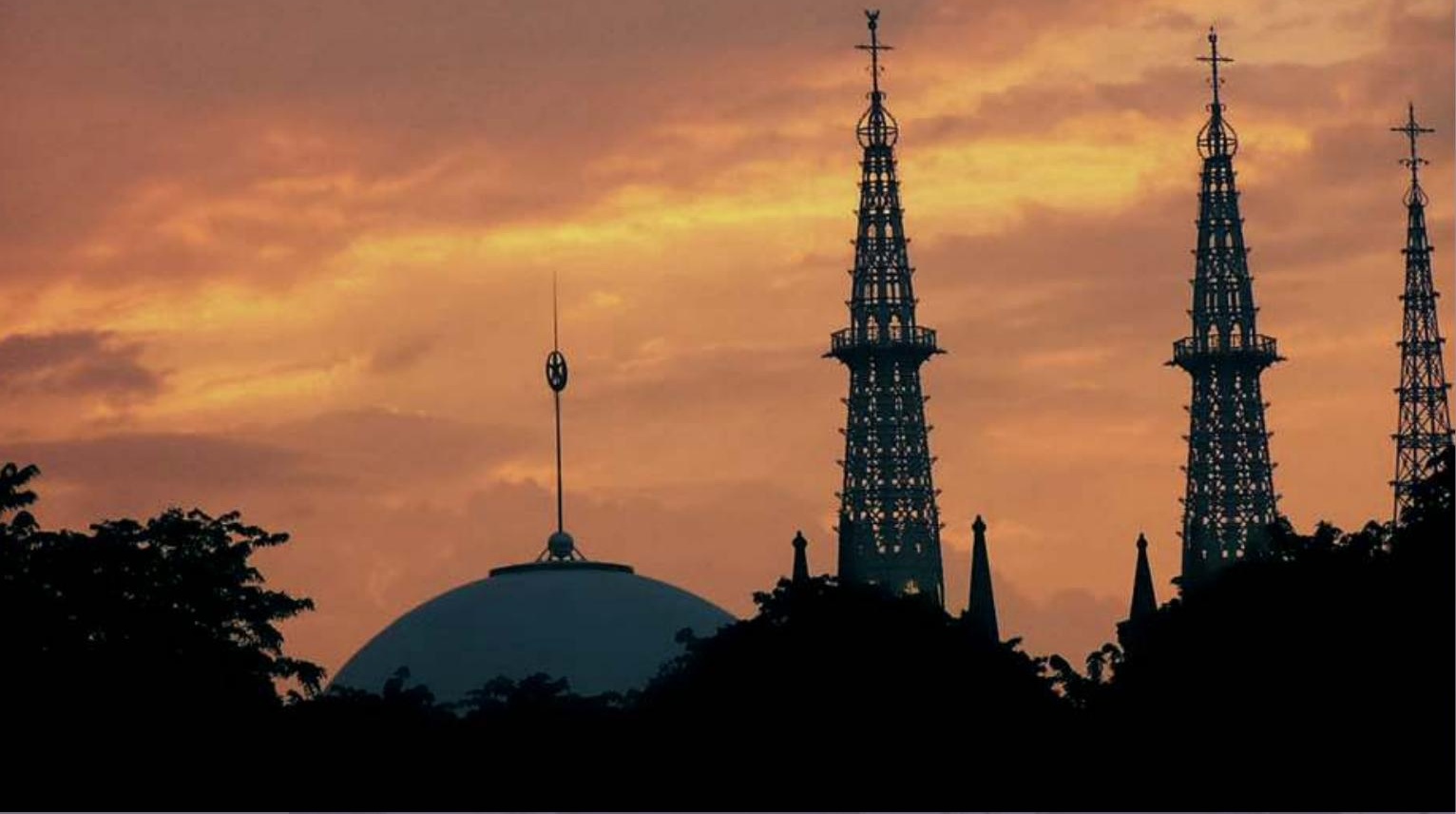




\title{
FEELING THREATENED
}

\author{
MUSLIM-CHRISTIAN RELATIONS \\ IN INDONESIA'S NEW ORDER
}

Mujiburrahman

ISIM DISSERTATIONS

ISIM / LEIDEN

Amsterdam University Press 
Cover illustration: ๑ Hanggan Situmorang

Cover design and lay-out: De Kreeft, Amsterdam

ISBN-13 9789053569382

ISBN-10 9053569383

NUR $\quad 741 / 717$

(C) ISIM / Amsterdam University Press, Leiden / Amsterdam 2006

Alle rechten voorbehouden. Niets uit deze uitgave mag worden verveelvoudigd, opgeslagen in een geautomatiseerd gegevensbestand, of openbaar gemaakt, in enige vorm of op enige wijze, hetzij elektronisch, mechanisch, door fotokopieën, opnamen of enige andere manier, zonder voorafgaande schriftelijke toestemming van de uitgever.

Voor zover het maken van kopieën uit deze uitgave is toegestaan op grond van artikel 16B Auteurswet 1912 jo het Besluit van 20 juni 1974, Stb. 351, zoals gewijzigd bij het Besluit van 23 augustus 1985, Stb. 471 en artikel 17 Auteurswet 1912, dient men de daarvoor wettelijk verschuldigde vergoedingen te voldoen aan de Stichting Reprorecht (Postbus 3051, $2130 \mathrm{~kb}$ Hoofddorp). Voor het overnemen van gedeelte(n) uit deze uitgave in bloemlezingen, readers en andere compilatiewerken (artikel 16 Auteurswet 1912) dient men zich tot de uitgever te wenden.

All rights reserved. Without limiting the rights under copyright reserved above, no part of this book may be reproduced, stored in or introduced into a retrieval system, or transmitted, in any form or by any means (electronic, mechanical, photocopying, recording or otherwise) without the written permission of both the copyright owner and the author of the book. 


\section{Feeling Threatened Muslim-Christian Relations in Indonesia's New Order}

\section{Een Gevoel Van Bedreiging}

De betrekkingen tussen moslims en christenen

in Indonesiës Nieuwe Orde

(met een samenvatting in het Nederlands)

ter verkrijging van de graad van doctor aan de Universiteit Utrecht op gezag van de rector magnificus, prof.dr. W.H. Gispen, ingevolge van het besluit van het college voor promoties in het openbaar te verdedigen op vrijdag 15 september 2006 des namiddags te 4.15 uur door Mujiburrahman geboren op 9 december 1971 te Amuntai, Zuid-Kalimantan, Indonesië 
Promotores:

Prof.dr. M.M. van Bruinessen

Prof.dr. K.A. Steenbrink

Dit promotieonderzoek werd mogelijk gemaakt door een onderzoeksbeurs van het International Institute for the Study of Islam in the Modern World (ISIM), Nederland. 


\section{Contents}

List of Abbreviations 9

$\begin{array}{ll}\text { Acknowledgment } & 13\end{array}$

$\begin{array}{ll}\text { Introduction } & 16\end{array}$

1. From Cooperation to Conflict 21

1. Short-lived Muslim-Christian Cooperation (1965-1966) 21

2. Muslim-Christian Conflict in the Early New Order 28

The Meulaboh Case: Muslim and Christian Parliamentary Questions 29

The Government's Responses $\quad 35$

The Muslim Attack on Christian Facilities in Makassar 38

The Deadlock of the Inter-religious Consultation 41

The Controversy on Freedom to Change Religion 48

Muslim-Christian Rivalry in Religious Propagation 50

Conclusion $\quad 54$

$\begin{array}{ll}\text { 2. Against Christianisation } & 57\end{array}$

1. The Restriction on Establishing New Places of Worship 57

2. Muslim Opposition to the WCC Assembly of 1975

The WCC Assembly and the Muslim Discourse on Christianisation 65

The Murder of an Anglican Church Minister 69

The Cancellation of the Assembly in Jakarta 70

3. Control of Religious Propagation and Foreign Aid 72

The Debates on International and National Occasions

(1972-1976) 72

Alamsyah's Attempts at Reconciliation with the Islamic Groups 78

Alamsyah's Decrees of 1978: Taking the Steps Further 81

Christian Opposition to the Decrees 83

Muslims' and Government's Responses 85

The Government Final Position: the Joint Decree of 1979

The Implication of the Decrees 89 
4. Muslim Opposition to Common Christmas Celebration 91 MUI's Fatwa on Common Christmas Celebration 92

Responses to the Controversy of the Fatwa 95

Alamsyah's Circular on the Celebration of Religious Days 98

Christian Opposition to the Circular 99

1993: The Fatwa Reintroduced 102

$\begin{array}{ll}\text { Conclusion } & 103\end{array}$

$\begin{array}{ll}\text { 3. Against the Islamic State } & 105\end{array}$

1. Ideological Debates in the Early New Order 106

The Debates on the Position of the Jakarta Charter (1968-1969) 109

The Debates on Pancasila's 'Ketuhanan Yang Maha Esa' 118

The Debates on the Department of Religion $\quad 125$

2. The Catholic-Military Alliance 134

Beek and Khasebul: Against Communism and the Islamic State 134

The Catholics in Opsus, CSIS and Golkar 139

Catholic Political Theology and Integralism of Pancasila 142

Muslim and Catholic Views of Beek's Group $\quad 145$

3. Pancasila as the Sole Basis 149

Conclusion 153

4. Religion, Family Law and the State 157

1. The Debates on Secular and Islamic Marriage Bills 157

The Soekarno Period: Secular vs. Islamic Marriage Bills 158

Early Years of the New Order: Muslim-Catholic Debates 160

2. The Debates on Marriage Bill of 1973

Muslim Accusations of a Catholic Conspiracy behind the Bill 166

Marriage Affairs: Between State and Religious Authority 170

Inter-religious Marriage: Christianisation or a Basic Human

$\begin{array}{ll}\text { Right? } & 177\end{array}$

3. Inter-religious Marriage between State Regulations and

Religious Doctrines

The State and Muslim Opposition to Inter-religious Marriage 183

State Regulations and Christian Views on Marriage 188 
4. The Ideological Debates on the Religious Court Bill 192 Christians' Arguments against the Bill 194 Muslim Reactions to Christians' Arguments 197 The Government's Position and the Compromise 201 Conclusion $\quad 204$

5. Religion, Culture and Education 207

1. Contesting Discourses on Indonesian Culture 207 The 1930s: Is Indonesian Culture Western, Javanese or Islamic? 208 1945-1965: Universalism as a Common Ground and Conflict 211 Secular vs. Islamic View: the Kipandjikusmin Affair (1968-1970) 214 The CSIS's Strategy of Culture and Muslim Opposition 216 Muslim and Christian Discourses on Religion and Javanese $\begin{array}{ll}\text { Culture } & 219\end{array}$ The Rise of Islamic Culture in National Politics in 1990s 221

2. Religion and State Educational Policies 223 The Failure of Attempts to Unify the Administration of Education 224 Secular Subjects in the Madrasah Curriculum during the New Order

Religion Classes: From Optional to Compulsory 227

PMP: An Ideological Challenge to Islamic Religion Classes 230

Comparative Religion: Another Challenge to Islamic Religion

Classes

Should Ramadan be Schooldays or Holidays? 236

DDC: Christianisation via the Library? 240

Against Christianisation: Controversy on Religion Classes in Private Schools

1. The Non-Ideological View of Islam 253 Positive Christian Responses to the Islamic Renewal Movement 256

2. Inter-religious Dialogue and National Development 264 Government Sponsored Dialogue on Religious Harmony and Development 
Critical Muslim and Christian Responses to the Government Initiatives

3. Politics, Incidents and Dialogue in the 1990s

The Monitor Affair and Dialogue

Private Initiatives in the 1990s: Dialogue for Democracy and Pluralism

Clashes in the Late 1990s and Dialogue as a Response

Conclusion

299

Notes

Bibliography

377

Samenvatting (Dutch Summary)

421

Curriculum Vitae 


\section{List of Abbreviations}

\begin{tabular}{|c|c|}
\hline ABRI & $\begin{array}{l}\text { Angkatan Bersenjata Republik Indonesia (Armed Forces of } \\
\text { Republic Indonesia) }\end{array}$ \\
\hline BAKIN & $\begin{array}{l}\text { Badan Koordinasi Intelijen Negara (The Coordinating Body } \\
\text { of State Intelligence) }\end{array}$ \\
\hline BAPPENAS & $\begin{array}{l}\text { Badan Perencana Pembangunan Nasional (Body for } \\
\text { National Development Planning) }\end{array}$ \\
\hline BPUPK & $\begin{array}{l}\text { Badan Penyelidik Usaha-Usaha Kemerdekaan (The } \\
\text { Investigating Committee for the Preparation of } \\
\text { Independence) }\end{array}$ \\
\hline BTI & Barisan Tani Indonesia (Indonesian Peasants Organisation) \\
\hline CSIS & Centre for Strategic and International Studies \\
\hline DDC & Dewey Decimal Classification \\
\hline DDII & $\begin{array}{l}\text { Dewan Dakwah Islamiyah Indonesia (Indonesian Council } \\
\text { for Islamic Propagation) }\end{array}$ \\
\hline DGI & $\begin{array}{l}\text { Dewan Gereja-Gereja di Indonesia (Indonesian Council of } \\
\text { Churches) }\end{array}$ \\
\hline DPRGR & $\begin{array}{l}\text { Dewan Perwakilan Rakyat Gotong Royong (Peoples' } \\
\text { Representative Council of Cooperation). The Indonesian } \\
\text { Parliament during Soekarno's Guided Democracy }\end{array}$ \\
\hline FKKS & $\begin{array}{l}\text { Forum Komunikasi Kristen Surabaya (Communication } \\
\text { Forum for Christians in Surabaya) }\end{array}$ \\
\hline Gasbiindo & $\begin{array}{l}\text { Gabungan Serikat Buruh Islam Indonesia (Consortium of } \\
\text { the Unions of Indonesian Muslim Workers) }\end{array}$ \\
\hline GBHN & $\begin{array}{l}\text { Garis-Garis Besar Haluan Negara (Mainlines of State } \\
\text { Policies) }\end{array}$ \\
\hline GESTAPU & $\begin{array}{l}\text { Gerakan September Tigapuluh ( The } 30^{\text {th }} \text { September } \\
\text { Movement) }\end{array}$ \\
\hline GKJW & Gereja Kristen Jawi Wetan (Christian Church of East Java) \\
\hline GMKI & $\begin{array}{l}\text { Gerakan Mahasiswa Kristen Indonesia (Movement of } \\
\text { Indonesian Christian Students) }\end{array}$ \\
\hline Golkar & Golongan Karya (Functional Group) \\
\hline GPIB & $\begin{array}{l}\text { Gereja Protestan Indonesia Barat (Protestant Church of } \\
\text { Western Indonesia) }\end{array}$ \\
\hline HMI & $\begin{array}{l}\text { Himpunana Mahasiswa Islam (Association of Muslim } \\
\text { Students) }\end{array}$ \\
\hline
\end{tabular}




\begin{tabular}{|c|c|}
\hline $\mathrm{HOCl}$ & $\begin{array}{l}\text { Huwelijks Ordonnantie Christen Indonesiers (Marriage } \\
\text { Regulations for Indonesian Christians) }\end{array}$ \\
\hline IAIN & $\begin{array}{l}\text { Institut Agama Islam Negeri (State Institute of Islamic } \\
\text { Studies) }\end{array}$ \\
\hline ICMI & $\begin{array}{l}\text { Ikatan Cendekiawan Muslim Indonesia (Indonesian Muslim } \\
\text { Intellectuals Association) }\end{array}$ \\
\hline IDI & $\begin{array}{l}\text { Ikatan Dokter Indonesia (Association of Indonesian } \\
\text { Doctors) }\end{array}$ \\
\hline Interfidei & Institute for Interfaith Dialogue in Indonesia \\
\hline KAMI & $\begin{array}{l}\text { Kesatuan Aksi Mahasiswa Indonesia (United Action of } \\
\text { Indonesian University Students) }\end{array}$ \\
\hline KAP-Gestapu & $\begin{array}{l}\text { Kesatuan Aksi Pengganyangan-Gerakan September } 30 \\
\text { (United Action to Crush the } 30^{\text {th }} \text { September Movement) }\end{array}$ \\
\hline KHASEBUL & Khalwat Sebulan (One Month Retreat) \\
\hline KISDI & $\begin{array}{l}\text { Komite Indonesia Untuk Solidaritas Dunia Islam } \\
\text { (Indonesian Committee for Solidarity with the Muslim } \\
\text { World). }\end{array}$ \\
\hline KNIP & $\begin{array}{l}\text { Komite Nasional Indonesia Pusat (Central National } \\
\text { Committee of Indonesia) }\end{array}$ \\
\hline KNPI & $\begin{array}{l}\text { Komite Nasional Pemuda Indonesia (National Committee } \\
\text { of Indonesian Youth) }\end{array}$ \\
\hline Kopkamtib & $\begin{array}{l}\text { Komando Operasi Keamanan dan Ketertiban (Command of } \\
\text { Security and Order Operations) }\end{array}$ \\
\hline Kostrad & $\begin{array}{l}\text { Komando Strategis Angkatan Darat (Army Strategic } \\
\text { Reserve Command) }\end{array}$ \\
\hline KPPN & $\begin{array}{l}\text { Komisi Pembaharuan Pendidikan Nasional (Commission } \\
\text { for the Reformation of National Education) }\end{array}$ \\
\hline KUA & Kantor Urusan Agama (Office of Religious Affairs) \\
\hline KWI & $\begin{array}{l}\text { Konferensi Wali Gereja Indonesia (Conference of } \\
\text { Indonesian Bishops) }\end{array}$ \\
\hline LAI & Lembaga Alkitab Indonesia (Indonesian Bible Institute) \\
\hline LEKRA & $\begin{array}{l}\text { Lembaga Kebudayaan Rakyat (Institute of People's } \\
\text { Culture) }\end{array}$ \\
\hline LKiS & $\begin{array}{l}\text { Lembaga Kajian Islam dan Sosial (Institute for Social and } \\
\text { Islamic Studies) }\end{array}$ \\
\hline LP3ES & $\begin{array}{l}\text { Lembaga Penelitian, Pendidikan \& Penerangan Ekonomi } \\
\text { dan Sosial (Institute of Research, Education and } \\
\text { Information on Social and Economic Affairs) }\end{array}$ \\
\hline
\end{tabular}




\begin{tabular}{|c|c|}
\hline LPHN & $\begin{array}{l}\text { Lembaga Pengembangan Hukum Nasional (Institute for } \\
\text { Development of National Law) }\end{array}$ \\
\hline LPKUB & $\begin{array}{l}\text { Lembaga Pengkajian Kerukunan Umat Beragama (Institute } \\
\text { for the Study of Religious Harmony) }\end{array}$ \\
\hline LSAF & $\begin{array}{l}\text { Lembaga Studi Agama dan Filsafat (Institute for the Study } \\
\text { of Religion and Philosophy) }\end{array}$ \\
\hline MADIA & $\begin{array}{l}\text { Majelis Dialog Antar-agama (Council for Inter-religious } \\
\text { Dialogue) }\end{array}$ \\
\hline MAN & Madrasah Aliyah Negeri (Public Senior High Madrasah) \\
\hline Manikebu & Manifes Kebudayaan (Culture Manifesto) \\
\hline MASBI & $\begin{array}{l}\text { Majelis Seni dan Budaya Islam (Council of Islamic Art and } \\
\text { Culture) }\end{array}$ \\
\hline MAWI & $\begin{array}{l}\text { Majelis Agung Wali Gereja Indonesia (High Council of } \\
\text { Indonesian Bishops) }\end{array}$ \\
\hline MNPK & $\begin{array}{l}\text { Majelis Nasional Pendidikan Katolik (National Council of } \\
\text { Catholic Education) }\end{array}$ \\
\hline MPR & $\begin{array}{l}\text { Majelis Permusyawaratan Rakyat (People's Consultative } \\
\text { Assembly) }\end{array}$ \\
\hline MPRS & $\begin{array}{l}\text { Majelis Permusyawaratan Rakyat Sementara (Provisional } \\
\text { People's Consultative Assembly) }\end{array}$ \\
\hline MUI & Majelis Ulama Indonesia (Indonesian Council of Ulama) \\
\hline NASAKOM & $\begin{array}{l}\text { Nasionalis, Agama, Komunis (Nationalism, Religion and } \\
\text { Communism) }\end{array}$ \\
\hline NU & $\begin{array}{l}\text { Nahdlatul Ulama (The Resurgence of Ulama). The } \\
\text { traditionalist Muslim organisation. }\end{array}$ \\
\hline OPSUS & Operasi Khusus (Special Operation) \\
\hline P3M & $\begin{array}{l}\text { Perhimpunan Pengembangan Pondok Pesantren dan } \\
\text { Masyarakat (Association for Developing Islamic Boarding } \\
\text { Schools and Society) }\end{array}$ \\
\hline P4 & $\begin{array}{l}\text { Pedoman Penghayatan dan Pengalaman Pancasila } \\
\text { (Guidelines for Internalisation and Application of } \\
\text { Pancasila) }\end{array}$ \\
\hline Parkindo & Partai Kristen Indonesia (Indonesian Christian Party) \\
\hline PDI & Partai Demokrasi Indonesia (Indonesian Democratic Party) \\
\hline PERKIM & $\begin{array}{l}\text { Pertubuhan Kemajuan Islam Malaysia (Body for the } \\
\text { Advancement of Islam in Malaysia) }\end{array}$ \\
\hline Perumnas & Perumahan Nasional (National Housing) \\
\hline PGI & $\begin{array}{l}\text { Persekutuan Gereja-Gereja Indonesia (Communion of } \\
\text { Indonesian Churches) }\end{array}$ \\
\hline
\end{tabular}




\begin{tabular}{|c|c|}
\hline PGRI & $\begin{array}{l}\text { Persatuan Guru Republik Indonesia (Association of } \\
\text { Teachers of Republic Indonesia) }\end{array}$ \\
\hline PII & $\begin{array}{l}\text { Pelajar Islam Indonesia (Indonesian Muslim High School } \\
\text { Students) }\end{array}$ \\
\hline PII & $\begin{array}{l}\text { Persekutuan Injili Indonesia (Indonesian Evangelical } \\
\text { Fellowship) }\end{array}$ \\
\hline PKI & Partai Komunis Indonesia (Indonesian Communist Party) \\
\hline PKKTLN & $\begin{array}{l}\text { Panitia Koordinasi Kerjasama Teknis Luar Negeri } \\
\text { (Coordinating Committee for Foreign Technical } \\
\text { Cooperation) }\end{array}$ \\
\hline PMI/Parmusi & Partai Muslimin Indonesia (Indonesian Muslims Party) \\
\hline PMII & $\begin{array}{l}\text { Pergerakan Mahasiswa Islam Indonesia (Indonesian } \\
\text { Muslim Students' Movement) }\end{array}$ \\
\hline PMKRI & $\begin{array}{l}\text { Perhimpunan Mahasiswa Katolik Republik Indonesia } \\
\text { (Association of Catholic Students of Republic Indonesia) }\end{array}$ \\
\hline PMP & Pendidikan Moral Pancasila (Pancasila Moral Education) \\
\hline PNI & Partai Nasionalis Indonesia (Indonesian Nationalist Party) \\
\hline PPKI & $\begin{array}{l}\text { Panitia Persiapan Kemerdekaan Indonesia (The } \\
\text { Preparatory Committee of Indonesian Independence) }\end{array}$ \\
\hline PPP & $\begin{array}{l}\text { Partai Persatuan Pembangunan (United Development } \\
\text { Party) }\end{array}$ \\
\hline PSI & Partai Sosialis Indonesia (Indonesian Socialist Party) \\
\hline REPELITA & $\begin{array}{l}\text { Rencana Pembangunan Lima Tahun (Five Year } \\
\text { Development Plan) }\end{array}$ \\
\hline RMS & Republik Maluku Selatan (Republic of South Maluku) \\
\hline SARA & $\begin{array}{l}\text { Suku, Agama Ras dan Antar-golongan (Ethnicity, Religion, } \\
\text { Race and Inter-class) }\end{array}$ \\
\hline SMA & Sekolah Menengah Atas (Senior High School) \\
\hline SMP & Sekolah Menengah Pertama (Junior High School) \\
\hline SMUN & $\begin{array}{l}\text { Sekolah Menengah Umum Negeri (Public Senior High } \\
\text { School) }\end{array}$ \\
\hline STT & Sekolah Tinggi Teologi (Academy of Theology) \\
\hline WCC & World Council of Churches \\
\hline
\end{tabular}




\section{Acknowledgements}

A great many people and institutions helped me in different ways to write this dissertation. First of all, I wish to express my gratitude to the International Institute for the Study of Islam in the Modern World (ISIM), Leiden, which provided me with a PhD fellowship over four years (2001-2005). I would also like to thank the Indonesian Government for allowing me to leave my obligations as a civil servant at the State Institute of Islamic Studies (IAIN) Antasari, Banjarmasin, during my time of study. My main supervisor, Prof. Martin van Bruinessen, helped me look at the issues discussed in this work from a social science perspective. My other supervisor, Prof. Karel A. Steenbrink particularly helped me to better understand the development of Christianity in Indonesia. Both of my supervisors also have several years of experience in doing research and making contacts with important Muslim and Christian leaders in Indonesia and they generously shared those experiences with me. Dr. Gerry van Klinken, Dr. Daniel Dhakidae and Dr. Djohan Effendi kindly spared their time to discuss certain issues of the thesis with me. I am also grateful for the feedback given to me by the participants who attended presentations of some parts of this study on various occasions, including at the ISIM PhD seminars (organized by Dr. Nathal Dessing), the International Convention of Asia Scholars in Singapore (August 2003), the Indonesia Council Open Conference in Canberra (September 2003) and the European Association of Southeast Asian Studies Conference in Paris (September 2004). I also thank Dr. Paule Maas who kindheartedly translated the summary of this dissertation into Dutch. Dr. G. E. Marrison and Dr. Simon Rae meticulously helped me with correcting and refining the English. Any remaining mistakes are of course entirely my responsibility.

I would also like to thank those people who helped me during my work on collecting the materials for this study. In Jakarta, Martin L. Sinaga and Trisno S. Sutanto helped me to make contact with Christian leaders and institutions. My colleagues at the State Islamic University (UIN) Syarif Hidayatullah (whose names I unfortunately cannot mention one by one) also helped me make contacts with important Muslim leaders in Jakarta. My access to the Muslim and Christian informants in Yogyakarta would not have been as easy without help from Wiwin Siti Aminah, the staff of the Institute for Interfaith Dialogue in Indonesia (Interfidei), Hairussalim, the staff of the Institute for Islamic and Social Studies (LKiS) and Ahmad Rafiq, lecturer at the State Islamic University (UIN), Sunan Kalijaga. My brothers Najib Kailani and 
Ahmad Muhajir also helped me with finding and copying some important materials from the Ignatius Library, Yogyakarta. I would also like to thank the staff of the KITLV Library and Central Library of Leiden University. In Jakarta, I was helped by the staff of the National Library, the National Archives, the library of Lakpesdam NU, the library of the Indonesian Islamic Propagation Council (DDII), the library of the Office of Research and Development of the Department of Religion (Litbang Depag), the library of the Indonesian Bishops Conference (KWI), and the library of Research and Development of the Indonesian Communion of Churches (Litbang PGI). My short visit to Surabaya was greatly facilitated by the help of the young NU activist, Fitriatun. I am also grateful to the staff of the Nadhlatul Ulama headquarters of East Java who allowed me to copy some materials from its library. I would like to thank those informants (whose names are mentioned in my notes, except a few who requested confidentiality) for their readiness to answer my questions. The plan for this project initially included a chapter discussing current developments after the New Order period with specific attention to the region of Makassar, South Sulawesi. I would like to apologize to those interviewees in Makassar for the fact that the chapter in question is not included in this work but will appear instead as a journal article.

During the period of more than four years working on this study, I was helped by several people to deal with important practical matters. In Jakarta, Kusmana and Kusnadi helped me find suitable accommodation for my temporary stay in Ciputat. In Yogyakarta, I was warmly welcomed at the student house, Bengkeng, in Sapen. The ISIM staff, particularly Mary Bakker and her successor Rapti Miedema, as well as Ada J. Seffelaar helped me deal with practical matters in the Netherlands. Other colleagues at the ISIM, particularly Muhammad Amer, Egbert Harmsen and Nadia Sonneveld, often kindly explained the meaning of several Dutch letters to me. SyuanYuan Chiou (Thomas) and his family frequently gave me moral and practical help when I faced difficulties in Leiden. Likewise, meeting and talking with other Indonesian students in Leiden helped reduce my loneliness in a foreign country. I thank all of these people for their help and warm friendship.

My family has been my most important source of strength. My father Jamhari Arsyad and mother Siti Maserah always prayed for the success of my study. I was shocked by the sudden death of my father at the time when this study was still in its middle stage. However, the strength of my mother and my brothers (Najib, Muhajir, Iqbal) as well as my youngest sister (Athiya) helped significantly reduce my sorrows. During the making of this study, my wife Mariani and my daughter Nawwal Hikmah patiently accepted my 
absence from home for several months. They also had to face the difficulties of living in a foreign country when they accompanied me to the Netherlands. I would like to express my deepest thanks to them and I dedicate this study to them. 


\section{Introduction}

Indonesia is home to the largest Muslim population in the world. The population census of 1971 indicates that $87.51 \%$ or 103.57 million of the Indonesians were Muslim. The percentage slightly increased to $88.22 \%$ in the year 2000 with a total number of 177.52 million. On the other hand, the most significant religious minority in the country is the Christians, who comprised $7.39 \%$ and $8.92 \%$ of the total population in 1971 and 2000 respectively. The Christian population has increased from 8.74 million in 1971 to 17.95 million in 2000 with an average rate of growth of $2.4 \%$ annually. This rate is higher than the rate of growth of the Indonesian population as a whole (1.83\%). ${ }^{1}$ Moreover, Christianity is the religion of the majority in some provinces outside Java, namely, in East Nusatenggara, Papua, North Sulawesi and Maluku, while in North Sumatra, West, Central and East Kalimantan and Central and South Sulawesi, it is the religion of a large minority. ${ }^{2}$

The Islamization of the Archipelago was initially carried out by Muslims of different regional and ethnic origins (apparently from the entire coastline from South Arabia to Southern China) around the $13^{\text {th }}$ to $15^{\text {th }}$ centuries. The more intensive process of Islamization occurred in $17^{\text {th }}$ to $18^{\text {th }}$ centuries when several indigenous Muslims performed the Hajj and stayed in Mecca to study Islam for several years and returned home to be advisors for local rulers. Islam continued to develop in the country through the $19^{\text {th }}$ and early $20^{\text {th }}$ centuries and at the same time contacts between the Indonesian Muslims and their co-religionists increased not only with those in the Islamic centre of Mecca but also in those of Cairo and India. The Islamization of Indonesia continues up to now and probably will never end. There have been various types of Islam coming to Indonesia, from the traditionalist Sunni Islam (as the majority) to the reformist Wahhabism, Ahmadiyya, Ikhwani activism and Shi'im. ${ }^{3}$

Although Islam is the predominant religion, there have been differences in degree and mode of acceptance of this religion among the Indonesians. In this context, there have been different positions among the Muslims concerning the relation between Islam and local religious beliefs and practices. Influenced by Muhammad 'Abduh's and Rashīd Ridā's Islamic reformism, Muhammadiyah, the Muslim organisation established in 1912 in Yogyakarta, propagates the idea of purification of Islam from local religious beliefs and practices. There is also Nahdlatul Ulama (NU), the traditionalist Muslim organisation established in Surabaya in 1926. The NU's religious 
view is based on the teachings of the traditional ulama, particularly of the Shafi'i school, and compared with Muhammadiyah, the NU is less opposed to local religious practices. On the other hand, there are nominal Muslims who embrace syncretistic religious beliefs and practices in which Islamic, Hindu and local religious traditions are combined. This group sometimes even saw Islam as a foreign religion endangering indigenous beliefs. In some places, there is antagonism between Islam and local customs or adat. ${ }^{4}$ In his classic study of the Javanese, the largest ethnic group in Indonesia, ${ }^{5}$ Geertz identified the nominal Muslims as abangan and its elite variant as priyayi. ${ }^{6} \mathrm{As}$ opposed to the abangan, in Geertz's typology, both NU and Muhammadiyah represent the santri variant, that is, the orthodox and practicing Muslims.

The different religio-cultural positions among the Indonesian Muslims are not inherently antagonistic to one another, but they are usually hardened when the proponents of each position compete in the political arena. When the draft of the Indonesian constitution was discussed a few months before the Proclamation of Independence in 1945, we soon find the clash between the santri leaders who wanted to establish an Islamic state and the abangan leaders who preferred a nationalist and secular state. The political development in the next decade, particularly the national elections of 1955 followed by the ideological debate in the Constituent Assembly, even hardened the antagonism between santri and abangan groups. Moreover, although the reformist and the traditionalist Muslims were initially involved in the same way in the struggle for an Islamic ideology, in some other important cases they have been opposed to one another for the sake of their respective political interests. Initially, in the early 1950s, NU was together with the reformist Muslims within the Islamic party, Masyumi, but when the NU leaders felt that their political interest was neglected, they left the Masyumi and declared NU an independent political party. By the late 1950s, while the Masyumi opposed Soekarno's Guided Democracy, the NU decided to support it. There are certainly other examples of political conflict between the traditionalist and the reformist Muslims in the following decades.

As among the Muslims, there are also differences among the Christians. In general, about two thirds of the Indonesian Christians are Protestant and the rest are Catholic. The Catholic missionaries started their work in Maluku, North Sulawesi and East Nusatenggara by sixteenth century under the patronage of the Portuguese and Spanish armed power. In the next century, when the armed traders of the Dutch East Indies Company (VOC) controlled North Sulawesi and Maluku, they converted the local Catholics to the 
Dutch Reformed Church. ${ }^{7}$ However, during the first two centuries of its rule, the Dutch in general did not support Christian missionary activities, particularly if the latter could endanger colonial economic interests. Only by the middle of nineteenth century when the colonial power was well established did the Dutch support and finance Christian missionary activities. Since this period, Catholic and Protestant missionaries intensified their activities and gradually achieved much success in several places like Java, North Sumatra, parts of Kalimantan, and Central and South Sulawesi. ${ }^{8}$ In short, the majority of the Christian Churches in Indonesia are the product of missionary work during the colonial period. These Churches continue to develop in independent Indonesia and constitute the mainstream Christians in the country. Around the middle of the twentieth century, American evangelicalism also penetrated Indonesia and continues to develop up to now.

The presence of Christianity in Indonesia, particularly in the form of social services like schools, universities, hospitals and orphanages, is found in almost all major cities of the country, including the regions dominated by Muslims. Thanks to the missionary schools, at least up to the early 1970s, the Indonesian Christians were much better educated than the majority of Muslims. ${ }^{9}$ With their good education, the Christians were qualified to take important positions in the new state of Indonesia. Furthermore, although many Protestant churches are associated with certain ethnic groups such as the Ambonese, Batak, Toraja, Minahasa, Javanese etc., after Independence, they tried to unify themselves under a national organisation. In 1945, several important Christian leaders in Jakarta established Parkindo (Partai Kristen Indonesia - the Indonesian Christian Party) that was intended to channel the political aspirations of the Protestants. Moreover, in 1950, the Protestant leaders established the DGI (Dewan Gereja-Gereja Indonesia - Indonesian Council of Churches), an association for the Protestant Churches all over the country. Since 1955, the Catholics have also had a national council called MAWI (Majelis Agung Wali Gereja Indonesia - High Council of Indonesian Bishops), and in 1961, the Pope established the hierarchy of the Catholic Church in Indonesia, so the status of this country as a region of mission was removed. ${ }^{10}$ Finally, the Catholics also had the Catholic Party (Partai Katolik), originally established in early twentieth century during the colonial period, and it became a political party in independent Indonesia up to early 1970s.

For more than two decades after Independence, Partai Katolik and Parkindo became the channels for the Christians to defend their political interests. However, after the fusion of the two parties with secular nationalist parties to form the PDI (Partai Demokrasi Indonesia - Indonesian Dem- 
ocratic Party) in the early 1970s, both MAWI (KWI) and DGI (PGI) ${ }^{11}$ appear to have become more active in responding to religio-political issues. As a religious minority amid the Muslim majority, the Christians always tried to find a suitable ally among the Muslims to defend their interests. In most cases, the Christians allied with abangan Muslims, particularly against the Islamic ideological ambitions of the santri Muslims. The abangan-Christian alliance in a way also meant that the Christians allied with those in power, because since Independence up to late 1980s, the state had been controlled mostly by the abangan. However, in 1990s when President Soeharto allied with santri groups, particularly the reformist Muslims, several secular and Christian intellectuals allied with the traditionalist Muslim leader, Abdurrahman Wahid, who opposed Soeharto's alliance.

In this study I shall analyse the religio-political issues that affected Muslim-Christian relations in Indonesia during Soeharto period (19661998). There exist a number of earlier studies of Muslim-Christian relations in Indonesia. Some of them, however, pay almost exclusively attention to the Muslim voices, while those of the Christians are less sufficiently or not at all taken into account. ${ }^{12}$ The result of these studies, therefore, is inevitably a one-sided picture (even though it is not necessarily un-objective). There are also other studies that try to look at both Muslim and Christian voices but they do not concentrate on the Soeharto period. ${ }^{13}$ In contrast to the existing studies, in this study I shall focus on the New Order period and will pay attention to the voices of Muslim and Christian leaders, as well as the Government.

The sources of this study include various Indonesian newspapers, magazines, books, unpublished documents and a number of interviews with important Muslim and Christian leaders. Different voices found in these sources will be analysed within the context of power relations among the agencies involved. Thus, I shall analyse groups of statements or the so called 'discourses' produced by respective Muslim and Christian leaders as well as the state, particularly those statements that affected Muslim-Christian relations in Indonesia. ${ }^{14}$ The questions addressed in this study are: Who developed a certain discourse? What was its socio political context? What was its line of reasoning (including, sometimes, how a religious tradition was interpreted)? How did the contesting discourses relate to one another? What was the channel or medium through which the discourse was made? What was the effect of the discourses on state policies? What was also its effect, if any, on social practices? Which discourse was suppressed or appropriated, and why? In this regard, I will analyse the discourses of the Muslims, 
the Christians and the state in three major areas of contestation, conflict and accommodation:

1. The Muslim discourse on the threat of Christianisation and the responses of the Christians and the state to it.

2. The Christian discourse on the threat of an Islamic State and the Muslim responses to it, and how this ideological issue influenced, and was influenced by, the state ideological policies.

3. The common discourses developed by the state, the Muslims, the Christians in the inter-religious dialogue.

This dissertation is divided into six chapters. Chapter 1 will discuss the political transition from Soekarno to Soeharto, and how the short MuslimChristian cooperation eventually developed into conflicts in the early years of the New Order. Chapter 2 will focus on the Muslim discourse on Christianisation and the Christians' and the Government's reactions to it. Chapter 3 will be developed to cover the Christian discourse on the threat of Islamic State or the Jakarta Charter, the Muslim attempts to defend it, and how this ideological debate was related to the ideological position of the regime. Chapter 4 will focus on the debates on the position of Islamic law within the state legal system, while Chapter 5 will cover the debates on culture and the position of religion in the state education system. Chapter 6 will focus on inter-religious dialogue developed by the Government, the Muslims and the Christians. This study will be closed with a general conclusion. 


\section{From Cooperation To Conflict}

Old and new, hope and fear came together to designate the period of political transition from Soekarno's Guided Democracy (1959-1965) to Soeharto's New Order (1966-1998). There was an assassination of six leading army generals, followed by the massacre of hundreds of thousands of Communists, real or suspected. There were also huge demonstrations of students in the streets, supported by the rising power of the army, to voice the 'people's demands.' There were new faces on the political stage demanding a radical reform, in addition to the old faces who took a more cautious position of wait and see. A number of old political prisoners were released, but at the same time the number of new political prisoners increased beyond the capacity of the existing prisons to contain them. Almost anything that was previously politically oppressed now reemerged. In short, the political scene was changing and moving towards a new structure that was not clear yet.

Both Muslim and Christian leaders were parts of this development. It was very unfortunate that the political and social development during this transitional period was not helpful in maintaining a harmonious relation between the two religious groups. Both religious groups were initially in the same boat with the army to fight against the Communists, and shared the benefits of religious revival afterwards. Nevertheless, not long after the defeat of the Communists, both religious groups were eventually trapped into conflict. In this chapter, I shall discuss the political development of this transitional period and how Muslim-Christian cooperation eventually turned out to be conflict in the early years of the New Order.

\section{Short-lived Muslim-Christian Cooperation: 1965-1966}

Having 'finished' the long political struggle for independence and integration of the state, in 1962 Soekarno's Government promised to pursue economic restoration programmes but the promise was not fulfilled. For domestic and international political reasons, in 1963 President Soekarno called for another political struggle: a confrontation with Malaysia. ${ }^{1}$ Consequently, western loans from the International Monetary Fund (IMF) and the United States for economic restoration were withdrawn, and according 
to one observer, the year 1963 became "the year of wasted opportunities." In the following years, the Indonesian economy declined more and more. Mackie observes that both in 1963 and 1964 the Government deficit reached roughly $50 \%$ of total expenditure and both prices and inflation almost doubled between December 1964 and June 1965, doubling again in the last few weeks of $1965 .^{3}$ The impact of the economic deterioration on the people was horrible. For the civil servants, to supplement their incomes, they had to take extra-jobs and become involved in certain corrupt practices. ${ }^{4}$ For ordinary people, the situation was very much worse. Mortimer notes that about one million people in Java and 18,000 people in Bali were starving. In a district called Wonosari in the south of East Java, it was reported that between two and six people starved to death daily. ${ }^{5}$

Soekarno, however, made another radical political move in international politics. In response to the seating of Malaysia as a non-permanent member of the United Nations Security Council, in January 1965, Soekarno decided to withdraw Indonesia from membership of the United Nations. In addition, domestic politics was also shaking. Soekarno was rumoured to be suffering from a serious illness, and therefore the question of power after him was at stake, especially within the circles of the two important domestic political powers: the Indonesian Communist Party (PKI) and the army. The leading political groups started calculating and preparing possible steps to face the succession. ${ }^{6}$

The whole crisis came to a head by the last few months of 1965, especially after the abortive coup of the so-called 'Gestapu', an acronym of Gerakan September Tigapuluh (The $30^{\text {th }}$ of September Movement). The Gestapu operation was actually enacted in the early morning of 1 October 1965 when six leading army generals were killed, and another target, General A.H. Nasution, the Chief National Army Commander, successfully escaped, his adjutant being killed in his stead. Lieutenant General Untung, the leader of the operation and the commander of one of the three battalions of the Palace Guard, the Cakrabirawa regiment, later in the morning announced on the national radio that the Movement was to safeguard the state and the life of President Soekarno against the alleged coup planned by the Council of Generals. Untung also announced a new organization called 'Dewan Revolusi' (Revolutionary Council) of which he appointed himself to be leader with others named as members. Nevertheless, later on that day, Major General Soeharto, the Chief of the Army's Strategic Reserve (Kostrad), started countering the Movement and gradually and successfully defeated and controlled it. According to the studies of the coup, on the day of 1 October 1965, 
President Soekarno and the top leader of the Indonesian Communist Party (PKI), D.N. Aidit, were in the Halim airbase, the headquarter of the Movement. ${ }^{7}$

There have been scholarly controversies regarding who actually planned and masterminded the Movement. ${ }^{8}$ In terms of the political development after the Movement, the question of the involvement of the PKI is the most crucial one. On one extreme, there is a theory arguing that the PKI was only a scapegoat. According to this theory, certain anti-Communist army officers and intelligence services used the Movement to urge the PKI to the treacherous action in order to find a rationale to banish the PKI. ${ }^{9}$ Another theory explains that the Movement was actually an internal army affair, that is, the rebellion of the low and middle-ranking army officers against their superior generals. According to this theory, the PKI activists, including the party leader, D.N. Aidit, were somehow controlled by the rebels rather than the opposite. ${ }^{10}$ Another theory explains that it was actually the PKI leaders who planned and masterminded the Movement as a coup attempt, to establish a Communist Government in Indonesia. This theory was accepted and promoted as the official version of the Movement by both military and civilian anti-Communist groups in Indonesia. ${ }^{11}$ In other words, the theory became the winner in Indonesian politics, regardless of the scholarly attempts to criticize or doubt the two extreme positions. ${ }^{12}$

The contribution of the civilians, including the Islamic and the Christian groups, to the success of the army in defeating the Communists after the coup was quite significant. ${ }^{13}$ On the evening of 1 October 1965, several reformist Muslim activists of the Association of Muslims Students, HMI (Himpunan Mahasiswa Islam), the Muslim High School students' organization, PII (Pelajar Islam Indonesia) and the Consortium of the Unions of Muslim workers, Gasbiindo (Gabungan Serikat Buruh Islam Indonesia) had met and agreed to form a Muslim Action Command against the Communists. All these associations were directly or indirectly affiliated with the banned reformist Muslim party Masyumi. The only leading activist affiliated with the traditionalist Nahdlatul Ulama (NU) who joined this movement from the beginning was Subchan ZE.

The idea of having a Muslim Action Command was soon dropped, after the Muslims had meetings with the Catholic student activists and the Army Commander of Jakarta, Umar Wirahadikusuma. With the support of the latter, these activists finally established Kesatuan Aksi Pengganyangan Kontra Revolusi (KAP) Gestapu (United Action for Crushing the Contra-Revolution, Gestapu). Subchan was elected to be its head and Harry Tjan Silalahi, 
the Catholic activist, to be its general secretary. The young Muslim reformist activists like Lukman Harun, Mar'ie Muhammad, Husein Umar, and Dachlan Ranuwihardjo also joined the leadership of the KAP-Gestapu.

In contrast, perhaps due to their close relations with Soekarno, the senior NU politicians as well as the Protestant activists and politicians were at first doubtful about supporting the KAP Gestapu. On 4 October 1965, the KAP Gestapu held its first public rally in which the activists made a joint statement demanding that Soekarno ban the PKI and its affiliated organizations and close the media supporting the Gestapu. The representatives of the Protestant party, Parkindo and the nationalist party close to Soekarno, PNI, who were also invited to this public rally, refused to sign the joint statement, but at the second public rally held on 8 October, a representative of Parkindo, G. Mayor Siagian, agreed to sign a similar statement. In the following weeks, the KAP Gestapu carried out similar public rallies, demonstrations and attacks on the PKI buildings in Jakarta.

Later, with the army, the KAP Gestapu leadership called a meeting of various student organizations, and on 25 October 1965, they agreed to establish a university students' front, KAMI (Kesatuan Aksi Mahasiswa Indonesia). Both Muslim and Christian student organizations also joined the KAMI. On January 1966, the KAP Gestapu was developed to become the 'Pancasila Front' and ever since its activities were much more in 'high politics' while mass demonstrations were taken over by the KAMI.

Outside Jakarta, cooperation of the army with civilians led to terrible violence in which hundreds of thousands of ex-PKI activists and suspects were killed, especially during the last three months of 1965 and early $1966 .{ }^{14}$ Along with the PKI, the traditionalist Muslim party, NU, had previously supported Soekarno's Guided Democracy. However, after the coup, a faction within the NU that soon became dominant, decided to cooperate with the army to exterminate the Communists. Among the NU members, it was the organization's paramilitary wing, Barisan Serbaguna (Banser) Anshor that became the most active group in killing the Communists. ${ }^{15}$ In contrast with the traditionalist Muslims, before the coup the reformist Muslims had been more persistently hostile to the PKI. This was partly because the reformist Muslims were opposed to Soekarno's Guided Democracy, and their party, Masyumi, was banned in 1960. Thus, it is not surprising if Masyumi sympathizers in Central and East Java were also involved in the massacre. ${ }^{16}$

There were also some accounts that Catholic activists took part in the killings. ${ }^{17}$ It is still unclear to me, however, to what degree Catholics were involved. According to an informant, the Catholic Church never officially 
endorsed any violence against the Communists. ${ }^{18}$ Another informant said that in Flores it was the army who invited seminary students to witness the killings, ${ }^{19}$ while another said that in Java the army trained some Catholic students to attack the Communists. ${ }^{20}$ In contrast, another account suggested that in Flores where Catholics comprised a majority, the army elicited the cooperation of some of the Catholic activists in the operations against the Communists. The Catholic priests in the region, however, strongly opposed the killings. This was at least indicated by a Catholic priest working in Bola parish, Flores, Yosef Frederikus da Lopez. On 6 March 1966, he tried to save the lives of 45 Communist suspects who had been detained by the military, but unfortunately, the priest could only save 10 of them. ${ }^{21}$

It is not easy to explain why this tragedy happened. For the army, this was probably a revenge for the assassination of the six generals and at the same time the elimination of their most powerful political rivals during the period of Soekarno's Guided Democracy. For the Muslims, there had been confrontation between them and the PKI not long before the 1965 coup. ${ }^{22}$ The most noticeable case was when the PKI encouraged its peasant organization, Barisan Tani Indonesia (BTI), to apply the land reform law (passed in September 1960) through the so-called unilateral actions (aksi sepihak) in 1964. This unilateral action inevitably led to clashes between the landowners, including the Muslim ones, and the PKI peasants. An observer said that at this time, various Surabaya newspapers reported "almost daily incidents in the villages, some of them between PKI and PNI supporters, but most involving PKI-led peasants in clashes with supporters of the NU and ex-Masjumi followers." ${ }^{23}$ In addition, the massacre can also be understood as a clash between the existing socio-political and cultural antagonism in the Javanese society, that is, between the nominal and syncretistic Muslims (abangan) versus the practicing and orthodox Muslims (santri). ${ }^{24}$

Many of the PKI suspects were not assassinated, but they had to suffer a terrible life in prisons. An Australian journalist, Hamish McDonald notes that:

The country's prisons, particularly in Java, became packed with detainees. Also new prison camps were quickly constructed. Between 1966 and 1972 over half a million people passed in and out of this prison system. Isolated from their families and any resort to legal protection, the prisoners were in many cases not even interrogated but simply thrown into gaol and forgotten. Miserably provided for, they were at the mercy of guards often nearly as deprived as themselves. Parcels sent in by relatives were plundered, bribes were exacted 
to allow authorized family contact, and in some cases the families of prisoners were harassed and blackmailed. ${ }^{25}$

For the anti-Communist groups, however, the physical annihilation or containment of the Communists was not enough unless it was followed by eradication of the Communist ideology in the country. From the end of June to early July 1966, the army leaders successfully organized the session of the Provisional People's Consultative Assembly (MPRS). ${ }^{26}$ It was in this session that the PKI as a political party and its Communist ideology were formally banned in Indonesia. In a decree issued by the MPRS, the Assembly stated its determination to ban the PKI because of its attempt to overthrow the Government of Indonesia. In addition, because Communism conflicts with the state ideology, Pancasila, the MPRS decided to ban any effort to spread and develop the ideology of Communism/Marxism-Leninism in the whole country. ${ }^{27}$

Certainly, Soekarno - whose political power now gradually decreased - was very unhappy with the MPRS's decree. For Soekarno, it was an open challenge to his 'synthetic' ideology of NASAKOM (Nasionalis, Agama dan Komunis) in which nationalism, Islam and Communism were supposed to cooperate under the Guided Democracy system. Since 1960s, NASAKOM had become one of the most important of Soekarno's political slogans, leaving aside his earlier interpretation of the state ideology, Pancasila. ${ }^{28}$ Therefore, in response to the decree, Soekarno quoted Confucius saying: "One general can destroy a thousand enemy soldiers but one thousand generals cannot uproot a man's conviction." He also said, "I now say without beating about the bush, I am a Marxist, I have said since the year '28, I am a nationalist, I am religious, I am a Marxist...Marxism is contained in my heart." ${ }^{29}$

What was then the strategy of the MPRS to replace Soekarno's NASAKOM, especially to eradicate its Communist element? There are at least two answers to this question. First, the MPRS adopted the idea of purification (pemurnian) of the application of Pancasila. This idea implies that there were some deviations from Pancasila during Soekarno's Guided Democracy that should be corrected by the MPRS. By emphasizing the importance of the purification of Pancasila, the army who controlled the MPRS session could effectively oppose Soekarno's NASAKOM, particularly its Communist element, without offering completely a new ideology. ${ }^{30}$ The MPRS, therefore, established a committee to investigate the teachings of Soekarno in order to purify those considered deviant from the Pancasila and the Constitution of $1945 .{ }^{31}$ 
Another ploy for opposing Communist ideology was to identify it with Atheism and opposition to religion. The elucidation of the MPRS decree No.XXV/1966 to ban the PKI and Communism stated that Communism was opposed to the basis of the Indonesian nation that was theistic (bertuhan) and religious (beragama). ${ }^{32}$ This idea was certainly not new: it had been previously promoted in the writings of Muslim and Christian intellectuals. The argument was more or less as follows: if the first principle of Pancasila, Ketuhanan Yang Maha Esa, implies a theistic belief, while Communism is identical with Atheism and opposed to religion, then it is clear that Communism is opposed to Pancasila. ${ }^{33}$ After the extermination of the Communists following the coup of 1965, this idea seems to have gained momentum. In addition to the elucidation of the MPRS decree no. XXV/1966 quoted above, another related theme was MPRS's decree No. XXVII/1966. The decree was actually concerned with three broad themes: religion, education and culture. The major concern of the decree was religious education. Article 1 of the decree stated that religion had to be a subject taught from elementary schools to university, and article 4 of the decree mentioned that one of the contents of education should be directed "to uphold noble morality and strengthen religious conviction." According to Harry Tjan Silalahi, a Catholic activist and one of the leading proponents of the movement against the Communists in the early years of the New Order, the underlying idea behind the decree was the assumption that Communism was identical with Atheism and against religion and therefore, religious education was considered an effective means to oppose Communism. ${ }^{34}$

There is another important thing in the MPRS decree No.XXVII/1966: in the elucidation of the decree, it was mentioned that to develop religious education in schools and universities "all religions recognized by the Government are given the same opportunity." ${ }^{35}$ What were the recognized religions? The MPRS's decree did not explain this. The answer can probably be found in the Soekarno's presidential decree number 1, 1965. This decree actually determined the rules to prevent "the misuse of and/or blasphemy against religion" (penyalahgunaan dan/atau penodaan agama). ${ }^{36}$ The elucidation of the decree mentioned that there were six religions followed by Indonesians, namely Islam, Protestantism, Catholicism, Hinduism, Buddhism, and Confucianism. ${ }^{37}$ Thus, the idea that religion was necessary to oppose Communism combined with the idea that there were recognized religions would logically lead to the understanding that everybody had to have religion or otherwise he or she could become a Communist suspect. 
The physical and ideological attacks on the Communists and Communism proved to be effective in eradicating their political influence on the people in the country. As noted, both the Islamic and Christian groups were in general the allies of the army in the fight against the Communists and Communism. Nonetheless, when the common enemy was obviously defeated, conflicts and tensions among the anti-Communist allies emerged, including between the Islamic and the Christian groups.

\section{Muslim-Christian Conflict in the Early New Order}

As has been noted, since 1966 a formal affiliation with one of the recognized religions had been considered necessary to dissociate one's self from Communism. It is not surprising, therefore, that there were 'sudden' religious conversions in this period, especially to Islam, Christianity, Hinduism and even Confucianism. ${ }^{38}$ However, for some reasons, in the eyes of many Muslims, conversion to Christianity was considered a threat. We do not know exactly how many people were converted to Christianity at that time. According to a statistical survey by a Catholic institution, the increase of the Catholic population in Indonesia from 1966 to 1967 reached $7.45 \% .{ }^{39}$ The survey explicitly notes that this increase was directly related to the consequences of the abortive coup. ${ }^{40} \mathrm{It}$ is also reported that after 1965 in Central Java, sometimes the number of people waiting for Catholic baptism was above the number of the parish members. ${ }^{41}$ Given the fact that there were many Protestant churches and denominations, it is not easy to know their actual figures. Fortunately, most of the Protestant churches had joined the Dewan Gereja-Gereja Indonesia, DGI (Indonesian Council of Churches), which was established in 1950. The retired army general and prominent leader of the DGI, T.B. Simatupang, notes that in 1967, compared with the data in 1964, there was "an increase of roughly 825,000 in the total membership of the 36 member-churches," in addition to "a considerable growth" of the members of the churches outside the DGI. ${ }^{42} \mathrm{He}$ also explains that the high increase of the church membership was found among three ethnic groups: the Javanese in East and Central Java, Karo Bataks in North Sumatra and among the Timorese. ${ }^{43}$

In general, the most considerable number of conversions was in Java. This is clearly indicated by a DG survey that almost all of the churches whose membership highly increased in the period between 1966 and 1970 were churches in Java, namely, Gereja Kristen Indonesia Jawa Timur (17\%), Gereja Kristen Jawa Timur Utara (15.5\%), Gereja Injili Tanah Jawa (12.2\%), Gereja- 
gereja Kristen Jawa (9\%), and Gereja Kristen Jawi Wetan (9\%). ${ }^{44}$ Although it is not an historical account as such, the following description of a Christian scholar and the Dean of the Faculty of Theology, Duta Wacana University, may help us understand the situation at that time.

In 1965, I was still in secondary school. Thus, I did not know much. But actually I saw and read books [on this event]. After 1965, there was a great optimism among the Churches, especially here in Java because of many peoples asking to be baptized to be Christians. There was even a story that in East Java, because so many people wanted to be baptized on that Sunday, the minister did not baptize in the normal way, by spraying water with hands, but by spreading water by a hose. I am not sure if it is true or not, but I think it is true. Thus, there was a great optimism that although the Gestapu was a tragedy and caused a lot of difficulties, it also opened the door to the Bible. The consequences were found everywhere. For instance, in Nusa Tenggara Timur and other Eastern areas, there was a kind of spiritual awakening. There were stories of miracles that Jesus appeared to somebody in certain places, water became wine like the stories told in the Bible and even there was a resurrection of the dead etc. We may not believe it, but that was the expression of the situation at that time... The story at that time was that the Churches were always full of people. There was optimism that in a short period all Indonesia would be followers of Jesus. ${ }^{45}$

Perhaps, because of this optimism, the DGI survey quoted above reported that 16 out of 35 of the missionary bodies in Indonesia had started their work after 1965, among them six established in 1968, four in 1969. It is also noteworthy that 30 out of the 35 missionary bodies came from the United States. ${ }^{46}$

\section{The Meulaboh Case: Muslim and Christian Parliamentary Questions}

The conversions to Christianity and the increase of Christian missionary activities did not disturb Muslim-Christian relations until the occasion of the Meulaboh case. ${ }^{47}$ The case concerned the controversy over a newly built Methodist Church in Meulaboh, a city in Aceh province. The Muslims in the city objected to the existence of the church because, they said, the majority of people living in the area were Muslims. This case then developed into an issue at the provincial level and the result was, the political authorities of the province decided that the church should be moved to another place. As 
a response to this case, on 17 June 1967, the representatives of the Protestant party (Parkindo) and the Catholic party (Partai Katolik) in the Parliament put forward a Parliamentary Question concerning the issue of religious freedom. ${ }^{48}$ This was later commonly known as "Simorangkir's Question", because it was presented by J.C.T Simorangkir, the top leader of the Parkindo and supported by ten other Christian politicians. ${ }^{49}$

The Meulaboh case was the first regional Muslim-Christian conflict that was brought to the National Parliament and caused considerable public debate. During the Soekarno period, at least one similar case had happened in Pasaman, a district in West Sumatra, bordering on Tapanuli in Northern Sumatra. Around 1950, some people from Sipirok (Tapanuli, North Sumatera) migrated to an area of Pasaman called Panti where many of the Muslims of Minang ethnic background had already been living. In 1957, the Tapanuli people intended to establish a church called 'Huria Kristen Batak Protestan' (HKBP) in Panti. The Minang Muslims objected to this plan and expressed their protest to the bupati (district head) and the Department of Religion in Pasaman. The Muslim protest, however, did not lead to their expectation. Probably because of the political tensions that led to the PRRI revolt in the following years, ${ }^{50}$ and because West Sumatra was one of the bases of the rebels, the case was naturally neglected. ${ }^{51}$

Unlike the Pasaman case, the political transition that was going on in Jakarta was more conducive to develop the Meulaboh case into a national political issue. Thus, soon after the public knew of Simorangkir's Question, there were some responses to the case by Muslims and Christians as well as the army. The army commander, General M. Paggabean, warned the public that they should be careful of the new Communist strategy to divide Indonesians along religious lines. ${ }^{52}$ In contrast, $\mathrm{HMI}$ activists demanded that the rulers would deal with the Meulaboh case locally, that is, not transform it into a national problem. ${ }^{53}$ There was a rather sharp statement by a Christian who said that the Meulaboh case was similar to the Islamic rebellious movement called Darul Islam. He further said that, just as the Darul Islam rebellion was successfully eliminated by the army, so it should now be left to the Government to decide on the Meulaboh case. ${ }^{54}$ It is worth noting that although the Meulaboh case occurred in the very early years of the New Order, the quoted statements reflect the common political discourse of the Soeharto regime: the alleged latent danger of the communist political intrigue (Panggabean's), the importance of maintaining political stability by restricting the scale of the conflict (HMI's), and the danger of the Muslims who wanted to establish an Islamic State (the Christians'). 
Probably because of Simorangkir's Question and the hot debates on the case in public, on 10 July 1967 the Muslim faction in the Parliament also proposed a Parliamentary Question on the issue of foreign aid to religious institutions. Lukman Harun, the leader the Muslim reformist youth organization, Pemuda Muhammadiyah, promoted the Question supported by other important Islamic figures in the country. ${ }^{55}$ This Question demanded that the Government control foreign aid for religious institutions, and it was clearly directed at the foreign aid for Christian missionary activities in Indonesia. Thus, although this Question was formally proposed to the Government, it was in a way also directed at the Christian parties in the Parliament that previously put forward the Question on religious freedom. In the words of the former general secretary of the Catholic Party, "there was a war of Parliamentary Questions".56

On 14 July 1967, the Indonesian Parliament (DPRGR) had a plenary session for Simorangkir to deliver an explanatory speech on his Question. Simorangkir's speech, as we shall see, was an important and early example of a Christian discourse on religious freedom in Indonesia's New Order. In his speech, Simorangkir began with a defense that the Question was not intended to incite tensions among the New Order supporters at all. He reminded the audience of the fact that they all had cooperated to exterminate the "Communist Gestapu/PKI" in order to create a political stability in the country. Thus, with this sense of togetherness, he said, there should be "a goodwill of all of us to create a harmonious condition among us as religious people" (i.e., as opposed to non-religious Communists). ${ }^{57}$ Again, Simorangkir's remarks represent the political discourse of the emerging regime: creating political stability, harmony, and identifying the PKI with Gestapu and anti-religion.

Simorangkir then explained that the background of the Question was the statement of the Ulama Council of Aceh dated 18 April 1967 concerning a newly built church in Meulaboh. In the statement - which was read and attached to his speech - the Ulama said that Aceh is a special territory of Indonesia where Islam and custom are interconnected. ${ }^{58}$ According to the statement, since 1964, as a "prologue to the Gestapu/PKI,"59 there was a church in Meulaboh, located close to the mosque of the Pasar Baru. Later on, the existence of the church could not be tolerated by the Muslims of Meulaboh. The local Government then gave permission to build a church in another part of Meulaboh called Blumer. In this too, the Ulama Council of Aceh demanded the local Government authorities of Aceh to withdraw the permission and the building of churches in West Aceh, especially in 
Meulaboh city and its close surroundings, to be stopped. In response to this demand, on 19 May 1967, the Government of Aceh decided to follow the demand and promised to help the process of moving the church to another place "where the Christians can observe their ritual very solemnly." ${ }^{60}$

Having read both the Ulama's statement and the Government decree, Simorangkir eventually came to the matter of the Parliamentary Question as follows:

1. Does the Government agree with us that the case [in Meulaboh] can be seen as a destruction of the spirit of tolerance among religious adherents in Indonesia?

2. Does the Government agree with us that the case was a kind of skepticism with respect to performing a pure application of the first principle of Pancasila?

3. Does the Government agree with us that any attitude of any group or anybody that hinders or curtails religious freedom means a rejection of human rights respected by all of us?

4. Does the Government agree with us that if no.3 happened, it will destroy the climate of national unity under the supervision of the New Order?

5. Does the Government agree with us that this kind of case will influence the possibility for the People's Consultative Assembly [MPRS] to prepare a declaration of human rights? ${ }^{61}$

6. Is the Government ready to take preventive or repressive steps, directly or indirectly, in order that this kind of case will not occur anymore in the Republic of Indonesian state that is based on Pancasila? ${ }^{62}$

Simorangkir's questions clearly reflect a Christian as well as the New Order's political discourse. As has been noted above, the idea of the purification of the implementation of Pancasila and the 1945 Constitution initially appeared in the sessions of the People's Consultative Assembly (MPRS) in June and July 1966. Moreover, in his speech on 1 June 1967 for the celebration of the birth of Pancasila, Soeharto reasserted that the strong-will (tekad) of the New Order's Government is to apply Pancasila in "a pure and consistent manner" (secara murni dan konsekuen), ${ }^{63}$ a statement that was to become like a necessary mantra in the New Order's discourse on Pancasila. It has been clear that Simorangkir used the expression to argue that the closing of the church in Meulaboh was a kind of pollution rather than purification of the implementation of the Pancasila and the Constitution of 1945. Last but not least, besides mentioning Pancasila, Simorangkir also frequently mentioned human rights, particularly the right to religious freedom, and this was in fact the core of his argument. 
One week after Simorangkir's speech, on 21 July 1967, Lukman Harun delivered his explanatory speech on the Question concerning foreign aid for religious institutions. Lukman Harun's speech is very important because it is an early example of Muslim discourse in the New Order against missionary activities, made by a reformist Muslim activist who played the role in the KAP Gestapu and was to become an important leader of Muhammadiyah and the contact person for the Muslim World League, Räbita al'Ālam la-Islämī. In the first part of his speech, Lukman Harun described his perception of the threat of Christian missions due to the existence of foreign aid. ${ }^{64}$ It was already known, he said, that foreign aid for the Christians took different forms such as money, church buildings, hospitals, means of transportation, scholarships, food etc. Lukman then referred to foreign media reports, namely Time, 16 June 1967 and Christian Science Monitor, 5 April 1967 which both mentioned that Christian communities in the United States collected $\$ 300,000$ for Christian missionary activities in Indonesia. Lukman also quoted an Indonesian press report that the Catholic Relief Service in New York in cooperation with the Indonesian Bishops Council (MAWI) provided 30 million pounds of food and medicine for the needy in Indonesia. Moreover, he explained that recently there had been a lot of foreign Christian missionaries coming to Indonesia. For Lukman Harun, the foreign aid was a kind of foreign intervention in Indonesian internal affairs. He said, "it has often been a historical reality when there is a foreign intervention, the positive spirit of tolerance of our nation is disturbed. The intervention can be in different forms and ways, one of them is the material and financial aid for certain religious institutions..." Lukman Harun then explained that the Christians developed unacceptable missionary methods to convert Muslims. Two examples were mentioned: unexpected door-to-door visits of Christian preachers, bringing the Christian scripture and magazines to Muslim homes and/or giving material aid such as food, medicine and the like to poor Muslims. As an implicit allusion to the Meulaboh case, Lukman Harun also said that the Christians often built churches in Muslim villages when almost no Christian lived there. For him, these Christian aggressive missionary activities were not in line with the tolerance based on Pancasila. He preferred to call them "a religious expansion directed to the people who are already Muslim. It is true that the expansion is not by armed forces, but by the forces of property and materials coming from abroad..." He eventually suggested that, "like other foreign aid, we are of the opinion that the aid for religion or religious institutions should come through the Government, that is, the Department of Religion." 
Having recommended that the Government should control the foreign aid, Lukman Harun also proposed that religious propagation should be restricted to those outside the recognized religions. For this matter, he referred to the Dutch colonial policy that was, for him, better than that of the independent Indonesia. He said, "Although the Dutch Government was really a Christian Government wanting to Christianize Indonesia, but more or less it still 'protected' the Indonesian Islamic community from missionary activities. Some regions were closed for missionary activities... But now, in our independent state, we can see all regions are open to, and become the target of, missionary activities." For Lukman Harun, this free condition was not in line with the religious tolerance stipulated by Pancasila. For him, "Our duty as believers, in accordance with the first principle of Pancasila, is to invite the whole nation of Indonesia to believe in One Almighty God, which means to have a religion. Let us compete to make the people who do not have religion yet become religious adherents..."

In short, Lukman Harun argued that the Christians used unfair methods to convert Muslims, particularly thanks to the foreign aid, and therefore, to protect Muslims from the Christian missions, the Government should (1) control the foreign aid; (2) restrict missionary activities only to the people who had no religion. These ideas, as we shall see, would be the enduring Muslim-Christian controversy in Indonesia's New Order.

Then, similar to Simorangkir's Question, Lukman Harun posed six questions to the Government. The questions were:

1. How much and what kind of foreign aid has been received by religious groups or religious institutions of Islam, Protestantism, Catholicism and Bali Hinduism in Indonesia during the last 5 years? ${ }^{65}$

2. From which countries does the aid come and what is the procedure for its entering Indonesia, and what is it used for?

3. In order that the development of religion in Indonesia should go smoothly, does not the Government agree with us to control and observe all kinds of aid coming from abroad?

4. How many foreign religious missionaries/preachers are working in Indonesia, what is the procedure for them to enter Indonesia, where do they come from [their citizenship], where are the places of their current work and what are their religions, and does not the Government agree with us to have an investigation and control of the religious missionaries/preachers coming from abroad? 
5. How many places of worship for Islam, Protestantism, Catholicism and Bali Hinduism (mosques, churches and temples) have been built during the last 5 years?

6. To maintain public order and to create a pure religious tolerance based on Pancasila moral, does not the Government agree with us that to establish new places of worship one should also take into consideration the regional and socio-psychological factors? ${ }^{66}$

\section{The Government's Responses}

After having some contacts with other Muslims and with the approval of the Acting President, Soeharto, the Minister of Religion, Saifuddin Zuhri was eventually ready to answer Simorangkir's Question on 21 July 1967. Before answering the Question, Saifuddin Zuhri explained the chronology of the Meulaboh case. He explained that the residents of West Aceh district, especially in the Meulaboh city, were almost all Muslims. Among the residents, there were a few Christians, who bought the land to establish a Methodist church with the permission of the local Government. According to Saifuddin Zuhri, initially, the residents of West Aceh did not really understand the purpose of buying the land. He said, "When it was known that the purpose was to establish a church, then there were sharp and strong reactions of the people, saying that the church should not be built at the centre of the Muslim community because it hurt their feelings very much. ${ }^{67}$ He also explained that on 24 April 1967 the mayor of the district organized a meeting between the Muslim and local church leaders to find a solution. The next day, the same meeting was reconvened and was also attended by a Catholic priest from Banda Aceh and the leaders of the Methodist Church from Medan. ${ }^{68}$ There was a deadlock in both meetings because the Muslims and Christians could not come to an agreement. Finally, the problem was brought to the regional Government of Aceh and the Government decided to (1) postpone the opening of the Church, (2) to find a way of providing a new place for the Church, (3) to do this, the Government would provide full assistance.

Saifuddin Zuhri then moved on to talk about religious freedom and tolerance and how it should be developed in Indonesia. He said that the state ideology, Pancasila, prescribes religious tolerance. However, Saifuddin Zuhri argued, any effort to develop religious life "should consider the real and specific conditions that may be found in a region." He also reminded the audience that Muslim communities were suffering from economic difficulties and therefore "the degree of their ability to afford religious development 
projects" was very low. This seems to imply that due to their poverty, Muslims became sensitive to the newly built church of the Christians because they could not do a similar project for their own religious life. He eventually concluded that religious freedom should be controlled by sensitively:

Any religious group in our state is entitled to freedom to build places of worship and to follow the teachings of its respective religions, but it should also be considered that to use this freedom one should not offend or hurt the feeling of the other groups. Because, to use the right of freedom that exceeds its boundaries in the sense that one prefers one's own interests without considering the feelings of others is a wrong way of using freedom. ${ }^{69}$

It seems that Saifuddin Zuhri realized that the psychological argument could be interpreted the other way around, that is, the Muslims were not tolerant to the Christians because the former could not control their own feelings and emotions. In this regard, Saifuddin Zuhri argued that being a majority, Indonesian Muslims had been quite tolerant toward the religious minorities. He said, "there are many examples in other countries where religious minorities do not have easiness any more than in Indonesia." This statement seems to imply that it was the Christian minority who did not appreciate the Muslim tolerance.

Thus, Saifuddin Zuhri's answer to Simorangkir's Parliamentary Question was obviously a support to the position taken by the Muslims in Aceh. This was quite different from his answer to Lukman Harun's Question delivered on 29 July $1967 .^{70}$ In his speech Saifuddin said that in principle the Government had no objection to foreign aid for religious institutions as far as it was not binding. He explained further that due to the economic crisis, the Government could not financially support religious developments in the country. The foreign aid, he said, might fill this gap. The Christians seem to be happy with this part of Saifuddin's position and their newspapers put the heading: "no objection to foreign aid to religious institutions."71 Nevertheless, within the frame of the Muslim argument, Saifuddin also reminded the audience that to receive the foreign aid, one should take into account psychological dimensions (i.e., the Muslim feelings) in order to avoid the tensions between the haves and the have nots. In addition, Saifuddin agreed with Lukman Harun that the foreign aid should be known and controlled by the Government. He explained further that due to the lack of time and the absence of rules for dealing with the issue, he could not answer adequately the matters raised in the Parliamentary Question regarding how much for- 
eign aid had been received by religious institutions in the past five years. For the future, he said, the Government would like to investigate and control foreign aid.

About two weeks after Saifuddin's response, on 16 August 1967, Soeharto delivered a formal national speech in front of Parliament in which he partly reacted to the Muslim-Christian controversies. He seemed not to support any of the parties but tried to reconcile the arguments of both sides. He emphasized that the state guarantees religious freedom of every citizen but also warned that religious propagation should not hurt the feelings of other religious groups. Based on the Pancasila and the Constitution of 1945 , according to Soeharto, religious freedom is guaranteed in the country and therefore, there is no reason to make a distinction between a religious majority and minority. In the tone of the Christian arguments, he argued that, "religious freedom is one of the most fundamental of human rights because religious freedom comes from the dignity of the human being as God's creature. The right to religious freedom is not a gift of the state or a gift of a group."72 Soeharto, however, warned the audience that religious freedom should not lead to conflicts between religious groups because this would benefit the anti-religious Communists. Moreover, in the tone of the Muslim position, Soeharto suggested that "to uphold religious tolerance, it is very wise that an adherent of a religion should not do something forbidden in another religion in front of the adherent of the latter...It should also be avoided spreading religion in ways that may hurt the feelings of people who happened to have a different religion.."73 Soeharto did not show his clear position on the issues raised in both Simorangkir's and Lukman Harun's Parliamentary Questions either. He did not directly comment on the Meulaboh case nor did he show his position if he agreed with either Muslim or Christian demand. He only said that, "it is really impressive and makes us proud that in a lot of places in Indonesia a church is close to a mosque and even in many places both Islamic and Christian communities cooperated to build a mosque or a church." ${ }^{14}$ In line with the Christians, Soeharto stated that religion was universal and, therefore, the state would not prevent Indonesian believers from having relationships with co-religionists outside the country in so far they conformed to the Indonesian law. ${ }^{75}$ In other words, foreign aid for religious institutions was welcome.

Apart from his ambiguous position, according to the former speaker of the Catholic faction in Parliament, Soeharto was unhappy with the Parliamentary Questions and asked to stop them. ${ }^{76}$ Soeharto's unhappiness seems to be understood by the Christians. The Christian faction in Parliament sent 
a letter addressed to the Speaker of the Parliament and forwarded to the President, the Minister of Religion and the Minister of Social Welfare. ${ }^{77}$ The letter - dated 22 August 1967, and read in front of the plenary session of the Parliament on 25 August 1967 - explained that having heard the speech of the President, especially the part dealing with religious matters, the Christians believed that the Meulaboh case could be entirely solved through consultation by the authorities in Aceh, and therefore, the Parliamentary Question was over and should not be extended by further discussion. The letter also mentioned that the DGI distributed a message, dated 14 August 1967, encouraging all Christians to maintain religious freedom and harmony and to eradicate all inter-religious suspicions. ${ }^{78}$ By contrast, the Islamic parties still proceeded with their Parliamentary Question and felt unsatisfied with the Government answer. On 16 December 1967, Lukman Harun delivered another speech in which he repeated his view that the Christians utilized foreign aid for religious expansion (ekspansi keagamaan) or "to make the Muslim community apostates" (memurtadkan ummat Islam).$^{79}$ Nonetheless, for the sake of political stability, the Government pressured the Islamic groups to stop discussing the Question, and to the Muslims' disappointment, in his response to it on 10 September 1968, the Minister of Religion, Mohammad Dachlan, tried to neutralize the Muslim complaints against the Christians. ${ }^{80}$

\section{The Muslim Attack on Christian Facilities in Makassar}

Not long after the tensions caused by the two Parliamentary Questions, on 1 October 1967, Muslims in Makassar attacked Christian buildings in the city. On 4 October Kompas reported that the attack resulted in some serious damage to Christian buildings and furniture. ${ }^{81}$ According to Muslim reports, the attack was triggered by a case involving H.K. Mangunbahan, a Christian religious teacher at the Economic High School, Makassar, who said to his students that Muhammad was a stupid person because he was illiterate, and that Muhammad only married his nine wives and lived in adultery with other women. The issue continued from 24 September to 1 October 1967. By 1 October 1967, the DGI of Makassar confirmed that Mangunbahan made that statement but considered it as his personal opinion. In the evening of that day, people who prayed at the mosques in the city of Makassar went out to the streets and attacked churches and other buildings. ${ }^{82}$ Nevertheless, if we read the Muslim account carefully, as Boland observes, the main reason for the attack was the Muslim perception of the aggressiveness and demonstration of Christian activities amid the Muslim majority in 
Makassar: one of them was the coming General Assembly of the DGI to be held in the city from 29 October to 8 November $1967 .{ }^{83}$

The Catholic magazine, Peraba, published a detailed description of the attack. According to this account, the attack was not spontaneous but well planned and organized. Peraba reported that the HMI in Makassar had two radio stations through which the provocative Muslim preaching was aired during the three months before the attack. The local weekly tabloid called Progressip also often published provocative views against the Christians. On the day of 1 October, the Muslim high school student organization, PII, gathered in front of a Muhammadiyah health centre in Makassar where they made a declaration stating that they were ready to die as martyrs to defend Islam. Moreover, on the same day, through the HMI radio stations, the HMI leader, Jusuf Kalla (who later, in 2004, was to become Indonesia's vice-president), instructed all members of $\mathrm{HMI}$ and other Muslim organizations to come to nearby mosques at 8 p.m. After the evening prayer ('ishā'), the Muslims started attacking the Christian buildings, and the loud-speakers of the mosques shouting out "Allahu Akbar, defend your religion, be a martyr!" The Christian buildings attacked in the incidents were 9 Protestant churches, 4 Catholic churches, 1 nuns' dormitory, 1 Academy of Theology, 1 office of the Catholic student organization, PMKRI, and 2 Catholic schools. ${ }^{84}$

The Makassar attack soon developed into a national issue in Jakarta. M. Natsir, the Muslim reformist leader said that the attack was not good but for him the case was an excess representing the culmination of Muslim disappointment at the Christians' aggressive missionary activities - a statement that can be interpreted as an excuse for the attack. ${ }^{85}$ Likewise, the editorial of the Muslim traditionalist newspaper, Duta Masjarakat, having described the recent Meulaboh case and door-to-door visits of certain Christian missionaries to Muslim homes, it stated that the Makassar attack should be understood through its causes. ${ }^{86}$ In contrast, none of the Christians agreed with the Muslim reasoning. The PMKRI activists said that the action was against Pancasila and asked the Government to investigate the case and bring the suspects to the judgment of the law. ${ }^{87}$ Likewise, the Catholic journal, Basis, besides criticizing Mangunbahan, lamented that the Muslims took the law into their own hands, that the local newspapers fanned the situation, and that the regional Army Commander did nothing to prevent the attack. ${ }^{88}$ Kompas's editorial in its comment on the attack, however, suggested that religious leaders should not exploit religious sensitivity and encouraged them to have a continued dialogue. ${ }^{89}$ 
Like the Catholics, the Protestants made critical statements on the attack. The leader of the DGI, T.B. Simatupang, wrote that for some people the attack was influenced by the former Islamic rebellious group (implying the Darul Islam movement) or the Communists; others said that it was because some people considered South Sulawesi as an Islamic region and therefore their understanding contradicted that of the Christians who understood any region of the country from the Pancasila (read: nationalist) perspective rather than that of religion; and some even said that it was a part of a plan to narrow the movement space of the Christians in the whole country. ${ }^{90} \mathrm{We}$ can assume that these possible explanations were actually the views found among the Christians because all of them tried to represent the Muslims as the enemy of Pancasila and the Christians. In addition, none of Simatupang's possible explanations refers to the Muslim claim that the attack was triggered by a blasphemy against the prophet and the aggressiveness of the Christian missions. J.C.T. Simorangkir, however, in his speech to the national congress of Parkindo in Bandung, 18-22 October 1967, partially responded to the Muslim claim. "We must acknowledge anyway that certain ways have been adopted by certain Protestant and Catholic missionaries that can endanger the cooperation and even the duty to proclaim the Gospel itself," he said. However, the main problem for him was not the aggressiveness of certain missionaries but religious freedom. He also praised the DGI of South Sulawesi that already corrected H.K. Mangunbahan who had committed blasphemy against Muhammad, even though it was "due to a provocative question of his Muslim student." ${ }^{\prime 1}$

Despite the Muslim attack, the military apparently did not want to cancel the General Assembly of the DGI in Makassar. General Sjarif Thajeb, one of the Vice Speakers of the Parliament (DPRGR), said that the Assembly should be allowed to proceed in the city because all regions in the country should be shared by all Indonesian people regardless of their respective religious backgrounds. ${ }^{92}$ Therefore, under the protection of the security forces, the General Assembly was successfully held. In response to the attack, the delegates of the Assembly said that it was "an internal violation (perongrongan) of Pancasila and the Constitution of 1945."93 The DGI leaders also encouraged the delegates in the Assembly to be more enthusiastic in proclaiming the Gospel. ${ }^{94}$ In a published message, the Assembly of the DGI reasserted that the Indonesian Constitution guarantees religious freedom for all citizens, and the Christians could accept a law concerning inter-religious relations on condition that it was produced by state authorities and based on the Pancasila, the Constitution of 1945 and Human Rights. ${ }^{95}$ 


\section{The Deadlock of the Inter-religious Consultation}

The 'law concerning inter-religious relations' mentioned in DGI's message above apparently indicates that the DGI had already heard something about a certain Government plan to solve the Muslim-Christian conflict. Indeed, about two months after the Muslim attack in Makassar, on 30 November 1967, the Government organized an Inter-religious Consultation. T.B. Simatupang noted that, after the General Assembly in Makassar, the DGI and MAWI (The High Council of the Indonesian Bishops) received a letter from the Government containing a draft of an agreement that was expected to be signed by the leaders of the religious groups on the day of the Interreligious Consultation. Both DGI and MAWI then asked the Government for more information regarding the draft. ${ }^{96}$ Probably to clarify the intention behind the draft and to find common ground among the invited participants, especially between Muslim and Christian leaders, two days before the Consultation, the personal assistant to the President, General Alamsyah Ratu Perwiranegara, and the new Minister of Religion, Mohammad Dachlan ${ }^{97}$ organized a private meeting for direct consultation.

The crucial issue discussed in the meeting was the draft of a charter proposed by the Government. Both Muslim and Christian leaders could agree on one point of the draft, that is, to establish an Inter-religious Consultation Board. However, the Christians disagreed with another crucial point, namely that religious propagation should not be directed towards people who already had a religion. ${ }^{98}$ In Muslim circles this idea had been previously around. Niewenhuijze noted that, inspired by the policy of the Dutch colonial Government to close some areas, especially the Muslim majority areas, for Christian missionary activities, by the early 1950s, there was a fierce debate in the Parliament of the State of East Indonesia between Muslims and Hindus on the one hand, and the Christians on the other, on this issue. ${ }^{99}$ Moreover, as has been mentioned before, in his explanatory speech for the Parliamentary Question, Lukman Harun also promoted a similar view. Last but not least, this view was also in line, though not identical, with both Soekarno's Presidential Decree No. 11965 and the MPRS's Decree No. XXVII/ 1966 dictating that there were recognized religions in the country. On the other hand, the Christians disagreed with the restriction and proposed an alternative formulation in which it was stated that without reducing religious freedom, religious propagation should avoid ways that could engender inter-religious tension. ${ }^{100}$

Despite the disagreement of the Christians with the idea of restricting missionary activities, when the Consultation was held, the Government still 
voiced the earlier proposal. In his opening speech, Soeharto said that the Consultation was held because of the current symptoms of inter-religious conflict in some regions of the country that might endanger the unity of Indonesia. He also repeated what he said in Parliament that the state ideology Pancasila and the Constitution of 1945 guarantee religious freedom to every citizen but at the same time the freedom should not lead to instability. In addition, although Soeharto seems to show an accommodation of the Christian interest in foreign aid by repeating the argument of the universality of religion, he tended to argue for the restriction of the Christian mission. He said: ${ }^{101}$

The Government will not hinder any endeavor to propagate religion. It is a great duty for all religions to invite those who do not have religion, who are still in Indonesia, to be convinced followers of religion... But the Government must feel annoyed when the propagation of religion is merely aimed at multiplying the numbers of followers, especially when the ways of propagation could create the impression that they were directed to the people who already embraced another religion.

How did the Muslim and Christian speakers defend their respective positions in the Consultation? The Christian speakers, A.M. Tambunan (Protestant) and I.J. Kasimo (Catholic) developed a nationalist rhetoric. A.M. Tambunan talked about nationalism as a common historical experience and destiny encompassing religious and ethnic differences.

Our Consultation is a National Consultation because we are trying to overcome things that can endanger our unity and integrity as a nation. Our Consultation is a National Consultation because we are the participants of the Consultation looking at ourselves as the inheritors of our common history as a nation, among other things, our common struggle to defend our Pancasila state from internal and external danger, as it is witnessed by the graves of the heroes in all parts of our country. Our Consultation is a National Consultation because we are bound to the same goal by a shared 'destiny.' Our Consultation is a National Consultation because all of the problems we face will be included and solved within the framework of our Pancasila state. ${ }^{102}$

The same voice can be heard from I. J. Kasimo, the prominent Catholic politician when he said: 
The history of our nationhood shows that the independence struggle of the Indonesian nation did not pay attention to religious, ethnic and geographic differences; [the people] were united in making sacrifices in the struggle to realize the great ideal: the independence of the nation... It should be mentioned here that more or less 40 years ago, the Youth Oath was declared: one nation, one people, one language. This oath was declared by the Indonesian youth regardless of the differences mentioned before. ${ }^{103}$

Why did the Christians use a nationalist rhetoric? As a religious minority, the Christians felt that a nationalist ideology was the best option to protect their interests in the midst of the Muslim majority. In addition, the political context was also relevant to the nationalist rhetoric because, as we shall see in Chapter 3, the ideological battle between the secular nationalists and the Islamic oriented groups began again in this period. In this regard, the Christians, the ruling army and the secular Muslims were all opposed to Islamic ideology.

While the Christians employed a nationalist rhetoric, the Muslims preferred to resort to historical apologetic. For instance, Idham Chalid, a Muslim traditionalist leader and the Minister of Social Welfare said, "Actually if we study a bit deeper, we shall find that in this Indonesian soil it is not appropriate to have religiously motivated conflicts because the coming of religions to Indonesia was historically quite unique that is called in scientific term a 'peaceful penetration."'104 In this regard, although Idham did not specify what the religion that came peacefully was, in the Muslim discourse it often means Islam, not Christianity. This is because among the Muslims, Christianity is often associated with colonialism, regardless of the actual complex relations between the two. This historical apology can also be found in the speech of the former Minister of Religion and the leader of traditionalist Muslims, K.H. Masjkur. He argued that although in Indonesian history Muslims contributed a lot to the struggle for independence, now some people tried to neglect this contribution and accuse the Muslims of being nonnationalists and anti-Pancasila. ${ }^{105}$ Masjkur, however, did not clearly explain the identity of the people who ignored the Muslim contribution, but one may guess that he had the Christians in his mind.

In addition to the historical apologetic, the outspoken reformist Muslim intellectual and the first Minister of Religion, Muhammad Rasjidi, developed a cultural apologetic in relation to the West and the Christians. He said, because the western countries could colonize African and Asian countries before the Second World War, they were proud of their success and under- 
estimated anything from the non-western people. For Rasjidi, this attitude was nothing but "the arrogance of cultural superiority." Rasjidi then implicitly accused the Christians of having the same arrogance when he said: "We, as an old man, still can remember that if one could not speak Dutch, one would not be appreciated, and also the religion of the Dutch was considered better than the religion of ordinary people." ${ }^{106}$

According to Rasjidi, the "arrogance of cultural superiority" is also expressed in the ideas of modernism, tolerance and human rights. Rasjidi said, the Christians claimed that their duty was to modernize the world. This implies that other religions were not modern. For him, the truth was that modernization was not inherent in Christianity because there were many other Christian countries whose lives were very far from being modern such as in Ethiopia, Latin America and others. Like 'modernity', 'tolerance' is another western concept used by Christians. Having summarized the history of religious conflicts in Europe to the end when the concept of religious tolerance was introduced, Rasjidi concluded that, "tolerance is a Christian idea for a Christian society." 107 Rasjidi then argued further that: "The tolerance promoted by the Christians now means that the Islamic society should keep silent whey they see that the Muslims are Christianized everywhere in all kinds of ways, including material persuasion. We cannot accept this."108 Similarly, for Rasjidi, the origin of the idea of human rights was a reaction to the Church's monopoly of all rights but the Indonesian Christians used it to justify their attempts to convert Muslims. With reference to Wilfred Cantwell Smith, Rasjidi argued that the arrogance of the West was rooted in the Christian doctrine that the whole world was divided into two sides: the 'damned' and the 'saved'. The duty of the Christians was to save the damned by converting them to Christianity.

The Christian rhetoric on nationalism and the Muslim historical and cultural apologetics were certainly developed to support their respective positions on the main issue: the restriction of religious propagation. The Protestant spokesman, A.M. Tambunan, presented the issue with reference to a dialogue between himself and Natsir. Tambunan said: "Last time, in a small meeting I explained that as Christians, we are bound to a divine mandate that among other things, is formulated in what follows:'... and you will be witnesses for me in Jerusalem, in all Judea and Samaria and to the ends of the earth' (Act 1:8). In another place, it is mentioned as follows: 'Go into the whole world and preach the gospel to the whole human race' (Mark 16:15)." According to Tambunan, Natsir who was present in the meeting responded to him that in Islam there was also a similar teaching called da'wah. Tam- 
bunan went on to say: "Muhammad Natsir formulated our problem on this issue as follows: 'Can we achieve a modus vivendi to live in our multi-religious state without betraying our respective beliefs?' I think, the problem formulated by Natsir, cannot be entirely solved in this Consultation." 109

Having heard Tambunan's speech, Natsir who was not scheduled to be one of the presenters in the Consultation, took the opportunity to respond. Natsir said that to undertake da'wah, Muslims have their ethical codes as a guide. Among the codes is that religious beliefs should not (and cannot) be enforced and that the da'wah should be done through wisdom, good advice and sharing opinions in a good way. In addition, according to Natsir, Muslims do not consider the Christians as heathens, but as the People of the Book (ahl al-kitäb). With regard to the da'wah, Muslims just invited them to the Islamic conception of monotheism and if they do not respond positively, the Muslims are advised to declare that they are Muslims, Ishhadū biannā muslimūn (QS 3:64). For Natsir, this means that Muslims can coexist peacefully with the Christians even though the latter do not accept Islam. The only thing the Muslims want from the Christians is to respect their Islamic identity: "We are the Muslims who already have sibghah, a distinctive identity. Therefore, do not disturb our identity! Do not make us the target of Christianisation (pengkristenan) activities! That is the only thing that we want from our Christian co-citizens," Natsir said. ${ }^{110}$

Unlike Tambunan and Natsir who referred to the teachings of their respective religions, the leader of the Catholic party, I.J. Kasimo, explained that to solve the problems of inter-religious disputes, one just has to go back to the law of the state. "The solution based on law is the strongest way to maintain the stability and harmony in society", argued Kasimo. ${ }^{111} \mathrm{He}$ explained further that what he meant by law was the existing law within the frame of the Constitution of 1945, Pancasila, human rights and Soeharto's presidential speech on 16 August 1967. By referring to human rights, as the Protestants did in the Conference in Salatiga and the General Assembly of DGI in Makassar, it is clear that Kasimo could not accept the Muslim proposal to restrict missionary activities. In this respect, Kasimo proposed that the Inter-religious Consultation should call all religious groups in the country to be tolerant towards each other without reducing everybody's right of freedom to choose a religion based on one's conviction and to carry out the obligation to spread one's religion "through ways that do not contradict the principles of just and civilized humanitarianism and in line with the noble ethics of conscience and the order of the applied law."112 
In the Consultation, the Christians also tried to convince the Muslim leaders that there was nothing to worry about from Christian missions. The Christian explanation, however, did not convince the Muslims. This means that there was no mutual trust between the leaders of the two religious groups anymore. Tambunan said:

There are two things that I want to say. First is regarding the news that I just heard a few days ago, as if there were a plan to Christianize Indonesia within several years. ${ }^{113}$ Not only to my knowledge that there is no such a plan, but also in terms of pure Christian thought, I think that plan cannot be made. According to the belief of the Christians, they are the witnesses of the truth and salvation in God, Jesus Christ, and only God by His Spirit can lead one to faith. That is why I say that within this frame of thought we cannot make a plan to Christianize a region in a certain number of years...

The second thing that I want to say is what has been heard sometimes, that is, "la conquête du monde musulman", means conquering the Muslim world. To my knowledge, which is not that deep, this term originally came from some missionaries some decades ago. This term and the conquering mode of thought, I am sure, is not found in the thought of Christian witnesses anywhere. What I can assert is that this term and that mode of thought cannot be found in the Indonesian Christian thought concerning the divine call and order to witness. ${ }^{114}$

In response to Tambunan's denial, Rasjidi said:

Dr. Tambunan just said that recently there has been an expression, "la conquête du monde musulman", conquering the Muslim world. He said that it is not true; the case was some decades ago and there is no intention to conquer the Muslim world, that is, to Christianize it. Although Dr. Tambunan said there is no such thing, I say there is. I have just finished reading the book by Dr. Hendrik Kraemer entitled The Christian Message in a Non-Christian World. In this book we can read clearly the Christian plans and efforts to Christianize the World, especially Indonesia. ${ }^{115}$

It should be noted that the expression "la conquête du monde musulman" was not from Kraemer. It was a title of a special issue of La Revue du Monde Musulman, published in 1913 and written by A. Le Chatelier, the editor of the journal. ${ }^{116}$ Why did Rasjidi refer to Kraemer not to Chatelier? In another work, Rasjidi actually referred to A. Le Chatelier, and it seems that, 
for Rasjidi, Kraemer's zeal to convert Muslims and his neo-orthodox theology was parallel with that of Samuel Zwemer, the most important of the missionaries described in Chatelier's work. ${ }^{117}$ In addition, Kraemer's works had been known to the Indonesian Muslims, and his Christian Message in a Non-Christian World was mentioned even in the year of its publication (1938) in an article of Natsir. ${ }^{118}$

The Consultation finally could not solve the whole dispute between the two parties. Thus, like what happened in the open talk two days earlier, both parties agreed to establish an Inter-religious Consultation Body, but the Christians did not accept an article of the draft of the charter concerning the restriction of religious propagation only for the people who did not have religion yet, while the Muslims could not accept the Christian view that religious freedom should not be reduced. On this point, the Consultation came to deadlock until midnight, and Soeharto did not come to close it officially. ${ }^{119} \mathrm{~A}$ journalist who was present at the Consultation reported that T.B. Simatupang "struggled like a lion to defend his Christian faith and conviction; his clothes became wet from the excessive sweat of his body; Ben Mang Reng Say, a Catholic, just nodded to confirm what Simatupang said while Natsir and Masykur did not speak much because they agreed with the Government's proposal."120

After the Consultation, the Muslims in general blamed the Christians as those who caused the failure of the Consultation. On the other hand, on 5 December 1967, A.M. Tambunan met the Acting President Soeharto to explain the position of the Christians in the Consultation, and on the same day Tambunan said to the press that for him the Consultation had not entirely failed, although its result was not satisfactory. ${ }^{121}$ In response to the Christian statement that the Consultation had not failed, HAMKA in his editorial for Pandji Masjarakat sarcastically wrote that as one of the participants of the Consultation, he eventually also concluded that the Consultation was actually successful and positive for both Muslims and Christians. It was positive for the Christians because in the Consultation the Christians openly declared that it was their sacred mission to proselytize Muslims. He argued further that, although in the Consultation Tambunan denied that there was a plan to Christianize Indonesia within 50 years, the denial was only of the number of years, not of the intention to convert the whole Indonesia! It was also positive for the Muslims because now they were strongly convinced that the Christians would not be happy unless Muslims followed their religion, as the Qur'an said (QS 2:120). It was positive for the Muslims because they now became much more aware of the Christian threat of "a new style of crusade" funded by foreign countries! ${ }^{122}$ 
On 7 December 1967, the press reported the speech of the Minister of Religion, Mohammad Dachlan, to the training of the PII in Palembang. ${ }^{123}$ In the speech, Dachlan said that the year 1967 was "characterized by unpleasant events caused by the activities of a certain religious group trying systematically to change Islam, the religion of the majority, into their own religion." Dachlan then explained that the missionary activities such as distributing rice to the poor, opening health centres and schools, door-to-door visits to Muslim homes and misusing Qur'anic verses to deceive and convert ignorant Muslims, all of these eventually led to the Parliamentary Questions and tensions among the supporters of the New Order.

Only two days later, both the Christian newspapers, Kompas and Sinar Harapan, published a statement of the DGI and MAWI, in which they strongly denied Dachlan's accusation. After the release of the Christian statement, the Islamic groups, both the traditionalists and reformists, soon made a joint statement supporting Dachlan's speech. ${ }^{124}$ However, perhaps due to the 'warning' of the military, on 13 December 1967, the Director of Information of the Department of Religion explained that the Minister's statement in Palembang should be understood as an attempt to maintain national unity and integrity rather than to create tensions and conflicts. ${ }^{125}$

\section{The Controversy on Freedom to Change Religion}

Our discussion so far demonstrates that the Christians tried to defend the freedom to build churches, to hold an assembly, and to preach Christianity to everybody. Despite Muslim opposition, the first and the second freedoms are already covered by section 2, article 29 of the 1945 Constitution: "The state guarantees the freedom of each citizen to embrace his or her religion and to observe the rituals according to his or her religion and belief." The freedom to preach religion to the people of another religion, however, is not explicitly mentioned in this article. Likewise, this article does not include explicitly the freedom to change religion as it was formulated in the article 18 of the Universal Declaration of Human Rights (UDHR). ${ }^{126}$ Therefore, for Christians, the best formulation of religious freedom was only found in the Constitution of 1949 of the Federal Republic of Indonesia because it was totally in line with the article 18 of the UDHR, while the formulations in both the Provisional Constitution of 1950 and the Constitution of 1945 (that had been reapplied since 1959) were still unsatisfactory, particularly because they did not explicitly mention the freedom to change religion. ${ }^{127}$ 
As the hope for a more democratic system reemerged after the fall of Soekarno, many Indonesian intellectuals were preoccupied with the issue of human rights and the Christians were actively involved. From 14-18 June 1967, a national symposium on human rights was organized by Lembaga Pembela Hak-Hak Asasi Manusia (Institute for the Protection of Human Rights) and took place in the BAPPENAS building in Jakarta. ${ }^{128} \mathrm{~A}$ few months later, on 3-5 November 1967, there was another seminar on human rights with specific reference to "the rule of law and arrest practices in Indonesia" and located in the Parahyangan Catholic University, Bandung. This seminar was also organized by the Lembaga Pembela Hak-Hak Asasi Manusia in cooperation with Parahyangan Catholic University, Maranatha Christian University and Pajajaran State University. The Bandung seminar's topic was obviously a response to the unlawful arrests of Communist suspects that were often carried out by the police or the army. ${ }^{129}$ Both symposium and seminar were also intended as a preliminary discussion before a charter on Human Rights was expected to be ratified by the MPRS in March 1968.

In its account of a session of the symposium on the issue of religious freedom, Kompas reported that Muslim and Christian scholars had different views of religious freedom without mentioning what the difference was. ${ }^{130}$ The respective papers by T.B. Simatupang and Muhammad Rasjidi presented to the seminar can probably give us certain clues about this difference. In his paper, Simatupang implied that the UDHR had to be totally accepted and therefore, religious leaders and the Government should cooperate to defend religious freedom. ${ }^{131}$ On the other hand, Rasjidi mentioned his usual view that the Christians deliberately used the idea of religious freedom to justify their efforts to convert Muslims. For Rasjidi, religious freedom was simply freedom to practice one's religion in one's religious community. ${ }^{132}$

As has been mentioned, the seminar on human rights was intended to be a preparation for a Charter on Human Rights, expected to be ratified by the MPRS in 1968. Nonetheless, the MPRS eventually failed to ratify the charter particularly because of the unresolved controversy between Islamic and Christian parties on the issue of religious freedom. ${ }^{133}$ Unlike the Christians, the Muslims could not accept the concept of religious freedom, especially freedom to change religion mentioned in the article 18 of the UDHR. Besides the Muslim fear of Christian missions, the Muslim objection to this article was influenced by the conservative idea that in Islam apostasy is not only forbidden but also deserves capital punishment. In this respect, the Islamic principle that there is no enforcement of religion (lā ikrāha fi al-dīn) seems to be applied only to those who have not become Muslims yet. ${ }^{134}$ 


\section{Muslim-Christian Rivalry in Religious Propagation}

For the Muslims, the frequent insistence of the Christians that religious freedom means "freedom of conversion, freedom to adhere to another religion than one's prior religion and freedom to preach one's religion to persons of other convictions"135 was a clear invitation to a free competition in religious proselytism. Accordingly, the Muslim programme after the disagreements with the Christians was to reinforce the $d a^{\prime} w a h$ movement. Several conferences on Islamic da'wah were organized only a few months after the MPRS's session of 1968. For reformist Muslims, however, the concentration on da'wah had been an option several months before, namely when they realized that the hope to rehabilitate their party, Masyumi, had gone with the wind. The reformist Muslims were initially optimistic of a return to the political stage because they previously proved to be a stubborn enemy of the PKI and Soekarno. Their expectation, however, did not come true because, by the end of 1966, the army prevented them from rehabilitating the Masyumi, and although the army later endorsed the establishment of a new party called Partai Muslimin Indonesia (PMI/Parmusi), the former prominent leaders of the Masyumi were not allowed to lead that party. Thus, without the leaders, the Parmusi could not be the surrogate of the Masyumi. ${ }^{136}$ Some former Masyumi leaders then decided to leave the arena of formal politics and concentrated on da'wah activities. Muhammad Natsir, the most prominent former leader of Masyumi, on 9 May 1967, established the Dewan Dakwah Islamiyah Indonesia, DDII (The Indonesian Council of Islamic Propagation). When Natsir was asked about his motives behind DDII, he said, "we are no longer conducting dakwah through politics, but engaging in political activities through dakwah."137 The Muslim controversies with the Christians from June 1967 to March 1968 seem to justify the reformist option further. In addition, for the traditionalist Muslims, the da'wah issue was also important because although the position of the Nahdlatul Ulama (NU) as a political party still survived, it was NU members that had more direct contacts with the abangan at the grassroots in Java.

One of the many seminars on da'wah was that organized by the Ulama Council of West Java in Tasikmalaya from 5 to 7 May, 1968. Both reformist and traditionalist figures attended the seminar. Idham Chalid, the leader of the traditionalists and Muhammad Natsir, the leader of the reformists, presented their respective papers at the seminar. Both leaders expressed their concern with the weaknesses of the Islamic da'wa activities and suggested to reinforce them. As a former leader of Masyumi party who just turned to da'wah activities, Natsir explained that there had been discussions among 
Muslims on da'wah programmes because it had been ignored for quite a long time. The reason was, according to Natsir, the Muslims had paid most of their attention to nurturing the political institution called the State. In this regard, Natsir criticized Islamic organizations that transformed themselves into political ones or at least divided their attention and energies between the social/da'wah and the political field. This strategy, according to Natsir, was wrong because "we forget that no matter how beautiful the political building that we want to build is, finally it must have a foundation on which it stands." ${ }^{138}$ Natsir then reminded the audience that it was not impossible that Islam would be annihilated in Indonesia as happened in Spain. For him, the Christian position in the Inter-religious Consultation clearly indicated that, "the Catholic and Protestant leaders strongly desire to Christianize the Islamic community in Indonesia."139

In line with Natsir, Idham Chalid also referred to the Islamic history in Spain and warned the audience that it should not happen in Indonesia. Idham, however, did not mention explicitly the context of the current Muslim Christian controversy. He argued that Muslims were to blame, not the other, if Islam could not survive in Indonesia. He said:

With regard to the problem of da'wah, we are often faced with the truth of the idea that well-organized falsehood sometimes can vanquish unorganized truth...There is no guarantee that Islam will survive in Indonesia...The one that can guarantee its survival is only the Islamic community itself... We often feel jealous of the development of 'the other' in doing their works, but we do not have an introspection regarding what we must do. ${ }^{140}$

For the da'wah programmes, the Muslims, particularly the reformist Muslims of DDII, probably developed contacts with the Muslim Middle East, especially Saudi Arabia and Kuwait. This is clearly shown by a book in Arabic explaining the flood of foreign aid for Christian missions in Indonesia, the Meulaboh and Makassar affairs, and the allegedly Christian plan to Christianize Java in 20 years and the whole of Indonesia in 50 years. The book also includes the Arabic translations of Soeharto's, Rasjidi's and Natsir's speeches in the Inter-religious Consultation and Lukman Harun's Parliamentary Question speech. The book is complemented by a survey of the foreign Christian institutions working in Indonesia. The book was probably written by a reformist Indonesian Muslim and circulated in the Middle East to gain financial support for da'wah programmes. ${ }^{141}$ 
On the other hand, despite Muslim negative attitudes, the Christians continued their missionary activities and the zeal to convert more and more people was quite strong or even became stronger in both Catholic and Protestant circles. In an article published in 1969, Simatupang explains that, as a response to the varied resistance to the Christian mission, the participants of the General Assembly of DGI in Makassar reasserted that the task of proclaiming the Gospel is essential to the Christian faith. For Simatupang, "to preach the Gospel to all creatures in order that they may believe will remain one of the most important aspects of the Christian mission to the end of the earth and to the close of the age." ${ }^{142}$ In this regard, Islam is seen as a preparation for, rather than an obstacle to the Christian missions because "Islam being a post-Christian religion in one way or another contains the impact of the Gospel. So with the coming of Islam to Indonesia, in an indirect way, the influence of Christianity reached the country prior to the coming of Christianity itself."143 In line with Simatupang, Cardinal Darmojuwono said, "to be a Catholic is the same as to be a missionary." He also explained further that, in the image of the Church as the mystical body of Christ, every Catholic as a part of the body, be they a priest or lay, young or old, villagers or city dwellers, all of them should take their parts in developing the Catholic Church in the country. ${ }^{144}$

The enthusiasm for evangelization among the Christians was also accompanied by the awareness that the most immediate problem to solve was how to serve the huge number of new converts. Simatupang said, if the number of the Christians were double or triple, then the number of the ministers should also be doubled or tripled and the role of the laity should be maximized and Christian service to society through schools, universities, hospitals and orphanages, should be increased. In addition, for him the Christian mission should be involved in the struggle for justice amid the process of modernization in the country. To do all of these, Indonesian Christians should cooperate with other Christians all over the world. ${ }^{145}$ By the same token, the problem of "the harvest is plentiful, but the labourers are few" was also discussed among Catholics. An article in a Catholic magazine suggested that to overcome the lack of the labourers, the Church should provide more roles for the lay-people. The article also argued that one must learn from the history of the Church that any successful effort needed courageous action and control of one's self to resist the temptation of richness because richness often led to weaknesses! ${ }^{146}$ Due to the shortage of priests, there was even a discussion among the Catholics to ask the Holy See for permission to ordain married men to the priesthood. Moreover, because the 
majority of bishops in the country in this period were not Indonesian, some argued for an Indonesianization of the Church leadership. ${ }^{147}$

As has been stated, the new converts were mostly those Javanese abangan who became Communist suspects or at least very vulnerable to being accused of being Communists, including their families. It is not surprising, therefore, if the Christians showed more sympathetic attitudes towards these people. ${ }^{148}$ This attitude seems to have appeared among the Protestants. In their Conference in Salatiga 1967, they clearly said that although Communism is opposed to the Christian faith, one should investigate the reasons why people became attracted to it and should treat the Communist members humanely based on love and patience. ${ }^{149}$ As has been noted, in the Bandung seminar, November 1967, the lay Catholics in the Parahyangan University participated in the discussion on the abuses of human rights in the unlawful arrest of Communist suspects. However, only after almost two years, we find that, on a statement, released on 31 March 1969, Cardinal Darmojuwono lamented the fact that there were some people who were tortured or arrested without evidence of being guilty. He said this could not be accepted because "those who are guilty should be treated justly and in accordance with human rights." ${ }^{150}$ He also suggested that the families of the political prisoners should be helped mentally and materially and not be isolated from social life.

The Catholic effort to help the political prisoners and their families was substantially implemented. A Catholic priest who worked for this mental and material help effort told me that based on his position as a supervisor of Pancasila mental guidance (pembina Pancasila) and through a network within the army, he could arrange for some other Catholic priests to come to the Communist prisoners in Buru island (the penal centre in the Moluccas), under one condition: they were not allowed to talk about the prisoners to the public. Under the protection of the army, he also could 'smuggle' food, especially rice and milk, to the islands. In order to ensure that the food would reach the prisoners, he also arranged certain portions of the food to be given to the policemen and other staff of the prison. To help the families of the prisoners to survive, he arranged a course for their wives to learn the skills of operating sewing machines. He also asked some university students in Yogyakarta to be the 'parents' for the children of the prisoners. For this, he rented some houses that could be occupied by a number of these children. In addition, he provided clinics for medical services in the prisons of the Communists by organizing students of the medical faculty and nurses of some hospitals to do this job. To provide the medicine, he tried to find 
outside resources. He acknowledged that for this material help, he received foreign aid from Europe and the United States. Nevertheless, he denied that this assistance was intended to convert people to Catholicism. He claimed that some of his 'adopted children' of Communist parents had even recently performed the pilgrimage to Mecca. ${ }^{151}$ Similarly, the Protestant Churches also helped the prisoners on Buru. Under the coordination of the DGI, they provided spiritual and socio-economic support to the prisoners and their families. Certain skill-training was given to the prisoners in order that once they were released they could find jobs and survive. Many of these people, unsurprisingly, converted to Protestantism. ${ }^{152}$

\section{Conclusion}

The emergence of Soeharto's New Order was mainly designated by the political collapse of the Communists and the increasing significance of religion in national politics. The identification of Communism with Atheism and anti-religion justified the importance of religion in national politics that in turn led to the necessity of formal affiliation with one of the recognized religions. One of the results of this situation was that both Islam and Christianity shared a high number of new converts. While in 1965-1966 the Muslim and Christian leaders cooperated with the army in the fight against the Communists, the political significance of religion in national politics eventually led them to conflict and rivalry. Certainly, the Muslim political frustration towards the ruling army and the Christian alliance with the latter helped increase the conflict as well.

Fear of Christian missions exacerbated by political frustration led the Muslim leaders to defensive and sharp statements against the Christians. The Muslims said that Christian mission was'religious expansionism', 'foreign intervention' and 'new style of crusade'; all of them referred to the so-called 'Kristenisasi' (Christianisation). ${ }^{153}$ The Muslim leaders, therefore, demanded that the Government control foreign aid and restrict religious missions only to people who had no religion. In response to the Muslim demand, the Christians argued for religious freedom, including freedom to build new places of worships, to hold religious assemblies, to preach religion to the followers of another religion, and to change religion.

The position of the state in these conflicts was in general ambiguous. The state approved the Muslim opposition to the newly built church in Meulaboh but it protected the Christian General Assembly in Makassar. The state welcomed foreign aid for Christian institutions but it also tried to 
support the Muslim demand not to make Muslims the targets of Christian missions. In Chapter 2, we will discuss the other cases in which the Government demonstrated the same ambiguity. The state's ambiguity was apparently because its interest was neither in religious freedom nor in containing Christian missions but in socio-political stability. It was for this reason that the Government pressured both Christian and Muslim leaders to stop discussing their respective Parliamentary Questions. Likewise, being the first inter-religious dialogue initiated by the New Order, the Inter-religious Consultation was not primarily intended to build mutual understanding but simply to end the conflict. This issue is to be discussed further in Chapter 6.

It is also important to note that the battle between the Muslim discourse on Christianisation and the Christian defense of religious freedom was also related to the ideological battle between the proponents of Islamic and secular nationalist ideology. Being the supporters of the latter, the Christians usually developed a nationalist rhetoric while the Muslim leaders in return promoted historical and cultural apologetics (that the Muslims were in fact true nationalists, and that religious freedom was a Western and Christian concept). The Muslim-Christian ideological debate, including the debates on the basis of the state, the position of Islamic law in national legal system and the position of religion in national education will be discussed in Chapters 3 to 5 respectively. 



\section{Against Christianisation}

Like a snowball, the discourse on Christianisation versus religious freedom discussed in the previous chapter continued to build up in the following decades, and the state became more closely involved. In 1967 Muslims in Meulaboh argued that they could not tolerate a newly built Methodist church because the majority of people living there were Muslims; then in 1969, the Government issued a decree in which this religious regionalism was accommodated. Lukman Harun's Parliamentary Questions in 1967 demanded that the Government control foreign aid for religious institutions; and in the same year, during the Inter-religious Consultation, the Muslims argued for the restriction of religious propagation to those outside the recognised religions. More than a decade later, in 1978, these two Muslim positions were translated into Government decrees. Finally, in 1967 the Muslims in Makassar opposed the General Assembly of the DGl; then in the early 1970s, the Islamic groups opposed the General Assembly of the World Council of Churches (WCC) that was to be held in Jakarta in 1975. In their reactions to these cases, as in 1967, the Christians consistently argued for religious freedom. Besides these continuing problems, a rather different issue emerged in 1981: the Indonesian Council of Ulama (MUI) produced a fatwa prohibiting Muslims from attending common Christmas celebrations. This fatwa eventually resulted in tensions between the Government, the MUI and the Christians. In this chapter, I shall discuss these cases in some detail.

\section{The Restriction on Establishing New Places of Worship}

In September 1968, the Catholic magazine, Peraba, reported that a Protestant church in Asahan, North Sumatra, and a storage room of a Catholic school in Samarinda, East Kalimantan, were burned, probably by Muslims. With regard to the case in Samarinda, it was reported that the Muslims around the school made a statement, saying that any new building (place of worship, school, clinic, dormitory) sponsored by a certain religion should not be established, unless it was endorsed by the society in the area. ${ }^{1}$ The Samarinda case apparently did not attract much attention from the Government and politicians in Jakarta.

Some months later, however, on 28 April 1969, a similar case happened in Slipi, Jakarta. Muslims attacked and burned a newly built church 
of GPIB (Gereja Protestan Indonesia Barat). When the Muslim leader Muhammad Natsir was questioned about the incident, he said that it should be understood by looking at the causes. For him, the cause was nothing but the Christianisation programmes directed at the Muslim community, one of them was to build churches in Muslim majority areas. He explained further that in Slipi, there were already five churches for 350 Christians found among 35,650 Muslims living in that area. This was why, he said, the establishment of the GPIB church did not receive permission from the Governor of Jakarta. The Muslims, therefore, protested, but there was apparently no measure taken by the authorities. The Muslim feeling of powerlessness, he said, eventually led to the physical attack. Natsir acknowledged that the attack was against the law, but for him this should not have happened if the Christians had not broken the law of the Government. ${ }^{2}$ In contrast, Peraba quoted the Protestant newspaper, Sinar Harapan, reporting that the attack was actually planned in a meeting of 100 people one day before. Thus, besides criticising the late responses of the security forces to the incident, Peraba accused the attack of being similar to that of the Communist tactics of unilateral action. Last but not least, the Christians demanded that those who were responsible should be judged by the law. ${ }^{3}$ Indeed, the Government reacted to the case. It was reported that after the incident, the police arrested two activists of Anshor, the traditionalist Muslim youth organisation, as suspects, and a few months later, the Government dismissed two army officers, one was a Muslim and another a Christian, because of their connections with the Slipi incident. $^{4}$

After these similar incidents since the Meulaboh affair in 1967, the Government finally decided to regulate and control two important religious activities that had become the polemical issues between the Muslims and the Christians: religious propagation, and the establishment of new places of worship. The Minister of Home Affairs, Amir Machmud, and the Minister of Religion, Mohammad Dachlan, issued a joint decree, dated 13 September 1969 , dealing with these two issues. The decree says that the Government will not hinder any effort to spread religion as long as it does not contradict the existing law and public order. The decree authorizes the regional Government to control both the manner and content of religious propagation. It is also explained in the decree that religious propagation (1) should not lead to inter-religious conflict; (2) should not be carried out through intimidation, deception, force or threat; (3) should not break the law, nor endanger security and public order. The decree also authorizes the regional Government to control the establishment of new places of worship, namely 
that people will not be allowed to build a new place of worship unless they get permission from the Governor or the subordinate authorized officials. To give permission, he or she should consider three things: (1) the view of the head of the Department of Religion in the region; (2) the city plan; (3) the situation and condition of the region. In addition, if it is needed (apabila perlu) the authorized official can ask the opinions of religious leaders and organisations of the region. Finally, if there is an inter-religious dispute because of religious propagation or the establishment of a place of worship, the local Government should act as a just and neutral mediator. In case of suspected crime in the dispute, the settlement of the case should be brought to the legal authorities. ${ }^{5}$

The decree can be seen as a combination and modification of the Christian view of religious propagation, and the Muslim position on the issue of establishing new places of worship. In line with the Christian view, the decree does not restrict religious propagation only to those outside the recognised religions, but also, in accordance with the Muslim demand, the decree stipulates that to give permission for establishing new places of worship, the authorised state official must take into consideration the 'situation and condition' of the region. Moreover, the official is recommended to ask the opinions of religious leaders and organisations of the region. In practice, this recommendation has become a necessity, and therefore, it has been difficult to erect a place of worship in an area where the majority of people do not belong to that religion. In general, however, the decree reflects the logic of 'law and order' of the New Order's Government. The Protestant magazine, Ragi Buana, published a full text of the decree and explained the Government's logic: "In order to maintain the unity and integrity of Indonesia and to avoid conflicts that could hinder the acceleration of modernization, the Government took an important step to overcome this problem through a joint decree of the Minister of Home Affairs and the Minister of Religion that is expected to be a guide for the policies on religious matters in Indonesia." 6

Nonetheless, the publication of the decree in Ragi Buana did not result in the Christians being happy with it. About one month later, the DGI and MAWI issued a joint memorandum criticizing the decree. Again, the main argument in the memorandum was for religious freedom.

Having examined the stipulations and articles of the joint decree and heard the voices from the regions telling of confusion and anxieties about the possible effects in enacting these regulations, we are of the opinion that the joint 
decree of the Minister of Religion and the Minister of Home Affairs could open the possibility that the freedom of every citizen to follow his or her religion, to perform the rituals based on his or her religion and belief, and to develop religion in accordance with the teachings of one's religion will not be guaranteed: in other words, it opens the possibility of prohibiting or refusing permission for something that is related to Human Rights. ${ }^{7}$

In addition, the memorandum stated that the decree was not clear regarding the authority of the regional Government whether it refers to the province, district or sub-district authority and whether the regional Government had a total authority on the issue or it still depends on the central Government. Last but not least, the memorandum argued that because the decree touches the fundamental issue of Human Rights, according to the Indonesian legal system the ministers did not have the authority to make such a decree. Both the DGI and MAWI finally asked the Government to review the decree. ${ }^{8}$

Actually, the Christians' main objection to the decree was to the regulations on the establishment of new places of worship. Ever since, the Christians have been in difficulties in establishing new churches, especially in Muslim majority areas. To solve the problem, the Christians sometimes used a house as a place for conducting the divine service. This strategy, however, did not always work because sometimes Muslims around the house also protested. In May 1975, the Minister of Home Affairs sent a telegram to all governors explaining that, based on a report of the state intelligence, there were disputes between Muslims and Christians in two places in Jakarta because the Christians made use of a house for divine services, while the Muslims opposed this activity because the majority of people living in the environment were Muslims. The Minister of Home Affairs then instructed all governors to persuade people not to use a house as a church because it might disturb security. On the other hand, the telegram also instructed the governors to take security steps to avoid possible excesses. The ambiguity of the telegram eventually led to different interpretations. The Department of Religion in certain provinces held that the telegram meant that the Minister of Home Affairs prohibited people from using a house as a place of worship. In reaction to this issue, the General Directorate of the Protestants of the Department of Religion in Jakarta sent a letter to all Departments of Religion in the provinces stating that the telegram was not intended to prohibit people from worshipping in a house, but to persuade them not to make a house a place of worship. Nonetheless, this interpretation was then 
annulled by another telegram of the Minister of Home Affairs to all governors explaining that what was prohibited was to "to make use of a house as a church", while gatherings of Christians in a house for familial purposes was not prohibited. ${ }^{9}$

Despite these telegrams, and because of the difficulties in getting permission to establish new churches in Muslim majority areas, the Christians still often used a private house or rented a hall for services and sometimes even established a new church without permission, and the Government usually did not react unless security was disturbed due to Muslim protests. In this respect, the Muslims often referred to the decree to justify their opposition to church buildings. ${ }^{10}$ In 1996, when a systematic attack on churches in Situbondo, East Java, occurred, Muslims said that only 3 out of 24 targeted churches had legal permission to operate. ${ }^{11}$ In reaction to this criticism, the Christian leaders sent a letter to the President, asking him to withdraw the decree based on the argument that it was against religious freedom. ${ }^{12}$ Moreover, some Christian leaders questioned whether the existing mosques also had legal permission. In other words, for the Christians, the implementation of the decree tended to be discriminatory. ${ }^{13}$

In fact, the decree also caused difficulties for Muslims living in a Christian majority area to establish a mosque. Gerrit E. Singgih said that where the Christians are a majority, "even in some parts of Java, for instance those who live in Christian villages in East Java, they act like Christians in a Christian country. In those villages, they do not allow Muslims to buy houses or lands, much less to erect mosques." 14

While the Christians sometimes mentioned the Muslim difficulty in order to justify their opposition to the decree, ${ }^{15}$ the Muslims concerned with Christianisation hardly talked about it, probably because they were used to thinking as a religious majority or perhaps for them it was a lesser evil compared with allowing Christians to build new churches more freely in Muslim majority areas.

The large number of denominations and the lack of ecumenism among the Protestants have also been among the reasons behind the emergence of new church buildings. Gerrit Singgih observes that Christians usually demanded the Government provide a church in a national housing area (Perumnas) but if there were two different denominations of Christians living there, they did not want to share the church, and so another denomination carried out their service in a house that would later on be transformed into a church. For Singgih, it is understandable if non-Christians saw this phenomenon as a "bad sign of trying to dominate the religious scene" and 
if the Government did not give permission for the establishment of this "metamorphosing church." He also observes that in some Perumnas areas one could find two church buildings of two different denominations standing side by side and even having the same service hours. On this, Singgih lamented: "What a bad advertisement for Christian fellowship and ecumenism! If Christians cannot get together to respond to their situation, how much more can they get together with the non-Christians?"16

\section{Muslim Opposition to the WCC Assembly of 1975}

During the New Order period, a person who played a central role in the Indonesian Council of Churches (DGI) was T.B. Simatupang. As a young man, T.B. Simatupang joined the Dutch colonial army and had his education in the Military Academy at Bandung from which he graduated in 1942. Later in the same year, he was captured by the Japanese and subsequently joined the nationalist movement. After the proclamation of independence in 1945, Simatupang was involved in the fight against the returning Dutch. Simatupang reached the peak of his military career when he was appointed Chief Staff of the Armed Forces in 1951. Nonetheless, in October 1952, he had a strong disagreement with President Soekarno and since then was gradually removed from the army leadership. He was eventually pensioned off in 1959 at the very young age of $39 .{ }^{17}$

One day in the early 1960s, Tudung Sutan Gunung Mulia (1896-1966), ${ }^{18}$ the founding father of three important Christian institutions: the Indonesian Council of Churches (DGI), the Indonesian Bible Society (LAI) and the Indonesian Christian University (UKI), visited T.B. Simatupang in his house. On this occasion, Mulia asked Simatupang to participate in the DGI activities. Simatupang agreed and ever since started his new career within the DGI. His involvement in the DGI was dealing with the issue of the relationship between church and society, an issue that was to become his main concern for the rest of his life. For this issue, the major question was, according to Simatupang, how to bridge the gap between theological thought and social realities. Since 1962, Simatupang had been involved in the conferences on church and society, both at national and international levels. In 1964, he was invited by the World Council of Churches (WCC) to stay some months in Geneva to prepare for an international conference on that theme. ${ }^{19}$ Simatupang chaired the section on politics when the conference was successfully held in 1966 in Geneva. It seems that after his involvement in the Geneva conference, Simatupang had become well known among the WCC function- 
aries. In the fourth Assembly of the WCC held in Uppsala, Sweden, in 1968, Simatupang was appointed a member of the central and executive committees of the WCC.

It was very likely that the close relationship between Simatupang and the WCC was one of the reasons why Jakarta was chosen to be the place for the fifth Assembly of WCC (planned to be held from 23 July to 8 August 1975). According to Simatupang, in a meeting of the executive committee of WCC in Sofia in 1970, there was a discussion on where the next Assembly of WCC was to be held. Because the previous Assembly took place in Europe (Sweden), the executives wanted the next Assembly to be held in Asia. The success of the second Assembly, held in New Delhi, India, 1961, was also the reason why the committee wanted to have another Assembly in Asia. In India the delegates for the Assembly had the opportunity to see the world of Hinduism, and it was expected that in the next Assembly they could see another world, the world of Islam. The first choice was Lebanon, but after considering the political situation in the Middle East, the committee decided to drop it. One of the members of the executive committee from India, M.M. Thomas, asked, "Why not in Indonesia?" Then everybody agreed and Simatupang had no choice but to try to find the possibility of holding the Assembly in his country. ${ }^{20}$

When Simatupang came back to Indonesia, he asked the NU leader, Idham Chalid, about the Assembly and the latter responded positively. Simatupang also came to see Soeharto, and the latter also welcomed the Assembly. According to Simatupang, Soeharto suggested that some of the delegates of the Assembly should stay in people's houses so that they could enjoy the spirit of cooperation among Indonesian people inspired by Pancasila. In August 1972, the representatives of the DGI, Lutheran World Federation and World Alliance of Reformed Churches met Soeharto in the Netherlands to talk about the Assembly. In response to them, the President said that Indonesia would be honoured to be the host of the Assembly. One year later, by the end of August 1973, the WCC confirmed that the Assembly would be held in Jakarta and decided to provide $\$ 1,211,700$ for it. ${ }^{21}$

Based on the positive responses, Simatupang started preparing all the matters related to the Assembly. Since mid December 1973, Simatupang released the details of the planned programmes of the Assembly to the public. The programmes included not only the meetings of the Assembly, but also other programmes such as film shows, music, puppets, drama and dance. All delegates were also invited to attend a religious service at the opening ceremony of the Assembly, and Sunday services held in different 
churches in Jakarta. The DGI expected about 3000 delegates and 500 foreign journalists to come. They would stay in humble hotels in Jakarta and travel by bus like ordinary people. To do this, they would be guided by their respective 'adopted families' in Jakarta. This 'assimilation' was expected to help the delegates understand the uniqueness of the unity in diversity of the Indonesian people and their high religious tolerance. T.B. Simatupang also explained that these programmes were not intended to be a show of force at all. ${ }^{22}$

Furthermore, the DGI had prepared some ideas to respond to the theme of the Assembly: "Jesus Christ as Liberator and Integrator." According to the DGl, these two themes of liberation and integration were very relevant to the condition of Indonesia. The DGI argued that Christianity in Indonesia had liberated people from primitivism, feudalism and colonialism. With regard to the New Order's development programmes, based on the Christian liberation perspective, Christians should have a positive, creative, but critical and realistic approach. The Christian liberation, therefore, does not only mean liberation of souls, but also from injustices and abuses of power. This liberation could not be enacted without the unity and integrity of the people. The DGI should develop an ecumenical movement among its members and non-members, with the Catholics and with all Christians all over the world. In addition, based on the Pancasila, the DGI should develop cooperation with the people of other faiths in Indonesia, including the Muslims. Again, this cooperation should be based on religious freedom guaranteed by the state. However, it was also noted that any religious propagation should not be through methods that were against human dignity and the noble values of religion. ${ }^{23}$

Despite of the Government's endorsement and the relevance of the Assembly to Indonesia according to the DGI's arguments, the Muslim leaders could not tolerate the Assembly. Commenting on the planned programs of the Assembly, the Muslim magazine Panji Masyarakat said that although T.B. Simatupang denied that the Assembly was a kind of show of force of the Christians, "for the Muslims who are very weak now, it is felt that it is a show of force." ${ }^{24}$ In May 1974, the reformist Muslim organization, Muhammadiyah, sent an official letter to the President, asking him not to allow the Assembly because "it will bring about widespread anxieties among the Islamic community." ${ }^{25}$ In June 1974, there were similar protests from the reformist Muslim students, PII, and the traditionalist ulama of the major Islamic boarding school, Jombang. In addition, the Rābita al-'Ālam al-Islämī, (the Muslim World League) that carried out an international meeting on da'wah in Mecca 
in April 1974, also sent a letter to the President voicing the same objection. ${ }^{26}$

The political climate from the end of 1973 to the second half of 1974 had probably contributed to the negative Muslim reactions. As we shall see in Chapter 4, by the end of 1973, there was a debate on the Marriage Bill in the Parliament. For the Muslims - despite the compromise that was finally reached - the proposed bill, which in some aspects contradicted Islamic law, was a conspiracy of the Christians and certain army officers of the regime to attack Islam. Less than a month after the Marriage Bill affair, serious riots occurred in Jakarta on 15 January 1974 (later popularly called 'Malari', an acronym of 'Malapetaka 15 Januari'). On that day - the day of the visit of the Japanese Prime Minister, Kaukuei Tanaka, to Jakarta - the students protested the Government policy on foreign investment, which in their opinion only benefited those in power and their cronies. Some observers explained that the Malari affair was strongly related to internal army rivalries. However, the regime, through the voice of Ali Moertopo, the Personal Assistant to the President, eventually pointed his finger at the critical civilian groups. He claimed that the incident was created by the agents of the former Indonesian Socialist Party (PSI) and the Muslim reformist party, Masyumi. Based on this one-sided accusation, the Government closed several newspapers, including Abadi, the newspaper of the Muslim reformists. ${ }^{27}$ Ali Moertopo's alliance with the Catholics in the Centre for Strategic and International Studies (CSIS) had convinced the Muslims that this was partly an army-Catholic conspiracy against the Islamic group. ${ }^{28}$

\section{The WCC Assembly and the Muslim Discourse on Christianisation}

Within this political context, what were the Muslim reactions to the Assembly? The Muslims considered it a provocative and aggressive movement of the Christians against the Muslims in Indonesia. Again, the term "Kristenisasi" (Christianisation) was at the very centre of the Muslim discourse. Some prominent Muslim intellectuals, especially the modernists, wrote articles and even a booklet about the danger of Christianisation and the necessity of strengthening Islamic propagation programs (da'wah) in cooperation with the Muslims of other countries.

Djarnawi Hadikusuma, the prominent Muhammadiyah leader and the former chairman of the reformist Muslim political party, Parmusi, wrote a long article entitled "Christianisation in Indonesia: Its Strengths and Weaknesses."29 For Djarnawi, Christianisation means "to christianise people massively by all possible efforts so that customs and relationships in society 
should reflect the teachings of Christianity. This kind of society will pave the way for the spread of Christianity. In the end, the spiritual and social life of people would be directed from and centralized in the church." ${ }^{30}$ Djarnawi explained further that Christianisation in a political sense was, "attempts to produce laws, regulations, actions or attitudes of the political authorities that open more opportunities for the spread of, or benefits for that religion (read: Christianity)." ${ }^{31}$ Djarnawi's definition of Christianisation clearly echoes the political atmosphere described above, especially the Muslim's perception of the army-Christian conspiracy against Islam. Djarnawi, however, did not directly relate the Assembly of the WCC to Christianisation. He only said that the WCC Assembly was against the principle of religious harmony, that is, the principle of mutual understanding, hence not holding a religious Assembly "in a place where the majority of the people adhere to a different religion." 32

Mohammad Natsir, another reformist Muslim leader, also wrote an article in which he alluded to the WCC Assembly. Natsir claimed that the DGI had produced a map in which Indonesia was divided into different areas of missions to be carried out by the churches under the DGI. Perhaps, Natsir said, in the coming Assembly of the WCC in Jakarta, the plan of the Christian missions would become clearer. With reference to the Christian newspaper, Sinar Harapan, 10 January 1973, Natsir explained that Christian missions had developed a new approach, that is, of socio-economic development. For this, an organization called The Council of Church's Participation in Development (CCPD) had been established and Indonesia was one of the targets of the CCPD's programmes. For the development programmes in 1973 - again with reference to Sinar Harapan, 25 May 1973 - Natsir said that the International Christian Aid had provided $\$ 150,000$ and the WCC gave $\$ 200,000$. Natsir argued that it would be very naïve not to think of the development programmes as a means to convert people. After the Inter-religious Consultation in 1967, he said, there had been a 'free fight for all' and 'survival of the fittest' in the field of religious propagation in Indonesia. In this regard, how could Muslims compete with the Christians, "how could a cart compete with an express train?" he said. ${ }^{33}$

Muhammad Rasjidi, another prominent Muslim reformist leader, wrote a booklet in response to the plan for the Assembly under the title: The Assembly of the World Council of Churches in Jakarta 1975 is a Challenge to the Islamic World. ${ }^{34}$ The introduction to the book - written anonymously by a person representing DDII - clearly reflects both the Muslims' fear of Christianisation and their political frustration towards the regime at this period. The 
DDII author explained that according to the Indonesian Christian media, the Assembly would be attended by thousands of delegates from 82 countries. The delegates would not only visit Jakarta, but also other places such as Medan, Bali, East Java and Central Java. For the DDII author, Indonesia was chosen to be the home for the Assembly because it was related to the Christian programmes to convert Muslims in that country. The DDII author then referred to an article, published in The Washington Post of 7 September 1973, saying that the Assembly in Jakarta would be an opportunity for other Christians to witness the success of Christian missions in Indonesia. ${ }^{35}$ Finally, the DDII author did not forget to express that, while the Muslims did not have a public voice anymore, the Catholics still had Kompas and the Protestants still had Sinar Harapan. As noted above, the Muslim reformist newspaper, Abadi was banned by the Government soon after the Malari affair in 1974.

Besides the introduction, the content of the book is interesting. Rasjidi started with a sketch of the modern development of Christian theology describing two important modern theological trends in Christianity: liberalism and neo-orthodoxy. For Rasjidi, the liberal views that Jesus is not God but a great master, that there is no original sin and that the Bible contains some inaccuracies but as a whole it has a very valuable historical meaning, all of these are very close to Islam. The neo-orthodox views, however, reaffirmed what the liberals had negated and therefore, were opposed to Islam. Besides Karl Barth, among the proponents of neo-orthodoxy, according to Rasjidi, was Hendrik Kraemer. Again, Rasjidi referred to Kraemer's book, Christianity in a Non-Christian World that was originally written for the International Mission Conference in Tambaran, India, 1938. Rasjidi explained very briefly several other similar conferences and indicated that the WCC was one of the results of a Christian ecumenical conference held in Utrecht, 1938. Nonetheless, because of the Second World War, the first Assembly of WCC was postponed to 1948, and took place in Amsterdam. Based on this analysis, Rasjidi concluded that if the WCC Assembly declared that it dealt with social problems such as human rights, education and health, these were actually a pretext for the real aims of the neo-orthodox theology, that is, to convert others to Christianity. Therefore, instead of receiving social aid from the WCC, Rasjidi preferred the other neutral institutions under the United Nations such as WHO, FAO and UNESCO.

Rasjidi explained that there were 'wise liberal Christians' in the West who warned the WCC not to hold the Assembly in Jakarta because it would disturb the relationships between Muslims and Christians. ${ }^{36}$ Rasjidi also wondered whether the proposal for the Assembly in Jakarta had come originally 
from the DGI rather than the WCC. If that was the case, he said, then it should be related to the psychology of the convert who, according to Stephen Neill, considers "the old world as the world of evils" and "wishes not to turn back in any way to be associated with that which to him is evil through and through." Rasjidi then suggested that instead of following the psychology of converts, it would be better for the DGI to go after "the wise liberal Christians" in the West. Last but not least, Rasjidi said, "the ink has not dried up yet to write protests and the tears are still dropping to counter the Christian efforts to impose a marriage law containing a lot of things against Islamic teachings in September last year. Now, we are faced with a new problem: Jakarta has been chosen to be the place for the WCC Assembly, 1975."37

Within the Muslim circles, the discourse on Christianisation was soon paired with the discourse on Islamization or da'wah. By now, the Indonesian Muslims had developed stronger relations with the Muslim Middle East. In 1973, Mohammad Natsir was appointed to be a General Advisor to the Secretariat of the Räbita and this was soon followed by his appointment to be the head of the Räbita office in Indonesia. ${ }^{38}$ As has been said, in May 1974, Räbita held a meeting in Mecca dealing with da'wah issues. Besides Mohammad Natsir of the DDII, Rasjidi and H.M. Sanusi of the Muhammadiyah were among the Indonesian delegates who came to the meeting.

In June 1974, there was a Conference of Ministers of Foreign Affairs of Islamic Countries that took place in Kuala Lumpur, Malaysia. On this occasion, the former Prime Minister of Malaysia, Tunku Abdul Rahman announced his da'wah project, started by establishing a huge building of 26 floors in Kuala Lumpur. The da'wah programmes were organized under an organization called the Body for the Advancement of Islam in Malaysia (Pertubuhan Kemajuan Islam Malaysia, PERKIM). Abdul Rahman's project received significant supports from other Muslim leaders, especially those of the Arab Middle East. It was reported that the Foreign Minister of Saudi Arabia, Sayed Omar al-Sakkaf, donated $\$ 50,000$ and Abdel Ati al-Obeidi, the Foreign Minister of Libya, donated $\$ 16.5$ million for Abdul Rahman's project. Commenting on the da'wa project in Malaysia, an Indonesian Muslim author, Rusydi, the son of HAMKA, said that the development in Malaysia was in contrast to the situation in Indonesia where not the Muslims but the Christians who were going to celebrate the success of their missionary activities in the Assembly of the WCC. Rusydi accordingly suggested that the Indonesian Muslims should follow the steps of their neighbour. ${ }^{39}$ It is noteworthy that between 1971 and 1973 the Indonesian Association of Muslim Students (HMI) and the Indonesian 'ulama significantly contributed to the da'wah courses for 
Malaysian students. ${ }^{40}$ Nonetheless, it seems that in 1974 , for the Indonesian Muslim youth like Rusydi, Indonesia had been left behind by Malaysia in the field of da'wah.

On the other hand, there was also an International Congress on World Evangelization from 16 to 25 July 1974, in Lausanne, Switzerland. An Indonesian Christian magazine of the DGI reported that ninety Indonesian Christian delegates came to the congress. It was also reported that in his speech at the opening ceremony of the congress, the American evangelist, Billy Graham, suggested that Christian missions should be based on the Bible and this issue should be discussed in the next Assembly of the WCC in Jakarta. ${ }^{41}$

\section{The Murder of an Anglican Church Minister}

Apart from the more positive discussions on da'wah and mission, an incident occurred on 29 June 1974. An Australian minister of the Anglican Church, Eric Constable, was killed at night when he was staying in a guesthouse of the Anglican Church in Jakarta. There was a controversy over the motives behind the violence. According to the official report of the police, the motive behind the killing was purely criminal. It was said that the killer wanted to rob Constable who had $\$ 500,000$ in cash with him. Both the Anglican Church and the Australian embassy in Jakarta, however, denied this account. Furthermore, one of the suspects later identified as Hasyim Yahya was not a poor man. He was a director of a company belonging to his family. ${ }^{42}$ So what was then the real motive behind this? In his account of the failure of the Assembly, Simatupang also mentioned the case with the following remarks: "it was said that the killing was a signal that similar incidents would happen more if the Assembly were held in Jakarta."43 To my knowledge, however, there was no Muslim writer who endorsed the violence in this period. Rusydi's article in Panji Masyarakat tended to believe that the case was a robbery based on the assumption that foreign ministers coming to Indonesia often brought a lot of money. Accordingly, he said, if Constable had $\$ 500,000$, one could imagine further how much money there was in the hands of hundred of foreign ministers working in Indonesia! ${ }^{44}$

Nonetheless, more than two decades later, a Muslim hardliner, Adian Husaini, the general secretary of KISDI (the Indonesian Committee for the Solidarity with the Islamic World), an organization close to DDII, claimed that in 1997, he met Hasyim Yahya in Mecca, a place where the latter escaped from Indonesia. According to Adian, Hasyim was a humble and religious person and calmly told him about the incident. Hasyim explained to Adian that the main reason behind his violent action was his resentment towards the 
perceived aggressive Christianisation indicated by the Marriage Bill affair and the planned Assembly of the WCC in Jakarta. According to Adian, based on some consultations with certain ulama, Hasyim believed that Christianisation is analogous to or even worse than physical attack on the Muslims and therefore, physical retaliation against a missionary is religiously justifiable. $^{45}$

\section{The Cancellation of the Assembly in Jakarta}

The Muslim protests and the killing of the Anglican minister had pushed the DGI into a very difficult position. The DGI finally decided to talk directly to both traditionalist and reformist Muslim leaders. Simatupang then made the appointments with the Muslim traditionalist politician, K.H. Masjkur and the Muslim reformist leader, M. Natsir. In his meeting with Masjkur in the Parliament office, T.B. Simatupang started with a formal question: "Was the DGI still in the borders of its rights to invite the WCC Assembly to Jakarta?" Masjkur answered, "The problem is not about right, but how to find something good for all of us." Masjkur continued, "It often occurs that when we are angry at our parents, we hit our younger brother." Having heard this point, Simatupang concluded that the Muslim protests were actually directed not against the DGl but the Government. With this idea in mind, Simatupang went to the house of the leader of the Muslim reformist, Mohammad Roem. Roem had been waiting there along with Rasjidi, but M. Natsir was absent. According to Simatupang, although Rasjidi explained about the Muslim fear of Christianisation, the meeting was very friendly. Nonetheless, there was no substantial change with regard to the Muslim objection to the Assembly. ${ }^{46}$

Was the objection of the Muslim leaders to the Assembly only an expression of their anger at the Government, as Masjkur said? I think it is only partially true because the Muslim fear of Christian missions was real, although this was exacerbated by the Muslim political frustration towards the regime.

In any case, having contacted the Muslim leaders, Simatupang also met with President Soeharto on 27 July 1974. After this meeting, it was clear to the public that Soeharto also wanted to cancel the Assembly in Jakarta. ${ }^{47}$ In order to save the face of the Government, however, thanks to Simatupang's diplomacy, it was the WCC rather than the Government that formally cancelled the Assembly. The decision was made in a meeting of the central executive committee of the WCC in Berlin, 12 August 1974 with the hope that "on another occasion in the future the WCC could enjoy the hospi- 
tality of the Indonesian church and nation." ${ }^{48}$ Commenting on the failure of the Assembly, Simatupang bitterly quoted a saying of the Irish Republican Army, "It is better to have fought and lost than never to have fought at all." ${ }^{49}$ Thus, the Christians were actually disappointed, but they could do nothing to avoid the cancellation.

In his Address to the Nation on 15 August 1974, Soeharto also alluded to the cancellation of the Assembly. He said that he was relieved by the cancellation of the Assembly. In the beginning, he said, the Government thought that the Assembly was a sign of trust and appreciation of religious tolerance of the Indonesian people. However, he explained further that the Government also wanted the Assembly not to be harmful to the national unity and stability. Thus, "if the Assembly could disturb the current national stability, then it should be held at another appropriate time." Soeharto also suggested that Indonesian society should be careful of certain rumours triggered by religious zeal because religion was a sensitive issue. To play with the issue of religion, he said, was like playing with fire that finally would burn one's self. Last but not least, Soeharto did not forget to say that to maintain inter-religious harmony, "religious propagation should not be directed to the people who already have religion." 50 Thus, as we can see, Soeharto consistently promoted the idea of political stability as the most important goal for the Government, even if it was achieved at the expense of religious freedom.

What was the response of the Muslim leaders to the cancellation? HAMKA, the Muslim reformist leader also expressed relief that the Assembly was cancelled. He hoped that this decision could be a good start for the Indonesian Christians to develop their tolerant attitude towards Muslims. He said further that religious harmony in Indonesia could actually be achieved and had been only disturbed by the coming of foreign missionaries. ${ }^{51}$ In contrast, the editorial of Suara Muhammadiyah said that the cancellation of the Assembly was truly a relief for the Muslims, but it did not mean that the Christians had become tolerant to them. The editorial also quoted a DDII activist who said that, the cancellation of the Assembly should be followed by stopping Christianisation activities in the country! ${ }^{52}$ In short, the cancellation of the Assembly did not significantly change the negative attitude of the Muslim leaders towards the Christians. 


\section{Control of Religious Propagation and Foreign Aid}

So far we have discussed the Government's accommodation of two Muslim demands: the restrictions on building new churches in Muslim majority areas and the cancellation of hosting the WCC Assembly in Jakarta. Nonetheless, there were two other Muslim demands since 1967 not yet considered by the Government: to control foreign aid as it was demanded by Lukman Harun's plea in Parliament, and to restrict religious propagation only for those outside the recognised religions as had been debated during the Inter-religious Consultation. The debates on these two issues on both national and international occasions continued in the 1970s, and the Government finally took the initiative to accommodate the Muslim demands in 1978.

The Debates on International and National Occasions: 1972-1976

In 1971, Abdul Mukti Ali was appointed to replace Mohammad Dachlan as the Minister of Religion. As a scholar interested in comparative religion, Mukti Ali was the first Minister of Religion who initiated inter-religious dialogue as a Government project. On the other hand, he was also concerned with the issues of religious propagation and foreign aid. ${ }^{53}$ In July 1972, the WCC organized a Muslim-Christian dialogue in Broumana, Lebanon. There were 42 Christians and Muslims from 20 countries in this meeting, and among them were Mukti Ali and P.D. Latuihamallo of the DGI. One of the important issues discussed in Mukti Ali's paper for the dialogue was the issue of foreign aid for religious institutions. In contrast to Lukman Harun who suggested in 1967 a Government control of the aid, Mukti Ali said:

I should like to suggest that the churches in the western countries also give aid to the non-Christian religious communities which constitute the majority in most developing countries. If such aid is only given to the Christian churches tensions will arise because of the unequal development of religious life in these developing countries.

The issue of religious propagation was also discussed in the dialogue, but Mukti Ali did not touch on it explicitly in his paper. On the final day of the dialogue, the participants produced a Memorandum. It was stated in it that religious freedom should be guaranteed for any religious minority, but at the same time it was emphasised that in doing religious missions, "proselytism should be avoided, whether by a majority intent upon pressing a minority to conform, or whether by a minority using economic or cultural 
inducements to swell its ranks." In addition, in line with Mukti Ali's suggestion on foreign aid, the Memorandum stated that: "We welcome the emerging willingness for religious communities' gifts of material and practical aid to be channelled not through a particular religious community but given for the whole community, wherever the need is greatest." ${ }^{55}$ As we shall see, the memorandum was to become one of the reference documents in MuslimChristian controversies in Indonesia.

Mukti Ali's concern with the issue of religious propagation was more explicitly stated in his speech to the national Christmas celebration in Jakarta, 1972. He said that it was "not possible to invite people who already have religion to convert to another religion, either by force or by giving material inducements." ${ }^{56}$ When I asked about this issue, Mukti Ali said that for him, to restrict religious propagation only for those outside the recognised religions could effectively prevent inter-religious conflicts. ${ }^{57}$ Thus, although Mukti Ali was known as a promoter of inter-religious dialogue, some people believed that he was in fact also concerned about Christianisation.

We have already quoted above that President Soeharto, in his comments on the cancellation of the WCC Assembly in Jakarta during his speech on 15 August 1974, also stated the importance of the restriction of religious propagation. Later in his speech to the Eighth Assembly of DGI in Salatiga, July 1976, Soeharto said that "religious propagation should not disturb the stability of society" and "the efforts to increase the number of followers and to establish places of worship should not create disturbances in society." He also suggested that foreign aid for religious institutions should be carried out through the Government in order to make sure that it was "used appropriately." ${ }^{58}$ After Soeharto's speech, the next day, the Protestant newspaper, Sinar Harapan quoted Cardinal Darmojowono who said that to lead people who did not have religion yet (those outside the recognised religions) to have religion was hypocrisy because it implied that people were forced to have religion and therefore, they would become insincere converts. ${ }^{59}$ With regard to the issue of foreign aid, the DGI Assembly asserted that foreign aid for churches in Indonesia was an expression of the universality of Christian faith and ecumenism. ${ }^{60}$ This seems to be an implicit rejection of Soeharto's suggestion that the aid should be carried out through the Government. Thus, the Christians obviously opposed the position of the Muslims and Soeharto on these two issues.

On the other hand, having noticed the Christian negative reactions, the Muslim leaders also made sharp comments against the Christians. Muhammad Natsir said that he could not understand Darmojowono's state- 
ment because there were missionary activities in Kalimantan to convert those who did not yet have a religion. Natsir claimed that there were 45 airstrips for the operation of helicopters and airplanes of the Christian missionaries in the region. ${ }^{61}$ Another Muslim leader, HAMKA, cynically stated that if Cardinal Darmojowono considered the missions to convert those who did not yet have a religion was hypocrisy, then one might conclude that the real aim of the Christian missions was to convert Muslims, while the missionary activities carried out to those who did not yet have a religion were simply a pretext. Darmojowono's statement and T.B. Simatupang's rejection of Government control of foreign aid, for HAMKA, indicated that the Christians felt strong vis-à-vis the Government. The spirit of Muslim jihad, he said, now was apparently found among the Christians! ${ }^{62}$

Besides the debates on the issues in Jakarta, just one month before the DGI Assembly in Salatiga, the WCC in cooperation with two co-convenors, David Kerr, the Director of the Centre for the Study of Islam and ChristianMuslim Relations in Birmingham, and Khurshid Ahmad, the Director of the Islamic Foundation, Leicester, organized a conference on Christian Mission and Islamic Da'wah, held in Chambésy, Geneva, 26-30 June 1976. The conference was actually a meeting of Muslim and Christian leaders, especially the representatives from Asia and Africa. Among the invited participants, there were two Indonesian representatives: the Muslim reformist, Muhammad Rasjidi and the prominent Christian scholar and Rector of Sekolah Tinggi Teologi (The Academy of Theology) Jakarta, Ihromi.

On the normative and theological basis, both Christian and Muslim speakers in the Conference acknowledged the missionary character of their respective religions. ${ }^{63}$ Nonetheless, if we look at the papers and discussions of the conference, we shall find that the major issue was Christian missionary activities among Muslims rather than the opposite. In fact, Lamin Sanneh, who presented a paper on Christian experience of Islamic da'wah in Africa, only discussed the historical development of the propagation of Islam and Christianity among the pagans in Africa rather than Islamic da'wah among Christians. ${ }^{64}$ This was in sharp contrast to the Muslim perception of Christian missions in Indonesia and East Africa described in the papers of Mohammad Rasjidi and Ali Muhsin Barwani respectively.

In his paper, Rasjidi described in detail his resentment at what he saw as Christian abuses of social services (diakonia) to convert Muslims such as giving money and food to the poor Muslims, and building new churches, schools and hospitals in Muslim majority areas. ${ }^{65}$ In response to the Muslim criticism of diakonia, Arne Rudvin argued that if we look at the New Testa- 
ment, diakonia is actually considered secondary to evangelism. However, modern missions tend to institutionalise and internationalise the diakonia, and the Christians had "too often succumbed to the temptation to make these institutions means of influence or of evangelisation." For him, this was unacceptable because "If we have any ulterior motive for our service, however good, diakonia is no longer an expression of agapé but becomes a propaganda instrument." Thus, he said, "I believe our Muslim brethren have a right to blame us for this." ${ }^{\prime 6}$

While Rasjidi's paper criticised the abuses of diakonia, Barwani criticised the Christian missionaries who cooperated with colonial power to attack Islam in East Africa. For Barwani, although East Africa had already obtained independence, it was still controlled by the colonialists, "not colonialists from abroad but people belonging to the Christian minority group, people who are the products of the colonial era of the missions and who still enjoy their blessings." ${ }^{67}$ The discussion on colonialism then touched Indonesia as well when a Muslim scholar, Ismail R. al-Faruqi made a sharp comment: "I personally do not agree to discuss with anyone who argues that there is no neo-colonialism today in, for example, Indonesia. And what concerns us very much here is the linkage between the missionary movement and neo-colonialism." Ihromi, the Christian representative from Indonesia, immediately reacted: "But we Christians in Indonesia feel a deep sense of solidarity with our Muslim fellow-citizens. We would like to see the growth of a sense of single citizenship shared by Muslims and Christians in Indonesia. You seem to disregard this when you accuse all the Christians in Indonesia of being in the hands of neo-colonial powers." ${ }^{\prime 68}$

The Christians, on the other hand, criticised the Muslims with regard to the issue of religious freedom. Rudvin said, "Surely one of the main reasons for the negative attitudes between Muslims and Christians is the treatment meted out to converts, probably on both sides. In Pakistan, I would go so far as to say that a convert in a major city will survive with his life, but probably not so in a village. " He then suggested that, "we as Christian and Muslim leaders should tell those for whom we are responsible not to abuse converts, not to ostracize them from the family nor from society, making them lose their inheritance, their jobs, etc." ${ }^{\prime 69}$ The Muslims' answer to the question was that in Islam there is freedom to convert. The prohibition of conversion from Islam should be understood as a political idea. Al-Faruqi argued that conversion out of Islam was not tolerated during the Madinah period because conversion at that time meant: "joining the polytheistic camp of Makkah which was in a constant state of war against the Muslims." 
In the case of Indonesia, Al-Faruqi tended not to allow freedom to convert for Muslims because "what we have heard [i.e., from Rasjidi's paper] about the situation confronting Islam in Indonesia is like a re-enactment of Madinah and Makkah."70

The Christian concerns with religious freedom and the Muslim resentment of colonialism and the abuses of diakonia were all finally covered in the statement made on the final day of the conference. It was stated that, "the Christian participants extend to their Muslim brethren their full sympathy for the moral wrongs which the Muslim world suffered at the hands of colonialists, neo-colonialists and their accomplices." With regard to religious freedom, it was stated, among other things, that "the Muslims as well as the Christians must enjoy the full liberty to convince and be convinced, and to practice their faith... [and] that an individual is perfectly entitled to maintain his/her religious integrity in obedience to his or her religious principles and in faithfulness to his or her religious identity." On the abuses of diakonia and the distribution of foreign aid, the conference "strongly urges Christian churches and religious organizations to suspend their misused diakonia activities in the world of Islam." Moreover, "the conference urges strongly that all material assistance donated by outside churches and religious organization henceforth be distributed wherever possible by the Governments and local communities of people for whom they are intended, respecting the dignity and integrity of the people concerned."71

The statement of the Conference quoted above could be a good foundation for creating better Muslim-Christian relations. Nonetheless, it is often the case that a well-formulated statement on paper does not work in reality at all. Further, neither the participants of the conference nor the WCC had any formal political authority to implement the stipulations of the statement. So, what was the significance of the conference? In the case of Indonesia, the conference, or more precisely the statement of the conference, has been referred to by both Muslims and Christians when a controversy on religious freedom and foreign aid emerged in the following years. In addition, after their return from the conference, both Ihromi and Muhammad Rasjidi almost immediately published accounts of the conference in the Christian and Muslim media respectively. Rasjidi and Ihromi, however, had different if not contradictory interpretations of the meaning of the statement of the conference.

In his account of the conference published in Berita Oikoumene, Ihromi did not touch the issue of religious freedom directly. He just emphasized the concept of citizenship for all Indonesians regardless of religion and ethnic- 
ity. As has been noted above, Ihromi had a discussion on this issue with alFaruqi. According to Ihromi, he explained to al-Faruqi and the other participants that the Indonesian word 'warga' and the term 'warga negara' used in the Indonesian Constitution contributes a deeper dimension to the concept of citizenship. The word 'warga' for Ihromi also means 'keluarga' (family) and therefore, the term 'warga negara' means that all Indonesian citizens are one family regardless of religious and ethnic background. In addition, there were at least two other important points in Ihromi's account. First, in the opening of the statement of the conference, it is said that: "In recognition that mission and da'wah are essential religious duties in both Christianity and Islam..." For Ihromi, this statement is very important because it acknowledges the integrity of the religion in question, that is, both Islam and Christianity are missionary religions. As we shall see, this part of the statement of the conference was to be frequently quoted by the Christian intellectuals when the Muslims tried to restrict missionary activities only for those outside the recognized religions. Second, Ihromi also touched the issue of diakonia. He said that on the fourth day of the conference, he explained to the participants that the Christians themselves would be the first to feel humiliated if people converted to Christianity only because they were hungry and needed some rice or homeless and needed a shelter from the Christians. Ihromi explained further that in order to avoid "cheap accusations" of the misuse of the diakonia (an implicit criticism of Rasjidi's paper in the conference), it was decided in the wording of the statement to put the clause "respecting the dignity and integrity of the people concerned." ${ }^{72}$

Unlike Ihromi, in the Muslim magazine, Media Dakwah, Rasjidi made a more complete report of the conference by giving a summary of the presented papers, translating the whole statement of the conference accompanied by his personal comments. ${ }^{73}$ Rasjidi's personal comments appear to be the most interesting part of the account. Commenting on the words of the statement that "the Muslims as well as the Christians must enjoy the full liberty to convince and be convinced", Rasjidi said that this is a true way to do the da'wa or mission because it suggests that one's conversion to a religion is not because of material temptation nor to enter school and get education but because he or she has been convinced by the truth of the beliefs of that religion. As we shall see, this comment is quite different from the comments of the Christians who used the statement to argue that religious propagation cannot be restricted only to those outside the recognized religions. Similarly, it is mentioned in the statement that, "the conference was grieved to hear that some Christians in some Muslim countries have felt themselves 
limited in the exercise of their religious freedom and have been denied their right to church buildings." To read this statement from the Indonesian case, particularly for the Christians, one should remember at least the controversy on the Methodist church in Meulaboh in 1967 and the joint decree of 1969. In contrast, commenting on the statement, Rasjidi said that the incident, according to Bishop Kenneth Cragg, occurred in Afghanistan, but there was no convincing evidence about it. It was said, according to Rasjidi, that the church was built without permission from the Government and that there was no Christian living in the area. Because of the lack of evidence, Rasjidi said, the statement used the word 'to hear.' Rasjidi then jumped to another case that during the war in Cyprus, the Greek Christians destroyed more than 100 mosques, while the churches in the area controlled by the Muslim Turks were not disturbed at all. Besides commenting on the issue of religious freedom, Rasjidi also commented on the issue of diakonia mentioned in the statement. He said that it was for the first time that the Christians acknowledged that there were abuses of diakonia. Rasjidi also welcomed the stipulation of the statement that any foreign aid for religious institutions should be distributed through the Government in order to prevent the abuses of diakonia.

\section{Alamsyah's Attempts at Reconciliation with the Islamic Groups}

The Indonesian elections in 1977 and the session of the People's Consultative Assembly (Majelis Permusyawaratan Rakyat, MPR) in 1978 had proved that the Islamic groups, in the words of an observer, had become "the principal opposition force." 74 The Islamic party, PPP, despite its small number of representatives compared to the Government's party, Golkar, had made a walk-out protest against the Government's accommodation of Javanese Mysticism (Aliran Kepercayaan) in the Mainlines of State's Policies (Garis-Garis Besar Haluan Negara,GBHN) and the Government's proposal on the Guidelines for Internalisation and Application of Pancasila (Pedoman Penghayatan dan Pengamalan Pancasila, P4). Both reformist and traditionalist Muslim leaders, inside and outside the PPP, were united in opposing the Government's accommodation of the Aliran Kepercayaan because they were afraid that it could be developed to be one of the recognized religions. The Muslim efforts to prevent Javanese Mysticism from gaining an official status had actually started in the early 1950s and they were relatively successful. Nonetheless, fortune had come for the mystical proponents when the MPR dominated by Soeharto's supporters, decided to include the Aliran Kepercayaan in the GBHN of $1973 .{ }^{75}$ There were Muslim protests against it, but 
not as strong as in 1978. Perhaps, because of stronger Muslim opposition, although the Aliran Kepercayaan was not eradicated altogether from the GBHN of 1978, the Muslim concerns were also accommodated. It was stated in the GBHN that the Aliran Kepercayaan was not a religion and should not be developed towards establishing a new religion. ${ }^{76}$ In addition, the Muslims could not accept the Government's concept of the P4 - that was to become the primary text for civic indoctrination - because it elaborated the values of Pancasila as guidance for personal and individual life. According to the Muslims, this interpretation of Pancasila would not only intervene in the religious sphere but also overshadow the responsibility of the state to implement the Pancasila values demanded by the Constitution. ${ }^{77}$ In this case, the Muslim protest did not bring significant change.

On one evening of early March 1978, in the private residence of President Soeharto in Cendana Street, Jakarta, Alamsyah Ratu Perwiranegara was in a serious conversation with the President. Soeharto explained to Alamsyah the current tensions and controversies during the session of the People's Consultative Assembly (MPR). Soeharto was worried about the increasing Islamic opposition to the Government and wanted Alamsyah to be the Minister of Religion to deal with the problem of how to accommodate the Islamic groups. In the beginning, Alamsyah was hesitant to take the job, but he eventually decided to do so. ${ }^{78}$ Before becoming the Minister of Religion, Alamsyah was known as one of the prominent army Generals close to Soeharto since the beginning of the New Order. He previously held some important political positions: as the Coordinator of the President's Personal Staff (1966-1968); the State Secretary (1968-1971); the Indonesian Ambassador to the Netherlands (1972-1974); and the Vice Chairman of the State Advisory Council (1975-1977). Because he came from a military background, in the beginning, some Muslims were not happy with him and he was even blackmailed on the first few days of his work in the Department of Religion. ${ }^{79}$

Nonetheless, after several months in office, Alamsyah had successfully established warm relationships with important Islamic political leaders and showed his willingness to accommodate certain 'Islamic interests.' One of Alamsyah's often quoted sayings to win the heart of the Muslims was to explain to the public that it was unfair to say that Muslims were anti-Pancasila, because "Pancasila was actually a gift of the Muslims to the Indonesian state." In addition, after a two-hour meeting with the President, Alamsyah explained to the public that the Aliran Kepercayaan would not be administered by the Department of Religion but by the Department of Education and Culture because, as the GBHN stated, they do not constitute a distinc- 
tive religion. ${ }^{80}$ Alamsyah's moves were relatively effective to win the heart of the Muslims who regarded him as an 'Islamic General' in contrast with other Generals like Soedjono Humardhani and Ali Moertopo, known to be close to Javanese Mystical groups and the Catholics; and General T.B. Simatupang, the leader of the Protestants in the DGI. ${ }^{81}$

Another move of Alamsyah that attracted public attention was his policy on Islamic da'wah. With the support of Soeharto and the Commander of Security and Order, Soedomo, Alamsyah tried to loosen the Government's control of Islamic preaching throughout the country. Previously, especially in the period close to the 1977 elections, da'wah activities were considered a security issue. Any Muslim gathering had to have permission from the civilian and military authorities, or at least to inform them 24 hours before. The main reason was because the Government was unhappy with the Islamic preachers who often criticized the Government's policies in their speeches. On May 1978, Alamsyah issued a decree regarding Islamic da'wah. It is mentioned in the decree that Islamic da'wa activities do not need prior permission from the Government authorities. However, the decree also mentions that the da'wah should not endanger national stability, national development, Pancasila and the Constitution of $1945 .^{82}$ Given the ambiguity of the decree, the Muslim responses were rather cautious. In general, however, the Muslims looked at the decree as a signal of the Government's accommodation of Muslim aspirations, especially because da'wah was not considered a security issue anymore and was returned to its 'original' place, the Department of Religion. ${ }^{83}$

In an interview with a leading Muslim magazine, Panji Masyarakat, in October 1978, Alamsyah explained openly that what he tried to do with the above moves was to establish a harmonious relationship between the Government and the Islamic groups. He offered an explanation that sounds like a political compromise between the regime and the Islamic groups. He said that both the Islamic groups and the Government should know what each of them disliked most and expected most. According to Alamsyah, what the Muslims disliked most was to consider Aliran Kepercayaan a distinctive religion, while what the Government disliked most was to find anti-Pancasila people among religious believers. What did each group most expect? According to Alamsyah, what the Muslim groups expected most was that religious preaching should not be strictly restricted, while what the Government expected most was that religious groups, in cooperation with the Government, should help maintain political stability and enact development programmes. The Government had already given what the Muslims wanted, and now they should in return give what the Government wanted. ${ }^{84}$ 
The 'give and take' relation between the Government and the Islamic groups seems to be what Alamsyah means by harmony between Government and religious groups, an element of his concept of 'the triad of harmony.' The other two are harmony among different religious groups or the so-called 'inter-religious harmony' and harmony among different groups of the same religion or 'intra-religious harmony.' 85

\section{Alamsyah's Decrees of 1978: Taking the Steps Further}

What were Alamsyah's policies on inter-religious harmony? In August 1978, Alamsyah issued two controversial decrees, one on religious propagation and another on foreign aid for religious institutions. As has been discussed in the previous chapter, these two issues had been at stake since 1967 and Alamsyah himself was very much involved in organizing the Inter-religious Consultation in that year. We have already mentioned that the Minister of Religion before Alamsyah, A. Mukti Ali, was also concerned with these two issues but - probably due to his weak political position - he did not take any radical step. Now, Alamsyah, without further discussions with the religious leaders, issued two decrees in which he clearly favoured the Muslim positions on these two issues. The decree no. 70 stipulates that religious propagation is not allowed (1) to be directed to the people who have another religion; (2) to use money, clothes, medicine etc. as a means to convert people; (3) to be carried out by spreading pamphlets, books, bulletins and magazines to the houses of people who have another religion; (4) to be carried out by a door-to-door visit to the houses of people who have another religion. ${ }^{86}$ As has been noted, the people who already have religion are the followers of one of the recognized religions. Thus, the followers of native religion are excluded.

With regard to the foreign aid for religious institutions, Alamsyah's decree no.77 mentions that any form of aid (personnel and/or material) given by a foreign Government, organization or individual to a religious institution should be based on the agreement or recommendation of the Minister of Religion. The decree also stipulates that religious institutions should provide education and training programmes for Indonesians to replace foreign religious workers working in the country. The programme should be started at the latest after six months following the issue of the decree and finished in two years at the most. ${ }^{87}$

According to Alamsyah, the decrees were Government policies that did not need any formal support from religious groups. He argued further that positive or negative reactions to the decrees were acceptable in a dem- 
ocratic state but they would not necessarily influence and change them. ${ }^{88}$ Alamsyah also explained that his policy on religious propagation was actually a follow up of what President Soeharto had suggested in his speech on 30 November 1967 to the Inter-religious Consultation and in another speech on 15 August 1974 before the Parliament. In addition, Alamsyah also referred to the speech of the Commander of the Armed Forces and the Minister of Defence, M. Panggabean (a Protestant) in a seminar in Aceh, on 28 October 1974 and the speech of the Chief Commander of Security and Order, Admiral Soedomo (also a Protestant) in Banyuwangi on 20 December 1975. All of them suggested that religious propagation should be based on the rules mentioned in the decree no. $70{ }^{89}$

Alamsyah also explained that the decree on foreign aid for religious institutions was not intended to hinder foreign assistance to religious institutions. The decree simply required that the Government should know "who receives the aid, from whom and for what." He believed that this transparency would help eradicate suspicions among religious groups. ${ }^{90} \mathrm{He}$ argued further that other countries had already adopted the same policy, and Indonesia was rather late. Last but not least, Alamsyah also referred to the Statement of the Conference on Islamic Da'wah and Mission in Chambésy, 1976, which also recommended the same policy. ${ }^{91}$

Of course, the Muslim leaders were happy with the decrees, and the Indonesian Council of Ulama (MUI) released a statement supporting the decrees on 9 September 1978. Only a few days later, the Indonesian Hindu Association (Parisada Hindu Dharma) and the Indonesian Buddhist Association (Perwalian Umat Budha Indonesia) also expressed their support for the decrees. ${ }^{92}$ What did the Muslim leaders say about the decrees? HAMKA, the head of the Indonesian Council of Ulama, said to the press that the regulation on religious propagation was significant to prevent radicalisation of the Islamic community. He explained that religious propagation carried out through a door-to-door visit could lead to fatal results because "for a fanatical Muslim, it is permitted to kill such a missionary." ${ }^{\prime 93}$ Further, Nuddin Lubis, a Muslim politician of the Islamic party, PPP, also extended his agreement with the decree on foreign aid for religious institutions, although he assumed that the regulation would be primarily used to control Saudi Arabia's aid for the Islamic educational institutions. ${ }^{94}$ Lubis' statement apparently contained some truth because, as has been mentioned earlier, since 1973, Mohammad Natsir was appointed to be the head of the Räbita office in Jakarta and so Muslim foreign aid from the Middle East, particularly Saudi Arabia, was probably channelled through Natsir. 


\section{Christian Opposition to the Decrees}

On the other hand, the Christians, both Protestants and Catholics, as one could expect, reacted negatively to the decrees. The DGI and MAWI even sent a letter to President Soeharto dated 24 August 1978 asking him to withdraw the decree no. 70 and then another letter dated 14 September 1978 asking the President to withdraw the decree no.77. Both the DGI and MAWI also asked for an audience with the President, but the latter never replied to this request. Nonetheless, they succeeded in arranging a meeting with the Vice-President, Adam Malik, the State Secretary, Sudharmono, the Minister of Social Welfare, Surono and the Minister of Religion himself. ${ }^{95}$ The Christian objection was also declared to the public through a joint press release of the DGI and MAWI on 15 September 1978. The press release also explained that the DGI and MAWI had sent two letters to Soeharto asking him to withdraw the decrees. The press release was not only published in the printed media but also broadcast on radio and television. ${ }^{96}$ In addition, on 28 September, the DGI and MAWI organized a joint team of six to make a critical review of the decrees and the team finished their work on 13 October 1978. In addition, from 19-21 October 1978, all functionaries of the DGI and 51 representatives of the churches outside the DGI, including the evangelical group, held a special meeting in Jakarta to discuss the same issue. The meeting finally published a message for the Christians in which the participants declared that they supported the joint action of the top leaders of the DGI and MAWI to oppose the decrees and invited the Christians to strengthen cooperation and ecumenism. ${ }^{97}$

If we look at the Christian arguments described in the work of the team of six, the main issue for the Christians was still religious freedom with strong emphasis on: (1) freedom to preach religion to other people of different religion, (2) freedom to convert or to change one's religion, and (3) freedom to cooperate with those who share the same faith anywhere in the world. As we have discussed, this interpretation of religious freedom was not new among the Christians. Nonetheless, the Christians also developed new arguments to support their interpretation. In general, they argued that the decrees were unconstitutional because they were not only against the religious freedom guaranteed by the Constitution of 1945, but also against the $\mathrm{P} 4$, the interpretation of Pancasila that had been recently ratified by the MPR but not referred to in the decrees. In addition, they also referred to the Muslim-Christian joint statements at the international conferences organized by the WCC. As has been discussed above, both Muslim and Christian 
intellectuals from Indonesia participated in the conferences in Broumana, 1972 and Chambésy, 1976. With regard to the issue of religious mission, the Broumana memorandum said, "while accepting that both religious traditions have a missionary vocation, proselytism should be avoided" which was parallel with the statement of the Geneva conference: "in recognition that mission and da'wah are essential religious duties in both Christianity and Islam..." and "the conference upholds the principle of religious freedom recognizing that the Muslims as well as the Christians must enjoy full liberty to convince and to be convinced." The Christians argued that these statements clearly indicated that preaching religion is an essential religious duty for both Muslims and Christians and therefore, the target of mission cannot be restricted. What should be done, therefore, was to restrict not the target of mission, but the ways through which the mission was carried out. Thus, in principle, the Christians did not have any objection to the point of the decree prohibiting religious mission carried out through material inducements because this was a wrong way of doing mission. In addition, the Christians were also worried that the restriction of the target of religious mission stipulated in the decree also meant a prohibition to change religion. In response to the Government's control of foreign aid, the Christians said that this was problematic, because the Church has a universal character transcending state boundaries. In this regard, unlike their argument for the freedom to preach religion, the Christians avoided referring to the statement of the conference in Chambésy, 1976 that clearly recommended that religious aid should be distributed through Government. Last but not least, the Christians also objected to the time limit given by the decree to train ministers and priests because, they said, priests and ministers could not be trained in only two years. ${ }^{98}$

Actually, in September 1978, the Christian criticisms of the decrees had been generally reported by the press before the Team of Six had finished their work. For instance, a leading Indonesian magazine, Tempo, already published the responses of the Christian leaders like T.B. Simatupang of the DGI, Leo Soekoto of the MAWI and the Christian politician, Sabam Sirait. ${ }^{99}$ In addition, Ihromi published an article in Sinar Harapan in which he referred to the statement of the Conference on Christian Mission and Islamic Da'wah quoted above and said that Rasjidi was one of its participants. According to Ihromi, the statement clearly asserted that, "da'wah and evangelisation could not be separated from the integrity of Islam and Christianity" and therefore both Muslims and Christians "must enjoy the full liberty to convince and to be convinced." 100 


\section{Muslims' and Government's Responses}

The Christian criticisms certainly triggered reactions, especially from the Muslims. Muhammad Rasjidi, for example, wrote a long article to respond to the Christian criticisms. As we have mentioned above, for Rasjidi, the right to convince and be convinced meant that everybody has freedom to choose a religion after being convinced by the truth of that religion. Thus, for him this statement had nothing to do with freedom to propagate religion by the means of social services. In this respect, it seems to me that for Rasjidi, there was no Christian mission in Indonesia that did not use social services to convert people. Similarly, according to Rasjidi the statement that mission is "an essential religious duty" should not be understood in a vacuum. In other words, religious mission should be understood within a specific context where the mission is carried out. The Christian objection to the decree meant that for them "this world was a vacuum space and so the Christian missionaries could enter it at will," he said. In fact, he said further, "the Government's decree no. 70 was intended to maintain the security of the developing nation, not to oppose a religious principle." In addition, Rasjidi argued, if the Christians said that the regulation not to preach religion to other people of a different religion implicitly meant a prohibition against conversion, then for the Muslims, the Christian objection to the regulation implicitly meant that the latter wanted to Christianise the Islamic community. Last but not least, Rasjidi quoted a paragraph of the Document of the Vatican Council II in which the Catholics indicated their open attitude and respect towards Muslims. Rasjidi eventually concluded that, "both the Catholic Church in the Vatican and the WCC had a more lenient attitude than the DGI and MAWI...Religious freedom understood by the MAWI and DGI as the right to Christianise Islamic communities is a great mistake at which the whole world would laugh."101

Besides the Muslims, the Government also responded to the Christian criticisms. On 10 October 1978, after a meeting with Soeharto, Alamsyah said that the President instructed him to continue with the application of the decrees. On that day, Alamsyah also provided explanations of each of the two decrees that in a way was also a response to the Christian criticisms. ${ }^{102}$ According to the explanations, to maintain national unity, security and development, the propagation of religion is not allowed to be directed to people who already have a religion. In addition, to be a more independent nation, the Government would try to reduce its dependency on foreign aid, including aid for religious institutions. Nonetheless, there are some positive points mentioned in the explanations: (1) the Government would 
not intervene in the freedom of anybody who voluntarily decides to convert to another religion or who wants voluntarily visits or listens to a religious preaching of any religion; (2) although the Government prohibits the use of material gifts such as food, medicine, cloth etc. to convert people, it would not prohibit the social services developed by religious institutions like schools and hospitals because they are considered a concrete realization of religious teachings and participation of religious groups in the national development. ${ }^{103}$ In addition, it was also explained that the Government's agreement or recommendation stipulated by the decree did not mean that foreign aid for religious institutions should be given physically to the Government. It only means that the Government should know "who receives what, from whom and for what."104

The explanation of the decree seemed to be relieving for the Christians, though not satisfying. This was particularly indicated by the positive comments in the press release of the MAWI, dated 16 November 1978. ${ }^{105}$ In general, however, the Christians still could not accept the decrees and demanded that the Government withdraw them. In their official response to the explanations of the decree, they said that national unity and development should not be opposed to the freedom of religion because according to the $\mathrm{P} 4$, religious freedom is a fundamental human right that is not given, but should be protected, by the state. Thus, what should be developed was not to restrict that freedom but how to use the freedom responsibly. They argued further that as far as the explanation of the decree was concerned, the Government still restricted the freedom to preach religion, even though the freedom to change religion was protected. ${ }^{106}$ In addition, in their response to the explanation of the decree on foreign aid, the Christians re-emphasized the universal character of the Church. They said, the decree could not be accepted because it indicated a Government's intervention in the internal affairs of Christian institutions. ${ }^{107}$

\section{The Government Final Position: the Joint Decree of 1979}

The controversy was not over yet. Instead of withdrawing the two decrees, on 2 January 1979, the Minister of Religion and the Minister of Home Affairs issued a joint decree concerning religious propagation and foreign aid for religious institutions. In general, the stipulations of the joint decree were similar to those of the two previous decrees. In his account, Alamsyah tried to show that the joint decree was not intended to displace the previous two decrees, but to strengthen them. ${ }^{108}$ They were strengthened because in the joint decree the authority to control the application of the decree lay in 
the hands of Governors at provincial level, and Mayors at district level, while other related Departments, including the Department of Religion at both levels, were under their coordination. Similarly, foreign aid did not only need the recommendation of the Department of Religion, but also the agreement of the Coordinating Committee for Foreign Technical Cooperation (Panitia Koordinasi Kerjasama Teknis Luar Negeri, PKKTLN). There was, however, a significant difference in the joint decree: the time limit for replacing foreign missionary personnel in the previous decree was removed. ${ }^{109}$ This was probably an accommodation of the Christian objection to the time limit (i.e., two years) mentioned in the Alamsyah's decree on the foreign aid.

On 9 January 1979, the representatives of the religious groups were invited to a meeting with the Minister of Religion, the Minister of Home Affairs, the Coordinator Minister of Social Welfare and the Cabinet Secretary to talk about the joint decree. As had happened before, all religious representatives agreed with the joint decree but the Christians (the DGI and MAWI) asked for more time to review it. ${ }^{110}$ The DGI and the MAWI then made a joint review of the decree dated 14 January 1979. Probably because the Christians now realized that the Government really wanted to proceed with the regulations, they did not ask the Government to withdraw but to revise it. First of all, they suggested that in the light of the issue of the joint decree, the previous two decrees should be suspended. With regard to the issue of religious propagation, the Christians found that there was a contradiction in the decree because while it was stated that the joint decree was not intended to restrict the efforts to develop and propagate religion, at the same time it specified some restrictions. Again, the Christians suggested that the restriction of the target of religious mission (only for those outside the recognized religions) in the decree should be eradicated, because what could be restricted was not its target, but the ways of carrying out the mission. Therefore, they suggested more or less the following formulation: "Religious propagation may not be carried out by methods contradicting the freedom and dignity of human beings and the majesty of religion such as giving money, food etc. as a means of persuasion; and spreading pamphlets etc. to people who do not want to accept them; and paying a doorto-door visit to the people who do not want to welcome it." With regard to foreign aid, the Christians said that because it was something new for them and for the PKKTLN, they hoped that there would not be bureaucratic difficulties. The Christians also explained that foreign aid for developing and propagating religion is not the same as aid for technical programmes and therefore they suggested that the Government should formulate a new and 
suitable regulation for the application of the decree. Last but not least, the Christians warned that the Government control at the province and district levels should not contradict religious freedom guaranteed by the Constitution of $1945 .^{111}$

Again, as a support to the joint decree and response to the Christians, Rasjidi wrote a along article on religious freedom. Rasjidi argued that in modern western history there were two different ways to protect religious freedom: the European way of 'jurisdictionalism' and the American way of 'separatism.' The difference is, while in jurisditionalism the state pays attention to religious activities, in separatism, the state does not interfere in religious affairs of the people unless they break the law. Both ways, argued Rasjidi, have the same goal: to guarantee the equality of religious groups before the law and the state. The difference was only because of different historical settings and experiences. In the article, Rasjidi also analysed the Documents of Vatican Council II, especially the decrees relating to mission and non-Christian religions (ad gentes and nostra aetate) and concluded that it was much more progressive than the attitude of the Catholic Church previously, but at the same time the Church was still trapped in the idea that it is only through Jesus and the mediation of the Church that one can attain salvation. Accordingly, the zeal to Christianise the whole world is still strong in the Catholic Church. Similarly, Rasjidi quoted at length the statement of the conference in Chambésy, 1976 and praised the Christian opposition to proselytism using the social services. On the other hand, Rasjidi said, according to the report in Ecumenical Press Service, 15 June 1978, by the beginning of 1979, one billion dollars had been collected for the project of evangelisation in the world through social activities coordinated by the WCC. Thus for Rasjidi, given the real threat of the Christian mission, there was no better way to maintain inter-religious harmony than to support the application of the joint decree of the Ministers of Religion and Home Affairs. In terms of religious freedom, for him, the decree was parallel with the European jurisdictionalism. ${ }^{112}$

It is noteworthy that foreign Christian missionary groups also broadcast the controversy on the decrees in their media. In Germany, the Asia Lutheran News described the decrees as the Indonesian "Anti-Mission Law" that banned people from changing their religion. ${ }^{113}$ Likewise, in Switzerland, Eduard Abel, the press secretary for the Swiss Mission Society wrote: "the decrees probably represent a concession to traditional Islam which... made considerable gains at the last elections. Certainly, Indonesia cannot be governed today without taking account of the wishes of the Muslims. 
Behind these wishes, the idea of an Islamic state according to the law of the shari'a is gaining strength, and this idea is being actively supported by influential Arab states." In another article, he wrote, "it is hoped, not only for the sake of the Christians but for peace and the future of all people in this huge Indonesian archipelago that the Suharto Government will be able to restrain Islamic aggressiveness..." ${ }^{114}$ A European Muslim convert, Ahmad von Denffer, responded that the foreign Christian accounts were false and likely to create a scary image of Indonesian Islam in the West. He also translated the decrees into English and published them, primarily as information for the Muslims in the world. ${ }^{115}$

\section{The Implication of the Decrees}

Despite the national and international criticisms and counter-criticisms, the Government, especially President Soeharto, seems to be firm that the policy was on the right track and timely. But, why did the decrees appear in 1978 and not before? As has been noted, the two previous Ministers of Religion, Mohammad Dachlan and A. Mukti Ali, did not make any decree dealing with these two controversial issues. Why did Alamsyah do so? I think it was probably not because of the "inexperience of the new minister" as A.G. Hoekema tried to guess. ${ }^{116}$ On the other hand, I think it is rather an exaggeration to say that "these decrees symbolized a victory for Muslims in their long struggle to impose Islamic ideas of religious freedom on the national and legal system," as Hyung-Jun Kim described. ${ }^{117}$ Apart from the fact that the stipulations of the decrees are similar to the Muslim ideas developed in 1967 , there was no indication that they were a direct outcome of their political struggle, let alone their victory. In other words, the initiative appears to have come from the Government rather than the Islamic groups. I think if we go back to the political situation in 1978 and Alamsyah's appointment described above, the decrees could be seen as one of the Government's efforts towards reconciliation with the Islamic groups.

Nonetheless, there was another side to the decrees: Alamsyah probably used them to oppose the Muslim discourse on Christianisation. Alamsyah said that the discourse came from certain Muslims who wanted to vent their anger on the Government and to get support from the Muslims in the Middle East. On the other hand, argued Alamsyah, the Christians also tended to exaggerate the success of the Christian mission in the country in order to gain more financial support from the West. According to Alamsyah, the discourse on Christianisation had created a bad image of the Indonesian Government in the eyes of the Muslims in the world, especially in the Middle 
East. Therefore, he tried to convince the Muslim leaders in the Middle East, including the leaders of the Räbita al-'Ālam al-Islämī that Christianisation in Indonesia was an untrue story. ${ }^{118}$ I believe that one of his ways (not the only way) to convince the Arab leaders was to tell them about the decrees. In a paper probably presented to an international Muslim audience, Alamsyah said that, his decrees could successfully reduce the tensions and social unrest caused by Muslims' negative reaction to the efforts of Christian missionaries to convert Muslims by various means, "particularly through material and financial aid."119

Nevertheless, apart from Alamsyah's relative success in repairing the image of Indonesia at the international level, the discourse on the threat of Christian missions in Indonesia both at the international and national levels did not recede. The Islamic Foundation in Leicester, for instance, published at least three booklets on Christian missions in Indonesia, two of them by a German Muslim convert, Ahmad von Denffer, published in 1981, and another by an Indonesian author, Rifyal Ka'bah, published in $1985 .{ }^{120}$ In this regard, it is interesting to know how the latter sees the decrees. As has been mentioned above, in 1979 the Islamic Foundation published the work of Ahmad von Denffer explaining the controversy over the decrees and translating them into English. After some years following the issue of the decrees, in his work, Rifyal Ka'bah said, "according to a Christian source, the two decrees remain on the books, and only a few foreign missionaries have been forced to leave the country." ${ }^{121}$

In fact, from the very beginning, there is an indication that the Muslims were not sure about the effectiveness of the decrees. In his talks to the Muslims during the controversies over the decrees in 1978 Mohammad Natsir said that the Muslim groups should participate and not totally rely on the Government to secure the application of the decrees. ${ }^{122}$ Natsir's warning was not entirely unrealistic because the decrees were to be loosely implemented by the Government. In subsequent years, the Muslim groups, especially the reformists, recorded many cases related to the practices of Christian missions that, in their opinion, broke the regulations of the decrees and the Government did not pay serious attention to them. ${ }^{123}$ In his recent work, a Christian author, Jan Aritonang, also acknowledged the loose application of the decrees. ${ }^{124}$ It should be noted, however, that the loose application of the decrees was not only because of the indifferent attitude of the Government, but also because the decrees do not have full legal force. This has been the main reason why some of the Muslims concerned with Christianisation have demanded that the decrees should 
be elevated to the level of law ratified by Parliament, and Alamsyah also suggested the same idea. ${ }^{125}$

Despite the loose application, what was the impact of the decrees on religious groups, especially the Christians? It seems that the effect of the regulation on foreign missionaries was almost immediate. In November 1979 , the secretary of the MAWI, Leo Sukoto, explained to the press that 400 out of 1000 foreign Catholic missionaries were ready to apply for Indonesian citizenship. ${ }^{126}$ Perhaps, this was the most possible step to take by the Catholic Church at that time: to change the formal status of the foreign missionaries instead of replacing them with indigenous Indonesians. According to Steenbrink, the application for citizenship was more successful than before but at the same time, visa applications for new workers had to face more difficulties than before. ${ }^{127}$ In contrast, the Protestant Churches of the DGI generally did not have the same problem because they had been mostly run by Indonesians, even though to carry out the projects of social services and development, they were still financially dependent on foreign funding. ${ }^{128}$ Despite the regulation, to my knowledge, there had been no serious obstacle for the churches to receive financial foreign aid, particularly for development (pembangunan) reasons.

What was the effect of the regulation on religious propagation? Perhaps, one way to answer this question is to see what was not covered in the DDII's accounts of Christianisation in the period after the decrees. Besides covering a large number of cases related to the alleged abuses of social services for proselytism by the Christians, the accounts hardly mention doorto-door visiting. Given the extreme sensitivity of the DDII to missionary activities, the absence of door-to-door visits in the accounts could be an indication of the effect of the decree. ${ }^{129}$ In 1984, the Government banned all publications of the Children of God sect, but there is no clear indication that the ban was one of the results of the application of the decree as Steenbrink assumed. ${ }^{130}$

\section{Muslim Opposition to Common Christmas Celebration}

On one of his morning Islamic lectures (kuliyah subuh) on the Radio of the Republic of Indonesia (RRI) in 1974, HAMKA received a question from one of his listeners: what was the appropriate attitude of Muslims if they were invited to celebrate Christmas by their Christian neighbours? Due to the lack of time, HAMKA could not answer the question directly on the RRI, but later he had a written answer to the question published in his magazine, 
Panji Masyarakat. In his answer, HAMKA explained that it was acceptable for Muslims to say "Merry Christmas," to Christian neighbours as an expression of religious tolerance, but they were not allowed to participate in the celebration itself. He compared Christmas with 'Idul Fitri for the Muslims: the Christians often sent "Happy Idul Fitri" cards to their Muslim friends but never participated in the Idul Fitri prayer in the mosque or square. For HAMKA, the most fundamental reason why a Muslim is not allowed to participate in a Christmas celebration is the theological belief behind Christmas that contradicts the Islamic fundamental faith ('aqidah). For the Christians, Jesus is the Son of God crucified to save sinful human beings; while for Muslims Jesus is only a human being who happened to be one of the prophets sent by God. In other words, to maintain the purity of faith, a Muslim is not allowed to participate in a Christmas celebration. It seems for him, the prohibited participation includes not only attendance but also to be a member of the organizing committee of the celebration. HAMKA also explained that, even for the celebration of the birth of the Prophet Muhammad, there had been controversies among the Islamic scholars. HAMKA quoted Ibn Taymiyah who said that the celebration of the birth of the Prophet is a religious innovation (bid'a) that was never carried out by the pious early generation of Islam. In Indonesia, according to HAMKA, the Islamic reformist group, Persatuan Islam, followed Ibn Taymiyah's view, while another group, Muhammadiyah could accept the celebration insofar there was no heterodox veneration of the Prophet in the celebration. Accordingly, HAMKA argued, if to maintain the purity of Islamic faith certain Islamic scholars prohibit Muslims from celebrating the birth of their own Prophet, then they must be forbidden to celebrate Christmas because its underlying belief contradict that of Islam. ${ }^{131}$ HAMKA eventually concluded that, if a Muslim participates in a Christmas celebration, then there are only two possibilities: (1) the Muslim is a nominal Muslim who does not understand the teachings of Islam; (2) there is a powerful Christian who can utilize his or her power to force Muslims to participate in the celebration under the pretext of Pancasila and "if this successfully works, they will make propaganda abroad that the influence of Christianity in Indonesia is going deeper. Therefore, new aid will come repeatedly."132

\section{MUI's fatwa on Common Christmas Celebration}

The above 1974 fatwa of HAMKA on Muslim participation in Christmas celebration did not trigger any controversy at all. In 1975, the Indonesian Council of Ulama (MUI) was established and HAMKA was appointed to be its first general chairman. ${ }^{133}$ About five years later, on 7 March 1981, the 
MUI issued a fatwa on the same matter. This fatwa was more elaborate and argumentative than that of HAMKA, but the conclusion was similar. ${ }^{134}$ It was mentioned in the fatwa that the MUI was concerned with some Muslims who had recently participated in Christmas celebration because of their wrong assumption that Christmas celebration and the celebration of the birth of the prophet Muhammad were the same. The fatwa was, therefore, aimed at guiding Muslims to the right religious path. According to the fatwa, Muslims are allowed to cooperate with non-Muslims on worldly affairs but not to mix their belief with that of non-Muslims. In view of that, some Qur'anic verses were quoted to explain that for Muslims, Jesus is only a prophet and that the Christian belief in the Incarnation and the Trinity is not acceptable. It was argued that Christmas celebration cannot be separated from the Christian belief in the nature of Jesus and therefore to participate in the celebration for a Muslim implies or at least can lead to syncretism and impurity of the Muslim belief.

But, was it possible to participate in the celebration without harming one's Islamic faith? Perhaps, to anticipate this question, the fatwa refers to the idea of shubha, something that cannot be clearly identified as religiously lawful or unlawful, a grey area between the two. Because it is an unclear area, if one enters it, one may enter the forbidden part. It is better for a Muslim, therefore, to avoid entering that area because according to a hadith: "anybody falls into a shubha, falls into a religiously forbidden action (harām)." In addition, an Islamic legal maxim was also quoted: "the prevention of harms should be given a priority over the search for benefits," (dar' al-mafäsid muqaddam 'alā jalb al-masālih). Perhaps, this legal maxim was quoted to argue against the arguments that there are good things if a Muslim participates in a Christmas celebration. The fatwa was concluded with an assertion that it is harām for Muslims to participate in Christmas celebration.

Unlike HAMKA's fatwa in 1974, the MUI's fatwa soon triggered tensions, especially between the MUI and the Government. There were at least two interrelated reasons why the Government was unhappy with the fatwa. First, it was worried about the rigid and inflexible stipulation of the fatwa that might disturb relations between Muslims, Christians and the Government. Second, the Government was annoyed by the unexpected circulation of the fatwa in society. According to Syukri Ghozali and E.Z Muttaqin, the chairmen of the MUI, besides the request of the Islamic community, the fatwa was originally requested by the Minister of Religion for internal use as a matter to be discussed with other religious groups before a pub- 
lic policy was made. Unfortunately, the fatwa leaked out to the public and naturally the Minister was angry. ${ }^{135}$ On 27 March, the MUI sent the fatwa to its branches in the provinces throughout Indonesia. The fatwa was also published in Buletin Majlis Ulama No. 3 (April, 1981) that was only printed in 300 copies. The fatwa, however, reached many people, including journalists. In a meeting between Minister Alamsyah and the leaders of the MUI on 23 April 1981, the Minister explained that he felt pushed into a corner by the circulation of the fatwa and therefore would like to resign. In response to Alamsyah's remarks, HAMKA said, "It is illogical for the Minister to resign. I am the one who is responsible for the circulation of the fatwa, therefore, I will resign." ${ }^{136}$ On 5 May 1981, the national daily Pelita, published the fatwa, but the next day, the same newspaper published a decree - dated 30 April 1981 and signed by HAMKA and the General Secretary of the MUI, Burhani Tjokrohandoko - explaining that, based on the consultation with the Minister of Religion, the MUI decided to withdraw the fatwa from circulation. It was also explained in the same letter that a Muslim was only prohibited from participating in ritual practices of a Christmas celebration. ${ }^{137}$

The decree was probably a compromise between the Government and the MUI. Nevertheless, it triggered some questions in society, especially among Muslims. Did the decree mean that the MUI withdrew its own fatwa? The answer could be positive because in the decree, only participation in ritual aspects of the Christmas celebration was prohibited, while in the MUI's fatwa the prohibition seems to be absolute. Because many questions emerged concerning the decree and its relation to the status of the fatwa, HAMKA made a press statement - dated 7 May 1981 and published in some national newspapers - in which he explained that the decree only withdrew the circulation, not the validity of the fatwa. ${ }^{138}$ Following the press release, HAMKA explained in an article that the fatwa was quite reliable because it was produced by the ulama from different Islamic organizations in the country. The problem was, he said, that the Minister of Religion expected it only for Government's information, not for the public. According to HAMKA, although the Government had the power to prevent the circulation of the fatwa, it could not invalidate the fatwa itself. He also explained that, based on some information from the Christians, Christmas celebration was a ritual practice. This was in line, he said, with the attitudes of the Ministers of Religion in the past to assign only Christian officials to attend Christmas celebrations. ${ }^{139}$

Thus, by the explanation, HAMKA clearly reaffirmed the absolute prohibition stipulated by the fatwa without directly invalidating the decree. 
This also indicates that HAMKA could not cooperate with the Government anymore. Accordingly, on 19 May 1981, he publicly declared his resignation from the chairmanship of the MUI. But, why should he make a compromise if he was ready to resign? In his letter of resignation read in a closed meeting of the MUI, HAMKA explained that the MUI was still needed in Indonesia and through the compromise he wanted to secure the existence of the MUI. ${ }^{140}$

\section{Responses to the Controversy of the Fatwa}

There were at least two important issues discussed among the Muslims following the conflict between the Government and the MUI. The first was to question the independence and role of the MUI in relation to the Government. The MUI was created by the Government in 1975 as an organization representing different leaders (usually not the top leaders) of the existing Islamic organizations in the country. There was unwillingness among the ulama to accept the Government's proposal, but they finally agreed, hoping that the MUI could function as a bridge between the Government and the Islamic community. ${ }^{141}$ In an article written a few days after his resignation, HAMKA explained that his involvement in the MUI was based on a sincere intention to serve Muslims and the country. Therefore, he said, when he was asked to be the General Chairman of the MUI in 1975, he proposed one condition: he would not be given a salary and pension by the Government. He realized, he said, the General Chairman of the MUI was not the same as muftis in Islamic countries who were paid by the Government. By this explanation, HAMKA probably wanted to show his relative independence from the Government. ${ }^{142}$ Indeed, according to the reformist Muslim leader, Mohammad Roem, HAMKA's reluctance to receive a Government salary was his political strategy to assert that an Islamic scholar could not be bought. ${ }^{143}$ This selfassertion was also indicated by another article of HAMKA after his resignation. He wrote a story of Imam Anas Ibn Mālik (d.795), the founder of one of the four Sunni schools of law. The story was about the attitude of the Imam to the ruler (khalifa) of the Abbasid Dynasty who invited him to be the mufti in Baghdad and asked for his permission to make his work, al-Muwatta, the second authoritative religious text after the Qur'ān and therefore, its copies would be multiplied and distributed to the regions ruled by the dynasty. The Imam refused both offers and decided to stay and teach in Medina to his death. For HAMKA, this was an ideal example of an Islamic scholar's relationship to a ruler. He said, "if we read the biographies of Islamic scholars, we would be embarrassed to be called an Islamic scholar, because we are too far from that ideal." ${ }^{144}$ As has been said, despite his concerns with the independ- 
ence of the ulama, HAMKA and some others like him still hoped that the MUI could function better in the future. ${ }^{145}$ HAMKA passed away just about two months after his resignation. If he had lived longer, he would have been annoyed to witness some cases in which the MUI could not avoid but to be silent if not a legitimising voice for the Government's interests. ${ }^{146}$ In fact, the fatwa on common Christmas celebrations was the only case in which the MUI was opposed to the Government during the New Order. ${ }^{147}$

The second Muslim discussion was on the MUI's fatwa itself. There were various criticisms of the fatwa during the controversy and most of them based on socio-political arguments, rather than scriptural or religious arguments. It should be noted here that the fatwa was also a response to a social phenomenon, namely, the growing practice of celebrating common Christmas celebration (Natal Bersama), especially at Christian schools and Government offices. This common celebration did not only include the Catholics and the Protestants, but also the Muslims. It was reported in certain media that some Muslim students at certain Christian schools were obliged to participate in Christmas celebrations in various ways: from giving financial support and singing religious songs to acting in a play as Mary, Jesus etc. during the celebration. Some Government offices also often organized common Christmas celebrations with non-Christians in those offices were involved. ${ }^{148}$ It was also not uncommon that the President, Ministers and other high-ranking officials were invited to come to Christmas celebrations, even though they were Muslims. For the MUI, this growing culture would lead to a negative impact on Muslim faith and therefore, could not be tolerated. In this regard, the MUI's fatwa can be seen as an absolute opposition to the existing social phenomenon.

In contrast, for Minister Alamsyah, the MUI's fatwa was too rigid by ignoring the socio-political reality of Indonesia. He said, we should remember that Indonesia is a religiously plural society; and to attend a religious celebration of another religion was a positive act to enhance the unity and integrity of the nation. He also argued that one could maintain one's religious faith and at the same time participate in a religious celebration of another religion but only in non-ritual aspects of the celebration. Samudi Abdullah, a Muslim author, responded rather positively to Alamsyah's view. He tried to find a compromise between Alamsyah's idea and the MUI's fatwa. For him, what was prohibited in the fatwa was participation not attendance at a Christmas celebration. For him, the participation included singing carols, dancing and praying, while attendance means: "just sit, keep silent and eat if a meal is offered." ${ }^{149}$ Nonetheless, to draw a clear distinction between 
the ritual and non-ritual was not as easy as a Muslim like Samudi expected. S.A.E Nababan, the General Secretary of the DGI, explained that for Protestants, the ritual and non-ritual in a Christmas celebration could not be separated. In contrast, J. Riberu of the MAWI explained that for the Catholics, it was a ritual or cult only if there was a Eucharist, that is, a priest offering a Mass. Beyond that, including burning candles, was not a cult. ${ }^{150}$

Another criticism of the fatwa came from Abdurrahman Wahid who was a prominent columnist at that time. In his column, he covered both issues: the position and authority of the MUI and the nature of the fatwa. For him, the MUI was created to be no more than a mediator between the Government and the Islamic community and this was the basic problem for the MUI. Because MUI's leaders were appointed by the Government, not by the Islamic community, its authority was unclear. He asked, if the MUI "was intended to be able to formulate a framework of decision making by itself, why did the top leaders of the existing Islamic organizations not become representatives in it?" With regard to the second issue, Abdurrahman Wahid said that the inflexible nature of the fatwa was a result of religious thought based on absolute postulates. It would be unfortunate, he said, if other religious groups also had the same exclusive view and consequently a Muslim who wanted to participate in a Christmas celebration should go secretly (because he or she was afraid of the MUI) but when the Muslim arrived at the place of the celebration, he or she would be expelled by the Christians! Abdurrahman Wahid eventually suggested, instead of dealing with the Christmas issue, it was better for the MUI to concentrate on more fundamental problems of society such as how Islam could help fight against poverty and ignorance; and the answer to this question should be detailed and concrete. ${ }^{151}$

Abdurrahman Wahid's criticism of the fatwa, no matter how strong it was, did not provide clear alternative religious arguments, nor direct responses to the social issues described by the proponents of the fatwa. ${ }^{152}$ This was the reason why the criticism did not force the proponents of the fatwa to develop new arguments. For instance, Hasan Basri, one of the MUI's chairmen, said that Abdurrahman Wahid did not understand the problem. Hasan Basri claimed that there had been some cases in certain regions where Muslims were invited and even forced to participate in a Christmas celebration. He said, as a response to this phenomenon, the fatwa was made to guard the purity of Muslim belief. ${ }^{153}$ Similarly, Iqbal Abdurrauf Saimima said that the fatwa was not about religious absolutism, but to guard a fundamental belief of Islam. He then referred to the statement of S.A.E Nababan of the 
DGI who said that in a Christmas celebration, the Protestants did not separate the ritual and non-ritual aspects. Finally, Saimima argued that Abdurrahman Wahid's suggestion that the MUI should provide detailed and concrete answers to the social problems of poverty and ignorance went too far because MUI was an organization of religious scholars, not technocrats. ${ }^{154}$

\section{Alamsyah's Circular on the Celebration of Religious Days}

Apart from the Muslim polemics on the fatwa, Minister Alamsyah wanted to proceed with his plan to talk to the leaders of all religious groups about the issue under a more general theme: "celebrations of religious feast days." This issue was then discussed in the Wadah Musyawarah Antar Umat Beragama (Forum for Inter-religious Consultation), a surrogate of the Badan Konsultasi Antar Agama (Body of Inter-religious Consultation) of 1967 that had no noticeable activities after its establishment. Since May 1979, Alamsyah had tried to revive the 1967 body through a series of discussions between the Government and the representatives of five recognized religions and about one year later, on 30 June 1980, the Wadah Musyawarah was finally established. ${ }^{155}$ Alamsyah then urged the Wadah Musyawarah to discuss the above issue and after several preliminary meetings, on 25 August 1981, all religious representatives in the Forum signed an inter-religious decree on the celebrations of religious feast days.

There are some important points stated in the decree, but as a result of negotiation and compromise, sometimes we may find unclear wording or an ambiguous meaning of a sentence. It was stated that, "the celebrations of religious feast days are basically held and attended by the followers of the religion in question, but it is normal if a follower of another religion respects them (turut menghormati) according to the principles of familial, neighbourly and cooperative relations, as far as it does not contradict the teachings of one's own religion." The word 'respect' was likely chosen as a compromise between those who allowed one's participation and those who did not. Another crucial point in the decree was that every teacher "is urged to equip him/herself with religious knowledge in order to ensure that the spirit of harmony among students would be established, as far as it does not reduce their respective religious convictions and beliefs." Perhaps, this statement was also a compromise between the Muslim representatives who wanted to prevent Muslim students at Christian schools from being involved in any Christian religious feast days and the Christian representatives who tried to find a more moderate solution. Last but not least, there are two recommendations mentioned in the decree, one for the Government offi- 
cials and another for the leaders of social institutions. It is suggested in the decree that the Government should pay attention to the need of religious life for all religious groups based on the principle of justice. If a Government official attends a religious ceremony of another religion, he or she should be "passive but respectful." It was also suggested that leaders of social institutions should provide the same opportunities for the people under their leadership to celebrate their respective religious feast days. They were also urged neither to enforce nor to prohibit their subordinates from performing the celebration and not to mix the beliefs and practices of different religions in that celebration. ${ }^{156}$

\section{Christian Opposition to the Circular}

According to the constitution of the Wadah Musyawarah, any decision made in the organization is morally binding and at the same time it becomes a recommendation for the Government. ${ }^{157}$ Accordingly, only one week after the decree was signed by the representatives of religious groups, Minister Alamsyah sent a circular (surat edaran) on the celebrations of religious feast days, dated 2 September 1981, to the high officials of the state, including the ministers, the speaker of the Parliament, the Commander of Security and Order, the Police Chief Officer and the Governors of the provinces. ${ }^{158}$ The circular soon triggered controversy, especially between Minister Alamsyah, some members of the Parliament, the Islamic leaders and the Christian leaders of the DGI and the MAWI. The circular was controversial mainly because it tried to differentiate clearly between the ritual and non-ritual aspects of every celebration of religious feast days. For some of the Members of the Parliament and the Christians of the DGI and the MAWI, the circular was a kind of state intervention in internal religious affairs of the people and therefore, it was against the Constitution, the P4, and Soeharto's speech on the working session of the Department of Religion a few months before. In response to the criticism of the circular, on 23 September 1981, Alamsyah explained that in his consultation with the President one day before, the President suggested that the circular should not be linked with anything but the goal of achieving the unity and prosperity of the nation. He said that the circular was not intended to intervene in people's internal religious affairs, but to avoid the possible negative effects of religious celebrations that might endanger the integrity of the nation.

The DGI and the MAWI, however, were not satisfied with Alamsyah's explanation. In their basic thoughts delivered to the Government, the Christians explained that the circular did not have a legal and constitutional 
basis. They argued that the circular consciously or unconsciously opened the door for the application of the Jakarta Charter (in which the application of the shari'a is prescribed) and this "contradicts the New Order's commitment to the Pancasila and the Constitution of 1945 in a pure and consistent manner." In short, the circular disturbed the certainty of law within the state. "Accordingly, the circular directly destroys the prestige of the Government altogether because the character of its content is threatening (=enforcement of will) that really contradicts the basis of Pancasila Democracy."159

In addition, for them the circular did not have moral force, because it contradicted the inter-religious decree on the celebration of religious feast days. In this regard, they mentioned at least four important points: first, as has been quoted above, the decree said that, "the celebrations of religious days are basically held and attended by the followers of the religion in question..." In the circular, the word "only" is inserted as follows: "the celebration of religious feast days is basically only held and attended by the followers of the religion in question..." The circular, however, does not cut out the rest of the statement of the decree that opens the possibility for anybody to 'respect' a religious celebration of another religion. For the Christians, however, the insertion of the word 'only' really matters because it gives the impression as if the Government wanted to regulate and intervene in the rituals of religions. Second, it was mentioned in the decree that Government officials are urged to pay attention to the religious need of their subordinates based on the principle of justice and their presence in a religious celebration of another religion should be passive and respectful. This statement is different from that of the circular because the circular only mentions that "if a Government official attends a religious celebration..." and does not mention the recommendation that the Government should pay attention to the religious need etc. Third, it is mentioned in the decree that every teacher is "encouraged to equip him/ herself with religious knowledge..." while in the circular it is stated that, "those who are responsible for schools and teachers..." The difference is, while the decree only indicates the teacher as a profession, the circular clearly puts the teacher in a school context. This means, for Christians, the Minister of Religion infiltrated the area of authority of the Minister of Education. ${ }^{160}$ Finally, in the circular there is suggestion for those who want to perform a religious celebration to consult with the Government official and religious leaders of the region; this is not mentioned in the decree at all. For the Christians, this gives the impression that a Government official can regulate religious worship. ${ }^{161}$ 
Accordingly, in a meeting with Alamsyah on 26 September 1981, the Christians demanded that he arrange another session of the Wadah Musyawarah to discuss the issue. Alamsyah replied that he would invite the religious representatives to the session in two weeks. On the other hand, there had been support for Alamsyah's circular from some members of the Parliament and the leaders of Islamic organizations, including the reformists of the Muhammadiyah and the traditionalists of the Nahdlatul Ulama. 162 In response to the Christian demand, the MUI sent a letter to the Minister suggesting that such a session was not needed anymore. ${ }^{163}$ In the end, the session of Wadah Musyawarah never took place.

Rusydi, the chief editor of Panji Masyarakat, wrote an article as a response to the controversy about the circular. He said, the circular was a normal matter because it was the duty of the Government to protect the beliefs of the people. To support the circular, Rusydi then repeated the argument underlying the fatwa on Christmas celebration, i.e., according to the reports received by the MUI, some Muslims had been persuaded and even forced by the Christians - sometimes by using authority and power - to attend a Christmas celebration. In contrast, he wondered: Was there any case where "a Christian was forced to attend Idul Fitri or Friday prayer?"164 In line with Rusydi, one of the chairmen of the MUI, Hasan Basri said that there was nothing in the circular contradicting the inter-religious decree as the Christians claimed. For him, the circular was not an intervention in religious worship because it was just a guide (petunjuk) regarding celebration of religious feast days. Sulaiman Fadli, a Member of Parliament even suggested that the Government upgrade the status of the circular to be a joint decree of Ministers. For the Muslims, the Christian negative reactions were evidence that the Christians considered the circular as an obstacle to their interest to develop an under-cover Christianisation campaign through common Christmas celebrations. ${ }^{165}$

As the time for Christmas celebration in 1981 came closer, the DGI and MAWI sent a joint letter to the Commander of Security and Order, Soedomo, explaining that despite the controversies, both the DGI and MAWI would tell the Indonesian Christians that Christmas celebrations would be held as usual. ${ }^{166}$ The DGI and the MAWI also published a joint message for Christmas, in which they encouraged the Christians to be involved in contributing to future development of the country, establishing national harmony, living a humble life and respecting the dignity of human beings. Although this message did not touch directly on the current controversy, it tried to describe the birth of Jesus as both astonishing and frightening. King Herod 
was astonished and extremely frightened to hear the Good News (Matthew 2:2-3) because he felt that his position was threatened. In addition, many people refused the news of the Birth of Jesus that was certainly beyond reason (Philip 4:7), namely that "the Word became flesh and dwelt among us" (John 1:14). The message eventually asserted that Christmas is the Good News of the Birth of Jesus Christ, God, the Saviour for all nations (Luke: 2:1012)..$^{167}$

\section{3: The Fatwa Reintroduced}

As we can see throughout our discussion on this issue, the controversy seems to have hardened the existing mutual suspicions between the Muslims and the Christians. About twelve years later, in December 1993, the top leaders of four Islamic organizations, Achmad Azhar Basyir of the Muhammadiyah, Ilyas Ruchiyat of the Nahdlatul Ulama, Anwar Haryono of the DDII and Hasan Basri of the MUI, issued a joint statement on Christmas celebrations, not only addressed to the Muslims but also to the Christians and the mass media. For the Muslims in general, the statement suggested to them that they should be faithful to the MUI's fatwa of 1981 on common Christmas celebrations, while Muslims who happened to be Government officials should follow the guidance of Alamsyah's circular. The statement also recognised the right of Christians to celebrate Christmas, but at the same time it suggested that they should not make the Christmas an extravagant and glamorous show because this might trigger social jealousy and disturb the integrity of the nation. Finally, the statement also persuaded the mass media to be aware of the fact that the majority of their clients were Muslims; and in view of that, they were expected to produce a proportionate and appropriate coverage and presentation of Christmas celebrations. ${ }^{168}$

How did the Islamic leaders explain the joint statement? Hasan Basri and Ilyas Ruchiyat said that they primarily wanted to remind Muslims who might forget the fatwa or even did not know of it. This meant that, as HAMKA had previously explained, the validity of the fatwa was still maintained, although its circulation was withdrawn. Hasan Basri explained further that he hoped that Christians would also respect the Muslims by not inviting them to Christmas celebrations. On the other hand, he said that it was allowed for Muslim Government officials to attend a Christmas celebration but not to participate in its rituals. ${ }^{169}$ The Muslim leaders also explained that recently, Christmas had been celebrated in luxurious and glamorous ways by certain people and this should be avoided in order not to trigger social jealousy. Moreover, they were concerned with the printed and electronic 
media that often published and broadcast programmes during the period around Christmas that were not in line with Islamic ethics. ${ }^{170}$ The latter issue seems to refer to the increasing pop culture, especially in urban areas, to celebrate Christmas and the New Year (with more emphasis on the latter). But why did the statement appear in 1993, not before? Perhaps, this was related to the development of national politics. Since the 1990s, when his relations with certain influential army generals had become weak, Soeharto decided to be allied with the Islamic groups. ${ }^{171}$ Within this context, the Muslim leaders seemed to be confident enough to publish the joint statement.

If the Muslim leaders felt it necessary to remind Muslims about the fatwa, does it mean that it did not have any influence on society? As early as 1981 following the controversy on the fatwa and the circular, a Catholic magazine explained that the Christians became sceptical and feared to invite Muslims to Christmas celebrations, although it was previously a common practice. In a village in the Yogyakarta province, it was reported that a Catholic had passed away and the Muslim neighbours made a visit of condolence to the Catholic family. Surprisingly, when the priest came to perform the ceremony for the dead, all of the Muslims decided to leave because they did not want to participate in a Catholic ritual. According to the magazine, a similar case had never happened before in that village. ${ }^{172}$

\section{Conclusion}

The Muslim discourse on Christianisation apparently reflects what an observer said that the Islamic groups in Indonesia were a majority with a minority mentality. ${ }^{173}$ The political marginalisation of the Islamic groups during the first two decades of the New Order helped create this mentality, that is, the Muslim feeling of being weak in relation to a very powerful enemy, particularly the ruling army. In this context, within the discourse on Christianisation, the Muslims expressed their feeling of being weak and powerless as against the religious expansion of the apparently powerful Christians supported by foreign aid. The logic of this discourse is that the state should protect the weak through certain regulations. For the Government, to fulfil the Muslim demands was apparently much easier than making other more significant political concessions. Moreover, the Muslim demands run parallel with the New Order's attempts to put all social forces under state control and to neutralise anything considered harmful to political stability. On the other hand, based on religious freedom, the Christians consistently opposed the state policies. Partly due to the Christian protests, in practice, the regula- 
tions have been only loosely implemented by the state. The state's ambiguous position finally left the controversy unresolved and it could resurface at any time.

We have also seen that the discourse on Christianisation versus religious freedom was developed by Muslim and Christian leaders respectively through public media and meetings. Given their influential positions in their respective religious communities, we can be sure that the effect of the discourses on society was significant. In other words, the antagonistic discourses helped increase distrust and suspicion between the two religious groups. Likewise, although the MUI had no authority to force people to follow its fatwa prohibiting Muslims from attending Christmas celebration, some accounts suggested that it had actually influenced people.

Thus, after the fall of the New Order, the problems continued to develop. In 2002, there was a discussion in the Department of Religion on the possibility of having a Religious Harmony Law. This idea was nothing but an effort to enhance the legal status of the decrees to the position of law ratified by Parliament. In October 2004, a group of Muslims barricaded a Catholic school in Cileduk, Jakarta, because it was used illegally for religious services, and for the same reason, 23 churches have been closed by Muslims in West Java in September 2005. On the other hand, voices condemning these actions and arguing for religious freedom and tolerance were also heard among the Christians and some Muslims. The stage is not closed yet; and the game is not over. 


\section{Against The Islamic State}

In February 1969, in his paper for a consultation of the DGI, T. B. Simatupang wrote: "Many Christians are preoccupied with the fear of an Islamic state...Most of the Christians assume that in their hearts, many of the Muslims want to attain a situation similar to that of Egypt or Malaysia where Islam is given the position of a state religion, and that the position of nonMuslim citizens is not entirely equal to that of the Muslims." ${ }^{1}$ The Christian fear of being treated as second-class citizens under an Islamic state was certainly not new in the history of the Republic of Indonesia. On 18 August 1945, just one day after the Proclamation of Independence, the Christians in the East of Indonesia asserted that they would not join the newly born state if it would apply the shari'a (Islamic law).

Simatupang's statement, however, indicates that the fear of an Islamic State was quite strong among the Christians in the late 1960s. Indeed, after the political collapse of the Communists and Communism, the contest between the Islamic ideology and the nationalist ideology re-emerged. As discussed in Chapter 1, during the Guided Democracy (1959-1965), Soekarno tried to combine the three major ideologies of Nationalism, Islam and Communism in his NASAKOM (Nasionalis, Agama, Komunis). Now when the Communists were defeated and Communism was banned in 1966, the contesting ideologies that remained in place were only Islam and nationalism. By the absence of the Communists, the Islamic groups felt politically more confident to pursue their ideological ambition. However, the Islamic ideology had to face its enduring rival, namely secular nationalism whose proponents were not only secular civilian Muslims and Christians but also the ruling military. The reason was, in addition to the fact that the Islamic groups were now the most viable political rivals for the military, the latter also had bitter memories of war against the Darul Islam movement that had launched armed struggle against the central Government between 1948 and 1962 to establish an Islamic State. ${ }^{2}$ Thus, a clash between the proponents of Islamic ideology and secular nationalism could not be avoided.

Because the military was in favour of the nationalist ideology, the Christians naturally allied with the former. A certain group among the Catholics even cooperated very closely with the military, not simply in opposing the Islamic ideology but in creating and supporting the political policies 
of the regime in general. The Christian-military alliance eventually helped create bad relations between the Christians and the Muslims, particularly the ideologically Islamic-oriented Muslims. On the other hand, by the mid 1980s, the New Order regime had forced all social and political organisations to take the ideology of the nationalists, Pancasila, as their sole basis. Although most religious organisations, including Islamic and Christian, eventually accepted the regime's demand, some of their leaders developed certain interpretations of Pancasila that were different from, or opposed to, that of the regime. In the present chapter, I shall discuss these issues in some detail.

\section{Ideological Debates in the Early New Order}

The ideological debates in the early years of the New Order were closely connected with the history of the Indonesian constitution since the preparation for independence. As a realization of the Japanese promise of Indonesian independence, on 1 March 1945, the Investigating Committee for the Preparation of Independence called 'Dokuritsu Zyunbi Tyoosakai' or 'Badan Penyelidik Usaha Persiapan Kemerdekaan' (BPUPK) was established. Besides the Indonesians, a few of the Japanese also became members of the BPUPK. ${ }^{3}$ In May, June and July, the 62 members of the BPUPK had some sessions to discuss the drafts of the state basis (dasar negara) and constitution. On the issue of the state basis, one group proposed Islam to be the ideology, while another aspired to a nationalist and secular ideology. To find a compromise, a sub-committee consisting of nine members was set up to concentrate on the formulation of the draft of the state basis that was also intended to be the preamble of the constitution and the statement to proclaim Indonesian independence. On 22 June 1945, the sub-committee finished its work, which was to be called 'the Jakarta Charter.' In a plenary session of the BPUPK in July 1945, without much debate, the Jakarta Charter was accepted. One basic point of the Islamic group's proposal accommodated in the Charter was the obligation of the Muslim citizens to observe the shari'a. This point, later known as 'the seven words', ${ }^{4}$ was put as the first and one of the five principles of the basis for the state. ${ }^{5}$

On 17 August 1945, on behalf of the Indonesian people, Soekarno and Mohammad Hatta declared Indonesian Independence. Ten days before, on 7 August 1945, the Japanese military administration allowed the establishment of the Preparatory Committee of Indonesian Independence (Panitia Persiapan Kemerdekaan Indonesia, PPKI) whose members were wholly 
Indonesians. ${ }^{6}$ On 18 August, the PPKI discussed the draft of the Preamble (i.e., the Jakarta Charter) and the Constitution of 1945. It was on that day that 'the seven words' were dropped due to the objection of the Christians of the Eastern parts of Indonesia. As a substitute, the first principle of the state basis was decided to be 'Ketuhanan Yang Maha Esa." This formulation is untranslatable; and as we shall see, its translation and interpretation was to become the centre of Muslim-Christian debates. Moreover, this formulation was later considered to be the distinctive feature of the basis of the state called 'Pancasila' as opposed to the seven words of the Jakarta Charter. ${ }^{8}$

After the 1955 elections, on 10 November 1956, a Constituent Assembly was inaugurated. The major responsibility of the Assembly was to make a decision on the ideology as well as the constitution of the state. The debates on the ideological basis of the state took place from 11 November to 7 December 1957. There were three visions for such a basis: some of the parties wished to see Islam as the basis of the state, others Pancasila and yet another, social-economic justice. ${ }^{9}$ The first two views had more supporters than the last one and therefore a compromise between the two was necessary. However, neither the Islam nor the Pancasila bloc could achieve the required two-thirds majority, and attempts to reach a compromise also failed. The Government eventually offered a suggestion that the state should return to the Constitution of 1945. The Islamic groups could accept the Government's proposal on the condition that the 'Islamic words' of the Jakarta Charter were incorporated. The Pancasila bloc, however, could not accept this proposal and another deadlock was unavoidable. Partly because of the deadlock and partly because of the political circumstances outside the Assembly, with the support of the military, President Soekarno finally issued a Decree on 5 July 1959 in which he proclaimed the return to the Constitution of $1945 .^{10}$ To accommodate the Islamic groups, it is mentioned in the consideration of the Decree that "the Jakarta Charter, dated 22 June 1945, inspires the Constitution of 1945 and constitutes a coherent whole with the Constitution."11 On 22 July 1945 the decree was finally accepted by acclamation in the Parliament.

Soekarno's decree had become a tentative solution to the ideological conflict until the collapse of his regime. Up to early 1966, the ideological conflict between the proponents and opponents of the Islamic ideology had not yet resurfaced. In January 1966, on the occasion of the $40^{\text {th }}$ anniversary of the NU, there was a parade in which people expressed some slogans written on the banners demanding a return to the Jakarta Charter. During the NU's celebration, the Christians did not show openly their opposition to 
the Jakarta Charter, and they even participated in the celebration. Feillard records the participation of priests, nuns and students of Catholic schools in the NU parade. ${ }^{12}$ Likewise, Sinar Harapan reported that the Protestants contributed the traditional music called 'angklong' to the NU's anniversary celebration in West Java. ${ }^{13}$

The ideological tensions apparently occurred for the first time after the coup of September 1965, in the session of the Provisional People's Consultative Assembly (MPRS) in June and July 1966. As discussed in Chapter 1, in order to establish a constitutional legitimacy for the rising power of the army and the illegitimacy of the previous regime, particularly its Communist elements, the MPRS session took the idea of a pure application of Pancasila and the Constitution of 1945. For the Islamic groups, this idea opened the question of the position of the Jakarta Charter mentioned in Soekarno's decree of 1959. In other words, if the decree was the main reason for the constitutional position of Pancasila and the 1945 Constitution, while the decree somehow mentioned the Jakarta Charter, would the idea of a pure application also include the Jakarta Charter?

In this context, the memorandum of the Parliament (DPRGR), dated 9 June 1966, on the sources of Indonesian law that was ratified by the MPRS Decree No.XX/1966, dated 5 July 1966, may reflect the ideological battle in the legislative body. The underpinning idea of the memorandum was to determine the constitutional basis of all state decisions, so they could become a true application of Pancasila and the 1945 Constitution. In general, the memorandum reflects a compromise between the proponents of Pancasila and those of the Jakarta Charter. It is mentioned in the memorandum that Pancasila is the source of all legal sources, but at the same time, it was mentioned that, with reference to Soekarno's decree of 1959, the Jakarta Charter is considered to inspire the Constitution of 1945, and to make up one whole with it. It is also mentioned that: "The formulation of the Preamble of the 1945 Constitution was actually based on the spirit of the Jakarta Charter, and at the same time the Jakarta Charter was based on the spirit of Bung Karno's speech on 1 June 1945 that is now known as 'the Speech on the Birth of Pantja Sila'" Nonetheless, the decree also declares that the Preamble of the 1945 Constitution which contains the basis of the state (i.e., Pancasila) cannot be changed by anybody, even by People's Consultative Assembly (MPR), because to change the Preamble means "to dissolve the state." ${ }^{14}$ Thus, compared to the high status of Pancasila, the position of the Jakarta Charter was unclear if not very weak, but it is somehow still mentioned in this decree. 
The Debates on the Position of the Jakarta Charter (1968-1969)

The tensions between the opponents and the proponents of the Jakarta Charter occurred more sharply in the session of the Provisional People's Consultative Assembly (MPRS) in March 1968 in which the Islamic groups failed to include the Charter in the Mainlines of State Policies (GBHN) due to the opposition of the military, the Christians and the secular nationalists. After this MPRS session, we find several polemical writings on the Jakarta Charter by both sides. With regard to the views of the opponents, we shall concentrate here on the Christian writings that sometimes also refer to those of the Muslim secular nationalists.

In general, by contrast with the ideological debates in the Constituent Assembly in which both the proponents of the nationalist and Islamic ideology tried to show why their respective ideologies were the best, ${ }^{15}$ the debates during the early years of the New Order were much focused on the interpretation of historical facts. Both Muslims and Christians seem to agree on basic historical facts around the Jakarta Charter (more or less as has been described above) but they developed different interpretations of these historical events to support their respective positions, that is, the Muslims wanted to prove the significance of the Jakarta Charter and consequently of Islam in the state, while the Christians tried to leave out or minimize its significance in order to keep a religiously neutral position of the state.

We have mentioned that the seven words of the Jakarta Charter stipulating the application of the shari'a for Muslim citizens were dropped on 18 August 1945, just one day after the Proclamation of Independence. How did the Muslims interpret this event, especially in the late 1960s? First of all, the Muslims tried to show that the Proclamation of Independence was strongly related to the Jakarta Charter. In his speech to the anniversary celebration of the Jakarta Charter, June 1968, the traditionalist Muslim leader and Minister of Religion, Mohammad Dachlan, said that, "the Jakarta Charter was a step forward for Independence" that was to become "the mover and the source of the spirit of the struggle of the Indonesian nation to defend its Independence."16 With reference to Muhammad Yamin, a nationalist and one of the members of the sub-committee who made the Jakarta Charter, Dachlan argued further that the content of the Proclamation of Independence is in accordance with the statement in the Jakarta Charter, and that the Charter actually designated the closing of the movement for Indonesian Independence in the twentieth century. ${ }^{17}$ Mohammad Roem, the reformist Muslim leader argued further that the first sentence of the Proclamation was even taken from the Jakarta Charter. ${ }^{18}$ 
Dachlan's and Roem's arguments appear to imply that the Indonesian state declared on 17 August was a state based on the Jakarta Charter. For the Muslims, therefore, the eradication of the seven words by the next day was nothing but an unfair political move of the secular nationalists. In this respect, the prominent reformist Muslim leader, Prawoto Mangkusasmito, argued that the decision made in the PPKI session on 18 August 1945 was much less representative than the agreement made by the sub-committee of the BPUPK on 22 June 1945. In the sub-committee, four persons represented the Islamic groups (Abdoelkahar Moezakir, Agoes Salim, Abikoesno Tjokrosoerojo and Wachid Hasjim), and five persons represented the nationalist groups (Soekarno, Mohammad Hatta, Achmad Soebardjo, Mohammad Yamin and A.A. Maramis).

This 4:5 power-balance was almost the same as the result of the democratic elections of 1955. Later, the votes for and against the Jakarta Charter and the Pancasila in the Constituent Assembly reflected the 4:5 power-balance as well. In contrast, the members of the PPKI were 27 and only 3 of them representing the Islamic groups. In addition, during the lobbying arranged by Mohammad Hatta in the morning of 18 August 1945, none of the Islamic group's representatives who were previously involved in the sub-committee was present. Wachid Hasjim who was invited to the lobbying, could not come because he was on the way to Surabaya. ${ }^{19}$ The only representative of the Islamic groups in the lobbying was Ki Bagus Hadikusomo who was not a member of the sub-committee. In short, for Prawoto, the decision made on 18 August 1945 to drop the seven words was far from representing the political reality of the Indonesian people. ${ }^{20}$ The reformist Muslim leader, HAMKA, even made a sharper comment on this historical event. He argued that before the existence of the Jakarta Charter, the movement of the struggle for independence in Indonesia was divided into two groups: the Islamic and the nationalist groups and there was no mutual respect of either group. It was only after the compromise formulated in the Jakarta Charter that both groups agreed to unite. Nonetheless, he said, only one day after the goal was achieved, that is, the Proclamation of Independence, the nationalists left the Islamic group behind. For HAMKA, therefore, the eradication of the seven words on that day was nothing but a reflection of "dishonesty, if not cheating" of the nationalists. ${ }^{21}$

There is a remarkable contrast between the Muslim interpretations of the historical events in 1945 and those of the Christians. Following the failure of the Islamic groups to include the Jakarta Charter in the GBHN during the MPRS session of March 1968 mentioned above, the Catholic magazine, 
Peraba, published a series of articles criticising the arguments of the proponents of the Jakarta Charter, one of the articles was a statement by the Catholic Party, while the others were written by the editor of the magazine or secular nationalists. With regard to the events of 1945, with reference to an article written by Sajuti Melik, one of the former members of the PPKI, the Catholic Party argued that the Jakarta Charter never had any legal force in history because it was simply a draft of the Preamble of the 1945 Constitution. Sajuti Melik even said, (argued the Catholic Party further), that there was no hard evidence that the sub-committee of the BPUPK really signed the draft of the Preamble on 22 June 1945, and that it was only Mohammad Yamin who initially called this draft the Jakarta Charter. Thus, for the Catholic Party, because the Jakarta Charter was simply a draft, there was nothing wrong with PPKI's decision to drop the seven words. ${ }^{22}$ Moreover, for the editor of Peraba, the eradication of the seven words was very significant for the unity of the whole nation. Therefore, the editor argued, those who currently demanded the recognition of the Jakarta Charter were "against the unity and integrity of the nation." ${ }^{23}$ The editor also argued that the dropping of the seven words also indicated that the proclaimed state was never meant as an Islamic state; and on the contrary to the Muslim claim, the Proclamation of Independence had nothing to do with the Jakarta Charter. ${ }^{24}$ According to the history of Proclamation, argued the editor, Soekarno and Hatta were initially sceptical of making the Proclamation, until the youths forced them to do so. These youths, who did not want to cooperate with the Japanese colonisers, did not want Indonesian independence to be associated with the Japanese, and therefore they refused to use any word from the Jakarta Charter, which was made by the Japanese-sponsored BPUPK, to be included in the Proclamation. This historical account, for the Peraba editor, was clearly set out in an article by Adam Malik, one of the youths who took part in that very historical event. ${ }^{25}$

The second important historical event related to the Jakarta Charter was Soekarno's decree of 1959 in which it was stated that the Charter inspires the 1945 Constitution and constitutes a coherent whole with it. Like their view of the historical events of 1945, the Christians saw that Soekarno's decree of 1959 did not provide any legitimacy for the application of the Jakarta Charter. For the Catholic Party, there are some reasons why the position of the Jakarta Charter in the decree was insignificant. ${ }^{26}$ First, the statement that the Jakarta Charter inspires the 1945 Constitution is mentioned in the considerations not in the dictums of the decree. It is agreed that in any decree, only the dictums, not the considerations have a legal force to be 
implemented. Secondly, the statement that the Charter inspires the 1945 Constitution is preceded by a clause, "we are convinced that..." and 'we' here refers to President Soekarno. ${ }^{27}$ Thus, for the Catholic Party, the statement is in fact Soekarno's personal conviction, and therefore, the validity of this conviction is still questionable. Third, the meaning of the word 'inspires' (menjiwai) should be that the Preamble of the 1945 Constitution originates from the Jakarta Charter, minus the seven words. If the word 'inspires' means that the seven words should be taken into the Indonesian legal system, then the Jakarta Charter does not inspire but replaces the Preamble of the 1945 Constitution. Fourth, the statement of the decree that the Charter "constitutes a coherent whole" (merupakan suatu rangkaian kesatuan) with the 1945 Constitution should be understood as an historical description, namely that the 1945 Constitution was preceded by the Jakarta Charter and that the latter was preceded by Soekarno's speech on the birth of Pancasila. The MPRS decree No.XX/1966 mentioning the same chronology, for the Catholic Party, should be understood in the same way as an historical description. In short, the Jakarta Charter does not have any significant constitutional position but an historical one.

In contrast, the Muslims tried to show that Soekarno's decree of 1959 truly gives the Charter a significant constitutional position. Mohammad Dachlan argued that the two key statements in the decree: 'inspires' and 'constitutes a coherent whole with the constitution' clearly indicate that the Charter is a valid legal source in the country and "one does not need to be a lawyer or professor to understand this." ${ }^{28}$ On the other hand, HAMKA mentioned the views of the leading professors of law and 'secular' intellectuals such as Soepomo, Muhammad Yamin and Hazairin who recognized the high political and juridical status of the Jakarta Charter. ${ }^{29}$ Another argument is to revisit the history of the decree. Prawoto argued that the wording in the decree for the Charter was clearly a response to the deadlock in the Constituent Assembly in which neither the Islamic nor the nationalist bloc could achieve the required two-thirds majority. The acceptance of the decree by Parliament on 13 July 1959, for Prawoto, indicates that both the Islamic and the nationalist blocs somehow felt that their respective aspirations were accommodated in the decree. ${ }^{30}$ In line with Prawoto, Dachlan and HAMKA tried to present some historical accounts of the political negotiation in the Constituent Assembly. HAMKA mentioned Soekarno's speech in the Constituent Assembly entitled "Res Publica, Sekali Lagi Res Publica" in which Soekarno wanted to include the Jakarta Charter for the sake of national unity and development. ${ }^{31}$ Moreover, both Prawoto and Dachlan mentioned 
the draft of the Bandung Charter proposed by the Government to end the deadlock in the Constituent Assembly. In the draft it is mentioned that the Jakarta Charter is a historical document that inspires the Preamble of the 1945 Constitution. In response to this draft, Ahmad Sjaichu, the politician of the NU party, asked the Government whether the statement on the Jakarta Charter was simply to recognise its historical position or whether it also influenced the article 29 of the 1945 Constitution concerning religion. The Government's answer was that the Jakarta Charter did not only influence the Preamble of the Constitution of 1945, but also the article 29. ${ }^{32}$ Despite the fact that the draft of the Bandung Charter was finally not accepted by the Constituent Assembly, for the Muslims, it gives a picture of the political negotiations that eventually led Soekarno to issue the decree. ${ }^{33}$

Besides the 'historical' arguments, the Muslims also responded to the view that the position of the Jakarta Charter was insignificant because it is mentioned in the considerations not in the dictums of the decree, and that it is simply Soekarno's personal conviction. Against these arguments, a certain Abdullah Sjahir said that any decree should be understood as a coherent whole. In other words, although the Charter is mentioned in the preliminary considerations, not in the dictums, it has a legal force. Moreover, the statement on the Jakarta Charter in the decree is obviously not Soekarno's personal conviction because he made it as the President of Indonesia. ${ }^{34}$ Finally, in contrast with the Christian view, for Dachlan, the memorandum of the DPRGR on the Indonesian legal sources ratified by the decree of the MPRS No. XX/1966 also includes the Jakarta Charter as a legal source. ${ }^{35}$

We have seen that in their 'historical' arguments, the Muslims tried to show that the Jakarta Charter was a political compromise between the Islamic and the nationalist blocs and that this compromise was taken because each bloc was almost equally strong (4:5 power balance), both in the sub-committee of the BPUPK and in the Constituent Assembly. If we look at the political context of the late 1960s, this proportionalist argument was probably an implicit criticism of the New Order regime that did not accommodate proportionally the Islamic groups in the political arena. If HAMKA wrote that the dropping of the seven words of the Jakarta Charter on 18 August 1945 was dishonesty if not cheating of the nationalists, this statement was somehow also directed at the nationalists, particularly the military, in 1968, the time when HAMKA wrote it.

On the other hand, for the Christians, to accept the Jakarta Charter was nothing but surrender to an Islamic state in which they would be discriminated against. In other words, while the Islamic groups considered the 
Jakarta Charter as a compromise between the idea of an Islamic state and a secular one, for the Christians the compromise was only found in Pancasila that still designates a religious nature for the state, but not a specifically Islamic religious nature. Therefore, like the military and the Muslim secular nationalists, the Christians emphasized that the acceptance of the Pancasila was necessary to maintain the unity and integrity of the state; and in contrast to the Muslim proportionalist arguments, the Christians politically preferred to argue for the shared national identity in which all other identities, including religious ones, melted away. The Christian fear of the Islamic state in this period was justified by the fact that not only were the Muslim leaders in Jakarta openly struggled for a constitutional recognition of the Jakarta Charter but also some regional Governments were trying to apply the shari'a in their respective areas. ${ }^{36}$

The Christians, however, had strong political allies to oppose the Jakarta Charter. As noted above, in the MPRS session of March 1968, the Islamic parties proposed that the Jakarta Charter be included in the GBHN, but the military, the Christians and the secular nationalists disagreed. The debate eventually came to a deadlock that "resulted in retention of the status quo, a situation which left secular nationalists pleased at the continued semi-separation of mosque and state and left Islamic organizations hurt and angry." ${ }^{37}$ Likewise, in June 1968, an association of Muslim youths and students called 'PMPI' (Pemuda Mahasiswa dan Pelajar Islam) ${ }^{38}$ wanted to celebrate the anniversary of the Jakarta Charter, but the Jakarta Military Commander did not give a letter of permission to carry out the celebration, and the Government asked the civil servants not to make any statement on the Jakarta Charter and discouraged them from participating in the celebration. By the next year (1969), Kiblat reported that the Military Commander of Tanjung Pura Division based in Pontianak, Colonel Soemadi, forbade any group to celebrate the anniversary of the Jakarta Charter because for him the ideology of the state was already clear in the Preamble of the Constitution of 1945 . $^{39}$

Being in alliance with the ruling military, by 1968 the Christians, particularly the Catholics, apparently became more confident in attacking the proponents of the Jakarta Charter. Articles and cartoons published in Peraba in this period clearly demonstrate this point. For instance, a report describes how "Muslim girls with head covering and sandals" applauded Mohammad Natsir when the latter mentioned the Jakarta Charter in his speech in Gadjah Mada University. ${ }^{40}$ The overall report gives the impression that the supporters of the Jakarta Charter were stupid Muslim villagers mobilised by the 
Muslim leaders. Another example is a cartoon in which a stubborn Muslim man wants to impose his own opinion on the Jakarta Charter saying: "We don't care about the opinions of others because we are always right." ${ }^{41}$ This cartoon seems to indicate that it was only the Islamic groups who wanted to impose their own opinion on the others, not the opposite.

On the other hand, the regime's policy to suppress the Islamic ideological discourse (particularly on the Jakarta Charter) in the following years helped increase the Muslim disappointment. Indeed, this policy was later criticised by both HAMKA who clearly supported the Jakarta Charter, and Abdurrahman Wahid who preferred Pancasila. ${ }^{42}$ For Abdurrahman Wahid, the policy of prohibiting people from discussing the Jakarta Charter would hinder the healthy process of achieving a consensus on the national ideology.

In addition to the opposition of the military, the Christians and secular nationalists, another problem faced by the Islamic groups regarding the Jakarta Charter was the difficulty of defining what actually the obligation of the Muslim citizens to perform the shari'a was. It was reported that in April 1968 , besides giving a warning to the public not to endanger political stability, Soeharto demanded that the Islamic leaders explain what really the meaning of "the Jakarta Charter that inspires the Constitution of 1945" was, in order to erase the suspicions of those who opposed it. ${ }^{43}$ In this context, Feillard notes that, on 8 April 1968, Soeharto asked the leaders of the Islamic parties (NU, Parmusi, PSII and Perti) to make an agreement on the definition of the position of the Jakarta Charter. For this purpose, a committee led by Prawoto Mangkusasmito was established. The committee, however, eventually did not reach their goal and the military asked them to stop. ${ }^{44}$ Likewise, from mid-1968 to early 1969, there was a discussion among the Islamic groups to hold a Congress of Islamic Community. The congress was intended to be the occasion for the Islamic groups to talk about the possibility of integrating their forces, and to discuss the concretisation of the Jakarta Charter. The Government, however, did not support the Congress, and after a series of postponements, it finally never took place. ${ }^{45}$

If we look at some views of the Muslims on the application of the shari'a in 1968-1969, we find that there was no clear consensus among them. The prominent Muslim intellectual, Hasbullah Bakry wrote that when the Muslims talked about the shari'a, they often referred to Islamic law contained in the classical books of the four Sunni schools. For him, many ideas in the books were outdated because they were written centuries ago in a very different socio-political context. Therefore, he said, the Muslims needed the 


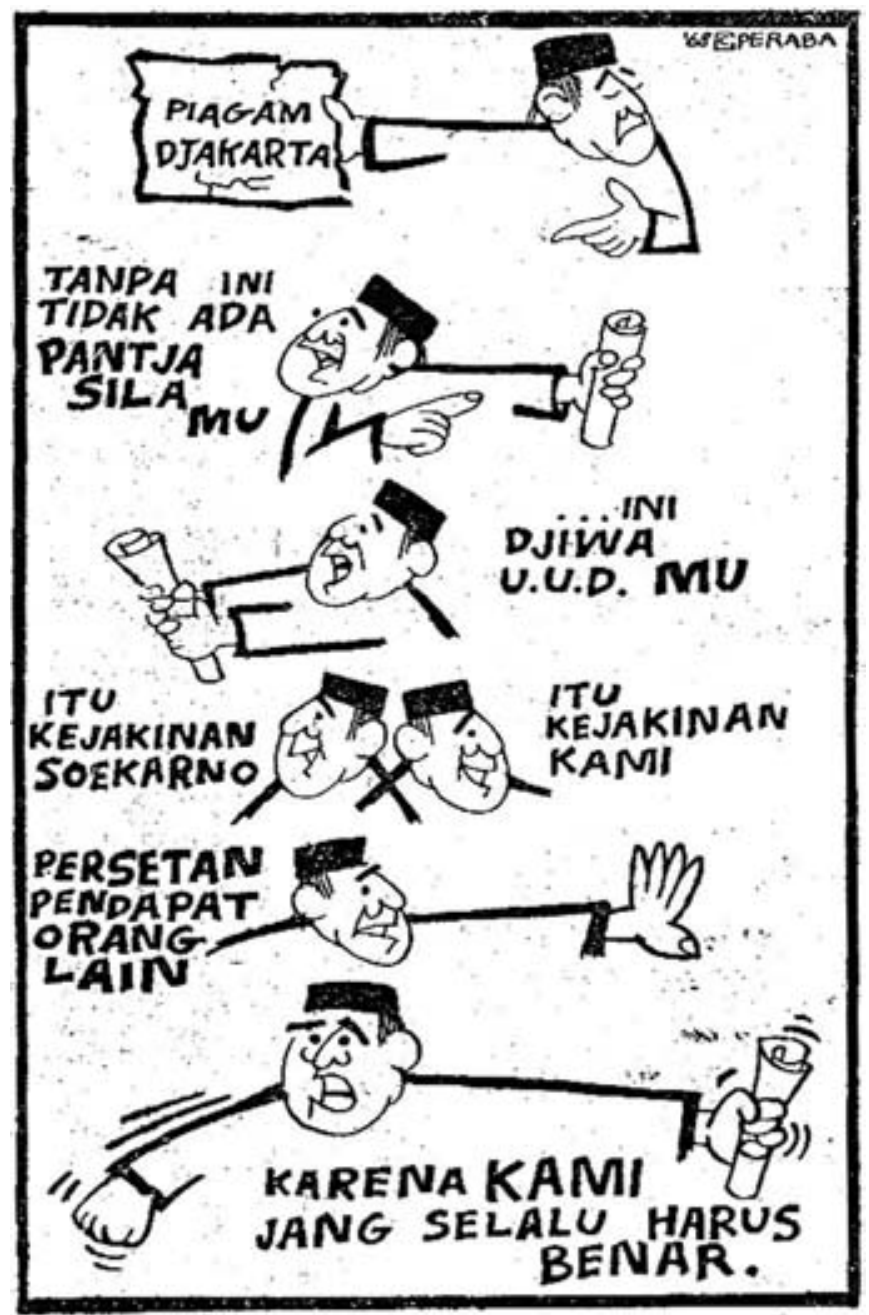

Cartoon from the Catholic magazine, Peraba (III July, 1968), 7. The cartoon shows a stubborn Muslim man wants to impose his opinion on the Jakarta Charter.

- He said: "The Jakarta Charter"

- "Without this, your Pancasila does not exist"

- "This is the spirit of your constitution"

- His opponent said: "That is Soekarno's conviction"

- He replied: "That is our conviction."

- "We do not care about the opinion of others."

- "Because we are always right." 
fresh and critical thinking of their own religious tradition to create concrete examples of Islamic law suitable to the Indonesian situation where non-Muslims also lived. ${ }^{46}$ However, apart from identifying the problem, Bakry himself did not explain what kind of Islamic law that was, in his opinion, suitable to the Indonesian situation. The other Muslim intellectuals tried to define more explicitly what the application of the shari'a was. In his comment on the plan for the Congress above, Kasman Singodemidjo expected it could establish an Islamic Council that could play a major role in developing Islamic concepts of all aspects of life such as the issue of determining the beginning and end of Ramadan, Islamic civil and criminal law, distribution of Islamic alms (zakat), and the treasury of Baitul Mal. ${ }^{47}$ Mohammad Saleh Suaidy, a former Masyumi activist, said that for the late 1960s, the realization of the Jakarta Charter was: (1) to finalize the draft of the Islamic marriage law that was still in the Parliament; (2) to manage the collection and distribution of zakat; and if this worked well, then a draft of zakat law could be proposed to the Parliament; (3) to unify the curriculum of Islamic schools in the country; (4) to enhance the efficiency and coordination of Islamic da'wah; (5) to reactivate the Islamic Scientific Council (Majelis IImiah Islam) as an institution to develop important Islamic concepts. ${ }^{48}$

The Muslim leaders in various regions outside Java also had different understandings of the application of the shari'a. In his observation conducted in 1969 Donald K. Emmerson said that the Islamic leaders in Medan and Padang were more moderate than those of Aceh. In Medan and Padang, the Islamic leaders preferred to make da'wah in the sense of advising people to follow the shari'a rather than forcing them through regional Government's regulations. In Aceh, however, they considered both da'wah and regulation were important. For instance, the regional Government of Aceh issued a regulation that on every Friday, from the period of the prayer-call to the end of the prayer, all offices and shops had to be closed. In a sub-district called Djeunieb where the pilot project of the application of the shari'a was carried out, on Friday, the Government provided the list of those present to check who came to the mosque for prayer, and those who did not. If a man were absent without acceptable reason, he would be warned, then advised and finally excommunicated. Emmerson said that there were only a few cases where a citizen broke the regulation and none of them reached the level of excommunication. ${ }^{49}$ The regional Government of Polewali Mamasa district in South Sulawesi, besides obliging Muslim men to go for Friday prayer, also obliged the Christians to go to church on Sundays, and there was a prohibition of worshipping idols. ${ }^{50}$ In Bima, West Nusa Tenggara, part of the applica- 
tion of the shari'a was the prohibition of propagating non-Islamic religions and establishing their places of worship in Muslim areas. ${ }^{51}$

Nonetheless, like its policy of suppressing the Muslim discourse on the Jakarta Charter, the Central Government eventually forced the regional Governments to terminate their respective initiatives to apply the shari'a. In 1989, Amir Machmud said that when he was the Minister of Home Affairs (1973-1983) he ordered the regional Governments of Aceh, Riau, Jambi and West Nusa Tenggara to withdraw certain regional regulations based on the shari'a. ${ }^{52}$ On the other hand, although there was no more intensive debate on the Jakarta Charter than the one in the late 1960s during the New Order, as we shall see in Chapter 4, this controversial issue re-emerged in 1973 and 1989 during the controversy on the Marriage Bill and Religious Court Bill respectively.

\section{The Debates on Pancasila's 'Ketuhanan Yang Maha Esa'}

As has been noted, on 18 August 1945, the seven words of the Jakarta Charter were dropped and substituted by the phrase 'Yang Maha Esa', so the first principle of the state philosophy, Pancasila, became: 'Ketuhanan Yang Maha Esa.' This sentence is difficult to translate and became the centre of controversy. The first word 'Ketuhanan' consists of the word 'Tuhan' combined with a prefix 'ke' and a suffix 'an.' While the word 'Tuhan' means 'God' or 'Lord', the meaning of the word 'Ketuhanan' is not that clear. Some simply think that 'Tuhan' and 'Ketuhanan' have the same meaning, i.e., God, while others tried to differentiate them: if 'Tuhan' means 'God' or 'Lord', then 'Ketuhanan' means 'Godliness' or 'Lordship.' The rest of the words, 'Yang Maha Esa', are an adjective describing, or an attribute of, the 'Ketuhanan.' The word 'Yang' is a conjunction to indicate an adjective, and the adjective is 'Maha Esa.' The word 'Maha' is used to indicate greatness, while 'Esa' means 'One.' The problem is, how are we to translate and explain the combination of 'Ketuhanan' and 'Yang Maha Esa'? ${ }^{53}$ How did the Muslims and Christian translate them and why?

For the Muslims, the most important part of this principle of Pancasila is the attribute 'Yang Maha Esa' because, first, it substitutes for the seven words; and second, for them, it means the Islamic theological principle of monotheism, tawhid. By emphasizing this meaning, the Muslims tried to affirm the Islamic dimension of Pancasila. If we go back to the ideological debate discussed above, this Muslim interpretation of the first principle of the Pancasila can be seen as the third stage of their ideological struggle. The first is the idea to make Islam the ideology of the state and as we have seen, 
the nationalists opposed this idea. Second, because the first idea could not be accepted, the Muslims tried to make a compromise with the nationalists and the result was the seven words of the Jakarta Charter. However, the seven words did not stay long, as less than one month after its formulation, they were dropped. Finally, without the seven words, the Muslims tried to give an Islamic meaning to the Pancasila by interpreting 'Yang Maha Esa' as the Islamic theological concept of monotheism.

In contrast, the Christians tried to emphasize the neutrality of the state towards religious groups. They and the other nationalists basically preferred the secular idea of separation between religion and state, but because of the opposition of the Islamic groups, the former finally made a compromise. For the Christians and the other nationalists, the compromise is the neither/ nor concept of the state, that is, Indonesia is neither a secular state nor an Islamic state, but a 'Pancasila state' in which religious groups, not only the Islamic groups, can develop their religious life under the protection and support of the state. In this context, for the Christians, the word 'Ketuhanan' provides the possibility to interpret the first principle of Pancasila in terms of the religious pluralism in the country. The grey area between a secular and an Islamic state, however, is certainly difficult to define and frequently became an area of conflict. In other words, while the Muslims often tried to push the state towards more involvement in religious affairs, the Christians frequently attempted to push the state towards a more secular and neutral position.

The debate on the interpretation of the Pancasila had already started at least in the early 1950s, when different ideological orientations were prompted to gain political dominance in the country. In this respect, perhaps one of the best examples of the early Muslim interpretation of the Pancasila with the emphasis on the 'Yang Maha Esa' is a booklet written by HAMKA in 1952. ${ }^{54}$ The main argument of the book is that the 'Ketuhanan Yang Maha Esa' is the very foundation of Pancasila and the other four principles are based on and derived from it. For every Muslim, HAMKA argued, the "Ketuhanan Yang Maha Esa" cannot be but the Islamic theological concept of monotheism (tawhid). With the belief that the One God is the alpha and omega of all things in the universe, a Muslim will see and act in this world on the guidance of God. HAMKA went on to argue that the other principles of the Pancasila are acceptable to the Muslims because of their belief in the One and only God. Humanism is inherent in Islam because the corollary of the monotheistic concept of God is the oneness of humanity. Similarly, Islam contributes to the national unity because this religion transcends ethnic and 
cultural differences. Democracy is also important for Muslims because Islam affirms the principle of egalitarianism, and the Qur'an requires Muslims to have consultation (shūrā) to solve their social problems. Finally, Islam also pays attention to social justice because according to the Qur'an and the Hadith, someone is not considered a Muslim if he or she does not care about the weak and the needy people.

Most of the Christian interpreters of the Pancasila in this period also argued that the Ketuhanan Yang Maha Esa is the very foundation of the Pancasila. However, they cautiously interpreted it in such a way that religious freedom would be secured. For example, Helmut Rosin, a Protestant missionary of Swiss origin working in Indonesia, argued that Pancasila can be understood as an ideology to achieve freedom, welfare, happiness and peace. The belief in God to be the guiding principle, while the other four principles of humanism, national unity, democracy and social justice depend on it. This idea is in line with the Christian doctrine that God became a humble human being who was allied with the poor and the weak and then was crucified to save people from sin, that is, to give them true freedom, welfare, happiness and peace. Within this framework, what is the role of the state for him? To say that God is the source of freedom, argued Rosin, means that we must let God seek for humans and let humans seek for God freely. In other words, with regard to religion, the state should protect the religious freedom of the people. Similarly the belief in God as the source of welfare, happiness and peace means that the state should maintain peace among different religious groups and at the same time provides them with welfare and happiness in this life. Nonetheless, it is not the state, but God who can provide the ultimate welfare, peace and happiness. ${ }^{55}$

In line with Rosin's view, a Jesuit of Dutch origin living in Indonesia, J.W.M. Bakker, who wrote a book on the Pancasila under the pseudonym of Rahmat Subagya, argued that Ketuhanan Yang Maha Esa is the foundation of Pancasila. For him, this principle means that the Indonesian people believe in monotheism as opposed to atheism, polytheism and pantheism. In this context, he argued that Communism is opposed to Pancasila because for Marx religion is the opium of the people. In addition, Bakker also warned that the principle must not be interpreted only in terms of Islamic doctrine of tawhid, because the idea of Ketuhanan Yang Maha Esa was the culmination of a long Indonesian history that includes not only Islamic but also Buddhist and Hindu traditions. ${ }^{56}$ In other words, the other religious groups could also interpret the principle in terms of their respective beliefs. Unlike Rosin, Bakker developed a nationalist rather than a theological interpreta- 
tion of Pancasila. He argued that the Ketuhanan principle only means that the Government and the people should realize that they are, in their national life, responsible to God. He complained that the leading position of the Ketuhanan was eventually used by some people to justify state intervention in religious affairs at the expense of nationalism and religious freedom. ${ }^{57}$

Bakker and Rosin indicated the importance of the word 'Ketuhanan.' Rosin argued that unlike the word 'Tuhan' that means 'God', the word 'Ketuhanan' has a vague meaning because it refers not to God as such, but to something divine (yang ilahi) and divine power (kuasa ilahi). Rosin eventually concludes that, "it cannot be denied that the formulation of 'Ketuhanan Yang Maha Esa' is a compromise between Islamic, Javanese and modern assumptions of religion that in turn opens the opportunity for various interpretations." ${ }^{58}$ In line with Rosin, Bakker argued that, as an abstraction of the word 'Tuhan', 'Ketuhanan' "is the best word that opens the opportunity for various interpretations according to one's religion and beliefs," and therefore, "the word 'Ketuhanan' in itself removes us from having a religious state," that is, a state based on Islam. ${ }^{59}$

There is another important argument developed by another Jesuit scholar, N. Driyarkara. He argued that like love, religion is a deep side of human life, and therefore, if the state cannot force someone to love another, then the state cannot force people concerning religious matters either. ${ }^{60}$ But, does this mean that for him the Pancasila state is a secular and a profane state? The answer is both 'yes' and 'no.' The Pancasila state is a secular state in the sense that it is not a manifestation or embodiment of religion, but it is not secular in the sense that the state is not opposed or indifferent to religion. In other words, the Pancasila state is neither a secular nor a religious state but something in between. Then Driyarkara said: "We acknowledge one risk, that is, the Pancasila state will sometimes pay less attention to religion and sometimes wants to intervene more than it deserves. But what is the system that does not have any risk? The existence of the risk only means that we must try to apply Pancasila in a truly pure manner." ${ }^{61}$

In his PhD thesis submitted to Princeton Theological Seminary in 1960 and published in 1965, the Protestant scholar, W.B. Sidjabat, also argued for the meaning of 'Ketuhanan' as a principle of religious pluralism. In line with Rosin and Bakker, Sidjabat said that the origin of the concept of Ketuhanan Yang Maha Esa should be traced back to the pre-Hindu period of the Archipelago, and therefore it should not be understood in terms of Islamic concept of God but "rather a general and neutral concept of God that gives room for everyone who worships God without becoming indifferent in mat- 
ters of religion." ${ }^{62}$ In addition, Sidjabat proposed a new thing that could not be accepted by some Muslims. He translated Ketuhanan Yang Maha Esa as 'Divine Omnipotent.' For Muslims, this translation was a deliberate attempt of the Christians to conceal the Islamic monotheistic meaning of'Yang Maha Esa' (the One God) into 'Yang Maha Kuasa' (the Omnipotent). ${ }^{63}$

After the coup of 30 September 1965 leading to the fall of Soekarno, the debate on the relationship between religion and state and the meaning of the Ketuhanan Yang Maha Esa continued. In this context, the Islamic groups appear to have been in a difficult position. The reason was that when the Islamic groups tried to reassert the important position of the Jakarta Charter, their opponents, including the Christians, charged them with being anti-Pancasila. This means that in addition to the defeated Communists, the Islamic group was the other enemy of Pancasila. For the Christians, the Ketuhanan Yang Maha Esa of Pancasila somehow contradicts the seven words of the Jakarta Charter, while the Muslims tried to argue that based on the decree of 1959, the Jakarta Charter inspired the Pancasila. This difficult position frequently pushed the Islamic groups to reassert their loyalty to Pancasila. In this context, perhaps, an article of HAMKA, written in this period is a good illustration of the Islamic group's difficult position. In November 1966, HAMKA wrote that when he paid some visits to certain regions of Indonesia, some Muslim youth activists told him "that recently there have been rumours accusing the Islamic groups of being anti-Pancasila" and "that the majority of the Islamic groups half-heartedly accept the Pancasila."There was even "an accusation that the Muslims want to replace the Pancasila with an Islamic State." HAMKA then rhetorically asked: "Is it plausible to you that the Islamic community whose religious foundation is tawhid, that is, the belief in the One Almighty God...does not accept the basis of the state, Ketuhanan Yang Maha Esa?...No! For us, the first basis of the state is the principle of our life." ${ }^{64}$

In the following years, the leaders of the Islamic groups tirelessly emphasized that the Pancasila, especially the Ketuhanan Yang Maha Esa is identical with the Islamic doctrine of tawhid. In 1967, the former Masyumi leader, Sjafruddin Prawiranegara, said that the Islamic party (probably Masyumi in his mind) was always loyal to the Constitution and the Pancasila. He asked rhetorically: "Please tell me which cabinet led by the Islamic party in the past broke the Constitution or abused Pancasila?"65 In 1968, in his Idul Fitri preaching in front of the Presidential Palace, HAMKA reasserted that, "Pancasila is void without the Ketuhanan Yang Maha Esa." Having identified the Ketuhanan Yang Maha Esa with tawhid, he compared the 
Pancasila with '10000,' in the sense that the first principle is mark 1 followed by four of zeroes, and therefore, without the 1, the four zeroes are nothing. ${ }^{66}$ In addition, Kasman Singodimedjo and Prawoto Mangkusasmito, argued that the reason why Ketuhanan Yang Maha Esa for them means tawhìd was the explanation made by Ki Bagus Hadikusomo, the Muslim leader who was present during the lobbying on 18 August 1945 when the seven words were dropped. ${ }^{67}$

In this context, how did Muslims consider the other interpretations, including the Christian views of the Pancasila? As has been discussed, in 1950s, the Christian writers were worried about the Muslim monopoly of the interpretation of the Ketuhanan Yang Maha Esa. In 1968 HAMKA, wrote that in the Preamble of the Constitution of 1945, it is mentioned that Independence was achieved due to the blessing of Allah. Therefore, he argued, Ketuhanan Yang Maha Esa must refer to the Muslim belief in the One God, Allah. ${ }^{68}$ HAMKA then explained that certain Christians argued that the Ketuhanan has a plural meaning, including the Christian doctrine of the Trinity. In this regard, although HAMKA assured that the Christians, the Hindus and the Buddhists have the right to interpret the Ketuhanan Yang Maha Esa according to their respective beliefs, he warned the Muslim leaders that for the Muslims it means nothing but tawhid. ${ }^{69}$ Nurcholish Madjid who was the Chairman of the Association of Muslims Students (HMI) made an explicit statement that the Ketuhanan Yang Maha Esa contradicts the Christian doctrine of Trinity. In his Idul Fitri preaching in 1968, Nurcholish called for saving the Pancasila from the Trinity:

Save the Ketuhanan Yang Maha Esa from being replaced with Trinitarianism. Save the Pancasila from being falsified for a second time, [that is], after few years ago the PKI tried to eradicate the role of the Ketuhanan Yang Maha Esa; now the Christians, both Protestants and Catholics, indigenous and foreigners with the support of the foreign aid, are working hard to change the Ketuhanan Yang Maha Esa with the Trinity! Let us prove who actually the safeguards or is the saviour of the values formulated in the Pancasila, and who closely or openly tries to undermine it. $^{70}$

The context of Nurcholish Madjid's words was the deadlock in the Inter-religious Consultation of 1967 discussed in Chapter 1 because the Christians refused to restrict their missionary activities only to those outside the recognized religions. In this regard, to attack the Christian's missionary activities, Nurcholish Madjid identified the Ketuhanan Yang Maha Esa with 
tawhid as opposed to the Christian doctrine of the Trinity to claim that the Christians were against Pancasila.

On the other hand, the Christians continued arguing that Ketuhanan Yang Maha Esa implies religious pluralism and religious freedom. In his paper for a consultation of the DGI in November 1969, T.B. Simatupang argued that Ketuhanan Yang Maha Esa should be understood as a constitutional rather than theological principle. If it is interpreted from a certain theological perspective, he said, then it becomes exclusive for a certain religion. In other words, for him, the state should not be based on theology, but the state should protect the freedom of people to develop their respective theologies. So what is the meaning of Ketuhanan Yang Maha Esa as a constitutional principle? For Simatupang it means that the state recognises that human life includes not only social but also transcendental aspects, and that the character of the state is neither atheistic nor theocratic. ${ }^{71}$

There were also similar views found in some articles published in the Catholic journal, Basis. For instance, M.S. Pusposaputro argued that existentially a human by nature realises that he or she is finite and contingent and therefore needs something absolute and transcendent. For Pusposaputro, Ketuhanan Yang Maha Esa is the principle of the state recognising this human existential and natural need. Thus, based on this principle, the state should create positive conditions for religious lives of all citizens but at the same time it should not intervene in their internal religious affairs. In other words, he said, the state based on Ketuhanan Yang Maha Esa is the state that recognises theism, "not theocratic but democratic theism."In this democratic theism, religious freedom is guaranteed because no religion becomes exclusively the basis of the state (negara agama) or becomes its official religion (agama negara)..$^{72}$

Another author named John Liku, in line with Pusposaputro's existential argument, said that because of their finiteness, human beings naturally realise something absolute, that is, God. However, he argued further that atheism is unnatural and therefore, people can declare that God does not exist or that God is dead but because of their natural religious inclination, they will create a certain type of devotion that is in a way similar to the devotion of religious believers in God. Thus, for Liku, the principle of Ketuhanan Yang Maha Esa means that the state recognises this human natural inclination and at the same time it guarantees religious freedom. Religious freedom is necessary because like the belief in God, freedom is also naturally embedded in human existence. If freedom and belief are both natural, then they should not contradict each another. If freedom should be guar- 
anteed, then is it wrong for the state to ban Communism (assumed to be anti-religious and atheist) in Indonesia? For John Liku, this ban is acceptable because the intrinsic goal of the state is to achieve the public interest. In other words, because Communism for him proved to be harmful to the public interest, the state has the right to ban it. ${ }^{73}$ Thus, John Liku's interpretation of Ketuhanan Yang Maha Esa is clearly opposed to both Islamic theological interpretation and to Communism.

The Muslim and Christian different interpretations of Ketuhanan Yang Maha Esa can be found in the following years of the New Order. Most of them, however, repeated similar arguments developed by their predecessors, but few of them proposed interpretations of Pancasila different from that of the Government. What makes those interpretations important, therefore, is not simply their respective arguments but the socio-political contexts in which they were produced. We shall discuss this topic later in the section on the Government regulation of 1985 that forces all social and political organisations to accept Pancasila as the basis of their respective organisations.

\section{The Debates on the Department of Religion}

We already discussed that on 18 August 1945, the PPKI that was dominated by the nationalists successfully kept aside the Islamic elements of the 1945 Constitution. The next day, on 19 August 1945, the aspiration of the Islamic group to establish a Ministry of Religion also failed because only six of the twenty-seven members of the PPKI could agree with this proposal. ${ }^{74}$ With the loss of 'the seven words' and the absence of the Ministry of Religion, the Islamic groups were just left with feelings of discontent. However, it seems that the historical development of the new state eventually pushed the secular nationalists into accommodating the aspirations of the Islamic groups. Deliar Noer said:

As the success of the revolution seemed already threatened by the possibility of the return of the Dutch, these feelings of discontent did not help the cause. Against this background, the decision for the establishment of the Ministry of Religion can be understood. The Government needed the full support of the Islamic group, and it was hoped that could be obtained, or at least courted, by the establishment of a Ministry of Religion. ${ }^{75}$

The Ministry of Religion (Kementerian Agama) was set up on 3 January 1946 and Muhammad Rasjidi was appointed to be its first Minister, in the cabinet led by Sutan Sjahrir. In the first months of his appointment, Rasjidi 
explained to the public that the Ministry of Religion would put the existing religions in their appropriate positions. Probably to reduce the fears of the religious minorities, Rasjidi also said that his Ministry would not intervene in the internal religious affairs of the people. Based on the Government's decrees issued in March and April 1946, the Ministry of Religion was authorized by the Government to take over certain works previously carried out by the other Departments during the colonial periods, namely: to take over the works of the Department of Home Affairs with regard to Islamic marriage, Islamic courts, mosques and pilgrimage (hajj); to take over the authority of the Islamic High Court from the Department of Justice; and to take over the section on teaching religion in schools from the Department of Education. In addition, the Ministry was authorized to take over three authorities of District Government: the so-called 'shumuka' during the Japanese occupation to be the Regional Religious Offices (Jawatan Agama Daerah); to appoint religious advisers for the so-called native courts (landraad); and to appoint a Muslim official called penghulu for a mosque.

However, the emergency situation of the revolutionary war during several months of his appointment did not help Rasjidi to develop the structure and function of the Ministry. ${ }^{76}$ The structure of the Ministry became clearer when Fathurrrahman Kafrawi replaced Rasjidi in October 1946. On 20 November 1946, Fathurrahman issued a decree about the structure of the Ministry of Religion, in which although the majority of sections dealt with Islamic affairs, there were two sections for the Christians: one for the Protestants and another for the Catholics. ${ }^{77}$ The creation of the Christian sections, and later the Hindu-Buddhist section, was probably to indicate that the Ministry was not entirely an Islamic Ministry.

In 1949, when the revolutionary war was almost over, the Minister of Religion, Wachid Hasjim defined the work of his Ministry, as covering twelve items. Besides the Islamic portfolios previously authorized to Rasjidi, the Ministry was also responsible for supporting religious (not only Islamic) teaching in schools and prisons; and to grant material help to build places of worship for religious groups. In addition, it was stated that the first two tasks of the Ministry were: (1) to make Ketuhanan Yang Maha Esa an operative principle in public life; (2) to be watchful that every citizen had the freedom to embrace his or her own religion and to worship according to that religion. ${ }^{78}$ These two items clearly refer to the article 29 of the Constitution of 1945 concerning religion. Thus, according to this definition, the duty of the Ministry was to realise the Ketuhanan Yang Maha Esa principle. 
Towards the end of the 1950s, C.A.O van Nieuwenhuijze wrote that the Ministry could be a good solution to the ideological conflicts between the nationalist and the Islamic groups, but at the same time he was rather sceptical whether the Ministry could eventually satisfy both groups. ${ }^{79}$ Later, another observer, B. J. Boland, seems to be more positive and optimist when he said:

Is it not likely that the existence of the Ministry of Religion tends to promote the idea of a multi-religious state rather than the idea of an Islamic State? In my opinion the existence of this Ministry can in due course result in an adjustment of the Indonesian population to the fact of a multi-religious society where the adherents of the various religions have to respect each other and each other's belief... The positive value of having a Ministry of Religion cannot be cancelled out by all shortcomings and mistakes, mismanagement and waste of money, which sometimes happen and form the debit-side to this Ministry, its regional offices and some of its officials. ${ }^{80}$

Both Nieuwenhuijze's scepticism and Boland's optimism are somehow reflected in the debates on the position of the Ministry. In fact, although the Ministry has never been abolished since its inception, it has been criticized and opposed by Muslims and non-Muslims for different reasons. The roots of this problem were consciously identified by the Minister of Religion, Wachid Hasjim in his speech to the joint conference of the Ministry of Religion and the non-political Islamic organizations in 1951. Wachid Hasjim explained that the Ministry was in a difficult position because it had to face three different groups: the Islamic groups, the secular groups and the religious minorities. The secular groups, according to him, were never happy with the Ministry because for them religion was an obstacle on the way to reaching freedom and development. For the religious minorities, they were basically happy with the Government's support of religious life, but as minorities they were worried that the Ministry would make discriminative policies against them. Finally, although the Islamic groups were happy with the Ministry, they frequently could not understand the true position of the Ministry in the state, and therefore they expected too much. He explained that Indonesian Government is not an Islamic Government and the Ministry of Religion is not an Islamic Ministry. The Government, therefore, would merely help religious groups on specific socio-religious affairs, not all of them. He therefore suggested that the Islamic groups should not be dependent on the Ministry because this would endanger the pillars of their own development. Last but 
not least, he explained that although the Islamic groups strongly supported the existence of the Ministry, they suffered from the lack of modern skills to run its administration. ${ }^{81}$

Perhaps, it is not an exaggeration to say that Wachid Hasjim's identification of the problems faced by the Ministry is true for almost any controversy related to the existence of the Ministry. Too much expectation and often combined with the lack of modern skills eventually led the Muslims working in the Ministry to misconduct, mismanagement and corruption that in turn brought about strong criticism from their fellow Muslims and non-Muslims. In addition, the religious minorities and the secular groups often suspected the Ministry to be a first step to an Islamic state. For the religious minorities, especially the Christians, their suspicions increased when they found that a certain policy of the Ministry was discriminative against them. In addition, because the Ministry was a political compromise between the Islamic and the nationalist ideological camps, the controversy on the existence of the Ministry naturally emerged when this compromise was disturbed, that is, when one group suspected that another group had gone beyond the acceptable limits.

In the meeting of the Council of Indonesian Churches (DGI) in May 1950, a participant asked Leimena, the prominent leader of the Protestant Party (Parkindo) about the existence of the Ministry of Religion. It is reported that Leimena said, "It is better not to abolish the Ministry of Religion because the Ministry is needed now. We should use the Ministry of Religion for our goal to show the essence of the Church ('t Wezen van de Kerk). But we should also know its boundaries and not coerce (forceren)." ${ }^{82}$ In line with Leimena, Sahulata, the chairman of the meeting even argued that the existence of the Ministry of Religion was a signal that the Muslims did not consider Indonesia an Islamic state. Likewise, in 1952, the prominent Indonesian Catholic leader, Mgr. Soegijapranata stated in a meeting of bishops that the establishment of the Ministry of Religion was a compromise, and it was intended by the nationalists to prevent Indonesia from being an Islamic State in the future. ${ }^{83}$ Nonetheless, in June 1953, this moderate attitude was soon changed into a demand to abolish the Ministry when the Christians knew that the Muslims publicly said that the latter wanted to establish an Islamic state in which the Islamic law applied. ${ }^{84}$ The first Indonesian elections were held in 1955 and probably by 1953 the ideological issues already emerged as a prelude to the campaigns for the elections. The Christian demand to abolish the Ministry seems to be related to this socio-political context. 
Perhaps, it was the same reason that motivated Rahmat Subagya alias Jan W.M. Bakker, a Catholic Jesuit of Dutch origin working in Indonesia, to oppose the existence of the Ministry. For Bakker, Ketuhanan Yang Maha Esa only meant that the Government and the people should be responsible to God and that religious freedom should be guaranteed by the state. He opposed the existence of the Ministry of Religion because for him it was politization of religion. He questioned how far the authority of the Minister of Religion went in relation to the Ministers of Justice, Education and Finance. If the authority of the Minister of Religion were below that of other Ministers, then that was a subordination and humiliation of religion; but if he were above the others, then the Ministry of Religion would become "a state within the state." He was also anxious lest the Ministry of Religion should control the theological and spiritual aspects of religious life. If this happened, he said, this would endanger religious freedom in the country. He argued that the works of the Ministry dealing with Islamic education, Islamic courts and marriage etc. made too much intervention in people's religious affairs. He finally suggested that "it is not Ketuhanan Yang Esa that must be changed but the Ministry of Religion should be aligned to the spirit of Pancasila. If it is impossible, then it is better that the Ministry... be abolished." 85

The Muslims, on the other hand, tried to defend the Ministry of Religion by developing certain arguments. Wachid Hasjim argued that the Ministry paid more attention to the Islamic schools, because unlike the Christian schools the Islamic schools were in a very bad condition, partly due to the fact that the Dutch gave very little subsidy to Islamic institutions compared with the Christian ones; that is, 1: 380. Similarly, he argued that during the colonial Government, the position of Islamic law on marriage and inheritance was inferior to the civil law because, he said, the major reason for the colonial Government to be involved in religious matters was to control, manipulate and weaken rather than to enhance the position of Islam in society. Therefore, he concluded, after Independence, the colonial policy should be reversed, that is, to support and enhance Islamic religious life. ${ }^{86}$ As we shall see in the next Chapters, these arguments were to be developed further by the Muslim leaders during the controversies on the Marriage, Religious Court and Education Bills.

In contrast, in his PhD thesis completed in 1960, Sidjabat argued that the involvement of both Dutch and Japanese colonial administrations in Muslim religious affairs somehow "paved the way for the Muslims to be even more convinced that the care of Islamic religious institutions is the essential 
religious duty of the state." ${ }^{17} \mathrm{He}$ also criticized the Muslims who accused the Christians of being favoured by the Dutch in receiving large subsidies for their institutions because "some of the money the Christians received was collected by the churches abroad, and not from the Dutch Government." 88 Having criticized the Muslim arguments to support the Department, Sidjabat said:

What one encounters in the present Ministry of Religious Affairs is nothing but a riddle. To be faithful to the meaning of the principle of Divine Omnipotence of the 'Pantja Sila' formally and juridically, the non-Muslims and the non-Christians should receive a proper place in the Ministry of Religious Affairs. And if this cannot be accomplished, a contradiction of principle or a grave mistake must be present somewhere in the scheme of the Ministry of Religious Affairs. ${ }^{89}$

After the fall of Soekarno, the debates on the existence of the Ministry that became the Department of Religion (Departemen Agama) since the 1960s re-emerged. Again, this was related to the re-emergence of the ideological issue that previously developed during the Soekarno period. In 1959, when Soekarno made the decree to return to the 1945 Constitution, the NU leader, Wahib Wahab, played an important role in the lobbying process behind the decree, and its statement, that the Jakarta Charter inspires the Constitution, was partly a result of his efforts. ${ }^{90}$ Soon after the decree, Soekarno appointed Wahib Wahab to be the Minister of Religion. In 1962, another NU leader, Saifuddin Zuhri, replaced Wahib Wahab. Not long after taking the position, Saifuddin tried to reformulate the work of his Department. In this formulation, besides referring to the article 29 of the 1945 Constitution, it was stated that the work of the Department was "to carry out the Presidential Decree concerning the Jakarta Charter that inspires the Constitution of 1945." 91

When Soekarno was removed, in 1967 Mohammad Dachlan, a traditionalist Muslim leader opposed to Soekarno, was appointed in the place of Saifuddin Zuhri. Dachlan reasserted that one of the missions of the Department of Religion was to "implement the Jakarta Charter in relation to the Constitution." 92 Unlike his predecessors, however, Dachlan had to face the unfriendly political circumstances surrounding this issue. As has been discussed, the debates on the Jakarta Charter versus the Pancasila were very serious during the early period of the New Order. In August 1968, the Catholic weekly magazine, Peraba, published an article discussing the current celebration of Indonesian Independence. Among other things, the article 
referred to a statement of the Catholic Youth (Angkatan Muda Katolik) questioning Dachlan's formulation of the work of the Department of Religion with regard to the Jakarta Charter. For the author of the article, in fact one should not ask that question, because the case was already clear, namely: "Consciously or not, the Minister of Religion had already broken the Constitution of 1945...Stop the works of the Minister of Religion. If there is no new Minister, it is better to dissolve the Department of Religion soon." ${ }^{\prime 93}$

In August and September of 1968, Dachlan was the target of sharp criticisms in Peraba. An article in the magazine criticised Dachlan's speech to the employees of the Department of Religion in Malang, East Java. It was reported that in his speech Dachlan said that every employee of the Department should become a fighter for Islam. For Peraba, this statement reflected Dachlan's dream of the Jakarta Charter. The magazine then asked: if every employee of the Department should be a fighter for Islam, how about nonMuslim employees, should they be removed or forced to convert to Islam? Thus, for Peraba, Dachlan's statement was discriminative and against Pancasila. ${ }^{94}$ In addition, Peraba criticised the fact that the Department of Religion monopolised the arrangement of the hajj, and there was also a report that the Department contributed to establishing some mosques. For the magazine, all of these indicated that in practice, Islam had become the religion of the state and the Jakarta Charter was implemented. ${ }^{95}$

In addition to Peraba, a certain Moh. Bazor published a pamphlet entitled "Departemen Agama?" in which the author strongly criticized the Department of Religion. According to Karel Steenbrink, Moh. Bazor was another pseudonym of J.W.M. Bakker. ${ }^{96}$ Like the Catholic Youth, he argued that Dachlan's inclusion of the Charter in the formulation of the Department's work was against the 1945 Constitution. If the Jakarta Charter is realized, he said, the authority of the Minister of the Department is similar to that of a Shaikh al-Islam or a Mufti A'zam in an Islamic theocracy. He also questioned why Dachlan did not realize the fact that the struggle for the Jakarta Charter always failed. In addition to this ideological issue, the author mentioned the cases of corruption involving high officials of the Department such as the Secretary General, M. Kafrawi and the Minister Wahib Wahab who were arrested because of allegations of corruption. The author also refers to mismanagement and corruption in the Department concerning the appointments of religious teachers, distributions of scholarships and the arrangement of the pilgrimage to Mecca. In short, the Department of Religion had already discredited the Islamic community and worsened inter-religious relations. Because of this, he said, more and more voices were heard wanting to 
dissolve the Department. The author eventually suggested that the Muslims must whole-heartedly accept secularisation in which the role of reason and science is more prominent than that of religion. The process of secularisation, he said, would only prevent religion from intervening in secular matters, but not remove religion from its appropriate position as the source of the spiritual life of society. In this regard, the Department should be reorganized in accordance with secularisation or otherwise it should be abolished. ${ }^{97}$

The Islamic groups were certainly unhappy with the Christian criticisms. In 1968, the two Muslim magazines Kiblat and Pandji Masjarakat published some articles to defend the existence of the Department. An anonymous author wrote an article in Pandji Masjarakat as a response to an article of a certain S. Broto, published in the Catholic newspaper, Kompas, Surabaya edition. In the article Broto had argued that the Department should be dissolved because religion is a private matter and not a state affair. The anonymous author argued that Broto's view clearly reflected the Christian view of separation between Church and state, and this could not be accepted by Muslims. For the Catholics, the author argued, this separation is fine because they already have the Vatican State regulating the religious life of all Catholics in the world, while Muslims do not have that kind of institution. The author finally quoted a Catholic writer, Louis Veuillot (1813-1883), ${ }^{98}$ who reportedly said that, if the Catholics are a minority, they demand religious freedom, but if they are majority, they oppose religious freedom and both positions are religiously justified. ${ }^{99}$

In Kiblat, two important Muslim reformist leaders, Abu Hanifah and Kasman Singodimedjo also tried to defend the existence of the Department. Both recognized that there was corruption and mismanagement in the Department, but for them it did not mean that the Department was to be dissolved. Like a dirty house, they said, what we should do is to clean the house, not to burn it. In addition, Kasman argued that as an institution, the Department was very important in Indonesia because it reflects the true Indonesian personality, the belief in God, Ketuhanan Yang Maha Esa. ${ }^{100}$ Moreover, Abu Hanifah warned that if Soeharto's Government dissolved the Department, political stability would be shaken. For Abu Hanifah, the demand to dissolve the Department meant that the secular groups considered the Islamic groups politically weak and therefore he encouraged the latter to enhance the integrity and cooperation among them. ${ }^{101}$

Despite strong Christian opposition to the Department of Religion, Soeharto's Government never decided to dissolve it. In addition, to my knowledge, there was no debate on the Department more intense than that 
which happened in the late 1960s. There was, however, a debate on the possibility of changing the name and structure of the Department. As we shall see below, in 1978, the MPR made a decree on Pancasila indoctrination (P4), despite the opposition of the Islamic party, PPP. In 1981, T.B. Simatupang argued that because P4 was already decreed by the MPR, the Department of Religion should be changed into 'Departemen Keagamaan.' Perhaps, the last term could be translated as 'Department of Religions' or 'Department of Religious Affairs.' What he meant by the term was that the Department should be the place where all religions have an equal position. He argued that, if we look at the history of the Ministry of Religion, we find that it was originally intended as a Department of Islam and therefore, the directorates for non-Islamic religions only functioned in a supplementary role. Thus, he suggested to the Government to change the structure of the Department. In this new structure, the personnel of each section of the Department should be religiously mixed in line with the principles of the Pancasila. ${ }^{102}$ Thus, instead of demanding the abolition of the Department of Religion as the Christians did before, now Simatupang suggested that the Department had to be transformed from being an 'Islamic Department' to be a 'Department of all religions'.

There were some Muslim negative responses to Simatupang's proposal. Muttaqien Darmawan wrote in Pelita newspaper that Simatupang's idea was like 'Nasakomisasi' (a reference to NASAKOM, Soekarno's combined ideology of Nationalism, Islam and Communism), that is, to put different and opposing groups in one organization. Muttaqien also argued that with regard to the recruitment of staff, the Department based its decision on Law No. 8 of 1974, in which it is mentioned that recruitment should be based on objective qualities, regardless of religious background. Muttaqien's argument was countered by Agus Matori HP. For the latter, Muttaqien's argument was weak because in reality the non-Muslims were only appointed in the non-Muslim sections. This is why, he said, Simatupang proposed that we should change the structure and then the personnel. Another Muslim author, Samudi Abdullah, wrote that what Simatupang suggested was a Pancasila theology, a kind of syncretism that is opposed even by Christian theology. In his response, Simatupang said that he did not propose a Pancasila theology but suggested how to develop Islam, Christianity and other religions within the Pancasila state. ${ }^{103}$ Apart from the debate, Simatupang's idea was never adopted by the Government. 


\section{The Catholic-Military Alliance}

In our discussion above, we have noted that the Christians were in the same position with the military to oppose the Islamic ideology. One of the consequences of this alliance was that some of the Christians became less critical, if not totally supportive of the dominating role of the military in Indonesian politics. The leader of the DGI, T. B. Simatupang, who was in fact a retired Army General, explained that the political role of the military, or the so-called 'dual function of the military' (Dwifungsi $A B R I$ ) was an historical necessity. The idea of dual function was initially introduced in the mid-1950s by General A.H. Nasution who said that the "army would neither seek to take over the Government nor remain politically inactive."104 During the New Order period, this doctrine was used to justify the military's dominant social and political role in the country. For Simatupang, the political role of the military was justified by its consistent role as the saviour of Pancasila from its two enemies: Communism and Islamic ideology. Simatupang realised that the dual function could lead to militarism; but he argued that although there was no historical example that a military regime would develop a democratic political system, it was not impossible that the military in Indonesia would achieve the opposite. In order to be the pioneer of democratisation, he suggested that the military should become both troops and strugglers based on their total commitment to the state ideology, Pancasila. ${ }^{105}$

Simatupang's endorsement of the military's dual function, with the hope that it would lead to democratisation, probably indicates that besides giving open support, he had certain reservations. Moreover, as has been noted in Chapter 2, Simatupang had been retired since 1959, so he had no direct influence on the army anymore. In contrast, a certain group among the Catholics developed a very close relation with the military. In this section, we shall discuss the forms of this Catholic-military alliance and how it affected Muslim-Christian relations in Indonesia.

Beek and His Khasebul: Against Communism and the Islamic State

In the debates on the Jakarta Charter, the Catholics were very much involved and courageous. One of the reasons was probably that the Catholics had already established strong relations with the ruling military by that time. These relations had started at least by the early 1960s, when the Catholics decided to cooperate with the military to oppose the Communists. The Catholic-military alliance was closely connected with the role of an influential but rather mysterious Jesuit, Father Joop Beek (1917-1983). ${ }^{106}$ Towards 
the end of Soekarno's Guided Democracy, Beek was worried about the possibility of a Communist takeover and therefore tried to prepare a standby underground Catholic movement to anticipate this threat. Another Dutch Jesuit, Dijkstra, established anti-Communist Pancasila unions of the peasants and workers (Petani Pancasila and Buruh Pancasila) to rival those of the Communists. According to Dijkstra, to defeat the Communists, one should win the poor people over. ${ }^{107}$ Dijkstra is described by one of his Jesuit colleagues as a person whose concerns were mostly with the economic problem of the little people like peasants and workers. He was very much against the idea of charitable love and insisted that justice is the most fundamental Christian value. ${ }^{108}$ Unlike Dijkstra's socio-economic approach, Beek seemed to prefer a top-down approach to influence or even control the political power to secure the Catholics from the Communist threat. According to Beek's calculation, the best political power to oppose the Communists at that time was the military. It seems for this reason that before the coup, Beek had already made contact with Ali Moertopo and other Kostrad officers. ${ }^{109}$

Since the early 1950s, Beek worked with students, particularly the university students of the Association of the Catholic Students of the Republic of Indonesia (PMKRI). After the coup, Beek's cadres of the PMKRI like Cosmas Batubara and the three prominent Chinese Catholics, Harry Tjan Silalahi and the two brothers: Liem Bian Kie and Liem Bian Khoen who took the Indonesian names, Jusuf Wanandi and Sofjan Wanandi respectively, were among the major players in removing the Indonesian Communist Party (PKI) and Soekarno from the political stage. In 1964, Harry Tjan became the General Secretary of the Catholic Party, and in 1966 he was elected as the General Secretary of the KAP-GESTAPU, the civilian alliance supported by the army to crush the Communists. ${ }^{110}$ Moreover, as the leading activists of the PMKRI, Cosmas Batubara, Liem Bian Kie and Khoen were among the leaders of the university students' front, KAMI, demonstrating against the Soekarno regime. ${ }^{111}$ Agustine Prasetyo Murniati, who was to become a Catholic feminist activist and theologian since 1984, was also involved in the KAMI. ${ }^{112}$

Beek's serious efforts to oppose the Communists were apparently related to the situation of the cold war. Thus, unsurprisingly, Beek was considered an agent of the CIA by the Indonesian leftists. ${ }^{113}$ More than that, alluding implicitly to a kind of conspiracy, W.F. Wertheim claims that Beek had already predicted the coup of 1965 and its consequences for the Communists some months before the event. ${ }^{114}$ The Dutch journalist, Aad van den Heuvel, even claimed that it was Beek who became the real puppeteer behind Soeharto's counter coup in $1965 .{ }^{115}$ It is certainly difficult to verify 
these claims; but they at least indicate that Beek was a very influential person in the fight against Communists and Communism in Indonesia.

In the struggle against the Communists, Beek's students cooperated with the Muslim activists, but when the Communists were obviously defeated, Beek considered Islam as another enemy. "At that time, there were people in Jakarta who wanted to make Indonesia an Islamic state. And it was true. Beek was worried about this, so he used his network to counter this movement," said Paul de Blot. ${ }^{116}$ The fear of an Islamic state was not uncommon among the Christians in general and the Catholics in particular, but "while other Catholics argued that the church should build contacts with the Muslims, Beek took a militant, antagonistic approach."117 For Beek and his followers, after the eradication of the Communists, there was an eitheror political option for the Catholics: to go under the Muslims or to embrace the army and they chose the latter as the lesser of the two evils. ${ }^{118}$

For a minority group like the Catholics in Indonesia, to achieve their political goal, a militant and well-organized movement was badly needed. It seems for this reason that Beek initiated a regular course for young Catholic cadres that was eventually institutionalised after the coup as 'khasebul,' an acronym for 'khalwat sebulan' (one month retreat). This programme was initially carried out at the student dormitory, Asrama Realino, Yogyakarta ${ }^{119}$ and then in 1967 moved to the newly built retreat house in Klender, East Jakarta. There is some information on this retreat house and Beek's khasebul programme in an oral history interview with the nun who was responsible to take care of the daily organisation of this place from 1967 to 1977 , Mathilda Maria van Thienen. ${ }^{120}$ She explained that the retreat house was a big complex of 3 blocks totalling 72 rooms with 144 beds. Beek came to Klender four times a year for his khasebul programme with a group of 100 trainees. Among them only 8 to 10 persons were female, while the rest were male. The programme was financially supported by parish or diocesan funds as well as by overseas sources, particularly from the Netherlands and Germany.

The khasebul programme was quite special and secret. The trainees included highly-motivated university students, activists, and village youth recommended by priests and bishops. Some former trainees of khasebul explained that a person who was recruited to join the programme should not tell anybody about it, including one's family and friends, otherwise one would be returned home. In addition, during the training, the names of the trainees were changed to new ones, so that they did not know each other's real identity. The trainees were also given a psychological test to discover each one's talent. This test was important for the future assignment of the 
trainee after the programme was completed. A former trainee explained that the test was quite reliable. He was told after the test that he was to become a good writer, and it proved to be true. ${ }^{121}$

During the programme, the trainees were taught leadership skills, public speaking, writing, group dynamics, and social analysis. The most special part of the programme was probably Beek's methods of disciplining the trainees. Tanter noted that "the courses were modelled on a mix of Jesuit and Communist techniques, based on self-discipline. They were conducted with a large measure of brutality: cadres were often involved in beating each other, being reduced to grovelling in the dirt, long daily sessions of mutual criticism, being woken in the middle of the night after a few hours of sleep, and so forth." ${ }^{122}$ The self-discipline training was obviously designed to create a militant, confident and loyal cadre. Mathilda Maria van Thienen explained that sometimes the trainees had to fast during the day and pray for the whole night. Beek himself also fasted and prayed along with them. A trainee who failed to follow the discipline would be punished, and at worst he or she would be returned home. Sometimes a trainee was returned home just one day before the whole programme was completed. To test the honesty of the trainees, Beek put secretly some paper money in a book placed in every bedroom. He recorded the serial numbers of the money. If the money was lost, in cooperation with van Thienen, Beek tried to identify the one who took the money, particularly through an investigation whether the money was used for transaction in the shop of the complex. Beek then interrogated the suspect, and as a result, the latter would be punished or returned home. ${ }^{123}$

The trainees were also indoctrinated with the teachings of the Church in relation to socio-political issues, and with the image of the real threat of the enemies and the methods to face them. Cosmas Batubara, for instance said that Beek trained the students how to counter Marxism-Leninism and how to identify and counter Communist actions, including how to sabotage a meeting. ${ }^{124}$ This was also applied to another enemy, Islam. In his thesis that touches on the khasebul case in a few paragraphs, Daniel T. Sparringa said that his informants denied that the training was oriented to countering Islam. ${ }^{125}$ My informants, on the contrary, said that besides the doctrine that as a Catholic activist one should attempt "to widen the kingdom of God," the trainees were led to believe that Islam is a threatening and scary enemy. B. Suryasmoro Ispandrihari, who joined the khasebul in 1988 said, "When I graduated from the khasebul, I became suspicious and fearful of anything that smelt Islamic such as a Muslim lecturer, a Muslim girl with head covering, the mosque in the campus, the HMI activists and even nominal Mus- 
lims." He explained that the method of the training was so effective that after graduating from the programme, one became unconsciously convinced that "Islam is the enemy of the Catholics... and if it is needed a khasebul graduate is ready to take arms to fight against Islam."126 Damai Pakpahan, a feminist and NGO activist said that she joined the khasebul in 1984 but decided to stop before the whole programme was completed. One of the reasons was that she could not accept the idea of fearing Islam because her mother and brother were Muslims. This experience, however, taught her to know that "if a Catholic appears to be Islamophobic, then he or she is probably a khasebul graduate." 127

On the last day of the programme, Beek and the trainees amazingly became very intimate. Although the trainees felt that Beek had been very harsh to them during the training, by the end there was no disappointment and hatred anymore. Every trainee, one by one, was given the opportunity to express his or her discontents to Beek personally. ${ }^{128}$ The trainees were finally proud of him, and also of themselves. Thus, the result of the training was, as Tanter put it, "a cadre completely faithful to Beek personally; Beek's men for life, who would do anything for him."129

After the training, the graduates established a network throughout the country. Khasebul's network is developed in a cell system. ${ }^{130}$ The system is probably similar to the work of a vertical cell system described in one of a series of books used for this programme. ${ }^{131}$ It is mentioned that the cell system proved to be very effectively used by the Communists to develop their movement in the world but that the cell system does not particularly belong to the Communists. It was also developed by the Christian leaders such as Jozef Cardijn, the founder of the Young Christian Workers (YCW) and Ignatius Loyola, the founder of the Jesuit Order. The book even claims that Jesus also used the cell system when he assigned the twelve Apostles to establish the early Christian mission. ${ }^{132}$

It is also asserted that the cells are not study clubs, but action groups whose aims are (1) "to renew everything in Christ" or "to Christianise all aspects of society," not primarily in the sense of teaching Christianity to non-Christians, but to develop a social, economic, political and cultural life based on the spirit of Christianity; and (2) "to create true Christian leaders." The major members of the cell are the lay-Catholics and they should be convinced that as Catholics they should become "the salt of the earth." In addition, every member of the cells should have a team under his or her leadership that could be mobilised for action. There were primarily two interrelated activities of the cells: regular meeting, and action. In the meeting, 
Gospel teachings were discussed in relation to social issues and then a plan was drawn up as to how the issues should be dealt with. In a vertical cell system, every cell mostly does not know the other cells and all of the cells are controlled at the top by a central board. ${ }^{133}$

The major responsibility of the members of the network was to make regular reports on political developments to Beek, and Beek alone. ${ }^{134}$ In order not to be identified by outsiders, the khasebul alumni were already taught during the training to use in their communications certain code-words. ${ }^{135}$ Every former trainee is assigned to work in accordance with his or her talent: to be a teacher, political activist, journalist etc., in either Catholic or nonCatholic organisations, including the Government institutions and Parliament. In short, through the khasebul programme, Beek gradually "built up what amounted to a personal intelligence network." 136

Beek passed away in 1983, but his khasebul training was continued by his former student, a Jesuit named Lukas Rustam Alamsyah. The khasebul network and training continued to work to the end of the Soeharto period and even up to the present. ${ }^{137}$ Besides some of the priests, Beek's prominent cadres in the Centre for Strategic and International Studies or CSIS (to be discussed below) have been certainly involved in the khasebul training. ${ }^{138}$ It was not uncommon that a khasebul graduate was given a job in the business institutions belong to the Catholic elites. It is also said that some of the university students who joined the khasebul network were rewarded with scholarships. ${ }^{139}$ A rebellious person like Suryasmoro Ispandrihari would easily lose these advantages. Another person, who wanted to keep his job, did not have any choice but to hide his personal discontents with the network.

\section{The Catholics in Opsus, CSIS and Golkar}

After the political defeat of the PKI in 1966, the cooperation between Beek's group and the army increased partly because both found a common interest in opposing the Islamic groups. In this context, May observes that, "fear of Moslems led some of the President's advisers into the arms of Catholic Action, with the strange consequence that a Dutch Jesuit played a part in shaping the Javanese junta's political ideas." 140 There were two important personal advisers of the president who cooperated with Beek's group: Ali Moertopo and Soedjono Hoemardani. As has been noted, Beek and his students had made close contacts with Ali Moertopo before and after the coup. These earlier contacts seem to have been more serious in 1967 when Liem Bian Kie (Jusuf Wanandi) became assistant to Ali Moertopo, while Kie's brother, Liem Bian Khoen (Sofjan Wanandi) became assistant to Soedjono Hoemardani. ${ }^{141}$ 
Beek's group also cooperated with Ali Moertopo in the intelligence network of the so-called Opsus an acronym of 'operasi khusus' (special operation) that was originally set up within the Kostrad (Army Strategic Reserve Command) in 1964 to find ways to end the confrontation with Malaysia. When Soeharto became President, the Opsus "evolved into a body notorious for political manipulation"142 and Ali Moertopo was appointed to be the Deputy Head of the State Intelligence Co-ordinating Body (BAKIN). Ali Moertopo actually built up various forces around him, including some former activists of Darul Islam. ${ }^{143}$ However, Beek's group was apparently the most influential one. According to General Soemitro, the important political rival of Ali Moertopo in early-1970s, it was through the Opsus channel that since 1969 some scholars of Beek's group had taken certain positions in BAKIN. ${ }^{144}$ The cooperation in the field of intelligence seems to be natural because, as has been discussed, Beek had established an intelligence network of his Catholic cadres.

Richard Tanter observes that Beek's "preferred Indonesia was nationalist, non-Islamic, with Christianity in a favoured position, supporting a Golkar-type Government."145 By the end of 1969, the regime developed the Sekber Golkar (Joint Secretariat of the Functional Groups) that was originally established in 1964 to counter-balance the PKI and its affiliated organizations, into a government-sponsored party. ${ }^{146}$ Before the first election of the New Order in 1971, Beek and his group were strongly involved in the establishment of Golkar. In this respect, while Van den Heuvel claims that Beek was "the inventor of Golkar party," ${ }^{147}$ Brian May more carefully explains:

There is no evidence that he [i.e., Beek] went so far as to advise them on the specific aims of Golkar, although he might well have done so, for he was closely in touch with Ali Murtopo's circle. What he certainly did was to discuss such matters as to how democracy was possible in a developing country; and he wrote an article, circulated in the Defence Department, in which he warned that Moslems were using Communist-type tactics to bring about an Islamic state. ${ }^{148}$

What is interesting in May's observation above is that Beek tried to convince the army that there were serious attempts by the Muslims to bring about an Islamic state. In other words, what seems significant is not whether Beek invented Golkar but the idea that the party was partly intended to oppose the Muslim interest in an Islamic state. Beek's Jesuit contemporary, Paul de Blot, said: "It was the residue, not Beek's concept itself that became Golkar. Golkar was the waste of the idea to oppose the Islamic state. The idea 
came from Beek but it melted and eventually became Golkar."149 ${ }^{14 h e r e f o r e, ~ i t ~}$ is not surprising that some of the prominent Catholic figures of Beek's group such as Jusuf Wanandi and Cosmas Batubara took important positions within Golkar's leadership, especially in the 1970s and 1980s. ${ }^{150}$ Batubara was even appointed Minister of People's Housing in two of Soeharto's cabinets. ${ }^{151}$

Besides the involvement in Opsus and Golkar, in 1971 Beek's group, in cooperation with Ali Moertopo and Soedjono Hoemardani, established the Yayasan Proklamasi, Centre for Strategic and International Studies (CSIS). According to Harry Tjan Silalahi, the origin of the CSIS was a small study group started in 1964 consisting of a few individuals who wanted to counter the philosophical discourse of Communism of the PKI. Besides himself, Harry mentioned Liem Bian Kie and Soedjati Djiwandono as members of the group. This group also cooperated with the Pancasila Front in 1966 when the latter was actively engaged in eradicating the PKI. In addition, in Western Europe, among the Indonesian students, there were two opposing camps: the rightist and the leftist. In 1965, Daoed Joesoef was still a student in Paris, and he was the one who mobilized the right wing of the Indonesian students and established the Association of Indonesian Students (PPI) there. In 1967, Ali Moertopo ordered Sofjan Wanandi to go to Western Europe to talk to the students. It was in this period that Daoed Joesoef in Paris, Surjanto Puspowardojo in Belgium, Hadisoesastro in West Germany and Biantoro Wanandi in Switzerland were contacted. After these contacts, both activists in Jakarta and Western Europe agreed to establish a study club. They then talked to Ali Moertopo about the idea and his response was very enthusiastic and at the same time Soedjono Hoemardani was ready to provide financial support, and this was possible for him because he was the personal assistant to President Soeharto for economic affairs. ${ }^{152}$

In an article entitled "Think Tank" dedicated to Ali Moertopo in memory of him one year after his death, Harry Tjan explained that CSIS was more or less intended to play a similar role to the RAND Corporation established in 1948 in Santa Monica, California. In the beginning, the RAND was a think tank or 'ideas factory' that only gave advice for the US Air Forces, but later on RAND was developed to be an institution for research on social, economic, and political affairs that helped provide information for the policy makers. The work of an institution like RAND (read: CSIS), for Harry Tjan, was very significant because as a non-government organization, it could move informally to identify national and international problems faced by the Government. The CSIS, therefore, was intended to be the think tank and ideas factory for Soeharto's Government. ${ }^{153}$ 
In the above article, Harry Tjan proudly identifies the CSIS with Ali Moertopo and Soeharto's New Order. Indeed, during the 1970s and the first half of the 1980s, the CSIS had significant influence within the Government, particularly because of the patronage of Ali Moertopo and Soedjono Hoemardhani as personal assistants to the President. General Soemitro said that Ali Moertopo was the one who struggled for the political status of the CSIS that in turn paved the way for this organization to have direct access to the structural institutions of the state, while "Soedjono looked for the funding that was widely said to have come from the state owned companies."154 Another patron of the CSIS was general Benny Moerdani, a Catholic and junior to Moertopo. They got to know each other when both were assigned for the Trikora operation in West Papua in the early 1960s. Both men became closer by the end of 1965 when Moerdani was appointed as the deputy to Moertopo who was the Intelligence Assistant of a Fighting Command for the Confrontation with Malaysia. ${ }^{155}$ When the CSIS was established in 1971, Benny was assigned in South Korea, but he did not fail to maintain regular contact with Moertopo and the CSIS. After the Malari affair in 1974, Moertopo successfully persuaded Soeharto to appoint Moerdani to be the G-I Intelligence Assistant of Security and Defence. Moerdani's career moved to its peak when he was appointed to be the Commander of the Armed Forces in $1983 . .^{156}$

To recapitulate what has been said, the cooperation between Beek's group and Ali Moertopo was almost perfect: in the Opsus intelligence network, in the Golkar political party and in the CSIS as a think tank, and all of them were strongly interconnected. According to Soemitro, on one occasion, Ali Moertopo tried to explain why he cooperated with the Catholics. It was reported that Ali Moertopo said, "You should know that this group is more dangerous than the Communists and they are adventurous intellectuals. Therefore, instead of allowing them to become wild, I put them into a stable!"157 This implies that Ali Moertopo felt that he could use them for his own political agenda. Nonetheless, who is using whom in politics is not a simple question to answer. For the Catholics of Beek's group, the cooperation was probably considered an effective way to secure their interests as a religious minority.

\section{Catholic Political Theology and Integralism of Pancasila}

Was there any more serious reason for the Catholics to justify cooperation with the military dominated regime? A prominent Catholic intellectual and head of the Research and Development section of the Indonesian news- 
paper, Kompas, Daniel Dhakidae, argues that the involvement of the Catholic intellectuals at the CSIS can be explained in terms of the Catholic political theology of the organic state. Within this theology, liberalism is rejected because of its emphasis on the role of individuals and Marxist-socialism is refused because class struggle is considered destructive to the existence of an organic state. This political theology can be traced back to Thomas Aquinas (d. 1274) who argued that the elements of cosmic order and the social order form a harmonious relation to one another in a hierarchy. ${ }^{158}$ The differences within the structure of the hierarchy are necessary because without differences, being is inconceivable. Consequently, to rule and to be ruled is something natural and equality for all individuals is absurd. The people who have the right to rule are those who have the power of intellect and at the same time the power to command. This is analogous to the rule of reason over the whole organs of human body. In the modern context, those who have the power of intellect are the educated, experts, professionals and technocrats. For the New Order context, the power to command seemed to rest in the hands of the army. Donoso Cartés, an Iberian Catholic theologian, argues further for the necessity of state dictatorship over the people because the state is considered the source of morality to guide the people who are naturally bad and sinful. For him, the role of the state over the people is somewhat parallel with that of Jesus, the God incarnate who was born and crucified to save sinful human beings. Last but not least, the idea of the organic state and the rejection of Marxist class struggle were also found in the encyclical, Rerum Novarum of the Pope Leo XII, issued in 1881. Later, despite the assertion of the Vatican Council II (1962-1965) that the authority of the political community should avoid despotism in its attempts to achieve the common good, the strong emphasis on the role of the state to maintain order can still be noticed. ${ }^{159}$

There were important changes of the Catholic doctrines in Vatican II, including the more tolerant and friendly attitude towards Muslims. Nonetheless, according to Dhakidae, these changes did not significantly influence the political attitudes of the Catholic activists in Indonesia, especially those in the CSIS who started their careers in late 1950s and early 1960s. In other words, they were more influenced by the pre-Vatican II political theology. ${ }^{160}$ This observation is in line with de Blot's explanation that the mentor of these Catholic activists, Father Beek, was a person who was very much influenced by the 'old' Catholic political theology. ${ }^{161}$

The Catholic political theology of the organic state is parallel, but not identical, with the military's preferred interpretation of Pancasila as an 
'integralism.' The idea of integralism was originally proposed by the Dutchtrained Javanese constitutional scholar, Soepomo, during the session of the BPUPK in 1945. In his speech to the BPUPK on 31 May 1945, Soepomo explained that there are three main concepts of state: the first is liberalism that emphasises individual rights, the second is Marxism that is based on class analysis, and the third is integralist in which individuals or class do not matter because the state and people are considered one and united as a family. Among these three concepts, Soepomo preferred the integralist concept because for him it was the most suitable to the Indonesian socio-political culture. ${ }^{162}$ Soepomo's idea, however, was not accepted by the BPUPK that finally preferred a constitutional democracy, even though with a strong presidency. Nonetheless, when Soekarno developed his Guided Democracy (1959-1965), he often emphasised that liberal democracy is not in line with Indonesian culture. After the fall of Soekarno, in 1968, the secretary of the MPRS, General Abdul Kadir Besar, in his analysis of the MPRS decrees, referred to Soepomo's integralist ideals as the appropriate source for understanding the 1945 Constitution. ${ }^{163}$ Later, the New Order regime used the integralistic ideals of family, harmony, unity and paternalism to interpret Pancasila as opposed to the three ideological alternatives: Islam, Communism and Liberalism. ${ }^{164}$ The regime then promoted this interpretation of Pancasila through the indoctrination programme on the Guidelines for Internalisation and Implementation of Pancasila (P4) decreed by MPR in 1978, and the school curriculum on Moral Pancasila Education (PMP) since early 1980s. In 1979, the regime established a specific body called 'BP7' for this indoctrination program organised under the Coordinator Minister of Politics and Security. Under the coordination of the BP7 that also had offices in all provinces, these courses on Pancasila were given to civil servants, students, teachers, lecturers, military personnel and even peasants in the villages. ${ }^{165}$

As the think tank for the New Order, the CSIS was involved in developing and promoting the integralist interpretation of Pancasila. In 1976, the CSIS published the speeches of Soeharto on Pancasila in which the President clearly emphasises, among other things, the integralist ideals of national unity as opposed to Marxist class differences, and the family as opposed to liberalism. ${ }^{166}$ Later the CSIS also published the English translation of the P4 and GBHN of 1978 that, as noted above, also promoted the integralist ideals. ${ }^{167}$ In the same year, the CSIS published a book by Ali Moertopo in which he argued that Pancasila was an Indonesian cultural concept that became a constitutional concept. What he means by the cultural concept was nothing but the values of harmony, family and religious tolerance. ${ }^{168}$ In 1985 , a 
Catholic intellectual of the CSIS, A.M.W. Pranarka published his study of the history of Pancasila. In this study, Pranarka argued that Pancasila was the true Indonesian ideological thought embedded in Indonesian culture. For Pranarka, this original ideology emerged particularly because of its encounters with two foreign ideological ideas: the western Hellenistic secular ideologies of socialism and Marxism, and the eastern Semitic ideology of Islam. In this encounter, argues Pranarka, it was Pancasila that successfully subsumed the two foreign ideological ideas, not the opposite. He then explains that unlike the Semitic concept of God that is based on transcendentalism, the principle of Ketuhanan Yang Maha Esa of Pancasila combines both immanent and transcendent views. Moreover, for him, this principle of Pancasila indicates that nothing is absolute except God, and that human beings are not totally free. This view of human beings, he said, leads to the idea that obligation is more important than right, and that every individual should develop self-control in order to maintain social harmony and consensus. ${ }^{169}$ Thus, Pranarka's view of Pancasila is obviously parallel with the integralist viewpoint.

\section{Muslim and Catholic Views of Beek's Group}

In the perception of many Muslims, the activities of Beek's group, particularly the CSIS, were considered a blatant Catholic-military conspiracy against Islam. In the Muslim perception, the fact that Ali Moertopo himself was a Muslim, and another prominent figure of the CSIS, Daoed Joesoef is also a Muslim, did not matter at all. For instance, Husein Umar, a long-time Muslim activist who currently is the General Secretary of the DDII, believed that the Government's objection to the Muslim demand to rehabilitate the Masyumi party and then its intervention in the leadership of the Parmusi by the late 1960s "was part of the grand design of the Christians - especially the Catholic activists, the offspring of the CSIS and the students of Father Beek - to marginalize Muslims in the Indonesian political arena." ${ }^{170}$ As we shall see in Chapter 4 and 5, the Muslims often blamed the Catholics of the CSIS as those who were responsible for making the Government's secular policies such as the Marriage Bill in 1973 and educational policies in 1980s.

One striking case of Muslim discontent with the CSIS is the polemic between A.M.W Pranarka and Muhammad Rasjidi in 1978. As noted in Chapter 2, in 1978 the Islamic party, PPP, made a walkout protest against the MPRS's decision to ratify the Government proposal on Pancasila indoctrination (P4) and to include Javanense Mysticism into the GBHN. Following this case, on 14 April 1978, Suara Karya, a newspaper established by both 
Moertopo and Hoemardani published an article written in interview form by A.M.W Pranarka. ${ }^{171}$ In the article, Pranarka argued that the Muslim protest at the MPR session demonstrated the struggle of nationalism against religion, especially Islam. "The problem is between Islam and nationalism, Christianity and nationalism... However, because the strongest, the clearest and the sharpest reaction in this process mainly came from Islamic leaders both inside and outside the PPP, the most significant clash seems to have been between Islam and nationalism," he said. ${ }^{172}$ Pranarka argued that nationalism in Indonesia must be analysed in terms of the Indonesian culture that developed since the early history of the country, that is, long before the coming of religions. For him, this culture of nationalism is the innermost dynamism of society, the élan vital or, with reference to Hegel, 'das werkende Geist' of Indonesian history. In the final analysis, for him, nationalism would defeat religion (read: Islam) and Pranarka warned:

Our nationalism is not a nationalism seeking for an enemy [or] against religion. The existing conflicts and hostilities were not brought about by nationalism but by the other side [i.e., Islamic groups]. Our nationalism seems to have a strong accommodative capacity. But perhaps because of this, it also has the power to crush (menggilas). It will not initiate fighting, but if it is challenged to fight, it has a very great capacity [to crush]. This appears in the history of our culture and the history of Indonesian politics. ${ }^{173}$

Muhammad Rasjidi took the initiative to refute Pranarka's view. According to Rasjidi, it is very contentious to theorise that nationalism has its roots in the early history of Indonesia, because even in Europe nationalism only began in the eighteenth century. Pranarka's theory of nationalism, for Rasjidi, was only based on his ambition to put Islam and nationalism in opposition. In fact, argued Rasjidi, it was the shared Islamic identity that initially unified various ethnic groups in the country to fight against the colonialists. ${ }^{174}$ Rasjidi also suspects that Pranarka's use of Hegelian philosophy was because for Hegel the state is a "divine spirit on earth." Rasjidi said:

What recently happened, according to A.M.W Pranarka was not because of nationalism, but because of the other side, that is, the Islamic side. This is a very remarkable statement because all people know that those who wanted to include Javanese mysticism and to make the P4 decreed by the MPR were not the Islamic community. In Pranarka's logic, the one who disagreed with the two issues is the one who brought about the hostility. This is exactly the same 
as what Hegel said, that people are not allowed to oppose the government because the government is the divine spirit on earth. ${ }^{175}$

For Rasjidi, Pranarka was clearly anti-Islam and arrogantly threatened the Islamic groups. He then questioned, was it because Pranarka was a Catholic? Rasjidi also said, if Pranarka followed the stipulations of the Vatican Council II, he would not be that hostile to Islam. Pranarka talked as a nationalist, but for Rasjidi it is possible that Pranarka is "a nationalist on the surface but a missionary inside." According to Rasjidi, without the inclusion of Javanese Mysticism into the GBHN, its followers would still have freedom to practice it. Thus, argued Rasjidi, the effort to have Javanese Mysticism mentioned in the GBHN was only to define the religious identity of the Javanese abangan as other than Islamic, so the number of Javanese registered as Muslims would decrease by 30 to 40 million. ${ }^{176}$

Despite Rasjidi's sharp and negative reaction, it seems that Pranarka did not try to counter it directly. Nonetheless, not long after the publication of his criticisms, without any notification, Rasjidi was pensioned off from his position as Professor of Islamic law at the University of Indonesia. ${ }^{177}$ It seems this may have happened because the Department of Education and Culture was controlled by the CSIS group: Daoed Joesoef was the Minister and Pranarka was the Secretary of the Committee for the Reformation of the National Education at the Department.

Indeed, it was not only the Muslims but also some of the Catholics who felt unhappy with the alliance of Beek's students with the regime. Agustine Prasetyo Murniati, one of the first generation of Beek's students, said that Sartono Kartodirdjo, a professor of history in Gadjah Mada University, was among the early Catholic intellectuals who opposed this alliance. ${ }^{178}$ In line with Kartodirdjo, one of Beek's colleagues reportedly said, "in theory Beek's ideas are fine, but in practice they are dirty." ${ }^{179}$ It is also reported that the involvement of Beek's group to secure a pro- Indonesian vote in the West Irian "Act of Free Choice" in 1969 was strongly attacked by other priests at an Indonesian Bishops' conference in 1971. ${ }^{180}$ According to Bourchier, "particularly towards the end of his life, the Jesuit Provincial and other church leaders attempted to remove him," but "the hierarchy was usually unsuccessful against Beek, although at one stage he was forced to return to Holland."181 There was also a protest movement of the so-called "pastor-pastor muda" (the young priests) against the activities of Beek's group and one of the priests was J.B. Mangunwijawa who sent several letters of protest to the Church leadership. ${ }^{182}$ For Mangunwijaya and the like, the Catholics of the 
CSIS were like Pilate in the New Testament who allied himself with the ruling power and betrayed Jesus and his teachings. ${ }^{183}$ Likewise, for St. Sunardi, the young prominent Catholic scholar said, Beek's students are the Catholic elites who have been obsessed with political interests and excessive fear of Islam. "In fact, they fear their own fear", he said. ${ }^{184}$

It seems, however, that the protests did not force the Church leadership to renounce its endorsement for the activities of Beek's group. The reason is, it seems, instead of supporting one group against another, the Church leadership tried to be a mediator accommodating both. This assumption is justified by an explanation made by Father Ismartono, a Jesuit who was working in the section of the inter-religious relations of the KWI. When I asked him about the difference between Beek's top-down and Dijkstra's bottom up approach to socio-political issues, he said that the difference was positive as a source of creativity and dynamism within the Church. "Instead of being contradictory, we considered them complementary," he said. ${ }^{185}$

Whatever the case may be, the priests had various reasons to justify Beek's activities. Paul de Blot, Beek's contemporary and fellow Jesuit, said that to understand Beek, one should understand how a Jesuit works. He explained that, before starting his work, a Jesuit should analyse the real situation around him and then decide what kind of concrete services he can offer to people based on his own skill and ability. Beek was a thinker, a genius and intuitive, but not good in making relations with those whom he considered to be his enemies. This is why Beek's strategy was exclusive and antagonistic. However, in view of the critical political situation during the early period of the New Order, Beek's approach is understandable. In other words, Beek's ideas and actions were acceptable in that period but were no longer so in later years let alone now. Therefore, he disagreed with Lukas Rustam Alamsyah and his colleagues who still continue Beek's khasebul. A Jesuit work, he said, cannot and should not be imitated because it is unique and conditioned by its historical context. ${ }^{186}$

Father Franz Magnis-Suseno, a Jesuit of German origin who worked in Indonesia from 1961 said that Beek's role "is always exaggerated, perhaps because in Indonesia people are interested in all kinds of conspiracy theories." He acknowledged that Beek conducted courses on general knowledge, Catholicism, public speaking, meeting techniques etc. for the young Catholics. Magnis-Suseno, however, said nothing about the specific features of the courses. He also explained that some of Beek's students became leading activists after the coup and "like the prominent figures of the HMI, they then became the cadres of Golkar." ${ }^{187}$ In other words, it seems that for him, 
there was nothing special about Beek's courses and cadres because they were more or less like those of the HMI. Moreover, Ismartono explained that as a Jesuit, Beek was assigned to guide the lay people who wanted to share Jesuit spirituality. To do this, Beek then nurtured some groups of the lay people, mostly the professionals and students, in the so-called 'Maria Congregation' and he conducted regular meetings with them. The one-month retreat was one of the types of these meetings. For Ismartono, Beek's authority as a priest of the Catholic Church was limited to this spiritual realm. In other words, whatever these lay people did outside spiritual matters was actually beyond Beek's ability, let alone the Church, to control it. He explained further that the CSIS group was not the only group with which Beek worked. There were some other groups that did not become a political movement like the CSIS, but people do not know about this. ${ }^{188}$

In contrast to Magnis-Suseno's hint, a former khasebul trainee said, the secret and hard nature of the training clearly indicates that khasebul is incomparable with most of the HMI. ${ }^{189}$ Likewise, in contrast to Ismartono's explanation of Beek's only spiritual role, a young Catholic activist said, "If the Church cannot control a group like the CSIS, why did she make it? If you dare to set a fire, you should know how to extinguish it." ${ }^{190}$ In this respect, a senior Catholic scholar said, "It is true that there is no formal tie between the Church and the CSIS, but there were informal meetings between the two, especially during the heyday of the CSIS."191

\section{Pancasila As the Sole Basis}

We have noted that the New Order regime took Pancasila and its integralist interpretation as the only acceptable ideology for the country. Three other ideologies, namely Communism, Islam and Liberalism were considered to be opposed to Pancasila. Since the late 1970s, the regime developed an indoctrination programme on Pancasila as an integralist philosophy for almost all parts of society. However, this was apparently still not enough. In 1983, the regime controlling the People's Consultative Assembly (MPR) produced the GBHN in which it was stated that, among other things, all political parties should be based solely on Pancasila. Thus, with this rule, the Islamic Party, PPP, had to take Pancasila, not Islam, as its basis. Two years later, with the agreement of Parliament, the Government issued the Law No.8/ 1985 requiring that all social organisations should be based on Pancasila. The regulation called 'asas tunggal' (the sole basis) soon triggered resistance, particularly from both Islamic and Christian organisations, even though 
most of them finally accepted or more precisely, adapted to this regulation. The acceptance of the regulation, however, did not mean that all groups accepted the Government interpretation of Pancasila.

Among the Islamic groups, the two most influential, the traditionalist Nahdlatul Ulama (NU) and the reformist Muhammadiyah, accepted the regulation. ${ }^{192}$ The NU even took Pancasila as its basis in its constitution before the regulation was issued, that is, in December 1984, while the Muhammadiyah formally declared it one year later. On the other hand, other reformist Muslims apparently became the strongest opponents of the regulation. For instance, Syafruddin Prawiranegara, the former leader of Masyumi, sent a letter of protest, dated 7 July 1983, to President Soeharto. Copies of the letter were sent to all Ministers, Islamic organisations and mass media. ${ }^{193}$ In the letter, Prawiranegara argued that Pancasila was originally intended only to be the philosophical basis of the state, not the sole basis for all political and social organisations. All organisations based on Islam, he said, had already existed and nobody considered them contradictory to Pancasila. Thus, this regulation was for him in fact contradictory to Pancasila. Among the reformist Muslim student organisations, two of them resisted this rule: the Pelajar Islam Indonesia (PII) and the Himpunan Mahasiswa Islam (HMI). In the case of the latter, there were two camps: one group accepted and the other refused, the former was later identified as the "HMI-Dipo" (referring to their headquarter in Jalan Diponegoro, Jakarta), while the latter called themselves the "HMI-MPO" (Majelis Penyelamat Organisasi, the Council to Save the Organization). The PII and HMI-MPO were, therefore, considered illegal organizations by the authorities during the period of the New Order.

The Christian organisations also had difficulties in accepting this regulation, even though they consistently supported Pancasila as the state ideology. For them, the sole basis of Christian organisations was nothing but Jesus Christ. In a meeting of the DGI, held in August 1984 in Bali, there was a debate between those who argued that Pancasila could be accepted as the sole basis and those who opposed it based on the statement in 1 Corinth 3:11, that only Jesus is the basis of the Church. Finally, the Bali meeting did not make any decision on this issue. The issue was discussed again in the Assembly of the DGl, held in Ambon on October 1984. In this Assembly, the DGI changed its name into PGI ${ }^{194}$ and Pancasila as the sole basis was asserted but at the same time Jesus Christ was considered as the basis of the church as well. In this regard, to differentiate the two bases, the Assembly used the word 'dasar' for Jesus and 'asas' for Pancasila. The Government, however, was not satisfied with the PGI's way because both 'dasar' and 'asas' mean the 
same. After negotiation with the Government, in 1986 the PGI decided to revise its Constitution, namely to put Pancasila in the article on 'asas' and Jesus Christ as 'dasar' in the article on Confession. ${ }^{195}$

Like the PGI, the Indonesian Bishops' Council (MAWI) also had certain reservations about the regulation. ${ }^{196}$ In a hearing with the Parliament in September 1984, the general secretary of MAWI, Leo Soekoto, said that the Catholic Church accepted Pancasila since 1945 as the ideology of the state. Now the regulation required that all social organisations should be solely based on Pancasila. He then questioned: "Where is one's faith if Pancasila is used to be the starting point of all social activities?" Moreover, for him, Catholic organisations are not secular social organisations because they are strongly dependent on and determined by the central leadership in Rome. Because the Government did not respond positively to the MAWI's objection, the latter tried to find the solution, but unlike the Protestants, the Catholics discussed the issue in closed meetings. In January 1987, the MAWI leaders met Soeharto to explain that in their meeting in November 1986, they made a decision that the name of the MAWI should be changed into KWI. ${ }^{197}$ In addition, the Statute of the KWI was made in accordance with the Government regulation. It is mentioned in the Statute of the KWI that "in the light of Catholic faith, KWI is based on Pancasila in social, national and constitutional life."

As hinted earlier, although most of the social organisations accepted the asas tunggal regulation, the ideological discourse did not stop, because Pancasila could be interpreted in different ways. In this context, Ramage's study demonstrates how Islamic, secular and military leaders developed various interpretations of Pancasila in this period. ${ }^{198}$ Ramage observes that for the military, the integralist interpretation of Pancasila even became more important after the wide acceptance of the regulation. Instead of saying that the military were the true fighters for Pancasila, since the late 1980s, the military argued that if togetherness and family-ness are the prime meaning of Pancasila, then the military's political role was simply natural. On the other hand, the Islamic leaders tried to interpret Pancasila in Islamic terms or in line with some secular and Christian intellectuals, they promoted Pancasila as the basis for liberal democracy. Thus, it is interesting to see how some Muslim and Christian intellectuals interpret Pancasila in this period.

For some of the Muslim leaders, Ketuhanan Yang Maha Esa was still the major reason why they could accept Pancasila. In a discussion organised by the Department of Religion, while Ahmad Azhar Basyir, the reformist Muslim leader, reasserted the earlier Muslim arguments, ${ }^{199}$ Achmad Siddiq, the 
General Chairman of the NU, developed the arguments further. Achmad Siddiq argued that Ketuhanan Yang Maha Esa implies that Indonesia is neither a secular nor a theocratic state. This means, he said, in the Pancasila state, the state supports the development of religion and at the same time religion supports the development of the nation and the state. One of the basic values of Islam, he said, is the middle way (tawassut) between two extremes. He suggested that Islam is a revealed religion of God, while Pancasila is an ideology, a result of human thought. In this regard, a Muslim should not fall into one of the two extremes: either to consider Islam as an ideology or to consider Pancasila as a religion. It does not mean, however, that Muslims cannot accept any ideology because Islam allows and even encourages its followers to think and reflect. Accordingly, an ideology can be accepted by Muslims as far as it is in line with the teachings of Islam. In this context, like the early Muslim leaders, Achmad Siddiq argued that Ketuhanan Yang Maha Esa for Muslims is nothing but tawhïd and "if other religious adherents could accept it, we would thank and pray," he said. He also asserted that within the Pancasila state, Islamic law can be developed within the legal system of the state and this is in line with the Ketuhanan Yang Maha Esa and the article 29 of the 1945 Constitution concerning religion. ${ }^{200}$

Nurcholsih Madjid, the former HMI chairman and the proponent of a non-ideological view of Islam since the early $1970 s^{201}$ responded positively to Siddiq's arguments. In addition, he developed some interesting ideas concerning Ketuhanan Yang Maha Esa. For Nurcholish, the replacement of the seven words with "Yang Maha Esa" must be welcomed because it means tawhid, something more principled than shari'a in Islam. In addition, Nurcholish argued that the dropping of the seven words by the PPKI on 18 August 1945 was not a betrayal by the nationalists, as some Muslims would say, because Mohammad Hatta who played a major role in the lobbying process, is a devout Muslim. ${ }^{202}$ Abdurrahman Wahid, the executive chairman of the NU in this period, also offered some interesting arguments on the relation between Islam and Pancasila. One of his ways to argue for Pancasila was to affirm that the five major purposes of the shari'a, namely protection of human life, property, reason, religion and family, is in line with Pancasila. In other words, instead of emphasising the relevance of Ketuhanan Yang Maha Esa, he asserted that the protections of human rights found in Islamic tradition are the appropriate frame in which to see Pancasila. ${ }^{203}$ As Ramage observes, in the 1990s, Abdurrahman Wahid became more outspoken in promoting Pancasila as the basis for democracy and human rights. ${ }^{204}$ 
Among the Protestant intellectuals, Eka Darmaputera was the one who made a critical analysis of Pancasila in 1980s. In his PhD thesis submitted to Boston College in 1982; and its summary was presented to the Seminar of Religions in 1985, ${ }^{205}$ Darmaputera tried to analyse Pancasila "as it operates in Indonesian society", that is, as it is understood within Javanese culture. ${ }^{206}$ In general, he argues that Pancasila is the very source of national identity to face the challenge of modernity or national development. For him, the neither-nor logic of Pancasila (the state is neither Islamic nor secular) was clearly influenced by the Javanese culture that emphasises inclusiveness and harmony, and this logic has successfully maintained the unity of Indonesia. However, to face the challenge of modernity, the neither-nor logic is not suitable, particularly at the level of ethics, that is, to determine right and wrong. For him, the ethical uncertainty would easily lead to despotism because, in practice, the one who determines right and wrong is the ruler. Later, in his paper to the Seminar of Religions in 1986, he argued further that the concepts of harmony and unity in the Javanese culture would lead to injustice, because within those concepts, differences are suppressed rather than protected, and the social gap is accepted as natural. ${ }^{207}$ In short, for Darmaputera, the interpretation of Pancasila should be transformed from the Javanese integralism into the liberal values of democracy and human rights. In line with Darmaputera, the Catholic priest, J.B. Mangunwijaya argued that the most relevant principles of Pancasila are the second principle of humanism and the fifth principle of social justice. Unfortunately, he said, in practice, these two important principles were clearly neglected by the Government. ${ }^{208}$

\section{Conclusion}

The Christian fear of an Islamic state or the Jakarta Charter in which the application of the shari'a is stipulated, became strong after the political collapse of the PKI in late 1960s. This fear was justified by the fact that the leaders of the Islamic groups openly tried to assert the constitutional position of the Jakarta Charter. On the other hand, the Muslim leaders were apparently still unsatisfied with the results of previous ideological debates that did not clearly accommodate their ideological interest. The fall of the PKI (that had previously supported the nationalists in the Constituent Assembly) somehow provided more confidence for the Muslim leaders to reassert their ideological interest. However, unlike the power balance of the political parties in the Constituent Assembly, during the Guided Democracy period the 
military had become another strong political faction, and it became much stronger after the collapse of the PKI. Because the military was much more in favour of the nationalist ideology of Pancasila, the Islamic groups inevitably had to face this powerful opponent. Because both the military and the Christians had the same ideological position against the Islamic groups, they became natural allies. Therefore, the Muslim-Christian tensions on the ideological issue during the New Order were strongly related to the political exclusion of the ideologically-Islamic oriented groups by the military dominated regime on the one hand, and the alliance of the Christians with the military on the other. In this Christian-military alliance, the Protestants apparently were not as close as the Catholics of Beek's group who cooperated with the regime in creating and developing Government policies in general. Because the regime often took suppressive measures on Islamic ideology and its proponents, the alliance of the Christians with the regime eventually led to Muslim-Christian tensions.

In the ideological debates, the Christians consistently promoted nationalism as the only common ground within which all the differences, particularly those with religious differences, could be encompassed. Thus, the Christians tried to interpret the first principle of Pancasila, Ketuhanan Yang Maha Esa in such a way that religious freedom, tolerance and pluralism are guaranteed by the state. Similarly, they attempted to interpret the position of the Jakarta Charter in Indonesian political history in such a way that it had only an historical and not a constitutional value. Finally, they demanded that the Department of Religion should not function as a Department of Islam, but of all religions without any discrimination; otherwise it should be abolished. The Muslims, on the other hand, often interpreted Ketuhanan Yang Maha Esa theologically, that is, as an expression of the Islamic creed, tawhid. Likewise, the Muslims tried to interpret the history of the drop of the seven words of the Jakarta Charter as the betrayal of the nationalists. To support the significance of the Jakarta Charter, the Muslims posed the proportionalist argument, that is, that the proponents of the Islamic ideology represented almost half of the members of the Constituent Assembly. Finally, for them, the Department of Religion was simply a concrete compromise between the nationalists and the Islamic groups.

The debates, however, were forced to stop by the regime by the late 1960s, and ever since the Islamic ideological discourse has been suppressed. Moreover, since the late 1970s, the regime promoted ideological indoctrination, in which Pancasila was interpreted in integralistic terms to justify the authoritarian regime. In 1985, the regime even forced all social and political 
organisations to accept the Pancasila as their sole basis. Some of the Islamic organisations resisted this regulation but most of them eventually accepted it. Both DGI and MAWI also initially had difficulties in accepting the regulation, but finally they did so. The wide acceptance of Pancasila, however, did not stop the ideological contest in the realm of interpretation. While the military officers still preferred the integralist interpretation, some Muslim and Christian intellectuals interpreted Pancasila in terms of democracy and human rights.

Since the fall of Soeharto, the Islamic forces have not been as united as in the 1950s and 1960s in demanding recognition of the constitutional position of the seven words of the Jakarta Charter. In fact, the supporters of the Charter were a minority in Parliament. On the other hand, many Christians have developed contacts and dialogue with Muslim leaders, particularly those who have been known as the proponents of the non-ideological view of Islam. Some of the young Christian intellectuals, both Protestants and Catholics, even suggested that their leaders should offer public repentance of their sin of cooperating with the military regime. Other Christians, however, still believe that there was nothing wrong with the past, and that they still have to be watchful of the Muslim ambition to realise an Islamic state. 



\section{Religion, Family Law and the State}

The ideological compromise between the secular nationalists and the Islamic groups that resulted in an unclear and negative definition of the nature of the Indonesian state (i.e., neither a secular nor an Islamic state) unavoidably created a 'grey area' that often became an area of conflict. Perhaps, one of the best examples of this conflict is the controversy on the position of Islamic family law within the national legal structure. While the Islamic groups demanded that the state accommodate the Islamic family law, the secular nationalists and the Christians opposed it. The New Order regime was initially very much in support of the secular nationalist position but eventually decided to make certain compromises with the Islamic groups. In both situations, however, Muslim and Christian leaders were generally trapped into antagonistic discourses. For the Muslims, the state accommodation of Islamic family law was necessary because Indonesia was not a secular state, while for the Christians such an accommodation was nothing but one step further towards an Islamic State. Both Muslim and Christian leaders also expressed their respective usual discourses: Christianisation and religious freedom. In this Chapter I shall discuss four groups of cases in which Muslim and Christian leaders were involved in the antagonistic discourse: (1) the debates on secular and Islamic marriage bills in the late 1950s and 1960s; (2) the debates on the marriage bill of 1973; (3) controversies on the application of the marriage law of 1974 in relation to Islamic and Christian teachings on inter-religious marriage; (4) the debates on the religious court bill.

\section{The Debates on Secular and Islamic Marriage Bills}

There were two parliamentary debates in which both secular and Islamic marriage bills were proposed at the same time, by secular nationalists and Islamic groups respectively. The first happened in the late 1950s, and the second one was in the late 1960s, the early years of the New Order. Although the Christians were in general in favour of the secular nationalist standpoint, they became apparently more outspoken since the early years of the New Order. Perhaps, the political collapse of the PKI made the Christians more concerned with the threat of Islamic political power. In what follows, we shall discuss the two cases chronologically. 


\section{The Soekarno Period: Secular vs. Islamic Marriage bill}

As discussed in Chapter 3, the Ministry of Religion was established in 1946, and it had the authority over, among other things, the administration of Muslim marriage affairs. This authority was based on Law 22/1946 that was initially applied to the areas of Java and Madura and then to Sumatra in 1949 and finally to the whole country in 1954 . The Law 22/1946 was only a procedural statute regulating the registration and control of marriage affairs without mentioning any substantive provisions. ${ }^{1}$ This was in a way a continuing of the status quo since the Dutch colonial Government established Islamic courts called 'Priesterraden' (Priests' Councils) in the late nineteenth century to deal with Muslim marriage affairs without specifying a codified Islamic family law to be applied. The substantive Islamic law referred to by the Islamic courts was simply certain classical Islamic law books, primarily of the Shafi'i school. In 1937, the Dutch Colonial Government proposed an ordinance to oblige Muslims to register their marriages, to have a monogamous marriage and to prevent a husband from divorcing his wife unilaterally. Having considered that the ordinance would threaten the precepts of Islamic law in particular and the political position of Islam in general, the Islamic groups strongly opposed it. Thus, by early 1938, the Colonial Government eventually decided to drop it. ${ }^{2}$ In contrast, since 1933 there had already been a codified family law for Indonesian native Christians, called the $\mathrm{HOCl}$ (Huwelijks Ordonnantie Christen Indonesiers), and this was maintained by the independent Indonesian Government. ${ }^{3}$

After the Revolutionary War (1945-1949) was over, there were attempts by the Ministry of Religion to codify an Islamic marriage law. The attempts, however, never succeeded, particularly because of unresolved conflicts between the Islamic groups and the secular nationalists. The Islamic groups, who primarily controlled the Ministry of Religion, tried to maintain its authority to administer Muslim marriage affairs in which Islamic law was applied, while the secular nationalists who controlled the Department of Justice, and who were supported by proponents of women's rights, wanted to have a unified and national family law regardless of religion. The interests of the two groups were apparently difficult to reconcile.

In October 1950, the Minister of Religion, Wachid Hasjim, established the Investigating Committee on Marriage Law, led by the nationalist, Teuku Muhammad Hasan. ${ }^{4}$ The members of the Committee consisted of some Muslims, Protestants and Catholics and women activists. After a series of internal discussions and consultation with various social organizations, in May 1953, the Committee decided to formulate three marriage bills: (1) the basic bill 
applicable to all citizens; (2) the substantive bill applied to Muslims, Protestants and Catholics; (3) the bill for those outside these three religious groups. In 1954, the Committee completed its work on the Islamic marriage bill. The Minister of Religion, however, was apparently dissatisfied with it. Perhaps, the bill contained some ideas of reforms of Islamic law and tended to abolish the authority of the Ministry of Religion to administer Muslim marriage affairs. Whatever the reason was, instead of proposing the bill, in 1954, the Minister of Religion submitted the Law 22/1946 to the Parliament in order to make it applicable to the areas beyond Java and Madura, and this was approved to become Law no. 35/1954. With this approval, the Ministry secured its authority to deal with Muslim marriage affairs.

Three years later, in September 1957, the Minister of Religion, Mohammad Ilyas, gave the Islamic marriage bill to the Cabinet with a note that there would be some amendments before it was to be proposed to the Parliament. Until early 1958, however, there was no further development of the bill. Partly for this reason, the nationalist party in the Parliament, the PNI, in February 1958, proposed a general bill for all citizens, regardless of religion. This bill came to be called 'Mrs. Sumari's bill' because she was the deputy proposing the bill. Mrs. Sumari's bill eventually pushed the Minister of Religion to propose an Islamic marriage bill (a refined version of the 1954 bill) to Parliament. The Parliamentary discussion on the bills, however, was not started until early $1959 .^{5}$

The Parliamentary debates, however, did not end with a compromise. Nani Soewondo, the activist of women's rights, explained that the Islamic parties defended polygamy as if it were a principle of marriage, even though the Government's bill itself put restrictions on it. ${ }^{6}$ Thus, the Muslim leaders apparently defended polygamy not simply as an expression of religious conservatism but more importantly as a symbolic ideological struggle against their opponents. On the other hand, Zaini Ahmad Noeh, a former official of the Ministry of Religion, noted that Mrs. Sumari's bill did not mention any Islamic court or Islamic judge but only spoke of the civil court and the civil judge. ${ }^{7}$ This meant that the bill would consequently abolish the authority of Islamic courts on Muslim marriage affairs. Thus, the conflict of interests was finally unresolved, and other efforts at negotiation outside the Parliament also failed. 


\section{Early Years of the New Order: Muslim-Catholic Debates}

To the end of the Soekarno period, Indonesia did not manage to produce a substantive law on marriage but the effort continued in the New Order period. In the session held several months after the coup, the MPRS issued a decree in which it was mentioned that a marriage law should be made soon. ${ }^{8}$ In the following year, on 22 May 1967, the Department of Religion proposed an Islamic marriage bill to the Parliament (DPRGR). On the other hand, the Department of Justice through the Institute for Development of National Law (LPHN) ${ }^{9}$ also prepared a marriage bill and this bill was proposed to Parliament on 7 September 1968. The second bill was supposed to provide the basic regulation on marriage while the Islamic marriage bill was expected to be one concerning its applications. ${ }^{10}$ The existence of the two bills reminds us of the contest between the Islamic marriage bill and Mrs. Sumari's bill in the 1950s, and as Emmerson observes, the bill of the Department of Justice was intended to neutralise the Islamic-law project of the Department of Religion. ${ }^{11}$ Nonetheless, it could also be an attempt to find a compromise because the idea was to make a consensus on basic regulations and then marriage laws were to be made for different religious groups with their respective specifications. ${ }^{12}$ The Ministry of Religion actually proposed a similar idea in 1959 to find a compromise with the nationalists, that is, by taking Mrs. Sumari's bill as the basic regulation and the Islamic bill as one of its derivative implementations. ${ }^{13}$

Again, Parliament failed to ratify the bills. Now, among those who opposed the Islamic marriage bill, the most active and outspoken group appears to have been the Catholic Party. It was reported that the members of the Catholic Party left the room whenever a discussion on the bill was started in the Commission dealing with the issue. ${ }^{14}$ More than that, as we shall see, the party also circulated a memorandum containing their arguments against the bill. The opposition of the Catholic Party was certainly not the only reason behind the failure. There were probably certain irreconcilable differences between the Islamic marriage bill and the other bill. As to this issue, a few years later, Asmah Syahroni, a member of Parliament of the Nahdlatul Ulama (NU) party, explained that the Islamic parties could not accept the bill of the Department of Justice unless it was entirely in line with the Islamic marriage bill. ${ }^{15}$ Thus, the disagreement was probably not simply between the Islamic parties and the Catholic Party, but also between the former and the secular nationalist groups. However, according to a Muslim account, the opposition of the Catholic Party somehow contributed to the failure of the ratification of the bill. They argued that the unwritten rule of 
the game in the Parliament was that any decision must be based on consensus. Thus, the Catholic Party's rejection of the bill made the consensus unachievable. ${ }^{16}$ This account also seems to imply that, if a vote were taken, the Islamic groups would have won. ${ }^{17}$

The Muslim-Christian debate on the bill was generally ideological. As has been discussed in Chapter 3, during the early period of the New Order the Islamic groups tried to reassert the significance of the Jakarta Charter, while the Christians and the military opposed it. For the Islamic groups, the Islamic marriage bill was an important example of the realization of the Jakarta Charter. In the consideration of the Islamic marriage bill, it is mentioned that the shari'a law could be enacted for Muslim citizens in the country, because the Presidential Decree of 1959 declares that the Jakarta Charter inspires the 1945 Constitution, and makes a coherent whole with the Constitution. The elucidation of the bill then stated that:

Almost all of the contents of the Jakarta Charter are included in the Preamble of the 1945 Constitution except the dependent clause following the word 'Ketuhanan' in the fourth paragraph, that is, 'with the obligation for the adherents of Islam to carry out the shari'a.' Due to the existence of the Decree of the President/ the Highest Commander of the Armed Forces, after the words 'Ketuhanan Yang Maha Esa' in the Preamble of the 1945 Constitution, the dependent clause mentioned above should be considered as included. Thus, it becomes: Ketuhanan Yang Maha Esa with the obligation for the adherents of Islam to carry out the shari'a. ${ }^{18}$

Harry Tjan Silalahi, who was the Secretary General of the Catholic Party, said that the major reason behind the objection of his party to the bill was the Jakarta Charter issue. ${ }^{19}$ In this context, the Catholic party circulated a memorandum concerning its basic views of the bills with an accompanying letter dated 1 February 1969 and signed by Harry Tjan Silalahi and F.X. Soedijono. In the beginning, the memorandum only reached the Parliament members, but later it was also published in the mass media. ${ }^{20}$ In the memorandum, the Catholics argued for an either/or choice between a nationalist state and a religious state, Pancasila and Jakarta Charter, and legal unification and legal differentiation. They argued that if we accept the bills, ${ }^{21}$ it means that we accept replacing the basis of the state, the Pancasila, with the Jakarta Charter and/or with religion. In the Pancasila state, the highest legal source is Pancasila, while the bills indicate that the ultimate legal source is revelation. Moreover, for the Catholics, the Ketuhanan Yang Maha Esa of 
Pancasila does not only refer to great religions but also to other religious phenomena, including the Javanese mysticism and local customs. ${ }^{22}$ The memorandum also opposed the institution of a Supreme Religious Court mentioned in the Islamic marriage bill because it might be developed later to be a Supreme Court for all other judicial aspects of life. In addition, if religious law is accommodated by the state, then there would be various laws for various religious groups and this legal diversity would in turn lead to a legal chaos. In other words, it is only a single and unified legal system, based on Pancasila that could maintain the legal order of the state. Last but not least, the enactment of religious laws by the state would be an abuse of religious freedom because the nature of law is to force people to be subject to it. The memorandum finally concluded that we should take an either/or choice: to save the Republic of Indonesia based on Pancasila or to destroy it and replace it with a new Indonesia based on religion. If we chose the latter, it would mean: (1) the highest legal source of the national law is the revelation of each religion; (2) the national law in a pure sense is applicable only to people who do not have a religion.

There were various Muslim responses to the Catholic Party's view, and some of them contain voices of anger stating that the Catholics demonstrated an intolerant and unfair attitude to the Muslims, adopting PKI's interpretation of Ketuhanan Yang Maha Esa and practicing the strategy of the end justifies the means. ${ }^{23}$ In general, instead of drawing a clear-cut demarcation line between secular and religious perspectives, the Muslims tried to find a compromise and common ground between the two. Again, the significance of the Jakarta Charter in the Presidential Decree of 1959 and the principle of Ketuhanan Yang Esa of Pancasila, were frequently used to maintain this position. Based on this, the Islamic groups advocated the idea of legal differentiation. They argued that the Dutch Colonial Government initiated this legal differentiation system in which the indigenous Christians should be subject to a marriage law different from the law for the Muslims and this policy was later simply adopted by the Indonesian Government. However, unlike the marriage law specified for the indigenous Christians $(\mathrm{HOCl})$, the marriage law for Muslims only regulated the registration of Islamic marriages, while the substance of Islamic marriage law was not yet codified. They argued that it was a pity that after more than twenty years of independence, the state still failed to make an Islamic marriage law for Muslim citizens who were the majority of the population. The Muslims claimed that the so-called nominal Muslims also preferred to have their marriage based on Islamic precepts. Thus, it was argued, the absence of the 
Islamic marriage law resulted in a lack of legal protection for families of the majority of the Indonesian population.

Despite Muslim resentment, why did the Christians argue for legal unification even though they already had the $\mathrm{HOCl}$, which implied legal differentiation? The answer is, as Daniel S. Lev has suggested, for the Christians, legal differentiation on marriage "could lead to similar demands for Islamic autonomy in other areas of social, political and economic life, which ultimately would threaten the minority interests of Christians." ${ }^{24}$ But why had the Catholic Party not expressed such a strong opposition to the Muslim demand before? Perhaps, as discussed in Chapter 3, the established alliance with the army generals close to Soeharto during these early years of the New Order helped increase the confidence of the Catholics.

\section{The Debates on the Marriage Bill of $\mathbf{1 9 7 3}$}

Since early 1972 up to mid-1973, there were voices in society, particularly from women, including Soeharto's wife, Ibu (Mrs) Tien, ${ }^{25}$ demanding that Parliament and the Government produce a marriage law. ${ }^{26}$ In July 1973, President Soeharto eventually proposed a new marriage bill to the Parliament and at the same time withdrew the previous bills, namely the Islamic marriage bill of 1967 and the bill on basic regulations on marriage of 1968. The new bill soon triggered strong negative reactions from the Islamic groups both inside and outside Parliament. The Muslim protests took different forms such as sending official letters to high state authorities, making press statements, organising meetings and demonstrations. Their protest reached its peak on 27 September 1973 when the Government representatives (Minister of Justice, Oemar Seno Adjie and Minister of Religion, A. Mukti Ali) were scheduled to answer the responses of the Parliament to the bill. On that day, when Mukti Ali was almost finishing his speech, some male and female Muslim students who were sitting in the gallery of the parliament hall shouted at him, while others stood up and held some papers written with words of protest against the bill, and the cry of 'Allāhu Akbar' was heard. Before the time came for Seno Adjie to speak, the situation had become so chaotic and noisy that the chairman decided to suspend the session. Having noticed the situation, the Ministers and many Parliament members decided to leave the room of the plenary session and at the same time students started occupying the seats in the room. The occupation by about 500 students continued for two hours before the security staff could finally control and disperse them, and the session was continued afterward without them. ${ }^{27}$ 
There are at least three inter-related reasons why the Islamic groups strongly opposed the bill. First, for them, several articles of the bill contradicted the precepts of Islamic law. Probably the most crucial one was the question on the validity of marriage. The bill stipulated that registration was the primary condition for the validity of marriage and other rules of marriage could be included insofar they did not contradict the bill. By taking the registration rather than religious precepts as a primary condition for the validity of marriage, the position of both Islamic family law and the Islamic courts was clearly threatened. It is not surprising, therefore, that the Muslims were strongly opposed to this secular aspect of the bill. The other articles of the bill opposed by the Islamic groups were related to the open permission for inter-religious marriages, the legal status of an adopted child and some other articles relating to women's issues such as polygamy, divorce and engagement. ${ }^{28}$

Secondly, in addition to their objections to several articles of the bill, the Islamic groups were anxious that the Islamic interest should be defended in the Parliament that was dominated by the supporters of the Government. The weakness of the Islamic force in the Parliament was the result of the New Order's first elections of 1971. In the elections, the Government's party, Golkar, obtained an amazing victory of $62.8 \%$ of the total vote, while the four Islamic parties: NU, Parmusi, PSII and Perti (to be fused into a single party, PPP, in 1973) only reached $27.12 \% .{ }^{29}$ Thus, with the additional 100 Government appointed members, mostly from the Armed Forces (ABRI), the Parliament was dominated and controlled by the supporters of the Government. ${ }^{30}$ Being aware of this weakness, the reformist Muslim leader, HAMKA wrote:

In writing this article I have not forgotten myself. I am well aware that my community, the Muslims, is in a very weak condition: politically weak, economically weak, weak in every field. There remains only one thing left in which we are still not weak, that is, our faith! It is precisely at this moment, when other groups see the Muslims outwardly weak and easily controlled, that a marriage bill [has been proposed]...If a bill like this is passed through the DPR (Parliament), simply by relying on power and the force of a majority vote, we wish to remind people in all humility that the Muslims will not oppose nor rebel, because it is very obvious that they are weak. However, for the sake of religious awareness, this law will not be accepted, and neither will it be implemented. Moreover, ulama who regard themselves to be the heirs of the wisdom of the Prophets will issue a fatwa that it is FORBIDDEN (harām) for Muslims to marry under this law, and will require that marriage is only to be carried out according to Islamic rules. ${ }^{31}$ 
Worse than that, the Muslims also doubted that the current leaders of the Islamic parties would seriously defend 'the cause of Islam.' The editorial of the reformist Muslim newspaper, Abadi, for instance, was very unhappy with Mintaredja, the executive chairman of Parmusi before the fusion and now the head of PPP, who said to the press that the bill did not contradict Islamic teachings. ${ }^{32}$ The Muslims also expressed their scepticism about the prominent Muslim traditionalist politicians in the PPP such as Idham Chalid and Masjkur. ${ }^{33}$ Last but not least, they also wondered if the Minister of Religion, Mukti Ali, was on their side. ${ }^{34}$

The third reason was that the Government had not consulted with any of the Islamic groups in preparing the bill, nor with the Muslim officials at the Department of Religion. ${ }^{35}$ As noted, because Law 22/1946 authorized the Ministry of Religion to deal with Muslim marriage affairs, the Ministry had always been involved in the previous efforts at drafting a marriage bill. Thus, with regard to the present bill, the Islamic groups felt totally neglected by the Government. This was the reason why when the Muslims insisted on the necessity for the Government to withdraw the bill, they also demanded to participate in preparing a new one. ${ }^{36}$ Similar suggestions were also heard from people outside the Islamic groups. ${ }^{37}$ Nonetheless, the Government wanted to proceed with the bill and consequently the Muslims tried to increase their pressure.

The above three inter-related reasons apparently pushed the Islamic groups to fight by all possible means, and their efforts proved to be effective. The authorities, particularly the Armed Forces (ABRI) eventually considered that this tense political atmosphere would endanger socio-political stability. Therefore, General Soemitro, the Commander of the Security and Order Operations (Kopkamtib) and Soetopo Joewono, the head of the Coordinating Body of State Intelligence (BAKIN), since October 1973 had initiated lobbying with the leaders of the Islamic party, PPP, and the Muslim leaders outside the Parliament. ${ }^{38}$ After a series of meetings, the PPP and ABRI finally found a compromise by the end of November 1973, but it was not publicised until the second week of December. ${ }^{39}$ Because all politics was ultimately controlled by ABRI, the civilian politicians of Golkar, the Government party, had no choice but to go along with the compromise reached by the former. Thus, on 22 December (the Indonesian Mothers' Day) 1973, the Parliament ratified the marriage bill, and then on 2 January 1974 the Government introduced it as the Law Number 1/ 1974.

There are several earlier studies of the marriage law of 1974. Some of them pay more attention to the content of the law itself and how it reflects 
a compromise between secular legal viewpoints and Islamic law. ${ }^{40}$ Another study is more focused on the political process of conflicts and negotiations leading to the birth of the law, and how this process reflects the political culture of the New Order regime. ${ }^{41}$ Some other studies try to find whether or not the law significantly affected people's marriage behaviour. ${ }^{42}$ In this section, I shall discuss some issues which are inadequately dealt with in the existing studies, that is, the controversies on the marriage bill of 1973 in which Muslim and Christian leaders were involved: (1) the Muslim accusation of a Catholic conspiracy, (2) the debates on the relation between state and religious authorities on marriage affairs, and (3) the debates on interreligious marriage.

\section{Muslim Accusations of a Catholic Conspiracy behind the Bill}

As noted above, the Islamic groups and the Department of Religion were not involved in preparing the bill. The Department of Justice was probably involved, even though the bill was officially submitted to the Parliament by the President, not by the Minister of Justice. However, it was apparently not the business of the Department of Justice alone. Harold Crouch noted that, "the decision to introduce the legislation appears to have originated with Ali Murtopo's staff, who regarded it as an issue to be exploited in furthering the process of 'secularizing' political Islam."43 Crouch, however, did not explain who Ali Moertopo's staff were. Among the Muslims, rumours spread that the drafters of the bill were the Catholics who allied with Ali Moertopo and joined Golkar. It was reported that a Muslim preacher (quoted anonymously) said in a religious gathering that the bill was intended by the Catholics to be an effective weapon to destroy the Islamic society through its smallest unit, that is, the family. The preacher also said that the Protestants supported this effort, but they were not in the forefront. ${ }^{44}$ There was also rumour that the Catholics wanted Indonesia to be a second South Vietnam where the Catholic minority ruled the Buddhist majority. ${ }^{45}$ Emmerson noted that by this time a theory of conspiracy circulated privately among the Muslim leaders. A Muslim leader told him that, "a Catholic priest in Central Java had planned the affairs with key Catholic leaders in the Government in order to Christianize Indonesia. The priest talked to a Chinese Catholic politician in Jakarta, who passed on the plan to two other Chinese, who influenced two abangan Javanese generals in favour of the plan, who, in turn, planted the idea in the president's mind through his wife." ${ }^{46}$ It seems that these rumours had become so serious that during the heat of the controversy, Admiral Soedomo (a Protestant), the Deputy Commander of the Security 
and Order Operations (Wakopkamtib) warned the press not to publish any news of SARA ${ }^{47}$ and threatened that the Government would withdraw the publication license of the media in question if they did so. ${ }^{48}$

Although there was no direct evidence for this accusation, for some Muslims, the close relation of the Catholic intellectuals at the CSIS with Golkar and the strong opposition of the Catholic Party to the Islamic marriage bill in 1969 were more than enough to justify this rumour. ${ }^{49}$ In this context, on 14 September 1973, Pedoman newspaper published the translation of an article, written by Anthony Reid in the June 1973 edition of Catholic Worker published in Australia. The same translation was also published in Panji Masyarakat. ${ }^{50}$ In the article entitled "The Catholics in Indonesia" Reid said, among other things, that (1) although the New Order Government was mostly controlled by the military and professional technocrats, the Catholics were over-represented in it; (2) a number of Catholics had close relations with the intelligence institution of Opsus (special operation); (3) although the Catholic Party gained very few votes in the election of 1971, they were already represented in Golkar; (4) by educating a substantial part of national elites in her educational institutions, the Church could establish indirect relations with branches of the Government; (5) in her attempt to find a secured shelter and central position in the national life, the close relations of the Church with the regime was a kind of triumph.

As we can see, Reid's article did not say anything about the bill, but for the Muslims, it was no less than a confirmation of their perception that the Government of the time disproportionately favoured the Christian minority, ${ }^{51}$ and this in turn provided a justification for the accusation against the Catholics. In this context, it is interesting to look at an article written by Rusydi (son of HAMKA), the editor of Panji Masyarakat, in which he developed a theory of a Catholic political intrigue behind the bill. ${ }^{52}$ Rusydi said, while the police arrested several students and interrogated each of them to find the perpetrator behind the incident in the Parliament House, the Muslims wanted to find who the drafter of the bill actually was. Was he the President? Rusydi assumed that President Soeharto was too busy to prepare the bill himself and therefore, he just signed it and proposed it to the Parliament. Moreover, Soeharto's recent speeches, argued Rusydi, indicated that the President seems to have had a different understanding of marriage law from that of the bill. ${ }^{53}$ If the perpetrator was not the President, was he the Minister of Religion? The answer was also negative because the section of public relations of the Department of Religion already denied that. Without trying to find another possible perpetrator, he then moved on to say: 
Facing the unanswerable questions, one is naturally reminded by the previous attitude of the extremist Catholics who opposed tooth and nail the Islamic marriage bill. They left the room of the session when the Islamic marriage bill was proposed, even though the bill did not apply to them. Attention is now more focused on the Catholics because of the recent news from abroad that has indicated great development of that religion in Indonesia. For instance, they have established cordial relations with important people, have taken up vital official positions, and have influenced Golkar, the party of majority [in the Parliament].

If Prof. Rasjidi said that the marriage bill is 'a case of undercover Christianisation' begun by a demonstration [on inter-religious marriage] in the Surakarta court, ${ }^{54}$ then it is plausible to assume that the Catholic experts are actually those who act behind the bill, causing anxieties in the Islamic community.

Rusydi theorised further that the group who promoted the bill was probably those who understood Islamic beliefs and intentionally made the bill like that in order to play off the Islamic community against ABRI. With this intrigue, he said, whatever happened, they would gain advantages: "If the bill is passed, the Islamic community will necessarily decrease quantitatively and qualitatively. If the bill is withdrawn, they have already succeeded for a certain period in arousing suspicions and hatred of the rulers towards the Islamic community."

The Catholic magazine, Hidup, published an article in December 1973 by an author named Sum Ireng (probably a pseudonym) to counter the Muslim accusation. ${ }^{55}$ Sum Ireng said that the accusation against the Catholics should be examined by this question: what do we mean by 'the Catholics'? Sum Ireng then examined alternative answers: the Church leadership or layCatholics? With regard to the former, Sum Ireng explained that in a meeting of bishops held in the middle of November 1973, in Jakarta, the bishops thought that, based on rational thinking, the bill would be acceptable as a state law. Nonetheless, they also proposed an amendment to an article of the bill concerning marriage-engagement that justified a forced marriage if the woman got pregnant. This indicated, argued Sum Ireng, that the bill had not been made by the Church leaders; or else, like Golkar, they would accept it without any reserve. With regard to the second alternative, Sum Ireng argued that at that time, there was no Catholic Party that was morally responsible to the Church. On the other hand, the Church had no right to warn and admonish Catholics who joined a non-Catholic organization. Thus, he said, "if the bill were made by Catholics (I do not know), then it should 
have been by those outside Catholic organizations, and therefore, it was not related to Catholicism and neither could be put on the shoulders of all Catholics." Sum Ireng eventually concluded that in fact those who had to be responsible for the bill were not the Catholics, but the Government, which was proposing the bill. It was implausible, argued Sum Ireng, that the Government proposed a bill other than its own or that it should propose a bill without a clear understanding of its content.

Besides the attempt to free the Catholic hierarchy and its affiliated organizations from the Muslim accusation, there was an effort to show that the Catholics were not a monolithic group. In October 1973, Tempo, wrote, "Since the heat of the controversy on the bill of marriage law, inter-religious relations in Indonesia have reached their lowest point...In this regard, the Catholic group has secretly or openly become the focus of attention." 56 For this reason, Tempo assigned George Junus Aditjondro, a lay Catholic and reporter of the magazine to cover the internal development within the Church. ${ }^{57}$ In his report, Aditjondro explained that there was a competition among the Catholics between those who opted for political involvement and those who chose the socio-economic and cultural orientation, and each of them tried to influence the young Catholics to be their respective cadres. Pater Beek was the prominent figure of the first, while two Jesuits, Chris Melchers and F. Danuwinata were among the proponents of the second. Probably because Beek's politically oriented group was more or less already known, Aditjondro focused his report on the second group, for whom the major problem of the Catholics was Indonesianization not only of the personnel of the Church hierarchy, but also and more importantly, of the Catholic attitude towards society. They argued that the Church's dependence on foreign aid as well as on the national political power would only alienate Catholics from the people, especially the Muslim majority. In other words, for them, to support the economic life of the lower class people and to integrate with Muslim society were more fruitful for the future of Catholicism than establishing an alliance with the regime. Thus, the second position could be better for Muslim-Catholic relations: but nevertheless the report said that the development and influence of this group would still depend on how far the Church hierarchy would accommodate them. ${ }^{58}$

Thus, the efforts to counter the Muslim accusation neither denied nor admitted that certain Catholics were involved in drafting the bill. The countering efforts only argued that the Catholic hierarchy and its affiliated organizations were free from the accusation or that not all Catholics were happy with the politically oriented Catholics close to the Government. The second 
effort, despite the ambiguous response from certain Catholic priests, ${ }^{59}$ seems to have created a positive reaction among Muslims, indicated at least by an article by a certain Sarmudi. He argued that Danuwinata's ideas were in line with the stipulations in the document of Vatican II called Nostra Aetate that promoted a positive attitude towards Muslims. For Sarmudi, this was also parallel with Natsir's idea of establishing a modus vivendi between Muslims and Christians, as both had to maintain their respective religious identities by not trying to convert each other. Sarmudi, however, was still in doubt whether the Church hierarchy would accept the ideas of Danuwinata and put them into practice. ${ }^{60}$

Despite the positive response to the non-politically oriented Catholics, there was no indication that the Muslims who already believed in the conspiracy behind the bill later changed their mind. For instance, about three years after the controversy, in his paper to the Conference on Christian Mission and Da'wa in 1976 in Chambésy, Muhammad Rasjidi wrote that, in 1973 the Government wanted to impose a secular marriage bill that "was prepared by Christian experts working in a special department of the Government." ${ }^{11}$ Rasjidi then said: "Christian missions are prepared to be in alliance with anyone, but are not prepared to see Muslims develop their individual as well as corporate life in accordance with Islam. Any effort to strengthen Islam amongst the Muslims, any effort to see that Islamic law and traditions are established in an overwhelmingly Muslim country are regarded as a threat by the Christians." ${ }^{12}$

\section{Marriage Affairs: Between State and Religious Authority}

As noted above, the marriage bill of 1973 determined that the legal validity of marriage was primarily based on registration by state authority rather than on religious precepts. This indicates that the bill was based on the secular idea of separation between state and religion. In this regard, the head of the Golkar faction ${ }^{63}$ in the Parliament, who was also a Catholic, Gregorius Sugiharto, said that marriage law "should not necessarily follow the teachings of any religion. Our country is not a religious state, why should we keep principles of religion in making the law?" and "if we always keep the teachings of religion, we shall never make progress." ${ }^{64}$ During the hearing in Parliament, the Government explained that the bill was inclusive for all marriages insofar the latter did not contradict the rules dictated in the bill. Thus, the bill was not against Islamic law because, argued the Government, Islamic marriage law was also applicable for the Indonesian Muslims who accepted the law as a customary law (hukum adat). ${ }^{65}$ In addition, the inclusive char- 
acter of the bill, explained the Government, was intended to accommodate a religiously and culturally plural society like Indonesia under a single marriage law applicable to all citizens. This legal unification for the Government was in line with the political doctrine called 'Wawasan Nusantara' (Archipelagic Perspective) stated in the Mainlines of State Policies (GBHN) of 1973 dictating that all islands of Indonesia are subject to a single national law serving the interest of the whole nation. As the Government party, Golkar also made similar arguments. ${ }^{66}$

The Muslims, on the other hand, certainly realized that the bill threatened the application of Islamic marriage law and the authority of the Department of Religion to administer Muslim marriage affairs. In this context, to defend their interests, the Muslims argued that Indonesia was not a secular state, and therefore, instead of registration, religious rules on marriage should be the primary determinant condition for the validity of marriage. However, unlike the previous debates on the Islamic marriage bill in 1969, during the hearings in the Parliament, the speakers of the PPP did not refer to the Jakarta Charter at all (perhaps because it was considered politically disadvantageous given the Government prohibition). What they tried to do was to interpret article 29, section 2 of the 1945 Constitution stating that: "the state guarantees the freedom of all citizens to embrace their own religion and to worship according to their religion and belief." Ischak Moro, one of the speakers of the PPP faction, argued that marriage in Islam is a part of 'ibādah (worship). For him, if article 29 of the Constitution says that the state must guarantee the freedom of all citizens to worship according to their religion, then any attempt to change religious rites of the citizens by the state, (in this case the rules in marriage) was against the Constitution. ${ }^{67}$ Another speaker of the PPP faction, Teuku H.M. Saleh went further to say that article 29 did not mean that the state guaranteed the freedom of citizens not to embrace a religion and not to worship according to their religion. ${ }^{68}$ In other words, it seems, if Ischak Moro argued that marriage law must not contradict religious rules, H.M. Saleh went further saying that the state must implement the religious law of every religious group. The implication of this view is that Indonesia had to have different legal provisions on marriage. In this regard, another speaker of the PPP, A. Balya Umar, argued that legal differentiation did not necessarily lead to legal chaos and disintegration. For instance, he said, in the USA, every State had its own marriage law and this did not make the country disintegrate or become legally chaotic. ${ }^{69}$

Unlike the arguments of the PPP speakers, outside the Parliament, the editorial of Panji Masyarakat (probably written by HAMKA), still men- 
tioned the Jakarta Charter. The editorial stated that the rulers had been successful in prohibiting Muslims from talking about the Jakarta Charter that stipulated the obligation of the Muslim citizens to follow the shari'a. The editorial then said: "So far, to our understanding, the purpose of shutting the mouths of those who still bravely touch the Jakarta Charter is to avoid hurting the feelings of the Muslims who claim to follow Islam but do not obey the shari'a...For us, [the prohibition] never means that those Muslims who obey the shari'a must get rid of it and follow the law of the rulers..."70 Thus, instead of arguing for the constitutional significance of the Jakarta Charter as the Muslims did in the late 1960s, this argument only stated that the Charter should be at least applied to the Muslims obeying the shari'a. This argument also seems to imply that through the bill the nominal Muslims unfairly imposed their own will on the pious Muslims.

On the other hand, the bill was in general very acceptable to the Christians, even though their support for it was understandably not too demonstrative. The support was more apparent in the articles published in the Catholic weekly magazine, Peraba. In its second edition of October 1973, a Peraba editorial emphasized that the state and religion have their respective realms with regard to marriage: the state regulates its civil aspects, while religion is concerned with its spiritual dimensions. ${ }^{71}$ This secular view was clearly in line with the view of the bill treating marriage as a civil issue. In addition, other articles in the magazine strongly supported the idea of legal unification (another fundamental idea underlying the bill). ${ }^{72}$ So far, I have not found a published article in the Protestant media supporting the bill. However, there exist two-pages of notes by T.B. Simatupang dated 6 September 1973, a piece provided for a meeting of the DGI leadership to discuss the controversy on the bill. In his notes, Simatupang wrote that the will of the Government to have a unified marriage law for all citizens regardless of their religion had to be supported. However, he also suggested that given the strong opposition of the Muslims, a solution was to be found in order to avoid the split of the nation. ${ }^{73}$

We have noted that the ideological conflict around the bill was eventually solved through a compromise between ABRI and PPP. Based on the compromise, the bill was amended before it was finally ratified by Parliament. There were five important points in the compromise: (1) Islamic marriage law would not be reduced or changed; (2) the role of Islamic institutions of the Department of Religion dealing with marriage affairs would not be reduced and changed; (3) all articles of the bill contradicting Islamic law would be eliminated; (4) divorce and polygamy should be regulated in order 
to avoid abuses; (5) article 2 would become: a. Marriage is valid if it is carried out according to the laws of respective religions and beliefs; b. Every marriage must be registered for the order of the state administration. ${ }^{74} \mathrm{It}$ is obvious that the compromise was very much in favour of the Muslim interests, and therefore, the Islamic groups were happy with it. ${ }^{75}$

In contrast, the Christians were unhappy with the PPP-ABRI compromise. On 12 December 1973, the DGI and MAWI wrote some important points of criticism of the compromise in a piece entitled "Pokok-Pokok Pikiran BPH-DGI dan MAWI" (Basic Thoughts of BPH-DGI and MAWI). This piece was then sent to the President, the speaker of the Parliament, the Commander of Social Security and Order, General Soemitro and other authorities ${ }^{76}$ and also published in Kompas and Sinar Harapan newspapers. ${ }^{77}$ The "PokokPokok Pikiran" started with the argument that article 29 of the Constitution of 1945 indicates that the essence of religion is based on "kerelaan" meaning consent and willingness of the person in question. Then it was stated: "In recent discussions on the marriage bill, we are afraid that there is a tendency that the state does not only protect religious freedom, but also it gives the impression that the state obliges the implementation of religious laws, at least in marriage." If the latter happens, then it contradicts the principle of consent and willingness with regard to religion. Moreover, if marriage is only valid if it is carried out according to respective religions and beliefs, then it will lead to the following fundamental questions:

1. Should a person who does not have a religion be obliged to get married according to a certain religion?

2. Is the marriage of a follower of religion valid if he or she for certain reasons did not get married according to his or her religion?

3. If the partners adhere to different religions - something that frequently occurs - according to which religion should they get married?

4. If one already got married according to a certain religion and then converted to another religion, is the marriage still valid and will he or she follow marriage rules of the new religion?

To accommodate these people, based on the article 27 of the 1945 Constitution in which it was stated that "all citizens are equal before the law", the DGI-MAWI suggested that the state must provide the opportunity for them to have a valid marriage according to the state law. Another problem for the Christians, particularly the Protestants, was that their churches do not have a complete marriage law. ${ }^{78}$ If a valid marriage should be based 
on religious law, then there would be a legal vacuum. Thus, the Christians argued, to fill the legal vacuum, every church would be obliged to set up her own marriage law and either the civil courts must know it or that every church would have her own court, and this certainly would lead to great difficulties.

The basic thoughts of the DGI-MAWI did not explicitly mention the ideological issue of the Jakarta Charter underlying the controversy on the bill. ${ }^{79}$ However, the editorial of the Catholic newspaper, Kompas referred to this issue, even though the Jakarta Charter was not explicitly mentioned (again, perhaps because of Government prohibition). ${ }^{80}$ According to Kompas, article 29 of the Constitution means that "the Government will not transform the norms of religious laws to be the norms of state law," otherwise, there will be abuses of the principle of consent and willingness to follow religion. In almost the same tone as that in which the Catholic Party stated, in the memorandum opposing the Islamic marriage bill in 1969, Kompas wrote:

The application of laws of different religions in the field of marriage will also open the possibility for efforts to apply the laws of religion to other fields of life. In fact, the state's existence is endangered if different laws are applied in that state... The application of laws of different religions is essentially the same as the applications of laws of different states within a single state!

It was based on these considerations, argued Kompas, that on 18 August 1945, the agreement was made "to use only the words 'Ketuhanan Yang Maha Esa' in the Preamble of the Constitution of 1945" (an implicit statement to remind the readers that the seven words of the Jakarta Charter were eradicated). Kompas eventually concluded that the best solution to the controversy was "to create a single and unified law that guarantees the order of statehood but at the same time opens the possibility for the application of religious rules for religious followers."

Despite the ideological issue, did the Christians offer an alternative wording to that of the PPP-ABRI compromise? If we look at the editorial of Kompas above, we do not find such an alternative but this was more explicitly mentioned in the editorial of Sinar Harapan published on the same day. Without mentioning the sensitive issue of the Jakarta Charter, Sinar Harapan suggested that the PPP-ABRI compromise on the validity of marriage could be accepted provided that a clause would be added acknowledging the validity of marriage based on state law. ${ }^{81}$ So, what was really the alternative wording? In a joint letter of the DGI and the MAWI to the Deputy 
Commander of Security and Order Operation, Admiral Soedomo, dated 19 December 1973, it was suggested that the wording should be: "Marriage is valid if it is carried out according to respective religions and beliefs and/or according to the state law." 82

Nonetheless, the ideas of the DGI and MAWI delivered through the media, lobbying with the authorities, and public statements of the Christian Youths, ${ }^{83}$ all of these could not change the compromise of the PPP-ABRI. Despite the political circumstances, perhaps the Christian opposition was rather late for an already-set up-deadline. In other words, if the deadline was 22 December, the Indonesian Mothers' Day, then the Christian opposition came out just within the week leading to the deadline. Indeed, the editorial of Sinar Harapan believed that the deadline was one of the reasons why ABRI decided to make a compromise with the PPP. Both Kompas and Sinar Harapan also criticized the fact that the compromise was an extra-parliamentary move harmful to the dignity of Parliament. ${ }^{84}$ Thus, the Christians were disappointed.

The failure of the Christians to change the PPP-ABRI compromise, however, did not prevent the Muslim leaders from countering the Christian views. One of them was the former Masyumi politician, Kasman Singodimedjo, who wrote an article in January 1974 responding to the editorial of Kompas, dated 17 December 1973 (parts of it have been quoted above) that actually included the points of the DGI-MAWI's basic thoughts. ${ }^{85}$ As was discussed in Chapter 1, Communism was identified with atheism since the beginning of the New Order. Kasman apparently took this idea and argued that the definition of the validity of marriage on a religious basis was actually based on the article 29 of the Constitution, section 1, indicating that the state is based on Ketuhanan Yang Maha Esa. For him, this means that the Indonesian state and society must be religious. He refused Kompas' view that religious freedom includes freedom not to believe in any religion, and that the application of laws of religions would destroy the state. "It is easy to prove" he said, "that the fear of Kompas editor is based on the idea that is anti-religion and anti-God, at least in its assumption that the law of God is worse than the laws and norms of human beings... What can we say! That is atheism!" Based on this proposition, Kasman then tried to answer a few questions of the Kompas editorial. If the partners adhere to different religions, which religion should they follow for their marriage? The answer is, for Kasman, if one of the partners' religions forbids interreligious marriage, they should follow the regulation of that religion. If a religion does not have a complete marriage law, how can its follower get 
married? The answer is, they should follow the religion that has a complete marriage law (implying Islam).

Besides the Muslim leaders, the Government also reacted to the DGIMAWI's basic thoughts. As noted, the DGI and MAWI sent the statement of their basic thoughts to the President and also asked for time to meet with him. President Soeharto then assigned the State Secretary, Soedharmono, to handle the issue. On 21 December 1973, one day before the ratification of the bill, the delegation of the DGI-MAWI was finally able to have a meeting with Soedharmono. In that meeting, Soedharmono said that the Government would reply to the questions mentioned in the DGI-MAWI's basic thoughts in a letter. On early March 1974, the DGI and MAWI eventually received that letter which was dated 31 January $1974 .{ }^{86}$

Nonetheless, the contents of the letter are unclear and ambiguous. ${ }^{87}$ Having explained that the article 29 of the 1945 Constitution guarantees religious freedom for all citizens, the letter then set out to answer the DGIMAWI questions one by one. First, if a person does not yet have a religion, (i.e., does not belong to one of the recognized religions), he or she is not obliged to follow a certain religion, and "this person can get married according to the ways (one of the ways) based on the applied laws [and] in line with this law." 88 Secondly, if a person who already belongs to one of the recognized religions but he or she decides to get married not according to the ways dictated by his or her religion, "then as long as the way is in line with the applied law, that marriage is valid; it means that on performing the marriage, that person follows a religion according to the ways that he or she chooses." ${ }^{19}$ Thirdly, as to the inter-religious marriage, based on religious freedom guaranteed by the Constitution, the Marriage Law is not intended to force one religion upon another, nor to encourage a person to convert to, or to marry with a follower of, another religion. In this context, if an inter-religious marriage "is carried out according to one of the ways that is in line with the Marriage Law - and this is to be chosen and agreed upon by both partners - then that marriage is valid." ${ }^{\prime 90}$ Fourthly, if a person is married according to a certain religion, and then afterward he or she is converted to another religion, then that marriage is still valid. If this person, after conversion, takes actions related to marriage, then the regulations of the religion that he or she is following are applied.

As we can see, the answers to the DGI-MAWI questions were positive but still ambiguous. They are positive in the sense that a person who does not follow one of the recognized religions; or a person who does not want to follow the marriage rules of his or her religion; and a person who wants 
to have an inter-religious marriage; all of them can have a legally valid marriage. Likewise, conversion will not invalidate one's marriage entered before the conversion. On the other hand, there is still ambiguity indicated by the repeated clause in the letter stating that those marriages are valid as long as they are in line with the applied laws in general and the Marriage Law in particular. If the Law defines the validity of marriage on a religious basis, can a couple get married not according to the requirements of religion? Does 'religion' here only include the five recognised religions? We shall come back to the problems later.

\section{Inter-religious Marriage: Christianisation or a Basic Human Right?}

About two weeks after the Government officially proposed the bill to Parliament, Muhammad Rasjidi wrote an article in which he argued that the bill was actually an under-cover effort of Christianisation. ${ }^{91}$ Rasjidi based his theory of Christianisation on the recent marriage case (it was on 21 June 1973) between Kus Supiah, the daughter of Pakubuwono XII, the king of the traditional Javanese Surakarta Court, Solo, with the Governor of Central Kalimantan, R. Slyvanus. ${ }^{92}$ Rasjidi highlighted two things in this marriage: firstly, Kus Supiah was a Muslim girl while Sylvanus was a Christian (Catholic) and therefore, for Rasjidi, the marriage was prohibited by Islam. Secondly, the marriage was held with a glamorous celebration, spending a lot of money, and attended by state officials, including the President and Vice President, Ministers, Governors and foreign diplomats. The food was arranged from Hotel Indonesia, Jakarta, and many of the VIP guests were brought from Jakarta by Hercules Aircraft of the Air Force. Rasjidi then said, "all of these happened and the Islamic community could only drop tears. Her excellency, Kus Supiah, is a victim of an ongoing tactic."

What was the 'ongoing tactic'? It was nothing but an under-cover Christianisation! For Rasjidi, the marriage in the Surakarta Court (that he called a 'tragedy') was just a prologue to the marriage bill proposed to Parliament. Article 11 section 2 of the bill stated that, "differences in nationality, ethnicity, place of origin, religion, beliefs and heredity are not hindrance to marriage." Rasjidi argued that here 'religion' was cleverly inserted so that a careless reader would neglect the significant difference between religion and the other personal attributes mentioned in the article. Anybody who has ever read Islamic law would know, argued Rasjidi, that only a Muslim man is allowed to marry a Christian woman, not the opposite. With reference to the Egyptian Muslim reformist, Rashīd Ridā, Rasjidi argued that for certain reasons a Muslim man could also be prohibited to marry a Christian 
woman. Rasjidi did not deny the fact that a man and a woman of different religious backgrounds could fall in love and decide to get married, but for him, this kind of case was extremely rare and "the emergency exit [for this marriage] has been available, that is, civil registration." The problem with the bill, argued Rasjidi, was "it makes an exceptional and rare thing [i.e., interreligious marriage] of a normal and basic thing, and the result intended through this is to make the normal and basic thing [i.e., marriage between co-religionists] exceptional." But how is it related to Christianisation? As quoted earlier, Rasjidi believed that the drafters of the bill were Christians, so it seems logical for him to claim that the bill was intentionally formulated in such a way that the Christians could easily develop their strategy to make use of inter-religious marriage as a means to convert Muslims. Rasjidi even believed that Muslim boys and girls of important state leaders were frequently 'hunted' by Christian boys and girls to be their future spouses. Last but not least, Rasjidi did not forget to mention the memorandum of the Catholic Party opposing the Islamic marriage bill in 1969. Quoting Louis Gardet, an advisor to Pope Paul VI, Rasjidi said, "Nowadays, it is difficult for a Muslim to believe in the goodwill of the Christians in politics." ${ }^{13}$ Later, when the DGI and MAWI openly opposed the PPP-ABRI compromise, Rasjidi found another justification for his theory. He said, after the publication of his article on the marriage bill as an under-cover Christianisation, he was accused of being the most fanatic Muslim and was asked to abandon his PhD title. In fact, he said, he was previously of the opinion that not all Christians were influenced by the ideas of missionaries, but "having read the basic thoughts of the DGI-MAWI, I just smile and got an idea to write this article under the title: Have Not I Reminded [You]?"94

During the hearings in Parliament, the PPP voiced objections to article 11 , section 2 of the bill, which opened the possibility of inter-religious marriage, but there was no explicit statement on Christianisation. Teuku Muhammad Saleh simply asserted that in principle Islam does not allow inter-religious marriage, while Asmah Syahroni argued further that the woman's position is weak in an inter-religious marriage because: (1) the man is the head of the family, so he has more power to impose his religion on his wife; (2) if both the man and the woman still want to maintain their respective religions, they cannot avoid tensions in their family life and therefore it is difficult to prevent such a family from disaster; (3) again in the second case, it is often that the woman would like to leave her religion rather than break up her family. ${ }^{95}$ These patriarchal arguments seem to defend the com- 
mon rule of Islamic law that Muslim women are not allowed to marry nonMuslim men. ${ }^{96}$

In contrast, R. Tubagus Hamzah, the speaker of the ABRI faction, argued that the increasing rate of urbanisation in the country would inevitably lead to relationships between people of different religious backgrounds. Therefore, inter-religious marriage was an inevitable social fact and it was more likely that the number of such marriages would increase in the future. Thus, to maintain social order and to avoid legal confusion, a marriage law should take this problem into account. ${ }^{97}$ In line with Tubagus, K.H. Kodratullah, the speaker of the Golkar faction, said that based on human rights, his faction could agree with the bill allowing inter-religious marriage. He argued further that to allow such marriage did not mean imposing a certain religion on the people or encouraging them to convert or persuading them to have an inter-religious marriage. ${ }^{98}$ Later, in its reaction to the responses of the factions to the bill, the Government also emphasized the human rights argument with additional remarks that, "for those religious believers who had a strong faith, they will not break the rules of their religion, even though in terms of human rights, they are not prohibited by the law to do that." ${ }^{\prime 99}$ In other words, it is fine for any religion to tell its followers that inter-religious marriage is prohibited, but this prohibition cannot be a regulation of the state because it is against human rights.

When the bill was ratified after it was amended according to the PPP-ABRI compromise, the statement allowing inter-religious marriage was dropped, and no alternative regulation was made. In other words, inter-religious marriage was simply left unregulated in the marriage law of 1974. However, there is another possibility provided by article 66 of the law stating that the previous laws such as the Code of Civil Law (Burgerlijk Wetboek), the Marriage Law for Indonesian Christians called ' $\mathrm{HOCl}$ ' (Huwelijks Ordonnantie Christen Indonesiers S. 1933 No.74) and the Regulations on mixed marriage (Regeling op de gemengde Huwelijken S. 1898 No. 158) "are not applicable insofar as they are already regulated by this law." This provided the way out for certain problems, including inter-religious marriage. In other words, based on the article 66, one can argue that if inter-religious marriage is not regulated by the Law, then the previous law that regulates or more precisely allows that marriage is applicable. ${ }^{100}$ The colonial Regulations on mixed marriage (i.e., marriage between partners subject to different laws) seem to provide this way out. Article 7 section 2 of the Regulations states that, "differences in religion, nationality and origin are not obstacles to mar- 
riage." ${ }^{101}$ It is obvious that this section is essentially the same as the article 11 , section 2 that was dropped from the bill.

On the day of the ratification of the bill, it seems only the PDI faction into which the former Catholic and Protestant parties fused, touched this issue. ${ }^{102}$ The speaker of the PDI faction, Sugiarti Salman, said that the article 2 and its elucidation, which define the validity of marriage on religious basis, ${ }^{103}$ did not provide a feeling of security for her group. This feeling of insecurity, she said, could be reduced by the existence of the article 66 that recognizes the applicability of existing laws as far as they are not regulated by the new law. ${ }^{104}$ Sabam Sirait (Protestant) and V.B. da Costa (Catholic) of the PDI party re-emphasized this argument when they were asked by Tempo about inter-religious marriage. ${ }^{105}$

Besides trying to find a way out, Eka Darmaputera, a Protestant intellectual who was to become a leader of the PGI, wrote an article responding to the Muslim accusation that inter-religious marriage was used by the Christians to convert others. ${ }^{106}$ He argued that the Marriage Law was a combination of two opposite mindsets: the modern and the dogmatictraditional thought. He compared the Law with an offspring of a marriage between a donkey and a horse. The law, he said, was already good in terms of protection of women's rights, but it still has problem with inter-religious marriage or what he called 'mixed marriage.' He then said:

On the mixed marriage as an under-cover Christianisation effort: alas if this truly happens! That love can make a person forgets all things, it is normal. But if there is a Christian who intentionally makes use of love as a bait to convert others, once again: alas! This person cannot be called a hero of faith because he/she digresses the holiness and nobility of marriage. Second, this marriage is not a Christian marriage because it is not based on sincere love, but polluted by hidden intentions. Third, Christianity does not benefit anything from that kind of marriage. On the other hand, if a Christian decides to convert to another religion because of the pressure of the marriage law or love, then Christianity has nothing to lose except its number.

In short, he said, any religion that makes use of marriage as a means to convert people would obtain insincere followers. "Like religion, love is very personal. It could be imposed from outside, but it can only live and grow from inside. Like religion, love is very human. It must see human as human." "Unfortunately," he concluded, "in practice, it is not uncommon that religion compartmentalizes human beings." 


\section{Inter-religious Marriage between State Regulations and Religious Doctrines}

In the Indonesian legal system, a law ratified by the Parliament will not be applied unless the Government introduces its implementing regulations. This system provides another opportunity for the Government and social forces to negotiate and make a certain 'modification' of the application of the ratified law. As noted, article 66 of the marriage law provides the possibility of applying previous laws not included in the new law. The Christians then tried to use this possibility by asking the Government to accommodate their interests in the coming implementation of regulations of the law. In this regard, DGI and MAWI sent a joint letter, dated 1 July 1974 to the State Secretary. ${ }^{107}$ In the letter, both MAWI and DGI suggested that: first, for implementing the regulations of the law, the procedure of marriage for the Protestants and the Catholics can be taken from sections 19 to 33 of the $\mathrm{HOCl}$ with appropriate changes. Second, it was stated that: "For legal certainty, it would be better to be clear regarding which marriage law is applicable for the Javanese mystical groups (Aliran Kepercayaan), [and this] is in one way or another related to the regulations on mixed marriage (Regeling op de Gemende Huwelijken, Staatblad 1898 No.158) that is by itself related to the Protestant, Catholic and other religious groups."

The first suggestion of the letter seems to mean not only that sections 19 to 33 of the $\mathrm{HOCl}$ were still relevant, but also that the DGI and MAWI wanted them to be applicable to all the Christians in Indonesia (because $\mathrm{HOCl}$ was originally applied only to the Javanese, Ambonese and Minahasan Christians). With regard to the second suggestion, it apparently dealt with two issues: one was on inter-religious marriage that somehow could be included in the regulations on mixed marriage, and another was on the Javanese mystical groups whose official status was not the same as the five recognized religions. In fact, the Islamic groups had strongly opposed state recognition of marriages according to the Javanese Mysticism since the parliamentary debate on the bill. ${ }^{108}$ For the Muslim santri leaders, the followers of Javanese Mysticism (who were typically abangan) were already Muslims, and therefore, their marriages should be registered as Islamic marriages. ${ }^{109}$ On the other hand, the Christians demanded the state recognition because for them it was related to their concern with religious freedom. Moreover, for the Christians, the abangan was a potential ally, particularly to face the political ambitions of the santri. ${ }^{110}$

The Government apparently accommodated the Christian suggestions. In the Implementing Regulations of the Marriage Law, introduced on 
1 April 1975, we find that article 2, section 3 states that the existing specific regulations for the registration of marriage are not to be reduced by the Regulations. This clearly opens the way for the previously applied law to be used, including the $\mathrm{HOCl}$. The accommodation of the Christian suggestions was more explicit in the decree of the Minister of Home Affairs concerning the registration of marriage and divorce in the Civil Registry Office, dated 1 October 1975. ${ }^{111}$ The decree states that registration of marriage and divorce at the Civil Registry Office should be carried out according to the previous laws, namely, the Codes of Civil Registration for European, Chinese and Indonesian Christians respectively and the Regulations on Mixed Marriage. These laws are applicable as long as they are not overruled in the Implementing Regulations of the Marriage Law, 1975. In addition, the Civil Registry Office is also authorized to register marriages and divorces of those who do not subject themselves to those laws and to the law 22/1946 regulating the registration of Islamic marriages and divorces. The last category seems to include the Buddhists and the Hindus, and arguably, the other religious groups such as the followers of native religions and the Javanese mystical groups.

From 1975 when the Marriage Law began to be applied in Indonesia up to early 1980s, inter-religious marriage between Muslims and non-Muslims, particularly Christians, could be contracted at the Civil Registry Office. The Implementing Regulations of Marriage Law determines that a marriage of a non-Muslim is registered at the Civil Registry Office, while Muslim marriage is performed and registered by the Office of Religious Affairs (KUA). In general, the KUA refuses a male or female Muslim asking to marry with a non-Muslim unless the latter converts to Islam. Likewise, the Civil Registry Office would in the beginning refuse to perform such marriages, but based on this refusal, the partners can ask permission to get married from the Civil Court (article 21 of the Marriage Law). In general, the Court gave the permission and ordered the Civil Registry to carry out that marriage. Sometimes, the Civil Registry Office was ready to perform the marriage without the permission of the Civil Court, on condition that the partners declared on a legal certificate before a notary that they willingly subscribed to the European Civil Code applicable in Indonesia. ${ }^{112}$

On the other hand, towards the end of the1970s, the Javanese mystical groups had to face problems to legalise their marriage. As discussed in Chapter 2, in the session of the MPR of 1978, the Islamic party, PPP, successfully pushed the MPR to decide that Javanese mysticism was not a religion and should not be developed to be an independent religion. In view 
of that, in September 1978, the Supreme Judge banned the circulation of marriage certificates of Yayasan Pusat Srati Darma, one of the Javanese mystical groups based in Yogyakarta. In October 1978, the Minister of Religion, Alamsyah Ratu Perwiranegara sent a letter to all governors explaining that marriage cannot be carried out according to Javanese mysticism because it is not a religion. ${ }^{113}$ In 1981, however, the head of the Supreme Court sent a letter to the Minister of Religion and the Minister of Home Affairs explaining that inter-religious marriage and marriages between the followers of Javanese mysticism should be accommodated under the Regulations on Mixed Marriage. ${ }^{114}$ Despite this letter, in practice, the partners in marriages according to Javanese mysticism still had difficulties in legalising their status. ${ }^{115}$

Although inter-religious marriage was relatively easy in the 1970s, since the mid-1980s it gradually became more and more difficult, and in the 1990s, it became almost impossible. Why did this happen? As noted, inter-religious marriage is unregulated in the marriage law. The solution to this legal vacuum was then to apply the previous law on mixed marriage. This solution, however, is still problematic because the marriage law states that marriage is valid if it is carried out according to respective religions and beliefs. If the religion of both or one of the partners prohibits inter-religious marriage, can that marriage be legalised? In fact, there has been a strong tendency among Muslims (and not less among non-Muslims) to prohibit inter-religious marriage. ${ }^{116}$ In this section, I shall discuss Muslim and Christian teachings on marriage, particularly inter-religious marriage, and how they affected and were affected by the state regulations.

\section{The State and Muslim Opposition to Inter-religious Marriage}

In 1952, long before the rise of the New Order, there was a controversy on inter-religious marriage. It was the case of a Muslim woman and a daughter of an official of the Ministry of Religion named Soemarni Soeriaatmadja who wanted to get married with a Christian man named Ursinus Elias Medellu. When they went to the Office of Religious Affairs, the head of the Office refused and said that Islam prohibited that marriage. Based on this refusal, Soemarni then asked permission from the Civil Court and she received it. The marriage was finally performed by a Christian minister and registered in the Civil Registry Office of Jakarta. In reaction to this marriage, in a huge public gathering in a mosque of Tanah Abang, Jakarta, the Muslims protested about that marriage and declared in a statement that it was prohibited in Islam and demanded that the Government annul it. Moreover, the General Secretary of the Ministry of Religion sent a letter to the Civil Reg- 
istry Office questioning why a Christian minister performed the marriage. The Civil Registry Office replied that it was based on the Regulations on Mixed Marriage that a woman will follow the law of her husband. Soemarni's father then had an appeal to the Supreme Court demanding the annulment of the Civil Court's permission on the basis that it neglected his authority as the guardian (wali mujbir) of his daughter. Later, in 1955, the Supreme Court finally refused the appeal based on the reason that the Regulations on Mixed Marriage did not require the Civil Court to consider the guardian's authority. ${ }^{117}$

Despite the Muslim disappointment with the case, it was clear that they opposed a marriage between a Muslim woman and a Christian man and there was no explicit statement prohibiting the opposite case. However, in 1960, the Muslim traditionalist organization, Nahdlatul Ulama, issued a fatwa prohibiting inter-religious marriage, including the marriage between a Muslim man and a Christian woman. The fatwa referred to the classical text of the Shafi'ite school, al-Sharqāwi. The argument of the original Arabic text quoted from al-Sharqāwi is the following: Basically a Muslim is not allowed to marry a non-Muslim, but a Muslim man is allowed to marry a woman of ahl kitāb provided that the woman is a kitäbiyyah khälisah (purely a woman of the Book) meaning that she embraces her religion (Judaism or Christianity) before the principles (usūl) of their religions were changed (tabdīl). In other words, the reason behind this exception is that the principles of ahl al-kitäb's religions were in line with those of Islam before they were changed or corrupted. Thus, if a woman of ahl al-kitäb embraces her religion after the change, or if one is sceptical whether she embraces that religion before or after the change, then a Muslim man is not allowed to marry her. Because the fatwa said that a Muslim man is not allowed to marry a Christian woman, the reference to this text means that the fatwa considered the Christian women in Indonesia not to be kitäbbiyyah khälisa. The same fatwa was reiterated in 1962, 1968 and 1989 with additional references to other shafi'te texts, which use similar arguments. ${ }^{118}$ In other words, in contrast to M. B. Hooker's reading, I find that there is no difference between the fatwa in 1960 and 1989 at all. ${ }^{119}$

Besides the NU's strict position, other Muslims did not share this view or shared the same view but based on different arguments. As has been mentioned, Rasjidi was the man who believed that the marriage bill of 1973 was an under-cover Christianisation and suggested that he preferred to prohibit both a Muslim man or woman from marrying a Christian. In contrast, by the middle of 1975, the Regional Council of Ulama (MUI) of Jakarta 
published a guide for Muslims regarding inter-religious marriage in which it was suggested that a Muslim man was religiously allowed to marry a Christian woman if he was sure that he could educate his children according to Islam. ${ }^{120}$ However, this implied that if the Muslim man could not educate his children according to Islam, he was not allowed to marry the non-Muslim. ${ }^{121}$

The wider Muslim consensus on the absolute prohibition of inter-religious marriage apparently emerged in 1980 when the Indonesian Council of Ulama (MUI) released a fatwā on this particular issue. ${ }^{122}$ The conclusion of the fatwā was:

(1) Marriage between a Muslim woman and a non-Muslim man is prohibited (harām); (2) A Muslim man is prohibited to marry a non-Muslim woman. There are different opinions concerning marriage between a Muslim man and a woman of the People of the Book (ahl al-kitäb). Having considered that its harms are more than its benefits, the Indonesian Council of Ulama gave a fatwa that such marriage is prohibited.

Atho Mudzhar argued that the fears of Muslim conversion to Christianity combined with the Muslim political frustration concerning the regime contributed to the fatwa's strict position. For him, the fatwa holds "a radical position, for it contradicts the explicit statement of the Qur'an" allowing a Muslim man to marry a woman of ahl al-kitāb (QS 5:5). In fact it was not radical if we remember the NU's fatwa in 1960 mentioned above. The difference is only in the arguments: the NU's fatwa was based on the idea of kitäbiyyah khälisah, while the MUI's fatwa relied on the idea of benefits (maslahah) versus harms (mafsadah) or the interest of Muslim community (masālih mursalah). Nevertheless, as Atho Mudzhar noted, the 1980 fatwa was distinctive particularly because unlike other's fatwas of the MUI that were usually issued through regular Fatwa Committee meetings, it was produced in the National Consultation of the MUI in which all representatives of the ulama of the provinces were present. ${ }^{123}$

Besides the fatwa, in1983 Soeharto issued a decree on civil registration, in which it was stated that one of the authorities of the Civil Registry Office was to register and produce certificates of birth, death, marriage and divorce of non-Muslims. ${ }^{124}$ This decree was then used by the Muslims to oppose inter-religious marriage involving a Muslim partner in the Civil Registry Office. Tempo reported that since 1984, the MUI-DKI Jakarta often criticized the Jakarta Civil Registry Offices regarding inter-religious mar- 
riages involving a Muslim partner. ${ }^{125}$ The Muslim protests became stronger in 1986 soon after the marriage between a popular singer, Jamal Mirdad (Muslim) and a famous actress Lydia Kandou (Protestant). ${ }^{126}$ Accordingly, in July 1986, the MUI-DKI sent letters of protest to the Governor of Jakarta and to the High Court of Jakarta. In September, with reference to the MUI's letters, in the name of the Minister of Religion, the Director General of the Council for Development of the Organs of Islamic Courts, sent a similar letter to the Governor of Jakarta. The letters argued that the current policy of the Civil Registry Office to register inter-religious marriages involving a Muslim partner was against the Marriage Law and the Presidential decree of 1983 mentioned above. ${ }^{127}$

After the protests, the representatives of the Regional Government of Jakarta, the Department of Religion, Regional Police of Jakarta and the State Intelligence Service held a meeting to discuss the problem. ${ }^{128}$ The meeting finally produced the following agreement: a marriage of a Muslim man with a non-Muslim woman should be registered at the KUA, while the marriage of a non-Muslim man with a Muslim woman was to be registered at the Civil Registry Office provided that the partners obtain the permission from the Civil Court. This agreement was stated in the Decision of the Head of the Civil Registry Office of Jakarta, dated 12 August, 1986. Likewise, by early September, the Department of Religion of Jakarta instructed all KUAs in Jakarta to allow marriages of a Muslim man with a non-Muslim woman. On the other hand, the MUI-DKI circulated guidance on inter-religious marriage, dated 30 September 1986 explaining that marriage between a Muslim woman and non-Muslim man is absolutely prohibited but a Muslim man is allowed to marry a non-Muslim woman of ahl al-kitāb provided that he is sure that he can guide his wife and children to Islam, and this marriage should be registered at the KUA. ${ }^{129}$

There are at least three important points in this agreement. Firstly, unlike the absolute prohibition of inter-religious marriage by the fatwa of the MUI in 1980, the MUI-DKI re-opened the possibility of marriage between a Muslim man and a non-Muslim (read: Christian) woman. To justify this position K.H. Rodhi Soleh of the Consultative Board (Syuriah) of the NU explained that although the Shafi'ite school prohibits such marriage, the other three Sunni schools allow it. ${ }^{130}$ Secondly, this allowable inter-religious marriage should be officially registered at the KUA. This means that, at least in theory, the KUAs in Jakarta had to leave their previous usual policy of refusing all inter-religious marriages without any distinction. Thirdly, the agreement somehow implicitly justified the legal validity of the civil marriage of a Mus- 
lim woman with a non-Muslim man, even though Islam considered this marriage invalid. In this context, Ichtijanto, the head of Research and Development of the Department of Religion argued that (1) although marriage at the Civil Registry Office was not performed according to any religious rules, it was better than marriages without a legal status; and (2) although the woman transgresses the rule of Islam, it was not worse than that she became an apostate. ${ }^{131}$ The last argument seems to imply that the civil marriage at the Civil Registry Office was better than requiring the Muslim woman to follow the religion of her husband.

In contrast, the well-known Muslim Supreme Judge, Bismar Siregar, argued that if a Muslim woman decided to marry a non-Muslim man, it means she left her religion for the sake of her husband. ${ }^{132}$ In this context, the case of a Muslim woman, Andy Vonny Gany who married a Christian man, Adrianus Petrus Hendrik Nelwan, is relevant. ${ }^{133}$ In 1986, having been refused by the KUA, they asked permission from the Civil Court, but the latter also refused based on the reason that article 2 of the Marriage Law requires religious legitimacy for the validity of marriage. They then appealed to the Supreme Court, and in 1989 the Court finally decided to accept their appeal. In its decision, the Supreme Court argued that although according to her religion a Muslim woman was not allowed to marry a Christian man, her request to marry him indicated that she did not care about her religious status anymore and therefore, the Civil Registry Office could carry out their marriage. As we can see, the Court's argument was similar to Bismar's view, but the latter disagreed with the Court on another point. Bismar basically agreed to legalize inter-religious marriage but for him the Civil Registry Office has the authority only to register not to carry out the marriage ceremony. In other words, the marriage should be carried out according to the rules of the religion of one of the partners, and if the man is a Christian it should be carried out by the Church and then registered at the Civil Registry Office and if he is a Muslim, it should be performed according to Islam and registered by the KUA. ${ }^{134}$

In 1991, there was another development relating to the inter-religious marriage issue. Since 1985, the Government initiated the project on the Compilation of Islamic Law that covered the issues of marriage law, inheritance and religious trust (waqf). This project reportedly had interviewed 166 ulama in ten cities, held seminars and workshops attended by professors of religious law, jurists, judges and Supreme Court justices, and by 1991 the project was completed. ${ }^{135}$ Perhaps to avoid controversies, the Compilation was not proposed to the Parliament. It was simply introduced through a 
Presidential Instruction in which the President instructed the Minister of Religion to publish it in order to be used by the Government authority and society as a guide to deal with the legal issues covered. ${ }^{136}$ Although the Instruction does not clearly oblige the state authority and society to use the Compilation, it has become the reference for the Islamic courts in Indonesia. In this context, articles 40 and 44 of the Compilation respectively state that a Muslim man and woman are prohibited from marrying a non-Muslim. ${ }^{137}$ However, it is unclear to me what the actual effect of the prohibition is. For example, to my knowledge, there is no case in which the Islamic court has dissolved a marriage of a Muslim with a non-Muslim based on the Compilation.

However, as many scholars observed, since the early 1990s, Soeharto had become closer to the Islamic groups. Perhaps, this was the reason why in practice inter-religious marriage became almost impossible in this period. If a couple wanted to maintain their respective religions, sometimes they just went abroad to get married because article 56 of the marriage law states that marriage outside the country is valid if it is held according to the law where the marriage takes place. In addition, people developed certain other tricks. First, in certain cases, before registering their marriage at the Civil Registry Office, the partners perform their religious marriage twice: one according to the husband's religion and another to the wife's religion. There are some examples of this way of marriage, ${ }^{138}$ even though religious doctrines would have difficulties to justify this practice. Second, one of the partners converts formally to the religion of the other partner just for marriage in the sense that the person was subsequently not committed to the new religion at all or even he or she privately or publicly returns to the earlier religion. Third, one of the partners decides to follow the religious marriage of the partner without conversion. This method can work if the religion in question allows inter-religious marriage. ${ }^{139}$

\section{State Regulations and Christian Views on Marriage}

Not long after the Civil Registry Office of Jakarta made the agreement with the Department of Religion that a marriage between a Muslim man and a non-Muslim woman was to be registered at the KUA and at the Civil Registry Office for the opposite case, both the PGI and KWI reacted together. ${ }^{140} \mathrm{In}$ a dialogue between the PGI and KWI on mixed marriage held in Malang, 1214 March 1987, both organizations considered the policy of the Jakarta Civil Registry Office as an enforcement of Islamic view on inter-religious marriage through state institutions. The policy was also considered against religious 
freedom because it hindered the freedom of the partners to choose freely where and according to which of the applied laws they will get married. Both organizations, however, were careful in expressing their objection to the policy, perhaps because the KWI-PGI dialogue was held close to the elections of 1987. In addition, the scope of the policy was only Jakarta province, while other provinces in Indonesia did not have such a policy, even though there was fear among the Christians that being the capital city, Jakarta would be referred to as an example by other provinces. ${ }^{141}$

Besides the shared concerns for religious freedom, there is an essential difference between the Catholic Church and the mainstream Indonesian Protestant Churches in their views of marriage. The Catholic Church gives marriage an inherent religious value: it is a sacrament. Therefore, similar to the Muslim belief in Islamic law, for the Catholic Church, a marriage is not valid unless it is carried out according to the Canon law. ${ }^{142}$ In contrast, being the heirs of the Dutch Reformed Church advocating strict separation between state and church, the Indonesian Protestants see that it is only the state, not the church that has the authority to validate marriage. Therefore, the role of the Protestant churches in marriage is only to bless a marriage already validated by the state. This does not mean, however, that all kinds of marriage legalised by the state will be blessed by the churches because every church has certain criteria to determine which marriages are to be blessed (for instance, certain churches refuse to bless inter-religious marriage and/or if the girl is already pregnant unless the couple make a confession.). ${ }^{143}$

Fridolin Ukur, the General Secretary of the PGI, noted that up to 1986, in general the marriage procedure for Protestant partners was first that they went to the Civil Registry Office and then went to the church to receive the blessing. This procedure is obviously in accordance with the above Protestant view on the validity of marriage. However, after 1986, some Civil Registry Offices reversed this procedure, i.e., they refused to register the marriages of Protestants unless they already received the church's blessing. ${ }^{144}$ In line with this policy, by the end of 1988, the Head of the Civil Registry Office of Jakarta instructed his subordinates that from January 1989 on, the Office should not register any marriage unless it was already valid according to religion, i.e., after the marriage was performed in the Church (for Christians), Vihara (for Buddhists) and Pura (for Hindus). ${ }^{145}$

Partly as a response to this problem, in July and October 1988, the PGI organized regional legal consultations among its members in Medan, Ujung Pandang and Ambarawa, and then a national one in Bogor, April 1989. ${ }^{146}$ The 
legal consultations discussed two important issues of marriage: the validity of marriage and inter-religious marriage. By the end of April 1989, the PGI made a Decision on these two issues. ${ }^{147}$ On the validity of marriage, the PGI Decision stated that for the Protestants: "Marriage is valid if it is first carried out in front of the official of the Civil Registry Office and then it was to be confirmed and blessed by the church." The Decision explains that marriage has both social and sacred aspects. As a social institution, marriage should be legalised by the state, i.e., by the Civil Registry Office. On the other hand, the church plays her role as "the tool at the hands of God to confirm and bless that marriage as something already existing and validated by the Government." This point of the Decision was likely made to achieve two purposes: (1) to reaffirm the 'truth' of the early marriage procedure; (2) to justify the procedure on a religious basis in order to conform the requirement of the marriage law. Secondly, with regard to inter-religious marriage, the PGI Decision reasserted that because it is not regulated by the Marriage Law, the Regulation on mixed marriage is applicable and therefore, "marriage for partners of different religions must be provided and legalised by the Civil Registry Office." Because there had been various attitudes of the churches towards inter-religious marriage, the Decision suggested that marriage was to be carried out at the Civil Registry Office and the blessing afterward could be done according to the specific rules of the church in question.

What are the various attitudes of the churches towards inter-religious marriage? Fridolin Ukur noted four points: (1) in general, the partners are advised to get married at the Civil Registry Office and so each of them can maintain his or her religion; (2) in general, the churches will not bless that marriage, but there is a certain church that provides a religious service as a sign that the marriage is accepted by the members of the congregation; (3) there is a church that blesses this marriage on the condition that the non-Christian partner makes a written testament that he or she will become Christian; (4) there is also a church that does not only refuse to bless, but also excludes a member if he or she marries a non-Christian. ${ }^{148}$ Gerrit E. Singgih gives another explanation. He said that in a certain church, the marriage could be blessed without conversion of the non-Christian as long as he or she promises to study Christianity and the children will be educated as Christians. However, Gerrit noted that this is often only a formal procedure that is not to be realised afterward. Sometimes if the minister does not oppose inter-religious marriage, he takes that procedure just to appease the congregation. Gerrit acknowledges that, sometimes there is fear among Christians that inter-religious marriage will lead to conversion from Christi- 
anity, but this fear is often heard in Christian majority areas, not in the region where Christians are in a minority. ${ }^{149}$ On the other hand, an Indonesian evangelist wrote in 1990 that inter-religious marriage can be a good opportunity to convert Muslims. He said, the "yearning for numerical growth must be kept alive in the believing spouse that the unbelieving partner will one day accept Christ as the Lord, even though that is not his or her purpose for marrying the non-Christian." ${ }^{150}$

The Catholic Church has a different policy on inter-religious marriage. A bishop can give a dispensation to a Catholic to marry a non-Catholic with certain conditions: (1) that the Catholic promises that he or she will maintain Catholicism; (2) that the children should be educated according to Catholicism; (3) that the non-Catholic partner should be told about these two promises. In this regard, the non-Catholic should also be told about the two basic Catholic doctrines of marriage: marriage must be monogamous and divorce cannot be taken. Based on these conditions, the priest can bless the marriage. If the non-Catholic wants to convert to Catholicism, he or she will be asked to study the religion for about one year. ${ }^{151}$

In 1990, a Catholic priest published a book on mixed marriage between Catholics and Muslims. ${ }^{152}$ The book identifies some problems of Muslim-Catholic marriage. First, for the Catholic Church such a marriage is not considered a sacrament, while for Muslims, if the woman is Muslim, the marriage is considered invalid. Secondly, Islam allows polygamy and divorce, while the Catholic Church does not. So, what will happen if a Muslim man married to a Catholic woman takes another wife? Perhaps, divorce is the answer, but because divorce is not allowed by the Church, the Catholic partner does not have any chance to have another Catholic marriage. Thirdly, both Islam and Catholicism oblige their followers to educate their children according to their respective religions. How should they educate their children then? Fourthly, with regard to the procedure of marriage, there are differences between the two religions. In Islamic marriage, there should be two witnesses and both of them must be Muslims. Moreover, if the Catholic is the woman, Islam will not require her to convert, but the Church requires her to have a dispensation from the bishop and this dispensation will not be given unless she promises to maintain her religion and to educate her children according to her religion. This is why the Church cannot accept marriage contracted by Muslims at the KUA. On the other hand, Muslims have difficulties in accepting a marriage ceremony held by the Church because they assume that the Muslim will convert to Christianity. Moreover, neither Islam nor Catholicism can accept a religiously doubled marriage (first according to 
Islam and second according to Catholicism or vice versa). The priest eventually laments that so far there has been no clear solution to these problems and at the same time it is not easy to convince young people about the risks of inter-religious marriage.

\section{The Ideological Debates on the Religious Court Bill}

Before the nineteenth century, the policy of the Dutch colonial power was just to leave the existing Islamic courts in Java, some places of South and North Sumatra, East and South Kalimantan, South and parts of North Sulawesi as they were. The authority of the courts related in general to marriage affairs, including inheritance. ${ }^{153}$ The Colonial Government, however, later tried to organise the Islamic courts through a Royal Decree mentioned in Staatblad 1882 No. 152. The Decree announced the establishment of 'priesterraden', an Islamic tribunal system operating along with the existing ordinary courts in the areas of Java and Madura. Later, the Staatblad 1937 declared the establishment of the same court called 'Kerapatan Qadi' in South Kalimantan; but at the same time it restricted the authority of all Islamic courts to deal only with Muslim marriage affairs to the exclusion of inheritance. The elimination of inheritance jurisdiction was influenced by the so-called 'reception theory' stating that Islamic law can only be applied after it is received as a local custom by people. ${ }^{154}$

After independence, the above two colonial statutes were still maintained. In 1948, the Government issued Law No. 19 on the authority of justice in which the religious court (peradilan agama, the term for an Islamic court) was not mentioned independently but placed under the authority of civil court. This Law, however, was never implemented, largely due to the opposition of the Islamic groups. In 1957, the Government issued the Regulation No. 45/1957 authorizing religious courts outside Java, Madura and South Kalimantan to deal with Muslim marriage as well as inheritance affairs. Subsequently, Law No. 19/1964 that was to be revised as Law No. 14/1970 mention that the authority of justice in Indonesia is carried out by four courts: general, religious, military, and state administration courts. ${ }^{155}$ Based on this Law, the Muslim efforts to strengthen religious courts continued in the following years. In 1971 the Minister of Religion, M. Dachlan, asked permission from the President to prepare a religious court bill in which the structure, authority and procedures of the court were to be determined, and then in 1972, the next Minister of Religion, A. Mukti Ali sent to the President a draft of the bill. Although there was no further development of the religious court 
bill in the next few years, the marriage law of 1974 (Article 63) explicitly affirms the authority of religious courts to deal with Muslim marriage affairs. The President finally endorsed the preparation of the religious court bill in 1983 , and by this time, the Departments of Religion and Justice cooperated in a team to prepare the bill. After a series of meetings and negotiations among the team members up to 1985, and then followed by two meetings with Golkar and ABRI factions in 1986, the concept of the bill was finally completed and the Government proposed it to the Parliament on 3 December 1988. About one year later, the bill was ratified and introduced as Law No.7/1989. ${ }^{156}$

The Law clearly strengthens the position of the religious courts. ${ }^{157}$ It unifies the name, authority, structure and procedures of the courts. The court is called "Peradilan Agama" (Religious Court) and its authority is to deal with Muslim legal matters on marriage, inheritance, wills (wasiat), gifts (hibah) religious endowments (waqf) and charity (sadaqa). The structure of the authority of the courts is set up at three levels: (1) the lowest level is Religious Court of the district; (2) in the middle is the Higher Religious Court of the province; and (3) at the top is the Supreme Court. ${ }^{158}$ Moreover, unlike the long standing policy since the colonial period, that the decisions of religious courts should be confirmed by civil courts to be effective, the Law dictates that this confirmation is not required and for this, a bailiff (juru sita) is appointed in the courts.

In his analysis of the development of Islamic courts to the early 1970 s, Lev had negative expectations about their future. Probably because of the serious defeat of Islamic parties in 1971 elections, Lev said that, "a major political shift in favour of Islam" was "an unlikely development."159 Indeed, the Religious Court Law was produced primarily not because of the strength of the Islamic party, PPP, but because of the support of the Government. Why did this happen? Andrée Feillard noted that many high ranking state officials believed that the Religious Court Law was a reward of the military for the Muslim acceptance of the Government regulation on the Pancasila as the sole basis for social organisations. ${ }^{160}$ In line with Feillard, Bahtiar Effendy argued that the state accommodation of religious courts was one of the results of the change of political views and strategy among the Muslim middle class, from aspiring to an Islamic state to a struggle for Islamic values within the framework of Pancasila. ${ }^{161}$ Mark Cammack, on the other hand, argued that the bill was actually consistent with the regime's policy of controlling Islam. The difference between the 1970s and the late 1980s was only a matter of political strategy. He wrote: "Rather than competing 
with Islam for legislative authority, the Government is seeking to appropriate the power to declare Islamic law. Instead of defeating Islam, the regime has decided to confiscate it." ${ }^{162}$

None of the above studies, however, adequately discusses the debates on the bill. In fact, there were positive and negative responses to the bill inside and outside Parliament. ${ }^{163}$ It was probably because of the controversy that the official responses of the Parliament were given quite late, that is, about six months after the Minister of Religion made his explanatory speech on the bill to Parliament in January 1989. ${ }^{164}$ Outside Parliament, there were many reports and articles published in newspapers and magazines responding negatively or positively to the bill. ${ }^{165}$ I would argue that by looking at these debates, we will see that the bill was not only a political shift (substantially or strategically) of the regime towards Islamic groups and vice versa, but also a continuity and change of the ideological debates in Indonesia. Moreover, as in the previous ideological debates, both Muslim and Christian leaders were now involved in a mutually antagonistic discourse.

\section{Christians' Arguments against the Bill}

As discussed earlier, in 1969, the Catholic Party opposed the Islamic marriage bill particularly because it was considered a realisation of the Jakarta Charter and one step further towards an Islamic State. This argument was taken up by the Christians but with certain modification due to the fact that Pancasila was now already formally accepted by almost all important social organisations. A Jesuit named S. Widjojo argued that the Muslim attempt to realize the application of the shari'a by the state in Indonesia never ended although the strategies changed over time. ${ }^{166}$ After the eradication of the 'seven words' in 1945, he said, the Muslim movement called Darul Islam/Tentara Islam Indonesia (DI/TII) took up an armed struggle to establish an Indonesian Islamic state but this failed. Then, after the elections of 1955, the Islamic parties tried to achieve the goal constitutionally in the Constituent Assembly and again this also failed. After these failures, he said, this group that he called 'the extreme right' changed their strategy: they formally accepted Pancasila and condemned the previous efforts to establish an Islamic state, but at the same time tried to find the ways in which the shari'a could be applied by the state. Having said that, Widjojo then rhetorically asked whether it was this extreme right group who prepared the bill or whether it was a compromise between this group and the Government. In any case, for him the bill was actually one step further towards theocracy. $\mathrm{He}$ argued that a state became a religious state when it obliges the citizens 
to obey religious law; and if the law was Islamic law, then it was an Islamic state. Moreover, although the bill only accommodated the application of Islamic family law, for him, it could be developed later to include other legal fields. Finally he argued that Pancasila was a true, indigenous and original ideology of Indonesia, while religion (read: Islam) was a foreign ideology. If Indonesia was already politically free from the colonial Government, he said, then it should also be free from colonialism by "a foreign ideology under the pretext of religion."167

Another Jesuit of German origin known as a public intellectual in Indonesia, Franz Magnis-Suseno argued in a different way to oppose the bill. His arguments were primarily based on the view that religion and the state are separate and different entities. Magnis said that the court is a fundamental realization of the state authority over its citizens. If religious law is applied in the court, then the legal authority of the state is taken away by religion because the state is subjugated to the norms outside itself, i.e., religious norms. The reason is, he said, that only religious authorities, not the state, have the authority to produce a religious law. The application of a certain religious law by the state, therefore, would produce a double loyalty of the citizens. Worse than that, it would make the state only a sub-administration of the religion in question. He went on to argue that when the seven words of the Jakarta Charter were removed, it primarily meant that all social groups should not impose their respective exclusive ideals upon the others. The elections in 1955 and the debates in the Constituent Assembly indicate that those who opposed an Islamic state were in fact mostly Muslims. Thus, he said, the problem with the bill was not simply between Muslims and nonMuslims, but with the nation as a whole. Last but not least, he reiterated that a state accommodation of extremist and fundamentalist group would not reduce their demands: "if they are given a finger, they will ask for the hand." 168

The Protestants also objected to the bill, but unlike the Catholic authors, they initially avoided bringing up the Jakarta Charter issue. The editorials of the Protestant newspaper, Suara Pembaruan, particularly in March and April 1989, focused their arguments on the importance of legal unification for national unity rather than explaining it as a realization of the Jakarta Charter. ${ }^{169}$ Here the Protestants repeated the Government's argument in 1973, that is, legal unification was constitutionally based on the concept called 'Wawasan Nusantara' (archipelagic perspective). In general, the regime used this concept to suppress all socio-political differences and put them into a single Government-defined national identity. The concept 
dictated, among other things, that there would be only one single law serving the interest of the whole nation. The concept was initially stated in the GBHN of 1973. In 1978, it was included as one of the important concepts of the Government indoctrination programme of Pancasila called 'P4' and in 1988 it was still included in the GBHN. The PDI faction in the Parliament, into which the Christian parties previously fused, developed the Wawasan Nusantara argument further. The PDI argued that the Law No.14/1970 (that justified legal differentiation and became the basis of the religious court bill) should be withdrawn because the Law was written before Wawasan Nusantara was adopted by the MPR. ${ }^{170}$ Finally, as in the past, the Christians argued that legal differentiation would lead to a legal chaos. However, now a new factual thing was added: recently the Hindus had demanded to have their own religious court as well. If every religion could have its own court, it was argued, the legal system of the country would be chaotic. ${ }^{171}$

In addition, the Protestants developed another interesting argument against the bill: they criticised the title of the bill, "Rancangan UndangUndang (RUU) Peradilan Agama" (Religious Court Bill). The word 'agama' (religion) in this title, they said, implies that the court would be related to all recognized religions in the country while in reality it was only for Muslims. The PGI also disagreed with the idea to change the title into 'RUU Peradilan Agama Islam' (Islamic Religious Court Bill) because not all elements of Islamic law would be applied in the court. The Protestants, therefore, suggested the title to be changed into a long one: "the law on Islamic courts dealing specifically with marriage, inheritance, gift, wills, religious endowments and charity affairs". ${ }^{172}$ Here we can see that the criticism of the name was related to the Christian concerns with the possibility of religious discrimination and expansion of the authority of the court to other legal fields. Unsurprisingly, this critique was also taken up later by other non-Muslim religious organizations such as the KWI (Catholics), Walubi (Buddhists) and Parisada Hindu Dharma (Hindus). ${ }^{173}$

Last but not least, the Christians demanded that, if the bill were ratified, Muslim citizens should be free to choose between civil and religious courts to deal with their civil legal affairs. Again, here, the Christians were concerned with the issue of religious freedom. They argued that the difference between Pancasila and the Jakarta Charter was that the latter obliged Muslims to follow the shari'a while the former did not and therefore, to be consistent with Pancasila, the freedom to choose had to be maintained. This argument was, more or less, explained by the representatives of the $\mathrm{KWI}$ and the PGI to Parliament in early July, $1989 .{ }^{174}$ The PGI went further to suggest 
that the religious freedom mentioned in article 29 of the 1945 Constitution should become the basis of the religious court law. The PGI also argued for the importance of a general law on religious freedom that was expected to be the umbrella for the religious court law and other relevant regulations. $^{175}$

It is noteworthy that there was a Christian minister supporting the bill. He was Victor Tanja, a minister of the Western Indonesian Protestant Church (GPIB) and a PhD graduate from Hartford Seminary, USA who had written a thesis on the Indonesian Muslim Student Association (HMI) and had friendly relations with many Muslims. On 6 July 1989, Pelita newspaper reported that Tanja distributed his handwritten article on the bill to the press, ${ }^{176}$ and then it was published in Editor by the next month. ${ }^{177}$ He argued that there was no reason to worry about the application of Islamic law in the religious courts insofar as it was subjected to the national legal system. For him, the bill would not lead to a realization of the Jakarta Charter because the authority of religious courts was limited only in personal law. Moreover, he said, the Jakarta Charter was the Preamble to the Constitution, while the bill was in a lower position, that is, under the Constitution. Tanja also argued that for Muslims, Islam without law was inconceivable and the implementation of the law would depend on the state. The accommodation of the Islamic personal law, argued Tanja, was in line with Pancasila and the 1945 Constitution. He eventually suggested that all citizens should accept the bill with an open heart.

\section{Muslim Reactions to Christians' Arguments}

There were several prominent Muslim leaders, most of them of reformist background, who responded to the Christian negative reactions to the bill. ${ }^{178}$ The Muslims accused the Christians of being intolerant, using sophistic and a-historical arguments, following the communist-provocative tactics, and covering a hidden agenda of Christianisation with a nationalist rhetoric. The Muslim arguments were certainly adapted to the fact that the regime had successfully forced most of the social organisations to adopt Pancasila as their sole basis.

In Chapter 1 and 2, I noted that the Muslim leaders suggested that religious tolerance could be achieved if religious propagation was not directed to the followers of the recognised religions. Now, 'tolerance' in the Muslim discourse meant allowing Muslims to regulate their religious life through the state legal system. For them, therefore, the Christians were intolerant because the latter opposed the bill that would only regulate Muslim reli- 
gious life and would not affect the Christians. ${ }^{179}$ The Muhammdiyah leader, Lukman Harun, said that the non-Muslim Governments of the Philippines, Singapore and Thailand allowed the Muslim minorities to have their own religious courts, so he asked why the Christian minority in Indonesia did not accept that the Muslim majority should have their own religious courts. ${ }^{180}$ In line with Lukman, A. Dahlan Ranuwihardjo said that if the Muslims tolerated the application of the western civil law that was inspired by a certain religion (read: Christianity) for non-Muslims in Indonesia, why the latter did not allow the Muslims to follow their own civil law. ${ }^{181}$ Muhammad Natsir, the most prominent Muslim reformist leader, noted that the Christians were consistently intolerant towards Islamic aspirations since what he called the 'ultimatum' on 18 August 1945 to erase the seven words of the Jakarta Charter, to their opposition to Islamic marriage bill in 1969 and now to the religious court bill. He warned that if any Muslim aspiration should be aborted through the opposition of the Christians, then it would not be surprising that the Muslims, despite their big sacrifice in the struggle for the independence, felt treated as second class-citizens. Natsir also warned that the Christians' tireless efforts to cancel the ratification of the bill through mass media and political lobbying would not help create inter-religious harmony because there could be "no harmony without tolerance." 182

How did the Muslims react to the Christians' view that the bill was a realisation of the Jakarta Charter or even of an Islamic State? Unsurprisingly, the Muslim leaders denied any connection between the bill and the two things opposed by the New Order regime. Moreover, by this time most of Islamic organisations formally accepted Pancasila as the sole basis. Yusril Ihza Mahendra, a lawyer and prominent Muslim reformist intellectual, criticized S. Widjojo's argument that a state applying Islamic law would become an Islamic state. This was wrong, he said, because the state would not become a Christian state or a Javanese state when the civil court applied the $\mathrm{HOCl}$ or the Javanese customary law respectively. ${ }^{183}$ Likewise, the prominent Muslim legal scholar, Ismail Suny, argued that the existence of religious courts was far from enough to be an attribute of an Islamic state because the authority of the court was very limited. This was the reason why, he said, non-Muslim countries like the Philippines, Singapore and Ceylon could accommodate Islamic courts. ${ }^{184}$ Moreover, for Yusril, Magnis-Suseno demonstrated a sophistic argument when the latter said that if the state applied religious law, then its authority would be taken over by religion. This argument for Yusril was false because the religious court was not a private but a state institution subject to the Supreme Court. ${ }^{185}$ In line with Yusril, a recent 
graduate of the Faculty of Law, Airlangga University, Heru Santoso rejected Magnis-Suseno's proposition that if the state applies religious law, then it is subject to the law not created by itself. For Heru Santoso, before becoming a state law, the Islamic law was just the raw material processed by the legislative body and so the final result of the process was a law produced by the state. ${ }^{186}$ Yusril added that one should realize that it was not necessary for the state to create an entirely new law because the state could accommodate the existing laws, including the Islamic law. ${ }^{187}$

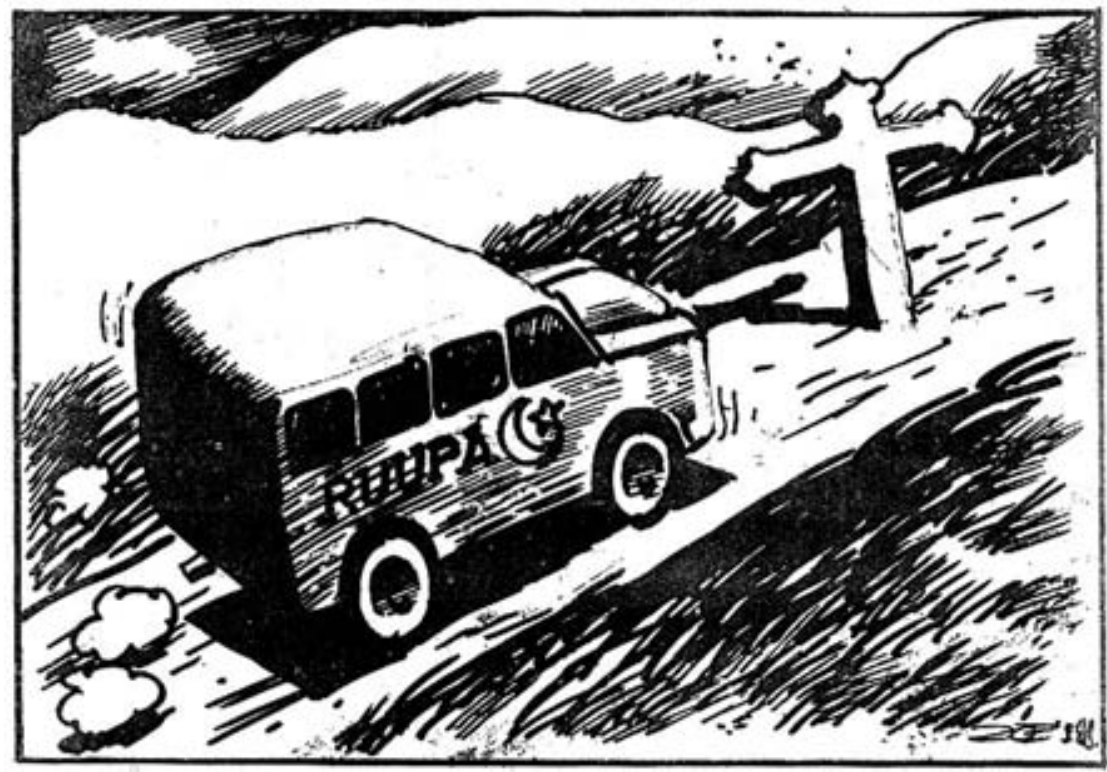

Cartoon from the Muslim magazine, Serial Media Dakwah (August, 1989), 12. The cartoon shows how the speedy car of the Islamic Religious Court Bill was stopped on its way by a big cross (symbolising the Christians).

Likewise, the Muslim leaders denied any connection between the bill and the Jakarta Charter. Yusril argued that, what the Christians opposed in 1945 was not the state accommodation of Islamic law, but the inclusion of the seven words in the Preamble of the Constitution. Therefore, argued Yusril, Muhammad Hatta, the nationalist leader who initiated the lobbying on 18 August 1945 to eradicate the seven words, said that the shari'a law can be proposed to the Parliament, and if it is accepted, then it becomes the 
state law. ${ }^{188}$ Nurcholish Madjid, a leading Muslim intellectual said that the suspicion about the bill as a realization of the Jakarta Charter was caused by the political trauma of the past. "Let's avoid such a trauma and look at the bill as a national process," he said. ${ }^{189}$ Similarly, Ali Yafie, the Muslim traditionalist figure stated that to relate the bill to the Jakarta Charter was "like seeing ghosts in broad day light." 190

As noted, the Jesuit, S. Widjojo said that the Islamic groups simply changed their political strategy by adopting Pancasila formally without changing their Islamic ideological ambition. In reaction to this charge, some of the Muslims accused the Christians of being insincere upholders of Pancasila and of having a hidden agenda of Christianisation. History tells us, said Yusril, after the eradication of the seven words, the Christians in the Moluccas were still not loyal to the Indonesian state because they declared the so-called South Maluku Republic (RMS) and rebelled against the central Government. ${ }^{191}$ Afif Amrullah, the reporter of Panji Masyarakat, and Hartono Mardjono, a prominent Muslim politician, said that they wondered why the Christians always talked about Pancasila to oppose any Islamic aspiration while in fact both the PGI and KWI were among the last social organizations to accept Pancasila as their sole basis. ${ }^{192}$ For Hartono, therefore, the Christians just pretended to be the upholders of Pancasila because they were worried that if Muslims followed the rules of Islam applied in religious courts, Christianisation in Indonesia would decrease. ${ }^{193}$ Likewise, for Rasjidi, Magnis-Suseno's arguments against the bill indicated that he spoke, "as if he were a secularist, atheist and allergic to religion, while in fact he was a Jesuit." ${ }^{194}$ For Rasjidi, therefore, there must be something else behind Magnis' arguments and this was nothing but his missionary goal as a Jesuit. Joesoef Sou'yb, a leading Muslim journalist and columnist, argued further that the Christian nationalist rhetoric on legal unification actually had a hidden purpose, that is, to maintain the application of the Christian civil law in Indonesia. He argued that the Civil Code of the Dutch colonial Government called the "Burgerlijke Wetboek" (BW) was originally applied to the Europeans and indigenous Christians and after independence it was applied to all citizens. Joesoef argued, the origin of the BW was the Napoleonic Civil Code, while the latter was based on the Roman law, customary law and Canon law. Because the Roman Empire had been a Christian empire since the fourth century, the Roman law was also a Christian law. Thus, he said, the Christians' strong negative reaction to the bill was motivated by the will to maintain "the applicability of the Christian law for Muslim society in Indonesia."195 
If the Christians said that the bill had something to do with the extreme right or Muslim fundamentalist groups, then in return the Muslims accused the Christians of using the tactics of the extreme left or the communists, another enemy of Pancasila in the New Order's ideological discourse. Yusril said that the way the authors in the Catholic weekly Hidup argued against the bill was as provocative as the communist newspapers, Bintang Timur and Harian Rakyat in the past. In another paragraph, Yusril warned the Catholics: "As a good Catholic, please do not imitate Aidit, Nyoto, Nyono and other communist leaders whose habit was to manipulate historical facts for the sake of group interests."196

Last but not least, the Muslim leaders disagreed with the view of the Christians on the absolute freedom for Muslims to choose between civil and religious courts. A. Ghani Abdullah, an important scholar of Islamic law, said that the freedom to choose would create dualism. It would be better, he said, to make clear that every Muslim had to bring their cases to the religious court. ${ }^{197}$ Similarly, in a hearing with Golkar faction, Ismail Suny asserted that to deal with marriage, inheritance and religious endowment cases, a Muslim had to go to the religious court. ${ }^{198} \mathrm{~A}$ similar view was expressed by the Indonesian Council of Ulama (MUI) in a meeting called the 'Orientation Forum on Religious Courts' attended by more than a hundred participants representing various Islamic organizations. ${ }^{199}$ In this regard, Natsir warned that Muslims should be aware of the Christian strategy to oppose the bill: first they tried to pressurize the Parliament not to ratify the bill and if this failed, they would concentrate on certain articles of the bill to find ways to weaken the authority of the religious court. ${ }^{200}$

\section{The Government's Position and the Compromise}

Because the bill was proposed by the Government, it is important to see how the Government and its main political forces in Parliament, Golkar and $A B R I$, reacted to the three important issues around the bill: (1) the relation between the bill and the Jakarta Charter or Islamic State; (2) the issue of legal differentiation as against legal unification; (3) the question on whether or not a Muslim has freedom to choose between religious and civil courts.

Unsurprisingly, like the Muslim leaders, the Government denied any connection between the bill and the Jakarta Charter. After a meeting with President Soeharto, one of the Muhammadiyah leaders, Lukman Harun, said that according to the President, the bill had nothing to do with the Jakarta Charter. Lukman also said that according to Soeharto, the bill was in line with article 29 of the 1945 Constitution guaranteeing the freedom of citi- 
zens to perform their respective religious worship because in Islam 'worship' (ibadah) includes not only performing rituals but also following religious rules contained in the Islamic family law. ${ }^{201}$ Later, the Minister of Religion, Munawir Sjadzali, elaborated this view by arguing that the word 'guarantees' (menjamin) in the article 29 does not mean that the Government should not be involved in facilitating the legal requirements of religious groups or otherwise Pancasila would become secularism. ${ }^{202}$ Thus, while the Islamic groups used the same argument to oppose the marriage bill proposed by the Government in 1973, now the Government took it up to defend the religious court bill!

In line with the Government, in Parliament, besides the PPP, Golkar and $A B R I$ factions said that they could generally accept the bill because the support of the state to religious life was truly based on Pancasila. ${ }^{203} \mathrm{How}$ ever, the ABRI faction also said that they could understand the anxieties of the people who considered the bill as a realization of the Jakarta Charter because historically there were some efforts to replace Pancasila with religion. Therefore, it was said that although the ABRI faction saw that the bill was in line with Pancasila, if there was evidence of efforts to replace Pancasila with religion, then $A B R I$ would be the first group prepared to fight against them. In this context, the ABRI suggested that one of the requirements to be a judge and administrator in the religious courts was to be untainted by any involvement in banned organizations, that is, Islamic or communist ones. ${ }^{204}$

Besides responding to the ideological issue, the Government also reacted to the Wawasan Nusantara argument. The Minister of Justice, Ismail Saleh, wrote a three-part article published in consecutive issues of Kompas. ${ }^{205} \mathrm{He}$ argued that the national law should be developed with three provisions: maintenance, reform and creation. To avoid a legal vacuum, Indonesia had to maintain the existing laws, even though many of these laws were inherited from the Dutch colonial Government. However, certain elements of these laws should be reformed and appropriated according to the present needs of the country. With regard to the fields untouched by the existing laws, Indonesia had to be creative in making new laws. Ismail explained further that the development of the national law should be based on three 'wawasan' (perspectives): first, 'wawasan nasional' (national perspective) means that the law should serve the interests of the nation; second, 'wawasan nusantara' (archipelagic perspective) that prescribes the unification of national law; third, 'wawasan bhinneka tunggal ika' (unity in diversity perspective) in which the state accommodates specific legal needs of certain groups. Based on these perspectives, the norms of Islamic law 
could be transformed into the national law as long as they were in line with Pancasila and the 1945 Constitution and relevant to specific legal needs of the Muslims.

Ismail Saleh's arguments were later taken up by the ABRI faction and the Minister of Religion, Munawir Sjadzali, to defend the bill. ${ }^{206}$ In addition, Munawir also responded to the demand of the opponents of the bill to withdraw Law No.14/1970, which states that the authority of justice consists of four courts (general, military, religious and state administration courts). As noted, the PDI faction argued that this Law should be withdrawn because it was against the Wawasan Nusantara adopted by the MPR in 1973, three years after the Law was introduced. In this context, Munawir argued that the Wawasan Nusantara was not adopted for the first time in 1973 as the PDI faction argued, but on 13 December 1957, the day of the Djuanda Declaration when Indonesia defined the extent of its territorial waters. Moreover, there had been three laws produced based on the Law No.14/1970 namely Law No.14/1985 on the Supreme Court, Law No. 2/1986 on the General Court and Law No.5/1986 on the State Administration Court. Therefore, Munawir called the religious court law the youngest that should be born out of the Law No. 14/1970. ${ }^{207}$ Last but not least, the Minister of Religion explained that legal distinction in the case of religious court law would not lead to inequality before the law or discrimination because the law was only to serve the needs of the Muslims, and not others. ${ }^{208}$

In our discussion above, we noted that Muslim leaders demanded that Muslims had no choice but to go to the religious court, while the Christians suggested that Muslims should be absolutely free to choose either the religious court or the civil court. The Government, ABRI and Golkar, however, proposed another position: for marriage affairs, Muslims had to go the religious court, while for other cases of inheritance, last testament and gift, they had the freedom to choose. ${ }^{209}$ The last position was also in line with article 49 of the bill. ${ }^{210}$ This position lay somewhere between the two extreme positions. This was probably also realistic because Islamic inheritance law was still not widely practiced, particularly in areas where local customs were commonly applied. On the other hand, the freedom to choose did not include Muslim marriage affairs because the Marriage Law of 1974 already authorized religious courts to deal with them. The Muslim leaders seemed to realize that this was the possible limit of the regime's accommodation of their aspiration. In March 1989, the chairman of the MUI, Hasan Basri, explained that article 49 of the bill was a compromise and the MUI would let the Parliament handle the issue. ${ }^{211}$ Therefore, it was not surprising that basically the 
Government position supported by Golkar and ABRI was finally maintained. Despite this compromise, the Muslims were certainly happy with the ratification of the bill, while for the Christians the compromise was somehow relieving. ${ }^{212}$ The former leading Catholic politician, Harry Tjan Silalahi said that the freedom to choose was a positive side of the Religious Court Law. "If the marriage law were also like that, it would have been better," he said. ${ }^{213}$

\section{Conclusion}

Our analysis of the debates on the position of Islamic family law has been developed by looking at the intricate relations between the triangle of the Christians, the Muslims and the Government. The Christians' opposition to the state accommodation of Islamic family law was rooted in their fears of an Islamic State. They were worried that if the state accommodated the Islamic family law, then the door was open for further expansion of Islamic law in other legal fields. As a religious minority, the Christians were worried that the state application of Islamic family law would lead to religious discrimination and abuses of religious freedom. For these reasons, the Christians opted for a secular and unified marriage law for all citizens regardless of religion. The leaders of Islamic groups, on the other hand, considered the state accommodation of Islamic family law necessary not only because the majority of the population was (at least formally) Muslim but also because for them family is a "microcosm of moral order", the last Islamic camp to be defended in the world dominated by the secular political order. ${ }^{214}$ Moreover, if Islamic family law were not accommodated by the state, then the authority of the Department of Religion on Muslim marriage affairs would be abolished, and this was a serious political loss for the Islamic groups. Finally, the Government (controlled by the secular nationalists and nominal Muslims) was initially in line with the Christian position. Many of the secular nationalists might have the same reasons as the Christians for preferring a secular and unified marriage law. However, for the Government, particularly the military, to maintain power and political stability was probably more important than the ideals of a secular state. Therefore, when the Muslim opposition to the secular marriage bill of 1973 reached the point of endangering political stability, the Government finally decided to make compromises. In the late 1980s, the Government even prepared and supported the religious court bill.

Thus, in the debates on whether the state should accommodate the Islamic family law, the Government position was not always consistent, while 
the positions of both Muslim and Christian leaders were generally consistent and therefore the change of the Government position did not change but sharpen the antagonism between the Muslim and Christian leaders. Likewise, one of the compromises between the Islamic groups and the Government was that the inter-religious marriage was left unregulated in the Marriage Law of 1974. This legal vacuum helped influence the inconsistent attitude of the Government towards inter-religious marriage: up to the early 1980s it was still very possible to have a legal inter-religious marriage, while in the 1990s this became very difficult if not impossible. By contrast, the Indonesian Council of Ulama (MUI) consistently opposed inter-religious marriage (particularly between a Muslim woman and a non-Muslim man) but a few Muslim intellectuals like Ichtijanto and Bismar Siregar argued for the basic right of partners of different religions to have a legal marriage. On the other hand, although there were different religious views of inter-religious marriage among the Christians, they consistently demanded that it should be accommodated by the state law.

However, there was development and exchange of arguments over time among the three parties. The Christians, for instance, took the Government argument on Wawasan Nusantara in 1973 to oppose the religious court bill in 1989, while to defend the bill the Government took the Muslim interpretation of article 29 of the 1945 Constitution in 1973. In addition, perhaps, the most disturbing thing in those debates was the mutual accusations and suspicions between the Islamic and the Christian leaders. No matter whether the suspicions and accusations were true or not, they already spread out to the public and possibly influenced both Islamic and Christian communities. The strong Muslim opposition to inter-religious marriage, for instance, has been partly influenced by the suspicion of Christianisation. Some Muslim scholars have recently tried to promote a new interpretation of Islamic sources to justify an absolute permission for inter-religious marriage. The opposition from other Islamic leaders to this idea, however, has been very strong, and it is difficult to expect that the idea will be widely accepted among the Islamic groups. 



\section{Religion, Culture And Education}

For a country like Indonesia, which consists of so many separate islands and more than a hundred ethnic groups, it is certainly difficult and problematic to define what Indonesian culture is. Moreover, inter-cultural contacts between the people of the Archipelago with people from other areas, before and during the colonial period, certainly affected the cultural development of the country. Despite the extreme complexity and variety of culture in the Archipelago, the intellectuals and politicians have been preoccupied with what Indonesian cultural identity is, and how it should develop. What are the elements of the existing culture that should be maintained, developed or left behind? What are the elements of foreign culture that should be adopted? The debates on these issues inevitably led to the questions on what kind of education the country should develop. In this context, tensions and conflicts between different ideological groups were almost inevitable. Our discussion in the previous chapters indicates that in the ideological debate, the Christians usually allied themselves with the secular nationalists to oppose the proponents of Islamic ideology. This is also the case in the debates on culture and education. In what follows, we shall discuss the debates and how they directly or indirectly affected Muslim-Christian relations.

\section{Contesting Discourses on Indonesian Culture}

The debate on what Indonesian culture is can be traced back at least to the1930s during the colonial period. For some decades, most of those who were involved in debating this issue were writers of novels, poets and journalists. Perhaps, the dominant role of these people was because they were seriously involved in developing the most important element of the Indonesian culture: the Indonesian language. In the later period, Muslim and Christian intellectuals also joined the debate. In this section, we shall discuss the development of the debates up to the New Order period. 
The 1930s: Is Indonesian Culture Western, Javanese or Islamic?

By the middle of the 1930s, the Indonesian literary personality and philosopher, Sutan Takdir Alisjahbana, instigated a debate that was to be known as 'the polemics on culture.' For him, there had not been anything to be called 'Indonesian culture' in the earlier history of the Archipelago. In the pre-Indonesia period, the peoples of the Archipelago never had a unified political and cultural identity. In other words, Indonesian culture was something of the future rather than of the past. Moreover, for him, if the Indonesian culture was based on the past, it would create problems. One of the problems was that each group would try to dominate the national culture. For instance, he said, if the spirit of the Javanese or Malay culture were imposed on the Indonesian culture, then the latter would become a slightly modified Javanese or Malay culture only. For the non-Javanese or non-Malay groups, this kind of national culture would certainly be unacceptable. In addition, for Alisjahbana, the cultural values of the past would only create a static rather than a dynamic society. To be a dynamic society, he said, the Indonesian culture should be orientated to western cultural values of egoism, individualism, materialism and intellectualism. For him, since people of the Archipelago had previously been able to absorb Hindu, Buddhist and Muslim cultures, then they could also adopt Western culture. In fact, he said, the emergence of the nationalist movement in the country was due to the influences of the Western culture. ${ }^{2}$

How could one develop Indonesian culture then? Alisjahbana's answer was clear: through education. Unfortunately, he said, the current orientation of education among the indigenous people was opposed to intellectualism, egoism, individualism and materialism. This orientation, argued Alisjahbana, was created by the native intellectuals who were preoccupied with the problems faced by Western societies. In fact, he said, the problem with the Indonesian people was not too much but too little intellectualism, individualism, egoism and materialism. This was the reason why, he said, the Indonesians were left behind by the West in the fields of science, technology and economy. He also argued that the fatalism and collectivism of the Indonesian culture was influenced by the monistic philosophy of India. The latter, therefore, should be replaced with dualism of the Semitic worldview of the West. Because Islam is also a Semitic religion, Alisjahbana suggested that the genuine teachings of Islam could go together with Western values. ${ }^{3}$ He finally asserted that only through the cultivation of the Western cultural values, could the Indonesian culture be in line with the international culture. ${ }^{4}$ In other words, it seems that for him Western values were universal. ${ }^{5}$ 
Alisjahbana's view triggered strong criticism from some other intellectuals, including the prominent nationalist leader, Soetomo. For Soetomo, Alisjahbana's view indicated that the latter was alienated from his own society. Any advancement in society, argued Soetomo, could not be separated from what had been achieved before. In other words, for Soetomo, to leave the existing tradition behind by cultivating Western cultural values as Alisjahbana suggested would never work in reality. Soetomo also argued that when he and his colleagues criticized Western education as too intellectualist, they did not actually refuse intellectualism as such. What they wanted was to offer an alternative model of education in which intellectualism was combined with loftier feeling and strong moral commitment. Likewise, they opposed individualism and egoism not in order to eradicate one's feeling of dignity, but to cultivate a strong personality ready to sacrifice oneself for the good of the people. Only through this type of education, he said, could one produce students who were proud of their own culture and ready to dedicate themselves in the struggle for independence. Soetomo also explained that he opposed materialism because education for the poor natives could only be developed if the teachers were not simply motivated by salary. In his explanation, Soetomo referred to the traditional 'pondok' (boarding school) and the current 'Taman Siswa' as the ideal model of an education system. In the pondok system, he said, teachers and students lived in the school environment together, so they could create close and warm relations, while in the Taman Siswa, students were introduced to the traditional arts. ${ }^{6}$

In fact, the Taman Siswa also adopted the pondok system, and Soetomo's concept of education was much more in line with that of the Taman Siswa rather than that of the Islamic traditionalist pondok where students only learned about Islam. ${ }^{7}$ The Taman Siwa was established by the prominent Javanese aristocrats, Soetatmo Soerjokosoemo and Soewardi Soerjaningrat in Yogyakarta in 1922. ${ }^{8}$ Although Soetatmo was the first leader of Taman Siswa, its success was at the hands of Soewardi who replaced Soetatmo after the latter died in 1924. On his birthday in 1928, Soewardi changed his name into Ki Hadjar Dewantara, a name indicating his belief in Javanese mysticism. ${ }^{9}$ Taman Siswa developed rapidly during the colonial period under Ki Hadjar's leadership, particularly because of his ability to offer an alternative education in which the Javanese tradition and Western education were combined. The relations between students and teachers were put in terms of a family in which students were considered as children and teachers as parents. The students were called 'anak' (child) and the teachers were called 'bapak' (father) and 'ibu' (mother). Ki Hadjar emphasised that there was no 
employer-employee anti-thesis in Taman Siswa because all members are one family, and issues within the organisation were dealt with together in peace and harmony, but in certain cases the General Leader could act as a dictator. $^{10}$

Taman Siswa's family-philosophy was attractive to the people because it could provide a strong sense of solidarity and nationalist identity as against the colonial system. This nationalist identity was enhanced by the fact that the Taman Siswa did not receive any Government subsidies. This was quite in contrast with the schools run by the reformist Muslim organisation, Muhammadiyah, and the Christian schools that received subsidies, particularly because they followed the Government curriculum. Taman Siswa, however, created its own distinctive curriculum combining traditional and modern subjects, including languages (Javanese, Malay, Dutch and English), traditional arts (singing, music and dance), arithmetic, science, history (including Javanese and Indies history), sports, handicrafts and general knowledge (current colonial affairs and general religious study). ${ }^{11}$

By looking at the cultural ideals of Taman Siswa, perhaps we can see more clearly the difference between Soetomo's and Alisjahbana's positions. Both sides actually wanted to establish a national cultural identity through education but to assert that identity, they chose different contrasts. For Alisjahbana, the contrast was the existing traditional culture, particularly the Javanese culture influenced by the monistic philosophy of India; while for Soetomo, the contrast was western culture embodied in the Dutch colonial power. For Soetomo, Alisjahbana's position was too Westernised and endangering to the nationalist spirit among the people, while for Alisjahbana, Soetomo's synthetic education would simply keep society static and pave the way for a certain group (read: the Javanese) to establish a cultural hegemony in the country.

We have noted that for Alisjahbana, the genuine teachings of Islam could be parallel with Western cultural values. Alisjahbana, however, was actually not an Islamic oriented intellectual and his position was that Islam could contribute to the Indonesian culture as long as it was in line with Western cultural values. ${ }^{12}$ This position is quite different from that of the Islamic leaders who put Islam in a high position to which all cultures should be subjected. In this context, it is noteworthy that although there was no Islamic leader involved in the polemics on culture, they were apparently aware of it. In 1937, the Muslim reformist leader, Mohammad Natsir, published a book entitled Cultuur Islam. ${ }^{13}$ The book does not mention anything about Alisjahbana's polemics, but nevertheless it was published in the period of 
the polemics. Moreover, the book was dedicated to "the new generation of Islamic youth" (dihadapkan kepada pemoeda2 Islam perangkatan baroe). This statement reminds us of Alisjahbana's group who called themselves 'new writers' (poejangga baroe). In his book Natsir simply describes the achievements of Islamic civilization in the Middle East during the Middle Ages. Almost no Indonesian Islamic culture was mentioned except a few examples of mosque architecture in the appendix of the book which was written by the Dutch convert and prominent architect, Prof. Kemal C.P. Wolff Schoemaker. The most important feature of the book is apparently Natsir's opening remarks in which he quotes H.A.R Gibb's statement: "Islam is indeed much more than a system of theology: it is a complete civilization." For Natsir, Gibb's statement indicates that the latter was an objective scholar who was free from religious fanaticism. Natsir's approval can be interpreted that, because Islam for him was a complete civilization, it could somehow become a civilization for Indonesia. In other words, the universal here is not Western but Islamic cultural values.

\section{5-1965: Universalism as a Common Ground and Conflict}

After the proclamation of independence, among the Indonesian writers and poets, a new generation that was to be called the 'Generation of 1945' emerged. The most prominent among them was the poet, Chairil Anwar, whose poetry conveyed individualist and heroic messages. Along with other literary men, in 1946, he established an association called 'Gelanggang' (arena). In contrast to the intellectuals of the 1930s, the 1945 Generation suffered the bitter experience of being under the Japanese occupation from 1942, and the revolutionary war against the returning Dutch about three years later. Bitter experiences under both periods proved to them that the East-West dichotomy was irrelevant. Both Eastern Japan and Western Dutch colonialism were opposed to something universal: human dignity. ${ }^{14}$

Therefore, unlike Alisjahbana, they now declared the universalism of culture without distinguishing the West from the East. In 1950, the Gelanggang activists published a declaration in which it was stated: "We are the true inheritors of the world culture, and we shall develop this culture in our own way...We do not bind anything with the Indonesian culture... Revolution for us is putting new values on outdated values that have to be left behind. We are of the opinion that revolution in our country is not finished yet." ${ }^{15}$ We can see here that universalism was asserted, a clear-cut definition of Indonesian culture was avoided and the revolution was considered unfinished. Thus, the national cultural identity became fluid, something that was 
to be continuously sought. In a way, the latter is in line with Alisjahbana's future-oriented conception of Indonesian culture. ${ }^{16}$

The declaration of 1950 apparently represented the view of the Western educated group rather than the whole spectrum of the existing views of culture. The different views of culture actually penetrated different realms of state institutions. As discussed in Chapter 3, the Department of Religion was established in 1946, and one of its duties was to control Islamic schools called 'madrasah.' This somehow indicates that the Islamic ideal of culture would be cultivated through the madrasah education. On the other hand, in the early revolutionary period, Ki Hadjar Dewantara was appointed the first Minister of Education of the young Republic. Some Taman Siswa activists were also recruited to the state schools and the educational bureaucracy. However, this does not mean that the cultural ideals of Taman Siswa strongly influenced the Ministry. As Kam Hing observed, the Ministry of Education gradually preferred professionalism and therefore, those who had been trained in Dutch education became more influential in formulating Government policies than the graduates of the Taman Siswa. Moreover, the state schools now became much more attractive to promising students than the Taman Siswa, partly because the latter still wanted to maintain its pre-war curriculum and educational policies. ${ }^{17}$ However, the role of the Taman Siswa in the struggle for independence was still highly respected. After his death in 1959, the Government declared Ki Hadjar Dewantara to be the Father of National Education, and his birthday, 2 May, to be the Education Day. More than that, Ki Hadjar's cultural ideal of family-ism, particularly the paternalistic democracy in which the leader could act as a dictator, was manifested in the national politics through Soekarno's Guided Democracy. ${ }^{18}$

It was during the Guided Democracy period that the debate on culture revived again. ${ }^{19}$ In contrast to the previous periods, the debate on culture was now influenced by the international cold war between the communist and the capitalist blocs. Within the country, the important political forces were the triangle of the Indonesian Communist Party (PKI), President Soekarno and the military. By the early 1960s, the PKI-affiliated Institute of People's Culture (LEKRA), ${ }^{20}$ became very active in campaigning against those writers and artists alleged to be the promoters of literature and arts for the bourgeois class, the capitalists and the imperialists. The LEKRA activists argued that art and literature should be dedicated to the ordinary people (rakyat) rather than to the bourgeoisie. In order to serve the ordinary people, they said, the art and literature should be based on the so-called 'socialist realism', which represents the real life of the people through the framework 
of socialist morals. This 'socialist realism' was then contrasted with 'universal humanism' which was considered a false slogan taken from Western imperialists to conceal their real interests. ${ }^{21}$

The clash between LEKRA and its opponents was inevitable. The writers and activists, who became the targets of LEKRA's criticisms, with some support from the military, tried to defend themselves. After a series of meetings, these writers (some of them were prominent Muslim and Christian intellectuals) eventually produced a declaration on August 1962 called 'Manifes Kebudayaan' (Culture Manifesto). The Manifesto stated: "For us, culture is the struggle for the perfection of the condition of human life. We do not put one aspect of culture before the other." With regard to the national culture, the Manifesto stated that it would be developed seriously and honestly as "the struggle for defending and developing our dignity as the Indonesian nation among other nations. Pancasila is the philosophy of our culture."22 Here we find an assertion of universalism similar to that of the 1950 declaration. However, unlike the latter, the Manifesto tried to establish some criteria for the national culture, i.e., it was to be developed to enhance the dignity of the nation based on Pancasila. The inclusion of Pancasila indicates the ideological position of the supporters of the Manifesto.

While Pancasila was declared to be the ideological basis of the Culture Manifesto to oppose LEKRA's Marxism, the Islamic groups asserted a rival Islamic ideology. In 1962, the Council of Islamic Art and Culture (MASBI) led by the Muslim reformist leader, HAMKA, published their view of culture. The MASBI asserted that culture is the manifestation of human spirit, emotion and action as a gift from God, and it is called Islamic culture if it is based on tawhid, the Islamic monotheism. In reaction to the LEKRA's slogan of 'art for people', the MASBI affirmed that 'art for devotion to God'. The MASBI explained that the devotion to God would by itself benefit the inner and outer life of human beings. The MASBI also stated that Islamic art and culture should promote noble ethics and be in line with Islamic rules. ${ }^{23}$ Later in December 1963, all Islamic parties and organisations cooperated to organise a National Consultation on Developing Moral and Islamic Arts. The Consultation finally made a "Manifesto of Islamic Culture and Arts". Besides stating that Islamic culture and art should be oriented to God, for the benefit of humanity, in its introduction, with reference to Soekarno's Decree of 1959, the Manifesto affirmed that the Jakarta Charter inspired the 1945 Constitution. Thus, here the Islamic politico-ideological stand was reaffirmed. ${ }^{24}$

The LEKRA activists reacted to both the Culture Manifesto and Islamic groups. HAMKA for instance, was accused by the LEKRA activists of plagia- 
rism. ${ }^{25}$ LEKRA's attacks on the Culture Manifesto group appear to have been stronger. They accused the Manifesto group of being opposed to Soekarno's revolutionary political stand and influenced by Western imperialists. LEKRA activists referred to the Manifesto by the mocking acronym: 'Manikebu' (literally meaning buffalo sperm). In this fight, the LEKRA eventually was the winner. On May 1964, Soekarno declared a ban of 'Manikebu'. The official reason for the ban was that the "Manifesto Kebudayaan" (letter 'o' was intentionally added here) indicated that the group was sceptical to accept the 'Manifesto Politik' (Political Manifesto) of the Government. ${ }^{26}$ As a result, the Culture Manifesto group had to meet bitter experiences: they were removed from certain official positions, the license of their publication was cancelled and their books were publicly burned. ${ }^{27}$ After the abortive coup of 1965 , however, the LEKRA was to suffer more: it was banned and its activists were imprisoned and some probably killed during the massacre of the Communists.

Our discussion so far demonstrates that up to the 1960s there were four major contesting views of culture in Indonesia: (1) the secular Western oriented view that eventually developed to be the universal humanism; (2) the Islamic view of culture; (3) the Marxist view of culture; (4) the re-actualisation of the Javanese culture as the national culture. After the abortive coup of 1965, the Marxist view was banned but the other three still survived. The questions now are: (1) how did the three cultural views compete and interact during the New Order? (2) What was the official Government view? (3) Because religion became politically much more important during the New Order, how did the different views of culture influence Muslim-Christian relations?

\section{Secular vs. Islamic View: the Kipandjikusmin Affair (1968-1970)}

In 1968, an important literary controversy emerged. When HAMKA was accused of plagiarism by LEKRA activists in the early 1960s, the prominent literary expert, H.B. Jassin defended HAMKA. By this time, both HAMKA and Jassin considered LEKRA as the common enemy, even though they actually had different views of culture: Jassin tended to a secular and Western view while HAMKA to the Islamic viewpoint. Just a few years after LEKRA was gone, however, the clash between the two different views of culture emerged. This was indicated by the controversy on a short story that appeared in the literary magazine Sastra in 1968, entitled "Langit Makin Mendung" (The Darkening Sky) written by a person who used the pseudonym of Kipandjikusmin. ${ }^{28}$ The story received strong negative reactions from the Islamic groups: Sastra 
was banned in Medan, its office in Jakarta was attacked by demonstrators and the Ministry of Religion prosecuted its editor, H. B. Jassin. The Muslims objected to the story's description of God wearing glasses, of the Prophet Muhammad who was bored with the leisurely life in Heaven and of the Angel Gabriel whose hair was grey and body was weak because of age, and of the moral corruption of the ulama during Soekarno period. Although Kipandjikusmin and Jassin later publicly apologized to the Muslim community, the Islamic groups still demanded that the case be brought to the court. When the case was tried in the court by early 1970, Jassin decided to take the responsibility for the story, and refused to reveal Kipandjikusmin's identity. In the same year, the court finally decided that Jassin was guilty of insulting Islam and was sentenced to one year's suspended imprisonment: he would not be imprisoned if he did not commit a further offence in the next two years. Jassin refused to accept the verdict and took the case to a higher court, but there was no further development of the case in the following years. ${ }^{29}$

Many writers defended Kipandjikusmin including several Christians. ${ }^{30}$ The editor of the Catholic magazine, Peraba, for instance, wrote that because Kipandjikusmin already apologised publicly to the Muslim community, he should be forgiven. To forgive, he said, was also in line with the teaching of religion that God is the Most Merciful. Moreover, for the editor, in this case, it was God, not human beings that had the right to forgive or punish Kipandjikusmin. ${ }^{31}$ Likewise, although many Islamic-oriented writers opposed the publication of the story, one of them, Bahrum Rangkuti, defended it based on the argument that Sufi literature in Islam also often described God in anthropomorphic terms. ${ }^{32}$ In his defence before the court, Jassin also quoted Sufi literature and some Qur'anic verses describing God in physical terms. ${ }^{33}$ Moreover, Jassin explained that Kipandjikusmin was born into a Muslim family but studied in a Catholic school. Kipandjikusmin's imagination, argued Jassin, was probably influenced by Christianity that allowed personification of God in all artistic works. If Islamic leaders still prohibited imagination, argued Jassin, a Muslim artist who preferred freedom would leave Islam. ${ }^{34}$

On the other hand, HAMKA, who attended the trial as a witness, disagreed with Rangkuti's and Jassin's arguments. HAMKA argued that the personification of God in Sufi literature was based on human love towards God, while Kipandjikusmin's imagination of God wearing glasses simply indicated that God's sight was imperfect. HAMKA was also unhappy with the unflattering description of the ulama in the story. For HAMKA, although there were bad ulama during the Soekarno period, Kipandjikusmin's description sug- 
gested that it was only the ulama who were corrupt. ${ }^{35} \mathrm{He}$ also could not accept the freedom of imagination developed in the Christian arts as Jassin suggested. For HAMKA, such freedom would only destroy the sacredness of Islam. HAMKA even claimed that since the Crusades, nobody had been able to produce, through his creative imagination, more hatred towards Muhammad than Kipandjikusmin. If there was no opposition to the story, he said, Kipandjikusmin would probably receive high compliment from the Catholic world. ${ }^{36}$ HAMKA's defence of the ulama and strong words against Christianity were no doubt influenced by the political frustration of Islamic leaders and Muslim-Christian tensions in the early years of the New Order.

\section{The CSIS's Strategy of Culture and Muslim Opposition}

We have seen that in the debate between HAMKA and Jassin on the Kipandjikusmin case, Christianity was mentioned in opposition to Islam. The Muslim-Christian dimension of the debate on culture is more apparent in the subsequent period of the New Order. In 1978, the personal assistant to President Soeharto, Ali Moertopo, published a book entitled Strategi Kebudayaan (Strategy of Culture). ${ }^{37}$ As discussed in Chapter 3, in cooperation with some intellectuals, particularly the Catholics, Moertopo established a think tank in 1971 called CSIS. Moertopo said that he prepared the book in cooperation with the CSIS intellectual, A.M.W. Pranarka (a Catholic). The term 'strategy of culture' was apparently introduced for the first time to Indonesia through the work of the Dutch scholar and Protestant philosopher, C.A. van Peursen, Strategie van de Cultuur, that was translated by the Indonesian Jesuit, Dick Hartoko and published with the cooperation of a Catholic and a Protestant publisher in $1976 . .^{38}$ In the book, van Peursen argues that human beings do not only have to understand but also to plan the development of their culture. It is this planning of culture that van Peursen called 'the strategy of culture.' Moertopo apparently used the term in this sense, even though his general analysis of culture was different from that of van Peursen.

If we compare Moertopo's arguments with the previous debates on culture, we can see that he tries to combine the idea of universal humanism with Taman Siswa's idealisation of the Javanese culture. The universal humanism was ironically developed to justify his essentialist view of Indonesian culture, while the Javanese ideals of family-ism were used to reject the political culture of opposition. He argued that the essence of culture is humanisation. The humanisation, however, is not understood in an abstract sense but in the context of the historical development of the culture in 
question. Thus, to understand the Indonesian culture or the humanisation in Indonesia, one should know the history of the country. He shamelessly claimed that the history of the culture of the Archipelago is actually one single history. The Indonesian culture, for him, could be traced back to the early history of the Archipelago in which people already believed in animism and even in the 'Ketuhanan Yang Maha Esa.' ${ }^{39}$ Later, he said, the original Indonesian culture continuously survived, even though it was enriched by Hinduism and then Islam through the acculturation process. The coming of the Westerners to the Archipelago in the subsequent period created a cultural dualism that eventually paved the way for the so-called 'national resurgence', leading to Indonesian independence. In this context, for him, Pancasila is the true manifestation of Indonesian culture in the sense that the principle of family-ism, cooperation and harmony is embodied in it. With regard to religion, he claims that the Indonesian culture never questions which religion is the best because the most important thing is how far a religion could contribute to humanisation. Now Indonesia had to face the challenges of the modern age, that is, economic development supported by science and technology. For him, Hinduism and Islam had already contributed to the development of the Indonesian culture in terms of religion, language, art and social systems, but not in terms of economics, science and technology. Therefore, he continued, the first urgency of the strategy of culture was economic development supported by science and technology. The second urgency of the strategy of culture was a strong national leadership and the third was education in which cultural potentials of the people were to be mobilised. Moertopo's point on the strong leadership was apparently made to justify the military's authoritarian rule.

We have mentioned in Chapter 3 that earlier in the same year (1978), the Muslim prominent intellectual, Muhammad Rasjidi engaged in a polemic against the CSIS intellectual, A.M.W. Pranarka, on nationalism and that, because of this, Rasjidi was pensioned off from his position as Professor of Islamic Law in the University of Indonesia. Now, when the book Strategi Kebudayaan appeared, Rasjidi took the opportunity to criticise it. Rasjidi believed that the book was actually written by Pranarka, not Moertopo because the ideas of the book were very similar to, if not totally the same as, Pranarka's view on nationalism. Rasjidi's view of the authorship of the book reflects his perception of a Catholic-military conspiracy behind it. There are at least two important points in the book criticised by Rasjidi, namely, its secular view of culture, and its attempt to identify Javanese abangan (nominal and syncretic Muslim) culture as authentic and separate from that of the santri (practic- 
ing and orthodox Muslims). For Rasjidi, although Pranarka was a Catholic, the latter pretended to be a secularist. To say that the essence of culture is humanisation, for Rasjidi, is nothing but to affirm a secular view of culture. This position was taken, argued Rasjidi, to eradicate Islamic identity from Indonesian culture. This is why the book states that Islam only enriched the Indonesian culture, while in fact, he said, Islam not only enriched but also changed Indonesian cultural identity. Rasjidi also reacted to the claim of the book that Indonesian culture is very tolerant in the sense that it does not overemphasize religious differences. In fact, argued Rasjidi, this argument was used by Pranarka to overemphasize the difference between the Javanese abangan Muslims and the other (santri) Muslims. ${ }^{40}$ In other words, to say that the authentic Indonesian culture does not pay much attention to religious differences is simply to assert the abangan religious attitude and to differentiate it from that of the santri that is considered to be religiously exclusive. For Rasjidi and other Islamic leaders, both abangan and santri should be put into a single category as Muslim. ${ }^{41}$

The reason why Rasjidi was very negative about the book was because it was written and published by the CSIS people who were politically very influential in the 1970s and the first half of the 1980s. Besides Ali Moertopo, another patron of the CSIS was Soedjono Hoemardani known as a guru to Soeharto in mystical affairs. Moreover, the head of the CSIS, Daoed Joesoef, was appointed as Minister of Education and Culture from 1978 to1983. Daoed Joesoef was actually born into a devout Muslim family, but in politics preferred secularism to Islamic ideology. ${ }^{42}$ He also showed a very sympathetic view of the Javanese mysticism. He wrote that Hoemardani's mysticism represents the national cultural identity. Because of Hoemardani, he said, the analysts of the CSIS could combine the scientific approach of the West with the contemplative and integrative approach of the Indonesian culture. By this combination, he said, the CSIS did not only become "the bearer of culture" but also "the developer of culture." ${ }^{43}$ In 1978, the Government appointed A.M.W. Pranarka to be the Secretary of the Commission for the Reformation of the National Education (KPPN). Being politically secular, Pranarka also had strong sympathy with Javanese mysticism. He did not only write on the teachings of Hoemardani, ${ }^{44}$ but also on those of Ki Hadjar Dewantara. By 1984, the CSIS developed cooperation with Taman Siswa in which Pranarka became the Head of the Consortium of Cultural Studies, Sarjana Wiyata, Taman Siswa. In his paper presented to the Consortium, Pranarka claimed that Ki Hadjar "is the authentic expression of the Indonesian personality." 45 
On the other hand, the Islamic leaders always protested against what they considered to be the attempts of the CSIS group in the Department of Education and Culture to implement their view of the strategy of culture. In the next section, we shall discuss some cases in which the Government educational policies were opposed by the Islamic groups. Here we shall just look at the more abstract level of the debate, that is, on basic views of education. We have noted that in 1978, the KPPN was established and Pranarka was appointed to be the secretary. The head of the KPPN was Slamet Iman Santoso, a Professor of Psychology and Rector of the University of Indonesia, Jakarta. Among the members of the KPPN, there were also some Muslim intellectuals. Thus, the KPPN was not totally controlled by Pranarka and Daoed Joesoef. However, the Islamic leaders were always suspicious of the role of Pranarka.

After its inception, the KPPN started collecting ideas for educational reforms. When the early draft of the KPPN's concept of reform (that had not yet been discussed) reached the Islamic leaders, the latter soon reacted negatively. The Indonesian Council of Ulama (MUI) stated that "there is adequately convincing evidence that in this concept of National Education, the Minister of Education and Culture uses the ideas of secularism by giving the important role to the Catholics [in its making]." ${ }^{46}$ In this context, Rasjidi even directly pointed his finger at Pranarka and his strategy of culture theory. ${ }^{47}$ After a series of discussions, in July 1979, the KPPN approved a preliminary draft of the educational reform and published it as a book. ${ }^{48}$ The publication of the draft was intended to encourage feedbacks from different groups of society, including the MUI. Again the MUI was critical of 'the cultural approach' mentioned several times in the book. Although the book defined the cultural approach as efforts to develop material and spiritual qualities of the human being, the MUI was apparently still unsatisfied. The MUI argued that the Mainlines of State Policies (GBHN) of 1978 stated that one of the goals of education was to cultivate 'takwa' (Arabic: taqwā), that is, to follow the orders of God and not to break His prohibitions. Therefore, argued MUI, unlike the KPPN's cultural approach, the GBHN dictated that education had a religious goal. For the MUI, KPPN's concept would bring education to atheism and secularism. ${ }^{49}$

\section{Muslim and Christian Discourses on Religion and Javanese Culture}

As we can see, the Muslim opposition to CSIS's strategy of culture was partly related to the Muslim negative perception of the role of the Catholics. Our questions: What was the Catholic priests' view of Indonesian culture? 
Was it parallel with that of the CSIS? In 1979, J.W.M. Bakker (under the pseudonym of Rachmat Subagya) wrote a book on the original religion of Indonesia. Like the CSIS intellectuals, he argued that the first principle of Pancasila, Ketuhanan Yang Maha Esa, reflects the original Indonesian religious culture. He also argued that when Hinduism, Buddhism, and Islam came to the Archipelago, the indigenous people did not entirely change their beliefs according to the religions. With regard to Islam, there were three reasons, he said, why Islam could not deeply penetrate Indonesian culture: (1) Islamization occurred collectively through the conversion of the rulers; (2) the Arabic character of Islam made it difficult for the natives to accept its teachings; (3) Islam did not have a theological frame to react to the spirituality of other religions. In contrast, when Christianity came, it tried to adapt to the indigenous beliefs, even though for this adaptation, the Christians still had to find the way in which both the universality of Christian message and the local culture could go together. ${ }^{50}$

Steenbrink has observed that Bakker's book on the indigenous religion as well as Y.B. Banawiratma's work on Jesus as a Guru in the Javanese culture and Franz Magnis-Suseno's work on the Javanese ethics indicate that the Catholics considered Javanese mysticism rather than Islam as their main partner of dialogue. He also noted that a similar tendency was to be found among the Protestants. In his footnote, Steenbrink refers to the tendency among the anthropologists and Catholic and Protestant missionaries to obscure the Islamic character of the Indonesian people. ${ }^{51}$ This last point seems to be more important than the dialogue issue. The Christians attended dialogues with the Muslims but in terms of the Javanese culture, the Muslims often emphasised the Islamic-ness of the abangan while the Christians and the secularists tended to describe the abangan as outside Islam. This is also indicated by Rasjidi's criticisms of Pranarka's view of culture above. Moreover, like the Christians, the Muslim intellectuals also studied Javanese mysticism. They usually suggest that the Javanese mysticism is a syncretism of Islamic and other religious beliefs, but Islam is actually its basis. ${ }^{52}$ Thus, the major issue here is actually a contest of discourses on Javanese mysticism. ${ }^{53}$

The discourses of the Muslims and Christians on culture and religion, however, did not always lead to antagonism. In 1983, the Muslim traditionalist leader, Abdurrahman Wahid, wrote that Islam should be indigenised (pribumisasi) in Indonesia. ${ }^{54} \mathrm{He}$ criticised recent tendencies among the Indonesian Muslims to Arabicise everything, from replacing the local religious terms with Arabic ones to making the architecture of the mosques similar to 
that of the Middle East. He argued that the early propagators of Islam in Java successfully indigenised Islam and this should be maintained. He asked: if the Christians now tried to build churches in the forms of local architecture, why should the Muslims leave their indigenous architecture of the mosques? Abdurrahman's arguments for the indigenisation of Islam, however, did not mean that he wanted Islam to monopolise the Indonesian culture. In fact, he was worried about the Arabisation trend among the Indonesian Muslims, because for him it would increase the exclusiveness of Islam. Thus, his concept of the indigenisation of Islam actually ended with a common struggle to enhance the dignity of human being, that is, the universal humanism. ${ }^{55}$

The tendency to see culture from the perspective of universal humanism can also be found among the Christians. Mangunwijaya was among the Catholic priests who consistently promoted this view of culture. Indonesian independence, he said, was only a formal political liberation. The most important liberation should be cultural, that is, to liberate people from being a nation of coolies and a coolie among the nations through education. In this context, he said that to liberate people from exploitation by others and to enhance human dignity is the essence of Catholic faith. ${ }^{56}$ Among the Protestants, we should mention here Th. Sumartana. In his PhD thesis written in 1980s, Sumartana analyses the Christian missionaries' attitudes towards Javanese culture. Sumartana showed a great sympathy with the Javanese Christian leader of the nineteenth century, Kiai Sadrach, who was opposed by some Dutch missionaries because of his syncretism. Sumartana also criticises the prominent Protestant missionary in the early twentieth century, Hendrik Kraemer, regarding the latter's negative view of syncretism. For Sumartana, many Christians saw syncretism negatively because they understand syncretism from a theological point of view. For him, to see syncretism positively, one should see it for its political meaning. "In this understanding, the absoluteness of religious conviction of one person is not set against the conviction of another person in a true or false dichotomy. Absoluteness must be directly confronted with the social problems that threaten the unity and welfare of humanity." ${ }^{57}$ Thus, syncretism leads to universal humanism.

\section{The Rise of Islamic Culture in National Politics in 1990s}

Since the early 1970 s to the late 1980 s, we can say that in general the politics of the New Order regime was much more secular and abangan Javanese cultural oriented. The Department of Education had also been controlled by people who had a similar cultural orientation. The secular cultural tendency can still be seen in the papers presented to the Seminar on Culture 
held in 1987 by the Faculty of Literature, University of Indonesia, Jakarta, in cooperation with the Department of Education and Culture. If we look at the proceeding of the Seminar, we can see that the term 'strategy of culture' was mentioned in many papers. There was no single paper discussing Islamic culture, and there was a paper opposing the view that Indonesian culture had been Javanised..$^{58}$ Moreover, for his $40^{\text {th }}$ marriage anniversary, in 1987, President Soeharto published a book containing Javanese proverbs with Indonesian and English translation dedicated to his children. A few years before, Soeharto was called the Father of Development (Bapak Pembangunan). Now, with this book, Soeharto apparently wanted to affirm that he was a Javanese wise father whom his children (Indonesian people) should follow. ${ }^{59}$ In this context, Shiraishi nicely analysed how the New Order regime skilfully developed Taman Siswa's idealisation of family into national politics. ${ }^{60}$

In the 1990s, however, the national politics became closer to Islam. Soeharto had problems with important military generals, and to counterbalance the military, he allied himself with the Islamic groups, particularly the reformist. In 1990, Soeharto supported the establishment of the Indonesian Muslim Intellectuals Association (ICMI). ${ }^{61}$ When Soeharto opened the ICMI meeting, it was reported that Soeharto demonstrated his skill in beating the traditional drum called 'beduk' used in the mosques in Indonesia to invite Muslims to perform daily prayer. The 'beduk' somehow symbolises santri culture. Moreover, by the same year he and his family went to Mecca to perform the Hajj. In 1994 and then 1995, the Government sponsored the festival of Islamic culture called 'Festival Istiqlal' in Jakarta. Artists and performers from different parts of Indonesia were invited to present Islamic arts and performances in the Festival. The intellectuals were also invited to several seminars during the Festival to discuss Islamic culture in Indonesia. Partly because the leader of ICMI was B.J. Habibie who was also the Minister of Technology, Islamic intellectuals also talked about how Indonesian Muslims could develop technology in the spirit of Islam. The proceedings of the seminar were then published under the title Ruh Islam Dalam Budaya Bangsa (the Spirit of Islam within the National Culture). ${ }^{62}$ The second Festival Istiqlal also featured a big Qur'anic manuscript called 'Mushaf Istiqlal.' The manuscript was designed by Muslim painters and artists in such a way that its margin combined different styles of decoration representing 42 regions of the country. ${ }^{63}$ Thus, the Qur'anic text (Islam) and Indonesian culture (decoration) are put together in the mushaf (manuscript). Nationalism and Islam were now put into harmony with each other. Islam was not portrayed as 
an ideology as opposed to Pancasila, but as the spirit within the national culture.

During this period, the Muslim intellectuals associated with ICMI often emphasised that the abangan-santri dichotomy was irrelevant. ${ }^{64}$ The prominent Muslim intellectual, Kuntowijoyo, said that santri-abangan dichotomy became fluid partly because religion classes had been given in public schools, so the children of abangan could learn Islam. ${ }^{65}$ To assert the Islamic-ness of the Javanese, another Muslim intellectual, Nurcholish Madjid, refers to Marshal Hodgson's criticism of Clifford Geertz's Religion of Java: "for those who knows Islam, his comprehensive data - despite his intention - show how very little has survived from the Hindu past even in inner Java and raise the question why the triumph of Islam was so complete."66 On the other hand, as a reaction to ICMI, the secular nationalist intellectuals and Christians as well as the traditionalist Muslim leader, Abdurrahman Wahid, established 'Fordem' (Forum Demokrasi). In fact, Abdurrahman Wahid was the only politically influential person in Fordem. He refused to join ICMI and argued that the new organisation was sectarian. Abdurrahman Wahid's manoeuvre was somehow relieving for the Christians because there was certainly fear among them to see the ascendancy of Islam in national politics.

\section{Religion and State Educational Policies}

In the debates on culture, we can see that different ideological outlooks led to different ideas of Indonesian culture; and these in turn led to different ideas of the education which Indonesian people were to receive. Although there were different outlooks in Indonesia, when the ideological conflict occurred usually two blocs were formed: the Islamic and the secular. We already showed in Chapter 3 that the ideological conflict eventually led to a compromise. In Chapter 4, we also argued that the ideological compromise was manifest in the dual administration of marriage affairs.

If we look at the education system of Indonesia, we can also see that the ideological compromise is manifest in it. First of all, Indonesia has a dual administration of education. The Department of Education and Culture controls general education (public schools and universities), while the Department of Religion has the authority over Islamic education, namely the state Islamic schools (from elementary to secondary level) called 'madrasah' and Islamic higher education, State Institute of Islamic Studies (IAIN). ${ }^{67}$ Then, besides the dual administration, a compromise is manifest in the curriculum of both types of education: the schools under the Department of Religion 
taught secular subjects of the Department of Education and Culture, while the general education under the latter should also include religion as one of its subjects. The compromise, however, is not always stable. It developed according to the political atmosphere in the country.

Besides the Government educational institutions, there are private madrasahs, schools and universities. To be entitled to state subsidies, the Government demands that they follow its curriculum and educational policies. Another advantage of following the Government curriculum was that the Government approved the diplomas of these private institutions, which means that the holder of the diploma could continue study at the Government educational institutions and could apply to be a Government employee. Many of the Muslim and Christian private educational institutions were included in this category and therefore, they were affected by the Government educational policies.

\section{The Failure of Attempts to Unify the Administration of Education}

There have been attempts to put the state Islamic educational institutions under the Department of Education but these never succeeded, due to the opposition of the Islamic groups. During the Soekarno period, there was an attempt to transfer the administration of the madrasah to the authority of the Department of Education. This was stated in the Eight Year Development Plan (1961-1969) that was proposed to the Provisional People's Consultative Assembly (MPRS). According to this plan, the role of the Department of Religion in the field of education would be limited to the training of its employees. In line with this, according to this plan, the programme for religious teachers' training that was controlled by the Department of Religion, was to be taken over by the Teacher-Training Schools under the Department of Education. Nonetheless, probably due to the opposition of the Islamic groups, the MPRS decided in 1960 and then in 1963 that madrasahs were to remain under the Department of Religion. ${ }^{68}$

During the New Order, there were at least two occasions in which the debate on the single vs. dual administration of education occurred. By the late 1970s, the idea of the unification of the administration of education was proposed by the officials of the Department of Education, the most influential among them were apparently of the CSIS background. The involvement of certain Catholics on this issue helped create a Muslim negative perception of the former. In a study of the Government educational policies from 19681978, Pranarka and Prijono of the CSIS identified the dual administration as one of the hindrances to the development of national education. ${ }^{69}$ Therefore, 
they suggested that the administration should be unified under the Department of Education. Similarly, in a closed meeting between the officials of the Department of Religion and those of the Department of Education, the representative of the latter, F.X. Soediono (a Catholic) said that to achieve the goal of national education successfully, the administration of education should be done only by the Department of Education. ${ }^{70}$ As noted earlier, in 1978, the Government established the Commission for the Reformation of the National Education (KPPN). The KPPN's book on Basic Thoughts on Educational Reform, published in 1979 also showed the tendency to unify the administration of education, even though it was not explicitly stated. ${ }^{71}$

The Muslim leaders responded negatively to the idea. For Rasjidi, the unification would not only reduce the authority of the Department of Religion but also would completely secularise the Islamic schools. In other words, for him, the problem was not simply with the formal unification of the administration but with the content of education that was to be developed by the Department of Education. For Rasjidi, this education would be based on Pranarka's secular strategy of culture. ${ }^{72}$ In line with Rasjidi, in its letter to the KPPN, the MUI criticised the KPPN's book that did not include madrasah as a part of the national educational institutions. ${ }^{73}$ The MUI demanded that the madrasah should be included, and its administration under the Department of Religion should be maintained. To secure this, the MUI suggested that the provision of the KPPN book that the President was responsible for the national education should be added with an explanation that the President should authorise the Department of Religion for the administration of religious education and the Department of Education for the administration of general education. ${ }^{74}$

One of the jobs of the KPPN was to prepare a draft of an education bill. When Joesoef was replaced by Nugroho Notosusanto as the Minister of Education, the latter continued the preparation of the bill by using the reports of the KPPN and other sources. After this long process of preparation, the next Minister of Education, Fuad Hassan finally proposed the bill to Parliament by the end of May $1988 .^{75}$ We have already discussed how the Muslim leaders were very suspicious of the works of the KPPN during Joesoef's ministry. Indeed, the education bill that was somehow originally prepared by the KPPN did not clearly accommodate Muslim educational interests. One of them, the bill neglected the state madrasahs and the authority of the Department of Religion to administer them. However, after the Muslim protests and a series of lobbying between the Muslim leaders, the Government and the Parliament, the bill was amended: madrasah education was men- 
tioned and the authority of the Department of Religion in its administration was affirmed. ${ }^{76}$ Parliament finally ratified the bill and the Government introduced it as the Law No. 2/1989 on the National Education System.

Secular Subjects in the Madrasah Curriculum during the New Order

Although the dual administration of education was maintained, the New Order Government tried to make the madrasahs' curriculum similar to that of the public schools under the Department of Education. In 1975 the Government introduced a curriculum reform for madrasahs. This reform was dictated by the joint decree of the Ministers of Religion (Mukti Ali), Education and Culture (Sjarief Thajeb) and Home Affairs (Amir Machmud). The reform was directed to include more secular subjects in the madrasah curriculum. The new curriculum consisted of $70 \%$ secular subjects and $30 \%$ religious subjects. For the secular subjects, the madrasah would simply follow the curriculum of the public schools. With this policy, a graduate of a madrasah could be accepted to continue study at the public schools and universities of the Department of Education.

Many Muslims reacted negatively to this policy and accused the Government of going too far to secularise madrasahs. Mukti Ali said that certain Islamic leaders outside Jakarta even warned him that he could be killed. ${ }^{77}$ Steenbrink noted that since the 1950s, the Department of Religion had already tried to reform the madrasah curriculum and the Muslim negative reactions seem to be not that strong. ${ }^{78}$ It seems, for some of the Muslims, the proportion of secular subjects (70\%) was too much and Mukti Ali's previous support for the marriage bill of 1973 helped increase their suspicions towards his policy. ${ }^{79}$ Moreover, many, if not most, of the madrasahs were in the hands of traditionalist Muslims of the NU who generally resented Mukti Ali. ${ }^{80}$ Despite the opposition, the curriculum reform was to be applied and Mukti Ali proudly recalled this as one of his achievements to improve Muslim education. ${ }^{81}$

We have noted that the position of madrasah education under the Department of Religion was affirmed in the Education Law of 1989. One of the main consequences of this inclusion was that the madrasah curriculum was to be more in accordance with that of the public schools of the Department of Education. Following the Education Law of 1989, in 1994 the Government decided to increase the secular subjects in the madrasah curriculum from $70 \%$ to $80 \% .^{82}$ This meant that the curriculum of the madrasah has become only slightly different from that of the public schools under the Department of Education. Moreover, previously, the study streams (jurusan) at the Public 
Senior High Madrasah (MAN) were divided into three: social science, natural science and religion (i.e., Islamic studies). Since 1994, in accordance with the study streams at the Public Senior High Schools (SMUN), the study stream concentrated on religion was abolished. Like those of the SMUN, the study streams of the MAN have become three: social science, natural science, and language. The difference between MAN and SMUN is only that MAN students have to learn a few Islamic subjects, but compared to the study stream on religion that was abolished, their study of Islam was not that profound. For better or worse, this change of the curriculum, on the one hand, equalized the position of the MAN graduates with those of the SMUN; but on the other hand, they became very much less qualified to be specialised in Islamic studies. This has become a serious challenge to the State Institute of Islamic Studies (IAIN) whose students have been mostly MAN graduates. ${ }^{83}$

\section{Religion Classes: From Optional to Compulsory}

Another important ideological issue in education is religion classes in public schools. Should religion become a compulsory subject or optional? From the end of 1945 to the early 1960s, religion was a non-compulsory subject in public schools and universities in Indonesia. ${ }^{84}$ In December 1945, the Central National Committee of Indonesia (KNIP) issued a declaration on education in which the religion class in public schools was also mentioned. It was stated that religion "should be given appropriate attention without reducing the freedom of those groups who want to follow their respective faiths." 85 This idea of freedom later coloured the provision of the Education Law of 1950 on religion classes. Article 20 of the Law states that "religion classes are to be carried out at the state schools and parents decide whether their child follows it or not." The elucidation of article 20 states that: "(a) Whether or not a type of school provides a religion class will depend on the age and the intellectual level of its students; (b) Mature students can decide to follow the religion class or not; (c) The nature of the religion class and its teaching hour will be determined in the regulations on the type of the school in question; (d) Religion class does not affect the promotion of a child." ${ }^{\prime 6}$ In line with the Law, in the 1960 the MPRS decided that the religion class was to be carried out in public schools and universities and at the same time the MPRS reaffirmed its non-compulsory character. ${ }^{87}$

The above policy seems to be a middle way between the Muslim demand to have a compulsory religion class and the view of the secular oriented groups and the Christians that Government schools had to be free from that class. Lambert Kelabora's explanation of the conflict of interests 
behind this policy appears to be helpful. Kelabora observed that for the Muslims, to make the religion class compulsory was important "to protect their offspring from possible conversion to Christianity," while for the Christians, this "would lead to the use of the Government funds and forces by the Moslem groups to propagate Islam to the detriment of Christianity." Likewise, if the religion class was compulsory, then "the children of the nominal Moslems would be forced by the Government to study Islam in order to be good Moslems," and this would in turn lead to "the gradual strengthening of the Moslem groups and to the weakening of the secular forces," and therefore, "the PNI, which drew its supporters mainly from nominal Moslems, rejected this policy." 88

Up to 1960, besides the Indonesian Nationalist Party (PNI) and the Christians, the other two strong political powers in the late 1950s, the PKI and the army, also supported the non-compulsory religion class policy. The political development after 1960, however, paved the way for a realization of the Muslim aspiration for the compulsory religion class. This change was not because of the increase of the Muslim political power but due to the serious political rivalries between the army and the PKI. Based on Soekarno's 'synthetic ideology' of Nationalism, Islam and Communism called 'NASAKOM', the PKI could introduce Communism at every level of society and in most educational institutions of the country. In response to this development, the army encouraged religious groups, particularly Muslims and Christians, to fight against the PKI. In certain Muslim majority areas in Java, Sumatra, Sulawesi and Kalimantan, the army supported the Muslim demand for compulsory religion class. ${ }^{89}$

The competition between the army and the PKI also occurred inside the administration of the Ministry of Education itself. Since 1961 to the end of the Soekarno period, there were two ministers in the Ministry. The competition happened when, Prijono, a former member of the orthodox Marxist party, Murba, was the Minster of Basic Education and Culture and General Sjarief Thajeb, an Acehnese and a high ranking officer, was the Minister of Higher Education and Science. It was through Sjarief Thajeb that the army and religious groups were able to develop a policy of compulsory religion class at the tertiary level. For this, they created the "Lembaga Pembina Pendidikan Agama pada Perguruan Tinggi" (Institute for Developing Religious Teaching of Higher Education) in 1963, headed jointly by the Minister of Higher Education and the Minister of Religion. ${ }^{90}$

On the other hand, in October 1960, Prijono who controlled primary and secondary education, introduced the so-called Pancawardhana 
(five principles of development) and later in February 1963, he linked the Pancawardhana with 'Pancacinta' (five loves) and the latter was formulated by the PKI dominated 'Lembaga Pendidikan Nasional' (National Education Institute). While the Pancawardhana still mentioned religious morality, the Pancacinta did not include it. ${ }^{91}$ For the enemies of the PKI, the inclusion of religious morality in the Pancawardhana was just lip-service and its absence in the Pancacinta proved this assumption. In other words, for them, both Pancawardhana and Pancacinta was nothing but the PKI strategy to eradicate the religious dimension of education in the country. The Muslims, both the traditionalists of NU and the reformists of Muhammadiyah, followed by the Christians and Hindus, opposed the Pancawardhana and Pancacinta. Although the 'Pancas' survived up to 1965 due to the protection of Soekarno, the debates on the issue paved the way for the compulsory religion class policy in the primary and secondary schools. In 1964, the Government declared that the religion class was one of the basic subjects in public schools and therefore, it would also affect the promotion of the child. "Thus, by 1965 religion was no longer an optional and non-compulsory subject..."92

The compulsory religion class policy became more strongly established after the abortive coup of 1965 and the rise of the New Order. In 1966, the MPRS released the Decree No. XXVII/1966 stating that religion was a compulsory subject from primary schools to universities. ${ }^{93}$ Moreover, the teaching hour and the target of the religion class were extended. In 1951 the Department of Education and the Department of Religion ruled that the religion class began at Grade IV of the Elementary School for 2 teaching hours ${ }^{94} \mathrm{a}$ week but it could be started at Grade I in specific regions and the teaching hours could be extended to no more than 4 hours. ${ }^{95}$ By contrast, in 1967 both Departments ruled that the religion class should be started at Grade I of the Elementary School and the teaching hours each week were: 2 hours for Grade I and II; 3 hours for Grade III; 4 hours for Grade IV to VI and all Grades of the Junior and Senior High Schools, while for universities only 2 hours per week. ${ }^{96}$ In addition, "the status of religion was elevated further to the position of Subject No.1, one of a group of six basic subjects designed to develop the spirit of Pancasila." ${ }^{\prime 9}$

This high status of the religion class, however, had to face some challenges in the following years of the New Order. The reason was, when the PKI had already been defeated, the military and other secular oriented groups who controlled the Government wanted to weaken their main political rival: the Islamic groups. In the MPR session of 1973, during the debate on the GBHN, the Government party, Golkar, wanted to abolish the religion class in 
state education but it was unsuccessful primarily because of the opposition of the Islamic party, PPP. ${ }^{98}$ The issue of the religion class became hot again when the Government proposed the education bill in 1988, because it did not mention religion as a compulsory subject. In an interview, the Minister of Education, Fuad Hassan, said that religious education was the parents' responsibility rather than the state's. The Islamic leaders soon opposed the bill. They reiterated the old arguments that without religious lessons, education would lead to secularism and that the GBHN of 1988 (as had been the case since 1978) already stated that one of the goals of education was to develop human qualities, including the religious qualities of believing and following the commands of God. ${ }^{99}$ After the Muslim protests, Parliament finally amended the bill and religion was included in the Education Law of 1989 as one of the compulsory subjects. Thus, the Islamic groups successfully defended the compulsory religion class policy during the New Order.

Bahtiar Effendi has argued that the inclusion of religion as a compulsory subject in the Education Law of 1989 was one of the indications of the political shift of the New Order regime towards the Islamic groups. ${ }^{100}$ This view is only partially true. If we look back to the New Order's policy on religion class since 1966, we find that the Law did not make any substantial change to the previous policy. Likewise, if we compare the previous efforts of Islamic leaders to defend their interests in education with what they did in the late 1980s, we can see that the latter was not as special as Sirozi's estimate. ${ }^{101}$ Perhaps, the challenge was even greater in the previous period than in the late 1980s. When Parliament responded to the bill, not only PPP but also Golkar and ABRI supported the inclusion of religion as a compulsory subject in the Law, while the PDI into which the Christian parties had fused, did not explicitly oppose it. ${ }^{102}$ Moreover, the National Council of Catholic Education (MNPK) also suggested that religion class should be included as one of the articles of the Education Law. ${ }^{103}$

\section{PMP: An Ideological Challenge to Islamic Religion Classes}

Although the secular oriented group never succeeded in abolishing the religion classes from public schools, they apparently tried another way to prevent the religion class from being used by the Islamic groups to enhance the latter's ideological orientation. We have noted that in the MPR session of 1973, the Government party, Golkar, wanted to abolish the religion class from state education but it failed. Golkar actually did not only want to abolish the religion class, but also suggested replacing it with Pancasila Moral Education. Of course, the Muslim party, PPP, as well as the Muslim leaders outside 
the Parliament, opposed Golkar's proposal. They argued that it was nothing but efforts to secularise the country because Pancasila without religion was empty and this would lead to the re-emergence of Communism. ${ }^{104}$

The debate finally ended with a compromise, that is, both the religion class and Pancasila Moral Education were accommodated. In the section on religion, the GBHN of 1973 stated that part of the efforts to enhance the facilities needed for the development of religious life was the inclusion of a religion class in the curriculum of state education from elementary schools up to universities. On the other hand, in the section on education, the GBHN stated that the development in the field of education should be based on Pancasila and therefore, the curriculum of all levels of education, from kindergarten to university had to contain Pancasila Moral Education. ${ }^{105}$

Thus, although the religion class was not abolished, Pancasila Moral Education was also approved. In the following years, the Government gradually enhanced the position of Pancasila Moral Education. In 1975 the Government changed the school curriculum and one of the changes was to replace the existing subject on 'Indonesian Civics Education' with 'Pancasila Moral Education' (Pendidikan Moral Pancasila, PMP). The schools started using the new curriculum in 1976. This meant that all state schools, including madrasahs, had to teach PMP. The position of the PMP became much stronger after the MPR approved the Government proposal on the Pancasila indoctrination program called 'P4' in 1978, despite the Muslim protests.

The ideological controversy around PMP emerged when the PMP textbooks were published. The Government did not provide a standard textbook of the PMP until October 1980. Thus, from 1976 to 1980, there were various PMP textbooks by different authors but the books were to be approved by the Department of Education before they could be used. During the absence of the standard PMP textbooks, an interesting case occurred. The PMP textbooks for Junior and Senior High Schools by two Muslim authors named Saidihardjo and Moekri S. triggered controversy. ${ }^{106}$ When they explained the first principle of Pancasila, Ketuhanan Yang Maha Esa, they wrote: "God does not have a father and mother. God does not have a son and is not labelled as a son." This statement is very similar to that of the sürat al-ikhlās of the Qur'an, ${ }^{107}$ and it could be read as an opposition to the Christian doctrine of the Trinity, even though the Holy Spirit was not mentioned.

A Catholic author named P. Rahardjo soon reacted to the textbooks and suggested that they should not be used in the Catholic schools. In addition, the Government authorities also reacted to the textbooks. The Director of Elementary and Secondary Education, Dardji Darmodihardjo, said that 
PMP was a compulsory subject that should be followed by all students of different religions. Therefore, he said, Moekri's and Saidihardjo's textbooks could make a Christian student confused. More than that, Soegijo, the Head of the Department of Education and Culture of the East Java province, prohibited all Junior and Senior High schools in his region from using the textbooks. Indeed, the books were not yet approved by the authorities of the Department of Education, but they were already sold in the market. Both of the Muslim authors, however, finally agreed to revise their books. ${ }^{108}$

After the decree of the MPR on the Pancasila indoctrination in 1978, the Government apparently became more serious in preparing the PMP textbooks. The Government finally produced the textbooks in 1980. The Islamic leaders soon showed their negative responses, primarily to the ideas related to inter-religious relations introduced in the books. For instance, the PMP textbook for Grade I of the Junior High School (SMP) explained that different religions were actually different ways leading to the same goal, that is, to God. To make this idea clearer to the students, the book presented different religions by analogy with a group of people who wanted to go to Jakarta but each of who took different vehicles, one a train, another a bus and the third a ship but all of who finally arrived at the same destination. Moreover, the textbooks also suggested that to develop religious tolerance one should participate in the celebration of religious festivities of another religion, not make friends only among co-religionists, and pray for the people of other religions. ${ }^{109}$ All of these ideas remind us of the ideals of religious tolerance of the Javanese mysticism considered to be the authentic Indonesian culture by the regime.

The Islamic leaders could not accept the ideas in the PMP textbooks. In this regard, the Islamic party, PPP, made a critical review of the PMP textbooks and delivered it to the Government on 13 June 1981. ${ }^{110}$ The PPP argued that the ideas in the PMP textbooks are against Islam. To say that all religions are leading to the same goal, for the PPP, is contrary to Muslim belief that Islam is the only true religion. Likewise, for the PPP, to attend a religious activity of another religion like Christmas celebration and to pray for unbelievers are forbidden in Islam, while to make friends among Muslims is encouraged based on the so-called called "ukhuwwah islämiyyah" (Islamic brotherhood). For the PPP, all of these indicated that the books contradicted the article 29 of the 1945 Constitution protecting the right of every citizen to follow his or her religion. Last but not least, for the PPP, to cultivate religious tolerance, one should not endanger religious beliefs or otherwise it would be counter-productive. 
It is unclear to me how far the Muslim protests were to influence the changes of the PMP textbooks in the following years. If there were such a change, I think it would not change the Government's basic ideological view of religious tolerance. It is certain that PMP was an important subject in the state education system up to the end of the New Order. Moreover, as discussed in Chapter 3, after 1985 all social and political organisations were obliged to accept Pancasila as their sole basis. This indicates, though indirectly, that the position of PMP was unchallenged. Moreover, in addition to religion and civics, the Education Law of 1989 declared that PMP was one of the compulsory subjects. ${ }^{111}$ Thus, despite the early Muslim opposition to PMP, it was placed side by side with religion as a compulsory subject by the Law.

\section{Comparative Religion: Another Challenge to Islamic Religion Classes}

We can see that the Muslim opposition to the PMP textbooks was clearly related to inter-religious issues. However, it was not specifically related to Muslim-Christian relations. Perhaps, among the Muslims, the PMP controversy was also considered a Muslim-Christian issue due to the fact that the PMP was introduced for the first time by the Department of Education during the ministry of the CSIS man, Daoed Joesoef. As noted, Joesoef is a Muslim but he preferred secularism to Islamic ideology in politics. Therefore, he could cooperate with the Catholic intellectuals of the CSIS who shared the same position. Like other secular intellectuals, Joesoef considered religious education as a family rather than a state responsibility. Joesoef also explained that his opposition to the religion class in public schools was because the Islamic religion class tended to cultivate the seeds of hatred towards other religions, fanaticism and hypocrisy. ${ }^{112}$ Joesoef's remark on the Islamic religion class is apparently too strong but there is some truth in it. In a study of the guidelines of the Islamic religious curriculum of 1975 and 1976 for public schools, Atho Mudzhar concludes that the curriculum paid very little attention (if any at all) to the idea of comparative religion or respect of other religions. The socio-political development around the religion class policy, he said, contributed to this exclusive tendency of the Islamic religious curriculum in the public schools. ${ }^{113}$

Because Joesoef believed that the Islamic religion class was used by Islamic leaders to cultivate inter-religious hatred, the Department of Education under his leadership suggested that the religion class should be changed from focusing on a single religion to a comparative study of reli- 
gion. In March 1979, in a meeting between the Department of Education and the Department of Religion, F.X. Soediono, a Catholic and the head of the Department of Education team, proposed this idea. The advantage of the comparative study of religion, he said, was that the student's knowledge would not be limited to a single religion. Soediono argued further that religious education as efforts to cultivate and experience religion was the responsibility of the family and religious institutions, not the Government.

Certainly this idea provoked Muslim negative reactions. Rasjidi for instance cynically said that this was "the core of the core" of what the Department of Education called "educational reforms."114 In the middle of 1979, Amir Hamzah, a Parliament member of the PPP, questioned Daoed Joesoef about this issue. Probably because of the Muslim opposition, Joesoef said that his Department never prepared a curriculum on comparative religion for public schools as it was reported in the press. Joesoef explained further that the paper presented by F.X. Soediono in the meeting was for a limited audience and it was prepared as a response to a paper by the Department of Religion. Thus, he said, this issue was not final and had to be discussed among the Government apparatus. He also asserted that the publication of the idea in the press was not the responsibility of his Department. ${ }^{115}$

The attempt to change religion class from focusing on one religion to the great religions, however, continued. In 7 November 1979, Kompas reported that Prof. Harsja W. Bachtiar, a high official at the Department of Education, suggested that the religion class in the universities should become a study of the great religions in the country. Bachtiar argued that as the well-educated section of the Indonesian society, university students had to develop communication and cooperation across religious differences and therefore they had to have a minimum knowledge of every religion of the Indonesian society. Bachtiar argued further to criticise the existing method of religion class in the university. He said that a religion class focused on a single faith would sharpen religious differences because first, students would be classified on a religious basis before receiving their respective religion class; and second, the teacher tended to claim the truth of the religion that was taught by discrediting other religions. Bachtiar was also critical of the existing method of teaching religion that emphasized memorising rather than reasoning and that a lecturer sometimes preferred to teach only a ritual practice (an implicit reference to the Muslim daily prayer). Bachtiar recognised that experts on comparative religion were very rare but he suggested 
that a textbook on this subject called 'Agama dan Mahasiswa' (Religion and the University Student) should be prepared by various experts of the five religions in Indonesia. ${ }^{116}$

Again, the Muslim leaders reacted negatively to this proposal. ${ }^{117}$ While both F.X. Soediono and Bachtiar used the term 'great religions', the Muslims called it 'Panca Agama' (five religions), a reference to the five recognized religions in the country (Hinduism, Buddhism, Catholicism, Protestantism and Islam). Rasjidi disagreed with this idea because for him as a subject, comparative religion or Panca Agama, tended to look at religion in terms of knowledge rather than belief, and therefore, it was a secular approach to religion. Likewise, Zakiah Daradjat, the head of the Directorate of Education of the Department of Religion, said that the religion class should be directed to cultivate the religious commitment of the students, and therefore, both the teacher and the students should be believers in the religion in question. Because the teacher had to be committed to his or her religion, HAMKA was of the opinion that neither a Muslim nor a non-Muslim could teach fairly the religions other than their own. Moreover, Rasjidi maintains that the Panca Agama would create confusion or indifference rather than commitment to religion because the religious knowledge of the students in the secular universities was generally very limited and the teaching period was very short. HAMKA eventually claimed that the idea to teach five religions was nothing but another effort of the secular groups to hinder the increasing Islamic awareness in society. More than that, Daud Ali, another Muslim intellectual and a Professor of Law at the University of Indonesia, suspected that the idea was actually to legalise hidden attempts to convert the followers of a certain religion (read: Islam).

The Muslim leaders also reacted to Bachtiar's criticisms of the method of teaching the religion class. Both Rasjidi and Deliar Noer (another prominent Muslim intellectual) agreed that certain teachers of the religion class emphasised memory rather than reason. However, the emphasis on memory, they said, was also found in other classes and so it was not distinctively the problem of the religion class and it could be improved in the future. Both Zakiah and Rasjidi disagreed with the view that teaching a single religion would sharpen religious differences and discredit other religions because, they claimed, Islam teaches its adherents to be tolerant to the followers of other religions. Moreover, Deliar Noer criticized Bachtiar's assumption that to be tolerant to the followers of other religions, one should understand those religions. Noer said that this assumption was false and not based on factual reality. For example, he said, Rasjidi understood Christianity and T.B. 
Simatupang understood Islam well, but both were almost always in opposition to each other because Rasjidi thought that Simatupang supported the Christian efforts to convert Muslims while Simatupang considered Rasjidi to be too fanatical. According to Noer, religious tolerance would emerge not from knowledge of other religions, but from a personal attitude of avoiding intervening and disturbing the religion of others. Thus, he said, the idea of teaching the subject of the great religions to university students was false because its underlying assumption was false.

Both Ministers of Religion and Education eventually talked about the issue. Alamsyah Ratu Perwiranegara, the Minister of Religion, said that the religion class was under the authority of his Department, not of another (that is, not the Department of Education). He also said that Panca Agama was a "crazy idea" if it meant that students were guided to be committed to five religions altogether. Alamsyah finally said that there was no obligation in Indonesia "for the people who already adhered to a certain religion to learn about other religions."118 On the other hand, Harsya W. Bachtiar did not try to defend his idea further publicly. In his reaction to the criticism, Daoed Joesoef explained that his Department never prepared a subject called 'Panca Agama' and that there was a certain group (an implicit reference to the Muslim leaders) who manipulated this issue to attack him. ${ }^{119}$ Thus, the study of the great religions or 'Panca Agama' in public schools and universities was never realised. However, as we shall see in Chapter 6, a more sympathetic approach to the study of other religions developed in the IAINs and Christian Academies of Theology (STTs).

\section{Should Ramadan be Schooldays or Holidays?}

Another Government educational policy that triggered Muslim protests during the New Order was on Ramadan holidays. Before the New Order period, this issue apparently never became a public controversy. In 1957, Saadoedin Djambek, a prominent Muhammadiyah leader, noted that up to that year, schools were officially on holidays for the whole Ramadan. However, he also noted that in fact there was almost no school without activities during the fasting month. The schools, in consultation with the students' parents, usually decided to give lessons for several days but the teaching hours were shortened. ${ }^{120}$ I do not know exactly what the Government policy from 1957 to the end of 1960s was, but it seems the policy was more or less the same. However, in 1970 the New Order Government decided that only two weeks of Ramadan were to be free. This policy was later changed in 1977 when the Government made the whole Ramadan free. ${ }^{121}$ 
The debates on Ramadan holidays during the New Order period appear to have been initiated in May 1975 when the Association of the Teachers of the Republic of Indonesia (PGRI) in cooperation with the National Committee of the Indonesian Youth (KNPI) held a seminar on school holidays. The Minister of Education, Sjarief Thajeb, supported the seminar and the representatives of the Department of Religion, Department of Education and Culture, PGRI, Golkar and private educational institutions joined the seminar as speakers or participants. Zakiah Daradjat was the speaker who tried to defend the importance of having a full Ramadan holiday. The other speakers had different views: Moh. Said Reksohadiprodjo from Taman Siswa argued for the abolition of Ramadan holidays, while Sadatoen, a representative of the Indonesian Doctors Association (IDI) suggested that several days of Ramadan should be holidays, but not all. ${ }^{122}$

The contrast between Daradjat's and Reksohadiprodjo's views reflected the tensions between Islamic and secular perspectives, while Sadatoen's position was a compromise between the two positions. For Zakiah, the main reason why Ramadan should be a full holiday was because it was the period in which Muslim children were educated outside the schools to practice and learn Islam. In contrast, Reksohadiprodjo argued that Ramadan could not be a holiday because it would disturb the school academic calendar, which was based on the Christian calendar (solar year) rather than the Muslim calendar (lunar year). Sadatoen, on the other hand, suggested that 3 days at the beginning of Ramadan would be better to be holidays in order to acclimatize the physical and mental condition of the students and teachers to fasting. The schools should then continue their activities afterwards, but the teaching hours should be shortened and more religion classes could be given. Then the schools should have holidays again for two weeks, namely one week before and another after the end of Ramadan. The result of the questionnaires distributed to the participants of the seminar indicates that most of them preferred this compromise position. ${ }^{123}$

The results of the seminar of 1975 , however, did not immediately persuade the Minister of Education and Culture, Sjarief Thajeb, to change the Government policy. As has been noted, from 1970 to 1977, the policy was that only two weeks of Ramadan were holidays, but in 1977 the whole of Ramadan was made a holiday. When Daoed Joesoef became the Minister, however, he made a different policy. In July 1978, he issued the decree No. 0211/U/1978 on the academic calendar system of schools. Article 6 of the decree stated that, basically, Ramadan was schooldays, but the fasting month 
was to be respected: 10 days of Ramadan were holidays, namely 3 days at the beginning of the month and 7 days around Idul Fitri ('îd al-fitr). ${ }^{124}$

The Muslim leaders soon opposed Joesoef's Ramadan policy. In general, for the Muslims the policy was nothing but an attempt to secularise the country. In this context, Rasjidi said that the policy was indeed in line with Pranarka's strategy of culture, and it was an expression of "the spirit of anti-Islam more serious than that of Dutch colonialism." 125 The reason was, as the traditionalist Muslim politician, Mahbub Djunaidi noted, the Dutch as well as the Japanese colonisers made Ramadan a full holiday. ${ }^{126}$ Moreover, the traditionalist Muslim leader, Saifuddin Zuhri, claimed that all Ministers of Education and Culture before Daoed Joesoef also determined that Ramadan was a holiday. ${ }^{127}$ HAMKA, the head of the Indonesian Council of Ulama (MUI) in his Friday sermon said that the policy was a serious ordeal and suggested the Muslims to undertake the qunūt nāzila, a special Muslim prayer said when facing an ordeal. ${ }^{128}$ Amir Hamzah, on behalf the Islamic party, PPP, argued that the policy was against the provisions of the GBHN of 1978 which stated that the facilities for religious life should be supported, and Article 26 of the Education Law of 1950, which stated that to determine school holidays, religion should be taken into account. Hamzah warned that the policy had created anxieties among the Muslims and disturbed the relationships between the Government and the Islamic communities. ${ }^{129}$

On the other hand, Daoed Joesoef tried to defend his policy. ${ }^{130} \mathrm{He}$ said that the policy was not a religious but an educational issue. With reference to the seminar in 1975, Joesoef said that Ramadan could not be a full holiday because that would disturb the school academic calendar. He argued further that the Government wanted to have a uniform academic calendar for all schools, so that the activities such as upgrading programs for teachers, school sport and art competitions and scout and guide programmes could be arranged without reducing the schooldays. Moreover, he said, to study in Ramadan was in line with the teachings of Islam and that the first verses revealed to Muhammad was in Ramadan in which God ordered human beings to read and study. For this religious justification, Joesoef was supported at least by two Muslim leaders: one was a Muslim cleric named Kholil Asy'ari who talked along with Joesoef in an Islamic preaching programme on the national television; ${ }^{131}$ another was Ali Hasj$\mathrm{mi}$, the general chairman of the MUI of Aceh. ${ }^{132}$ In addition, Joesoef argued that in other Muslim countries such as Saudi Arabia, Pakistan and Malaysia, Ramadan was not a holiday either. He also maintained that the policy was not opposed to Article 26 of the Education Law, because its provision 
stated that not only religion, but also education, were to be taken into considerations. ${ }^{133}$

Joesoef's explanation, however, did not convince the Muslims. The Muslim organizations like Muhammadiyah, al-Washliyah, Nahdlatul Ulama, the MUI and others, were all equally opposed to the policy. ${ }^{134}$ From March to June 1979, lobbying between the Islamic groups and the Government was quite intensive, but nothing could finally change the policy. In a meeting with the MUI on 29 March 1979, Daoed Joesoef even said that he would review the Government subsidies for Muhammadiyah private schools, if they did not follow his policy. ${ }^{135}$ In the beginning, tensions also occurred between the Department of Religion and the Department of Education. The General Directorate of Islamic Education sent a letter, dated 2 May 1979, to all state madrasahs in which it was stated that Ramadan would be a holiday. ${ }^{136} \mathrm{How}$ ever, the madrasahs under the Department of Religion eventually had to follow Joesoef's policy. ${ }^{137}$ In this respect, in the beginning the Muslims seem to have expected the Minister of Religion, Alamsyah Ratu Perwiranegara, to support them but in fact he did not. In a meeting with the representatives of Islamic organisations, Alamsyah said that the Government policy would not be changed and at the same time he told them that President Soeharto guaranteed that national education would not lead to secularism or the destruction of religion. ${ }^{138}$ By the end of May, a delegation of the MUI had a meeting with Soeharto who suggested that, as a compromise, the holidays for Ramadan could be prolonged to more than the 10 days the decree stated but the MUI disagreed. ${ }^{139}$

When Ramadan came in July 1979, the Government finally proceeded with its policy, by issuing guidelines for teaching and learning activities in Ramadan in which it was stated, among other things, that the teaching hours were to be shorter than usual, the religion class should be intensified, and school canteens had to be closed. ${ }^{140}$ On the other hand, the Muslim private schools affiliated with Muhammadiyah, NU and other Islamic organizations, did not follow the Government policy. As has been stated earlier, private schools normally received Government subsidies insofar that they followed the Government curriculum and policies. In this context, the disobedience of the Muhammadiyah schools provided a justification for Joesoef to realise his threat. In a meeting with the Heads of Department of Education and Culture of all provinces, Joesoef instructed them to stop and withdraw Government aid for some Muhammadiyah schools. Joesoef's step certainly made the Muslims more disappointed. Ridwan Saidi, the reformist Muslim politician said that Joesoef actually demonstrated the corruption of power, while 
Abdurrahman Wahid, the Muslim traditionalist leader, said that it was "the arrogance of bureaucracy." 141

The controversy on the issue, therefore, helped sharpen the tensions between the Muslims and the secular-oriented groups. The Christians were probably in line with the Government position, even though they were not very much involved in the controversy. It is noteworthy that a Catholic priest named J.C. Tarunasayoga, wrote a comment on this controversy in Tempo. He said that the Catholics also fast for 40 days, leading to Easter, but they did not ask the Government to free schools for the fasting, because they "tried to be mature." He also emphasized that Golkar and the military were in fact politically strong, but they did not demand Ramadan to be holidays too. These remarks clearly indicate support for the Government policy, and criticism of the Muslim demand; but nevertheless, I do not find any Muslim reaction to it. ${ }^{142}$ However, for many of the Muslims, Daoed Joesoef's alliance with the Catholics at the CSIS somehow indicated that the Christians contributed to or at least supported Joesoef's educational policies.

Other Ministers of Education during the New Order period subsequently continued Daoed Joesoef's Ramadan policy. On the other hand, Muslim opposition to the policy seemingly did not increase in the years after $1979 .{ }^{143}$ Perhaps, some Islamic private schools even finally decided to follow the policy in order to secure Government subsidies. Perhaps, when the policy was applied, the Muslims found that it was not as alarming as they expected before. Indeed, the eradication of Ramadan holidays apparently did not decrease, or even arguably increased, the opportunities for the young generation to study Islam.

\section{DDC: Christianisation via the Library?}

Our discussion so far demonstrates that the Muslim leaders were always suspicious of the Government's secular-orientated educational policies. The Muslim leaders also suspected the involvement of the Christians in making Government policies, particularly during Joesoef's ministry. In 1981, the Muslims opposed another Government policy on the library catalogue system. The case itself is far from being so important but the Muslim reaction to it was rather serious. The Muslim leaders accused the Government of doing Christianisation via the library. This reaction can be read as an example of Muslim oversensitivity to Christianisation or of Muslim usage of the discourse on Christianisation to attack the secularists.

The origin of the case was the project of the Department of Education and Culture on standardization of educational facilities in 1980/1981. To 
standardise the public school libraries throughout the country, this project produced a Guide for the Libraries of Senior High Schools. The Guide, perhaps unexpectedly, became another target of Muslim protests. Jusuf Hasjim, a Muslim traditionalist politician in the PPP, objected to the Guide because he found that it was heavily based on a Christian book classification system, i.e., the Dewey Decimal Classification (DDC), a book classification created by an American librarian, Melvil Dewey (1851-1932). Because Dewey was a Christian, it was reasonable that the DDC provided a higher proportion of classifications of Christian books compared to that of other religions, including Islam. Actually there were various modifications of the DDC, but the one that was used in the Guide was almost the same as the one used in the library of the Christian University, Satyawacana (UKSW), Salatiga. ${ }^{144}$

While Dardji Darmodihardjo, the Director of Primary and Secondary Education, said that it was only a simple and not serious case, the Muslims claimed the opposite. There were various Muslim responses to this case. 145 The politicians like Jusuf Hasjim and Amir Hamzah used the rhetoric of Pancasila. They said Pancasila accommodated not only Christianity but also other religions and so the Guide contradicted Pancasila. The Muslim professional librarians had more scientific responses: Halimah Majid, the librarian of the State Institute of Islamic Studies, Jakarta, said that the DDC system should be modified and adapted to Indonesian needs. She herself had already developed the DDC according to the Islamic subjects for the library in her Institute. Likewise, A. Azis Baco suggested that the Department of Education should be open to cooperate with other librarians to develop a classification system more applicable to Indonesia. The other respondents tried to relate the case with Christianisation. The Muslims argued that the intended result behind the policy was that the Government would provide a large numbers of books on Christianity and very few on Islam let alone other religions. In this regard, HAMKA said that the Guide was related to the rumour that the Christians planned to Christianise Java in 25 years and Indonesia in 50 years. ${ }^{146}$ Likewise, an author wrote in Aula, the magazine of Nahdlatul Ulama (NU), that the Guide was nothing but "Christianisation through the library."147

In this context, it is interesting to see how Aula tried to describe how the interest behind Joesoef's controversial policies finally became more identifiable with this case. Aula wrote that the best known Minister among Muslims was Daoed Joesoef, the Minister of Education whose name consisted of two names of the Islamic prophets mentioned both in the Bible and the Qur'an. Aula then explained that in the Christian tradition, it was said that the Virgin 
Mary was betrothed to Joesoef (Joseph), the son of Daoed (David), and so this name was only slightly different from the name of the Minister: Mary's betrothed was Joesoef Daoed, while the Minister was Daoed Joesoef. The magazine explained further that Joesoef's policies, one after another had surprised the Muslims. If one analogised Joesoef's surprises with a pistol to shoot Muslim bodies, Aula said, the book classification case helped identify "what kind of pistol he used and who actually ordered it."148 Thus, Joesoef was identified with a Christian figure (Mary's betrothed) and his educational policies were accused of being ordered by the Christians.

\section{Against Christianisation: Controversy on Religion Classes in Private} Schools

The Muslim concern with Christianisation in education is more obvious if we look at the controversy on the policy on religious instruction in private schools. To understand this, we should trace back the historical development of the issue. As noted earlier, the Education Law of 1950 dictated that the religion class was optional in the sense that students had the freedom to follow or not follow the class. In this context, in July 1951, the Minister of Religion and the Minister of Education and Culture released a joint regulation on the religion class at schools. The regulation, stated, among other things, that: (1) a religion class was to be given according to the religious adherence of respective students; (2) a religion class was only given if there were at least 10 students of the religion in question in the class; (3) students who adhered to a religion different from the one taught in the class, or students who adhered to the religion in question but whose parents did not allow them to follow the class, were allowed to leave during the teaching hour; (4) the religious teacher was forbidden to teach something that could hurt the feelings of the followers of another religion and belief. ${ }^{149}$

When the New Order emerged, there was actually no change of regulation on the religion class, except that the freedom was restricted. We have already mentioned that in contrast to the provision of the Education Law of 1950, in 1966 the MPRS decreed that religion class was compulsory and therefore, all students had to follow a religion class willingly or not. However, this did not mean that they had no freedom of choice, because the elucidation of the Decree stated that, "(1) all religions recognized by the Government will have the same opportunity; (2) for the sake of tolerance and human rights, every student is free to choose a religion class according to personal conviction and will." 150 This decree seems to indicate that, although the religion class was compulsory, if the school in question provided differ- 
ent religion classes (supposed that there were 10 Christian students and 10 Muslim students in the class, so the school could provide two religion classes according to the joint regulation), the students were free to choose one of them.

In practice, it is probably safe to claim that in public schools students rarely chose a religion class different from their own beliefs. The controversy on this issue, therefore, was not primarily related to public schools but private schools, particularly the Christian schools. Many Muslim parents preferred to send their children to study at Christian private schools because the latter could provide a high quality of learning and training. As in many other countries, the Christian schools in Indonesia have been developed since the colonial period when the Christian missionaries started their mission in the Archipelago. These schools did not only produce the early prominent Christian leaders of the new Republic of Indonesia, but also helped eradicate illiteracy among the natives throughout the country. ${ }^{151}$ With the long experience and tradition of managing modern education, the Christian schools, particularly in some major cities of Indonesia, successfully proved that the performance of their students was often better than that of those in the Islamic private schools. ${ }^{152}$

For many of the Muslims concerned with religious education, the enrolment of many Muslim students in the Christian schools has been alarming because the students only received a Christian religion class. The prominent Muslim leaders said that a Muslim child who studied at a Christian school would face at least two dangers: the child might be converted to Christianity; or become a sceptical and uncommitted Muslim. ${ }^{153}$ The Muslim concerns with this issue seem to be already found in the joint regulation of the Ministers of Religion and Education of 1951, which stated that it was applicable to private schools if their respective authorities were willing to do so, or if parents of no less than 10 students of the school wanted their children to be given a religion class of a certain religion. In the latter case, the elucidation of the regulation stated that the Government would provide a religious teacher for the religion in question and help find the place to carry out the class, if the authority of the private school did not allow its school building to be used for the class. It was also mentioned that often parents could not avoid sending their children to a private school because there were no other schools in their area, even though in terms of religion they could not agree with the principles and aims of that school. In this case, the elucidation of the regulation suggested that those children should not be forced to learn a religion different from the religion of their parents. ${ }^{154}$ 
I have no idea if there was any example in which Muslim parents whose children studied in a Christian school tried to manage an Islamic religion class for their children in accordance with the provision of the joint regulation. Nonetheless, it seems to be reasonable to assume that this kind of case scarcely happened because parents who wanted their children to study at a Christian school usually had to sign a statement of agreement that their children would only receive Christian religious education. For the parents, this was somehow simply a necessary consequence for anybody who studied in a Christian private school. Moreover, it could be safe to assume that only few devout Muslim parents sent their children to Christian schools, while many of them were not devout and practicing Muslims and did not care too much about the religious education of their children.

To face this challenge, some Muslim leaders tried to do at least three things: first, they tried to convince the Muslim communities through media and preaching that to study in a Christian school was harmful to the Islamic commitment of children; second, the Muslims tried to establish and develop better Islamic private schools to compete with the Christian schools; third, they demanded a state regulation obliging every private school to provide a religion class according to the religion of the students. The last attempt seems to indicate that the provision of the joint regulation of 1951 above was far from satisfying the Muslims. On the other hand, this attempt was not easy because while the first and second aims were only Muslim internal affairs, the third aim had to face opposition from the Christians and others who shared or sympathised with the Christian objection.

The idea to oblige Christian schools to provide Islamic religion classes for Muslim students was somehow parallel with the Muslim demand in 1967 that religious propagation should not be directed to the people who already adhered to one of the recognised religions. ${ }^{155}$ In August 1968, the reformist Muslim party, PMI, demanded that the Government should implement the compulsory religion class policy dictated in the MPRS decree No.XXVII/1966 for both public and private schools and universities. The PMI also demanded that the religion taught in the class should be the religion of the students. ${ }^{156}$ The Muslim concern with this issue continued in the following years. In 1973, Muhammad Natsir, the Muslim reformist leader, complained that Muslim students in Christian schools were obliged to follow a Bible study and to participate in Christian rituals. If one questioned this practice, Natsir said, the school's reply was that it was the regulation of the school and "if you object to this, why do you study here?"157 In 1974, Natsir wrote in Media Dakwah to urge the Indonesian authorities to follow Malaysia's policy that 
Muslim students at Christian schools were provided with an Islamic religion class. ${ }^{158}$ In the conference on Islamic Da'wa and Christian Mission in 1976 (discussed in Chapter 2), Rasjidi also reiterated Natsir's complaints. ${ }^{159}$ Perhaps, partly because of Rasjidi's complaint, one of the points of the Statement of the Conference was: "It also agrees that the family and community should have the right to ensure the religious education of their children by organizing their own schools, or by having teachers of their own denomination to teach religion to their children in the school, or by other suitable means." 160 Indeed, in his account of the conference, Rasjidi explained that this point of the Statement means that Christian schools should provide Islamic religion classes for Muslim students and allow them to go to the mosque for Friday prayer. ${ }^{161}$ Later during the controversy on the Alamsyah's decrees on religious propagation and foreign aid for religious institutions in $1978,{ }^{162}$ Rasjidi returned to this point of the Statement of the Conference and suggested that it should become a regulation because it had not yet been included in the decrees. ${ }^{163}$

On the other hand, the Christians were also aware of the Muslim concerns with this problem. In response to the PMI's demand in 1968 quoted above, the Catholic magazine, Peraba, stated that the compulsory religion class policy could only be applied to public, not private schools. Peraba also referred to the elucidation of the MPRS decree No.XXVII/1966, which stated that students had the freedom to choose a religion class that they wanted to take. ${ }^{164}$ By contrast, in October 1973, Tempo reported that among the Catholics, a former priest and a prominent Catholic leader, J. Riberu, and a Jesuit, Danuwinata, shared the Muslim concerns. Riberu was reported to have said, "If the mission of education is to enhance human dignity, then give every student the freedom to follow the religious instruction that he or she wants, and do not involve non-Catholic students in prayer and the Eucharist." Riberu, therefore, suggested that the Catholic schools should provide religious teachers according to the religions of the students. In this context, Danuwinata said that if a student received at school instruction in a religion different from that at home, he or she would suffer from "dualism and tensions in personality and this contradicts the principles of education." Danuwinata even suggested that non-Catholic students who wanted to learn about Catholicism should do so outside the Catholic school. According to Tempo, because of this radical idea, it was rumoured that Danuwinata wanted to eradicate the Catholic religion class at the Catholic schools, and the Jesuit General in Rome had to come to Jakarta to deal with the case. As a result, Danuwinata was removed from his position at the Indonesian 
Bishops Council (MAWI). ${ }^{165}$ On the other hand, it was not surprising that the Muslims were happy with Riberu's and Danuwinata's idea, even though the Church hierarchy apparently opposed them. ${ }^{166}$

The Christian opposition to the idea of teaching non-Christian religions in Christian schools, however, was more noticeable in 1985 when the Christians became suspicious of a Government regulation. ${ }^{167}$ In January 1985, the General Directorate of Elementary and Secondary Education issued a regulation in which it was stated that a student of Junior High School (SMP) and Senior High School (SMA) had to fill in a form to determine which religion class of the five recognized religions he or she wanted to follow and this form also had to be signed by the parents. For the students of the elementary schools, the form was to be filled in and signed by their parents only. Both the DGI and MAWI soon reacted negatively to this regulation. They argued that the regulation was against religious freedom because the obligation to choose only one religion meant to reduce the opportunities for students to learn about other religions. Leo Soekoto, the secretary general of MAWI said that religious freedom means that a person had the opportunity to review his or her own religion and compare it with other religions. In short, both the DGI and MAWI were worried that due to the regulation, every student would have difficulties in changing religion.

The main concern of both DGI and MAWI, however, was not simply religious freedom; they were anxious whether the regulation was to be applied to the Protestant and Catholic private schools. If the regulation was applied to the Christian schools, then they had to provide a religious teacher for every class that had at least 10 non-Christian students who followed the same religion. As has been noted, the joint regulation of the Ministers of Religion and Education of 1951 dictated that this rule was only applicable to private schools if the latter willingly submitted to it. The Christians were worried that the 'willingness' was to be changed into an 'obligation' by the new Government policy. In this regard, to defend themselves, the Christians did not talk about religious freedom but the right of private educational institutions to be independent from state intervention. They said that the state had to respect the right of a private school to maintain its own distinctive character.

In response to the Christian criticisms, the Minister of Education and Culture, Nugroho Notosusanto, said that religious freedom at schools was still guaranteed. He said that the regulation did not force students to embrace any but their own respective religions. Notosusanto also said that a student who converted to another religion, could take the religion class 
of the new religion. The problem with this, he said, was simply with the curriculum because a religion class in Grade I was lower and simpler than that of the upper Grades. For this problem, he suggested that the student should study the materials of the religion class below the current Grade. Last but not least, he asserted that the regulation was only for Government schools, not private schools. On the other hand, the leader of the MUI, E.Z. Muttaqien, said that he had no objection to the regulation because it was intended to establish exactly the religious affiliations of the students, so the Government could provide religious teachers in accordance with the needs of the students in that school. ${ }^{168}$

Despite the Christian criticisms, the Government proceeded with a higher level of regulation on this issue. In April 1985, the Minister of Education and Culture, Nugroho Notosusanto and the Minister of Religion, Munawir Sjadzali, issued a joint decree on the implementation of religious education at the elementary and secondary schools. In its introduction, the joint decree stated that it replaced the joint decree of 1951. The joint decree states, among other things, that: (1) at the Government schools, the religion class should be given for at least two teaching hours a week; (2) the students are obliged to follow the religion class according to their respective religions; (3) the students who follow Javanese mysticism (Aliran Kepercayaan) must follow the religion class of one of the five religions that the student chooses; (4) if there are at least 10 students of the same religion in a class, their religion should be taught in the class; (5) if there is no teacher to teach a certain religion in a school, then a temporary teacher of the religion in question can be appointed; (6) a religion class for the students whose religion is not taught in the class is to be given by a religious master (pembina agama) of that religion. ${ }^{169}$

I do not have further information about how the Christians and Muslims responded to the joint decree. One thing, however, certainly happened: it was not applied to private schools. This was indicated by the fact that during the MPR session of 1988, the Muslims wanted to include in the GBHN that the regulation on religion classes was to be applied to private schools. Lukman Harun, the Muslim leader of Muhammadiyah said that Muhammadiyah schools were ready to provide religious teachers of other religions if there were students who needed them. However, this idea failed to be included in the GBHN apparently because the Government party, Golkar, and the military did not support it. ${ }^{170}$ Several months later, however, the Muslims had a phrase successfully inserted into the elucidation of the article 28, section 2 of the Education Law, 1989. The phrase stated that the teacher 
of the religion class had to be a believer in that religion and the students had to be of the same religion. ${ }^{171}$ For both Feillard and Effendy, the inclusion of this statement in the Education Law was evidence of the New Order's accommodation of Islam. ${ }^{172}$ As both of them asserted, however, it was not eventually applied to private schools. Thus, the final and actual result of the inclusion of the statement in the Education Law was nothing but reaffirmation of the Government's previous policy. This, once again, indicates that the regime always tried to accommodate to a certain extent both the Muslim and the Christian interests even in the period when the Government was in general more favourable to other Muslim interests.

To illustrate this point, it is important to see the development of the controversy on this issue before and after the ratification of the education bill. The elucidation of the article 28 , section 2 , was originally proposed by the PPP faction and supported by both the ABRI and Golkar factions in Parliament. However, the PDI, which had emerged out of fusion of the previous Christian parties with the nationalist PNI, opposed it. The PDI's opposition was consistently maintained up to the end of the debate on the bill. ${ }^{173}$ The formal argument put forward by the PDI was that the elucidation was inconsistent with the article 28 , section 2 itself, because the article was on the qualifications of a teacher ${ }^{174}$ while its elucidation mentioned the qualification of both student and teacher (that is, in religion classes, both student and teacher had to be of the same religion). This also meant that the PDI would only agree provided the elucidation stated that religious teacher had to be a follower of the religion in question, but not the students. In the plenary session on 6 March 1989 for the ratification of the bill, the speaker of the PDI faction, Soebagjo stated that his faction could accept the bill with a specific note on the elucidation of the article 28 , section 2 . Besides reiterating the above arguments, he warned that the elucidation would create a socio-political condition that could disturb or hinder national development. When the chairman of the session asked whether all members of the Parliament agreed to ratify the bill, Djufri, a PDI deputy, interrupted and questioned the continuity of the specific note of his faction. The chairman said, because the PDI faction stated that it could accept the bill even with a specific note, it meant that all factions agreed to ratify the bill. The bill was then officially ratified.

Outside Parliament, both Catholic and Protestant leaders voiced their objection to the elucidation of the article 28. Unlike the PDI's formal arguments, both Catholic and Protestant leaders clearly stated that their objections were primarily because they were afraid that the provision of the elu- 
cidation of the article 28 was to be applied to private schools. They insisted that the Christian schools should be allowed to maintain their distinctive character (meaning to teach only Christianity). With regard to freedom of choice, the Christian schools, as usual, would ask the parents of new students if they agreed to follow the regulation of the school on this issue. ${ }^{175}$

In response to the Christian objections, the Minister of Education, Fuad Hassan, the General Chairman of Golkar, Wahono, and the Speaker for ABRI faction, Sundoro Syamsuri, all said that the distinctive character of private schools was to be secured in the Government regulation to implement the Law. The Christians were certainly happy with this promise and hoped it would become true. On the other hand, the Muslims consistently demanded that the rule that both student and teacher had to be of the same religion was to be applied to private schools as well. The leaders of Muhammadiyah, A.R. Fachruddin and Lukman Harun reasserted that Muhammadiyah schools were ready to provide religious teachers of other religions. ${ }^{176}$ However, the Government seems to have acted consistently with the policy that the rule in the elucidation of the article 28 should only be applied to public not private schools and this was affirmed in the Government regulation no. 29/1990. The Muslims, unsurprisingly opposed this regulation, claiming it deviated from the Education Law and demanded that the Government review it. ${ }^{177}$ However, the New Order Government never changed it.

\section{Conclusion}

Like the debate on the Jakarta Charter as against Pancasila, and on religion and marriage law discussed in the preceding chapters, the ideological debate on culture and education during the New Order period affected Muslim-Christian relations mostly because the Christians allied with the secular oriented groups to oppose the proponents of Islamic ideology. It is interesting that, in its idea of the strategy of culture, the CSIS (as the think tank of the New Order up to the mid-1980s) skilfully combined the secular view that the essence of culture is humanisation with the ideal of the family in Javanese culture originally developed by Taman Siswa in the pre-independence period. This combination apparently led to the justification of state authoritarianism, and the exclusion of the Islamic ideological view of culture. Being politically marginalised, the proponents of the Islamic ideology reacted negatively to the CSIS's strategy of culture and blamed the Catholics as the brain behind it. Moreover, there was a contest of discourse between the Christians who emphasised the non-Islamic character of the abangan, 
and the Muslims who argued for the opposite. However, we also find that certain Muslim and Christian intellectuals took the universal humanist perspective. In the 1990s when Soeharto drew closer to the Islamic groups, the discourse on culture in national politics changed. Islam was now called the "spirit of the Indonesian culture." This means that the state accommodated Islamic culture but not in the politico-ideological sense. The ideology was still Pancasila, but its spirit was portrayed as Islamic. Certainly, as a religious minority, the Christians were worried to see this political development.

The different ideological views of culture inevitably entered the educational realm. Again, the Christians allied with the secular nationalists to oppose the Islamic ideological interest in education. The support of certain Christian intellectuals for the secular nationalists in the state can be seen in the debates on educational policies during the New Order such as those on single as against dual administration of education, on optional versus compulsory religion class policy, on Pancasila Moral Education or Comparative Religion as against Islamic Religion, and on Ramadan as schooldays not holidays. Perhaps, the Islamic leaders' bitter experiences in defending their interests in education against the secular nationalists with whom the Christians allied themselves also helped increase the Islamic groups' negative perception of the Christians.

Moreover, there is one educational issue in which the Islamic groups have been more obviously opposed to the Christians, that is, the religion class in private schools. The Muslim leaders were worried about Muslim students who only got a Christian religion class in Christian private schools. Having realised that they could not prevent Muslim parents from sending their children to Christian schools, the Islamic leaders tried to use the Education Law to force the schools to teach Islam to the Muslim students. The effort of the Islamic leaders, however, never succeeded during the New Order. After the fall of Soeharto, this issue became the centre of controversy during the debate on the new Education Law of 2003. Despite strong opposition from the Christians, the Islamic groups successfully included in the Law a provision stating that students are entitled to religious education in their own religion and to be taught by a teacher of the same religion. But an important question remains unanswered: is it going to be applied to private schools? 


\section{Inter-religious Dialogue}

In the preceding chapters, we discussed the Muslim fear of Christianisation and objection to secularism on the one hand, and the Christian fear of an Islamic state and defence of religious freedom on the other. At times, when the relations between Muslims and Christians were tense and mutual suspicions were strong, the Government intervened as a presumed fair and neutral intermediary. However, the political contexts in which a certain Muslim-Christian antagonism occurred frequently led the Government to portray ambivalence: sometimes it supported certain demands of the Islamic groups and sometimes, in line with the Christians, it opposed them. In any case, the Muslim-Christian antagonisms apparently led some of the Christians to believe that their rights as religious minorities could be better defended through cooperation with the Government rather than with the Islamic groups. Likewise, some of the important leaders of the Islamic groups believed that they could realise their interests more easily if they allied themselves with the Government. This situation necessarily strengthened the polarisation between the two religious groups.

Nonetheless, there were also efforts to bridge the gap between the two religious groups through dialogue. There were two types of dialogue, one was sponsored by the Government and another was initiated by private institutions. In the former case, the Government usually invited the representatives of religious groups as participants. The Government also determined the theme of the dialogue that was usually focused on how peaceful inter-religious co-existence could be established and how each religion could contribute to national development. The theme indicates that through the dialogue the Government primarily wanted to maintain socio-political stability for the sake of development. This security approach was indicated by the fact that the Government sometimes organised a dialogue simply as a reaction to an inter-religious incident and it often tended to support the position of the religious majority against the minority. The Inter-religious Consultation of 1967 discussed in Chapter 1 is a good example. We can also find the same tendency in the Government sponsored dialogues in the following decades.

The dialogue initiated by private institutions was generally pioneered by the Christians and responded to positively by the leaders of other religions. Probably due to the influences of modern liberal ideas and the new challenges faced by the Christian missions, by the second half of the1960s, 
both the Vatican and the World Council of Church (WCC) called for dialogue. Following the decision of the Vatican Council II (1962-1965) to look at nonChristian religions in a more positive way, the Catholic Church encouraged her followers to engage in inter-religious dialogue. In 1967 and 1968, a Catholic priest named Cletus Groenen wrote 12 articles in the Catholic weekly, Penabur, on the relevance of Vatican II to Indonesia. ${ }^{1}$ Bakker noted that in 1968 an inter-religious meeting of Muslim, Catholic, Protestant and Buddhist leaders was successfully held in Sukabumi, West Java. Later in 1970, the religious leaders who participated in this meeting visited Cardinal Darmojowono in Semarang and in that visit they asserted their commitment to establish inter-religious harmony. ${ }^{2}$ The dialogue in Sukabumi was probably due to the efforts of Groenen who worked in West Java during this period. ${ }^{3}$

In line with Vatican II, in a consultation held in March 1967, in Kandy, Ceylon, the WCC decided to promote dialogue with other faiths. Later in 1970, the WCC organised an inter-religious dialogue in Ajaltoun, Beirut and then in 1971, the Central Committee of the WCC established a Sub-Unit on Dialogue with People of Living Faith. Ever since, the WCC has actively organised international inter-religious meetings in different places of the world. ${ }^{4}$ As noted in Chapter 2, since 1968, the leader of the DGI, T.B. Simatupang was a member of the Central Executive Committee of the WCC. It is not surprising, therefore, that some prominent Indonesian Muslim and Christian leaders were invited to participate in the international meetings organised by the WCC. These Indonesian participants often wrote their respective accounts of the meetings when they returned home. ${ }^{5}$

Thus, the Christian and the Muslim leaders were already involved in dialogue since the early years of the New Order. However, the proponents of inter-religious dialogue were actually a minority among the Muslim and the Christian leaders. What I mean by 'the proponents' here are those who not only participated but also believed in the importance of dialogue for establishing inter-religious understanding and cooperation. Among the Muslims, the proponents of dialogue were mostly the promoters of the non-ideological view of Islam that emerged in the early 1970s and became stronger in the following decades. For the Christians who had been afraid of an Islamic state, these Muslim leaders were certainly the most natural allies. Moreover, most of the promoters of the non-ideological view of Islam also did not concentrate on Christianisation as their major discourse (even though, they or at least some of them were personally concerned with Christianisation too). Thus, along with the Christians and others, they developed the common discourse on development, democracy and pluralism. 
Both the Protestant and the Catholic proponents of the dialogue were also a minority. Father Ismartono, a Jesuit who worked in the KWI, identifies three types of Catholics, and only one of which, 'the humanist group' concerned with social issues is interested in dialogue. The other two groups, the 'charismatic' and the 'ecclesia-centric', are not, because the former is much more interested in the spiritual experience, while the latter is characterised by a concentration on internal church affairs. ${ }^{6}$ Regarding the Protestants, one could make a contrast between 'the ecumenicals' and 'the evangelicals': the former are generally interested in dialogue while the latter are not. Given the fact that there are so many Protestant churches, we can certainly find a spectrum of positions along the line between 'the evangelicals' and 'the ecumenicals'. Most of the leaders of the PGI are generally more active in dialogue than those of the Indonesian Evangelical Association (PII). ${ }^{7} \mathrm{How}-$ ever, according to Th. Sumartana, the prominent Protestant intellectual, the involvement of the PGI leaders in dialogue did not mean that all churches in the PGI were pro-dialogue because the PGI leadership often could not effectively influence its members. ${ }^{8}$ It is noteworthy that like the Muslim proponents of dialogue, both the Catholic humanists and the Protestant ecumenists also opposed the idea of an Islamic state but at the same time they developed criticisms of aggressive missionary activities.

In the 1970s inter-religious dialogue in Indonesia was mostly sponsored by the Government. The privately-initiated dialogue started more seriously in the early 1980s. Later, in line with the increasing demand for democratization, in the 1990s inter-religious dialogue organised by private institutions also increased. In this context, Steenbrink pointed out to us a very interesting contrast between dialogues sponsored by the state and those carried out through private initiatives. ${ }^{9}$ In what follows, I will pay more attention to the two types of dialogue in terms of development, interaction, convergences and contrast of their respective discourses. Before discussing the two types of dialogue, I shall discuss the emergence of the non-ideological view of Islam as an important background to the Muslim-Christian dialogue in Indonesia.

\section{The Non-Ideological View of Islam}

As discussed in Chapter 3, the ideological debate on Pancasila versus the Jakarta Charter soon re-emerged after the fall of Soekarno. The debate sharply marked the political tensions and rivalries between the Islamic groups on the one hand, and the military and its secular and Christian allies 
on the other. The military leaders apparently realised that after the collapse of the Communist Party, their strongest political rival would be the Islamic groups. In this context, in contrast to Soekarno's accommodating policy in relation to ideological differences, Soeharto's Government tried to impose Pancasila as the only valid and legitimate ideology for the country. The Government, therefore, tried to remove the Islamic political ideology from among the Islamic groups, and at the same time encouraged the cultural and ritual dimensions of Islam - a policy that was often considered by some Indonesian and foreign observers to be close to that of the Dutch colonial Government. ${ }^{10}$

The strong Government opposition to Islamic ideology certainly made both the traditionalist and reformist Muslims unhappy. However, the reformist Muslims had more political frustration because in 1966 the military refused the rehabilitation of their party, Masyumi, and subsequently prohibited its former leaders from running the newly established reformist Muslim party, Parmusi. This political frustration eventually pushed the younger generation of reformist Muslims, particularly the activists of the Association of Muslim Students (HMI), to find a way out. It was in this context that the so-called 'renewal movement' emerged from among the HMI leaders in the late 1960s, and became widely debated in the early 1970s. ${ }^{11}$ The embryo of the movement was a weekly discussion circle called the 'Limited Group', held in the house of Mukti Ali from 1967 to 1971. Besides Mukti Ali himself, the participants of the discussion were the prominent HMl activists in Yogyakarta such as Ahmad Wahib, Djohan Effendi and Dawam Rahardjo, while Nurcholish Madjid who studied in Jakarta sometimes also came to join them. Occasionally, the circle invited non-HMI and non-Muslim participants such as the poet Rendra, and the Catholic student activist, Pranarka, as well as foreign researchers like B.J. Boland and James Peacock.

One of the major issues discussed in the Limited Group circle was the relationship between Islam and politics and the crucial question was, whether the dominant view among the Islamic groups that Islam should be referred to as a political ideology was to be maintained or not. In the discussions, Djohan Effendi, Ahmad Wahib and Dawam Rahardjo eventually found that the ideological view of Islam was theologically and historically baseless and politically unpromising. In short, for them, Islam should not be an alternative to Pancasila. When Ahmad Wahib and Djohan Effendi disseminated this view among other HMI activists, internal tensions within the organization emerged, that eventually forced them to resign from the HMI in 1969. After the resignation of these two prominent HMI leaders, however, 
Nurcholish Madjid, the chairman of the Central Board of the HMI in Jakarta who was previously sceptical if not totally opposed to Djohan Effendi's and Ahmad Wahib's ideas, wrote secretly to them that he personally agreed with their views. ${ }^{12}$

Accordingly, by early 1970, in a paper presented to a meeting of four organisations of young Indonesian Muslims: HMI, PII (Pelajar Islam Indonesia - Muslim Students of Indonesia), GPI (Gerakan Pemuda Islam Muslim Youth Movement) and Persami (Persatuan Sarjana Muslimin Indonesia - Association of Indonesian Muslim Graduates), Nurcholish Madjid declared the necessity of the renewal of Islamic thought. ${ }^{13}$ Inspired by Harvey Cox's The Secular City, Nurcholish Madjid argued that while secularism as a materialistic philosophy was opposed to Islam, secularisation was not, because the latter means a dynamic process in which people acknowledge the authority of reason and science to deal with worldly affairs. In other words, he said, secularisation was 'desacralisation', that is, the profanation of things wrongly treated as sacred. Secularisation in this sense, he said, was in line with the Islamic belief that nothing was absolutely sacred but God; and that the human was the vicegerent of God (khalifa). As the vicegerent of God, every human being had to use the rational faculty to understand and explore the material and social realities of the world, and to be ready to learn from, and to be open to, good ideas coming from any source. Later in 1972, in his speech delivered in Jakarta's cultural centre, Taman Ismail Marzuki, Madjid said that the roots of the Muslim idea of the Islamic state were religious legalism and apologetics. He argued that Muslim legalism was influenced by the Islamic law developed in the Islamic traditional discipline called figh, while in fact, he said, figh had to be radically reformed before it could be applied to a modern society. In addition, for him, the Muslim reference to Islam as a political ideology was nothing but an apologetic reaction to Western ideologies like socialism and nationalism. Madjid said that apologetics was not the right solution to Muslim problems because it was defensive in nature, and in the long run it would have a boomerang effect.

Nurcholish Madjid's renewal ideas soon reached a wider audience, because his paper was published in the media and also distributed to other student activists by his friends. The senior reformist Muslim leaders like HAMKA, Muhammad Natsir and Muhammad Rasjidi, as well as the prominent HMI leader in Bandung, Endang Saifuddin Ansari, soon reacted negatively to Madjid's ideas. In fact, Madjid was not the first general chairman of the HMI who opposed the Islamic state idea. In the early 1950s, when the 
tensions between different political ideologies increased before the coming elections of 1955, rather than supporting the aspiration of the Islamic parties for an Islamic state, the general chairman of the HMI, Dachlan Ranuwihardjo, declared his support for the idea of a national state. ${ }^{14}$ However, it seems, the general political frustration among the reformist Muslims, Madjid's use of such a controversial term as 'secularisation' and his ability to justify his view in Islamic theological terms thanks to his educational background in Islamic studies; all apparently helped create stronger and more serious opposition to his ideas. Nonetheless, because the New Order Government really opposed the ideological orientation of the Islamic political parties, the non-ideological view of Islam promoted by Nurcholish Madjid and his associates was, as Boland put it, "in all probability not unwelcome to the Government."15

\section{Positive Christian Responses to the Islamic Renewal Movement}

If the Government welcomed, or even supported, the Islamic renewal movement, then what were the responses of the Christians to this movement? This question is important for at least two reasons: firstly, this nonideological view of Islam was in line with the political aspiration of the Christians who were afraid that Indonesia would turn into an Islamic state; secondly, the question of the relevance of religion to modern society bothering the proponents of the renewal movement, was actually not a specific question for the Muslims, but for all believers of all religions in the world.

Indeed, there were positive responses to the Islamic renewal movement from the Christians. In 1973, J.W.M Bakker, a Jesuit of Dutch origin, wrote an article in the Catholic journal, Orientasi, on the Muslim view of secularisation. ${ }^{16}$ In line with Madjid, Bakker argued that secularisation was an unavoidable historical process in which the authority of religion on worldly affairs was transferred to the authority of reason. For Bakker, religious authorities should welcome secularisation because it liberated both religion and reason, and put each of them in their respective appropriate places. On the other hand, for him, if religious authorities opposed secularisation, secularism would necessarily replace religion. In an apologetic tone, Bakker said that compared to Catholicism, Islam had more theological difficulties in accepting secularisation, because while the First Vatican Council (1870) asserted the transcendence of God in relation to the autonomy of human beings and nature, the dominant theological view in Islam emphasised the all-embracing power of God at the expense of the autonomy of human beings and nature. 
Bakker then moved on to some examples of how Muslims in different countries like Turkey, Egypt, Pakistan and finally Indonesia, faced the issue of secularisation. In the nineteenth century, Turkey introduced secularisation through the Tanzimat reform but the ulama opposed it and as a result, in the next century, Mustafa Kemal Attaturk proposed secularism. In Egypt, the debate on secularisation started in 1925 when the ulama strongly opposed 'Ali 'Abd al-Rāziq's al-Islām wa usūl al-hukm (Islam and the Principles of Government) in which he argued that the mission of the Prophet Muhammad was not to establish a state but to guide the spiritual life of human beings. Despite the opposition of the ulama, secularisation in Egypt proceeded, particularly since the presidency of Gamal Abdel Nasser and then Anwar Sadat. In Pakistan, President Ayub Khan appointed Fazlur Rahman to carry out the Islamic reforms; but the fierce opposition of the conservative ulama to the reforms eventually pushed Rahman to leave his country. In Indonesia, Bakker said, in 1940 Soekarno angered the ulama when he initiated the debate on secularisation in his articles on 'the rejuvenation of Islam' in which he praised 'Abd al-Raziq's view and the policy of Kemal Attaturk. Later, argued Bakker, the debate on secularisation continued in the debate on Pancasila versus Islam in the Constituent Assembly in 1957. Bakker observed further that prominent Muslim leaders in general were consistently opposed to secularisation, until Nurcholish Madjid declared the Islamic renewal movement in 1970. Bakker lamented that those who opposed Madjid's view did not understand the difference between secularism and secularisation and wrongly saw that secularisation was a distinctive problem faced by Christianity in the West. It was regrettable, Bakker argued, that none of the critics referred to the problem of secularisation faced by the other Muslim countries. In his final remarks, Bakker asserted that he believed that the future of Indonesian Islam was in the hands of the proponents of secularisation and this was nothing but good for the advancement of Islam itself.

In line with Bakker, Victor Immanuel Tanja, a minister of the Protestant Church of West Indonesia (GPIB) also made a sympathetic assessment of the Islamic renewal movement. Tanja took a Ph.D. programme in theology at Hartford Seminary, USA, from 1973 to 1979 and wrote a thesis on the HMI and its position among Islamic reform movements in Indonesia. ${ }^{17}$ In his thesis, Tanja tried to trace back the history of the $\mathrm{HMI}$ and its relation to the early Islamic reform movements in Indonesia, like Jong Islamieten Bond, Sarekat Islam, Persatuan Islam and Muhammadiyah and the reform movements in the Middle East, particularly the two Egyptian reformists, Muhammad 'Abduh and Rashīd Ridā. Based on this historical account, Tanja argued that the ideas of reform 
or renewal proposed by the HMI activists like M. S. Mintaredja, Deliar Noer, Dawam Rahardjo and particularly Nurcholish Madjid were much more in line with 'Abduh's liberal position while the ideas of their opponents like Rasjidi, Natsir, Saifuddin Anshari and HAMKA were close to the conservative stand of Rashīd Ridā. In this context, Tanja said that he disagreed with Kamal Hassan who, in Tanja's view, saw that Madjid's renewal movement was merely a political accommodation to the military regime of the New Order. For Tanja, the positive attitude of the proponents of the renewal movement to secularisation and their rejection of the idea of an Islamic state should be seen as a religious position validly chosen from within the Islamic tradition itself. Tanja also believed that these ideas would be a very good foundation for establishing positive inter-religious relations in Indonesia. ${ }^{18}$

There were positive and negative responses to Tanja's thesis, particularly when it was translated into Indonesian and published in 1982. Perhaps, among the books published in that year, Victor Tanja's book was the one most widely discussed and reviewed, particularly among Muslim reformists. HMI activists in Jakarta and Yogyakarta organised seminars to discuss the book in which Tanja was often invited to speak. Besides numerous reviews of the book published in the media, a former HMI activist, Agussalim Sitompul, even wrote an entire book to criticise it. ${ }^{19}$ The fact that the book was about the HMI and its author was a Christian minister apparently stimulated curiosity, sympathy and criticism among many Muslims. There are at least two important points in the criticisms of Tanja's book: firstly, some historical accounts of the book are inaccurate; secondly, Tanja was too eager to identify Madjid's renewal movement with the HMI as an organisation. The last point seems to be more interesting because some of the $\mathrm{HMI}$ activists like Agussalim Sitompul and Djohan Effendi, obviously disagreed with Tanja's position. Sitompul said that Madjid's idea on secularisation was never approved as the official position of the HMI. ${ }^{20}$ In line with Sitompul, Djohan Effendi said that as a student organisation, the HMI was much more like a transit station for Muslim activists rather than a permanent place. In this context, he said that the $\mathrm{HMI}$ as an organisation was always sceptical about supporting the renewal movement and therefore, these ideas went out of the organisation along with Madjid when the latter finished his chairmanship. ${ }^{21}$ On the other hand, Nurcholish Madjid was naturally happy with Tanja's book. In his letter to the reformist Muslim leader, Mohamad Roem, dated 29 March 1983, Madjid wrote: "many people criticise the book but I think, its account of myself is ironically better and more honest than the one written by my acquaintance, Muhammad Kamal Hassan."22 
Both Djohan Effendi and Agussalim Sitompul were probably right in their criticisms of Tanja's analysis. However, if we remember his background as an Indonesian Christian minister, we may see that Tanja's tendency to identify Madjid's ideas with the HMI as an organisation was perhaps motivated consciously or unconsciously by his eagerness to see the $\mathrm{HMI}$ as a potential partner in dialogue and cooperation. Likewise, Madjid's happiness with Tanja's book could be more personal in nature but at the same time it could also become the seeds of mutual understanding between the two important leaders in particular and the Muslims and the Christians who shared their ideas in general.

The interest of the Protestant intellectuals in the Islamic reform movement is also reflected in the annual programme called 'Seminar AgamaAgama' (Seminar of Religions). Started in 1981, the Research and Development Office of the PGI organised a one-week Seminar on Islam for about 20 students coming from different Protestant Academies of Theology (STT) throughout Indonesia. The seminar was designed to give those students a general understanding of Islam, particularly the development of Islam in Indonesia. The important person behind this programme was Olaf Herbert Schumann, a German minister of the Lutheran Church who worked in the Research and Development Office of the PGI from 1970 to 1981. From 19641966, Schumann studied Islam in Cairo and then in 1975 wrote a PhD thesis on the Arabic Muslim literature on Jesus. When he worked in Indonesia, Schumann also taught Islam as a subject in some STTs, and wrote some books on inter-religious dialogue. Although he was appointed Professor of Missiology in Hamburg University in 1981, he still regularly visited Indonesia to teach in the STTs and to support the seminar. ${ }^{23}$

The topics of the seminar gradually developed from the phenomena of Islam in Indonesia to the topics of common concern like modernisation, social justice, the environmental crisis, human rights, and religion and culture. The number of students who participated in the seminar also gradually increased and the speakers were extended from the Muslim and Protestant figures to the Catholic, Hindu and Buddhist intellectuals and so it became a 'Seminar of Religions.'24 In this context, besides the fact that many of the Muslim speakers invited to the Seminar of Religions were those names commonly associated with the same stream of Islamic reform, ${ }^{25}$ the first two seminars clearly paid specific attention to the Islamic renewal movement. The first seminar in 1981 discussed the book by Harun Nasution called Islam Ditinjau Dari Berbagai Aspeknya (Islam Viewed from Its Different Aspects). ${ }^{26}$ In addition to Nasution's book, Th. Sumartana, one of the important per- 
sons behind the seminar, presented his paper on the controversial diary of Ahmad Wahib recently published in that year. Even more than the first seminar, the second one in 1982 was focused on the issue of Islamic reforms in Indonesia and the literatures discussed in the seminar were Victor Tanja's thesis, the diary of Ahmad Wahib and the works by Deliar Noer and Harun Nasution on Islamic reform. ${ }^{27}$

In his paper for the second seminar, having referred to the books by Deliar Noer and Harun Nasution, T.B. Simatupang, the prominent leader of the PGI, argued that the Islamic modern movements were not competitors to, but one of the components of the nationalist movement in Indonesia. In other words, both Christians and Muslims were in fact nationalists. In addition, for Simatupang, the ideas of the Islamic renewal movement of the HMI described in Victor Tanja's thesis should also become the concern of the adherents of other religions. Thus, for him, the same nationalist impetus and the same concern with the relevance of religion to modern society were the very foundation of Muslim-Christian cooperation to develop the country. ${ }^{28}$

Another book discussed in the seminar was the diary of Ahmad Wahib. We have mentioned that Wahib was among the early promoters of the nonideological view of Islam in the late 1960s. Wahib was killed in a motorcycle accident in March 1973 and his diary was posthumously published in 1981. The publication of the diary as a book soon triggered controversies among the Muslims: while his friends and sympathizers were fascinated by Wahib's critical and honest view of Islam, others called it a heresy or a tragedy for Islam. ${ }^{29}$ Having investigated the book, the Indonesian Council of Ulama (MUI) even asked the Department of Religion to restrict its distribution. ${ }^{30}$ Despite the opposition, perhaps because its Islamic view was favourable to the Government, the latter never banned the book and it was one of the bestsellers in Indonesia in 1981. ${ }^{31}$

In general, besides his obvious support for secularisation and his criticism of certain established orthodox teachings of Islam, Wahib made some of the Muslims angry because while he was very critical of Islam and Islamic leaders, he highly praised certain Catholic priests whom he knew very well. In the early 1960s when he was a student of the Faculty of Natural Science, Gajah Mada University, Yogyakarta, Wahib used to stay in the Catholic student dormitory, Realino. There he experienced direct and warm encounters with the Catholics through daily conversation, sports, music etc. It was partly this experience that led him to oppose the simple dichotomy of Muslim and non-Muslim. His close and warm relations with some of the priests whom he considered good and sincere people led him, in his note on 16 September 
1969 , to question the theological view that non-Muslims would simply go to Hell in the hereafter. ${ }^{32}$ On 13 December 1971, Wahib wrote that he dreamed of the Virgin Mary wearing a white dress and smiling at him. This dream was quite impressive to him as he wrote: "I am not a Christian, but I do not know why I found peace and calm in my mind when I faced her. Would this happen in my real life?"33 In 1971, Wahib moved to Jakarta and studied at the Academy of Philosophy, Driyarkara, an institution established and run by the Catholics. If we remember the Muslim-Christian tensions during the period of Wahib's notes (1968-1973) recorded in this book, we shall soon realise that he was really a unique person among the Muslim activists.

Th. Sumartana chose Wahib's diary as his focus for discussing the Islamic renewal movement both in the first and the second seminar. In 1981, Sumartana wrote two articles on Wahib's diary: one in Tempo, and this was the paper presented to the first seminar and another in the academic journal, Prisma, and this was later presented to the second seminar in $1982 .{ }^{34}$ Moreover, the second seminar also invited Ismed Natsir, one of the editors of the diary, to present a paper on Ahmad Wahib. In his paper, Ismed Natsir objected to those who said that, having been influenced by the Catholic priests, Wahib eventually lost his faith in Islam. In fact, Natsir said, Wahib was born into a committed Muslim family, and when he returned home, he often was a preacher in the Muhammadiyah mosque of his hometown, Sampang, Madura. However, as a young man, argued Ismed Natsir, Wahib opened himself to any influence without fear of losing his religious identity. Natsir also referred to some notes found in Wahib's original diary, but not included in its published edition to indicate that Wahib was actually a very pious and committed Muslim. ${ }^{35}$ On the other hand, Sumartana argued that the dogmatism and exclusivism criticised by Wahib were actually not phenomena specific to Islam, and therefore Wahib's diary should be taken as an example of a creative and critical assessment of religion for all believers, including the Christians. Moreover, for Sumartana, due to the influence of their western masters since the colonial period, many of the Indonesian Christians consciously or unconsciously believed that Islam was identical with underdevelopment and ignorance. In fact, argued Sumartana, he did not find any example among the Christians who developed such a creative and fresh religious thought like Ahmad Wahib. To emphasize his point, Sumartana quoted Wahib, who wrote in his diary that secularisation was still problematic in the Christian world but the Indonesian Christians immediately accepted it without criticisms, and therefore, Wahib questioned whether this attitude was based purely on ideal reasons or simply because they were 
afraid of the aggressiveness of the Islamic groups. For Sumartana, this was truly an honest question to the Christians.

Our discussion so far demonstrates how the Christians responded positively to the emergence of the renewal movement among the reformist Muslim activists. In fact, a similar development was also found among the Muslim traditionalists of the Nahdlatul Ulama (NU). The most prominent proponent of the non-ideological view of Islam in the NU circle was Abdurrahman Wahid who was to become the President of Indonesia in 1999. In the early 1970s, when he had just come back to Indonesia from his study in Baghdad, Abdurrahman Wahid still believed in Islam as an ideology. ${ }^{36}$ However, probably after having contacts and discussions with leaders of the renewal movement like Nurcholish Madjid, Djohan Effendi and Dawam Rahardjo, by the mid 1970s, he had already abandoned the ideological view of Islam. By this time, Wahid was often invited to give a lecture on Islam in the regular course for the ministers of the East Java Christian Church (GKJW) in Malang. In this context, Greg Barton found that Wahid's explicit support for Madjid's secularisation idea was clearly expressed in a paper presented to a meeting of the GKJW ministers in 1976. ${ }^{37}$ This evidence indicates that at least since the second half of the 1970s, Wahid was already known in the Christian circle as a traditionalist Muslim intellectual who supported a non-ideological view of Islam. Furthermore, since 1982 Wahid was among those who were often invited to speak in the annual Seminar of Religions organised by the PGI. The following report of the second Seminar in 1982 may illustrate how the Christians were happy with Abdurrahman Wahid's serious involvement.

Starting at 9 in the morning, he (Abdurrahman Wahid) talked openly about the history and position of the NU in local and national politics. The discussion was quite interesting, and he was so generous with his time that he continued till 3.00 p.m. even though the actual timetable for him was from 10.30 to 12.00 . This lecture provided much new knowledge to the participants who were 'blind' to socio-political issues and the development of Islamic renewal movement in Indonesia. ${ }^{38}$

However, up to 1984, Wahid was not yet the top leader of the NU, and so the influence of his ideas on the organisation was still limited. In addition, the lateness of the development of the renewal ideas in the NU circles was also due to its formal political position. Unlike the reformist Muslims, who could not rehabilitate their political party, Masyumi, the NU's participation 
in national politics was not formally disturbed by the New Order regime, at least to the end of the 1970s. However, at every election, many NU activists were often pressurised to support the Government party, Golkar. Initially, NU played a dominant role in the Islamic party, PPP, and led protests against some of the Government's policies. Being unhappy with the NU's frequent attitude of opposition, the Government tried to subdue the NU faction within the PPP. By the early 1980s, the reformist Muslim politician in the PPP, Djaelani Naro who had a close relationship with the Government, eventually expelled several important NU representatives within the party. By 1983 NU was under more pressure to choose either accommodation or opposition to the Government. In the National Consultation of 1983 in Situbondo, the NU finally made two significant concesions: (1) to withdraw from formal politics, so that its formal ties with the PPP were cut; and (2) to accept Pancasila as the basis of the organization. ${ }^{39}$ The second decision was related to the MPR Decree on the GBHN of 1983 in which it was stated, among other things, that Pancasila had to be the sole basis of all social organisations. In this regard, the NU proved to be the first religious organisation to accept this rule before it was officially declared by President Soeharto as the Law No. $8 / 1985 .{ }^{40}$ Wahid was certainly one of the major proponents of the two significant decisions in Situbondo, and by the next year (1984) he was elected Executive Chairman of the NU. Ever since, he became increasingly influential both inside and outside the NU.

Under Wahid's leadership, the NU also became more attractive to both foreign and domestic social researchers. In this context, a minister of the Huria Kristen Batak Protestant (HKBP) Church named Einar Martahan Sitompul wrote an MA thesis on the "NU and Pancasila" that was submitted to the STT Jakarta in 1988 and published in the following year. ${ }^{41}$ In his study, Sitompul tried to uncover the historical development of religious thought within the NU in response to the socio-political changes from 1926 when the NU was established to its $27^{\text {th }}$ Congress in 1984 . Sitompul looked at the orthodox Sunni tradition and how the NU took those elements of the tradition to justify its particular position in a certain socio-political context. He argued that although the NU took different positions in relation to the sociopolitical changes of the country, they should not be interpreted simply as evidence of NU's political opportunism. The rich materials of the orthodox Sunni tradition, Sitompul argued, provided the NU with a flexible, adaptive and contextual political attitude without losing its basic Islamic principles. In this context, Sitompul maintained that the NU's acceptance of Pancasila as its basis was based on serious religious reasoning and therefore, it was 
not a temporary political tactics but an assertion of the NU's responsibility for the future of the nation as a whole.

We can say that Sitompul's study was an attempt to see the NU sympathetically from its own religious point of view. No matter whether his analysis of the NU was objective or not, Sitompul probably represented the view among the Christians who felt very positive about NU's non-ideological view of Islam and its acceptance of Pancasila as the basis of the organisation in 1983. In other words, the NU somehow did not represent the threat of the Islamic State any more to the Christians. Moreover, when the thesis was published, Abdurrahman Wahid wrote an introduction in which he affirmed that according to the traditional fiqh, Indonesia was a state based on a peace agreement (där al-sulh) between Muslims and other groups and therefore, it should be accepted and defended by the Muslims. ${ }^{42}$ Wahid also wrote that he was very grateful for Sitompul's study, not only because it was a sympathetic description of the NU but also because it was a good example of how all religious groups could learn from one another. "This process of learning from one another among us [that is, religious groups] will certainly enrich our knowledge and understanding of our own state and the problems it faces," wrote Wahid. ${ }^{43}$

\section{Inter-religious Dialogue and National Development}

We have mentioned that to weaken and control the political force of the Islamic groups, the power holders of the New Order suppressed the Islamic ideological orientation of the Islamic socio-political forces. The Government's negative policy towards Islamic ideology, however, was accompanied by a positive call for development, particularly economic development. The latter was strongly justified by the fact that the country had suffered from serious economic deterioration inherited from the Soekarno regime. In this context, the proponents of the New Order often said that if the political parties and other social forces during the Soekarno period were 'ideologyoriented', then now they had to be 'programme-oriented.' In other words, for the New Order supporters, instead of being preoccupied with ideological issues that would only bring about unnecessary socio-political conflicts, all social forces should direct their energies to the common concern of the whole nation called 'modernisasi' or 'pembangunan'.

The first term (modernisasi) is none but 'modernisation' while the second term (pembangunan) is more or less a translation of the English word 'development'. ${ }^{44}$ The meaning of the two terms could probably be differen- 
tiated, but for our analysis here the differentiation has a very limited significance, particularly because the New Order regime tended to use both terms as identical. If we look at the book by the 'architect' of the New Order, Ali Moertopo, for instance, we find that he refers to the two terms interchangeably without clear differentiation. ${ }^{45}$ In his study of Muslim responses to modernisation, Hassan does not clearly differentiate the two terms either. Hassan, however, demonstrates that the Muslim ideological responses were more directed to modernisasi than to pembangunan. ${ }^{46}$ Perhaps, this was the reason why the Government eventually preferred the term pembangunan to modernisasi.

The Government idea on development probably came from Soeharto's economic advisors since 1966 led by Widjojo Nitisastro, a PhD in economics from the University of California, Berkeley, who was to become the Head of the Body for the National Development Planning (Bappenas). ${ }^{47}$ 'Development', however, was not adopted as a formal Government policy until a few years later. In his speech to the MPRS in August 1967, Soeharto said that his administration was preparing a Five Year Development Programme (REPELITA) that was expected to be ratified by the MPRS in 1968 and to be implemented by the Government in $1969 .{ }^{48}$ Indeed, in 1968 the MPRS approved the REPELITA and ever since, development or pembangunan had been the most central discourse of the New Order regime and almost as sacred as Pancasila and the Constitution of 1945. All Government officials repeated the word Pembangunan again and again in their speeches; all students from elementary to university levels should memorize what Pembangunan was; all religious leaders were encouraged to speak about the function of religion to support Pembangunan; and Soeharto was eventually called the Father of Pembangunan.

Among the religious groups, the Christians appear to be the earliest group who responded very positively to the idea of modernisation. In June 1967, the Indonesian Council of Churches (DGI) organised a Conference on Church and Society in which the major issue discussed was how the churches could contribute to modernisation and development of the country. Soeharto, who was the Acting President, came to the Conference and delivered a sympathetic speech. ${ }^{49}$ The Conference was probably supported by the WCC because, as noted in Chapter 2, since 1962 the leader of the DGI, T.B. Simatupang, had been involved in similar conferences both at the national and international levels. In general, the Conference emphasized that the churches had to motivate their members to participate in modernising the country in the fields of politics, law, economy and culture. In terms of 
socio-cultural modernisation, the Conference suggested that the Christians should maximise the functions of the Christian social service institutions such as schools, universities, health centres, orphanages and publications. ${ }^{50}$ With regard to the modernisation of politics, the Conference was rather worried about the dominant role of military officers in the state institutions, but it still hoped that the military could lead the country to a democratic political system. On economic development, the Conference suggested that the churches could motivate their members to participate in cooperatives; to create the vocational education needed by modern industries; and to tell the real economic situation of the country to foreign churches so that the latter could ask their respective Governments to provide aid for Indonesia. The Conference was also concerned with modernisation of the national law, and it was in this context that Islam was mentioned. The Conference stated that the Christians had to reckon with Islam and Islamic law seriously, to avoid antagonism and confrontation with the Muslims, and "if there is a view that in terms of modernisation Islam is a 'laggard', then the concern of the Christians was to help them to be 'innovators."'51

In line with the Protestants, the Catholics also made a positive response to modernisation. In the above seminar, Father Dick Hartoko, a Jesuit and editor of the Catholic cultural magazine, Basis, was invited to present a paper on the Catholic view of modernisation. In his paper, Hartoko explained that Thomas Aquinas (d.1274) was the earliest theologian who opened the door for modernisation because he argued that science and reason on the one hand, and revelation and faith on the other, had their respective autonomous realms. However, in the following centuries, said Hartoko, the Church was still unfriendly to science, and her positive attitude to it was just introduced in the modern period by Pope Leo XIII (1810-1903) and then followed by Pope John XXIII (1881-1963). Accordingly, the Vatican Council II and its aggiornamento, said Hartoko, tried to bring the Church positively into the middle of the modern world. Hartoko argued further that in the past, Christian love was realised by individuals through charities, but in the modern period, Christian love should be realised collectively through the so-called modernisation. "If the people of Samaria helped others by giving oil and wine, then we are now to cure the wounds of our nation and all human beings by carrying out modernisation," he wrote. ${ }^{52}$ Besides Hartoko's paper, it is noteworthy that the major involvement of some Catholic intellectuals and activists in the Centre for Strategic and International Studies (CSIS) was also evidence of their serious support for Government modernisation. ${ }^{53}$ 
In contrast to the Christians, the Muslims responded differently to the Government call for modernisation and development. The negative and oppositional political attitude of the military towards the Islamic groups in the early years of the New Order, particularly to the reformist Muslims, was the main reason why the Muslims were sceptical if not totally negative to the Government call for modernisation. In his study of this topic, Hassan classified three types of the reformist Muslim responses to modernisation. ${ }^{54}$ The first was the ideological response characterised by a defensive attitude and high concern with the influences of western culture embodied in modernisation. For instance, Nurcholish Madjid wrote in 1968 that modernisation was only compatible with Islam as far as it means 'rationalisation' not 'Westernisation'. Hassan explained that the reformist Muslims suspected that modernisation was nothing but efforts of the secularists in the Government to eradicate all traces of Islam in public life. I also would like to add that for some of the Muslims 'Westernisation' could also means 'Christianisation.'The second type was what Hassan called 'the idealist response', which put the national development within the framework of Islam as a comprehensive system covering social, economic, political and spiritual fields. The idealists generally believed that only through the application of the shari'a by the state could the 'true' national development be realised. Therefore, among their most important agenda were the unification of Islamic political forces, the establishment of autonomous Muslim social and economic institutions, and the intensification of Islamic propagation (da'wah) programmes. The third type was the accommodationist response characterised by efforts to put Islam and Islamic groups in congruence with the Government views, by proposing a non-ideological view of Islam and an open attitude to Western culture. ${ }^{55}$ This type of response mainly came from the proponents of the renewal movement in the early 1970s.

\section{Government Sponsored Dialogue on Religious Harmony and Development}

After the elections of 1971 in which the Government party, Golkar, obtained a spectacular victory, the Government became more active to persuade religious groups to support Pembangunan. In this context, in September 1971, A. Mukti Ali was appointed to be the Minister of Religion. Ali Munhanif has noted that Ali Moertopo and Soedjono Hoemardani, the two important Personal Assistants to President Soeharto and the patrons of the CSIS, played a decisive role in Mukti Ali's appointment. ${ }^{56}$ Mukti Ali was a nonNU figure, a former activist of the reformist Muslim school student union, 
PII (Pelajar Islam Indonesia), and in the early 1950s used to work as a secretary in the Central Board of the Masyumi, but in 1955 had decided to study abroad. ${ }^{57}$ As noted, in the early years of the New Order, Mukti Ali hosted the 'Limited Group' discussion circle, the embryo of the renewal movement among the HMI activists. ${ }^{58}$ Moreover, thanks to his study at McGill with Wilfred Cantwell Smith, Mukti Ali had sympathy with other religions, so by the late 1960s he initiated an inter-religious dialogue in Yogyakarta, even in his own house. ${ }^{59}$ Mukti Ali's track record apparently matched the interests of the New Order Government. First, as a reformist Muslim, he was expected to eliminate the long-established dominance of the NU in the Department of Religion. The NU was an important wing of the Islamic party, PPP, and the marginalisation of the NU people in the Department was partly related to the Government attempts to force all civil servants to be Golkar loyalists. Secondly, as the patron of the renewal movement and an activist in interreligious dialogue, Mukti Ali was perhaps expected to be able to bridge the gap between the Government, the Muslims and the Christians. Thirdly, Mukti Ali was politically weak, because he had no personal power base, neither in a political party nor in the Islamic organisations like NU or Muhammadiyah.

Before his appointment, Mukti Ali accompanied by Ali Moertopo and Soedjono Humardani, met Soeharto in the latter's house. In that meeting, Soeharto said repeatedly that he expected Mukti Ali to pay serious attention to development (pembangunan). ${ }^{60}$ Indeed, during his ministry, Mukti Ali always tried to explain the relationship between religion and development, and all of his speeches published in nine volumes were entitled "Agama dan Pembangunan" (Religion and Development). Actually, about one week before his appointment as the Minister of Religion, on 3 September 1971, Mukti Ali was invited by the German Cultural Foundation to deliver a lecture on religion and development at the Goethe Institute, Jakarta. ${ }^{61}$ This English lecture was soon translated into Indonesian and delivered to various audiences on different occasions in October $1971 .{ }^{62}$ In this lecture, Mukti Ali argued that the ultimate goal of development was "the development of the whole man and of all men." This meant that for him, development should include both the spiritual and material dimensions of human life. Thus, he rejected the idea that both secularism and Westernisation were inherent in development. He also emphasised that development programmes should give priority to social justice over economic growth. He strongly believed that the teachings of all religions were a positive support to development and therefore, religious believers should "move out of their religious ghettos and narrow communal interests" to support development. ${ }^{63}$ 
When Mukti Ali started his ministry, he stressed the importance of inter-religious dialogue for national development. Inter-religious dialogue, he said, could be an effective means to increase the participation of religious groups in development and to prevent them from inter-religious conflicts. ${ }^{64}$ This preventive function of the dialogue was certainly parallel with the Government view that socio-political stability was necessary for development. In an interview with me, Mukti Ali said that the relations between Muslims and Christians at that time were "as if they did not know each other" and this situation, he said, could easily lead to a dangerous conflict. ${ }^{65} \mathrm{His}$ project on inter-religious dialogue, therefore, was strongly related to what he frequently referred to as "the harmony of religious life" (kerukunan hidup beragama), that is, peaceful co-existence of religious groups.

The harmony of religious life is a social condition in which all religious groups could live together without losing their basic right to perform their respective religious duties. Everybody lives as a good religious believer in a harmonious and peaceful condition. Therefore, the harmony of religious life cannot emerge from blind fanaticism and indifference to the rights and feelings of the others... . The harmony of religious life can only be obtained if every religious group becomes open-hearted [lapang dada] to one another. ${ }^{66}$

The harmony of religious life, he said, should be developed within the principle of 'agreement to disagree.' ${ }^{67}$ This means that in a dialogue one was ready to accept and respect the other totally, that is, with all of the latter's aspiration, customs, mode of life and religious conviction. ${ }^{68}$ The principle of agreement to disagree was related to Mukti Ali's strong opposition to apologetic discourses developed by some Indonesian Muslim intellectuals against non-Islamic religions. ${ }^{69}$ Instead of developing apologetics, Mukti Ali suggested Muslim scholars should look at other religions in a more sympathetic way, that is, by looking at the views of the believers of the religion in question or the insiders' perspective. Some scholars called this approach 'phenomenological.'Among the proponents of this approach was Wilfred Cantwell Smith with whom Mukti Ali studied at the Institute of Islamic Studies, McGill University from 1955 to $1957 .{ }^{70}$ Not long after his return to Indonesia, in 1958, Mukti Ali joined the Ninth Congress for the History of Religions in Tokyo in which many scholars of the subject from all over the world participated. This meeting seems to have made Mukti Ali more convinced of the importance of this approach to the study of religions. ${ }^{71}$ In early 1960s, Mukti Ali introduced this approach through the subject called 'the Science of Comparative Religion' (Ilmu Perbandingan Agama) to his students at the Insti- 
tute of Islamic Studies (IAIN), Sunan Kalijaga, Yogyakarta. ${ }^{72}$ This subject was also to be taught in all IAINs all over the country.

As the Minister of Religion, Mukti Ali tried to develop the principle of agreement to disagree through the project on the harmony of religious life. He appointed Djohan Effendi, the former activist of the Limited Group, to be the head of the project. According to Djohan, there were three main programmes of the project: meetings of religious leaders, a programme of social research and camps bringing together students of different religious backgrounds. From 1972 to 1977, there were 23 dialogues of religious leaders held in 21 cities all over the country. The participants of the dialogues included Government officials, religious leaders of Islam, Protestantism, Catholicism, Hinduism, Buddhism, Confucianism, and even of Javanese mysticism and local beliefs. ${ }^{73}$ In general, the dialogue was still far from Mukti Ali's ideal of agreement to disagree but it was quite different from the debate in the Inter-religious Consultation of 1967. Djohan Effendi explained: ${ }^{74}$

The goal of the dialogue was not to discuss theological issues, but social issues as a common concern, or the so-called development issues. ${ }^{75}$ These were to be discussed from the perspective of every religion. The important thing in the dialogue was not the decisions taken in it but personal contacts and friendships among the participants. Within two or three days, they stayed in the same place, had the same meals together and shared jokes. Thus, they became close to one another.

The second activity was a social research programme and this was carried out since 1976 in seven regions. The research was carried out by a team of seven involving Muslim and non-Muslim scholars and the topic of the research was determined by the team. ${ }^{76}$ Before the field research, the members of the team were briefed in the Training Programme on Religious Research (Program Latihan Penelitian Agama, PLPA). Started in 1975, the programme was organised and financed by the Office of Research and Development of the Department of Religion. Karel Steenbrink, who also taught in the programme, noted that the PLPA was organised in a place where "all participants had to stay for three months together" and they were "stimulated to select inter-religious relations or even tensions as the special topic for their one-year field research, which followed the three months training." 77 In his assessment of this project, without explaining whether the results of the research were important or not, Djohan Effendi only emphasised that the programme was a good opportunity for people 
of different religions to develop intimate relations and to learn from one another. $^{78}$

The third programme of the project was student camping. This was initiated in 1977 in Jakarta and Medan. In Jakarta, the participants of the camping were students of the State Institute of Islamic Studies (IAIN), the Academy of Theology (STT) Jakarta (Protestant), and the Academy of Philosophy Driyarkara (Catholic). In Medan, the participants were activists of Muslim student organisations (HMI and PII) and the Protestant student organisations (GMKI). During the camps, the participants had discussions with some invited speakers and among themselves. On the final day, they performed a voluntary work together for the community where the camp was held. Again, for Djohan, the important thing in this programme was personal contacts and the experiences of being together with people of different religions. ${ }^{79}$ The programme, he said, provided the participants with early personal contacts from a young age, and so when they graduated and became the leaders of their respective religious groups, they would not have difficulties in communicating with each other. ${ }^{80}$

So what was the result of the project? In this respect, it is important to look at Steenbrink's observation of the programme on dialogue:

Quite often they produced optimistic and sometimes embellished statements about the positions and practices of various communities. The unifying Pancasila ideology was very often quoted as a great support for the harmony of religions and their cooperation for national development... An important result of these meetings was that often for the first time religious leaders came together in the pleasant atmosphere of a comfortable conference centre with good food and often luxurious facilities, serving as start of informal exchanges as well. One of the weak sides of the initiative was that it started as a 'project' with many single and unique initiatives. There was generally no other follow up for an inter-religious meeting than the publication of the minutes, which were published in extenso and spread in about 1000 copies. $^{81}$

With regard to the social research programme, Steenbrink made a similar observation:

Several results of this investigation were doctrinal and embellishing as well. For instance: Pancasila ideology propagates harmony of religions and this was therefore, supported by a vast majority. Nearly all concrete conflicts were imputed to non-religious factors or only some individuals were blamed not 
groups. But quite a few of this research provide us with very concrete data and honest reports about mutual perceptions and complaints. ${ }^{82}$

Djohan Effendi, the head of the project, was far from satisfied with the project as well, and therefore, he would probably agree with Steenbrink's observation. However, as has been indicated, Djohan Effendi thought that the project was somehow a good beginning to open the locked door of communication among the leaders of religious groups. On the other hand, he actually wanted to proceed to a more serious dialogue in which sensitive theological issues, for instance, could be discussed. This was the reason why he was later more comfortable with, and even became one of the initiators of, inter-religious dialogue organised by private organisations. ${ }^{83}$

The minimal achievement of the dialogue could also be related to the Government's simple expectation that inter-religious dialogue would enhance socio-political stability for the sake of development and therefore, the emphasis was much more on peaceful coexistence than on creating mutual understanding and cooperation among the religious groups. Furthermore, like other Government development projects, inter-religious dialogue was a project from which the civil servants received extra income additional to their regular low salaries, and so sometimes they took the project without clear understanding of, or commitment to it. Last but not least, because the project was a Government initiative, the religious groups were somehow still suspicious of the Government intentions. Mukti Ali remembered that when he proposed the dialogue programme both Muslims and Christians were suspicious: "they said to me, it was meaningless" (mengada-ada). ${ }^{84}$

The Christians particularly became more suspicious of Government intentions when the latter wanted to establish a Body for Inter-religious Consultation (Badan Konsultasi antar Umat Beragama). As discussed in Chapter 1 , a similar institution had already been established in the Inter-religious Consultation of 1967; but since its inception it had no clear activity. The origin of the idea to establish the body apparently did not come from Mukti Ali but from the President and the military. ${ }^{85}$ This idea was obviously in line with the New Order's corporatism in the sense that religious groups as social forces were to be put in an organisation that could be controlled and managed by the power holders. This was also in line with the Government view that religious groups should be controlled to create socio-political stability for the sake of development. The Christians' suspicion of the Government was related to the latter's proposal that the body was expected to hold an inter-religious consultation on "the ethical code for religious propagation." 
As discussed in Chapter 2, like his predecessor, Mukti Ali also wanted to restrict religious propagation only to those outside the recognised religions, while the Christians consistently opposed this idea. Partly because of the Christian opposition to the proposed topic for the inter-religious consultation, and partly because there was no consensus among religious leaders on the position and function of the body, Mukti Ali finally failed to establish the body and no inter-religious consultation was held. ${ }^{86}$

In 1978, Alamsyah Ratu Perwiranegara, a retired army general, was appointed to Mukti Ali's position. Alamsyah continued the dialogue programme and at the same time he put it more clearly within the framework of maintaining the socio-political stability for development. In this respect, Alamsyah proposed that religious harmony should be developed into 'a triad of harmony', that is, intra-religious harmony (harmony among different sects and groups within the same religion), inter-religious harmony and the harmony between religious groups and the Government. ${ }^{87}$ As discussed in Chapter 2, as parts of his policy on inter-religious harmony, without further consultation with the religious leaders, Alamsyah issued two decrees, one on the restriction of religious propagation and another on the Government control of foreign aid for religious institutions. Both decrees were certainly welcome by the Muslim leaders but strongly opposed by the Christians.

Moreover, by contrast to Mukti Ali, after a series of meetings between the religious leaders and the Government since1979, in 1980 Alamsyah successfully created the Forum for Inter-religious Consultation (Wadah Musyawarah Antar Umat Bergama) in which the organisations of five recognised religions were represented. In his speech at the inauguration of the Forum on 30 June 1980, Alamsyah said: "Since I have been in office as the Minister of Religion, I have always suggested to [you] to strengthen religious harmony [because] it is a primary factor in the development and strengthening of national stability and defence." ${ }^{88}$ Alamsyah also said that the inter-religious dialogue during the Mukti Ali era was more academic and philosophical, while now he would like to develop a more pragmatic one. The Government, he said, would support the development of religious life, and if the believers of different religions "cannot help each other, at least they do not disturb each other." ${ }^{89}$

As one would expect, it was the Government that dictated the issues to be discussed by the Forum rather than the religious groups themselves. As noted in Chapter 2, one of the issues discussed in the Forum concerned the celebration of religious feast days. In addition, in 1982, the Government asked the Forum to give advice on certain moral and social issues like drug 
abuse and alcoholic drink; and to organise prayers for rain in a long dry season. Moreover, as a former personal secretary to the President, Alamsyah was able to obtain considerable financial support for his programmes. In this context, since 1983, the representatives of religious leaders in the Forum, high Government officials and members of Parliament paid a joint yearly visit to places of worship and social institutions of different religions in the provinces. This activity was financed by the Department of Religion and widely covered by press and television. However, later when this programme was evaluated, some religious leaders questioned the value and sincerity of this way of dialogue. ${ }^{90}$

In interviews, I asked Mukti Ali and Djohan Effendi about their respective opinions regarding Alamsyah's policies. Mukti Ali said that Alamsyah did not really continue his dialogue programme because he was a military man who did not understand religion very well and could not be involved in dialogue. ${ }^{91}$ Djohan Effendi argued further that there was a shift of emphasis from Mukti Ali to Alamsyah: while the former believed that religious harmony should be developed through dialogue, the latter believed that religious harmony could be effectively maintained through regulations. ${ }^{92}$ It seems both Djohan Effendi and Mukti Ali were only partially right. As we already discussed above, there is somehow continuity between Mukti Ali's and Alamsyah's policies on dialogue. The issue was not simply the contrast between a religious scholar and a military man or between dialogue and regulation but the fact that the Government idea of dialogue was based on the top-down approach to maintain the socio-political stability needed for development. Both Mukti Ali and Alamsyah were somehow trapped within this approach.

The next Minister of Religion, Munawir Sjadzali (in office from 1983 to 1993) also continued the project on religious harmony, but it was apparently not his first concern. One important thing that Munawir Sjadzali did with the Forum for the Inter-religious Consultation in late 1983 was to invite religious leaders to discuss the Government intention to make Pancasila the sole basis for all social organisations. His attempt through the Forum was apparently not very successful because although all of the religious organisations represented in the Forum later accepted the regulation, this acceptance was more a result of internal discussion within the religious organisations themselves rather than that of the Forum. ${ }^{93}$ In addition, as we shall see, the following Minister of Religion, Tarmizi Taher (in office from 1993 to1998) reinforced the project but this was much more in response to incidents than a deliberate effort to support the Government development discourse. 


\section{Critical Muslim and Christian Responses to the Government Initiatives}

If we look at the Christian writings in the early 1970s, we find that there were positive responses to Mukti Ali's dialogue programme. In his book published in 1972, J.W.M Bakker, for instance, described with great sympathy how Mukti Ali from the late 1960s until he became the Minister of Religion in 1971 tirelessly promoted inter-religious dialogue. ${ }^{94}$ Likewise, Eka Darmaputera, a Protestant minister who was to become the leader of the PGl, wrote in 1973 that since Mukti Ali became the Minister, there were positive developments in terms of inter-religious relations in the country. To show implicitly the contrast between Mukti Ali and his predecessors, Darmaputera said that Mukti Ali could put himself as the Minister of all religious groups, and his dialogue programme was not a reaction to a certain inter-religious incident but a preparation to face the future together. Nonetheless, for Darmaputera, the dialogue initiated by the Government should be considered only as a beginning and therefore, it had to be improved. Dialogue, he said, should not be simply "to see each other" but "existential encounter" in which everybody was expected to be ready to accept and to be accepted by the others without neglecting their respective differences. The national development, argued Darmaputera, demanded not only interreligious harmony but also inter-religious creativity. ${ }^{95}$

Almost a decade later, in 1982, the Muslim traditionalist leader, Abdurrahman Wahid, also criticised the Government-sponsored dialogue. For him, this dialogue was illusory because instead of talking openly about the existing inter-religious problems, it tended to hide them behind ceremonial smiles. The dialogue, he said, was in fact merely a series of monologues in which the participants tried to reiterate their respective religious teachings in relation to the Government development programmes and their loyalty to the state ideology, Pancasila. ${ }^{96}$ On the other hand, Wahid explained that outside the formal dialogues initiated by the Government, informal communication between religious groups began to emerge and for him this was a more promising pattern of inter-religious relations. He observed that in this communication, the young theologians and activists of different religions tried "to create a common theology of human development and social justice."

What was actually 'the common theology of human development and social justice'? This theology apparently originated from discussions among religious intellectuals, particularly Muslim and Christian intellectuals on development issues since the early 1970s, that is, in the period when Mukti Ali promoted his idea on religion and development. Through both 
discussion forums and their writings, those intellectuals tried to think about the position of religion in relation to development, sometimes from their respective religious teachings and sometimes in more universal terms.

Two articles written by Th. Sumartana in Tempo may serve to illustrate this theology. In an article published in 1974, Sumartana criticised two popular slogans on religion and development. ${ }^{97}$ The first slogan was "Religion provides the motivation for development". For Sumartana, this slogan clearly used religion to justify rather than to direct and influence development. Behind the slogan, he said, there was a philosophy of a dualism of the human being: the soul and the body. The former was considered as the realm for religion where motivation was supposed to lie, and the latter was the realm of action where development actually operated. This would finally lead religion, he said, to be left in its own realm without any influences on the concrete decisions and actions of development. The second slogan was "to develop a human developer". This slogan, he said, could avoid the soul-body dualism of the first slogan, but at the same time it fell into another dualism, that is, between humanity and the world. This view, he said, tended to neglect the fact that the human being was not such a strong creature as could change the world. In other words, this slogan, he said, would lead religion to ignore the socio-structural realities involved in the process of development. Within these two slogans, argued Sumartana, one could find the traditional and established framework of religion in which religion was still considered as the centre of everything and the store of prefect truths. This framework eventually led religion to lose its power to criticise development, namely human beings and their world. Moreover, because the two slogans were based on the traditional and established religious framework, they would only contribute to harden religious groupings. In short, for Sumartana, religion should function as a critical voice in the framework of development; and to create this function, religion should be freed from its traditional exclusive framework.

The second article was on religion and social justice, published a few months before the above article. ${ }^{98}$ In this Sumartana proposed some critical questions on the possibility of enhancing social justice through religion. He said, there were many people whose incomes depended on their role as religious leaders. Then he asked, was it appropriate for a religious leader to become rich? This question was important, he said, particularly if one expected that a religious leader had to struggle for social justice. It was true, he said, that religion did not forbid anybody being rich, but who else could see the urgency of social justice better than a poor person? In fact, he said, wealth was a primary support in society to develop injustice. Without answering this 
question, he moved on to another question: should religion specifically serve the poor people? Sumartana's answer to this question was more than a simple yes or no. A religion that cannot be effectively involved in the issue of social justice, he said, was a poor religion and a religion of poverty. However, he said, one should not identify the poor with social justice, because like the rich, the poor were not free from sin and therefore, they could become oppressors when they became rich. What was then the appropriate position of religion on the issue of social justice? For Sumartana, to answer this question, one could look at how religion dealt with Marxism. He then asked: "Can religion seek social justice without being trapped in Marxism and without falling into the impasse of Marx's concept of human being? Can religion struggle for the need of the poor without deifying poverty and the poor?"

Sumartana's appeal to religion to function as a voice critical of development and as a force to enhance social justice was obviously parallel with the so-called theology of liberation developed by Catholic theologians in Latin America. It is interesting that the theology of liberation was highly appreciated in Indonesia not only by the Catholic theologians but also by Protestant and Muslim intellectuals. If we look at the articles on religion and development published in the prestigious journal called Prisma from 1975 to 1984 , we find that the theology of liberation was introduced by both Catholic and Protestant intellectuals. ${ }^{99}$ The importance of the articles lies in the fact that Prisma was not a Christian journal at all. The journal was published by the Institute of Research, Education and Information on Social and Economic Affairs (Lembaga Penelitian, Pendidikan \& Penerangan Ekonomi dan Sosial, LP3ES), a Non-Government Organisation (NGO) established by the early 1970 s by some intellectuals of Indonesian Socialist Party (PSI) and Masyumi backgrounds. In the first edition of Prisma, its editor, Ismid Hadad, explicitly stated that the journal was intended to be a free discussion forum on economic development, and social and cultural changes in Indonesia. ${ }^{100}$ Thus, it is not an exaggeration to say that Prisma was a medium of dialogue, and the fact that both Muslim and Christian intellectuals wrote in the journal indicates that it was also a medium of dialogue for them.

Indeed, the dialogue truly took place and this was indicated by the fact that some of the Muslim intellectuals and activists later tried to establish an Islamic version of the theology of liberation. Dawam Rahardjo, a Muslim reformist intellectual and one of the leaders of the LP3ES, for instance, in 1983, organised a seminar by inviting a Catholic priest, Kees Bertens, a Muslim theologian, Harun Nasution and a foreign scholar, Karel A. Steenbrink, to discuss the possibility of developing an Islamic theology of libera- 
tion. To Rahardjo's disappointment, Harun Nasution said that the issue of social justice in Islam was not a theological ('ilm al-kaläm) but legal issue (figh), and because his expertise was in kaläm not figh, he could not propose something similar to that of the Christian theology of liberation. ${ }^{101}$ In fact, there is a lot of material in Islamic tradition, including 'ilm al-kaläm, which can be developed to be an Islamic liberation theology. Why was Nasution reluctant to develop this type of theology? Perhaps, he was worried about its political implications. As a theologian who worked in the State Institute of Islamic Studies (IAIN), Jakarta, he was known as supportive rather than critical of the Government modernisation programmes. On the other hand, the Muslim proponents of liberation theology were generally NGO activists who were not dependent on the Government but on foreign funds. Thus, for them, to be critical of the Government was normal if not necessary.

Despite the above seminar, Dawam Rahardjo could eventually find the Islamic theological reflections similar to the Christian liberation theology in the works of the Egyptian philosopher Hassan Hanafi and the Iranian religious intellectual Ali Shari'ati. ${ }^{102}$ Rahardjo was certainly not the only Muslim intellectual who was interested in Hassan Hanafi's and Ali Shari'ati's writings in particular and liberation theology in general. In fact, the interest of the Muslim intellectuals in the theology of liberation increased in the late 1980s and the early 1990s. In 1987, the Protestant publisher, Sinar Harapan, published a book on the theology of liberation by a Catholic priest named Wahono Nitiprawiro. ${ }^{103}$ The book was originally a thesis submitted to the Catholic Institute of Theology and Philosophy, Kentungan, Yogyakarta. The book was soon banned by the Government, but it had already reached the hands of student activists, particularly in Java, and became the topic of closed discussions among them. In June 1988, the NU activists in Yogyakarta, organised a seminar on the Islamic perspectives of the "theology of development", another euphemism for the "theology of liberation." There were at least two papers in the seminar trying to find elements of liberation in Islamic teachings: the papers by Masdar F. Masu'di and Moeslim Abdurrahman respectively. ${ }^{104}$ These two Muslim intellectuals later published their respective books on how Islam should function as a transforming force to enhance social justice. ${ }^{105}$ Another Muslim intellectual who had the same concern was Mansour Fakih who argued that Harun Nasution's rational Islamic theology should be replaced with a theology concerned with the weak and the oppressed. ${ }^{106}$

By the early 1990s, several activists of the Muslim traditionalist student organisation, PMII (Pergerakan Mahasiswa Islam Indonesia), who established the Institute of Islamic and Social Studies (Lembaga Kajian Islam dan 
Sosial, LKiS) in Yogyakarta, translated and published the works of foreign Muslim intellectuals who promoted the idea of liberation from Islamic perspectives, particularly the works of Hassan Hanafi and the Indian thinker Asghar Ali Engineer. ${ }^{107}$ These activists also frequently visited or invited the Catholic theologian, J.B. Banawiratma, to study the Catholic theology of liberation. The interest of the PMII activists in the theology of liberation was also related to their experience in the field, particularly in the Kedung Ombo affair in the late 1980s. The Government constructed a dam in Kedung Ombo between 1985 and 1989 and this was to the disadvantage of the poor people living in that area who lost their land, without adequate compensation from the Government. The PMII activists were disappointed to find that the Muslim leaders in that area supported the Government, while the Catholic priest, Mangunwijaya, came there to support the demand of the people. This experience inspired these activists to study the Catholic theology of liberation and to find a similar perspective within the Islamic teachings. ${ }^{108}$

In fact, both Islamic and Christian traditions contain teachings on social justice. Perhaps, the special thing here was that the Muslim activists wanted to learn about the concept of social justice from the Christian theology of liberation. Religious boundaries then became irrelevant because social justice was considered a common concern for all. It became an alternative to the early Muslim-Christian antagonist discourses on Islamic as against secular ideology and at the same time it was a criticisms of the Government discourse on development. These Muslim activists, however, were a minority among the Indonesian Muslims. Many Muslim leaders were also concerned with social justice, but they did not feel it important to learn from the Christians or to cooperate with them.

\section{Politics, Incidents and Dialogue in the 1990s}

By the late 1980s, there were indications that the Government had become more accommodating to Islamic groups. In 1989, some Muslim interests were accommodated in the Education Law, and in the same year the Religious Court Law was ratified. In 1990, Soeharto supported the establishment of the Indonesian Muslim Intellectuals Association (ICMI). In 1991, Soeharto signed the Presidential Instruction on the Compilation of Islamic Law to be applied in the Islamic Courts. Soeharto also supported the establishment of the Islamic Bank (Bank Muamalat Indonesia) and the Muslim newspaper, Republika. After the 1992 elections, many of the Mus- 
lims associated with ICMI became ministers of Soeharto's new cabinet, and the economic ministries that had been previously controlled by Christians were henceforth headed by Muslims. ${ }^{109}$ There was also a decline of the influence of the Christians in the higher positions of the intelligence services and armed forces. While a group of Catholics in cooperation with certain army generals established the CSIS in early 1970s, now the ICMI also established a think tank called the Centre for Information and Development Studies (CIDES). It was said that some of the ICMI leaders thought that it was the time for them to take 'revenge' on the Christians.

Why was this? Hefner argued that state accommodation of Islam was a positive response to the emergence of the Muslim middle class in particular and the success of the Islamization of Indonesian culture in general. ${ }^{110} \mathrm{On}$ the other hand, without entirely denying what Hefner said, Liddle emphasised that this 'Islamic turn' was strongly related to Soeharto's political tactic to make sure that he was to be re-elected as President by the MPR, rather than a true accommodation of Islam. ${ }^{111}$ It seems, as Bruinessen argued, both the socio-cultural and political explanations were important to understand Soeharto's Islamic policies. ${ }^{112}$

In line with the above analysis, in Chapter 4 and 5, I argued that although both the Education Law and the Religious Court Law somehow indicated Government accommodation of Islamic interests, there were also compromises or limits to this accommodation. I also indicated that despite the compromises, the debates on the drafts of the two Laws had negative impacts on Muslim-Christian relations in the country. In this context, I would say that Liddle was probably right to say that Soeharto's close relation with the Muslims was primarily a political tactic to counter- balance the opposition of some important army generals rather than a genuine accommodation of Islam. However, we cannot deny the fact that Soeharto's accommodation with former Muslim opponents helped increase the fear of the Islamic threat among the Christians. Thus, no matter whether this fear was groundless or not, it affected their attitudes to and relations with the Muslims. In what follows, we shall discuss some cases to see how inter-religious dialogue developed in this political context.

\section{The Monitor Affair and Dialogue}

In September 1990, the weekly tabloid Monitor carried out a poll on 'the most admired person' and the result of the poll was published in its 15 October 1990 edition. The result indicated that President Soeharto was top, while the editor of the tabloid, Arswendo Atmowiloto, was ranked 10 
and below him $\left(11^{\text {th }}\right)$ was the Prophet Muhammad. This result, particularly the low position of the Prophet, soon triggered protests from the Muslims who perceived a deliberate provocation. Many Muslim leaders made sharp remarks against the case, and there were also demonstrations in the streets that eventually led to physical attacks on the office of the tabloid. Many Muslims demanded that the Government prosecute Arswendo, and some demonstrators even demanded the death penalty for him. In general, the Government reaction to this case was in line with the Muslim demands: the tabloid was banned, Arswendo was prosecuted and he finally received a five-year sentence (but was released after four). ${ }^{113}$

The strong Muslim opposition in this case was partly because many Muslims considered it as a case of inter-religious relations. First of all, Arswendo was a Catholic (he originally came from a Javanese abangan family and converted to Catholicism when he married a Catholic woman). Moreover, the tabloid belonged to a highly successful Catholic publishing house called 'Kompas Gramedia Group'. Hefner noted that by the end of the 1970s the Group had gained a dominant place in the Indonesian print media industry. "In the mid-1990s this media conglomerate dominated the publishing industry, owning all parts of some twenty-three magazines and six newspapers, as well as the country's largest publishing house."114 On the other hand, the Muslims, particularly the reformists, had been very upset for a long time because their newspaper, Abadi, was banned in 1974 and subsequently there was no good Muslim newspaper that could compete with the Catholic newspaper, Kompas. While many Muslims read and contributed their articles to Kompas, among the Muslim hardliners this newspaper has been perceived as a Catholic instrument directed against Islam. Its name was often mockingly explained as an acronym of 'Komando Pastor' (the priest command). Moreover, Muslim magazines like Panji Masyarakat and Kiblat, could not compete with secular and popular magazines produced by the Gramedia Group either.

In an article published in1980, M. Amien Rais, the Muhammadiyah intellectual who was to become the speaker of the MPR in 1999, had expressed his resentment of the weak condition of the Muslim media in the country with a cry: "save our soul". ${ }^{115}$ Amien Rais explained that the influential printed and electronic media in the United States like the Washington Post, the New York Times and Newsweek, and the television networks such as $A B C, C B S$ and NBC were very much controlled by the Jewish minority. This was the reason, he said, why the Jews could effectively influence American politics. Therefore, Amien Rais warned the Muslims that the influence of 
the Christian media in Indonesia should not be underestimated. He argued that media were never neutral and the Muslims should not be so naïve as to expect that the Christian media would help them to publish things for the Muslim interest. In another article, having mentioned Kompas as the major newspaper in the country, Amien Rais said that Indonesian Muslims were so dependent on the Christian newspaper to express their ideas and positions as to be like the orphans who relied on the affection of the Christians. ${ }^{116}$

Many other Muslims shared Amien Rais' concern, particularly the Muslim reformists of the DDII, and their protests against the tabloid were obviously related to it. ${ }^{117}$ The leader of the Kompas Gramedia Group, Jacob Oetama, was apparently aware of this problem, so he agreed with the banning of Monitor and even fired Arswendo from an important position in the company. More than that, Jacob Oetama voluntarily returned the licence of another publication of his company, Senang magazine, to the Government in order to prevent more protests. Senang No. 34 (21 September-4 October 1990) edition had published a sketch of an Arab man without clear face with a halo around his head. The sketch was intended to illustrate the content of a letter from a reader who said that while he was in Saudi Arabia, he dreamed of the Prophet Muhammad, but he could not remember what the Prophet looked like. Many Muslims still believed that the Prophet could not be visualised, so the sketch became another target of Muslim protest. Jacob's decision to stop Senang was relatively effective because the Muslim protest against Senang was not as strong as that against Monitor. ${ }^{118}$

What was the effect of the Monitor affair on Muslim-Christian relations? If we look at Muslim comments on this case, some of them blamed Monitor (read: the Catholics) as a troublemaker amid the existing inter-religious harmony. "If you want to maintain religious harmony, do not hurt the feelings of another religious group, even though you personally do not like that religion," said Mohammad Natsir. ${ }^{119}$ In line with Natsir, Amien Rais said that the Monitor affair was an insult to the Islamic community and a disturbance of the existing inter-religious harmony maintained by the Government. ${ }^{120}$ Another Muslim leader, Nurcholish Madjid who usually spoke for moderation and tolerance, now accused those behind the Monitor (probably he had the Catholics in mind) of being arrogant. He said, "I do not see Arswendo as a person, but I see a mechanism behind it. Its essence is arrogance, carelessness, insensitivity and so forth. Therefore, [he] must be given a maximum punishment...[and] Monitor must be banned forever." ${ }^{121}$ He also said, because of the Monitor and 
Senang cases, that inter-religious dialogue should be temporarily suspended. The General Chairman of the PGI, Sularso Sopater and Cardinal Darmojowono also criticised Monitor and Senang but in more moderate terms. ${ }^{122}$

On the other hand, the leader of the PGI, Eka Darmaputera, said that he believed that Arswendo had not intended to insult Islam. Moreover, Y.B. Mangunwijaya, the prominent Catholic priest, said the Monitor affair did not disturb Muslim-Catholic relations in the villages. The people who were angry, he said, were those who could speak in the media and had vested interests. ${ }^{123}$ Among the Muslim leaders, it seems that only Abdurrahman Wahid was publicly critical of the Muslim attitudes to the Monitor. The Muslims, he said, should not be angry and violent. If they disagreed with the Monitor, they could boycott the tabloid; but they should not demand to ban it. ${ }^{124}$ He lamented the Muslim violent attack on the Monitor office and accused those Muslims of having an inferiority complex. He said, "Islam is a religion of peace and love but they made Islam an angry and hateful religion."125

In response to this situation, the Muslim NGO, Perhimpunan Pengembangan Pesantren dan Masyarakat (P3M) organised a seminar on "religion and the plurality of the nation" on 21 November 1990, in Jakarta. ${ }^{126}$ The seminar was more or less an inter-religious meeting because the speakers and participants in the seminar were important religious leaders, particularly of Islamic and Christian backgrounds. P3M had been established in the early 1980 s as a continuation of the LP3ES'development projects for Islamic boarding schools in Indonesia funded by Friedrich Naumann Stiftung (FNS). The leadership of P3M included both reformist and traditionalist Muslims. The initiative of the P3M seems to have received sympathy from both Muslim and Christian leaders as well as from the Government. The Minister of Religion, Munawir Sjadzali, gave a keynote speech to the seminar, and the speakers were Franz Magnis Suseno, M. Sastrapateja (both were Catholic priests), Victor Tanja (a Protestant minister), M. Quraish Shihab, Ali Yafie (both were traditionalist Muslim scholars), Aswab Mahasin (a reformist Muslim intellectual) and Aggi Tjeje (a Buddhist).

What was the effect of the seminar, particularly for the Catholics? Franz Magnis-Suseno wrote two articles referring positively to the seminar. His positive assessment was probably not free from embellishment but at the same time we can see that he was quite happy with the Muslim initiative. He wrote that the seminar impressed him very much because many important religious leaders came to it and discussed sensitive issues openly and critically. He was also impressed by the fact that his paper on the absoluteness and relativity of religion from a Catholic perspective was almost paral- 
lel with Quraish Shihab's paper analysing the same topic from an Islamic point of view. In his paper, Shihab explained that Muslims were convinced that Islam was the best religion, but at the same time they should leave the judgment on the followers of other religions to God. For Magnis-Suseno, this was in line with the Vatican Council II statement that did not only require the Christians to respect other religious believers but also emphasised that the latter could attain salvation if they lived according to their respective religious teachings. This humble religious attitude, he said, was a good basis for inter-religious tolerance in the country. ${ }^{127}$

In contrast to the above article, Magnis-Suseno's second article talked much more openly about the socio-political contexts in the year 1990 and the relevance of the seminar. He said that as a member of a Christian minority, he could not deny the fact that the year 1990 was marked by some important events for the Muslim majority, among them the establishment of ICMI and the Monitor affair. Many of his Christian friends, he said, were concerned with these developments, particularly the explosion of Muslim anger against Monitor. They could not really understand, he said, why the Monitor affair was connected with the inter-religious issue as the tabloid did not have any connection with the Catholics. However, he said, he was optimistic about the future of religious harmony in Indonesia. Again, Magnis-Suseno praised P3M's seminar as a good example of how the Muslims were ready to develop brotherhood with the Christians. ${ }^{128} \mathrm{He}$ also argued that although there were strong protests against the Monitor, he did not find any Muslim statement questioning "the equal rights of the Christians as co-citizens." In other words, in their protests, there was no indication that the Muslims wanted to treat the Christians as second-class citizens under an Islamic State. As we can see, although it sounds positive, Magnis-Suseno's remarks could also be read to indicate that the fear of an Islamic State had actually increased among the Christians.

\section{Private Initiatives in the 1990s: Dialogue for Democracy and Pluralism}

In 1991, Th. Sumartana whom we have met before as one of the promoters of liberation theology obtained his doctorate from the Vrije Universiteit , Amsterdam. By the same year, through his contacts with Christian leaders in Europe and Muslim and Christian intellectuals in Indonesia, Sumartana initiated an institute for inter-religious dialogue called 'Dialog Antar Iman' (DIAN) or 'Institute for Inter-faith Dialogue in Indonesia' (Interfidei), located in Kaliurang, Yogyakarta. The Interfidei was then officially inau- 
gurated on 10 August $1992 .{ }^{129}$ Sumartana's initiative was supported by some prominent Muslim and Christian intellectuals and student activists. ${ }^{130}$

Sumartana highly respected Mukti Ali as the initiator of inter-religious dialogue in the country. ${ }^{131}$ However, Sumartana was not satisfied with the New Order's view that dialogue was simply to create religious harmony or peaceful co-existence. For him, inter-religious dialogue should have a broader goal, namely to develop an open and democratic Indonesian society, and this was the main goal of the Interfidei. In his speech at a book launch of the Interfidei in 1993, he said:

The Institute [Interfidei] wants to show its concerns with the movement for changes in society towards a more autonomous, democratic and creative common life. This is probably the most important mission of this Institute, namely to create a communicating, mature and democratic society that is used to questions and able to have different opinions [i.e.,] an open and pluralistic society. This pluralistic nature would in turn become the most human way to solve our social problems together peacefully. ${ }^{132}$

Thus, Sumartana believed that, through dialogue, all religions could develop their respective potentials to create a democratic society. As noted, by the early 1990s, there was anxiety among some intellectuals that Soeharto would use Islam through the ICMI channel for his political interest at the expense of religious minorities. As the Chairman of NU, Abdurrahman Wahid was the most important Islamic leader who refused to join ICMI. In March 1991, Wahid supported by several Muslim, secular and Christian intellectuals established the Democracy Forum (Fordem). Sumartana's view was parallel with, though not identical to, the concern of the Democracy Forum. Indeed, the second book published by Interfidei (consisting of the texts of lecturers delivered at the Institute) contained a paper by Wahid in which he expresses quite similar views to those of Sumartana on the important role of religion in developing democracy. ${ }^{133}$

Because Sumartana believed that religion could be an effective force for democracy, he strongly criticised certain attitudes of the Christians that, in his opinion, were opposed to democracy. In Chapter 5, we noted that Sumartana was very sympathetic to the Javanese syncretistic Christian leader, Kiyai Sadrach and very critical of Western missionaries. For Sumartana, Indonesian Protestantism of the $19^{\text {th }}$ and $20^{\text {th }}$ centuries which the country inherited from the Western missionaries was anti-peasants, anti-workers, pro- the West, and intolerant of Islam. The Christians in Indonesia, he said, 
could not be a democratic force unless they were freed from all of these characteristics. ${ }^{134}$ Moreover, due to the fact that Muslims comprised the majority in Indonesia, Sumartana was very eager to stimulate democratic ideas among the Indonesian Muslims. ${ }^{135}$ This was why among the first projects of Interfidei was to make critical summaries of the works of Indonesian Muslim intellectuals. ${ }^{136}$ This idea is apparently in line with Sumartana's activity in the Seminar of Religions in the early 1980s discussed above.

The activities of Interfidei took different forms including regular discussions, seminars, publications, research and common prayer. The initial funding of the Institute came from the Dutch Reformed Church, particularly through Sumartana's close friend, the Rev. Jaspert Slob. Later, the Institute also received support from the Asia Foundation, the Inter-Church Organisation for Development Cooperation (ICCO), the Konrad Adenauer Stiftung (KAS) etc. Interfidei was also very active in organising conflict resolution programmes in the areas affected by the conflicts between Muslims and Christians in the late New Order and afterwards. It was in this period that the Interfidei developed its network in the outer islands. ${ }^{137}$

Like other programmes of dialogue that are generally elitist, one may wonder whether the dialogue initiated by Interfidei really helped increase mutual understanding and cooperation among religious groups. When the attacks on churches in different places happened by the late 1990s, some people questioned whether inter-religious dialogue was useful anymore. The bloody conflicts between Muslims and Christians in Ambon and Poso after the fall of Soeharto increased this scepticism. However, for Sumartana, the incidents even indicated that inter-religious dialogue was really needed. In other words, for him the problem was not because inter-religious dialogue was useless, but because there were still few people who were eager to be involved in it. ${ }^{138}$ Sumartana never changed his mind that religions could function to support democracy. In his reflection on the religious-classethnic-political conflicts of the late 1990s, he still wrote: "religious values actually can be a supporting force for efforts to defend human rights and to activate the democratisation process." 139

Several young activists who joined Interfidei came from the Muslim traditionalist student organisation background, PMII. In our discussion on theology of liberation earlier, we also mentioned the role of those activists who gathered in the LKiS in promoting the ideas of liberation in Islam. LKiS was established in the early 1990s by some leading PMII activists in Yogyakarta as an informal discussion group, and later as an NGO. Since its inception, the LKiS has been committed to developing tolerant, democratic 
and liberating Islamic ideas. One of its important activities was a programme called 'Learning Together about Islam as a Force of Transformation and Tolerance' (Belajar Bersama Islam Transformatif dan Toleran). Funded by the Asia Foundation, the programme was started in 1997 and still continues. The participants of the programme were senior students of Islamic boarding schools (pesantren), university students and activists. There are four topics discussed in the programme: critiques of religious discourses, religion and feminism, Islam and politics, and inter-religious dialogue and reconciliation. On the session on inter-religious dialogue and reconciliation, the participants were asked to recount their respective concrete experiences and impressions with other religious believers. These experiences were then discussed together with an expert or activist in the field. Christian activists and intellectuals have been frequently invited to contribute their knowledge and experience to this programme. The influence of this programme on the young Muslims has probably been very limited but it is obviously a positive Muslim initiative.

In Jakarta, as in Yogyakarta, there were also initiatives to carry out inter-religious dialogue. One of the important Muslim NGOs in Jakarta to be mentioned here is the Paramadina Foundation established in 1986. The most important person behind Paramadina is none but the promoter of the non-ideological view of Islam in the early 1970s, Nurcholish Madjid. The idea of establishing this institution was originally Dawam Rahardjo's and Madjid demanded that Utomo Dananjaya be involved as an organizer. ${ }^{140}$ By the end of the 1970s, Madjid had gone to follow a doctoral programme at the University of Chicago, where he had the opportunity to study with the Pakistani scholar, Fazlur Rahman. Having completed his PhD degree in 1984, he came back to Jakarta and established the Paramadina, which was intended to be an institution where he could develop and disseminate his ideas. The audience targeted by the Paramadina was the middle and upper class Muslims, whose position was considered influential on the socio-political development of the country. The most important activity of Paramadina was the Religious Study Club (Klub Kajian Agama, KKA) in which middle and upper class Muslims could learn and discuss Islamic teachings openly. Discussions were usually held in very fine hotels in Jakarta, and Madjid was the main person who determined the theme of the discussion. Usually Madjid presented a paper on a certain topic, while another invited speaker would speak about the same topic but from a different perspective.

The early topics of the KKA were much more focused on Islam in general, particularly on the question of Islamic reform and its relevance to mod- 
ern life. In this regard, besides developing his early ideas on Islam and modernization, he also developed an Islamic inclusive theology. ${ }^{141}$ What I mean by 'inclusive' here is a theological view which tries to embrace the other faiths without neglecting one's distinctive religious identity. Madjid argued that the Qur'anic use of the term 'Islam' sometimes refers to the teachings revealed to Muhammad, and in other passages refers to the message sent to earlier prophets as well. In this context, the term 'Islam' should be understood in its generic meaning, that is, a total submission to God. According to this interpretation, although the form of Islam revealed to Muhammad is somehow the perfect one, it does not abrogate the other Islams. Those who believe in other Islams, therefore, can attain salvation. Who are they? To answer this question, Madjid refers to the Qur'anic term ahl al-kitäb, which means 'people of the book'. According to the classical Qur'anic exegesis, the term refers exclusively to Jews and Christians, but with reference to Rashìd Ridā, Madjid argued that the term also includes Buddhists, Hindus and Confucians.

By the second half of the 1980s, Madjid's theological views on other religions were already widely debated but they became a subject of controversy after he delivered a speech on the subject in the prestigious cultural centre in Jakarta, Taman Ismail Marzuki in 1992. ${ }^{142}$ While Madjid's supporters argued that this theology was relevant to a modern and pluralistic society, the Muslim reformists of the DDII saw it an attempt to destroy Islam from within. The Christians, on the other hand, gave sympathetic comments. Franz Magnis-Suseno for instance said that although he was a Catholic, he hoped that he would be a Muslim in its generic meaning, that is, a person who totally submitted to God. ${ }^{143}$ Likewise, the Catholic theologian, J.B. Banawiratma wrote that Madjid's idea on Islam in its generic meaning was similar to Karl Rahner's idea on 'anonymous Christianity'.144 However, it should be noted that the Christians were sometimes also disturbed by Madjid's apologetic tendencies. His apologetics are primarily related to his attempts to justify his view that Islam is much more 'modern' in substance than Christianity by referring to some historical incidents in the West when the Church opposed scientific development. He sometimes also opposed the Christian doctrine of the Trinity by referring to some works of the Western scholars. Franz Magnis-Suseno reacted critically to these apologetic tendencies. ${ }^{145}$

Madjid's inclusive theology was then developed further by intellectuals affiliated with Paramadina. In contrast to the PMII activists in Yogyakarta who were attracted to liberation theology, the middle and upper class Muslims in Jakarta were apparently much more interested in Sufism, the 
spiritual teachings of Islam. Thus, the discourse on Islam in Paramadina also moved towards the need of its market. However, like liberation theology, in general Sufism also encourages religious tolerance. In this context, Budhy Munawar-Rachman, a young reformist Muslim intellectual who worked in Paramadina, tried to develop Madjid's inclusive theology further into a pluralistic theology based on the so called 'perennial philosophy' or al-hikmah al-khälidah. ${ }^{146}$ This philosophy was known in Indonesia through the works of Frithjof Schuon, Huston Smith, Seyyed Hossein Nasr and the like. According to this philosophy, every authentic religious tradition has two levels of truth: the esoteric and the exoteric. Religions are different only at the exoteric level, but at the esoteric level they are the same. In other words, there is a transcendental unity of religion. Two other activists of Paramadina, Komaruddin Hidayat and Wahyuni Nafis later co-wrote a book on the perennial philosophy. ${ }^{147}$ The interest in the perennial philosophy was strongly related to the increasing interest of some of the Indonesian Muslims in the study of speculative Sufism of Ibn al-'Arabī, 'Abd al-Karīm al-Jīlī and the like. In this context, Kautsar Azhari Noer, another activist of Paramadina, introduced Sufism as a tolerant and pluralistic tradition of Islam. Noer was a lecturer on comparative religion at the IAIN Jakarta and wrote a PhD thesis on Ibn al-'Arabi which was published by Paramadina. ${ }^{148}$ Noer has been apparently involved in Paramadina activities since the second half of the 1990s.

In general we can say that compared with the controversy in the early 1970s, the new theological ideas introduced by Madjid and his friends in the 1990s had a much wider audience and supporters. Perhaps, these ideas significantly influenced a number of Muslim middle and upper class but certainly not the majority of Indonesian Muslims. Few Muslim reformist intellectuals of Muhammadiyah like Amin Abdullah and Abdul Munir Mulkhan supported these ideas, but they were a minority in the organisation. ${ }^{149}$ The inclusive theology and perennial philosophy were not so attractive to NU intellectuals either because the latter felt more comfortable with developing a new interpretation of fiqh (close to the Christian liberation theology) rather than abstract theological reflections. However, at least these ideas successfully stimulated discussions among Muslim intellectuals and students in the 1990s.

The dissemination of the new ideas among the Muslim intellectuals and the Muslim middle class in general was partly facilitated by a journal called Ulumul Qur'an. This journal was established in 1989 by the Institute for the Study of Religion and Philosophy (Lembaga Kajian Agama dan Filsafat, LSAF). The editor of the journal was the director of LSAF, M. Dawam 
Rahardjo, the Muslim intellectual whom we have met before as one of the proponents of the Islamic renewal movement in the early 1970s and the prominent activist of LP3ES who was interested in developing an Islamic theology of liberation as well as the person who originally proposed the establishment of Paramadina. Rahardjo explained that the journal was intended to be a medium of critical discussion on science and culture in the spirit of the Qur'an, that is, the first revelation to the Prophet, Iqra' (read!). He also emphasized that the journal was directed to the Muslim middle class and at the same time it was also open to non-Muslims who shared the same concerns to develop human civilization. ${ }^{150}$ Therefore, besides articles on Islamic philosophy, theology, mysticism and other Muslim social and cultural issues, the journal also published articles on non-Islamic religions written by Muslim and non-Muslim authors. The Protestant theologian Victor E. Tanja and the Jesuit Magnis-Suseno were among the contributors to this journal. During the New Order period, Ulumul Qur'an proved to be a successful journal and its distribution reached even the cities outside Java.

In the mid-1990s, the activists of Paramadina developed contacts with the Christian intellectuals from the KWI and PGI to discuss the possibility of creating an institution for dialogue. On 10 November 1995, they had a meeting in the office of the Christian magazine, KAIROS, Jakarta, followed by another meeting in the PGI office. The result was that they eventually agreed to establish a society for inter-religious dialogue called MADIA (Majelis Dialog Antar Agama). ${ }^{151}$ The members of MADIA include not only Muslims and Christians but also intellectuals of other religious groups. Djohan Effendi was also active in the background behind MADIA. In the beginning, MADIA's activity consisted of discussions on theological issues held in different places: in Paramadina, KWI or PGI offices. One interesting thing in MADIA's activity was that they usually closed their meetings with prayers, offered alternately according to the respective religions of the participants. The MADIA activists became much more responsive to socio-political issues by the late 1990s when incidents involving religious symbols happened in the country. MADIA sometimes made public statements voicing religious tolerance and cooperation and received strong support from Abdurrahman Wahid. ${ }^{152}$

It is also noteworthy that the theological discourse on pluralism also developed among the Christians during this period. We have mentioned in the first section of this chapter that, started in 1981, the Research and Development Office of the PGI organised a Seminar of Religions every year. The fifteenth Seminar of Religions was held in September 1995 in Salatiga 
and the topic was "theologising in the context of religions in Indonesia." In this seminar, Th. Sumartana and E.G. Singgih were the Protestant speakers who developed theological reflections on pluralism. In his paper, Sumartana urged that the Christians should develop a Christian theology in the context of religious pluralism or what he called 'theologia religionum.'This theology, he said, should emphasise the universal dimensions of the existing Christian theology without sacrificing its uniqueness. He suggested that the universal dimensions of the doctrine of the trinity could be developed in theology and pneumatology rather than Christology. For him, the problem with the existing Christian theology in relation to other religions lies in its too much emphasis on Christology and therefore, it became exclusive. For him, only when the universal dimension of the Christian theology was developed were the Christians able to talk with other religious groups about common problem and common mission. ${ }^{153}$

In line with Sumartana, E.Gerrit Singgih argued that, in the existing Christology, there was too much emphasis on the divinity of Christ rather on his human nature. Thus, the balance between Christ's divinity and humanity should be re-emphasised in order to develop a contextual theology. He also criticised the Christian theological view that salvation could only be obtained through faith in Christ. For him, this was the reason why certain churches were involved in 'Christianisation', that is, they tended to use social services as a means to convert others. By developing a scriptural exegesis, he argued, in the context of the present pluralistic society, Christian theology should look at good work as a realisation of, rather independent from, faith. With this theological understanding, he said, instead of using social services to convert others, the Christians should be open to cooperate in carrying out good works with other religious believers. ${ }^{154}$ Similarly, the prominent Catholic theologian, J.B. Banawiratma, suggested in the seminar that Christian theology should be developed in a dialogical, critical and contextual approach in which the integrity of Christian belief in Christ was maintained but at the same time it was open to others. For him, sharing religious experience, theological reflections, socio-ethical analysis and common actions, all of these could be the basis of the theology of religions. ${ }^{155}$

Nonetheless, this type of Christian theological thought was apparently still marginal among the mainstream Indonesian Christians. Among the Protestants, a few promoters of this theology can be found in the Christian Academy of Theology, Jakarta and the Faculty of Theology, Duta Wacana, Yogyakarta. One of these theologians told me that although he developed liberal theological ideas in the academic circle, he did not dare to propose 
them to his own congregation. ${ }^{156}$ The Catholics were apparently also very cautious with the pluralist theology. The priest who initiated inter-religious dialogue in 1967, C. Groenen wrote in 1994 that a Christian theology that was not concerned with soteriological Christology (the doctrine of salvation through Christ) could not be the basis for honest dialogue, being too abstract and unrealistic. It was unrealistic because of the fact that evangelisation was still the characteristic of Christianity. He also said that, although the Catholic Church positively encouraged dialogue, the position of the Church was in fact very traditional and conservative, because it asserted that Christ is the alpha and omega, and that in him the perfect revelation and all means of salvation are found. ${ }^{157}$

\section{Clashes in the Late 1990s and Dialogue as a Response}

In 1996 and 1997, some violent incidents occurred in different cities of Indonesia such as Situbondo, Tasikmalaya, Banjarmasin and other places in which a high number of churches were burned by the rioters. As a reaction to these incidents, inter-religious meetings were organised either by the Government or by the religious groups themselves. In this section, we shall restrict our discussion to the Situbondo incident. In addition, we will also discuss some Government initiatives to reinforce the project for religious harmony in this period.

On 10 October 1996, a riot occurred in Situbondo, a city dominated by the Muslim traditionalists of the NU, most of them ethnic Madurese, and with a vibrant, mostly ethnic Chinese, Christian minority. ${ }^{158}$ In the riot, 24 churches, some Christian schools and a number of Chinese shops were burned or attacked, and five people were killed. The incident started at the courthouse where the trial took place of a person named Saleh who was accused of promoting heretical Islam and insulting the respected religious leader of Situbondo, K.H. As'ad Syamsul Arifin. The crowd that gathered in the courthouse was apparently not satisfied with the verdict and then tried to attack Saleh. Along with the police and the prosecutors, Saleh then escaped from the back door of the courthouse. In that situation, somebody improbably cried: "he is in the church" and the crowd moved to the nearby church and burned it. The crowd then continued burning the other churches, Christian schools and Chinese shops.

There was strong evidence that the riot was engineered. The rioters were mostly not local people: they were carried by special trucks from outside the town. When they burned the churches, these people moved systematically under the instruction of their leaders. The Saleh affair was also very 
curious. Local people considered Saleh to be mentally ill, so it was not significant to prosecute him. The prosecutor, however, proceeded and charged him with blasphemy. After the incident of 10 October 1996, rumours spread that some of the NU people arrested by the police were tortured in prison, and even that one of them, Ahmad Siddik, was dead. A tape recording circulated on which a man claiming to be Ahmad Siddik said he had been tortured by a Christian military interrogator.

As noted, the Chairman of NU, Abdurrahman Wahid, was the most important opposition voice to the Government in this period. Having investigated the incident, the NU activists were convinced that it was engineered by anti-Wahid agents to discredit his leadership. They believed that the incident was orchestrated to provoke conflicts between NU's followers and the Christians to indicate that Wahid's political claim for democracy and religious tolerance was nonsense. Wahid himself publicly pointed his finger at the General Secretary of ICMI, Adi Sasono and his subordinate, Eggy Sudjana as the masterminds of the riot but they denied the accusation. Hefner noted that Wahid was also informed that certain army generals close to the Chairman of ICMI, B.J. Habibie, were involved in providing logistical support to the rioters. ${ }^{159}$

What was the effect of the riot on Muslim-Christian relations? Both $\mathrm{NU}$ and Christian leaders had the same perception that the incident was engineered. Therefore, they initiated some private meetings to prevent further violence. Having realised that the tape-recorded interview of Ahmad Siddik was a deliberate provocation, both NU and Christian leaders agreed to block its circulation. ${ }^{160}$ As an expression of solidarity with Ahmad Siddik, Christian leaders paid a visit to his family and distributed charities. ${ }^{161}$ Wahid also mobilised the activists of the NU paramilitary group, Banser Ansor, to protect churches from further attacks. One week after the incident, on 17 October 1996, the leaders and activists of the NU and the Christians organised a meeting in the Satellite Hotel, Surabaya. In the meeting, the Christians and the Muslims made a common statement condemning the incident, asking the Government to maintain security in the city and to put those who were responsible to trial. In the same meeting that was attended by about 200 participants, Wahid gave a lecture in which he explained his fear that a similar incident might happen again and urged those present to do their best to prevent it. He also explained that since the second half of the 1970s, he already had good relations with the Christians in East Java, particularly through his involvement in the training courses for ministers of the East Java Church (GKJW). Wahid argued that, instead of trying to establish a peaceful 
co-existence, the Muslims and the Christians should develop mutual understanding through honest dialogue, "like the dialogue carried on by Interfidei." He reminded the audience that as a Muslim leader he saw it as his duty to exercise self-critique. He explained that he had often criticised the Muslim's misunderstanding of non-Muslims, and the interpretations of certain Qur'anic verses used by certain Muslim preachers to promote animosity towards Christians. ${ }^{162}$

One important lesson from the incident for the Christians was that to be close to the Government did not mean that the regime would always protect them. Cooperation with the Muslims was apparently more important than with the Government authorities. In this context, the Christian leaders and activists in Surabaya regretted that the PGI leadership in Jakarta did not react immediately to voice the concerns of the Christians in Situbondo. Because of the indifferent attitude of the PGI, the Christians then established the Communication Forum for Christians in Surabaya (FKKS). ${ }^{163}$ Moreover, the FKKS initiated private investigations of the incident, including making a number of photographs of the burned churches and then published them on the internet. ${ }^{164}$ Some of these pictures were later published in a book, and its English version was sent to foreign countries. ${ }^{165}$

As noted earlier, there were other similar incidents in Indonesia, which occurred in different places in 1996 and 1997. These gave a bad impression of the Government; and worse than that, the conservative Christian lobby in the USA tried to eliminate Indonesia from the list of privileged trade partners. In reaction to this development, the Minister of Religion, Tarmidzi Taher, travelled to the USA and gave lectures to project a positive image of harmonious relations between religions in Indonesia. The Government also organised and financed international inter-religious meetings. There were at least two international inter-religious conferences generously financed by the Government in 1997, one was held in the luxurious Horison Hotel, Jakarta, with the participation of the Hartford Seminary and Temple University; and another was held in Leiden, the Netherlands. ${ }^{166}$

The Department of Religion also revived the earlier project on religious harmony that had been rather marginalised in the previous years. This project was partly given to the Institute for the Study of Inter-religious Harmony (Lembaga Pengkajian Kerukunan Umat Beragama, LPKUB). The LPKUB was originally established in October 1993 at the State Institute of Islamic Studies (IAIN), Sunan Kalijaga, Yogyakarta. Besides organising inter-religious dialogue, in 1995 the LPKUB started an English journal called Religiosa: Indo- 
nesian Journal on Religious Harmony. The LPKUB appears to have received much more funding from the Government after the incidents in the late 1990s. Like most of the other Government projects, it was finally disappointing. To use the money, the officials in Jakarta and the people of LPKUB in Yogyakarta decided to acquire land for establishing a conference building. If one thinks of efficiency, this decision was strange because there are plenty of places in Yogyakarta that can be rented with much less cost. Worse than that, after the land was bought (located near to the Yogyakarta airport), it ended with a series of land disputes. In 1998, the building was half finished, but the money was already gone. The head of the LPKUB was Burhanuddin Daya, a professor of comparative religion at the IAIN Sunan Kalijaga. He was personally also disappointed with the project but too weak to confront the high officials above him. ${ }^{167}$

Besides his activity in the LPKUB, Burhanuddin Daya had been engaged in dialogue on several occasions in Indonesia and abroad. However, he seems to have been pessimistic about the efficacy of dialogue. He acknowledged that the dialogue organised by the Government often led to formal conversations rather than open communication. However, he was not satisfied with the dialogue organised by private institutions either. He said, most of the privately organised dialogues were funded by the Christians, so the Muslim participants would have psychological difficulties in talking openly. He also believed that Christianisation was real and to deny it was like hiding behind a piece of grass. For him, the main problem of interreligious relations was not religion, but the socio-economic gap between the rich Christians and the poor Muslims. ${ }^{168}$

By this period, the Government also financed two big research projects on the violent incidents in general and inter-religious relations in particular. The project on the violent incidents was carried out by a team in Yogyakarta under the supervision of Loekman Soetrisno, a Catholic and leading anthropologist of Gadjah Mada University. The team consists of Muslim and nonMuslim social scientists and activists. The second project investigating the view of religious preachers on other religions was conducted by the team of the Office of Research and Development of the Department of Religion, the Centre for the Study of Islam and Society (PPIM) IAIN Jakarta, the Institute for the Study of Politics and Economy, University of Indonesia (LSPEUI), the Rectors of the Academy of Theology (STT) Jakarta, the Academy of Philosophy, Driyarkara, the Academy of Buddhism, Nalanda, Jakarta, and Hindu University in Denpasar. The psychologist of the University of Indonesia, Sarlito W. Sarwono (a Muslim) was the head of the whole team. The Rectors of the 
religious academies helped create a team in their respective institutions to carry out research in the field.

Compared with the reports of similar research projects in the 1970s that were full of embellished statements, the report of this research project was much more critical. Perhaps, the incidents of the late 1990s pushed the teams of the research to be critical. The result of the first research project gave us some important and critical analysis of the socio-economic, political and religious background of the incidents in Sanggau Ledo, East Timor, Tasikmalaya, Banjarmasin, Sampang, Situbondo and Pekalongan. The conclusion of the research suggested that there were some social factors contributing to the violent incidents, namely the wide economic gap between one group and another in the structure of society, the psycho-social anxiety of the underprivileged group about the Government development projects, distrust of the Government bureaucracy, socialisation of militant religious teachings and the distrust of religious communities towards their respective leaders. ${ }^{169}$

The second research project suggested that after analysing the questionnaires and interviews conducted with 1216 religious preachers of the five religions in nine cities, namely Metro (Central Lampung), Maumere (East Nusa Tenggara), Temanggung (Central Java), Malang (Est Java), Badung (Bali), Sumenep (Madura), Minahasa (North Sulawesi), Pontianak (West Kalimantan) and Samarinda (East Kalimantan), the team concluded that in general, in terms of social interaction with the people of other religions, the religious views of the preachers were moderate. However, in theological terms, most of the non-Muslim respondents had an inclusive attitude while those of most of the Muslims were exclusive. The team also said that because the Muslims were the majority in the country, this exclusive attitude potentially strengthened inter-religious tensions. The team also suggested that the Government regulations on inter-religious relations and MUI's fatwa on Christmas celebration (all discussed in Chapter 2) did not create but disturbed religious harmony in society. Therefore, the team suggested that the Government should reduce the regulations and let the religious groups themselves decided what was the best for them. ${ }^{170}$

\section{Conclusion}

The rise of the promoters of the non-ideological view of Islam that happened in the early 1970s, and became stronger in the following decades, was certainly an important force behind the development of interreligious dialogue in Indonesia. For the Christians who had been afraid of 
the threat of an Islamic State, the promoters of the non-ideological view of Islam were naturally good potential allies. Without the ideological gap, the Christians felt that they could talk about a common concern with these Muslims. In the early 1970s, these Muslims who worked in the Government, particularly A. Mukti Ali and Djohan Effendi, started the project on dialogue. The project was intended to create the conditions of the socalled religious harmony, that is, inter-religious peaceful co-existence. The common concern defined in this official dialogue was nothing but a Government project on development. The project might have initially helped open inter-religious communication among religious leaders but did not truly create inter-religious understanding and cooperation. In most cases, it was the Government rather than the religious leaders that determined the topic of the dialogue. Thus, the dialogue became simply a formal meeting of religious leaders in which mutual suspicions were suppressed under the sweet smile of the participants. The other Government related initiatives such as the research on inter-religious issues and the joint-visit to places of worship, were not free from the same tendency either. Due to the incidents, in the 1990s, the Government revived this project. In this respect, besides the report of the research project that was unusually critical, the other initiatives seem to have served the organisers rather than to have enhanced inter-religious cooperation in society.

Some of the Christians and Muslims eventually felt that they should develop dialogue by themselves. As a reaction to the Government proposed discourse on the role of religion to support development, these Muslim and Christian intellectuals developed a critical discourse on development through the theology of liberation. In this context, the Christians and Muslims found that social justice was to be the common concern for all in relation to the Government led development programmes. In reaction to Soeharto's shift in political alliance from abangan Muslims and Christians to reformist Muslims in the 1990s, some Muslim and Christian intellectuals cooperated in promoting democracy and pluralism. The political shift apparently made some Christian leaders more convinced that cooperation with the Muslims, particularly the Muslim proponents of democracy, would be better than maintaining the Christian dependence on the regime. It was in this period that some of the prominent Muslim and Christian intellectuals developed theological ideas to support a tolerant and open attitude towards other religious believers. Although these theological ideas only had a limited influence on people's behaviour, they represented a serious attempt on the part of Muslims and Christians to create 
better inter-religious relations. One might say that no matter how good the Muslim-Christian discourse on religious tolerance and pluralism was, it would have little impact on inter-communal relations in real life. Indeed, the socio-political cooperation between Muslims and Christian was still rare. However, if we remember the Situbondo case in which Muslim and Christian leaders successfully cooperated to prevent further violence, we should not be so pessimistic. 


\section{Conclusion}

Muslim-Christian relations have been an important element of the social and political dynamics of Indonesia during the New Order period, and an ever sensitive object of Government policy. In this study, I have focused on the discourses and political behaviour of Muslim and Christian leaders as well as the state elites concerning inter-religious relations in order to better understand the nature of these relations and their development over time. These discourses were analysed through a reading of utterances on a wide range of occasions and in different socio-political contexts, including Parliamentary sessions, Government organised meetings, religious sermons, meetings of religious organisations, demonstrations, conferences and seminars. The development of power relations between the Islamic groups, the Christians and the state strongly influenced the features of the discourses. There were antagonistic as well as common discourses between the Muslims and the Christians. In response to the Muslim-Christian antagonistic discourses, the state often adopted an ambiguous position that eventually led to further controversies between the two religious groups. On the other hand, the state determined and imposed a certain discourse as a common discourse for all. Some Muslim and Christian leaders responded positively to this state-imposed common discourse, while others opposed it and proposed an alternative common discourse. The Muslim-Christian discourses certainly influenced the mutual perceptions and actions of the two religious communities. The discourses also shaped state policies on religio-political issues, and how they were implemented in reality.

The relations between Muslims and Christians have been tense because of mutual suspicions existing between them. These mutual suspicions have been reflected in, and exacerbated by, the antagonistic discourses in which the Muslim and Christian leaders perceived each other as a threat against their respective religious communities. Among the Muslims, the Christian threat has been called 'Kristenisasi' (Christianisation). In the Muslim discourse, Christianisation meant unfair and aggressive efforts to convert Muslims to Christianity such as by offering money, food, education, and health care to the poor Muslims; building a church in a Muslim majority area; encouraging Christians to marry Muslim partners in order to convert the latter; inviting Muslims to participate in Christmas celebrations under 
the pretext of religious tolerance; and teaching Christianity to Muslim students in Christian schools. In the Muslim discourse, Christianisation could also mean a political conspiracy of the Christians with other enemies of Islam, particularly the secularists, inside and outside the country, to weaken the Islamic groups culturally, politically and economically. Christianisation was therefore described as a 'new style of crusade', 'religious expansionism', 'foreign intervention', 'arrogance of cultural superiority' inherited from the West, and 'intolerant to Muslim feelings.'

The discourse on the threat of Christianisation sometimes led several Muslims to violent action, by attacking church buildings and Christian schools. Moreover, the Muslims also demanded that the Government control and restrict Christian missions by (1) making strict requirements for obtaining permission to erect a new place of worship; (2) restricting religious propagation only to those outside the five recognised religions; and (3) controlling foreign aid for religious institutions; (4) prohibiting inter-religious marriage; (5) requiring that religion classes given at schools should be taught by a teacher whose religious background was the same as that of students. The Muslim leaders also tried to intensify Islamic propagation ( $\mathrm{da}^{\prime} w a h$ ) programmes to compete against the Christian mission. To protect the Islamic community from the perceived threat of Christianisation, the Muslim leaders developed exclusive interpretations of religious doctrines, such as a total rejection of freedom to convert from Islam by reaffirming the classic Islamic doctrine on apostasy (an apostate could be killed, though it was noted that this could not be applied in a non-Islamic state like Indonesia); prohibiting Muslims from participating in Christmas celebration by emphasising that the Christian doctrine of the Trinity could endanger Muslim monotheistic belief; prohibiting inter-religious marriage between a Muslim and non-Muslim based on the idea that the prevention of possible harm (conversion from Islam of the Muslim partner and his or her children) has priority over obtaining benefits of marriage. The political marginalisation of the Islamic groups by the regime apparently helped increase the Muslim exclusive religious outlook.

The Christians, on the other hand, denied the existence of what the Muslims called Christianisation efforts. Moreover, for the Christians, the five aforementioned Muslim demands to the Government were opposed to the idea of religious freedom. For the Christians, religious freedom meant: the freedom to build churches in all regions of Indonesia, including the Muslim majority areas, the freedom to preach religion to anybody, the freedom to change religion, the freedom to cooperate with co-religionists outside the 
country (that is, to receive foreign aid), the freedom to participate in religious celebrations of another religion, the freedom to follow religious teachings without any pressure from the state; and the freedom to teach Christianity to all students in Christian schools, as long as they or their parents agreed. The Christians used two important arguments to support their understanding of religious freedom, namely nationalism and human rights. Nationalism for them meant that all citizens are equal before the state on the basis that all of them shared the same nationality. Other allegiances such as religion, race, geographic origin, should be submitted to nationality. In this sense, nationalism is in line with individual human rights, particularly the right to religious freedom. Thus, for the Christians, the five aforementioned Muslim demands to the Government were against nationalism and human rights. Moreover, although in terms of religious doctrines, inter-religious marriage (and probably conversion from Christianity too) was a controversial issue among the Christian Churches, as a religious minority, they never hesitated to support religious freedom. Likewise, it was the idea of religious freedom that led the Christians to demand state recognition of marriages based on Javanese Mysticism, while the Muslims opposed it. Certainly, we cannot also ignore that the supporters of Javanese Mysticism (who were mostly abangan) were the likely political allies for the Christians. In contrast, for the Muslim leaders, the adherents of Javanese Mysticism were actually Muslims (but less Muslim than the santri), and therefore, they should marry according to Islam. This case apparently reflects the Muslim struggle against local religious customs and beliefs.

The responses of the regime to the Muslim discourse on Christianisation and the Christian defence of religious freedom were always ambiguous. In certain periods, when the regime felt it the need for reconciliation with the Islamic groups, the former accommodated certain demands of the latter in the Government decrees. However, because the Christians consistently opposed these decrees, they were not strictly implemented. This was because the interest of the regime lay neither in curbing Christian missions nor in enhancing religious freedom, but in maintaining political power and controlling socio-political stability. The joint decree of the Ministers of Religion and of Home Affairs in 1969 clearly accommodated the Muslim demand to control the erection of new places of worship. This decree has created difficulties for Christians wishing to build a new church, especially in Muslim majority areas (as Muslims also had difficulties in erecting a mosque in Christian majority areas). However, there were also some cases in which new churches were built without permission and the Government did not 
react, until the Muslim protests emerged. Likewise, in 1978 the Government issued decrees to restrict missionary activities only to those outside the recognised religions, and to control foreign aid for religious institutions. In practice, however, the decrees were loosely implemented. With regard to inter-religious marriage, the compromise between the regime and the Islamic groups resulted in a strange decision: the Marriage Law of 1974 does not clearly mention whether inter-religious marriage is allowed or not. In practice, whether inter-religious marriage was possible, difficult or even impossible, depended very much on the socio-political development in the country. While up to the 1980s inter-religious marriage was still possible, though sometimes difficult, in the 1990s when the regime was close to the Islamic groups, it became almost impossible. Last but not least, in the Education Law of 1989, the regime eventually accommodated the Muslim demand to require that teacher and students had to be of the same religious background, but because of the Christians' objection, this rule was not implemented in private schools.

Apart from the Government ambiguity, did Christianisation truly happen? In the Introduction, I noted that according to the Government statistic for the year 2000, the percentage of population that is Muslim is $88.22 \%$ (177.5 million), and this was almost similar to the previous Government statistics. On the other hand, the Christian population has increased from $7.39 \%$ (8.74 million) in 1971 to $8.92 \%$ (17.95 million) in 2000 with an average rate of growth of $2.4 \%$ annually, and this is higher than the rate of growth of the whole population (1.83\%). If the statistics are reliable, then we can say that Christianisation of those who already adhered to Islam did not widely happen because the Muslim population was generally stable. The increase of the Christian population was probably due to the success of Christian missions directed to the people living in several remote areas of the country, that is, to those who did not belong to one of the recognised religions.

Despite the statistics, after the fall of Soeharto, the Muslim discourse on Christianisation continued influencing Muslim-Christian relations. During the making of the Education Law of 2003 there was a hot controversy on the issue of religion classes. Despite strong opposition from the Christians, the Islamic groups successfully included in the Law a provision stating that students are entitled to religious education in their own religion and to be taught by a teacher of the same religion. This was obviously a culmination of what had happened on this issue during the New Order period. Likewise, based on the Government decree of 1969 on the rules of erecting new places of worship, in October 2004, a group of Muslims barricaded a Catholic 
school in Cileduk, Jakarta because it was illegally used for religious services, and for the same reason, 23 churches were closed by Muslims in West Java in September 2005. There has also been a controversy on the Muslim proposal for what is called the 'Religious Harmony Bill' (RUU-KUB), which is actually an effort to enhance the legal status of the Government decrees of 1969 and 1978 to the position of law ratified by Parliament. By the end of September 2005, the Indonesian Council of Ulama (MUI) reaffirmed its earlier fatwa on the prohibition of inter-religious marriage and at the same time it prohibited Muslims from participating in a common prayer in which believers of different religions come together to pray alternately for the sake of a common interest. The MUI also declared that pluralism, liberalism and secularism are against Islam. In contrast to what happened during the New Order period, however, there have been more Muslim activists and intellectuals who openly opposed these Muslim exclusive religious attitudes.

Whereas the Muslims felt insecure and threatened by Christianisation, the Christians were afraid of the threat of an Islamic State. For the Christians, to have to live under an Islamic state in which the sharīa law was implemented would mean that they would be turned into second-class citizens. As a religious minority, the Christians preferred the secular political view of separation of religion and state. After the Communist Party (PKI) was physically and politically destroyed in the late 1960s, the Islamic groups felt more confident in pursuing their ideological ambition. On the other hand, to protect themselves from the threat of the Muslim ideological ambition, the Christians decided to ally with the emerging power of the army. This political choice was apparently natural for the Christians because, like the politically secular-oriented Muslims among the civilians, the army was known as the strongest proponent of the nationalist (as opposed to the Islamic) ideological outlook.

The Christian political choice eventually produced certain consequences. One was that the Christians became the supporters, or even contributors to the making of the authoritarian New Order regime. While T.B. Simatupang, the leader of PGI, still hoped that the military regime would willingly support democracy, an important group among the Catholics established a strong alliance with the regime in some important political institutions, namely in the state intelligence operations, in the Government party, Golkar, and in the think tank called the Centre for Strategic and International Studies (CSIS). The CSIS intellectuals were involved in developing the official interpretation of the state ideology, Pancasila, in which the secular political view was combined with Javanese ideals of family-ism. They also 
played an important role behind the Government secular policies on education and culture.

Although the CSIS, at least to the mid-1980s, actually represented much more the state than the Catholics, the involvement of the Catholic intellectuals in this think-tank helped create a bad image of the Catholics among the Muslims. It often happened that the Muslim political frustration with the regime manifested itself as a strong negative perception of the Catholics. On the other hand, when the regime became more accommodating to Islamic ideological demands, the Muslim-Christian antagonism did not stop because while the regime was not always consistent with its ideological position, the Christians were consistent in their opposition to the Islamic ideology. When the regime accommodated the demands of the Islamic groups during the controversy on the marriage bill in 1973, or when the regime proposed the Religious Court Bill in 1988, both Catholic and Protestant leaders cooperated to oppose it.

The Muslim-Christian antagonism also continued in the 1990s, the period when the regime allied with the Islamic groups. In the late 1980s, Soeharto had a conflict with some important army generals who had previously supported him. In order to maintain his power, Soeharto then allied with the Islamic groups, particularly the reformist Muslims. In 1990, Soeharto supported the establishment of the Association of Indonesian Muslim Intellectuals (ICMI). Many of the ICMI activists then became the representatives of the Government party, Golkar, and some of them were appointed as ministers in Soeharto's cabinet. Just as in the early 1970s a certain group of Catholics in cooperation with the military had established the CSIS, so now ICMI established the Centre for Information and Development Studies (CIDES) which was also intended to become a think tank for the Government. It was said that certain ICMI leaders felt it was the time to take 'revenge' on the Christians. There is no doubt that the Christians and other religious minorities were very scared of this political development. Moreover, the favouring of Muslims over Christians in this period had disturbed the old balance of power between the two communities in such places as the Moluccas. The civil war in the Moluccas which occurred after the fall of Soeharto was partly because the Christian elites try to regain what they have lost.

It should be noted, however, that although the regime accommodated some Muslim demands, it never tolerated the idea of Islam as an alternative political ideology to Pancasila. The New Order regime continuously prohibited people from speaking publicly about support for an Islamic State or the Jakarta Charter, and by the mid-1980s it forced all social organisa- 
tions, including religious ones, to adopt Pancasila as the sole basis in their respective constitutions. Through an indoctrination programme started by the late 1970s, the state tried to impose its own interpretation of Pancasila based on family-ism and corporatism. This official interpretation was then opposed to three other ideologies: Islam, Communism and Liberalism. It is not surprising that under these political circumstances, the non-ideological view of Islam became dominant in the public sphere.

The non-ideological view of Islam, however, could not be simply perceived as a temporary political option, particularly for its proponents who took this view out of long internal discussions since the early 1970s. After the fall of Soeharto in 1998 and the rise of democracy in Indonesia, we can see that, unlike the situation in the 1950s and the late 1960s, the Islamic ideology is not the common cause for all Islamic groups anymore. It is the nationalist outlook rather than Islam that has become the official basis of the two important Muslim political parties: PKB (Partai Kebangkitan Bangsa) established by the Muslim traditionalist leader, Abdurrahman Wahid, and PAN (Partai Amanat Nasional) established by the Muslim reformist leader, $\mathrm{M}$. Amien Rais. In addition, although after the fall of Soeharto the top leader of Golkar have been reformist Muslim activists (Akbar Tanjung and then Jusuf Kalla), this party has never changed its nationalist ideology into the Islamic one. Without support of these three important political parties, it is certainly difficult for the other Muslim political parties officially based on Islam such as PPP (Partai Persatuan Pembangunan), PBB (Partai Bulan Bintang) and PKS (Partai Keadilan Sejahtera) to realise their ideological ambitions. In other words, the threat of an Islamic state is not as serious as before.

Besides the antagonistic discourses on the threat of Christianisation and the Islamic State, there were also Muslim-Christian common discourses imposed by the state or developed by Muslims and Christians themselves. The state claimed that the common cause for the nation after the fall of the Soekarno regime was economic restoration. Therefore, the common discourse for the state was development and modernisation or the so-called 'Pembangunan'. State officials often emphasised the claim that the development programmes could not work without political stability, and therefore, they urged religious leaders to avoid conflicts and to create inter-religious harmony, that is, peaceful inter-religious co-existence. State officials also encouraged religious leaders to engage religion as a supportive force for the development programmes. The Government project on inter-religious dialogue in particular and religious harmony in general was primarily directed to these ends. 
In the early years of the New Order, the Christian leaders appeared to be quite supportive of the Government discourse on development, while the Muslim groups were still sceptical, if not opposed to it. By the mid-1970s, however, critical voices against the Government development programmes emerged in Christian and Muslim intellectual circles. Influenced by the Catholic liberation theology of Latin America, these intellectuals tried to develop a critical religious discourse on development, by emphasising the universal value of social justice. Thus, social justice became the common cause for all, and this idea was developed further among several younger Muslim activists in the 1990s, and became their ideology of social action.

The Muslim-Christian common discourse developed primarily because of the emergence of the non-ideological view of Islam in the early 1970s that became stronger in the following decades. This view of Islam certainly provided a religious justification for the regime, but at the same time it showed a peaceful face of Islam for the Christians who had been afraid of the threat of an Islamic State. Like the Christians, the proponents of non-ideological Islam considered Pancasila as the best ideology of the state. Thus, when the state imposed Pancasila as the sole basis for social organisations, they did not have any problem. However, along with some Christian and other intellectuals, these Muslims tried to oppose the state interpretation of Pancasila. In the 1990s, in response to the Soeharto' political alliance with the Muslim reformists, some prominent Muslim and Christian intellectuals cooperated in developing a common discourse on democracy and pluralism.

All in all, our discussion demonstrates that religion in Indonesia was (and is) very much a public issue, and had been increasingly so during the New Order period. The ideological compromise between the secular and the Islamic oriented group, that Indonesia is neither secular nor Islamic, certainly provides a grey area for debates, negotiations and compromises between the secular and the religious. This study also indicates that Muslim and Christian leaders have been involved in debates on almost all important socio-political issues, including state ideology, law, culture, education, democracy and development. The significant political influence of both religious communities in Indonesia is indicated by the fact that the state could not totally suppress either the voices of the Muslims or the Christians in those debates, and even it tried to accommodate both, resulting in the ambiguities. Thus, the issues of Muslim-Christian relations are too important to neglect for anyone who wants to understand this country and who expects the best for its future. 
Because most, if not all, of the Muslim-Christian issues are in fact political problems, they should be resolved, I believe, through a 'suitable' political system and culture. Perhaps, the current democratic political system is one of the answers, but a democratic system will not work without support of democratic culture in society. The respect for human rights and the mutual trust between groups in society will certainly not come out of the blue. Mutual trust between religious groups cannot develop if their leaders make a protest when their own group is discriminated against but become silent when it happens to another group. The religious leaders not only should support and develop the discourses on the principles of democracy and human rights but also should prove, in response to actual cases, that they truly hold these principles. I believe that both Islam and Christianity also teach these principles. 



\section{Notes}

\section{Notes Introduction}

1. See Leo Suryadinata, Evi Nurvidya Arifin and Aris Ananta, Indonesia's Population:Ethnicity and Religion in a Changing Political Landscape (Singapore: ISEAS, 2003), 104.

2. The census of 2000 shows that the Christians are $87.67 \%$ in East Nusa Tenggara; $75.51 \%$ in Papua; $69.27 \%$ in North Sulawesi (excluding Gorontalo); $50.19 \%$ in Maluku (excluding North Maluku); $31.40 \%$ in North Sumatra; $34.01 \%$ in West Kalimantan; $17.32 \%$ in Central Kalimantan; $17.20 \%$ in Central Sulawesi; $13.83 \%$ in East Kalimantan; and 9.40\% in South Sulawesi. See Suryadinata, Arifin and Ananta, Indonesia's Population, 115-6.

3. See Martin van Bruinessen, "Global and Local in Indonesian Islam"Southeast Asian Studies Vol.37 No. 2 (September, 1999), 158-175.

4. The often cited example of adat-Islam conflict is the matrilineal custom in Minangkabau, West Sumatra, versus the patrilineal orientation of Islamic law. See Taufik Abdullah, "Adat and Islam: An Examination of Conflict in Minangkabau" Indonesia No. 2 (1966), $1-24$.

5. The Javanese comprises $41.71 \%$ ( 83.8 million) in 2000. See Suryadinata, Arifin and Ananta, Indonesia's Population, 31-2.

6. Clifford Geertz, The Religion of Java (New York: Free Press, 1960).

7. See Adolf Heuken, 'Be my Witness to the Ends of the Earth!"The Catholic Church in Indonesia Before the $19^{\text {th }}$ Century (Jakarta: Cipta Loka Caraka, 2002).

8. See Th. Van den End and J. Weitjens, Ragi Carita 2: Sejarah Gereja di Indonesia 1860an - Sekarang (Jakarta: BPK Gunung Mulia, 1989).

9. Gavin W. Jones, "Religion and Education in Indonesia” Indonesia (October, 1976), 19-56.

10. Huub J.W.M. Boelaars, Indonesianisasi: Dari Gereja Katolik di Indonesia Menjadi Gereja Katolik Indonesia trans. R. Hardawiyana (Yogyakarta: Kanisius, 2005), 139-44; 162-66.

11. Since 1987, MAWI has become KWI (Konferensi Wali Gereja Indonesia - Indonesian Bishops Conference) and since 1984, DGI has become PGI (Persekutuan Gereja-Gereja Indonesia - Indonesian Communion of Churches). See Chapter 3.

12. One of these studies is the last section of B.J. Boland, The Struggle of Islam in Modern Indonesia (The Hague: Martinus Nijhoff, 1982) which provides an interesting survey of Muslim responses to Christianity, especially to the issue of mission in the late 1960s, while the responses of Christians to Islam are not discussed. Another study is Alwi Shihab's Membendung Arus: Respons Gerakan Muhammadiyah Terhadap Penetrasi Misi Kristen di Indonesia (Bandung: Mizan, 1998). If one looks at the title of the book (originally a PhD thesis, Temple University, 1995), one would expect that the book extensively discusses the role of the reformist Muslim organization, Muhammadiyah, in opposing Christian missions in Indonesia. In fact, this is discussed only in the last chapter of the book. Another work is Ismatu Ropi, Fragile Relation: Muslims and Christians in Modern Indonesia (Jakarta: Logos, 2000). This book (originally an MA thesis at Institute of Islamic Studies, McGill University, 1998) gives a very short discussion of the Muslim responses to Christianity in Indonesia from the colonial period up to the Soeharto period. The most recent study is Fatimah Husein, Muslim-Christian Relations in the New Order Indonesia. The Exclusivist and Inclusivist Muslims' Perspectives (Bandung: Mizan, 2005). This book (originally a PhD thesis, Melbourne University, 2004) discusses Muslim-Christian rela- 
tions in Indonesia during the Soeharto period from the perspective of Muslim theological viewpoints categorized as 'exclusivist' and 'inclusivist'. In fact, the book mixes events and developments of the Soeharto period with those of the following period.

13. For instance, W. B. Sidjabat, Religious Tolerance and the Christian Faith: A Study Concerning the Concept of Divine Omnipotence in the Indonesian Constitution in the Light of Islam and Christianity (Jakarta: BPK, 1965).This study discusses Muslim and Christian theological views of religious tolerance from independence period to the early 1960s. Another study is Wendelin Wawer, Muslime und Christen in der Republik Indonesia (Wiesbaden: Franz Steiner Verlag, 1974). This study discusses Muslim-Christian relations in Indonesia since the colonial period up to the early years of the New Order (1969). Another is Karel A. Steenbrink, Dutch Colonialism and Indonesian Islam, Contacts and Conflicts 1596-1950 (Amsterdam: Rodopi, 1993) in which he discusses how Christian missionaries perceived Muslims and vice versa during the Dutch colonial period and in the period immediately following Independence. The development during the Soeharto period is only discussed in the last chapter. The most recent study is Jan S. Aritonang, Sejarah Perjumpaan Kristen dan Islam di Indonesia (Jakarta: BPK, 2004). He discusses the history of Muslim-Christian conflicts in Indonesia, covering almost 'the whole period', that is, from 1511 to 2003.

14. My usage of the word'discourse' is in line with, but perhaps narrower than, the definition given by Michel Foucault. For him, "the term discourse can be defined as the group of statements that belong to a single system of formation; thus I shall be able to speak of clinical discourse, economic discourse, the discourse of natural history, psychiatric discourse." See Foucault, The Archeology of Knowledge Trans. A.M. Sheridan Smith (New York: Pantheon Book, 1972), 107-8. Thus, for Foucault, scientific disciplines are examples of what he means by 'a single system of formation.' In this study, the system of formation of the statements is not a scientific discipline but the nature of relations between Muslims, Christians and the State. In addition, the analysis of religious phenomena in terms of discourse and power relations is developed in particular by Talal Asad in his Geneologies of Religion: Discipline and Reasons of Power in Christianity and Islam (Baltimore: John Hopkins University Press, 1993); and The Idea of an Anthropology of Islam (Washington: CCAS, Georgetown University, 1986).

\section{Notes Chapter 1}

1. See Donald Hindley, "Indonesia's Confrontation with Malaysia: A Search for Motives," Asian Survey, Vol. 4 No. 6 (June, 1964), 904-13.

2. Guy J. Pauker, "Indonesia in 1963: The Year of Wasted Opportunities," Asian Survey, Vol. 4 No.2 (February, 1964), 687-94.

3. J.A.C. Mackie, Problems of the Indonesian Inflation (Ithaca, NY: Cornell University, Department of Asian Studies, 1967), 2; 41.

4. Mackie, Problems of the Indonesian Inflation, 81-91.

5. Rex Mortimer, The Indonesian Communist Party and Land Reform: 1959-1965 (Monash Papers on Southeast Asia, No. 1, 1972), 31.

6. J.D. Legge, Soekarno: A Political Biography (London: Allen Lane The Penguin Press, 1972), 358-86.

7. For a more detailed account of Gestapu, see the studies quoted below.

8. For an analysis of these theories, see for instance, Harold Crouch, The Army and Politics in Indonesia (Ithaca: Cornell University Press, 1978), 101-125. 
9. See W. F. Wertheim, "Suharto and the Untung Coup - The Missing Link", Journal of Contemporary Asia No. 1 (1970) 50-7 and his "Whose Plot? New Light on the 1965 Events" and Coen Holtzappel, "The 30 September Movement: A Political Movement of the Armed Forces or Intelligence Operation?" Journal of Contemporary Asia, Vol. 9 No. 2 (1979), 197-215 and 216-40.

10. Benedict R. Anderson and Ruth T. McVey, A Preliminary Analysis of the October 1, 1965 Coup in Indonesia (Cornell: Modern Indonesia Project, Cornell University, 1971) and their "What Happened in Indonesia," The New York Review of Books Vol. 25 No.9 (June, 1978).

11. Nugroho Notosusanto and Ismail Saleh, The Coup Attempt of "September $30^{\text {th }}$ Movement" in Indonesia (Djakarta: Pembimbing Masa, 1968) and Sekretariat Negara Rl, Gerakan 30 September, Pemberontakan Partai Komunis Indonesia, Latar Belakang, Aksi dan Penumpasannya (Jakarta: Sekneg, 1994). The last book is known as the 'Buku Putih' (white book).

12. Some scholars argue that the PKI was involved, but cannot clearly determine the degree of its complicity. Hughes wrote: "There is no question of course that the Indonesian Communist Party was up to its neck in the coup attempt. But still open to debate is whether the Communists planned the whole thing and gave the actual signal to jump, or whether the Communists jumped at somebody else's beckoning." See John Hughes, Indonesian Upheaval (New York: David Mckay Company, 1967), 114. Crouch said: "While it appears clear that the PKI was indeed involved, the circumstances and extent of its involvement are still unclear." See Crouch, The Army and Politics, 101. In contrast, Legge argues that the PKI was "a leading partner in a limited plot designed to shift the domestic power balance in its favor and to improve its position without endangering its existence. It interacted with a group within the army - a group which had its own purposes and which is not to be regarded as composed of secret Communists or puppets under PKI control." Legge finally concludes that, “... an interpretation in terms of a major PKI involvement in a plot which also had elements of intra-army rivalry would seem to fit the main facts and be very credible." See Legge, Soekarno, 394-5.

13. The following historical account is taken from Donald Hindley, "Alirans and the Fall of the Old Order" Indonesia No. 9 (April, 1970), 40-2 and Lukman Harun, "14 Tahun Yang Lalu: Sekelumit Kenangan Dalam Pengganyangan Gestapu/PKI" Panji Masyarakat No. 280 and 281 (October, 1979), 10-15 and 12-17. Lukman Harun's account is precious because he was involved in the events described.

14. For the account of the killings, see Hughes, Indonesian Upheaval, 152-194; Robert Cribb (ed.), The Indonesian Killings, 1965-1966: Studies from Java and Bali (Clayton: Monash University, 1990); Geoffrey Robinson, The Dark Side of Paradise: Political Violence in Bali (Ithaca: Cornell University Press, 1995), Robert W. Hefner, The Political Economy of Mountain Java: An Interpretive History (Berkeley: University of California Press, 1993) 209-215; and Hermawan Sulistiyo, Palu Arit di Ladang Tebu: Sejarah Pembantaian Massal Yang Terlupakan (Jombang-Kediri, 1965-1966) (Jakarta: Gramedia, 2000). For the cases in Flores, see R.A.F. Paul Webb, "The Sickle and the Cross" Journal of Southeast Asian Studies Vol. 17 (1986), 94-112; and R.H. Barnes, "Fransiskus/Usman Buang Duran: Catholic, Muslim, Communist" Bijdragen Tot de Taal, Land en Volkenkunde Vol. 159 (2003), 1-29.

15. Martin van Bruinessen, NU, Tradisi, Relasi-RelasiKuasa, Pencarian Wacana Baru (Yogyakarta: LKiS, 1994), 82-89.

16. Bruinessen, $N U$, Tradisi, 84. Boland discovered that the important Muslim reformist organization, Muhammadiyah, published a fatwā in Suara Muhammadiyah magazine, November 1965, that the extermination of the PKI is a religious duty and nothing less 
than a holy war (jihād). See B.J. Boland, The Struggle of Islam in Modern Indonesia (The Hague: Martinus Nijhoff, 1982), 146. Hefner notes that, to form an anti-Communist alliance with the Muslims, the army organized military training for the HMI activists in Surabaya, Malang and other parts of East Java. See Robert. W. Hefner, Civil Islam, Muslims and Democratization in Indonesia (Princeton: Princeton University Press, 2000), 54-5.

17. An Australian journalist notes that, "at Jogjakarta, Roman Catholic students would leave their hostels at night to take part in the execution of truckloads of Communists already taken prisoners." See Hamish McDonald, Suharto's Indonesia (Honolulu: The University of Hawaii Press, 1981), 53; 102. W. F. Wertheim also notes: "According to reliable information which I got from an Australian colleague, in Indonesian Timor over 3,000 people have been killed - in this case not by Muslim extremists but by Catholic radjahs and large land owners allied to the military command."' See his "Indonesia Before and After the Untung Coup" Pacific Affairs Vol. 39 no.1-2 (Spring-Summer, 1969), 123.

18. Interview with Father Ismartono, Jakarta, 15 December 2003.

19. Interview with Daniel Dhakidae, Jakarta, 12 December 2003. Dhakidae was a student at a Catholic seminary in Flores and remembers that the students replied negatively to the army's invitation.

20. Interview with a former Catholic activist, Yogyakarta, 12 January 2004.

21. Viator Parera, "Membangun Jemaat Yang Rukun dan Memasyarakat" in Ignas da Cunha et. al, Berpastoral di Tengah Badai, Potret Gereja Maumere 1956-1969 (Maumere: LPBAJ, 1999), 94-97. The main topic of the book is a description of the role of a priest, Hendrik Djawa, who worked in Maumere, Flores, immediately after the killings. Hendrik played a successful role as a peacemaker among the Catholics of different ethnic groups who, due to the tragedy of the killings, almost fought each other.

22. For some cases in East Java, particularly Surabaya, see Jacob Walkin, "The Moslem-Communist Confrontation in East Java 1964-65" Orbis (Fall, 1969), 822-47.

23. Rex Mortimer, The Indonesian Communist Party and Land Reform: 1959-1965, 48. To avoid the land reform law some Muslims gave their land as a pious trust to an Islamic school. See Lance Castles, "Notes on the Islamic School at Gontor" Indonesia No.1 (April, 1966), 36-37.

24. See Robert R. Jay, "History and Personal Experience: Religious and Political Conflict in Java" in Robert F. Spencer (ed.), Religion and Change in Contemporary Asia (Minneapolis: University of Minnesota Press, 1971), 143-164; and Clifford Geertz, After the Fact: Two Countries, Four Decades, One Anthropologist (Cambridge: Harvard University Press, 1995), 3-11.

25. McDonald, Suharto's Indonesia, 217.

26. Besides Parliament (DPRGR), the members of the MPRS included other representatives of various categories, including the army.

27. See "Ketetapan MPRS No: XXV/MPRS/1966" in Abdul Kadir Besar, Himpunan KetetapanKetetapan MPRS (Djakarta: Pantjuran Tudjuh n.d.), 88-91

28. For an analysis of Soekarno's ideological slogans, see Legge, Soekarno, 335-357. For an analysis of the NASAKOM, see Ruth T. McVey, "Nationalism, Islam and Marxism: the Management of Ideological Conflict in Indonesia" in Soekarno, Nationalism, Islam and Communism, Trans. Karel H. Warouw and Peter D. Weldon (Ithaca: Modern Indonesia Project, Cornell University, 1970), 1-34. This book is a translation of Soekarno's article published in 1926.

29. Crouch, The Army and Politics in Indonesia, 207. 
30. Compare with Roger K. Paget, "The Military in Indonesian Politics: The Burden of Power", Pacific Affairs Vol. 40 No. 3-4 (1967/1968), 307.

31. See "Ketetapan No: XXVI/ MPRS/ 1966 in Besar, Himpunan Ketetapan, 92-7.

32. See "Pendjelasan Ketetapan MPRS No.XXV/MPRS/ 1966" in Besar, Himpunan Ketetapan, 91.

33. For instance, Abu Hanifah (a Muslim reformist leader) and J.W.M Bakker (a Catholic priest) took this view. Another Muslim reformist leader, Agus Salim, however, emphasized that 'Ketuhanan Yang Maha Esa' should also mean that the state guaranteed the freedom not to believe in God. See Abu Hanifah, Kedudukan Agama dalam Negara2 Modern dan Merdeka (Yogyakarta: Kementrian Agama RI, 1948), 21; Rahmat Subagya [J.W.M. Bakker], Pantjasila Dasar Negara Indonesia (Yogyakarta: Basis, 1955), 57-8; Agus Salim "Kementrian Agama dalam Republik Indonesia" in Kementrian Agama (Jakarta: Pertjetakan Negara, n.d.), 10-11; 14.

34. Interview with Harry Tjan Silalahi, Jakarta, 22 December 2003.

35. See "Ketetapan No.XXVII/MPRS/1966"in Besar, Himpunan Ketatapan, 101.

36. According to Saifuddin Zuhri, the Minister of Religion at that time, he insisted Soekarno should make the decree to oppose the Communist anti-religious agitation in the early 1965. See the anecdotes around this issue in Saifuddin Zuhri, Berangkat Dari Pesantren (Jakarta: Gunung Agung, 1987), 507-9; 546-7. Perhaps, by the decree Soekarno wanted to maintain the Muslim support for him and to put himself as a balancer of the existing socio-political forces.

37. See "Penjelasan Atas Penetapan Presiden Republik Indonesia Nomor 1 Tahun 1965 Tentang Pencegahan Penyalahgunaan dan/atau Penodaan Agama" reprinted in Weinata Sairin (ed.), Himpunan Peraturan di Bidang Keagamaan (Jakarta: BPK, 1994), 265-268. It should be noted here that the phrase 'recognized religions' (agama yang diakui) is not explicitly used in the decree. Moreover, it also does not prohibit other religions such as Shintoism, Zoroastrianism and Judaism from existing. Apart from the decree, the six religions were recognized by the state in the sense that they were accommodated by the Department of Religion. However, in 1979 Confucianism was dropped from the list of the recognized religions. Suryadinata observes that this was related to the assimilation policy of the New Order Government for the Chinese. See Leo Suryadinata, "Kong Hu Cuisme dan Agama Kong Hu Cu di Indonesia: Sebuah Kajian Awal" in Abdurrahman Wahid et al., Konfusianisme di Indonesia: Pergulatan Mencari Jati Diri (Yogyakarta: Interfidei, 1995), 198-201.

38. For the account of the Hindu revival, see M. L. Lyon, "The Hindu Revival in Java: Politics and Religious Identity" in J.J. Fox, Indonesia: The Making of a Culture (Canberra: Research School of Pacific Studies, 1980), 205-220; for the account of Confucianism, see Leo Suryadinata, "Confucianism in Indonesia: Past and Present" Southeast Asia, an International Quarterly Vol. 3 (1974), 898. In addition, many of the Karo people in North Sumatera converted to Islam. See Muhammad Husin Hitam's letter to the editor, "Surat Da'wah dari Atjeh" in Pandji Masjarakat No. 19 (October, 1967), 9-10. Similarly, according to a Muslim leader in Makassar, Saleh Putuhena, after the coup, the ex-PKI in Makassar tried to intensify their commitment to Islam. Interview with Saleh Puhena, Makassar, 15 December 2002.

39. Compared with the previous years, however, this increase was not spectacular. There was a $5.28 \%$ increase in $1964 / 65$ and $5.60 \%$ in $1965 / 66$. The percentage calculation is derived from the numbers provided in A.G. Baan, Ichtisar Statistik Tentang Geredja Katolik di Indonesia: 1949-1967 (Lembaga Penelitian dan Pembangunan Sosial, 1968), Table 56. 
40. Baan., Ichtisar Statistik, 11.

41. Anonymous, Sedjarah Geredja Katolik di Indonesia (Djakarta: Sekretariat Nasional K.M./ C.L.C, 1971), 149. The book is one of the serials provided for Catholic Cadre Training.

42. Most of the ethnic churches, if not all, joined the DGI from the very beginning, while some other churches, especially the Evangelical and Pentecostal ones, joined the DGI later or remain outside. According to a survey held by the DGI, in 1972, the members of the churches outside the DGI comprise $10.42 \%$ of the total number of Christians in Indonesia. See F. Ukur and F.L. Cooley, Jerih dan Juang: Laporan Nasional Survai MenyeIuruh Gereja di Indonesia (Jakarta: Lembaga Penelitian dan Studi DGI, 1979), 94-114. In 1974, the Evangelical churches established their own organization, namely the Indonesian Evangelical Fellowship (Persekutuan Injili Indonesia, PII). The churches under the DGl were then considered 'ecumenical' in contrast to the 'evangelical' churches under the PII. See David H. Tulaar, "You Must Be Born Again: A Preliminary Study of Evangelicalism in Indonesia" (Masters Thesis, Faculty of Theology, University of Amsterdam, 1997).

43. T.B. Simatupang, "The Situation and Challenge of the Christian Mission in Indonesia Today" South East Asia Journal of Theology Vol. 10 No. 4 (1969), 22. For a comparative study of religious conversion of two ethnic groups, see my article "Religious Conversion in Indonesia: the Karo Batak and the Tengger Javanese" Islam and Christian Muslim Relations No.1 Vol. 12 (January, 2001), 23-38. It is noteworthy that some of the Chinese also converted to Christianity from Confucianism or Buddhism because they wanted to dissociate themselves from something that can be related to China and Communism. An Indonesian Chinese scholar told me that when he was a child, he saw that his father looked very sad with tears in his eyes when he was burning some of his religious books. When he became older, he eventually understood that his father was sad because the latter, for certain reasons, had to leave his 'Chinese' religious tradition and convert to Christianity (Interview in Surabaya, 7 January 2004).

44. Ukur and Cooley, Jerih dan Juang, 198. An American missionary of Baptist Church background claims that between 1965 and 1971, there were more than 2 million people in Java converted to Christianity. See Avery T. Willis, The Indonesian Revival: Why Two Millions Came to Christ (South Pasadena: William Carey Library, 1977). This figure appears to be exaggerated.

45. Interview with Gerrit E. Singgih, Yogyakarta, 15 October 2002.

46. Ukur and Cooley, Jerih dan Juang, 102-104.

47. Despite the importance of the case, B.J. Boland only mentions the Meulaboh case in passing. See Boland, The Struggle of Islam, 180; 231.

48. For an analysis of the development of these parties up to the immediate period after the coup, see Paul Webb, Indonesian Christians and Their Political Parties, 1923-1966: The Role of Partai Kristen Indonesia and Partai Katolik (Townsville: James Cook University, 1978). After the coup, the PKI was removed from the Parliament. With the power stipulated in Soekarno's Letter of 11 March 1966 and strengthened by the MPRS's decree No. IX/1966, in January 1967, Soeharto appointed 108 new parliament members, raising the total to 350. See, Crouch, The Army and Politics in Indonesia, 216.

49. See Sinar Harapan, 17 June 1967; Kompas, 19 June 1967. Sinar Harapan is a daily newspaper, appears in the afternoon, commonly associated with the Protestants. Kompas is a morning daily newspaper, commonly associated with the Catholics. However, a Catholic publication in 1971 resented that Kompas did not like to be considered as the voice of the Catholics anymore. See Anonymous, Sedjarah Geredja Katolik, 144. In fact, 
besides the 'liberal' Muslims, up to now many Catholic intellectuals, including some prominent priests, still often contribute their articles to Kompas.

50. PRRI is 'Pemerintah Revolusioner Republik Indonesia' (Revolutionary Government of Indonesia), an anti-Soekarno uprising centred in Sumatra 1958-61.

51. By 1973, there was an effort of the Muslims to revive the case, but again it failed to attract Government's attention. See Anonymous, Christianization in Indonesia: A Preliminary Study (Jakarta: Lembaga Islam Untuk Penelitian dan Pengembangan Masyarakat, 1980), 41-2.

52. Sinar Harapan, 22 June 1967.

53. Sinar Harapan, 27 June 1967. Likewise, a Muslim Aceh figure, Teuku Abdullah Basir, came to the Sinar Harapan office to ask the editor not to exaggerate the case. The editor replied that the case needed serious attention because it touched the principle of religious freedom. Sinar Harapan, 29 June 1967.

54. Sinar Harapan, 14 June 1967. The speaker was Samuel S. Parantean, the secretary of the Body of Christian Worship Organizers (Badan Penyelenggara Kebaktian Kristen) in the student action committee Laskar Ampera Arief Rachman Hakim.

55. There were 25 people from various Islamic organizational backgrounds who signed the Parliamentary Question. See Kiblat, No. 5 (August, 1967), 31. See also Pandji Masjarakat No.14 (July, 1967), 13. Kiblat and Pandji Masjarakat were two important Islamic magazines, managed by the reformist Muslims but the traditionalist Muslims were also among their subscribers.

56. Interview with Harry Tjan Silalahi, Jakarta, 22 December 2003.

57. See "Interpelasi Peristiwa Meulaboh, Kabupaten Atjeh Barat oleh Anggota DPRGR, JCT Simorangkir" Microfilm No. 2145/71, KITLV Library, Leiden. In Saifuddin Zuhri's autobiography, there is a reprint of Simorangkir's speech, but it is not complete. See Zuhri, Berangkat Dari Pesantren, 568-570. Saifuddin Zuhri made a few mistakes regarding the dates of events around the Parliamentary Question and did not mention Lukman Harun's Parliamentary Question at all.

58. Aceh province was decided to be a special territory in Indonesia since 1959. One of the specialties is its 'Islamic' character. Aceh is often proudly labeled as 'the verandah of Mecca.' Boland observes that "for an Atjehnese himself, being an Atjehnese is equivalent to being a Muslim; it is simply inconceivable that a real Atjehnese could adhere to a religion other than Islam." See Boland, The Struggle of Islam, 174.

59. The use of the phrase 'prologue to Gestapu/PKI' is in the original.

60. According to Sinar Harapan, since 8 April there had been intimidations of the Christians in Southeast Aceh and on 17 April, the Council of Ulama of West Aceh demanded that Christian churches in Aceh to be closed. On 20 April there was an effort to destroy a Methodist Church but this was able to be prevented by the police. See Sinar Harapan, 9 and 13 June 1967.

61. This is to be discussed below.

62. Interpelasi Peristiwa Meulaboh Kabupaten Atjeh Barat. These questions are also fully quoted in Saifuddin Zuhri, Berangkat dari Pesantren, 568.

63. See Kompas, 2 June 1967.

64. See the full text of the speech, "Pidato Drs. Lukman Harun di Hadapan Sidang Pleno DPRGR Tanggal 21 Juli 1967 Sebagai Pendjelasan Mengenai Interpelasi Tentang 'Bantuan Luar Negeri Kepada Agama2 Atau Badan2 Keagamaan di Indonesia", Kiblat No. 6 (August, 1967), 13-15.

65. Lukman did not mention Buddhism and Confucianism here even though both were officially recognized by the Government. Perhaps, he considered them too small to be sig- 
nificant or because of their strong association with Chinese identity. Lukman, however, mentioned Balinese Hinduism. Perhaps he considered the latter an important religious minority and expected that the Hindu leaders also shared the fear of the Christian missionary activities.

66. See"Interpelasi Dalam DPRGRTentang Bantuan Luar Negeri kepada Agama2 atau Badan2 Ke-Agamaan di Indoensia," Kiblat No.5 (Agustus, 1967), 25.

67. In the original: "hal tersebut sangat menusuk perasaan mereka." Saifuddin Zuhri, "Keterangan Pemerintah Tentang Peristiwa Geredja di Atjeh Barat"Kiblat, No.5 Vol.5 (August 1967), 16. The text of the speech is also printed in Zuhri, Berangkat dari Pesantren, 570576.

68. This may be a strong clue that the Christians who built the church in Meulaboh were people of Batak ethnic background. Most of the important Protestant leaders in Jakarta who spoke about the Meulaboh case were also Bataks such as T.B. Simatupang, A.M. Tambunan and J.C.T Simorangkir.

69. "Keterangan Pemerintah Tentang Peristiwa Geradja di Atjeh Barat," 17. Emphasis added.

70. For a complete text of Saifuddin Zuhri's response, see "Keterangan Pemerintah Sebagai Djawaban Terhadap Interpelasi Drs. Lukman Harun dkk Soal Bantuan Luar Negeri Kepada Agama2 atau Badan2 Keagamaan di Indonesia" Kiblat No.7 (September, 1967), 4-5; 9.

71. See Sinar Harapan, 29 July 1967 and Kompas, 31 July 1967.

72. See Pidato Kenegaraan Pd. Presiden Republik Indonesia Djenderal Soeharto di Depan Sidang DPRGR, 16 Agustus, 1967 (Jakarta: Doa Restu, 1967), 25. Compare with the statement of the Indonesian Council of Churches on religious freedom in this period in S.A.E. Nababan, Panggilan Kristen Dalam Pembaharuan Masjarakat: Laporan Konperensi Nasional Geredja dan Masjakarat (Jakarta: BPK, 1986), 30.

73. Pidato Kenegaraan, 26. Italics mine.

74. Pidato Kenegaraan, 26.

75. In response to Lukman's Parliamentary Question, the DGI was reported to state this argument. See "Pantjasila Milik Semua Agama” in Kiblat No.6 Vo. 15 (August, 1967), 11. I could not find the Christian original source (it seems from Sinar Harapan) quoted in the magazine.

76. Interview with Harry Tjan Silalahi, Jakarta, 22 December 2003.

77. The letter can be found in the documents of Interpelasi Peristiwa Meulaboh. For a published edition of the letter, see "Interpelasi JCT. Simorangkir dkk." Ragi Buana No. 44 (September, 1967), 26-27. For the account of the plenary session of the Parliament, see "Simorangkir dkk. Mundur" in Pandji Masjarakat No. 18 (September, 1967), 6.

78. The whole text of the message is published in Ragi Buana No. 44 (September 1967), 32.

79. For Lukman Harun's speech, see"Kesulitan Ekonomi Jg Diderita Rakjat Indonesia Dipakai Kristen Untuk Mengekspansi Ummat Islam" Kiblat no. 15 and 16 (January, 1968), 21-22 and 12-13;37.

80. Perhaps, due to its unusual contents, Dachlan's speech was not published in the Muslim magazines but in the Catholic one. See the full text of Dachlan's speech under the title, "Menteri Agama Djawab: Pemerintah Jakin, Kegiatan Agama adalah Positif" Peraba (IV, September 1968), 6-8. For an expression of Muslim disappointment, see Rusjdi, "Nasib Interpelasi Lukman Harun dan Nasib Umat Islam" Pandji Masjarakat No. 33 (September, 1968), 3-4.

81. Kompas, 4 October 1967. 
82. See "Fakta Sebab Musabab Peristiwa Makassar" in Kiblat No. 10 (October, 1967), 47 and Pandji Masjarakat No. 19 (October, 1967), 25. See also HAMKA, "Peristiwa Makassar" Pandji Masjarakat No. 20 (October, 1967), 3-4. For the Christians' disapproval of Mangunbahan's statement, see Kompas, 5 October 1967.

83. Boland, The Struggle of Islam, 230. The General Assembly was actually planned more than a year before in a meeting of the important leaders of the DGI in February 1966, in Sukabumi. For the records of the meeting, see Tengoklah, Aku Djadikan Semuanja Baru, Vol. 1 and 2 (Djakarta: Badan Penerbit Kristen, 1967). The title of the book is the Indonesian translation of "Behold I make all things new" (Rev. 21:5). The word 'baru' (new) is certainly parallel with the idea of 'orde baru' (new order).

84. See Peraba No. 30 (25 October 1967), 5-7. This account is quoted verbatim in Wendelin Wawer, Muslime und Christen in der Republik Indonesia (Wiesbaden: Franz Steiner Verlag, 1974), 226-8.

85. Kiblat No. 10 (October, 1967), 48-9.

86. See "Persitiwa Makassar" Duta Masjarakat, 6 October 1967.

87. Kompas, 6 October 1967.

88. See "Pemberontakan thd Pantjasila" Basis No. 2 Vol. 17 (November, 1967), 62. In line with this criticism, Paget observed that "the local and regional military commanders (since replaced) did little to forestall or suppress them, and soldiers participated with the Islamic student organizations in some of the attacks." See Paget, "The Military in Indonesian Politics", 311.

89. See the editorial entitled "Itikad Baik Kita Semua" Kompas, 9 October 1967.

90. T.B. Simatupang, "Tjatatan Perdjalanan: Mengunjungi 4 Daerah dgn Tjiri jg Chas" Ragi Buana No. 45 (October, 1967), 9.

91. J.C.T Simorangkir, Manuscript Sejarah Parkindo (Jakarta: Yayasan Proklamasi, 1989), 9495.

92. See Pandji Masjarakat No. 20 (October, 1967), 5-6 quoting Sinar Harapan, 9 October 1967.

93. Olaf Schumann, "Suatu Pengamatan Tentang Hubungan Antar umat Beragama di Indonesia Dilihat dari Sudut pandang DGI" in J.M.Pattiasina and Weinata Sairin (eds.), Gerakan Oikomene, Tegar Mekar di Bumi Pancasila (Jakarta: BPK Gunung Mulia, 1990), 276.

94. See Simatupang, "The Situation and Challenge", 25 ; and "Hasil-Hasil Sidang Lengkap DGI ke IV" Berita DGI (February, 1968), 30-1.

95. "Pesan Sidang Lengkap DGI dari Kota Makassar" Ragi Buana No. 47 (December, 1967), 19.

96. See T.B. Simatupang, Membuktikan Ketidakbenaran Suatu Mitos (Jakarta: Sinar Harapan, 1991), 241.

97. He was appointed to replace Saifuddin Zuhri on 11 October 1967, when the Makassar incident was still hotly discussed. Dachlan was among a few Muslim traditionalists who joined the Democratic League to oppose Soekarno's Guided Democracy, while Saifuddin was very close to Soekarno. For the biography of Dachlan, see Kamal Muchtar, "K.H. Mohammad Dachlan: Departemen Agama di Masa Awal Orde Baru" in Azyumardi Azra and Saiful Umam (eds.), Menteri-Menteri Agama RI, Biograpi Sosial Politik (Jakarta: INIS, 1998), 245-67. For Dachlan's political role, see Bruinessen, NU, Tradisi, 75;90-91.

98. See Kiblat No. 14. Vol. 15 (December, 1967), 46-47.

99. C.A.O van Nieuwenhuijze, "Religious Freedom in Indonesia" The International Review of Mission Vol. 40 (1951), 99-100.

100. According to the account of the Christians, the draft of the Charter that was to be discussed in the Consultation contained four alternative formulations. It seems, all of 
them could be considered as either a support to the Christian position on 'religious freedom' or to the Muslim position on 'restriction of proselytization'. Muslim accounts of the Consultation usually did not refer to these alternative formulations, while the Christian accounts usually mentioned them as an entirely Government proposal. See L. Soebijat, "Kristen Katolik Jang Salah!?" Peraba (25 February 1968), 3; and "Tinjauan Mengenai Keputusan Menteri Agama Nomor 70 dan 77 Tahun 1978 dalam Rangka Penyelenggaraan Kebebasan Beragama dan Pemeliharaan Kerukunan Nasional" in Sairin, Himpunan Peraturan, 455-6.

101. See "Sambutan Pedjabat Presiden Republik Indonesia" al-Djami'ah, No. 3 (May, 1968), 7-8 with slight alteration. All speeches in the Consultation are printed in this issue of the journal. Al-Djami'ah is an academic journal published by the State Institute of Islamic Studies (IAIN) Sunan Kalijaga, Yogyakarta. B.J. Boland made a summary of the speeches delivered in the Consultation, see, Boland, The Struggle of Islam, 234-237. However, he does not explore further the discursive strategies of the Muslim-Christian discourse.

102. See"Pidato Sambutan Dr. A.M. Tambunan SH," al-Djami'ah, No. 3 (May, 1968), 19. Tambunan's speech was also published under the title "Dalam Agama Tidak Ada Paksa" in Ragi Buana No. 47 (December, 1967), 2-7.

103. "Pidato Sambutan I.J.Kasimo" al-Djami'ah, No. 3 (May, 1968), 23-24.

104. "Sambutan Menteri Nagara Kesra." al-Djami'ah, No. 3 (May, 1968), 9.

105. "Pidato Sambutan K.H.Masjkur" al-Djami'ah, No. 3 (May, 1968), 33-34.

106. "Pidato Sambutan Dr. H.M. Rasjidi" al-Djami'ah, No. 3 (May, 1968), 35-36.

107. "Pidato Sambutan Dr. H.M. Rasjidi", 41.

108. "Pidato Sambutan Dr. H.M. Rasjidi", 41.

109. "Pidato Sambutan Dr. A.M. Tambunan,", 20.

110. M. Natsir, "Missi dan Zending Mendjadikan Umat Islam sebagai Sasarannja" al-Djami'ah, No. 3 (May, 1968), 45.

111. "Pidato Sambutan I.J. Kasimo", 24.

112. "Pidato Sambutan I.J. Kasimo", 26.

113. This was related to the Muslim accusation of the Christian plan to Christianise Java in 20 years and Indonesia in 50 years. It initially appeared in 1963 in the Muslim magazine, Suara Muhammadiyah No. 25 (1963), 5. The magazine published a document allegedly produced by both Catholic and Protestant leaders in a meeting held in Malang, East Java, in 1962. The document stated that the Christians would use various ways to convert Muslims: through education, health care services, inter-religious marriage etc. The document is quoted at length in Wawer, Muslime und Christen, 219. When the Muslim-Christian tensions increased in 1967, this issue became hot again. It is noteworthy that, although the leaders of the mainstream Christians denied this accusation, some of them whom I interviewed recognised that there had been a few marginal Christian sects obsessed with Christianising Indonesia within a certain period of time.

114. "Pidato Sambutan Dr. A.M. Tambunan", 22.

115. "Pidato Sambutan Dr.H.M. Rasjidi", 42.

116. The "la conquête du monde musulman" is a description of the Protestant missionary activities in the Muslim world. It attracted some Arab intellectuals and it was soon translated into Arabic by Muhib al-Dīn al-Khatīb and published in al-Muayyad newspaper in Egypt under the title al-Ghära 'Ala al-'Ālam al-Islämī. The translation attracted a wider Muslim public in the Middle East and was therefore published in al-Manär in Egypt and al-Ittihād al-'Uthmānī, a newspaper published by the young Turk association, Jam'iyya al-Ittihād wa al-Taraqqi, based in Beirut. The whole translation and the Muslim 
polemics with the editors of La Revue du Monde Musulman were published in A. Le Chatelier, al-Ghāra 'Ala al-'Ālam al-Islämì (Cairo: al-Matba'a al-Salafiyya, $1350 \mathrm{H}$ ).

117. Muhammad Rasjidi, Sidang Raya Dewan Gereja Sedunia di Jakarta 1975 Merupakan Tantangan Terhadap Dunia Islam (Jakarta: Dewan Dakwah Islamiyah Indonesia, 1974), 26; 46; 52-4.

118. Mohammad Natsir, "Suara Adzan dan Lontjeng Geredja 'Islam' Dalam Conferentie Zending 1938" in his Islam dan Kristen di Indonesia (Jakarta: Bulan Bintang, 1969), 49. Rasjidi said that he read the third edition of the book, published in 1956. See Rasjidi, Sidang Raya, 52. Kraemer views Islam as a superficial religion that believes in a far away transcendent God. Moreover, in the tone of the Durkheimian sociology of religion, Kraemer said that Muslims are bound together by mechanical solidarity, which often hinders Christianization efforts. See his Christian Message in a Non-Christian World (London: Edinburgh House Press, 1938) 215-26;353-365. For a summary of Kraemer's views, see Karel A. Steenbrink, Dutch Colonialism and Indonesian Islam: Contacts and Conflicts 1596-1950 (Amsterdam: Rodopi, 1993), 111-3.

119. Kiblat No. 14 (December, 1967), 47. See also "Hasil-Hasil Musyawarah Antar Agama" alDjami'ah Vol.7 (May, 1968), 47.

120. Rosihan Anwar, "Prof. Dr. H.M. Rasyidi Pengungkap Gamblang Hubungan Antaragama di Indonesia" in Endang B. Ananda (ed.), 70 Tahun Rasyidi (Jakarta: Harian Umum Pelita, 1985), 156-157. In his personal account of the meeting, T.B. Simatupang said that the discussion was very emotional. As a Christian, he argued that he could not deny the command of Christian Scripture to spread Christianity to the whole world. Even if he and other Christian representatives were ready to sign the proposed agreement, it would not be followed by the Christian public because they knew that it was against Scripture. On this hot debate, a Muslim representative suggested that both Muslims and Christians could make a simple joint statement saying that they could accept what had been said by the President in his speech. Having realized that it was a 'clever' move, Simatupang rejected the suggestion by arguing that to accept the speech of the president was a bad culture of the Soekarno's Old Order! See his Membuktikan Ketidakbenaran Suatu Mitos, 243-4. It is noteworthy that similar disputes also occurred in inter-religious meetings at provincial levels. See for instance the cases in West Java in Jan Aritonang, Perjumpaan Islam dan Kristen di Indonesia (Jakarta: BPK Gunung Mulia, 2004), 392-4; and Banjarmasin, in P.W. PIl, Kristenisasi di Kalimantan Selatan (Peristiwa 'Saloh' Dengan Rangkaian Sekitarnya) (Banjarmasin: P.W. PII, 1969).

121. See "Sekitar Musjawarah Kerukunan Agama" Basis No. 4 Vol. 17 (January, 1968), 123-4.

122. HAMKA, "Musyawarah Antar Agama Tidak Gagal", Pandji Masjarakat No. 21-22 (December, 1967), 3-6.

123. See "Menteri Agama K.H.M. Dachlan: Ada Jang Mau Ganti Agama Islam dengan Agama Mereka" Antara, 7 December 1967, reprinted in Panji Masjarakat No. 21-22 (December, 1967), 12.

124. For the text of the Islamic groups'statement, see Pandji Masjarakat No. 21-22 (December, 1967), 34 and Kiblat No. 15 (January, 1968), 20.

125. See "Sekitar Musjawarah Kerukunan Agama" Basis No. 4 Vol. 17 (January, 1968), 124.

126. Article 18 is: "Everyone has the right to freedom of thought, conscience and religion; this right includes freedom to change his religion or belief, and freedom, either alone or in community with others and in public or private, to manifest his religion or belief in teaching, practice, worship and observance." 
127. See Rahmat Subagya (J.W.M. Bakker), Pantjasila Dasar Negara Indonesia (Yogyakarta: Basis, 1955), 51-4. See also J.C.T. Simorangkir and Ben Mang Reng Say, Tentang dan Sekitar Undang-Undang Dasar 1945 (Jakarta: Djambatan, 1975), 86-88.

128. For the account of the symposium, see Kompas, 15-19 June 1967.

129. See "Seminar Hak Azasi Manusia" Basis No. 3 Vol. 17 (December, 1967), 97. See also Eddy Damian (ed.), Prasaran, Pembahasan dan Kesimpulan Seminar Hak-Hak Asasi Manusia di Bandung, The Rule of Law dan Praktek2 Penahanan di Indonesia (Bandung: Alumni, 1968).

130. Kompas, 17 June 1967.

131. See T.B. Simatupang, "Sumbangan Agama Terhadap Hak-Hak Asasi Manusia" printed in his Dari Revolusi ke Pembangunan (Jakarta: BPK, 1987), 49-54. Likewise, in the Conference on Church and Society held in June 1967, the DGI asserted that, "the article on religious freedom in our Constitution should explicitly include the freedom to change religion responsibly." See Nababan, Panggilan Kristen, 30.

132. See Muhammad Rasjidi, "Kebebasan Beragama" Kiblat No. 7 (September, 1967), 19-21.

133. For a Muslim account of the deadlock, see "Tak Ada Pintu Untuk Pemurtadan Agama" in Kiblat No. 21 (April, 1968), 4-5; 50-51. For a Catholic account, see "Gagal ?? Berhasil ??" Praba (25 March 1968), 3-4 and "Piagam Hak-hak Azasi Manusia Didjungkir Balikkan!" Praba (25 April 1968), 5;12. For a thorough political analysis of the MPRS session, see Herbert Feith, "Suharto's Search for a Political Format" Indonesia No. 6 (October, 1968), 88-105.

134. See for instance, HAMKA, Hak2 Azazi Manusia Antara Deklarasi PBB dan Sjari'at Islam (Djakarta: Pandjimas, 1971), 9-12; 16-25. In addition, HAMKA could not also accept the article 16 of the UDHR that opens the door for inter-religious marriage. He said, Islam does not allow a female Muslim to marry a male Christian. See also Chapter 4.

135. Karel A. Steenbrink, "Christian Faith in an Indonesian Environment" Exchange, No.5 (1973), 19.

136. For an analysis of the political development concerning the reformist Muslim party during this period, see Allan A. Samson, "Army and Islam in Indonesia" Pacific Affairs, Vol. 44 No.4 (Winter, 1971-1972), 551, note 8. See also his "Islam in Indonesian Politics," Asian Survey, Vol. 8 No. 12 (December, 1968), 1001-1017 and Kenneth Ward, "Some Comments on Islamic Reactions to Recent Developments in Indonesia" Review of Indonesian and Malaysian Affairs Vol.2 No.2 (1968), 37-46a.

137. Yusril Ihza Mahendra, "Combining Activism and Intellectualism: The Biography of Mohammad Natsir" Studia Islamika Vol. 2 No. 1 (1995), 129. It seems to mean that the final goal of the $d a^{\prime} w a$ is still to control the state. The difference is just that the Islamization of society should come before, rather than after, the Islamization of the state.

138. M. Natsir, "Fungsi Da'wah Dalam Rangka Perjuangan" in Kiblat No. 24 (May, 1968), 8.

139. Natsir, "Fungsi Da'wah", $9 ; 44$.

140. Idham Chalid, "Operasi Dakwah" in Kiblat No. 24 (May, 1968), 45.

141. Parallel with the al-Ghära 'Ala al-'Álam al-Islämī cited above, the book is entitled Ghära Tabshïriyya Jadīda 'Ala Indūnīsiyā (New Missionary Invasion of Indonesia) published by al-Dār al-Kuwaitiyya, 1968. In the first edition of the book, the author was anonymous. The second edition, however, has a pseudonym: Abū Hilāl al-Indūnīsy, published by Dār al-Shurūq, 1984.

142. Simatupang, "The Situation and Challenge", 25.

143. Simatupang, "The Situation and Challenge", 15.

144. See his introduction to Anonymous, Sedjarah Geredja Katolik, 6-7.

145. See his "The Situation and Challenge", 24-25. 
146. A.J.M. Pusposupadmo, “Harus Bagaimana? Panennja Melimpah, Pekerdja Kurang” Penabur No. 13 (August, 1969), 196-7.

147. Steenbrink, "Christian Faith", 7-15.

148. In contrast, such a sympathetic attitude was hardly found among the Indonesian Muslim leaders. Boland observes that one of the few Muslims who had sympathy with the Communists' misery was the well-known Indonesian writer, Bahrum Rangkuti. See Boland, The Struggle of Islam, 144.

149. Nababan, Panggilan Kristen, 32-33.

150. See the document entitled, "Pernjataan Geredja Katolik di Indonesia Mengenai Beberapa Masalah Penting di Tanah Air." I thank Father Ismartono for giving me a copy of this document. As has been noted earlier, in Flores, 1966, there was opposition from a priest in the region to the army's operations against the Communist suspects. However, as an institution, the Catholic Church in the region could do nothing but wait a 'formal call' from Jakarta on this issue. In this regard, it seems that the Cardinal's call in 1969 was rather late. For this institutional reason, see John Prior, "Terobosan Pastoral Di Tengah Badai Zaman" in da Cunha, Berpastoral di Tengah Badai, 206-212.

151. Interview with Paul de Blot, Nyenrode, 22 July 2003. In contrast, Rasjidi claimed that a family of the prisoners told him that this kind of help would not be given unless the prisoner and his or her family converted to Catholicism. See "Pidato Sambutan Dr.H.M.Rasjidi", 38.

152. Aritonang, Sejarah Perjumpaan, 413-4. Aritonang, however, does not mention specifically what the socio-economic supports were.

153. None of the Muslim writings and speeches quoted above mentioned the term "Kristenisasi". Mohammad Natsir used the term "pengkristenan," while Lukman Harun used the clause "memurtadkan ummat Islam". I found an early example of using the term "Kristenisasi" in the title of a media report, "Ummat Islam Flores Timur Tolak Kristenisasi" Kiblat No. 10 (October, 1968), 20-1. The term "Kristenisasi" apparently has been more in usage since 1970s.

\section{Notes Chapter 2}

1. 1. See "Gudang SD. Katolik Dibakar" and "Geredja di Asahan Dibakar" Peraba (I September, 1968), 6. In October 1968, the same magazine reported that due to Muslim opposition, a plan to establish a new building for a Catholic foundation in Madiun was postponed. See "Berita dari Madiun: Badan2 Hukum Katolik Tak Punja Hak Hidup?" Peraba (IV October, 1968), 6.

2. See the interview in Mimbar Demokrasi No. 85 (May, 1969) reprinted in Muhammad Natsir, Mencari Modus Vivendi Antar Ummat Beragama (Jakarta: Media Dakwah, 1980), 224.

3. See "Tjatatan" and "Dirusak" in Peraba No. 16 (April IV, 1969), 1-3.

4. See "Catatan" and "Dirusak" in Peraba and also "Ekor dari Peristiwa Slipi" Kiblat No. 4 (July, 1969), 31.

5. See "Keputusan Bersama Menteri Agama dan Menteri Dalam Negeri No. 1/BER/MDNMAG/1969 Tentang Pelaksanaan Tugas Aparatur Pemerintahan Dalam Menjamin Ketertiban dan Kelancaran Pelaksanaan Pengembangan dan Ibadat Agama oleh Pemeluk-Pemeluknya" in Weinata Sairin (ed.), Himpunan Peraturan di Bidang Keagamaan (Jakarta: BPK, 1994), 3-6. 
6. See Ragi Buana No.69 (October, 1969), 38-40. The Muslim magazine, Kiblat, also published the text of the decree but without any comment. See Kiblat No. 10 (October, 1969), 38.

7. See "Memorandum" in Sairin, Himpunan Peraturan, 443. Italic is original.

8. "Memorandum" in Sairin, Himpunan Peraturan, 444-6.

9. For the texts of the telegrams and the letter, see Sairin, Himpunan Peraturan , 447-52.

10. For some examples of Muslim protests in West Sumatera, South Sumatera, Jakarta, West Java and Yogyakarta regions see Lukman Hakiem (ed.), Fakta \& Data Usaha-Usaha Kristenisasi di Indonesia (Jakarta: Media Dakwah, 1991), 79-85; 99-100; 134-41; 147-51; 160 $1 ; 182-6$.

11. See Aula: Majalah Nahdlatul Ulama (November, 1996), 21.

12. See Paul Tahalele and Thomas Santoso (Eds.), Beginikah Kemerdekaan Kita? (Surabaya: FKKS, 1997), 189. The Situbondo incident is discussed in Chapter 6.

13. Interview with Thomas Santoso, Surabaya, 7 January 2004.

14. Gerrit E. Singgih, "Contextualisation and Inter-Religious Relationship in Java: Past and Present" The Asian Journal of Theology Vol. 11 No. 2 (October, 1997), 257.

15. In his criticism of the decree, one of the leaders of the PGI, Weinata Sairin, said that according to some reports, Muslims had difficulties to establish a mosque in Bali (Hindu majority area) and East Timor (Catholic majority area). Interview in Jakarta, 19 December 2003.

16. Singgih, "Contextualisation and Inter-Religious Relationship", 258.

17. T.B. Simatupang, Membuktikan Ketidakbenaran Suatu Mitos (Jakarta: Sinar Harapan, 1991), 86-98;131-47;162-83. The disagreement occurred in a meeting between Soekarno and the army leaders, including Simatupang, on 17 October 1952 concerning Soekarno's move to remove A.H. Nasution from his position as the Army Chief Staff. For a short biography of Simatupang in English, see Frank. L. Cooley, "In Memoriam:T.B. Simatupang, 1920-1990" Indonesia No. 49 (1990), 145-52.

18. For his biography, see "Menjambut Hari Lahir Jang ke-70 dari Prof.Dr. S.T.G.Mulia" Ragi Buana No. 24 (January, 1966), 3-8; 86. For his biography leading to independence period, see Gerry van Klinken, Minorities, Modernity and the Emerging Nation (Leiden: KITLV, 2003), 68-81.

19. Simatupang, Membuktikan Ketidakbenaran, 14-17; 196-205.

20. Simatupang, Membuktikan Ketidakbenaran, 253.

21. "Rencana Untuk Sidang Raya WCC di Jakarta Ditegaskan Kembali" Berita Oikoumene Vol. 1 No. 9 (September, 1973), 4-5. Later the budget was increased to $\$ 1,400,000$, See Berita Oikoumene Vol. 2 No.8 (August, 1974), 3.

22. Sinar Harapan, 14 December 1973. See also"Dari Edinburgh ke Jakarta"Berita Oikoumene Vol.2 No. 3 (March, 1974),1-5; "Karena Keunikan Saja" Tempo (20 July 1974), 7.

23. SeeT.B.Simatupang et. al., Buku Persiapan Sidang Raya Dewan Gereja-Gereja Seduia Tahun 1975 (Jakarta: BPK Gunung Mulia, 1974), 11-41.

24. See "Berita dan Komentar" Panji Masyarakat No. 149 (April, 1974), 6-7.

25. See"PPMuhammadiyah dan Konferensi Dewan Gereja Sedunia"in Suara Muhammadiyah No. 10 (May, 1974),3. For a complete text of the letter, see Panji Masyarakat No. 155 (July, 1974), 12.

26. Suara Muhammadiyah No. 7 (April, 1974), 1 and No. 15 \& 16 (August, 1974), 7; Panji Masyarakat No. 153 (June, 1974), 31.

27. For the Malari affair, see Harold Crouch, The Army and Politics in Indonesia (Cornell: Cornell University Press, 1978), 312-17; Hamish MacDonald, Suharto's Indonesia (Honolulu: The University Press of Hawaii, 1981), 136-40. 
28. On the CSIS, see Chapter 3.

29. See Djarnawi Hadikusuma, "Kristenisasi di Indonesia: Kekuatan dan Kelemahannya", Suara Muhammadiyah No. 13, 14, 15\&16, and 17 (July, August and September, 1974).

30. Suara Muhammadiyah, No. 13 (July, 1974), 13.

31. Suara Muhammadiyah, No. 13 (July, 1974), 14.

32. Suara Muhammadiyah, No. 17 (September 1974), 16.

33. Mohammad Natsir, "Sekali Lagi Kerukunan Hidup Antar Agama: Sumbangsih Untuk Prof. Dr. Verkuyl" Panji Masyarakat No. 129 (June, 1973), 16-18. The same article was also published in Kiblat Vol. 21 No. 3 (July, 1973), 18-20;32.

34. Muhammad Rasjidi, Sidang Raya Dewan Gereja Sedunia di Jakarta 1975 Merupakan Tantangan Terhadap Dunia Islam (Jakarta: Dewan Dakwah Islamiyah Indonesia, 1974).

35. The article, written by Barbara Howeel, was translated into Indonesian and published initially during the controversy on the marriage bill in Abadi newspaper, 5 October 1973, then in Kiblat No. 11 (November, 1973), 17-18 under the title, "Meningkatnya Kristenisasi di Indonesia." The same translation was published again during the controversy on the WCC Assembly in Suara Muhammadiyah No. 8 (April, 1974), 12;15;22. For a specific response to Howeel's article, see A. Hassan Purwo, "Washington Post dan Kristenisasi di Indonesia", Suara Muhammadiyah No. 12 (June, 1974), 11;17;24. Purwo claimed that before converting to Islam, he was an assistant to a Christian missionary. He argued that Barbara was a missionary journalist who often exaggerated the success of the Christian missions. Based on the statistics provided by the Indonesian Christian newspapers, Sinar Harapan and Kompas in 1971, Purwo said that Howeel's account of the conversion of millions of people to Christianity after the coup was an exaggeration. More interestingly, Purwo said that Muslims would not be jealous of the success of the Christian social institutions such as schools, universities and hospitals because Muslims would also enjoy the services of these institutions. It seems to me that Purwo's view was a reflection of the ambiguity of the Muslim discourse on Christianization: it was portrayed as a real danger but at the same time it was not really a successful project to be afraid of!

36. In contrast, according to Simatupang, the objection of the Western countries to the Assembly was because they were afraid that it would legitimise the position of Soeharto's Government that had oppressed the progressive groups in the country. See his Membuktikan Ketidakbenaran, 254.

37. Rasjidi, Sidang Raya Dewan Gereja Sedunia, 61-3.

38. Yusuf A. Puar, "Karir Internasional Natsir Dalam Muktamar dan Rabithah" Panji Masyarakat No. 242 (March, 1978), 12-13.

39. Rusydi, "Sidang Raya Dewan Gereja Sedunia di Indonesia dan Pengislaman Massal di Malaysia" Panji Masyarakat No. 155 (July, 1974), 10-12; Azkarmin Zaini, "Malaysia dan Masa Depan Kerjasama Islam" Suara Muhammadiyah, No. 15\&16 (August, 1974), 13;289.

40. According to Shamsul A.B., some of these courses were held in Malaysia by the Indonesians. There were also a few groups "consisting mainly of potential leaders, went to Indonesia to attend courses of one month's duration." Shamsul said that he was one of them. The contacts with the Indonesians were very important at least to 1973. Since 1974 when the Malaysian Government started sending Malaysian youth to study abroad, especially in the English speaking countries, contacts with the Muslims of Pakistan, Libya, India, Iran and Saudi Arabia had significantly developed. See Shamsul Amri Baharuddin, "A Revival in the Study of Islam in Malaysia" Man Vol. 18 No. 2 (1983), 401. 
41. See "90 Orang Indonesia Hadir Di Kongres Pekabaran Injil" Berita Oikoumene Vol. 2 No. 7 (July, 1974), 2-3.

42. According to a press account, in his action, Hasyim Yahya was accompanied by two other persons. Hasyim Yahya was badly injured in a fight against an army guard, while the two others escaped. A servant named Sakimin was also killed in the incident. Constable (64 years) had arrived in Jakarta three weeks before after serving a congregation in Isfahan, Iran. For a more detailed account of the incident, see "Terbunuhnya Sang Pendeta" and "Direktur Bersandal Jepit" Tempo (13 July 1974), 48-50; and "Pendeta Anglikan Dibunuh di Jakarta" Berita Oikoumene Vol.2 No.7 (July, 1974), 4-5.

43. Simatupang, Membuktikan Ketidakbenaran, 254.

44. Rusydi, "Sidang Raya Dewan Gereja Sedunia di Indonesia", 10. See also "Berita dan Komentar" in Panji Masyarakat No. 155 (July, 1974), 12-13.

45. According to Adian, Hasyim Yahya referred to the QS 2:190-1 which enjoins upon Muslims to fight against those unbelievers who are fighting against them. See Adian Husaini, Gereja-Gereja Dibakar: Membedah Akar Konflik SARA di Indonesia (Jakarta: Dea Press, 2000), 109;13; and Interview with Adian Husaini in Jakarta, 23 August 2002.

46. Simatupang, Membuktikan Ketidakbenaran, 255-6.

47. "SR Dewan Gereja Sedunia Mungkin Tak Jadi di Jakarta" Suara Muhammadiyah No.15\&16 (August, 1974), 7.

48. See "Rencana Sidang Raya DGD di Jakarta Dibatalkan" Berita Oikoumene Vol. 2 No.8 (August, 1974), 2-3.

49. Simatupang, Membuktikan Ketidakbenaran, 258.

50. "Pidato Presiden Tentang Agama" Panji Masyarakat No. 158 (September, 1974), 7.

51. "Berita dan Komentar" Panji Masyarakat No. 158 (September, 1974), 6.

52. "Sesudah Batalnya SR DGS Di Jakarta" Suara Muhammadiyah No. 17 (September, 1974),3.

53. A more detailed discussion on Mukti Ali is presented in Chapter 6 .

54. See A. Mukti Ali, "Religions, Nations and the Search for a World Community" in his Agama dan Pembangunan di Indonesia, Bahagian III (Jakarta: Biro Humas Depag RI, 1973), 223.

55. See "Memorandum" in Mukti Ali, Agama dan Pembangunan, Bahagian III, 33; 37. It is also published in International Review of Mission Vol. 61 No. 244 (October, 1972), 407-16.

56. See Ali Munhanif, "Prof. Dr. Mukti Ali, Modernisasi Politik Keagamaan Order Baru" in Azyumardi Azra \& Saiful Umam (eds), Menteri-Menteri Agama Rl: Biografi Sosial Politik (Jakarta: INIS-PPIM, 1998), 306.

57. Interview with Mukti Ali, Yogyakarta, 28 September 2002.

58. Sinar Harapan, 1 July 1976 and "Setelah Presiden Ke Salatiga" Tempo ( 10 July 1976), 5-7.

59. Original: "Mengagamakan orang yang sudah beragama adalah munafik." See Sinar Haparan, 2 July 1976.

60. Sinar Harapan, 13 July 1976.

61. Sinar Harapan, 5 July 1976.

62. HAMKA, "Mengagamakan Orang Yang Belum Beragama, Munafiq?" Panji Masyarakat No. 204 (August, 1976), 5-8.

63. See Arne Rudvin, "The Concept and Practice of Christian Mission", 381 and Isma'il R. alFaruqi, "On the Nature of Islamic Da'wa" International Review of Mission Vol. 65 No. 260 (October, 1976), 374-84; 391-400. Theological debates following each of these papers are quite interesting.

64. Lamin Sanneh, "Christian Experience of Islamic Da'wa with Particular Reference to Africa" International Review of Mission Vol. 65 No. 260 (October, 1976), 410-23. 
65. Muhammad Rasjidi, "The Role of Christian Missions, the Indonesian Experience" International Review of Mission Vol. 65 No. 260 (October, 1976), 425-38.

66. Rudvin, "The Concept and Practice of Christian Mission", 381.

67. See his "A Muslim Experience of Christian Mission in East Africa" in International Review of Mission Vol. 65 No. 260 (October, 1976), 442.

68. See International Review of Mission Vol. 65 No. 260 (October, 1976), 446.

69. See "Discussion on Religious Freedom" International Review of Mission Vol. 65 No. 260 (October, 1976), 447-8.

70. See "Discussion on Religious Freedom", 451.

71. See "Statement of the Conference on 'Christian Mission and Islamic Da'wah' Chambésy, June 1976" International Review of Mission Vol. 65 No. 260 (October, 1976), 456-9.

72. Ihromi, "Islam-Kristen Bertemu di Jenewa," Berita Oikoumene Vol. 4 (August, 1976), 30-1. See also Ihromi, "Hubungan Antaragama" in Endang Basri Ananda (ed.), 70 Tahun Prof. Dr. H. M. Rasjidi (Jakarta: Harian Umum Pelita, 1985), 171.

73. See "Laporan Prof. Dr. H.M. Rasjidi Tentang Konperensi Meja Bundar Da'wah Islam dan Missi Kristen di Geneva Tgl. 26-30 Juni 1976" Serial Media Dakwah No. 35 (1976), 2-18.

74. R.William Liddle,"Indonesia 1977:The New Order's Second Parliamentary Election,"Asian Survey Vol. 18 No. 2 (1978), 179.

75. See Julia D. Howell, "Indonesia: Searching for Consensus" in Carlo Caldarola (ed.), Religions and Societies: Asia and the Middle East (Amsterdam: Mouton, 1982), 530-4.

76. For the Muslim opposition see for instance, "PP Muhammadiyah: Tentang Rancangan GBHN dan Aliran Kepercayaan;"; "Bung Hatta: Kata'Kepercayaan' Penguat Kata 'Agama'”; "Majelis Ulama Tolak Aliran Kepercayaan," in Panji Masyarakar No. 234 (November 1977). See also, "Tap MPR 1973 dan Tap MPR 1978" Panji Masyarakat No. 245 (April, 1978), 7. See also Chapter 3.

77. For the text of the official reasons of the Islamic party, PPP, to oppose P4, see "Alasan Penolakan Partai Persatuan Tentang Rancangan Pedoman Penghayatan Pancasila," Panji Masyarakat No. 237 (December, 1977), 54-8.

78. See Alamsyah's biography, Suparwan G. Parikesit and Krisna R. Sempurnadjaja, H. Alamsjah Ratu Perwiranegara, Perjalanan Hidup Seorang Anak Yatim Piatu (Jakarta: Sinar Harapan, 1995), 243-6.

79. Parikesit and Sempurnadjaja, H. Alamsjah Ratu Perwiranegara: Perjalanan Hidup, 247.

80. Accordingly, in 1979 a directorate was established in the Department of Education and Culture called "Direktorat Pembinaan Penghayat Kepercayaan" and its first director was Arymurthy, the leader of the Sumarah mystical group. See Paul Stange, "Legitimate Mysticism in Indonesia" Review of Indonesian and Malaysian Affairs Vol. 20 No. 2 (1986), 91.

81. Certainly, there was personal rivalry among the leading Generals around Soeharto, especially between Alamsyah on the one hand and Ali Moertopo and Soedjono Hoemardani on the other. When Alamsyah was the Vice Chairman of the State Advisory Council, he had another rival: General T.B. Simatupang. The uneasy relationships between the two increased when Alamsyah became the Minister of Religion. Alamsyah claimed that T.B. Simatupang did not say hello to him for about seven years after he said to the public that Pancasila was a Muslim gift to the Indonesian state, while Hoemardani, since 1978 to his death never wanted to talk him. See Parikesit and Sempurnadjaja, H. Alamsyah. Ratu Perwiranegara: Perjalanan Hidup, 214-20; 283-4; 239;307-11. See also Crouch, The Army and Politics, 306-8.

82. See"Keputusan Menteri Agama No. 44Tahun 1978Tentang Pelaksanaan Dakwah Agama dan Kuliah Subuh Melalui Radio" in Sairin, Himpunan Peraturan, 69-70. 
83. For the Muslim responses to Alamsyah's moves, see "Masalah Da'wah Kembali Ke Departemen Agama" and "Da'wah dan Kuliah Subuh Lewat Radio Tak Perlu Izin," Panji Masyarakat No. 248 (June, 1978), 5-6; 9. See also, "Simakkan Alamsyah dan Langkahnya" Panji Masyarakat No. 257 (October, 1978), 10-13.

84. See "Jangan Bertepuk Sebelah Tangan (Wawancara Dengan Menteri Agama H. Alamsyah)" Panji Masyarakat No. 257 (October, 1978), 14-5.

85. SeeParikesitand Sempurnadjaja, H. Alamsyah.RatuPerwiranegara:Perjalanan Hidup, 2645 and H. Alamsyah Ratu Perwiranegara, Pembinaan Kerukunan Hidup Umat Beragama edited by Djohan Effendi (Jakarta: Departemen Agama, 1982), 79-92.

86. “Keputusan Menteri Agama Republik Indonesia No. 70 Tahun 1978 Tentang Pedoman Penyiaran Agama" in Sairin, Himpunan Peraturan, 50-1.

87. See“Keputusan Menteri Agama Republik Indonesia No.77 Tahun 1978 Tentang Bantuan Laur Negeri Kepada Lembaga Keagamaan di Indonesia," in Sairin, Himpunan Peraturan. 56-9.

88. See "Menteri Alamsyah Menjawab" Tempo (23 September 1978), 54.

89. Ratu Perwiranegara, Pembinaan Kerukunan Hidup Umat Beragama, 59-60. This'paternalistic' argument is also found in Muslim writings. See for instance, Muhammad Natsir, Mencari Modus Vivendi, 11;30-1.

90. See "Jangan Bertepuk Sebelah Tangan", 15.

91. See "Sebelum dan Sesudah Kedua Surat Keputusan Itu," and "Menteri Alamsyah Menjawab" Tempo ( 23 September 1978), 53-4.

92. See "Menteri Alamsyah Menjawab", 55. For a complete text of the MUl's statement supporting the decrees, see "Majelis Ulama Indonesia Dukung Keputusan Menteri Agama" Mimbar Ulama Vol. 3 No. 23 (September/October, 1978), 55.

93. See "Sebelum dan Sesudah Kedua Surat Keputusan Itu," 53 . Because this is a descriptive statement, it is unclear whether HAMKA agreed with the fanatic position or not.

94. "Sebelum dan Sesudah Kedua Surat Keputusan Itu," 53.

95. See "Seputar Keputusan Menteri Agama No. 70 \& 77 Tahun 1978 dan Prosesnya," Berita Oikoumene (November, 1978), 17-21. According to this report, before the issue of the decrees, Alamsyah had already explained in his speeches that religious propagation to people of different religion would be prohibited and that foreign aid for religious institutions would be controlled. He also invited religious leaders to come to a meeting on 30 June 1978; but one day before he cancelled it.

96. For the text of the press release, see "Siaran Pers DGI dan MAWI," Kompas,16 September 1978 and "DGI dan MAWI Tolak SK Menteri Agama No, 70 dan No. 77 Tahun 1978" in Berita Oikoumene (16 September, 1978), 7. For the spread of the press release, see the report in "Seputar Keputusan Menteri Agama No. 70 \& 77 Tahun 1978 dan Prosesnya," 19-20.

97. See "Pesan Sidang Istimewa BPL-DGl: Harus Dijaga Agar Kebebasan Tidak Bahayakan Kerukunan" Sinar Harapan, 21 October 1978 and reprinted in Hidup No. 41 (5 November 1978), 1124. See also “BPL-DGI Dukung Sikap Langkap BPH DGI - MAWI Mengenai SK Menteri Agama" and "Pesan Sidang Istimewa BPL-DGI 1978" Berita Oikomene (November, 1978), 4-7.

98. See "Tinjauan Mengenai Keputusan Menteri Agama No. 70 dan 77 Tahun 1978 Dalam Rangka Penyelenggaraan Kebebasan Beragama dan Pemeliharaan Kerukunan Nasional" in Sairin, Himpunan Peraturan, 453-76. See also T.B. Simatupang, "Catatan Tentang Kedua SK Menag" Berita Oikoumene (October, 1978), 3 and "Catatan Tentang Keputusan Menteri Agama No. 70/1978 Tentang Pedoman Penyiaran Agama" Berita Oikoumene (October, 1978), 16-17.

99. “Mengapa Mereka Resah?" Tempo (23 September 1978), 55-7. 
100. Ihromi, "Kewajiban Essensiil" Sinar Harapan, 27 September 1978. The article was reprinted in the Catholic magazine Hidup No. 42 (12 November 1978), 1147. See also Ihromi, "Respect for the Integrity of Another's Religion" The South East Asia Journal of Theology Vol. 14 No. 2 (1973), 61-3.

101. Muhammad Rasjidi, "Islam dan Kristen di Indonesia" Panji Masyarakat No. 258 (November, 1978), 10-14. For Rasjidi's critical analysis of the Vatican Council II, see below.

102. See "Instruksi Presiden: Pelaksanaan SK No. 70 dan 77 Diteruskan" Sinar Harapan, 10 October 1978. See also "Instruksi Presiden Kepada Menteri Agama" Panji Masyarakat No. 257 (October, 1978), 7. This explanation was also broadcasted on TV and radio, see "Seputar Keputusan Menteri Agama No. 70 \& 77 Tahun 1978 dan Prosesnya,"21.

103. See"Penjelasan Atas Keputusan Menteri Agama RI No. 70 Tahun 1978 Tentang Pedoman Penyiaran Agama" in Sairin, Himpunan Peraturan, 52-55. See also an account of Alamsyah's speech to the Christians, "Bebas Pilih Atau Pindah Agama Karena Keyakinan Bukan Berdasarkan Bujukan" Sinar Harapan, 6 November 1978, reprinted in Hidup No. 44 (26 November 1978), 1208.

104. See "Penjelasan Atas Keputusan Menteri Agama No. 77 Tahun 1978 Tentang Bantuan Luar Negeri Kepada Lembaga Keagamaan" in Sairin, Himpunan Peraturan, 60-62.

105. See "Siaran Pers Sidang MAWI 1978" Hidup No. 44 (26 November 1978), 1204-5. However, I do not find any Protestant source indicating a positive response to the explanations.

106. See“Tanggapan Terhadap Penjelasan Atas Keputusan Menteri Agama No. 70 Tahun 1978 Tentang Pedoman Penyiaran Agama," in Sairin, Himpunan Peraturan, 477-82.

107. See"Tanggapan Terhadap Penjelasan Atas Keputusan Menteri Agama No.77 Tahun 1978 Tentang Bantuan Luar Negeri Kepada Lembaga Keagamaan di Indonesia," in Sairin, Himpunan Peraturan, 483-487.

108. Parikesit and Sempurnadjaya, H. Alamasyah Ratu Perwiranegara:Perjalanan Hidup, 265-6; and Ratu Perwiranegara, Pembinaan Kerukunan Hidup Umat Beragama, 68.

109. See "Keputusan Bersama Menteri Agama dan Menteri Dalam Negeri No. 1 Tahun 1979 Tentang Tatacara Pelaksanaan Penyiaran Agama dan Bantuan Luar Negeri Kepada Lembaga Keagamaan di Indonesia," in Sairin, Himpunan Peraturan, 63-8.

110. Ratu Perwiranegara, Pembinaan Kerukunan Hidup Umat Beragama, 70-1.

111. See"Tanggapan DGI-MAWI Atas Keputusan Bersama Menteri Agama dan Menteri Dalam Negeri No. 1 Tahun 1979 Tentang Tatacara Pelaksanaan Penyiaran Agama dan Bantuan Luar Negeri Kepada Lembaga Keagamaan di Indonesia," in Sairin (ed.), Himpunan Peraturan, 488-99.

112. M. Rasjidi, "Kebebasan Beragama Menurut Islam," Mimbar Ulama Vol. 3 No. 27 (February, 1979), 9-26. The article was reprinted in a booklet form under a shorter title, Kebebasan Beragama (Jakarta: Media Da'wah, 1979).

113. See "Indonesian Churchman Speaks Out For Freedom of Religion," reprinted in Ahmad von Denffer, Indonesia: Government's Decrees on Mission and Subsequent Developments (Leicester: The Islamic Foundation, 1979), II-2.

114. See Eduard Abel, "Religious Freedom Crisis Hits Indonesian Churches" and "Will Indonesia Resist Islamic Fanaticism?" in Denffer, Indonesia: Government's Decrees, II-3 and II-4.

115. See "Introduction" in Denffer, Indonesia: Government's Decrees.

116. A.G. Hoekema, "Indonesian Churches: Moving Towards Maturity" Exchange No. 21 (December, 1978), 6.

117. Hyung-Jun Kim, "The Changing Interpretation of Religious Freedom in Indonesia," Journal of Southeast Asian Studies 29 No. 2 (1998), 367.

118. Parikesit and Sempurnadjaya, H. Alamasyah Ratu Perwiranegara, Perjalanan Hidup, 27980. Alamsyah was relatively successful in establishing good relations with the Muslims 
in the Middle East, especially Saudi Arabia. According to Sri-Edi Swasono, an economist who worked for Alamsyah as a staff expert, eight of ten projects proposed in 1980 to the Islamic Development Bank were approved. Swasono explained that this was primarily because of Alamsyah's successful lobbies with the important leaders in Saudi Arabia, including the King Khālid Ibn 'Abd al-'Azīz and the Secretary General of the Rābita, 'Alī al-Harakan. In September 1981, Alamsyah was also successful in organizing an International Conference of Islamic Media in Jakarta sponsored by the Rābita. See Parikesit and Sempurnadjaya , H. Alamsyah Ratu Perwiranegara, Perjalanan Hidup, 2824 and Sri-Edi Swasono, "Penegasan Pak Alamsyah: Pancasila Hadiah Ummat Islam," in Sempurnadjaja, H. Alamsyah Ratu Perwiranegara 70 Tahun, 61-4. In April 1981, the Indonesian Ambassador to Saudi Arabia, Teuku Mohammad Hadi Thayeb said to the press that there was no Christianisation in Indonesia. In May, 1981, a-Mujtama', a Kuwaiti magazine, wrote that the statement was a lie because besides the two decrees of the Minister of Religion, the leader of the DGI, T.B. Simatupang recently said in a speech to a WCC meeting that the Indonesian Christians should develop good relations with Christian army officers and increase the number of Christian schools and hospitals in the country. See al-Mujtama' No. 529 Vol. 11 (19 May 1981), 29. Unsurprisingly, I found a copy of the al-Mujtama's account in the appendix of DDII's Taktik Baru Dalam Pekabaran Injil (Jakarta: DDII, 1981).

119. See Alamsyah Ratu Perwiranegara, "Islam and Other Religions: a Case of an Inter-religious Life in Indonesia," Dialog Vol. 7 No. 14 (March, 1983), 10. There is no explanation when and where exactly the paper was originally presented, but it is mentioned in the body of the text that it was addressed to an international symposium.

120. Ahmad von Denffer, Indonesia: How Muslims Are Made Christians (Leicester: The Islamic Foundation, 1981); Ahmad von Denffer, Indonesia: a Survey of Christian Churches and Mission Among Muslims (Leicester: The Islamic Foundation, 1981) and Rifyal Ka'bah, Christian Presence in Indonesia: a View of Christian-Muslim Relations (Leicester: The Islamic Foundation, 1985).

121. Rifyal Ka'bah, Christian Presence in Indonesia, 59. He refers to an article by Robert Erny, "Variety and Harmony Mark Fast-Changing Indonesia," Pulse, Vol. 19 No. 6 (March 23, 1984), 3.

122. Mohammad Natsir, Sekali Lagi: Kerukunan Hidup Umat Beragama di Indonesia (Jakarta: Media Da'wah, 1978), 69-70.

123. See for instance, Lukman Hakiem (ed.), Fakta \& Data Usaha-Usaha Kristenisasi di Indonesia, and H.M. Goodwill Zubir and Sudar Siandes (eds.), Potret Gerakan Kristenisasi di Indonesia Versi Da'i LDK Muhammadiyah (Jakarta: LDK PP Muhammadiyah, No Date).

124. Jan S. Aritonang, Sejarah Perjumpaan Kristen dan Islam di Indonesia (Jakarta: BPK, 2004), 434-5

125. Alamsyah Ratu Perwiranegara, "Strategi Perjuangan Umat Islam di Bidang Hukum," in Amrullah Ahmad (ed.), Dimensi-Dimensi Hukum Islam Dalam Sistem Hukum Nasional: mengenang 65 Th. Prof.Dr.Bustanul Arifin SH (Jakarta: Gema Insani Press, 1996), 245.

126. See "Bersedia Jadi WNI"Berita Buana, November 19, 1979, reprinted in Mohammad Natsir, Mencari Modus Vivendi Antar Umat Beragama, 69. In 1977, only 31.25\% (500 out of 1600) ordained Catholic priests were Indonesians. In 1980, the figure changed to: 45.91\% (770 out of 1677) were Indonesians. See Ahmad von Denffer, Indonesia: a Survey of Christian Churches and Mission Among Muslims, 13 and Alex Soesilo Wijoyo, "Kehadiran Gereja Minoritas di Tengah Mayoritas Muslim," Ummat Baru (1981), 393.

127. Karel A. Steenbrink, "Indonesian Churches 1978-1984: Main Trends, Issues and Problems" Exchange Vol. 13 No. 39 (1984), 7. 
128. On the foreign financial support for the DGl, see Frank. L. Cooley, The Growing Seed (Jakarta: BPK Gunung Mulia, 1981), 236-7.

129. No case of door-to-door visiting is found in Lukman Hakiem (ed.), Fakta \& Data UsahaUsaha Kristenisasi di Indonesia and neither in a report of DDII, Kristenisasi di Indonesia Tahun 1988-1990 (Jakarta: DDII, 1991). In Lukman's edited book, we find a case of distribution of Bibles in some schools in Jakarta by the Gideon International and another case of distribution of Christian brochures in a street of Padang Panjang city, West Sumatra. See pp., 77-8; 119-25. I only find one specific case of door-to-door visiting by Adventist missionaries, occurred in October 1979 in Malang. See "Polisi Lawang Tahan 3 Orang Yang Melanggar Etik Penyiaran Agama," Pelita, 13 October 1979 reprinted in Natsir, Mencari Modus Vivend, 77-8.

130. Steenbrink, "Indonesian Churches 1978-1984", 7. If we look at the text of the Attorney General's decision and its press release to ban the publications of the Children of God sect in Indonesia, we do not find any direct reference to either Alamsyah's decree on religious propagation or the joint decree. The rationale of the ban was not the sect's ways of propagation, but its teachings that allegedly promote free sex. See "Keputusan Jaksa Agung RI No. Kep-058/J.A/194 Tentang Larangan Peredaran Barang-Barang Cetakan Yang Memuat Ajaran Kepercayaan Children of God" and "Press Release Jaksa Agung RI" in Sairin, Himpunan Peraturan, 273-8.

131. In one of his works, Ibn Taymiyyah said that some Muslims celebrated the birth of Muhammad as an imitation of the Christians who celebrated the birth of Jesus. For him, any imitation of non-Muslim religious practices is forbidden in Islam. Moreover, the imitation of the Christians also includes participation in their religious festivals, including Christmas. See Ibn Taymiyyah, Kitāb lqtidā al-Sirāt al-Mustaqīm, Mukhālafat Ashāb al-Jahīm (Cairo: al-Matba'a al-Sharqiyya, 1907), 107;141. See also Muhammad Umar Memon, Ibn Taimiya's Struggle Against Popular Religion With an Annotated Translation of His Kitāb lqtidā al-Sirāt al-Mustaqīm, Mukhālafat Ashāb al-Jahīm (The Hague: Mouton, 1976), 220;243.

132. See HAMKA, "Toleransi: Bukan Pengorbanan 'Aqidah" in Panji Masyarakat No. 142 (January, 1974), 32-4.

133. It is noteworthy that, according to Hasan Basri who was to become the General Chairman of the MUI (1985-1998), in the first meeting between the MUI's functionaries and Suharto in 1975, HAMKA tried to convince the president that the Muslim perception of the threat of Christianisation in the country was true. See Hasan Basri, "Catatan Kenangan Untuk Buya," in Solichin Salam (ed.), Kenang-Kenangan 70 Tahun Buya HAMKA (Jakarta: Yayasan Nurul Islam, 1978), 78-80.

134. The fatwa is already discussed by Steenbrink, "Indonesian Churches 1979 - 1984" 1012; and Mohammad Atho Mudzhar, Fatwas of the Council of Indonesia Ulama: A Study of Islamic Legal Thought in Indonesia 1975-1988 (Jakarta: INIS, 1993), 101-4; and Mohammad Atho Mudzhar, "The Council of Indonesian Ulama on Muslim Attendance at Christmas Celebration" in Muhammad Khalid Masud, Brinkley Messick and David S. Powers (eds.), Islamic Legal Interpretation: Muftis and their Fatwas. (Cambridge: Harvard University Press, 1996), 230-41. For the original Indonesian text of the fatwa, see Fatwa Majlis Ulama Indonesia Tentang Perayaan Natal Bersama (Jakarta: Dewan Dakwah Islamiyah Indonesia, 1981). Steenbrink gave a very short discussion of the fatwa. Mudzhar discusses it in detail but does not pay serious attention to the voices of the Christians and neither to the view of the Muslims who opposed the fatwa. Finally, both Steenbrink and Mudzhar do not discuss further implication of Alamsyah's circular. My discussion below will fill this gap. 
135. This important reason is unnoticed in the previous studies quoted above.

136. In his biography, Alamsyah tried to neglect his conflict with HAMKA and blamed an anonymous third party who allegedly provoked HAMKA to resign. Parikesit and Sempurnadjaya, H. Alamsyah Ratu Perwiranegara, Perjalanan Hidup, 267-8.

137. See "Buya, Fatwa dan Kerukunan Beragama" Tempo (30 May 1981), 12-15.

138. The press release was published in Berita Buana, Suara Karya and Kompas dailies. It was also published in Panji Masyarakat No.324 (May, 1981), 9. In an interview with Tempo magazine, HAMKA said, "My hands were shaking when I had to withdraw it. People would certainly think that I am Satan. The ulama abroad will all certainly be amazed. Don't you think how bad I am?" See "Buya, Fatwa dan Kerukunan Beragama," 13.

139. HAMKA, "Bisakah Suatu Fatwa Dicabut?" Panji Masyarakat No. 324 (May, 1981), 7-9.

140. Mudzhar, Fatwas of the Council of Indonesia Ulama, 62.

141. See "MUI, Kisah Sebuah Jembatan" Tempo (30 May 1981), 15-17.

142. HAMKA, “Niat Yang Tulus" Panji Masyarakat No. 325 (June, 1981), 7.

143. Mohammad Roem, "Politik HAMKA" in Salam, Kenang-Kenangan 70 Tahun, 8-12.

144. HAMKA, "Ulama Pewaris Nabi-Nabi" Panji Masyarakat No. 326 (June, 1981), 7-8. This story is quite famous among the ulama in Indonesia. In 1994, I heard a similar story from Abdurrahman Wahid when he tried to defend his oppositional attitudes to the regime.

145. See "MUI, Jembatan Siapa?" Panji Masyarakat No. 326 (June, 1981), 12-16.

146. Martin van Bruinessen, "Indonesia's Ulama and Politics: Caught Between Legitimising the Status Quo and Searching for Alternatives" Prisma, the Indonesian Indicator No. 49 (1990), 61-3.

147. Certainly, it is misleading to say that the MUI only functioned to serve the interest of the Government rather than that of the umma. For a more recent and sympathetic study of the MUI and its fatwas, see Nadirsyah Hosen, "Behind the Scenes: Fatwas of Majelis Ulama in Indonesia (1975-1998)" Journal of Islamic Studies Vol. 15 No. 2 (2004), 147-79. Nadirsyah is the son of Ibrahim Hosen, the head of the Fatwa Committee of the MUI, 1981-2000 period.

148. See"Buya, Fatwa dan Kerukunan Beragama"Tempo (30 May 1981), 14. See also M. Amien Ely, "Bahaya 'Natalan Bersama' Bagi Pelajar-Pelajar Islam" Panji Masyarakat No. 327 (June, 1981), 53-4. In this article, M. Amien described the experience of his son who was instructed by a priest in a Catholic school in Ambon to act in a play for a Christmas celebration. M. Amien then explained his objection to the priest, and the latter finally agreed to free his son from that play.

149. Samudi Abdullah, "Tentang Perayaan Natal Bersama" Panji Masyarakat No. 325 (June, 1981), 54-5.

150. See "Buya, Fatwa dan Kerukunan Beragama", 13-4. In contrast, according to a Protestant minister, Gerrit E. Singgih, to burn the candle is also ritual. Interview with Gerrit E. Singgih, Yogyakarta, 16 January 2004.

151. Abdurrahman Wahid, "Fatwa Natal, Ujung dan Pangkal" Tempo (30 May 1981), 17.

152. In contrast, in his article published in December 2003, Wahid posed a scriptural argument. He said, because the Qur'an mentioned with high respect the miracle of Jesus' birth, the Muslims have to respect or even celebrate it regardless of the fact that the Christians believed that Jesus is the Son of God. See his, "Harlah, Natal dan Maulid" in www.gusdur.net (accessed 14 January 2004).

153. See "MUI, Jembatan Siapa?" Panji Masyarakat No. 326 (June, 1981), 12.

154. Iqbal Abdurrauf Saimima, "Ujung Pangkal Suara Cak Dur" Panji Masyarakat No. 326 (June, 1981), 14-15. 
155. See Monografi Kelembagaan Agama di Indonesia (Jakarta:Departeman Agama, 1982), 2135. See also "Amanat Menteri Agama dan Lain-lain pada Saat Pembentukan WMUAB" in Sairin, Himpunan Peraturan, 506-17.

156. See"Keputusan Pertemuan LengkapWadah Musyawarah Antar Umat Beragama Tentang Peringatan Hari-Hari Besar Keagamaan," in Sairin, Himpunan Peraturan, 518-521.

157. This also means that any agreement of the Wadah Musyawarah is not legally but morally binding. See article 6 number 2 of the "Pedoman Dasar Tentang Wadah Musyawarah Antar Umat Beragama," in Sairin, Himpunan Peraturan, 23-6.

158. For the whole text of the letter, see Sairin, Himpunan Peraturan, 35-40.

159. See "Pokok-Pokok Pikiran DGI dan MAWI Serta Usul Penyelesaian Atas Masalah Yang Ditimbulkan Oleh Surat Edaran Menteri Agama Nomor MA/325/1981 Tanggal 2 September 1981 Perihal Penyelenggaraan Hari-Hari Besar Keagamaan," in Sairin, Himpunan Peraturan, 522-7. See also the letter of the DGI and MAWI to the Commander of Security and Order, Admiral Sudomo, dated 23 October 1981 in HAK Kerukunan Vol. 3 and 4 No. 16, 17, 18 (September-November 1981, January 1982), 64-5.

160. The Minister of Education at this period was Daoed Joesoef, a Muslim who worked with the Catholic intellectuals in the CSIS. See Chapter 5.

161. See "Tanggapan MAWI-DGI" HAK Kerukunan Vol. 3 and 4 No. 16, 17, 18 (SeptemberNovember 1981, January 1982), 53-62. The same text is reprinted as "Tanggapan Atas Surat Edaran Menteri Agama Nomor MA/325/1981 Tanggal 2 September 1981 Perihal Penyelenggaraan Hari-Hari Besar Keagamaan," in Sairin, Himpunan Peraturan, 528-36.

162. See newspapers' accounts reprinted in the Catholic magazine HAK Kerukunan Vol. 3 and 4 No. 16, 17, 18 (September-November 1981, January 1982), 34-53.

163. See "Mereka Menolak SE," 11-12.

164. Rusydi, "Mengembangkan dan Melindungi Akidah Ummat" Panji Masyarakat No. 337 (October, 1981), 12-13.

165. See "Mereka Menolak SE", 11-12.

166. For the text of the letter, see HAK Kerukunan Vol. 3 and 4 No. 16, 17, 18 (SeptemberNovember 1981, January 1982), 68.

167. See "Pesan Natal Bersama DGI Dan MAWITahun 1981" HAK Kerukunan Vol. 3 and 4 No. 16, 17, 18 (September-November 1981, January 1982), 69-71.

168. The text of the joint statement was printed and distributed by the DDII. The text was also published in HAK Kerukunan Vol. 15 No. 86-87 (1994), 54.

169. "Umat Islam Diharamkan Ikut Natal Bersama," Panji Masyarakat No. 777 (December, 1993), 68-9.

170. See "Surat Natal Dari Istiqlal" Tempo (1 January 1994), 35.

171. See Chapter 6.

172. See HAK Kerukunan Vol. 3 and 4 No. 16, 17, 18 (September-November 1981, January 1982), 67. Hyung-Jun Kim who carried out research in a small village in Yogyakarta from 1992 to 1994 also observed that Muslims avoided sending an invitation card for a religious gathering to a non-Muslim. See his "The Changing Interpretation of Religious Freedom," 370-3 and his "Unto You Your Religion and Unto Me My Religion: Muslim-Christian Relations in a Javanese Village," Sojourn Vol. 13 No. 1 (1998), 62-85. The negative effect of the fatwa was also found among Batak people whose clan members consist of Muslims and Christians. Interview with Einar Sitompul, a minister of HKBP Church, Jakarta, 15 December 2003.

173. W.F. Wertheim, Moslems in Indonesia: Majority with Minority Mentality (Townsville: Occasional Paper No.8 of South East Asian Studies, James Cook University, 1980). 


\section{Notes Chapter 3}

1. T.B. Simatupang, "Agama-Agama Dalam Pembangunan Negara Pancasila" in his Dari Revolusi ke Pembangunan (Jakarta: BPK, 1987), 157.

2. See C. van Dijk, Rebellion Under the Banner of Islam: the Darul Islam in Indonesia (The Hague: Martinus Nijhoff, 1981).

3. Adnan Buyung Nasution, The Aspiration for Constitutional Government in Indonesia: A Socio-legal Study of the Indonesian Konstituante 1956-1959 (Jakarta: Sinar Harapan, 1992), 10.

4. The complete Indonesian wording is "Ketuhanan dengan kewajiban menjalankan syariat Islam bagi pemeluk-pemeluknya."

5. For the text of the Jakarta Charter and a small debate on related issues among the BPUPK members, see Muhammad Yamin, Naskah Persiapan Undang-Undang Dasar 1945 Vol. 1 (Jakarta: Yayasan Prapantja, 1959), 154; 259; 261-2; 391-3.

6. Nasution, The Aspiration for Constitutional Government, 11.

7. For the minutes of the session of the PPKI, see Yamin, Naskah Persiapan, Vol. 1, 399-406.

8. Pancasila is a Sanskrit word that means five principles. The other four principles include just-civilised humanitarianism, Indonesian unity, democracy and social justice. In the Preamble of the Constitution of 1945 , the term 'Pancasila' is not mentioned. It was Soekarno who introduced the term in his speech on 1 June 1945 at the session of the BPUPK. For the speech, see Yamin, Naskah Persiapan, Vol. 1, 61-81. The speech was originally without title but later in 1947, Soekarno published the speech entitled Lahirnja Pantja-Sila ( Medan: Bin Harun, 1947).

9. On this debate see, Nasution, The Aspiration for Constitutional Government, 59-130; 31398 and Ahmad Syafi'i Maarif, Islam dan Masalah Kenegaraan: Studi Tentang Percaturan Dalam Konstituante (Jakarta: LP3ES, 1985).

10. For the political development leading to the decree, see Daniel S. Lev, The Transition to Guided Democracy: Indonesian Politics, 1957-1959 (Ithaca: Modern Indonesia Project, Cornell University, 1966), 257-277.

11. Original:"Piagam Jakarta tertanggal 22 Juni 1945 menjiwai Undang Undang Dasar 1945 dan adalah merupakan suatu rangkain kesatuan dengan konstitusi tersebut."

12. Andrée Feillard, NU vis-à-vis Negara: Pencarian Isi, Bentuk dan Makna Trans. Lesmana (Yogyakarta: LKiS, 1999), 122-123; 127.

13. See Sinar Harapan, 2 January 1966.

14. For the decree and the memorandum, see"Ketetapan MPRS No. XX/MPRS/1966 Tentang Memorandum DPR-GR Mengenai Sumber Tertib Hukum Republik Indonesia dan Tata Urutan Peraturan Perundangan Republik Indonesia" in Abdul Kadir Besar, Himpunan Ketetapan-Ketetapan MPRS (Jakarta: Pantjuran Tudjuh, 1969), 39-56.

15. See the studies by Nasution and Maarif quoted above.

16. Mohammad Dachlan, "Piagam Djakarta Sumber Hukum Mendjiwai UUD 1945" Part 1, Kiblat No.3 (July, 1968), 6-7.

17. Dachlan, "Piagam Djakarta Sumber Hukum" Part 1, 45. Similar argument is developed by Endang Saifuddin Anshari in his Piagam Jakarta 22 Juni 1945, Sebuah Konsensus Nasional Tentang Dasar Negara Republik Indonesia (1945-1959) (Jakarta: Gema Insani Press, 1997), 52-3. Originally an MA thesis at the Institute of Islamic Studies, Mc Gill University, 1976, this book is a comprehensive study of the Jakarta Charter from the perspective of a proponent. The first Indonesian edition of the book was published in 1981 by Pustaka Salman, Bandung. 
18. The first sentence is, "We, the Indonesian people herewith proclaim the Independence of Indonesia." In its original: "Kami bangsa Indonesia dengan ini menyatakan kemerdekaan Indonesia." It should be noted here that the Jakarta Charter referred to by Roem is the whole draft of the Preamble of the Constitution of 1945, not specifically the seven words. See Mohammad Roem, "Pentjulikan dan Proklamasi" Part 3 Kiblat No.8 Vol. 17 (September, 1969), 22.

19. In contrast, Andrée Feillard argued that Wachid Hasjim was indeed present during the lobbying. Her view is based on an interview with Wachid Hasjim's wife and the accounts by Mohammad Hatta and Ki Bagus Hadikusomo. See her NU vis-à-vis Negara, 39-41.

20. Prawoto Mangkusasmito, "Rumus Pantja Sila dan Sedjarah Singkat Pertumbuhannya" Kiblat No.2 (June, 1968), 6-7;46-48; and his "Beberapa Saat Yang Menentukan Dalam Sedjarah Kita" Kiblat No. 3 (July, 1969), 6; 48-9. The articles are reprinted in Prawoto Mangkusasmito, Pertumbuhan Historis Rumus Dasar Negara dan Sebuah Projeksi (Jakarta: Hudaya, 1970), Chapter 1 and 2. Feillard observes that this argument was also taken by the NU in 1968. See her NU vis-à-vis Negara, 135-6. Anshari also took this argument in his Piagam Jakarta, 22 Juni 1945, 52-3.

21. HAMKA, "Mengapa Mereka Masih Ribut? Mari Kita Berpahit-Pahit, Kaum Muslim Belum Puas Dengan Kemerdekaan Ini" Pandji Masjarakat No. 30 (1968), 3-5. The article is reprinted in his Dari Hati Ke Hati Tentang Agama, Sosial Budaya dan Politik (Jakarta: Panjimas, 2002), 310-18.

22. See "Pendapat Partai Katolik Tentang Piagam Djakarta" Peraba (I June, 1968), 3-4; 12. Sajuti Melik's article was originally published in the 'New Order's press' of Bandung, Mahasiswa Indonesia, April 1968 and reprinted in Peraba. See Sajuti Melik, "UUD '45 \& Piagam Djakarta" Peraba (15 May 1968), 5-6.

23. See "Ada 'Strategi Bertahap' Kehebohan 'Piagam Djakarta'" Peraba (III July 1968), 6.

24. See "Beberapa Kesimpulan" Peraba (II June, 1968), 3-4.

25. Adam Malik's article was originally written on 1 January 1948. This article was reproduced in Peraba with some comments in brackets by the editor under the title: "Riwayat Proklamasi: Tidak Diambil dari 'Piagam Djakarta'” Peraba (II August, 1968), 6-7; 8. Despite the Jakarta Charter issue, the 'heroic' role of the youths in the Proclamation is also a controversial historical issue. Mohammad Hatta made some critcisms of such accounts in his Sekitar Proklamasi (Jakarta: Tintamas, 1969).

26. See "Pendapat Partai Katolik Tentang Piagam Djakarta".

27. The prominent Protestant politician J.C.T. Simorangkir and the Catholic, Ben Mang Reng Say later adopted this argument. See J.C.T. Simorangkir and B. Mang Reng Say, Tentang dan Sekitar Undang-Undang Dasar 1945 (Jakarta: Djambatan , 1975), 8.

28. Dachlan, "Piagam Djakarta Sumber Hukum," Part 1, 45. See also Kasman Singodimedjo, "Mengungkap Problem Hukum: Dekrit 5 Djuli 1959" Kiblat No. 20 (March, 1968), 9-10.

29. HAMKA, "Mengapa Mereka Masih Ribut?" 3.

30. Mangkusasmito, "Rumus Pantjasila," 47.

31. HAMKA, "Mengapa Mereka Masih Ribut?, 3. For the whole text of Soekarno's speech, see Yamin, Naskah Persiapan, Vol. 1, 653-702.

32. Daniel S. Lev noted that, "to avoid the interpretation that preambles are not binding, NU members stood in the Konstituante in May to insist that the obligation of Moslems to follow the Islamic law must be fitted into article 29 of the 1945 Constitution, dealing with religion." See, The Transition to Guided Democracy, 264. For the texts of A. Sjaichu's question and the government's answer, see Yamin, Naskah Persiapan Vol.1, 621.

33. Mangkusasmito, "Rumus Pantjasila", 47-8; Dachlan, "Piagam Djakarta Sumber Hukum Mendjiwai UUD 1945," Part 2, Kiblat No. 4 (July, 1968), 16. 
34. Abdullah Sjahir, "Lagi Tentang: Piagam Jakarta" Peraba (III June, 1968), 6-7. Anshari later also takes this argument in his Piagam Jakarta 22 Juni 1945, 136-7.

35. Dachlan, "Piagam Djakarta Sumber Hukum," Part 2, 16.

36. See "Negara Pantjasila Dirongrong: Pelaksanaan Piagam Djakarta Semakin Meluas" Peraba (II April, 1969), 5. In his article quoted above, T.B. Simatupang also hinted at these regional cases. See his Dari Revolusi ke Pembangunan, 157.

37. Samson, "Islam in Indonesian Politics," 1013.

38. The PMPI was an association of 36 Muslim youth organizations established in 1967 initially as a reaction to the Israeli-Palestinian war. See Feillard, NU vis-à-vis Negara, $133 ; 136$.

39. See Kiblat No. 4 (July, 1969), 25.

40. See"Natsir di UGM: Piagam Djakarta mendapat tepuk tangan dari mahasiswa jang pakai kudung..." Peraba (May 15, 1968), 5.

41. See Peraba (III July, 1968), 7.

42. HAMKA, "Pembahasan Dari Hal Intisari Undang-Undang Dasar 1945", dalam Solichin Salam (ed.), Kenang-kenangan 70 Tahun Buya HAMKA (Jakarta: Yayasan Nurul Islam, 1978), 279-80; Abdurrahman Wahid, "Kisah Sebuah Anak Kalimat" Tempo (7 November 1981) and reprinted in Melawan Melalui Lelucon: Kumpulan Kolom Abdurrahman Wahid di Tempo (Jakarta: Pusat Data \& Analisa Tempo, 2000), 238-40.

43. See "Appeal Baru Presiden Suharto" Kiblat, No.23 (May, 1968), 4-5. Regarding the President's warning, Kiblat quoted Angkatan Bersenjata, 11 April 1968 and Kompas, 1 April 1968.

44. Andrée Feillard, NU vis-à-vis Negara, 131-2; 138.

45. See Kiblat No. 16 (January 1969); Kiblat No. 2 (June 1969), 26 and Pandji Masjarakat No.49 (December 1969), 16.

46. Hasbullah Bakry, "Problim Piagam Djakarta Bagi Umat Islam di Indonesia” Peraba (II June, 1968), 7-8.

47. See the interviews with him in Kiblat No. 8 (September, 1968), 19-22; No. 9 (October, 1968), 31-2; No. 11 (November, 1968), 46-7;50.

48. See "Sesudah Peringatan Piagam Djakarta Mau Apa?" Kiblat No. 4 (July, 1968), 19. The Majelis IImiyah Islam was established in 1962 as an organization of experts to discuss the issues related to Islamic law. The Chairman was Hazairin, a professor of law at the University of Indonesia. Kasman Singodimedjo was the Vice Chairman and Saleh Suaidy was the General Secretary. Its members were about 50 persons. See M. Saleh Suaidy, "Sumbangan Pikiran Tentang Pembahasan Hukum Islam di Indonesia" Kiblat No. 1 Vol. 17 (June, 1969), 26.

49. Donald K. Emmerson, "Kesan Sebuah Perdjalanan ke Sumatera: Pelaksanaan Unsur2 Sjariat Islam," Kiblat No. 9 (October, 1969), 24-29.

50. See "Penjembahan Berhala Diantjam 6 Bulan" Praba (25 March 1968), 4.

51. See "Pelaksanaan Piagam Djakarta Semakin Meluas" Peraba (II April, 1968), 5.

52. See Suara Karya, 16 June 1989; and "Peradilan Agama: Kebutuhan atau Kecemasan" Tempo (24 June 1989), 22-3.

53. Anshari collects nine different translations: (1) The Department of Information: Belief in the One Supreme God; (2) The Department of Religious Affairs: Belief in God, the One; (3) Muhammad Yamin: Belief in the All-Embracing God; (4) W.B. Sidjabat: Divine Omnipotence; (5) Harun Hadiwijuno: The Absolute Lordship; (6) R.M. Kafrawi: The Being of Supreme Deity of Oneness; (7) B.J. Boland: Belief in the One and Only God; (8) Justus M. van Kroef: The Absolute Unity of God; (9) C.A.O van Niewenhijze: The Overlordship of God Who is Absolutely One. Anshari himself preferred: Belief in God Who is Absolutely One. See his 
Piagam Jakarta 22 Juni 1945, 47 Note 8. In addition, T. B. Simatupang translates it: One Godhead and Eka Darmaputera: One Lordship. See T.B. Simatupang, "This is My Country" International Review of Mission 63 (July, 1974), 317; Eka Darmaputera, Pancasila and the Search for Identity and Modernity in Indonesian Society: a Cultural and Ethical Analysis (Leiden: E.J. Brill, 1988), 193.

54. HAMKA, Urat Tunggang Pantjasila (Djakarta: Pustaka Keluarga, 1952).

55. Helmut Rosin, Pantja-Sila (Djakarta: Badan Penerbit Kristen, 1951), especially, 16-37.

56. Rahmat Subagya, Pantja Sila Dasar Negara Indonesia (Yogyakarta: Basis, 1955),49.

57. Subagya, Pantja Sila, 34-5;46-7; 55-7.

58. Rosin, Pantjasila, 43.

59. Subagya, Pantja Sila, 64.

60. N. Driyarkara, "Pancasila dan Religi" reprinted in Driyarkara Tentang Negara dan Bangsa (Yogyakarta: Kanisius, 1980), 60-1. The article was initially published in 1959.

61. Driyarkara, "Pancasila dan Religi", 63. Italics in original.

62. W.B. Sidjabat, Religious Tolerance and the Christian Faith: A Study of the Concept of Divine Omnipotent in the Indonesian Constitution in the Light of Islam and Christianity (Djakarta: BPK, 1965) 43; 74.

63. See for instance, Prowoto Mangkusasmito, "Beberapa Saat Jang Menentukan Dalam Sedjarah Kita," Kiblat No. 2 (June 1968), 49; and Nurcholish Madjid, Islam, Doktrin dan Peradaban (Jakarta: Yayasan Wakaf Paramadina, 1992), Ixxxii-xcii.

64. HAMKA, "Siapa Anti Pantjasila!" Pandji Masjarakat No. 4 (November, 1966), 3-4;12. The same article is reprinted in HAMKA, Dari Hati Ke Hati Tentang Agama Sosial-Budaya Politik, 273-9.

65. Syafruddin Prawiranegara, Islam Sebagai Agama Perdamaian, Persatuan \& Persaudaraan serta Pelindung Pancasila (Djakarta: Ruhul Islam, 1967), 19.

66. HAMKA, "Pantjasila Akan Hampa Tanpa Ketuhanan Yang Maha Esa" Pandji Masjarakat No. 23 (January, 1968), 29.

67. See an interview with Kasman, "Pantjasila Akan tetap Sakti Djikalau Diridhoi Allah" in Kiblat No. 11 (November, 1969), 55; and Mangkusasmito, "Beberapa Saat Jang Menentukan", 49.

68. In fact, in Indonesia, the Christians also called God, 'Allah.' Nonetheless, Muslims usually pronounce the word 'Allah' with a thick emphasis on the double 'I' following the original Arabic pronunciation, while the Christians pronounce it with a thin 'I', perhaps originally because the western missionaries had difficulty to follow the correct Arabic pronunciation.

69. HAMKA, "Ketuhanan Yang Maha Esa" Pandji Masjarakat No. 23 (January, 1968), 3-5; and reprinted in HAMKA, Dari Hati Ke Hati Tentang Agama Sosial-Budaya Politik, 242-6.

70. Nurcholish Madjid, "Selamatkan Pantjasila Agar Tidak Dipalsukan" Pandji Masjarakat No. 24 (January, 1968), 13.

71. T.B. Simatupang, "Konstitusi dan Perundang-Undangan Dalam Negara Pancasila Yang Membangun" in his Dari Revolusi ke Pembangunan, 183.

72. M. S. Pusposaputro, "Pantjasila dan Kebebasan Agama” Basis No. 9 Vol. 17 (June, 1968), 261-72.

73. John Liku, "Pantja Sila Terhadap Objeksi” Basis No. 11 Vol. 18 (August, 1969), 358-67.

74. Deliar Noer, The Administration of Islam in Indonesia (Ithaca: Cornell Modern Indonesia Project, 1978), 12.

75. Noer, The Administration of Islam, 33. 
76. See Azyumardi Azra, “H.M. Rasjidi BA:Pembentukan Kementrian Agama dalam Revolusi” in Azyumardi Azra and Saiful Umam (eds.), Menteri-Menteri Agama RI Biografi SosialPolitik (Jakarta: INIS, PPIM, Litbang Depag, 1998), 8-10.

77. For the structure, see Noer, The Administration of Islam, 20.

78. B.J. Boland, The Struggle of Islam in Modern Indonesia (The Hague: Martinus Nijhoff, 1982), 108-9.

79. C.A.O van Nieuwenhuijze, Aspects of Islam in Post-Colonial Indonesia (The Hague:W. van Hoeve Ltd., 1958), 236-43.

80. Boland, The Struggle of Islam, 110.

81. Wahid Hasjim, "Tugas Pemerintah Terhadap Agama" in H. Aboebakar (ed.), Sedjarah Hidup K.H.A Wahid Hasjim dan Karangan Tersiar (Jakarta: Panitia Buku Peringatan Alm. K.H.A. Wahid Hasjim, 1957), 873-77.

82. Jan S. Aritonang, Sejarah Perjumpaan Kristen dan Islam di Indonesia (Jakarta: BPK, 2004), 289.

83. See Huub J.W.M. Boelaars, Indonesianisasi. Dari Gereja Katolik di Indonesia Menjadi Gereja Katolik Indonesia Trans. R. Hardawiryana (Yogyakarta: Kanisius, 2005), 128.

84. Aritonang, Sejarah Perjumpaan, 289-90.

85. Subagya, Pantjasila, 60-66. In an article published in Dutch, Bakker argued that from the very beginning, the Ministry was "a bulwark of Islam and an outpost for an Islamic State." See Boland, The Strunggle of Islam, 106.

86. Wahid Hasyim, "Sekitar Pembentukan Kementrian Agama RIS" in Kementrian Agama (Djakarta: Pertjetakan Negara, no date), 3-8.

87. Sidjabat, Religious Tolerance, 50.

88. Sidjabat, Religious Tolerance, 51.

89. Sidjabat, Religious Tolerance, 60.

90. Abdul Aziz, "K.H. Muhammad Wahib Wahab: Kementrian Agama pada Masa Demokrasi Terpimpin" in Azra and Umam, Menteri-Menteri Agama RI, 193.

91. Muhammad Abdul Ghofur, "KH Saifuddin Zuhri:Eksistensi Agama dalam Nation Building" in Azra and Umam, Menteri-Menteri Agama RI, 222.

92. Anshari, Piagam Jakarta 22 Juni1945, 62, quoting KMA No.56/1967.

93. Pransa, "17 Agustus" Peraba, (August II, 1968), 3-4. The last part of the article was reprinted in Kiblat No. 8 (September, 1968), 33.

94. See "Pegawai Dept. Agama Harus Djadi Pedjuang Islam" Peraba (IV August, 1968), 4.

95. See "Agama Islam Agama Negara?" Peraba (I September, 1968), 5.

96. Conversation with Steenbrink, 2004.

97. Moh. Bazor, Departemen Agama? (no publisher and date [probably 1969]), 7-24;40-42.

98. Veuillot was a French ultra conservative who defended the rights of the Pope in Italy 1869-1870 when the Pope was expelled from his political power by the nationalist party of Victor Emmanuel.

99. See "Masih Perlukah Dept. Agama?" Pandji Masjarakat No.24 (January, 1968), 19-20.

100. See "Issue Menghapuskan Departemen Agama" in Kiblat No. 2 (June, 1968), 24-5;33.

101. Abu Hanifah, "Lampu Merah Buat Ummat Islam Indonesia" Kiblat No. 3 (July, 1968), 41.

102. T.B. Simatupang, “Pandangan Umum Terhadap Konsep Garis-Garis Besar Haluan Negara (GBHN) Yang Akan Datang," Sinar Harapan 14-15 May, 1981 and reprinted in T.B. Simatupang, Iman Kristen dan Pancasila (Jakarta: BPK, 1984), 155-67.

103. See Samudi Abdullah, "Tentang Teologi Pancasila: Catatan Untuk T.B. Simatupang" Panji Masyarakat No. 327 (June, 1981), 64-5; T.B. Simatupang, "Sama-Sama Menolak Teologi Pancasila" Panji Masyarakat No. 329 (July, 1981), 6. Both Muttaqien Darmawan's and Agus Matori's articles are quoted in this article. 
104. Harold Crouch, The Army and Politics in Indonesia (Ithaca: Cornell University Press, 1978), 24.

105. See Simatupang's lecture delivered to a discussion organised by PMKRI in 1970 in his Dari Revolusi ke Pembangunan, 229-35. See also his lecture in the CSIS in 1986 in H.M. Victor Matondang (ed.), Percakapan Dengan Dr. T.B. Simatupang (Jakarta: BPK, 1989), 89-118.

106. Joop Beek, a Jesuit of mixed Dutch and Indonesian origin, was born in the Netherlands on 12 March 1917 and died in Indonesia on 17 September 1983. In 1935, he joined the Jesuit Order in Mariendaal (a House located in the small town of Grave, the Netherlands), and one year later was sent to Indonesia as a novice. He began his study at Giri Sonta, near Semarang and in the Ignatius College in Yogyakarta from 1939 to 1941. He was put in prison by the Japanese in July 1942 and released but then interned by the Indonesian Republic for seven months in 1946. He then went to Maastricht to study theology and was ordained a priest in 1948. From 1952 to 1956, he worked with students in Jalan Code, Yogyakarta. In 1957, in the same city, he started the student dormitory, Asrama Realino, where he worked until 1959. He worked at Gunung Sahari, Jakarta from 1960-1961, and at Jalan Kramat VII/25 school in Jakarta until 1974. From 1975 to his death, he worked at Gudang Peluru, Jalan Kepu Selatan, Jakarta. Beek took Indonesian citizenship sometimes in the 1970s. This biography is taken from David Bourchier, "Beek, Father Jopie SJ (Joop)" (no date and publisher). I thank Gerry van Klinken for giving me this valuable paper.

107. Interview with Paul de Blot, Nyenrode, 22 July 2003 and with Francis Wahono, a former Jesuit and a director of an NGO called 'Cindelaras' in Yogyakarta, 14 January 2004.

108. Interview with Paul de Blot, Nyenrode, 22 July 2003.

109. Hamish MacDonald, Suharto's Indonesia (Honolulu:The University of Hawaii, 1981), 102.

110. See Chapter 1.

111. See Leo Suryadinata, Prominent Indonesian Chinese: Biographical Sketches (Singapore: Institute of Southeast Asian Studies, 1995), 216-17; and "Apa dan Siapa-Cosmas Batubara" in www.pdat.co.id/hg/apasiapa/html/C/ads,20030617-02,C.html (accessed 15 March 2005).

112. Interview with Agustine Prasetyo Murniati, Yogyakarta, 7 October 2002.

113. Promoedya Ananta Toer and Stanley Adi Prasetyo (eds.), Memoar Oei Tjoe Tat (Jakarta: Hasta Mitra, 1995), 317-18.

114. W.F. Wertheim, "Whose Plot? New Lights on the 1965 Events," Journal of Contemporary Asia Vol.9 No. 2 (1979), 206.

115. Quoted in W.F.Wertheim,"Indonesia's Hidden History of 1965: When Will the Archives be Declassified?" in Bob Hering (ed.), Pramoedya Ananta Toer 70 Tahun: essays to honour Pramoedya Ananta Toer's $70^{\text {th }}$ year (Den Haag: Yayasan Kabar Seberang, 1995), 301. For the whole interview in Dutch, see Henk Maasen and Paul Ophey, "Aad van den Heuvel over the best bewaarde geheimen van Azië: De speler die de Wayang-poppen manipuleerde" Indonesia Magazine (July-August, 1993), 12-15. In 1991, Van den Heuvel published a novel entitled Het Stenen Tijdperk in which he discloses some hidden activities of Beek in a pseudonym, Herman Sloot.

116. Interview with Paul de Blot, Nyenrode, 22 July 2003.

117. McDonald, Suharto's Indonesia, 102.

118. Brian May, The Indonesian Tragedy (London: Routledge \& Kegan Paul, 1978), 238. See also Heru Cahyono, Pangkopkamtib Jenderal Soemitro (Jakarta: Sinar Harapan, 1998), 37.

119. Interview with Paul de Blot, Nyenrode, 22 July 2003; McDonald, Suharto's Indonesia, 102.

120. A tape recording of this interview (in Dutch) is registered as KMM 526 in the Katholiek Documentatie Centrum, Radboud Universitiet Nijmegen University. I thank Karel A. 
Steenbrink for locating and transcribing this source and sharing its content with me. This source hereafter is referred to as Mathilda Maria van Thienen.

121. Confidential interview, Yogyakarta, September 2002.

122. Richard Tanter, "Beek, Father J. van. SJ" Appendix 1 of his "Intelligence, Agencies and Third World Militarization: A Case Study of Indonesia" (PhD. Thesis, Monash University, 1991). The brutality in the training is also confirmed by my informants. The sanctions given to those who could not fulfil their assignments were very hard: one said that he was tightened on a chair and put in a dark room and a snake (probably not poisonous) was put on his shoulders; another said that he was tied without clothes except his underwear and mud was poured onto his body and then he was kept there for the whole night while mosquitoes freely bit him; another said that she was confined to a room without food for three days. Interviews in Yogyakarta, September and October 2002.

123. Mathilda Maria van Thienen.

124. See "Cosmas Batubara: Pater Beek Bukan Agen CIA"in Tim ISAI, Bayang-Bayang PKI (Jakarta: ISAI, 1995), 43.

125. Daniel T. Sparringa, "Discourse, Democracy and Intellectuals in New Order Indonesia: A Qualitative Sociological Study" (PhD Thesis, Flinders University of South Australia, 1997), 250-1.

126. Interview with B. Suryasmoro Ispandrihari, Yogyakarta, 30 September 2002. See also his book, Penampakan Bunda Maria, Counter Discourse Atas Hegemoni Gereja \& Rezim Orde Baru (Yogyakarta: KesAnt, 2000), 24. Suryasmoro Ispandrihari is a former khasebul trainee who later decided to leave the khasebul alumni network. It is unclear to me why he rebelled but I got the impression that it was because of internal conflict among Catholic activists. His book, which circulated in a very limited number of copies, is apparently the first Indonesian source explaining the khasebul programme to outsiders. His account of the khasebul might be exaggerated but my interviews with other Catholic activists (including one person who claimed that he was still active in the network) mostly confirmed Ispandrihari's account.

127. Interview with Damai Pakpahan, Yogyakarta, 4 October 2002.

128. Mathilda Maria van Thienen.

129. Richard Tanter, "Beek, Father J. van. SJ".

130. Interview with a former Jesuit, Francis Wahono, Yogyakarta, 14 January 2004.

131. There was a series of books on Kursus Kader Katolik (Catholic Cadre Courses) published in the early period of the New Order. For the khasebul level, the books include the following titles: Kursus Berpidato (public speaking) Teknik Berdiskusi (techniques of discussion) Metode Tiga Tahap (three- stage method), Aksi Propaganda (propaganda action) and Sel dan Tatakerdjanja (cell and its work). By this period, students at the Catholic seminaries who were not khasebul trainees could also read the books because they were available in the library. Confidential Interview, December 2003.

132. Anonymous, Sel dan Tatakerdjanja (Kursus Kader Katolik, Sekretariat Nasional K.M. Gunung Sahari 88, Djakarta V/3, 1968), 5-9.

133. Anonymous, Sel dan Tatakerdjanja, 13-14;26-37;49-49-74. General Soemitro, the former Operational Commander for Restoration of Security and Order (Pangkopkamtib) in the early 1970s said: "It is also mentioned in a document that this group [Beek's] has networks in all sub-districts in Java, namely through an information bureau. Thus, if Jakarta wants to blow up an issue, then in a wink of the eye, the information has already reached Surabaya." Cahyono, Pangkopkamtib Jenderal Soemitro, 35-6 
134. Interview with Paul de Blot, Nyenrode, 22 July 2003. In his recent article, Batubara also hints at the importance of the report of the khasebul alumni. See Cosmas Batubara, "Pemikiran dan Pandangan Harry" in Hadi Soesastro, J. Kristiadi and Arief Priyadi (eds.), Budi dan Nalar: 70 Tahun Harry Tjan Silalahi (Jakarta: CSIS, 2004), 106.

135. The list of the codes is revealed in Ispandrihari, Penampakan Bunda Maria, 73-5. For example, 'Pak Nurman' is a code for 'Nahdlatul Ulama,' and 'mBak Sis' for 'CSIS.'

136. Tanter, "Beek, Father J. van. SJ".

137. The term 'khasebul' has been changed into 'madha' an acronym for 'mawas diri harian' (daily introspection). Interview with B. Suryasmoro Ispandrihari, Yogyakarta, $30 \mathrm{Sep}$ tember 2002 and 12 January 2004.

138. Interview with Damai Pakpahan, Yogyakarta, 4 October 2002. Ispandrihari, Penampakan Bunda Maria, 23, note 5.

139. Interview with Andry Kristiawan Sutrisno and B. Suryasmoro Ispandrihari, Yogyakarta, 14 October 2002.

140. May, The Indonesian Tragedy, 159. Jenkins notes: "At the time of the 1977 general elections, Suharto received Ignatius Joseph Kasimo, Frans Seda and several other leaders of the former Catholic Party. Before the group was seated the president is said to have declared: 'Our common enemy is Islam!'” See David Jenkins, Suharto and His Generals: Indonesian Military Politics 1975-1983 (Ithaca: Cornell Modern Indonesia Project, 1984), 29.

141. Suryadinata, Prominent Indonesian Chinese, 216-17.

142. McDonald, Suharto's Indonesia, 36.

143. McDonald, Suharto's Indonesia, 101; Jenkins, Suharto and His Generals, 56-9.

144. Cahyono, Pangkopkamtib Jenderal Soemitro, 36-7.

145. Tanter, "Beek, Father J. van SJ."

146. For a detailed account of Sekber Golkar and its transformation, see Leo Suryadinata, Military Ascendancy and Political Culture: A Study of Indonesia's Golkar (Athens: Ohio University Center for International Studies, 1985), Chapter 1 and 2; David Reeve, Golkar of Indonesia: An Alternative to the Party System (Singapore: Oxford University Press, 1985), Chapter 5 and 6.

147. Quoted in Wertheim, "Indonesia's Hidden Histroy of 1965", 301.

148. May, The Indonesian Tragedy, 238.

149. Interview with Paul de Blot, Nyenrode, 22 July 2003.

150. In 1971, Cosmas Batubara was a member of the Central Executive Board while Jusuf Wanandi was Deputy Secretary General. In 1973-1978, both of them were at the Central Executive Board: Wanandi was Secretary General for General Matters and Planning and Batubara was Secretary for Organization and Education. In 1978-1983, Batubara was secretary and member of the Supervisor's Council and Wanandi was Deputy Treasurer. In 1983-1988, Batubara was secretary and member of the Daily Board of the Supervisor's Council and Wanandi was in the Department of Foreign Relations of the Central Executive Board. For a complete list of Golkar's leadership in this period, see Suryadinata, Military Ascendancy, 147-54.

151. Cosmas Batubara is of Batak origin while Beek's other prominent students are Chinese. Perhaps this was the reason why only Batubara became one of Soeharto's ministers, while Jusuf Wanandi and Sofyan Wanandi were only appointed as members of the Parliament (DPR) and the People's Consultative Assembly (MPR). While Jusuf Wanandi was more active in intellectual discourses at the CSIS, Sofyan Wanandi was more active in business and known as one of the Chinese conglomerates in Indonesia. In 1978, another student of Beek, Harry Tjan Silalahi was appointed to be a member of the State 
Advisory Council (DPA). There is another prominent Catholic who held some important ministerial positions, that is, J.B. Sumarlin. He worked for ten years (1973-1983) as the Deputy of the Head of the Body of the State Development Planning (Bappenas) and at the same time was the Minister of Empowering State Apparatus (Menpan). From 1983-1988, he was the head of the Bappenas and at the same time the Minister of the National Development Planning. It seems, however, Sumarlin was not counted as an ally by Beek's group. Sumarlin was one of the 'Berkeley Mafia', that is the economists who graduated from the University of California and led by Widjojo Nitisastro and became the economic team of the Government. According to Soemitro, the CSIS group disliked and wanted to replace Nitisastro's group in 1970s, but did not succeed. The economist of the CSIS was Panglaykim, a professor of economics of Chinese descent at the University of Indonesia. Cahyono, Pangkopkamtib Jenderal Soemitro, 84-6; and "J.B. Sumarlin Mengabdi di Pusat Kebijakan Ekonomi" in www.tokohindonesia.com/ensiklopedi/j/jb-sumarlin/index.sthtml (accessed 15 March 2005).

152. Interview with Harry Tjan Silalahi, Jakarta, 22 December 2003. See also Harry Tjan Silalahi, "CENTER Lahir dari Tantangan Jaman" in CSIS 20 Tahun (Jakarta: CSIS, 1991), 18; 20-1.

153. HarryTjan Silalahi, "ThinkTank"in Sekar Semerbak, Kenangan Untuk Ali Moertopo (Jakarta: Yayasan Proklamasi, CSIS, 1985), 334-41.

154. On another occasion, Soemitro also mentions two Chinese businessmen who probably funded the CSIS: Nyo Han Siang, the boss of the AK Building, Jakarta and Liem Bian Khoen (Sofjan Wanandi). See Heru Cahyono, Pangkopkamtib Jenderal Soemitro, 36; 43; Ramadhan K.H., Soemitro (Mantan Pangkopkamtib) Dari Pangdam Mulawarman Sampai Pangkopkamtib (Jakarta: Sinar Harapan, 1994), 253.

155. Julius Pour, Benny Moerdani: Profil Prajurit Negarawan (Jakarta:Yayasan Kejuangan Panglima Besar Sudirman, 1993), 302-4.

156. See "Setelah Malari Benny Datang," Forum Keadilan No.2 (May 13, 1993), 15.

157. Cahyono, Pangkopkamtib Jenderal Soemitro, 37.

158. Another Christian thinker, Nicholas of Cusa (d. 1464) reformulated this idea further by developing a doctrine of 'universal harmony' in which he explained the harmonious hierarchy of the cosmos based on a Trinitarian configuration. See Nicholas of Cusa, The Catholic Concordance, Trans. Paul E. Sigmund (Cambridge: Cambridge University Press, 1991).

159. Daniel Dhakidae, Cendekiawan dan Kekuasaan Dalam Negara Orde Baru (Jakarta: Gramedia, 2003), 616-35.

160. Dhakidae, Cendekiawan, 656-7.

161. Interview with Paul de Blot, Nyenrode, 22 July 2003.

162. For comprehensive and critical study of Soepomo's speech on the integralistic state, see Marsillam Simanjuntak, Pandangan Negara Integralistik: Sumber, Unsur dan Riwayatnya dalam Persiapan UUD 1945 (Jakarta: Grafiti, 1994).

163. Simanjuntak, Pandangan Negara Integralistik, 52-3.

164. Donald J. Porter, Managing Politics and Islam in Indonesia (London: Routledge, 2002), 30 3.

165. BP7 is'Badan Pembinaan Pendidikan Pelaksanaan Pedoman Penghayatan dan PengamaIan Pancasila' (The Body for Supervising the Education on the Implementation of the Guide for Internalisation and Actualisation of Pancasila).

166. Krissantono (ed.), Pandangan Presiden Soeharto Tentang Pancasila $2^{\text {nd }}$ Edition (Jakarta: Yayasan Proklamasi, CSIS, 1976), 52; 60. 
167. See P-4, The Guide to the Living and Practice of Pancasila and GBHN, The Broad Outlines of the State Policy (Jakarta: Yayasan Proklamasi, CSIS, 1978).

168. Ali Moertopo, Strategi Kebudayaan (Jakarta: CSIS, 1978), 61-3.

169. A.M.W. Pranarka, Sejarah Pemikiran Tentang Pancasila (Jakarta: CSIS, 1985), 356-61.

170. Interview with Husein Umar, Jakarta, 22 October 2003.

171. The full text of Pranarka's article entitled "Secara Kulturil Nasionalisme Adalah Dalil Dasar Sejarah Indonesia" is reprinted in Muhammad Rasjidi, Strategi Kebudayaan dan Pembaharuan Pendidikan Nasional (Jakarta: Bulan Bintang, 1980), 44-57.

172. Pranarka, "Secara Kulturil", 48.

173. Pranarka, "Secara Kulturil", 55.

174. Rasjidi, Strategi Kebudayaan, 24; 29-30.

175. Rasjidi, Strategi Kebudayaan, 33.

176. Rasjidi, Strategi Kebudayaan, 28; 34-5;39.

177. Soebagijo I.N. “Dari Saridi ke Rasjidi” in Endang Basri Ananda (ed.), 70 Tahun Prof. Dr. H.M. Rasjidi (Jakarta: Pelita, 1985), 77.

178. Interview with Agustine Prasetyo Murniati, Yogyakarta, 7 October 2002.

179. McDonald, Suharto's Indonesia, 102.

180. McDonald, Suharto's Indonesia, 102.

181. Bourchier, Beek, "Father Jopie SJ (Joop)." According to Soemitro, General Soetoepo Jowono, the head of BAKIN in the early 1970s once asked the Vatican to remove Beek from Indonesia and this was successful but only for a short period. Soemitro, however, does not clearly specify how long and when exactly Beek was removed. Cahyono, Pangkopkamtib Jenderal Soemitro, 34-5.

182. Interview with Daniel Dhakidae, Jakarta, 18 December 2003 and with B. Suryasmoro Ispandrihari, Yogyakarta, 30 September 2002. According to Ispandrihari, Mangunwijaya once translated 'khasebul' into 'khasebol' an acronym for 'khalwat serba boleh' (literally means 'all is permissible retreat') to imply that the ideology of the khasebul is 'the end justifies the means.'

183. Interview with Francis Wahono, 14 January 2004.

184. Interview with St. Sunardi, Yogyakarta, 2 October 2002.

185. Interview with Father Ismartono, Yogyakarta, 5 October 2002.

186. Interview with Paul de Blot, Nyenrode, 22 July 2003.

187. Email communication, 23 September 2002.

188. Interview with Father Ismartono, Yogyakarta, 5 October 2002.

189. Confidential Interview, September 2002.

190. Interview with Andry Kristiawan Sutrisno,Yogyakarta, 14 October 2002. He said that, when he graduated from the Martoyodan Middle Seminary, Yogyakarta, he was advised by a priest on not joining the khasebul. He then followed the advice.

191. Confidential Interview, Jakarta, December 2003.

192. For a discussion on Muslim responses to the regulation, see Faisal Ismail, Islam and Pancasila: Indonesian Politics 1945-1995 (Jakarta: Litbang Depag, 2001), Chapter 3.

193. For an English translation of the letter, see Syafruddin Prawiranegara, "Pancasila as the Sole Foundation" Indonesia No. 38 (October, 1984), 74-83.

194. The new ' $P$ ' refers to 'Persekutuan' (Communion) as differentiated from the old ' $D$ ' that refers to 'Dewan' (Council). The official explanation of this change is to develop ecumenism among the Protestant churches. See the text of PGI's Constitution, in Weinata Sairin (ed.), Himpunan Peraturan di Bidang Keagamaan (Jakarta: BPK, 1994), 372-92.

195. Aritonang, Sejarah Perjumpaan, 440-2. 
196. J.W.M. Boelaars, Indonesianisasi: Dari Gereja Katolik di Indonesia Menjadi Gereja Katolik Indonesia trans. R. Hardawiyana (Yogyakarta: Kanisius, 2005), 326-36.

197. The old 'MA' refers to 'Majelis Agung' (High Council), while the new ' $K$ ' refers to 'Konferensi' (Conference). The official explanation of this change was that the new Canon Law (introduced in 1983) did not mention 'Council' of Bishops but Conferentia Episcoporum. See Boelaars, Indonesianisasi, 332.

198. See Douglas E. Ramage, Politics in Indonesia: Democracy, Islam and the Ideology of Tolerance (London: Routledge, 1995).

199. Namely that 'Yang Maha Esa' is tawhïd according to Ki Bagus Hadikusomo and therefore the Islamic law can be applied by the state. See Ahmad Azhar Basyir, "Hubungan Agama dan Pancasila," in Peranan Agama Dalam Pemantapan Ideologi Negara Pancasila (Jakarta: Badan Litbang Agama: 1984/1985), 41-44.

200. Achmad Siddiq, "Hubungan Agama dan Pancasila"in Peranan Agama Dalam Pemantapan Ideologi Negara Pancasila, 21-34.

201. Nurcholish Madjid's renewal movement is discussed in Chapter 6.

202. Nurcholish Madjid, "Pembahasan Atas Makalah K.H. Achmad Siddiq'Hubungan Agama dan Pancasila"' in Peranan Agama Dalam Pemantapan Ideologi Negara Pancasila (Jakarta: Badan Litbang Agama: 1984/1985), 35-8.

203. See Mujiburrahman, "Islam and Politics in Indonesia: the political thought of Abdurrahman Wahid," Islam and Christian-Muslim Relations Vol. 10 (October 1999), 339-352.

204. Ramage, Politics in Indonesia, 45-74.

205. On this regular Seminar, see Chapter 6.

206. Eka Darmaputera "Beberapa Catatan Sosio-Kultural Tentang Masalah Sekitar Identitas dan Modernisasi di Indonesia" in Kumpulan Rekaman Hasil Seminar Agama-Agama Bidang Islam V dan VI (Jakarta: Litbang PGI, no date). For his thesis, see Darmaputera, Pancasila and the Search for Identity and Modernity.

207. Eka Darmaputera, "Keadilan Dalam Pancasila: Suatu Analisa Budaya" in Kumpulan Rekaman Hasil Seminar Agama-Agama Bidang Islam V dan VI (Jakarta: Litbang PGI, no date).

208. See Mujiburrahman, "The Diaspora Church in Indonesia: Mangunwijaya on Nationalism, Humanism and Catholic Praxis" Journal of Ecumenical Studies No. 4 Vol. 38 (2001), 4668.

\section{Notes Chapter 4}

1. Daniel S. Lev, Islamic Courts in Indonesia: A Study in the Political Bases of Legal Institutions (Berkeley: University of California Press, 1972), 54-5. For the text of the Law, see Hasbullah Bakry, Kumpulan Lengkap Undang-Undang dan Peraturan Perkawinan di Indonesia (Jakarta: Djambatan, 1978), 119-30.

2. Zaini Ahmad Noeh,"Perkembangan Setelah Undang-Undang Perkawinan”, a supplementary chapter to Daniel S. Lev, Peradilan Agama Islam di Indonesia: Suatu Studi Tentang Landasan Politik Lembaga-Lembaga Hukum $2^{\text {nd }}$ Edition (Jakarta: Intermasa, 1982), 3279.

3. For the text of $\mathrm{HOCl}$, see Weinata Sairin and J.M. Pattiasina (eds.), Pelaksanaan UndangUndang Perkawinan Dalam Perspektif Kristen (Jakarta: BPK, 1994), 391-411.

4. The following account is taken from Nani Soewondo, Kedudukan Wanita Indonesia Dalam Hukum dan Masyarakat (Jakarta: Ghalia, 1981), 86-96; Noeh, "Perkembangan Setelah Undang-Undang Perkawinan", 330-332; Sudargo Gautama, Segi-Segi Hukum Peraturan Perkawinan Campuran Revised Edition (Bandung: P.T. Aditya Bakti, 1996), 
255-60. The last book was originally a PhD thesis submitted to the Faculty of Law, University of Indonesia in 1955. It is noteworthy that Nani Soewondo was a leading activist of women's rights and a member of the Committee; Zaini Ahmad Noeh used to be an official of the Ministry of Religion in the Islamic Court Section and Sudargo Gautama was a leading scholar of law in Indonesia.

5. Sudargo Gautama noted that on 11 February 1959, the Indonesian Communist Party (PKI), also proposed another marriage bill. Gautama, Segi-Segi Hukum Peraturan, 259. Maria Ulfah, Nani Soewondo, Zaini Ahmad Noeh and others did not mention this fact at all and this was, perhaps, because they wrote during the New Order. Moreover, it is unclear to me whether the PKI's bill was also included in the Parliamentary discussions. In any case, this obviously indicates that the legislation on marriage was a politicoideological battlefield.

6. To practice polygamy, the bill required the husband (1) to get permission from his early wife or wives; (2) to make a written testament that he must be just to his wives; and (3) to prove that he could fulfil their needs. In addition, the bill also stipulated that polygamy could be prevented by a written testament of a husband in the marriage contract. Soewondo, Kedudukan Wanita Indonesia, 98.

7. Noeh, "Perkembangan Setelah Undang-Undang Perkawinan", 332.

8. See Decree No. XXVII/MPRS/1966 on People's Welfare. The marriage law was mentioned in article 1, section 2 of the decree. For a full text of the decree, see Abdul Kadir Besar, Himpunan Ketetapan-Ketetapan M.P.R.S. (Jakarta: Pantjuran Tudjuh, 1969), 105-8.

9. President Soekarno established the LPHN (Lembaga Pembinaan Hukum Nasional) on 30 March 1958. Structurally, the LPHN was under the Prime Minister's supervision, but later, since May 1961, it was under the Minister of Justice. On 26 August 1974, President Soeharto changed the LPHN into BPHN (Badan Pembinaan Hukum Nasional) and made it a unit of the Department of Justice. See Soewondo, Kedudukan Wanita Indonesia, 268.

10. Noeh, "Perkembangan Setelah Undang-Undang Perkawinan," 333.

11. Donald K. Emmerson, Indonesia's Elite: Political Culture and Cultural Politics (Ithaca: Cornell University Press, 1976), 228-9.

12. See few quotations from the Bill of the Department of Justice in B.J. Boland, The Struggle of Islam in Modern Indonesia (The Hague: Martinus Nijhoff, 1982), 167.

13. Soewondo, Kedudukan Wanita Indonesia, 100-2.

14. See "RUU Perkawinan, Aksi dan Reaksi" Tempo (8 September 1973), 7. Boland mentions a debate on polygamy but it is unclear whether this issue was the main reason for the deadlock. See Boland, The Struggle of Islam, 167-8.

15. See "Sambil Menanti Undang-Undang Hawa" Tempo (30 June 1973), 50.

16. See Hasbullah Bakry, "Kerjasama Islam-Kristen Perlu Ditingkatkan" Kiblat No. 7 (September, 1969), 24 and the account of Anwar Harjono's view in Tempo (30 June 1973), 50.

17. Indeed, the editor of Kiblat noted that at that time, 13 factions (fraksi) in Parliament agreed, 2 abstained and 1 rejected the bill. See "RUU Perkawinan" Kiblat No. 8 (September, 1973), 46.

18. Andrée Feillard, NU vis-à-vis Negara: Pencarian Isi, Bentuk dan Makna Trans. Lesmana (Yogyakarta: LKiS, 1999), 129-30, quoting the official text of the elucidation of the bill.

19. Interview with Harry Tjan Silalahi, Jakarta, 22 December 2003.

20. Kiblat reported that Operasi newspaper published the contents of the memorandum in five days consecutively, that is, from 14 to 19 April 1969. See Kiblat No.22 (April, 1969), 4-5. Later Kiblat also published the full text of the memorandum in May, while the Catholic weekly Peraba published it in July. See "Pokok2 Pikiran Fraksi Katholik Men- 
genai Rantjangan Undang2 Perkawinan Umat Islam," Kiblat No. 23 (May, 1969), 17-20; see also "Pokok-Pokok Pikiran Fraksi Katolik: Rantjangan Undang2 Ketentuan2 Pokok Perkawinan dan Rantjangan Undang2 Tentang Peraturan Pernikahan Umat Islam," Peraba (July I, 1969), 3-6. The memorandum was reprinted in Muhammad Rasjidi, Kasus RUU Perkawinan Dalam Hubungan Islam dan Kristen (Jakarta: Bulan Bintang, 1974), 34-9.

21. I used the plural word because the original title of the memorandum indicates that it was directed against the two bills, although its main target was clearly the Islamic marriage bill.

22. This is a strong clue that the alliance between the Catholics and the Javanese abangan military officers was now well established.

23. See "Katholik Mulai Praktekkan Adjaran Paulus 'Segala Sesuatu Halal Bagiku' (Korintus 6:12)" Kiblat No. 22 (April, 1969), 4-5 quoting anonymous Muslim views from Operasi and Abadi newspapers. See also the interview with Kasman Singodimedjo entitled "Untuk Ketertiban Masjarakat: Perlu Segera Dikeluarkan UU Pernikahan" Kiblat No. 1 (June, 1969), 21-23. Ki Urip Sekaten, "Wahai Ummat Pantjasilais: Waspadalah! Kaum Sekularis Penghalang Lahirnja Undang-Undang Perkawinan Ummat Islam di Indonesia," Kiblat No. 22 (April, 1969), 12-14; 26.

24. Lev, Islamic Courts in Indonesia, 139-40.

25. She was very much against polygamy and probably wanted to prevent her husband from imitating the previous President, Soekarno, who was polygamous.

26. Arso Sosroatmodjo \& Wasit Aulawi, Hukum Perkawinan di Indonesia (Jakarta: Bulan Bintang, 1978), 22-4. Rachmawati S. "Kawin Cerai, Pengadilan dan KB" Tempo (30 June 1973), 47-8.

27. There was no record of serious violence but several students were arrested. See "RUU Perkawinan: Sumpah Para Ulama" Tempo (1 September 1973), 6; "Demonstrasi: Ada 'Allahu Akbar' Dari Luar" Tempo (6 October 1973), 6-7; "RUU Perkawinan: Bumbu-Bumbu Masakan Baru" Tempo (13 October 1973), 6; "Demonstrasi: 13 Yang Bebas" Tempo (3 November 1973), 13; "Berita dan Komentar" Panji Masyarakat No. 137 (October, 1973), 6-7; "Berita dan Komentar" Panji Masyarakat No. 138 (November, 1973), 7.

28. On these articles and their later amendments, see Muhammad Kamal Hassan, Muslim Intellectual Responses to 'New Order' Modernization in Indonesia (Kuala Lumpur: Dewan Bahasa dan Pustaka, 1982), 147-54. June S. Katz \& Ronald S. Katz, "The New Indonesian Marriage Law: A Mirror of Indonesia's Political, Cultural, and Legal System" The American Journal of Comparative Law Vol. 23 (1975), 653-81; Nani Soewondo, "The Indonesian Marriage Law and Its Implementing Regulations" Archipel 13 (1977), 283-313.

29. For a complete figure of the vote of all parties compared with the votes in 1955 elections, see B.B. Hering and G.A. Willis, The Indonesian General Election of 1971 (Bruxelles: Cente d'Etude du Sud-Est Asiatique et de l'Extreme Orient, 1973), 15b. On the elections, see Ken Ward, The 1971 Elections in Indonesia: An East Java Case Study (Victoria: Monash University, 1974).

30. Hamish McDonald, Suharto's Indonesia (Honolulu: Univerity of Hawaii, 1981), 108.

31. HAMKA, "RUU Perkawinan Yang Menggoncangkan" Panji Masyarakat No. 134 (September, 1973), 4-5;33; also published in Kiblat No. 7 (September, 1973), 9-10 and Harian Kami 24 August 1973. A summary of the article is given in Emmerson, Indonesia's Elite, 231-2.

32. See "RUU Perkawinan dan Ummat Islam" Abadi, 13 August 1973, reprinted in Sekitar Pembentukan Undang-Undang Perkawinan Beserta Peraturan Pelaksanaannya (Jakarta: Dirjen Hukum dan Perundang-Undangan, Departemen Kehakiman, 1974), 152-3. 
33. There is a report that Muslim students insisted that Idham Chalid not compromise but reject the bill. See "Demonstrasi: Ada 'Allahu Akbar' Dari Luar" Tempo (6 October 1973), 6. Several students also came to Masjkur's house and tried to prevent him from attending the parliament session unless he promised that he would struggle for eliminating the articles of the bill contradicting the Islamic law. See Soebagio I.N., K.H. Masjkur, Sebuah Biografi (Jakarta: Gunung Agung, 1982), 226-7.

34. Mukti Ali was under military protection from demonstrators during the controversy. See Feillard, NU vis-à-vis Negara, 192. In an article, Rasjidi later bitterly said that Mukti Ali "almost approved the secular marriage bill." See Muhammad Rasjidi, "Pergolakan Pemikiran Islam: Sebuah Tragedi" Panji Masyarakat No. 346 (January, 1982), 42-3. It is noteworthy that Mukti Ali was politically weaker than the previous Ministers of Religion. See Chapter 6.

35. Panji Masyarakat No. 135 (September, 1973), 7-8.

36. See M. Sanusi, "Demi Keamanan dan Suksesnya Pembangunan: Tarik Kembali RUU Perkawinan" Panji Masyarakat No. 135 (September, 1973), 6.

37. Seefor instance,"Rencana Undang-Undang Perkawinan"Indonesia Raya, 23 August 1973, reprinted in Kiblat No. 7 (September, 1973), 8 and Aminah Norman, "Dua Kepentingan Dalam RUU Perkawinan" Indonesia Raya, 4 September 1973, reprinted in Sekitar Pembentukan, 165-170.

38. McDonald, Suharto's Indonesia, 134; Heru Cahyono, Pangkopkamtib Jenderal Soemitro dan Persitiwa 15 Januari '74 (Jakarta: Sinar Harapan, 1998), 151-2. For the NU's role in the lobbying, see Feillard, NU vis-à-vis Negara, 192-7. For the involvement of the reformist Muslim leaders, see "Berita dan Komentar," Panji Masyarakat No. 137 (October, 1973), $5-7 ; 34$.

39. The content of the compromise is discussed below.

40. See the studies quoted in note 28 .

41. Emmerson, Indonesia's Elite, 228-45.

42. See for instance, June S. Katz \& Ronald S. Katz, "Legislating Social Change in a Developing Country: The New Indonesian Marriage Law Revisited" The American Journal of Comparative Law Vol. 26 (1978), 309-20; Mark Cammack, Lawrence A. Young and Tim Heaton, "Legislating Social Change in an Islamic Society - Indonesia's Marriage Law" The American Journal of Comparative Law Vol. 44 (1996), 45-73.

43. Crouch, The Army and Politics, 313.

44. See "Khotbah Buat Negarawan dan Si Polan," Tempo (15 September 1973), 43.

45. See "RUU Perkawinan, Aksi dan Reaksi" Tempo (8 September 1973), 7.

46. Emmerson, Indonesia's Elite, 239-40.

47. SARA is an acronym of Suku (ethnicity), Agama (religion), Ras (race) and Antar-golongan (inter-class). Based on the idea of political stability for the sake of development, the New Order Government prohibited people from talking about issues of conflict of SARA publicly. In terms of religion (Agama), the issues include the Jakarta Charter or Islamic State and Christianisation.

48. See "Berita dan Komentar" Panji Masyarakat No. 136 (October, 1973), 9.

49. See"RUU Perkawinan, Aksi dan Reaksi" Tempo (8 September 1973), 6-8. General Soemitro also believed that the bill was the work of the CSIS. See Cahyono, Pangkopkamtib Jenderal Soemitro, 40-1; 150. Husein Umar of the DDII had the same opinion as Soemitro. Nonetheless, Harry Tjan Silalahi of the CSIS denied any involvement in drafting the bill and pointed his finger at the CSIS group's rival in Golkar, the State Secretary, Sudharmono. Interviews in Jakarta with Husein Umar, 22 October 2003; and Harry Tjan Silalahi, 22 December 2003. On the CSIS, see Chapter 3. 
50. See "'Catholic Worker'Apa Kegiatan Orang Katolik di Indonesia" Panji Masyarakat No. 136 (October, 1973), 25.

51. This perception was implicitly stated in an article written by Natsir about two months before the controversy. Natsir wrote that in contrast to the Muslim minorities in India, Thailand and the Philippines who suffered from discrimination, the Christian minorities in Indonesia did not. "The Christian minority groups can live peacefully side by side with the Muslim majority and even they can take important positions in the Cabinet and state apparatus of both military and civil services of the central and regional governments. They can become a Minister, a Governor of the Central Bank, a Commander of Armed Forces, a Commander of Regional Defence and Security, a Commander of a Military Division, a Commander of Military Resort, a Commander of Military District, and any position without discrimination. They can even lead and control the largest party and political faction in Indonesia, that is, Golkar, inside and outside the legislative body." See Mohammad Natsir, "Sekali Lagi 'Kerukunan Hidup Antar Agama': Sumbangsih Untuk Prof. Dr. Verkuyl" Panji Masyarakat No. 129 (June 1973), 16. Italics mine.

52. Rusydi, "Siapa Dalangnya?" Panji Masyarakat No. 138 (November, 1973), 8-9.

53. In his speech on 16 August 1973, the President asserted that in the state based on Pancasila "marriage is strongly related to religious and spiritual elements." See "Presiden Suharto: Perkawinan Sangat Erat Dengan Unsur2 Keagamaan dan Kerohanian" Kiblat No. 7 (September, 1973), 4.

54. This case and Rasjidi's article are to be discussed below.

55. Sum Ireng, "Siapa Konseptor RUU Perkawinan?" Hidup No. 48 (23 December 1973), 759.

56. See "Fokus Kita" Tempo (20 October 1973), 1.

57. George J. Aditjondro is actually one of the khasebul alumni but he is also among the earliest cadres who decided to leave the khasebul network. On khasebul, see Chapter 3.

58. See "Katolik: Bola Salju Mulai Menggelinding ?" Tempo (20 October 1973), 45-8.

59. There was a response to Tempo's coverage from Y.B. Mangunwijaya, a priest who was to become famous in the following decades. He wrote that some Catholic priests were unhappy with the report, but he suggested that whether it was partial or not (he thought it was), it was good for the Church to be more critical of herself. Using Kantian terms, he argued that the report only covered the 'phenomena' not the 'noumena' of the Church. See Y.B. Mangunwijaya, "Menangkap Tanda2 Tempo" Peraba (November I, 1973), 6-7.

60. Sarmudi,"Perkembangan Pemikiran Baru Dikalangan Gereja Katholik di Indonesia:Usaha Mencapai Modus Vivendi Antara Islam dan Nasrani" Panji Masyarakat No.142 (January, 1974), 16-17.

61. Muhammad Rasjidi, "The Role of Christian Missions: the Indonesian Experience" International Review of Mission Vol. 65 No. 260 (October, 1976), 432.

62. Rasjidi, "The Role of Christian Missions", 435.

63. I use the word 'faction' here to refer to the Indonesian word 'fraksi' which means a political grouping in the Parliament. Since 1973 to the end of the New Order, there were four 'fraksi': PPP, PDI, Golkar and ABRI.

64. Hassan,Muslim Intellectual Responses, 151 quoting The Jakarta Times, 15 August 1973. The Muslims were certainly upset with Sugiharto's statement. It was reported that in Bandung, Muslim demonstrators said that the statement indicated that Golkar deceived the Muslim voters because in its campaign for the election, the party promised to develop religious values in the country. See "Berita dan Komentar" Panji Masyarakat No. 140 (December 1973), 8-9. 
65. This is clearly a reiteration of the so-called 'reception theory' introduced by Dutch scholars, C. Snouck Hurgronje (1857-1936) and C. van Vollenhoven (1874-1933). The idea is that law should be 'indigenous' and foreign laws (Islamic and Western laws) can only become the law for the natives if they are already received into the indigenous one. The indigenous was nothing but adat (custom) that already existed among various ethnic groups in the country. The proponents of Islamic law opposed this theory, and one of them called it a theory of the Devil. See Lev, Islamic Courts, 196-8. Likewise, adat regulations were sometimes also in rivalry or even in conflict with Christian rulings on marriage. See John M. Prior, Church and Marriage in an Indonesian Village: a Study of Customary and Church Marriage among the Ata Lio of Central Flores (Bern: Verlag Peter Lang, 1987).

66. See the speeches of Golkar's speaker, Nelly Adam Malik, of the Minister of Justice Oemar Seno Adjie and of the Minister of Religion, A. Mukti Ali in Sekitar Pembentukan, 43-52; 72-3; 131-6.

67. See his speech in Sekitar Pembentukan, 76-77.

68. See his speech in Sekitar Pembentukan , 102.

69. See his speech in Sekitar Pembentukan, 82-7. For Muslim arguments for legal differentiation outside Parliament, see Anwar Haryono, "RUU Perkawinan, Kesadaran Hukum dan UUD '45" published in Abadi, 27 August 1973 and Kiblat No. 7 (September, 1973), 7-8; Syafruddin Prawiranegara, "Komentar Atas RUU Perkawinan: Contohlah Yang Baik Walaupun Darimana" Panji Masyarakat No. 137 (October, 1973), 11-13; Mohammad Hasan, "RUU Perkawinan dan Politik Hukum Pemerintah" Panji Masyarakat No. 138 (November, 1973), 24-6; and "RUU Perkawinan: Mencabut \& Merubah" Tempo (22 September 1973), 8-9.

70. "Rencana Undang2 Tentang Perkawinan (I)" Panji Masyarakat No. 133 (August, 1973), 4

71. See "Menanggapi RUU Perkawinan" Peraba (October II, 1973), 3.

72. See "Mendesaknya: Kesatuan Hukum Perkawinan" Peraba (October III, 1973), 2;4-5; F.X. Sudiyono, "Mungkinkah Unifikasi Undang2 Perkawinan" (I-III) Peraba (December I, II and III, 1973), 9, 8-9 and 8 respectively.

73. T.B. Simatupang, "Catatan Berhubung Dengan Rancangan UU Tentang Perkawinan" (a copy of this document is found in a dossier of Litbang PGI, Jakarta).

74. See Abadi, 10 December 1973; Berita Antara, 11 December 1973;"RUU Perkawinan:Yang Didrop \& Dirubah" Tempo (15 December 1973), 6-7.

75. On the day of the ratification of the amended bill, the speaker of the PPP, Ali Yafie, said that it was truly based on Pancasila. See his speech in Sekitar Pembentukan, 212-15. In an interview he said: "The government bill was a copy of the Code of Civil Law on marriage inherited from the Dutch. The legal principle of the Code was that marriage is a civil event... However, what was finally accepted was a new principle, namely that marriage law for Indonesians is based on Pancasila in which religion is one of its determining factors. Therefore, article 2 states that marriage is valid if it is based on religion and then followed by registration. This was a new principle of the national law and in fact this principle is truly based on Pancasila." Interview in Jakarta, 14 December 2003.

76. Copies of the letters to these officials are found in a dossier of Litbang PGI, Jakarta.

77. The "Pokok-Pokok Pemikiran BPH-DGI dan MAWI" was published in Kompas and Sinar Harapan, 19 December 1973. This piece is reprinted in Rasjidi, Kasus RUU Perkawinan, 44-6; and Sairin and Pattiasina, Pelaksanaan Undang-Undang Perkawinan, 248-9.

78. This issue will be discussed further below. This problem was more explicitly stated in the DGI-MAWI joint letter sent to General Soemitro, dated 16 December 1973. The copy of the letter is found in a dossier of Litbang PGl, Jakarta. See also "Demi Perikemanu- 
siaan dan Ketertiban Hukum" Sinar Harapan, 19 December 1973, reprinted in Muhammad Rasjidi, Kasus RUU Perkawinan, 52-3.

79. It is noteworthy that in the meeting between the joint delegation of the DGI-MAWI and General Soemitro along with other state officials on 21 December 1973, it was reported that Soemitro was rather angry to hear that ABRI was accused of deviating from the Constitution and accommodative to the Jakarta Charter. This seems to indicate that for Soemitro, it was the Christians who made that accusation. (See Minutes of the meeting entitled "Risalah Pertemuan di Wisma Yani" found in a dossier of Litbang PGI, Jakarta).

80. See "Para Penyusun UUD '45 Sudah Berikan Jalan Keluar" Kompas, 17 December 1973 reprinted in Rasjidi, Kasus RUU Perkawinan, 47-8.

81. See "Mengapa Surat Kabar Ini Begitu Getol Mengenai RUUP?"Sinar Harapan, 17 December 1973 and reprinted in Rasjidi, Kasus RUU Perkawinan, 49-51.

82. Original: "Perkawinan adalah sah apabila dilakukan menurut hukum masing-masing agamanya dan kepercayaannya itu dan/atau menurut perundang-undangan negara." A copy of the letter is available in a dossier of Litbang PGI, Jakarta.

83. I found at least two copies of a public statement of the Christian students, one is a joint statement of the activists of the Catholic and Protestant students dated 19 December 1973 and another made by the leaders of Student Union of the Indonesian Christian University, dated 10 December 1973. Copies of the statements are found in a dossier of Litbang PGI, Jakarta. In addition, on 12 December Sinar Harapan published a similar statement by the "Komite Kesatuan Nasional Generasi Muda Indonesia" (United Committee of Indonesian National Youth). All of the statements demanded that marriage law should be consistent with the Pancasila and the Constitution of 1945, particularly article 29 that guarantees religious freedom and article 27 that stipulates equality before the law.

84. See"Mudah-Mudahan Pengalaman Seperti Ini TidakTerulang" Sinar Harapan 21 December 1973; "Hakekat RUU Perkawinan" Kompas, 22 December 1973 reprinted in Rasjidi, Kasus RUU Perkawinan, 55-9.

85. See Kasman Singodimedjo, "UUD ' 45 Tidak Boleh Diselewengkan Dalam Pembuatan Perundang-undangan Apapun, Termasuk Pembuatan UUP" Abadi, 10 January 1974; reprinted in Rasjidi, Kasus RUU Perkawinan, 61-7.

86. These events are indicated by the joint letter of the DGI and MAWI to the President, dated 12 December 1973, the DGI's letter to State Secretary, dated 7 March 1974 and another DGI letter to its members dated 5 March 1974; all are found in a dossier of Litbang PGI, Jakarta.

87. The full text of the letter is reprinted in Sairin and Pattiasina, Pelaksanaan UndangUndang Perkawinan, 250-2.

88. Original: "Orang tersebut dapat kawin menurut cara (salah satu cara) berdasarkan peraturan perundang-undangan yang berlaku sesuai dengan Undang-Undang ini."

89. Original: “...maka sepanjang cara itu sesuai dengan peraturan perundang-undangan yang berlaku, perkawinan itu syah pula; dengan pengertian bahwa orang tersebut pada saat melangsungkan perkawinan memeluk agama sesuai dengan cara-cara perkawinan yang dipilihnya."

90. Original:"...sepanjang perkawinan itu dilakukan menurut salah satu cara sesuai dengan Undang-Undang Perkawinan ini - tentunya yang dipilih/disepakati oleh kedua calon mempelai - maka perkawinan itu adalah syah."

91. Muhammad Rasjidi, “Kristenisasi Dalam Selubung?"Nusantara 18 August 1973; Abadi 20 August 1973; and in his Kasus RUU Perkawinan, 9-14. 
92. Sylvanus was 46 (or 40 in another account) years old while Kus Supiah was 22 . Rasjidi also mentioned that Kus Supiah already had a beloved one named Abdullah Suwarna, a Muslim and young like her. In addition to Rasjidi's article, other minor detailed account of the marriage is taken from "Tradisi Keraton Sala Pecah" Panji Masyarakat No. 130 (July, 1973), 32.

93. Louis Gardet is a French priest, working in Cairo for a long time as an Islamologist. Perhaps, Rasjidi met Gardet when the former studied in France with Louis Massignon. Information from Karel A. Steenbrink through e-mail, 26 May 2005.

94. Muhammad Rasjidi, "Sekitar RUU Perkawinan: Bukankah Aku Telah Memperingatkan?" Abadi 22 and 24 December 1973; Panji Masyarakat No. 143 (January, 1974), 15-17 and his Kasus RUU Perkawinan, 22-29.

95. See the speeches of Teuku Muhammad Hasan and Asmah Syahroni in Sekitar Pembentukan, 95-6; 104.

96. Different Muslim opinions on the opposite case are discussed below.

97. See the speech of Tubagus Hamzah in Sekitar Pembentukan, 60.

98. Sekitar Pembentukan, 126.

99. Sekitar Pembentukan, 134.

100. For a discussion on the applicability of the Regulations on mixed marriage, see S. Pompe, "Mixed Marriages in Indonesia: Some Comments on the Law and the Literature," Bijdragen tot de Taal, Land en Volkenkunde No. 144 (1988), 259-275 and S. Pompe, "A Short Note on Some Recent Development with Regard to Mixed Marriage in Indonesia," Bijdragen tot de Taal, Land en Volkenkunde (1991), 261-272.

101. The Indonesian translation of the original Dutch text of the Regulations is available in Sairin and Pattiasina, Pelaksanaan Undang-Undang Perkawinan, 387-90. For a study of the Regulations, see Gautama, Segi-Segi Hukum Peraturan.

102. The summary of the speeches was reported in Sinar Harapan, 24 December 1973.

103. Article 2 section 1 states "Marriage is valid if it is carried out according to respective religions and beliefs", and its elucidation is: "With this formulation of article 2 section 1 , there is no marriage outside the laws of respective religions and beliefs as it is in line with the 1945 Constitution. The meaning of religious laws of respective religions and beliefs includes the laws applied to groups of religions and beliefs as long as they are not contradictory to or not differently stated in this law."

104. See her speech in Sekitar Pembentukan, 208-10; 220-1.

105. See "Bila Sri Ketemu Martinus (Dan Mau Kawin)" Tempo (5 January 1974), 5.

106. Eka Darmaputera, "Kawin Campur Dalam UUP" Tempo (19 January 1974), 38.

107. The full text of the letter is printed in Sairin and Pattiasina, Pelaksanaan Undang-Undang Perkawinan, 253-4.

108. During the parliamentary debates, Feillard noted that the PPP tried to hinder the recognition of the marriage of the Aliran Kepercayaan by insisting the use of the word 'Tuhan' instead of 'Ketuhanan' in the wording of the Law but did not succeed. See Andree Feillard, NU vis-à-vis Negara, 196. See also "Bagaimana Aidit Kawin?" Tempo (5 January 1974), 6-7.

109. See Muhammad Rasjidi "Abangan dan Kebatinan Tidak Perlu Wadah di Dalamnya" Abadi 29 November 1973, reprinted in his Kasus RUU Perkawinan, 15-21.

110. For the Muslim-Christian discourse on santri and abangan, see Chapter 5.

111. See "Keputusan Menteri Dalam Negeri Nomor 221a Tahun 1975 Tentang Pencatatan Perkawinan dan Perceraian pada Kantor Catatan Sipil Sehubungan Dengan Berlakunya Undang-Undang Perkawinan Serta Peraturan Pelaksanaannya" in Sairin and Pattiasina, Pelaksanaan Undang-Undang Perkawinan, 308-10. 
112. Soebadio, Perjuangan Untuk Mencapai, 24-5; L.M. Gandhi, "Hukum Perkawinan Antar Agama Dari Masa Ke Masa" in Sairin and Pattiasina, Pelaksanaan Undang-Undang Perkawinan, 141.

113. For this letter and other relevant letters from both the Minister of Religion and the Minister of Home Affairs, see Sairin and Pattiasina, Pelaksanaan Undang-Undang Perkawinan, 318-336.

114. The full text of the letter is printed in Sairin and Pattiasina, Pelaksanaan Undang-Undang Perkawinan , 339-41.

115. For later reported cases, see for instance, "Mau Kawin Dipersulit" Tempo (30 December 1989), 15. See also John R. Bowen, Islam, Law and Equality in Indonesia (Cambridge: Cambridge University Press, 2003), 249.

116. According to Ali Yafie, when the bill was discussed by the Parliament, there was a hearing with the leaders of religions concerning inter-religious marriage and all of them said that such marriage was religiously prohibited. Interview with Ali Yafie, Jakarta, 14 December 2003.

117. See all of the documents related to this case in Gautama, Segi-Segi Hukum, 347-69.

118. See fatwas No. 297 and 376 in Abdul Aziz Masyhuri, Masalah Keagamaan: Hasil Muktamar Dan Munas Ulama Nahdlatul Ulama (Surabaya: PP Rabithah Ma'ahidil Islamiyah, 1997), 225-6; 339-41.

119. M.B. Hooker wrote: "In 1960 a fatwa repeated the well-known rule that a Muslim man might marry a khitabiyya [sic] - that is, a female Christian or Jewess whose ancestors had entered their respective religions before the Prophethood of Muhammad. The source cited is kitab Asy-Syarqawi II/237. However, in 1989 a fatwa decided the exact opposite, prohibiting inter-religious marriage using exactly the same source of authority (plus some others)." M.B. Hooker, Indonesian Islam: Social Change Through Contemporary Fatāwa (Honolulu: University of Hawaii, 2003), 77. In fact, like my reading of the fatwa, Muhammad Ali also saw no difference between the two fatwas. See Muhammad Ali, "Fatwas on Interfaith Marriage in Indonesia" Studia Islamika Vol.9 No. 3 (2002), 11 13.

120. Atho Mudzhar, Fatwas of the Council of Indonesia Ulama: A Study of Islamic Legal Thought in Indonesia 1975-1988 (Jakarta: INIS, 1993), 87.

121. Indeed, some important ulama argue that because most children are very close to, and educated by, their mothers, it is better to prohibit a Muslim man to marry a non-Muslim woman. Interestingly, some Indonesian Muslim intellectuals have used precisely the same argument to allow a Muslim woman to marry a non-Muslim man. See Zainun Kamal, "Kawin Antar Umat Beragama" and Siti Musdah Mulia, "Islam dan Pernikahan Antar Agama" in Penafsiran Baru Islam Atas Pernikahan Antar Agama (Seri KKA Paramadina ke-200, 17 October 2003).

122. The fatwa is dated 1 June 1980. It is later published in both Muslim and Christian publications. See for instance a booklet produced by the Indonesian Council of Ulama entitled Tuntunan Perkawinan Bagi Ummat Islam (Jakarta: MUI, 1986), 71-73; and Sairin and Pattiasina, Pelaksanaan Undang-Undang Perkawinan, 337-8.

123. Mudzhar, Fatwas of the Council of Indonesia Ulama, 86;89.

124. See"Keputusan Presiden RI No.12 Tahun 1983 Tentang Penataan dan Peningkatan Pembinaan Penyelenggaraan Catatan Sipil" in Sairin and Pattiasina, Pelaksanaan UndangUndang Perkawinan, 342-6.

125. See "Menguji Cinta di Depan Hukum" Tempo (1 November 1986), 54.

126. Jamal and Lydia got married on 30 June 1986. In fact, there were other similar cases before, such as marriages between: Tetty Kadi (Catholic) and Bawono Judo (Muslim); 
Emilia Contessa (Muslim) and Rio Tambunan (Protestant); Camelia Malik (Muslim) and Reynold Panggabean (Protestant); Bob Tutupoly (Protestant) and Rosmaya Nasution (Muslim).Thus, the Jamal-Lydia marriage was just another case that bothered the ulama concerned with the examples demonstrated by celebrities. See "Dari Kus Ondowiyah Sampai Camelia Malik" Tempo (1 November 1986), 56-8.

127. The letters are largely quoted and translated in M.B. Hooker, Indonesian Islam, 78-9.

128. See R. Harmani Arioso, "Pelaksanaan Pencatatan Perkawinan 'Antar Agama' pada Kantor Catatan Sipil Propinsi DKI Jakarta" in Sairin and Pattiasina, Pelaksanaan UndangUndang Perkawinan, 102.

129. For the texts of the Decision of the Head of the Civil Registry and the MUI-DKI's guidance, see "Seruan Majelis Ulama Indonesia DKI Jakarta Tentang Perkawinan Antar Agama" and "Keputusan Kepala Kantor Catatan Sipil DKI Jakarta, 1986" in Sairin and Pattiasina, Pelaksanaan Undang-Undang Perkawinan, 376-84.

130. "Menguji Cinta di Depan Hukum" Tempo (1 November 1986), 55.

131. "Menguji Cinta di Depan Hukum", 56.

132. "Menguji Cinta di Depan Hukum", 55.

133. See "Buka-Tutup Pintu Kawin Campuran" Tempo (24 June 1989), 36-7.

134. See S. Pompe, "A Short Note on Some Recent Developments", 261-272; and Bowen, Islam, Law and Equality, 242; 247-8.

135. See John R. Bowen, "Legal Reasoning and Public Discourse in Indonesian Islam" in Dale F. Eickelman and John W. Anderson (eds.), New Media in the Muslim World: the emerging of public sphere. Bloomington: Indiana University Press, 1999), 83-97.

136. See"Instruksi Presiden RI No. 1 Tahun 1991"in Himpunan Peraturan Perundang-Undangan Dalam Lingkungan Peradilan Agama (Jakarta: Departemen Agama, 2001), 313-4.

137. In an interview with me, the former head of the Compilation project, Busthanul Arifin, said that he disagreed with the argument that the state should accommodate inter-religious marriage or otherwise, there will be a legal vacuum. For him, any legal vacuum is acceptable as long as it is in line with Indonesian culture. For instance, he said, there is a legal vacuum on gay marriage in Indonesia. Interview in Jakarta, 19 December 2003.

138. Few cases like this are reported in Tempo (1 November 1973), 52; 57.

139. See O.S. Eoh, Perkawinan Antar Agama Dalam Teoridan Praktik (Jakarta:Srigunting, 1996), 130-8.

140. The DGI became PGI and MAWI became KWI by the mid of 1980s, see Chapter 3 .

141. See "Pengantar Singkat" and "Beberapa Catatan Pihak Katolik Mengenai Hasil Dialog PGI-KWI Tentang Kawin Campur" in KWI, "Dialog KWI-PGI Tentang Kawin Campur" Hak Kerukunan (Jakarta: KWI, 1987), 7; 117-18. See also Suharto, "Beberapa Segi Hukum Perkawinan di Indonesia Khususnya Perkawinan Campuran Antar Agama," and "Rangkuman Hasil Dialog KWI-PGI Tentang Perkawinan dan Kawin Campur" in Sairin and Pattiasina, Pelaksanaan Undang-Undang Perkawinan, 92-3; 169-71.

142. Interview with Father Ismartono, Jakarta, 15 December 2003.

143. Interviews with Gerrit E. Singgih, Yogyakarta, 16 January 2004; Einar Sitompul, Jakarta, 15 December 2003; Weinata Sairin, Jakarta, 19 December 2003; all of them are important Christian theologians and ministers of the churches affiliated with the PGI. It should be noted here that according to J.L. Ch. Abineno, the General Chairman of the PGI, there are certain Protestant churches in Indonesia that considered marriage as a sacrament or semi-sacramental. See J.L. Ch. Abineno, "Peneguhan dan Pemberkatan Nikah" in Sairin and Pattiasina, Pelaksanaan Undang-Undang Perkawinan, 26-8.

144. Ukur also noted that other Civil Registry Offices still followed the old procedure while some others accepted both the old and the new procedures. See Fridolin Ukur, "Prob- 
lematik Pelaksanaan Perkawinan di Indonesia Dalam Pengamatan PGI" in Sairin and Pattiasina, Pelaksanaan Undang-Undang Perkawinan, 12.

145. See "Instruksi Kepala Kantor Catatan Sipil DKI Jakarta" in Sairin and Pattiasina, Pelaksanaan Undang-Undang Perkawinan, 385-6.

146. For the reports on these consultations, see "Rangkuman Hasil Konsultasi Hukum di Wilayah-Wilayah Tentang Undang-Undang Perkawinan" and "Hasil-Hasil dan Kesimpulan Konsultasi Hukum Tentang Pelaksanaan Undang-Undang Perkawinan" in Sairin and Pattiasina, Pelaksanaan Undang-Undang Perkawinan, 152-168.

147. See “Ketetapan Sidang MPL-PGI Nomor 01/MPL-PGI/1989" in Sairin and Pattiasina, Pelaksanaan Undang-Undang Perkawinan, 146-51.

148. Fridolin Ukur, "Problematik Pelaksanaan Perkawinan di Indonesia Dalam Pengamatan PGI" in Sairin and Pattiasina (eds.), Pelaksanaan Undang-Undang Perkawinan, 16.

149. Interview, Yogyakarta, 16 January 2004. Einar Sitompul who is a minister of the biggest Christian Church in Indonesia, Huria Kristen Batak Protestant (HKBP) said that his Church also refuses to bless inter-religious marriages, even though he himself tried to develop a theological argument for accepting that sort of marriage. Interview, Jakarta, 15 December 2003. In contrast, Weinata Sairin, a minister of Gereja Kristen Pasundan (GKP) said that his Church blesses inter-religious marriages. Interview, Jakarta, 19 December 2003.

150. Rufus Alexander Waney, "Missiological Dimensions in Inter-religious Marriages Between Christians and Muslims in Indonesia" (M Th. Thesis, Fuller Theological Seminary, 1990), 111.

151. Interview with Father Ismartono, Jakarta, 15 December 2003. See also two articles by Piet Go OCarm, "Perkawinan Campur Menurut Kitab Hukum Kanonik 1983 dan Statuta Perkawinan Regio Jawa 1983" and "Penyeledikan Kanonik Kawin Campur" in Dialog KWI-PGI Tentang Kawin Campur, Hak Kerukunan (Jakarta: KWI, 1987), 37-50.

152. Al. Purwahadiwardoyo, Perkawinan Menurut Islam dan Katolik:Implikasinya dalam Kawin Campur (Yogyakarta: Kanisius, 1990).

153. Lev, Islamic Courts in Indonesia, 10-12.

154. See note 65 above.

155. For a more detailed account, see Zaini Ahmad Noeh and Abdul Basit Adnan, Sejarah Singkat Pengadilan Agama Islam di Indonesia (Surabaya: Bina Ilmu, 1983) Chapter 2; Tim Penyusun, Kenang-Kenangan Seabad Peradilan Agama di Indonesia (Jakarta: Departemen Agama, 1985), 25-45.

156. Tim Penyusun, Peradilan Agama di Indonesia: Sejarah Perkembangan Lembaga dan Proses Pembentukan Undang-Undangnya (Jakarta: Departemen Agama, 1999), 36-59.

157. For an analysis of the Law, see Mark Cammack, "Indonesia's 1989 Religious Judicature Act: Islamization of Indonesia or Indonesianization of Islam" Indonesia No. 63 (1997), 143-68.

158. The Supreme Court supervises all courts. Thus, it is not distinctively religious, but some experts on Islamic family law are appointed as Supreme Judges there.

159. Lev, Islamic Courts in Indonesia, 231.

160. Feillard, NU vis-à-vis Negara, 394. See also Chapter 3.

161. Effendy, Islam and the State in Indonesia, 149-51; 156-60.

162. Cammack, "Indonesia's 1989 Religious Judicature Act", 168. See also his "Islamic Law in Indonesia's New Order" International and Comparative Law Quarterly Vol. 38 (January, 1989), 53-73.

163. See "Sebuah RUU dengan Lapang Dada" Tempo (24 June 1989), 26; see also "RUU PA, dari Pak Harto sampai Victor Tanja" Panji Masyarakat No. 614 (June, 1989), 22-4. 
164. See Kompas, 13 June 1989 in Dokumentasi Klipping Tentang Rancangan Undang-Undang Peradilan Agama (Jakarta: CSIS, 1989), 5.

165. In addition to the clippings collected in Dokumentasi quoted above, see Zuffran Sabrie (ed.), Peradilan Agama dalam Wadah Negara Pancasila (Jakarta: Logos Wacana Ilmu, 2001). This book contains twenty opinion articles and more than thirty press accounts and editorials on the bill.

166. S. Widjojo, "Peradilan Agama: Antara Negara Agama dan Negara Pancasila" Hidup No. 7 (12 February 1989), 28-9; 50; and "Kesaktian Pancasila dalam Tantangan" Hidup No. 10 (March 1989), 40-1 reprinted in Sabrie, Peradilan Agama, 97-108.

167. For more debates on Pancasila as 'the authentic ideology', see Chapter 3 and 5.

168. Franz Magnis Suseno, "Seputar Rencana UU Peradilan Agama"Kompas 16 June 1989 copied in Dokumentasi, 184-6 and reprinted in Sabrie, Peradilan Agama, 29-36.

169. See the following editorials of Suara Pembaruan: "RUU Peradilan Agama dalam Rangka Wawasan Nusantara" 17 March 1989; "Hanya Ada Satu Hukum Nasional” 28 March 1989; Pendekatan 'Ad Hoc' Dapat Timbulkan Keadaan Semrawut" 17 April 1989; all reprinted in Sabrie, Peradilan Agama, 257-65. See also Dokumentasi, 108-9; 210-11.

170. See Kompas and Suara Karya 13 June 1989; copied in Dokumentasi, 5-7. See also"RUU PA, Tiga Fraksi Tanpa Ragu” Panji Masyarakat No. 615 (June, 1989), 12-13; “Peradilan Agama: Kebutuhan atau Kecemasan" Tempo (24 June 1989), 22.

171. See Suara Pembaruan 17 May 1989 reprinted in Sabrie, Peradilan Agama, 221-5. See also "Ketatapan Sidang MPL PGI No. 03/MPL-PGI/1989 Tentang Sikap Gereja-Gereja Terhadap Rancangan Undang-Undang Peradilan Agama (RUUPA)" in Weinata Sairin, Himpunan Peraturan di Bidang Keagamaan (Jakarta: BPK, 1996), 550-3. It is noteworthy that Tempo published a cartoon picturing different religious courts that were crowded by people whereas no body came to the civil court. See Tempo (4 February 1989), 9.

172. See "RUU Peradilan Agama dalam Rangka Wawasan Nusantara" Suara Pembaruan, 17 March 1989; "Pertanyaan Keenam Untuk Fraksi di DPR" Suara Pembaruan, 5 June 1989; and T.B. Simatupang, "Menyempurnakan RUUPA Demi Memantapkan Persatuan \& Kesatuan Bangsa" Suara Pembaruan 29 June 1989; all is reprinted in Sabrie, Peradilan Agama, 182-90; 257-9; 273-6.

173. See Media Indonesia 4 July 1989; Kompas and Pos Kota, 5 July 1989 reprinted in Sabrie, Peradilan Agama, 229-38.

174. See Kompas and Suara Karya 5 July 1989 in Dokumentasi, 103-6. See also the editorial entitled "Dijamin Tidak Menjurus ke Piagam Jakarta" Suara Pembaruan 14 June 1989 reprinted in Sabrie, Peradilan Agama, 277-9.

175. For a complete text of the PGI's suggestions, see "Usul-Usul PGI Tentang Perubahan Terhadap RUUPA" in Sairin, Himpunan Peratuan, 554-7. All of the PGI ideas were also covered in T.B. Simatupang, "Menyempurnakan RUUPA Demi Memantapkan Persatuan \& Kesatuan Bangsa" Suara Pembaruan 29 June 1989 reprinted in Sabrie, Peradilan Agama, 182-90.

176. See Pelita 6 July 1989 in Dokumentasi, 108. See also "RUU PA di Mata Victor Tanja" Panji Masyarakat No. 617 (July, 1989), 12.

177. See Victor Tanja, "RUU PA" Editor No. 48 (5 August 1989) reprinted in Sabrie, Peradilan Agama, 76-8.

178. The Muslim traditionalists of the NU seem to play more roles in political lobbying. It does not mean, however, they did not pay attention to the debates on the bill. The NU magazine, Aula, released at least two reports on how the bill was opposed by what it called "the enemies of Islam." See "RUU Peradilan Agama Maju, Datang Penghalang" 
Aula (May, 1989), 51-6; “RUUPA Lahir Karena Tuntutan Sejarah" Aula (August, 1989), 248.

179. See “Dimana Toleransi Mereka" Serial Media Dakwah (August, 1989), 7-11; Rusydi, “RUUPA, Kerukunan Agama," Panji Masyarakat No. 616 (July, 1989), 10-11; Michael Vatikiotis, "Islamic Courts Law to Test Religious Tolerance" Far Eastern Economic Review (8 June 1989) in Dokumentasi, 181.

180. See "Menggugat Protes Naif" Serial Media Dakwah (August, 1989), 12.

181. A. Dahlan Ranuwihardjo, "Negara, Agama dan Hukum: Sebuah Pendekatan Falsafi" Pelita June 21, 1989 reprinted in Sabrie, Peradilan Agama, 66-75.

182. Muhammad Natsir, "Tanpa Toleransi Tak-kan Ada Kerukunan!" Serial Media Dakwah (August, 1989), 18-19 reprinted in Sabrie, Peradilan Agama, 120-5.

183. Yusril Ihza Mahendra, "Catatan Buat Majalah Hidup" Panji Masyarakat No. 616 (July, 1989), 8-9 reprinted in Sabrie, Peradilan Agama, 114-9. It was also published under the title, "Sekitar RUUPA: Menjawab Mingguan Hidup" Serial Media Dakwah (August, 1989) 58-60.

184. See an interview with him entitled "Dari Usaha Awal Pak Harto..." Panji Masyarakat No. 607 (April, 1989), 14-5.

185. Yusril Ihza Mahendra, "Kedaulatan Negara dan Peradilan Agama" Pelita 27 June 1989 reprinted in Sabrie, Peradilan Agama, 42-9.

186. Heru Santoso, "Seputar RUU Peradilan Agama Yang Berputar-putar" Kompas June 21, 1989 reprinted in Sabrie, Peradilan Agama, 37-41.

187. Mahendra, "Kedaulatan Negara dan Peradilan Agama".

188. Mahendra, "Kedaulatan Negara dan Peradilan Agama". See also Muhammad Hatta, Sekitar Proklamasi 17 Agustus 1945 (Jakarta: Tintamas, 1969), 59-60.

189. See "Si Bungsu Yang Ditunggu Bukan Hantu" Tempo (4 February 1989), 81.

190. "Si Bungsu Yang Ditunggu Bukan Hantu".

191. Mahendra, "Catatan Buat Majalah Hidup".

192. See Chapter 3.

193. See "RUU Peradilan Agama Mulai Digugat" Panji Masyarakat No. 607 (April, 1989), 15 and "Dimana Toleransi Mereka" Serial Media Dakwah (August, 1989), 9.

194. Muhammad Rasjidi, "Seputar Rencana UU Peradilan Agama" Panji Masyarakat No. 616 (July, 1989), 27-31 reprinted in Sabrie, Peradilan Agama, 50-65.

195. Joesoef Sou'yb, "BW dan RUU PA" Panji Masyarakat No. 618 (July, 1989), 26-7.

196. Mahendra, "Catatan Buat Majalah Hidup".

197. See "Pengadilan Serambi Milik Kita Bersama" Tempo (4 February 1989), 76.

198. See Kompas and Suara Pembaruan, 27 June 1989; in Dokumentasi, 96;98.

199. See Merdeka and Pelita 11 July 1989 in Dokumentasi, 116-7.

200. Natsir, "Tanpa Toleransi Tak-kan Ada Kerukunan!"

201. See Antara, 29 May 1989; Suara Pembaruan and Berita Yudha, 30 May 1989 in Dokumentasi, 72;92 -93. See also "RUU PA, dari Pak Harto sampai Victor Tanja" Panji Masyarakat No. 614 (June, 1989), 22-4. Later, Soeharto said a similar view when B.M. Diah, the leader of Yayasan 17 Agustus, met him. See Pelita 22. June 1989 in Dokumentasi, 76.

202. See the text of Munawir Sjadzali's speech to Parliament, "Landasan Pemikiran Politik Hukum Nasional" Pelita 24 June 1989 in Dokumentasi, 36-8.

203. For a complete text of Golkar and ABRI's views, see "Pemandangan Umum Fraksi ABRI: Rancangan Undang-Undang Perdilan Agama" Pelita 17 June 1989 and "Pendapat FKP atas RUU Peradilan Agama" Pelita 20 June 1989 in Dokumentasi, 14-18; 19-23. 
204. Compare with the editorial of the ABRI's newspaper entitled "Peradilan Agama Tidak Merugikan Non-Muslim" Angkatan Bersenjata 23 June 1989 reprinted in Sabrie, Peradilan Agama, 314-7.

205. Ismail Saleh, "Wawasan Pembangunan Hukum Nasional" Kompas 1-2 June 1989 and "Eksistensi Hukum Islam dan Sumbangannya Terhadap Hukum Nasional" Kompas 3 June 1989 reprinted in Sabrie, Peradilan Agama, 165-181.

206. See "Pemandangan Umum Fraksi ABRI: Rancangan Undang-Undang Peradilan Agama" Pelita 17 June 1989; Munawir Sjazdali, "Landasan Pemikiran Politik Hukum Nasional" Pelita 24 June 1989 in Dokumentasi, 14-8; 36-8. See also “Dari Piagam Jakarta ke Wawasan Nusantara" Tempo (24 June 1989), 27-8.

207. See "Menunggu Lahirnya si Anak Bungsu" Tempo (24 June 1989), 30-1.

208. See Munawir Sjadzali, “Landasan Pemikiran Politik Hukum Nasional” Pelita 24 June 1989; "RUU Peradilan Agama Harap Diterima Dengan Lapang Dada" Pelita 26 June 1989 in Dokumentasi, 36-42.

209. See"Pemandangan Umum Fraksi ABRI: Rancangan Undang-Undang Perdilan Agama" Pelita 17 June 1989; "Pendapat FKP atas RUU Peradilan Agama" Pelita 20 June 1989; Munawir Sjadzali, "'"RUU Peradilan Agama Harap Diterima Dengan Lapang Dada" Pelita 26 June 1989 in Dokumentasi, 14-23; 39-42.

210. Article 49, section 1 of the bill states that: "Religious Court is assigned and authorised to investigate, decide on and settle cases in the first level among Muslims regarding: (1) marriage; (2) inheritance, last request and gift carried out according to Islamic law; (3) pious trust and charity." Then, the elucidation of article 49 states that an inheritance case would be under the authority of the religious court if the parties decided to follow Islamic law.

211. See Pelita 6 March 1989 in Dokumentasi, 88.

212. See "Telah Lahir si Anak Bungsu" Tempo (23 December 1989); "Goool...(R)UUPA" Panji Masyarakat No. 633 (December, 1989), 14.

213. Interview with Harry Tjan Silalahi, Jakarta, 22 December 2003.

214. See Dale F. Eickelman and James Piscatori, Muslim Politics (Princeton: Princeton University Press, 1996), 83-4.

\section{Notes Chapter 5}

1. The articles of the debate are collected in Achdiat K. Mihardja (ed.), Polemik Kebudajaan (Djakarta: Balai Pustaka, 1948). See also an overview of the polemics in A. Teeuw Modern Indonesian Literature Vol.1 (The Hague: Martinus Nijhoff, 1979), 35-8.

2. Mihardja, Polemik Kebudajaan., 11-19.

3. Mihardja, Polemik Kebudajaan.,35-41; 52-55; 100.

4. Mihardja, Polemik Kebudajaan, 136; 138.

5. It is noteworthy that in his exile in Banda Neira of Maluku islands, the Indonesian nationalist leader, Sutan Sjahrir, also wrote in his diary something about this issue. His view was in general similar to that of Alisjahbana: he saw the West had a very dynamic mentality, while the East was decadent. However, in his final remarks, he proposed universalism: "Why should we choose between being a slave and a master, why should we choose between the Capitalist West and the Slavish East? We should not prefer one of them: we can reject both of them because they actually have to be and is being to be of the past." See his notes dated 31 December 1936 and 12 March 1937 in Sutan Sjahrir, Renungan dan Perjuangan (Jakarta: Dian Rakyat and Djambatan, 1990), 157-60; 173-6. 
For Sjahrir, the universal here was apparently socialism (he was to be the leader of PSI, the Indonesian Socialist Party). Because Sjahrir wrote the statement in his diary during the exile, we cannot consider it as part of the polemics during the 1930 s.

6. Mihardja, Polemik Kebudajaan, 42-51.

7. In the polemics on culture, the leader of Taman Siswa, Ki Hadjar Dewantara, was also involved, but probably because he saw that Soetomo's arguments were adequate, he did not make more arguments against Alisjahbana. See Mihardja, Polemik Kebudajaan, 122-5. In fact, the link between Soetomo and Taman Siswa was not simply at the level of the idea. Soetomo was the founder of Boedi Oetomo in 1908, an organisation that was initially intended to improve the position of the Javanese aristocratic group but later developed to be a nationalist movement. Ki Hadjar was a member of Boedi Oetomo but he later left it. When Ki Hadjar established Taman Siswa, Boedi Oetomo presented their schools in Medan and Jakarta to the former. See Kenji Tsuchiya, Democracy and Leadership: The Rise of the Taman Siswa Movement in Indonesia Trans. Peter Hawkes (Honolulu: University of Hawaii Press, 1987), 81-2.

8. On Taman Siswa, see Ruth T. McVey, "Taman Siswa and the Indonesian National Awakening" Indonesia No. 4 (October, 1967), 128-49; Lee Kam Hing, "The Taman Siswa in Postwar Indonesia" Indonesia No. 25 (April, 1978), 41-59; and Tsuchiya, Democracy and Leadership.

9. Both Soetatmo and Soewardi were members of the Selasa Kliwon society formed in 1921 by nine Javanese men for the purpose of spiritual training. The name 'Ki Hadjar Dewantara' reflects this spiritual outlook. 'Ki' was equivalent to 'Kijai', that is, a title for a person who discovered the hidden secret of mankind and religion; 'Hadjar' is equivalent to 'adjar' means to teach; and 'Dewantara' is 'dewa-antara' which signifies himself as "a teacher who mediates for God." Tsuchiya, Democracy and Leadership, 41; 63-4.

10. See Ki Hadjar Dewantara, "Some Aspects of National Education and the Taman Siswa Institute of Jogjakarta" Trans. Ruth McVey Indonesia No 4 (October, 1967), 150-68.

11. Tsuchiya, Democracy and Leadership, 66-7.

12. Sutan Takdir Alisjahbana Perkembangan Sejarah Kebudayaan Indonesia Dilihat dari Jurusan Nilai-Nilai (Jakarta: Idayu, 1975), 38. Alisjahbana became more appreciative to Islamic thought in his old age. See his Pemikiran Islam Dalam Menghadapi Globalisasi dan Masa Depan Umat Manusia (Jakarta: Dian Rakyat, 1992).

13. Mohammad Natsir, Cultuur Islam (Bandoeng: Pendidikan Islam bg.Penjiaran, 1937).

14. H.B. Jassin, Angkatan 45 ( Jakarta: Jajasan Dharma, 1951).

15. For the full text of the declaration called "Surat Kepercayaan Gelanggang" dated 18 February 1950, see Asrul Sani, Surat-Surat Kepercayaan (Jakarta: Pustaka Jaya, 1997), 3-4.

16. Cf. Teeuw, Modern Indonesian Literature Vol. 1, 126-9.

17. Kam Hing, "The Taman Siswa in Postwar Indonesia", 43-51.

18. Tsuchiya, Democracy and Leadership, 211-15.

19. Teeuw, Modern Indonesian Literature Vol. 2, 27-39. Teeuw, however, does not discuss the Islamic ideological discourse on culture.

20. On LEKRA, see Keith Foulcher, Social Commitement and the Arts: 'the Indonesian Institute of People's Culture' 1950-1965 (Clayton: Southeast Asian Studies, Monash University, 1986).

21. Pramoedya Ananta Toer, Realisme Sosialis dan Sastra Indonesia (Jakarta: Lentera Dipantara, 2003). It is originally a paper presented to a seminar in the University of Indonesia in 1963. 
22. For the full text of the Culture Manifesto, see D.S. Moeljanto and Taufiq Ismail (eds.), Prahara Budaya: Kilas Balik Ofensif LEKRA/PKI dkk. (Kumpulan Dokumen Pergolakan Sejarah) (Bandung: Mizan-Republika, 1995), 160.

23. See "Musyawarah Seniman dan Budayawan Islam" Gema Islam Vol.1 No.1 (1962), 25-7 reprinted in E. Ulrich Kratz (ed.), Sumber Terpilih Sejarah Sastra Indonesia Abad XX (Jakarta: Kepustakaan Populer Gramedia, 2000), 475-80.

24. See"Manifes Kebudayaan dan Kesenian Islam" Gema Islam Vol. 2 No. 45 (1963), 9 reprinted in Kratz, Sumber Terpilih Sejarah Sastra, 508-11.

25. HAMKA's romance, Tenggelanya Kapal Van der Wijck was accused of being a copy of the work of the Egyptian writer, Mustafa Lutfi al-Manfaluti, Majdulin. See Junus Amir Hamzah and H.B. Jassin (eds.), Tenggelamnja Kapal Van der Wijck dalam Polemik (Jakarta: Mega Book Store, 1963).

26. Moeljanto and Ismail, Prahara Budaya, 355.

27. Moeljanto and Ismail, Prahara Budaya, 355-412.

28. Kipandjikusmin, "Langit Makin Mendung" Sastra No.8 (August, 1968), 3-8. For its English translation, see Christine Deakin "Langit Makin Mendung: Upheaval in Indonesian Literature" Archipel No.11 (1976), 87-105.

29. Deakin, "Langit Makin Mendung", 85-6. Deakin also noted that the real name of Kipandjikusmin was Sudihartono.

30. For a collection of the articles on the controversy, see H.B. Jassin, Polemik: Suatu Pembahasan Sastera dan Kebebasan Mencipta Berhadapan dengan Undang2 dan Agama (Kuala Lumpur: Pustaka Antara, 1972).

31. Pransa Atmawidjaja, “Tuhan Tak Lagi Punja Maaf?” Peraba (II December 1968), 7.

32. Bahrum Rangkuti "Imadjinasi, Observasi dan Intuisi pada Tjerpen Langit Makin Mendung" Pandji Masjarakat No. 53 (March, 1970), 4-5; 26-7.

33. His defence in the court is published as H.B. Jassin, Heboh Sastra 1968: Suatu Pertanggungan Jawab (Jakarta: Gunung Agung, 1970).

34. Jassin, Heboh Sastra, 1968, 29-30; 75.

35. HAMKA, "Sajang RangkutiTidak Hadir"Pandji Masjarakat No. 53 (March, 1970), 5-7; 20-22; 26.

36. HAMKA, "Imadjinasi" Pandji Masjarakat No. 60 (July, 1970), 3-4.

37. Ali Moertopo, Strategi Kebudayaan (Jakarta: CSIS, 1978).

38. C.A. van Peursen's Strategi Kebudayaan was published in 1976 by Kanisius and BPK and republished by the Catholic Kanisius alone in 1988.

39. For the debates on this phrase, see Chapter 3.

40. Muhammad Rasjidi, StrategiKebudayaan dan Pembaharuan Pendidikan Nasional (Jakarta: Bulan Bintang, 1980), 63-111.

41. To support this position, Rasjidi refers to the view of the Dutch scholar, C. Snouck Hurgronje (1857-1936). See Muhammad Rasjidi, Islam dan Indonesia di Zaman Modern (Jakarta: Bulan Bintang, 1968).

42. In his autobiography written in the style of a novel story entitled Emak, Joesoef explains that he was born in Medan, North Sumatra, into a Muslim family. He says that his father is Acehnese but he does not explain the ethnic background of his mother (I got the impression that she is Malay). Besides studying religion in madrasah in the afternoon, his parents pushed him to study at the Dutch school. His uncle was an important nationalist activist and was exiled by the colonial Government to Digoel in the 1930s. His uncle and father preferred secular nationalism to Islam as the future ideology of Indonesia, and Daoed Joesoef follows their views. In this novel, Joesoef also shows his belief that the original religious attitude of the native is very tolerant. Joesoef was 
apparently approached a few years after the coup by the Jakarta Catholic activists when studying in Paris. Joesoef studied economics in Paris and obtained Docteur de I'Université in 1967 and Docteur d'Etat in 1973. Joesoef proudly says of that he is the first Indonesian awarded the degree of Docteur d'Etat. For his study, he received scholarship from the Ford Foundation and later from the CSIS. See Daoed Joesoef, Emak (Jakarta: Aksara Karunia, 2003) and "Siapa Daoed Joesoef" in Kadjat Hartojo, Harry Tjan Silalahi and Hadi Soesastro (eds.), Nalar dan Naluri: 70 Tahun Daoed Joesoef (Jakarta: CSIS, 1996), 674-6.

43. Daoed Joesoef, "Bapak Soedjono Hoemardani dan Metoda Tradisional KontemplatifIntegralistik" in Soedjono Hoemardani: Pendiri CSIS (Jakarta: CSIS, 1987), 24-37.

44. A.M.W. Pranarka, "Kasunyatan, Sangkan Paran, Kasampurnan: Mengangkat Pemikiran Bapak Soedjono Hoemardani dalam Studi Analitikal" in Soedjono Hoemardani, 48-80.

45. A.M.W. Pranarka, "Relevansi Ajaran-Ajaran Ki Hadjar Dewantara Dewasa ini dan di Masa yang Akan Datang" in Wawasan Kebangsaan, Ketahanan Nasional dan Wawasan Nusantara (Yogyakarta: Lembaga Pengkajian Kebudayaan Sarjana Wiyata Taman Siswa, 1986), 1-31.

46. The MUI's statement on the Catholic role is found in Ibrahim Madylao, "Tanggapan Terhadap Pokok-Pokok Pikiran Pembaharuan Pendidikan Nasional" Panji Masyarakat No. 286 (January, 1980), 11-14 quoting "Risalah Kronologis Peranan Dewan Majelis Ulama Indonesia dalam Masalah Pendidikan Nasional dan Libur Ramadhan." The "Risalah Kronologis" was previously published in the MUI's magazine, Mimbar Ulama, but it did not include the statement on the Catholic role. See Mimbar Ulama No. 31 (June, 1979), 2934.

47. Rasjidi, Strategi Kebudayaan, 111-15.

48. KPPN,Pokok-PokokPikiran Pembaharuan Pendidikan Nasional (Jakarta:Departemen Pendidikan dan Kebudayaan, 1979).

49. For the MUI's general view of education and the full text of MUI's letter to the KPPN dated 15 November 1979 see Mimbar Ulama No. 37 (January/February, 1980), 49-61. See also, "Saran-Saran Majelis Ulama Terhadap Pembaharuan Pendidikan Nasional" Panji Masyarakat No. 285 (December, 1979), 12-15.

50. Rachmat Subagya, Agama dan Alam Kerohanian Asli di Indonesia (Jakarta: Yayasan Cipta Loka Caraka, 1979), 22-32; 212.

51. Karel A. Steenbrink, Dutch Colonialism and Indonesian Islam: Contacts and Conflicts 15961950 (Amsterdam: Rodopi, 1993), 147.

52. See Muhammad Rasjidi, Islam dan Kebatinan (Jakarta: Bulan Bintang, 1971); HAMKA, Perkembangan Kebatinan di Indonesia (Jakarta: Bulan Bintang, 1971); and the polemics in Warsito S., Muhammad Rasjidi and Hasbullah Bakry, Di Sekitar Kebatinan (Jakarta: Bulan Bintang, 1973).

53. This is also indicated by a correspondence between a Muslim and a Catholic intellectual. In 1995, the prominent Indonesian Muslim intellectual, Nurcholish Madjid, with reference to Steenbrink's remarks, questioned Franz Magnis-Suseno if there was such a conspiracy to separate Islam from the Javanese. Magnis-Suseno denied it and said that the interest in the Javanese culture among the Catholics was based on the Catholic theology of inculturation. In terms of dialogue, he said, most of the dialogues he attended were with Islam not with Javanism. (I received the copies of the letters from Steenbrink. I saw them for the first time circulating among students of the State Institute of Islamic Studies (IAIN), Jakarta in 1995).

54. Abdurrahman Wahid, "Salahkah Jika Dipribumikan?" Tempo (16 July 1983) reprinted in his Melawan Melalui Lelucon (Jakarta: Pusat Data \& Analisa Tempo, 2000), 62-4. 
55. See Abdurrahman Wahid, "Pribumisasi Islam" Muntaha Azhari and Abdul Mun'im Saleh (eds.), Islam Indonesia Menatap Masa Depan (Jakarta: P3M, 1989), 81-96; and Mujiburrahman, "Islam and Politics in Indonesia: the Political Thought of Abdurrahman Wahid" Islam and Christian-Muslim Relations Vol. 10 (October 1999), 339-352.

56. Mujiburrahman, "The Diaspora Church in Indonesia: Mangunwijaya on Nationalism, Humanism and the Catholic Praxis" Journal of Ecumenical Studies Vol. 38 No. 4 (2001), 444-69.

57. Th. Sumartana, Mission at the Crossroads: Indigenous Churches, European Missionaries, Islamic Association and Socio-Religious Change in Java 1812-1936 (Jakarta: BPK, 1994), 340.

58. The Minister of Education and Culture, Fuad Hassan, also presented a paper in the Seminar. This partly indicates that the Seminar was strongly supported by the Government. For the proceeding of the Seminar, see Muhadjir (ed.), Evaluasi dan Strategi Kebudayaan (Jakarta: Fakultas Sastra UI, 1987).

59. Soeharto, Butir-Butir Budaya Jawa (n.p., 1987).

60. Saya S. Shiraishi, Young Heroes: the Indonesian Family in Politics (Ithaca: Southeast Asia Program, Cornell University, 1997).

61. See Robert W. Hefner, "Islam, State and Civil Society: ICMI and the Struggle for the Indonesian Middle Class" Indonesia No. 56 (1993), 1-37; R. William Liddle, "The Islamic Turn in Indonesia: a Political Explanation" The Journal of Asian Studies Vol. 55 No. 3 (1996), 613-34; Martin van Bruinessen, "Islamic State or State Islam? Fifty Years of State-Islam Relations in Indonesia," in Igrid Wessel (ed.), Indonesien am Ende des 20 Jahshunderts (Hamburg: Abera-Verlaag, 1996), 19-34.

62. Aswab Mahasin (ed.), Ruh Islam dalam Budaya Bangsa 5 Vols. (Jakarta: Yayasan Festival Istiqlal, 1995).

63. On the Mushaf Istiqlal, see Kenneth M. George, "Designs on Indonesia's Muslim Communities" The Journal of Asian Studies Vol. 57 No. 3 (August, 1998), 693-713.

64. See Robert. W. Hefner's anecdote in his "Islamizing Capitalism: On the Founding of Indonesia's First Islamic Bank" in Mark R. Woodward (ed.), Toward a New Paradigm: Recent Developments in Indonesian Islamic Thought (Tempe: Arizona State University Press, 1996), 291-322.

65. Kuntowijoyo, “Konvergensi dan Politik Baru Islam” preface to Abdul Munir Mulkhan, Runtuhnya Mitos Politik Santri (Yogyakarta: Sipress, 1992), ix-x.

66. This is quoted in his different papers. For his English paper, see Nurcholish Madjid, "Islamic Roots of Modern Pluralism: Indonesian Experiences" Studia Islamika No. 1 Vol. 1 (1994), 61, quoting Marshal G.S. Hodgson, The Venture of Islam Vol.2 (Chicago: The University of Chicago Press, 1985), 551 in footnote.

67. On the Islamic educational institutions, see B.J. Boland, The Struggle of Islam in Modern Indonesia (The Hague: Martinus Nijhoff, 1982), 112-23.

68. Karel A. Steenbrink, Pesantren, Madrasah, Sekolah:Pendidikan Islam dalam Kurun Modern (Jakarta: LP3ES, 1986), 99.

69. Onny S. Prijono and A.M.W. Pranarka, Situasi Pendidikan di Indonesia Selama Sepuluh Tahun Terakhir Bagian I (Permasalahan) (Jakarta: CSIS, 1979), 161-2.

70. Quoted in Rasjidi, Strategi Kebudayaan, 113.

71. See KPPN, Pokok-Pokok Pikiran.

72. Rasjidi, Strategi Kebudayaan, 113-14.

73. See KPPN, Pokok-Pokok Pikiran, 12.

74. See the letter in Mimbar Ulama No. 37 (January/February, 1980), 59. 
75. See Lukman Harun, Muhammadiyah dan Undang-Undang Pendidikan Nasional (Jakarta: Pustaka Panjimas, 1990), 8-10.

76. On the Muslim efforts, see Muhammad Sirozi, Politik Kebijakan Pendidikan di Indonesia: Peran Tokoh-tokoh Islam dalam Penyusunan UU No. 2/ 1989 (Jakarta: INIS, 2004).

77. See Ali Munhanif, "Prof. Dr. A. Mukti Ali: Modernisasi Politik Keagamaan Orde Baru” in Azyumardi Azra and Saiful Umam (eds.), Menteri-Menteri Agama RI: Biografi Sosial-Politik (Jakarta: INIS, PPIM and Litbang Depag, 1998), 313-15.

78. Steenbrink, Pesantren, Madsarah, Sekolah, 96-102; 233-39.

79. See Chapter 4.

80. Mukti Ali was not an NU figure and was close to the reformist Muslims of Muhammadiyah. When he was in office, he removed the NU figures from important positions in the Department. Mukti Ali's appointment and his removal policy were somehow related to the regime's efforts to eliminate the influences of the NU people who previously dominated the Department for more than a decade and to force them to be Golkar loyalists. See Munhanif, "Prof. Dr. A. Mukti Ali," 287-92.

81. Interview with Mukti Ali, Yogyakarta, 28 September 2002.

82. Muhammad Sirozi, Politik Kebijakan Pendidikan, 43.

83. This is probably one of the reasons why Jakarta and Yogyakarta IAINs are being transformed into the State Islamic University (UIN).

84. The major reference for this section is Lambert Kelabora, "Religious Instruction Policy in Indonesia" Asian Survey Vol. 16 No. 3 (1976), 230-48.

85. For the full text of the declaration, see Soegarda Poerbakawatja, Pendidikan dalam Alam Indonesia Merdeka (Jakarta: Gunung Agung 1970), 342-43.

86. Poerbakawatja, Pendidikan dalam Alam, 143. Kelabora provides a slightly different translation. See "Religious Instruction" 241.

87. Kelabora, "Religious Instruction,", 242-3; Steenbrink, Pesantren, Madrasah, Sekolah, 93.

88. Kelabora, "Religious Instruction", 239;41. Italics original.

89. Kelabora, "Religious Instruction", 243.

90. Kelabora, "Religious Instruction", 244.

91. The Pancawardhana are (1) the development of love of nation and fatherland, and development of national, international and religious morality; (2) the development of intellect; (3) the development of the artistic emotions and feelings of awe and beauty; (4) the development of handicrafts; (5) the body development. The Pancacinta includes (1) love for the nation and country; (2) love for science and knowledge; (3) love for work and people who work; (4) love for peace and friendship amongst nations; (5) love for parents. See Kelabora, "Religious Instruction", 245. For the original Indonesian version of Pancawardhana, see Poerbakawatja, Pendidikan dalam Alam, 420.

92. Kelabora, "Religious Instruction," 246-7.

93. See the MPRS Decree No. XXVII/1966 in Ketatapan-Ketatapan MPRS (Jakarta:Departemen Penerangan RI, 1968), 109-12.

94. Normally 1 teaching hour was 45 minutes.

95. Poerbakawatja, Pendidikan dalam Alam, 381.

96. Steenbrink, Pesantren, Madrasah, Sekolah, 92-94.

97. Kelabora, "Religious Instruction," 247.

98. For a general account of the MPR session, including the controversy on religion class policy, see "Dari Sidang 13 Hari di Bulan Maret" Tempo (31 March 1973), 5-10.

99. This is a free translation of "beriman dan bertakwa terhadap Tuhan Yang Maha Esa."

100. Bahtiar Effendy, Islam and the State in Indonesia (Singapore: ISEAS, 2003), 154-6.

101. Sirozi, Politik Kebijakan Pendidikan. 
102. The PDI speaker in the parliament said, "Religion class was an obligation to be carried out meticulously, proportionally and responsibly." For the responses of Golkar and ABRI factions, see Suara Karya 9 September 1988; of PPP and PDI factions, see Pelita 12 September 1988 and Angkatan Bersenjata, 10 September 1988 in Dokumentasi Klipping Tentang Undang-Undang Tentang Sistem Pendidikan Nasional Vol.1 (Jakarta: CSIS, 1989), 29-30; 38-9.

103. See Suara Karya 25 August 1988 in Dokumentasi Klipping Vol 2, 49.

104. See the editorials, "Pendidikan Agama di Sekolah2"Panji Masyarakat No. 126 (May, 1973), 5-6; "Moral Pancasila" Panji Masyarakat No. 128 (June, 1973), 4-5; Sidi Gazalba, "Antara Moral Pancasila dan Agama" Panji Masyarakat No. 127 (May, 1973), 12-13.

105. See the text of the GBHN of 1973 in Arnicun Aziz (ed.), Lima GBHN (Jakarta: Sinar Grafika, 1994), 428; 430.

106. This is reported in "Yang Resmi Datang, Rezeki Hilang (?)" Tempo (4 October 1980), 19.

107. "Say: He is God, the One. God is the Absolute. He begets not, nor is He begotten. And there is none Like unto Him." (Q.S. 112: 1-4).

108. "Yang Resmi Datang, Rezeki Hilang (?)".

109. See some quotations of the PMP textbooks, in Samudi Abdullah, "Mengintip Buku PMP Yang Resmi" Panji Masyarakat No. 309 (December 1980), 45-7 and his "Mengintip Buku PMP Lagi" Panji Masyarakat No. 323 (May, 1981), 22.

110. See Muhammad Sulaiman \& Murtadho Makmur, "Stemmotivering Fraksi Persatuan Pembangunan: Tinjauan Terhadap Buku Pelajaran PMP," Panji Masyarakat No. 329 (July, 1981), 40-3.

111. The article 29 of the Law, section 2 states that the curriculum of all levels of education must cover Pancasila Education, Religious Education and Civics Education.

112. See Joesoef, Emak, 232-7; 368-9.

113. Atho Mudzhar, "Religious Education and Religious Harmony in Indonesia," Mizan Vol. 1 No. 2 (1984), 16-25.

114. Rasjidi, Strategi Kebudayaan, 115.

115. See "Jawaban Menteri P\&K Daoed Joesoef", 12-13.

116. Bachtiar's views were quoted in "Beberapa Komentar Tentang Panca Agama" Panji Masyarakat No. 287 (January, 1980), 15.

117. The reference for the following description of the views of Zakiah Daradjat and Daud Ali is "Beberapa Komentar Tentang Panca Agama", 15-19. The references for HAMKA's and Rasjidi's view are "Hamka Tak Setuju Konsep 'Panca Agama", a reprint of Merdeka, 20 December 1979, and the interview with Rasjidi entitled "Penertiban Mata Kuliah Agama" in Panji Masyarakat No. 286 (January, 1980), 14-15 and HAMKA, "Panca Agama Bukan Kejutan" Panji Masyarakat No. 287 (January 1980), 6-8. For Deliar Noer's view, see his "Sekali Lagi: Masalah Pendidikan Agama di Perguruan Tinggi" Panji Masyarakat No. 293 (April, 1980), 10-13.

118. See "Alamsyah: Panca Agama Ide Gila" Panji Masyarakat No. 287 (January, 1980), 7.

119. See "Bantahan Menteri P\&K tentang Panca Agama" Panji Masyarakat No. 287 (January, 1980), 19.

120. Saadoedin Djambek, "Libur Besar Dalam Bulan Puasa”initially published in Dunia Madrasah No. 31/32 (March/April, 1957) and later reprinted in the proceedings of the seminar on school holidays in 1975 entitled Hari Libur Sekolah Bagian Integral Dari Kalender Pendidikan (Jakarta: PB-PGRI, 1975), 55-6.

121. See Joesoef's speech to Parliament, "Jawaban Menteri P\&K Daoed Joesoef Terhadap Pertanyaan Anggota DPR-RI Drs. Amir Hamzah" Panji Masyarakat No. 274 (July, 1979), 12.

122. See all the papers in Hari Libur Sekolah. 
123. Hari Libur Sekolah, 103; 123-128.

124. See the text of the decree in Anonymous, Pendidikan Agama dan Kaitannya dengan Libur Sekolah Bulan Puasa (Jakarta: Mercu Baru, 1979), 81-92.

125. Rasjidi, Strategi Kebudayaan, 112.

126. Mahbub Djunaidi, "Bulan Puasa, Anak-anak Sekolah” Tempo (26 May 1979), 11.

127. Saifuddin Zuhri, "Pendidikan Nasional dan Pendidikan Agama"Pelita 9 May 1979 reprinted in Anonymous, Pendidikan Agama,140-6. See also Saifuddin Zuhri, "Hari Depan Anak-anak Yang Didambakan Melalui Pendidikan Terpadu" Mimbar Ulama No. 31 (June, 1979), 20-8.

128. See Pelita 30 April 1979, reprinted in Anonymous, Pendidikan Agama, 113-4.

129. See Amir Hamzah, "Tanggapan Terhadap Pendirian Menteri P\&K Daoed Joesoef Tentang Liburan Puasa" Panji Masyarakat No. 274 (July, 1979),10-11.

130. See Berita Buana, 25 May 1979 reprinted in Anonymous, Pendidikan Agama, 93-5.

131. See Pelita 28 May 1979 reprinted in Anonymous, Pendidikan Agama, 185.

132. Ali Hasjmi, "Catatan Kecil tentang Daoed Joesoef" in Hartojo, Silalahi and Soesatro (eds.), Nalar dan Naluri,29-31.

133. See "Jawaban Menteri P\&K Daoed Joesoef ", 12-13.

134. See Pelita , 5, 12, 17, 28, 29 May and 14 June 1979 in Pendidikan Agama, 150-90.

135. See Anonymous, Pendidikan Agama, 111-12. According to Joesoef, in that meeting, the Muhammadiyah leader, Kasman Singodimedjo said, "we will free our schools [in Ramadan] even though because of that, we do not receive subsidies." Having heard that, Joesoef replied, "Okay, I will review the subsidies." See "Jawaban Menteri P\&K Daoed Joesoef " 12.

136. For the text of the letter, see Anonymous, Pendidikan Agama, 193-8.

137. See "Jawaban Menteri P\&K Daoed Joesoef " 12.

138. See Pelita 9 May 1979 in Anonymous, Pendidikan Agama, 115-8. President Soeharto apparently supported Joesoef's policy and therefore, Alamsyah could do nothing to change it. Alamsyah seemed to be upset about this, and his relationship with Joesoef became worse when the latter refused to give permission for the Saudi Arabian Embassy to establish the Institute for Islamic and Arabic Studies in Jakarta. According to Alamsyah, Joesoef said that Muslims were already fanatics and if they studied at the Institute, they would become even more fanatical. A meeting was held between Alamsyah, Joesoef, the Minister of Foreign Affairs, Mochtar Kusumaatmaja, and the Minister of Social Welfare, Surono, to solve the problem. In the meeting, Joesoef still refused to give permission and Alamsyah was so angry that he hit Joesoef. The Institute finally was allowed to operate in Jakarta under the permission of the Department of Foreign Affairs not the Department of Education. See Suparwan G. Parikesit \& Krisna R. Sempurnadjaja (eds.), H. Alamsyah Ratuperiranegara, Perjalanan Hidup Seorang Anak Yatim Piatu (Jakarta: Sinar Harapan, 1995), 269-71.

139. See Berita Buana 22 May 1979 in Anonymous, Pendidikan Agama, 160-3. See also "Libur, Tidak, Libur..." Tempo (2 June 1979), 8-9.

140. See "Memang Bukan Asbur" Tempo (7 July 1979), 48.

141. See "Pemutusan Subsidi Muhammadiyah: Kebijakan Yang Tidak Bijak" Panji Masyarakat No. 303 (September, 1980),12-6. Joesoef, however, on one occasion affirmed but on another denied this policy. Later, Amir Hamzah from the PPP reacted to Joesoef's denial by showing evidence of the application of the policy to Muhammadiyah schools. See Amir Hamzah, "Tanggapan Terhadap Keterangan Daoed Joesoef" Panji Masyarakat No. 305 (October, 1980), 11-3. See also T. Mulya Lubis and Fauzi Abdullah (eds.), Langit 
Masih Mendung: Laporan Keadaan Hak-Hak Asasi Manusia di Indonesia 1980 (Jakarta: LBH and Sinar Harapan, 1981), 75-6.

142. See Tempo (16 June 1979), 6.

143. In 1981, Panji Masyarakat lamented that the issue of Ramadan holidays seems to be forgotten and therefore, it tried to reaffirm the Muslim demand for a full Ramadan holidays. See "Libur Puasa: Menggugat Sebuah 'Kebijaksanaan"' Panji Masyarakat No. 329 (July, 1981), 13-15.

144. Towa P. Hamakonda, the librarian of the UKSW, wrote Pengantar Klasifikasi Persepuluhan Dewey. Compared to this book, the content of the Guide was almost the same. See "Persandingan Antara P dan K dan Towa" Panji Masyarakat No. 315 (February, 1981), 14-5.

145. See "Pedoman itu Tidak Ber-Pancasila" Panji Masyarakat No. 315 (February, 1981), 11-2.

146. HAMKA, “Pedoman Perpustakaan SLTA” Panji Masyarakat No. 315 (February, 1981), 7-8.

147. Soeleiman Fadely, "Kristenisasi Lewat Perpustakaan" Aula (March, 1981), 8-9.

148. See "Lagi-Lagi Terkejut Oleh Olah Daoed" Aula (March, 1981), 6-7.

149. See the text of the joint regulation in Poerbakawatja, Pendidikkan dalam Alam, 380-3.

150. See elucidation of the MPRS Decree No. XXVII/ 1966 in Ketetatapan-Ketatapan MPRS (Jakarta: Departemen Penerangan Rl, 1968), 122.

151. See Gavin W. Jones, "Religion and Education in Indonesia" Indonesia (October, 1976), 1956; Paul Webb, Indonesian Christians and Their Political Parties 1923-1966: The Role of Partai Kristen Indonesia and Partai Katolik (Townsville: James Cook University, 1978) and Gerry van Klinken, Minorities, Modernity and the Emerging Nation: Christians in Indonesia, a Biographical Approach (Leiden: KITLV, 2003).

152. Gatra reported that in 2002, many of the Christian private schools were among the top ten scores of the national school exam but there was only one Islamic private school among them. See "Bukan Ombak Penggoyah Iman" Gatra (21 June 2003), 42. The constant attraction of the Christian schools seems to indicate that their achievements in the previous years were not that different.

153. Muhammad Natsir, Sekali Lagi Kerukunan Hidup Umat Beragama di Indonesia (Jakarta: Dewan Dakwah Indonesia, 1978), 65-8; and interview with Husein Umar, Jakarta, 22 October 2003.

154. Poerbakawatja, Pendidikkan dalam Alam, 383-7.

155. See Chapter 1.

156. See Peraba (III September, 1968), 2.

157. Muhammad Natsir, "Sekali Lagi Kerukunan Hidup Antar Agama: Sumbangsih Untuk Prof. Dr. Verkuyl" Kiblat No. 3 (July, 1973), 19.

158. It is reprinted in Mohammad Natsir, Mencari Modus Vivendi Antar Umat Beragama (Jakarta: Media Dakwah, 1980), 37.

159. See Muhammad Rasjidi, "The Role of Christian Missions: the Indonesian Experience" International Review of Mission Vol. 65 No. 260 (October, 1976), 430.

160. See point 3 of the "Statement of the Conference" International Review of Mission Vol. 65 No. 260 (October, 1976), 458.

161. See "Laporan Prof. Dr. H.M. Rasjidi tentang Konferensi Meja Bundar Da'wah Islam dan Missi Kristen di Geneva Tgl. 26-30 Juni" in Serial Media Dakwah No. 35 (1976), 15.

162. For the controversy see Chapter 2.

163. Muhammad Rasjidi, "Islam dan Kristen di Indonesia" Panji Masyarakat No. 258 (November, 1978), 14.

164. See Peraba (III September, 1968), 2.

165. See "Katolik: Bola Salju Mulai Menggelinding?" Tempo (20 October 1973), 48. 
166. See Sarmudi, "Perkembangan Pemikiran Baru Dikalangan Gereja Katholik di Indonesia: Usaha Mencapai Modus Vivendi Antara Islam dan Nasrani" Panji Masyarakat No.142 (January, 1974), 16-17.

167. This case is reported in "Silakan Memilih Agama" Tempo (13 April 1985), 69.

168. See "Silakan Memilih Agama".

169. For a complete text of the decree, see Weinata Sairin (ed.), Himpunan Peraturan di Bidang Keagamaan (Jakarta: BPK, 1994), 316-23.

170. See "Kepercayaan adalah Kepercayaan" Editor No. 30 (19 March 1988), 44.

171. Original: "Tenaga Pengajar pendidikan agama harus beragama sesuai dengan agama yang diajarkan dan agama peserta didik yang bersangkutan."

172. Effendy, Islam and the State, 154-6; Feillard, NU vis-à-vis Negara, 394-6.

173. The chronology of the PDI's opposition and some relevant press reports were quoted at length in Harun, Muhammadiyah dan Undang-Undang, 72-88.

174. The article 28 , section 2 stated that a teacher had to be qualified in teaching the subject, to be committed to Pancasila and the 1945 Constitution and to believe and follow God's commandments.

175. See Suara Pembaruan 3 March 1989 and Kompas 8 March 1989 copied in Dokumentasi Vol. 1, 102-4. For a complete text of PGI's suggestion on this issue, see "Ketetapan Sidang MPL-PGI Nomor 02/MPL-PGI/1989" in Weinata Sairin, Partisipasi Kristen Dalam Pembangunan Pendidikan Indonesia Menyongsong Milenium Ketiga (Jakarta: BPK, 1998), 178-81.

176. See Kompas and Suara Karya 10 March 1989; Suara Karya and Suara Pembaruan 11 March 1989; Suara Karya, Kompas and Suara Pembaruan 14 March 1989 in Dokumentasi Vol. 2, 106-16. See also "Guru Agama Kembali Diributkan" Panji Masyarakat No. 606 (March, 1989), 12-3.

177. See "PP No.29/1990 Harus Ditinjau Kembali" Panji Masyarakat No. 698 (October, 1991), 71-4.

\section{Notes Chapter 6}

1. J.W.M. Bakker, Piagam 'Nostra Aetate' Konsili Vatikan II:Tafsiran Zaman Kita, Zaman Dialog Antar-Agama (Yogyakarta: Kanisius, 1972), 102.

2. Bakker, Piagam 'Nostra Aetate', 110-1.

3. Karel A. Steenbrink, "Patterns of Muslim-Christian Dialogue in Indonesia (1965-1998)" in Jacques Waardenburg (ed.), Muslim-Christian Perceptions of Dialogue Today: Experiences and Expectations (Leuven: Peeters, 2000), 105.

4. See Stuart Brown, Meeting in Faith: Twenty Years of WCC Sponsored Dialogues (Geneva: WCC, 1989); and Jutta Sperber, Christians and Muslims: The Activities of the World Council of Churches (Berlin: De Gruyter, 2000).

5. For instance, A. Mukti Ali made an account of the dialogue in Ajaltoun in his Dialoog Antar Agama (Yogyakarta: Yayasan Nida, 1970), 25-44; the dialogue in Broumana, 1972 in his Agama dan Pembangunan di Indonesia, Bahagian III (Jakarta: Biro Humas Depag RI, 1973), 39-48. Both Rasjidi and Ihromi made reports on the dialogue in Chambésy, Geneva in 1976. See "Laporan Prof. Dr. H.M. Rasjidi Tentang Konperensi Meja Bundar Da'wah Islam dan Missi Kristen di Geneva Tgl. 26-30 Juni 1976" Serial Media Dakwah No. 35 (1976), 2-18; and Ihromi, "Islam-Kristen Bertemu di Jenewa," Berita Oikoumene Vol. 4 (August, 1976), 30-1.T.B. Simatupang also made a report on the Muslim-Christian 
dialogue in Colombo in 1982 in his Kehadiran Kristen dalam Perang, Revolusi dan Pembangunan (Jakarta: BPK, 1986), 142-52.

6. Interview with Father Ismartono, Jakarta, 26 July 2002.

7. For a study of the Indonesian evangelical movement, see David H. Tulaar, You Must Be Born Again: a Preliminary Study of Evangelicalism in Indonesia (Master Thesis, Faculty of Theology, University of Amsterdam, 1997).

8. Interview with Th. Sumartana, Yogyakarta, 24 September 2002.

9. Steenbrink, "Patterns of Muslim-Christian Dialogue", 78-112.

10. This policy is, as many observers have commented, very similar to that which was recommended by C. Snouck Hurgronje. See Harry J. Benda, "Christian Snouck Hurgronje and the Foundation of Dutch Islamic Policy in Indonesia" The Journal of Modern History Vol. 30 No. 4 (1958), 338-47.

11. For the studies of the renewal movement, see B.J. Boland, "Discussion on Islam in Indonesia Today" in Studies On Islam (Amsterdam: North Holland Publishing Company, 1974), 37-50; Muhammad Kamal Hassan, Muslim Intellectual Responses to 'New Order' Modernisation in Indonesia (Kuala Lumpur: Dewan Bahasa dan Pustaka, 1980); Fachry Ali and Bahtiar Effendy, Merambah Jalan Baru Islam (Bandung: Mizan, 1986); Greg Barton, Gagasan Islam Liberal di Indonesia: Pemikiran Neo-Modernisme Nurcholish Madjid, Djohan Effendi, Ahmad Wahib dan Abdurrahman Wahid Trans. Nanang Tahqiq (Jakarta: Paramadina, 1999); Bahtiar Effendy, Islam and the State in Indonesia (Singapore: ISEAS, 2003).

12. See Ahmad Wahib's account of the tensions among the HMI leaders in Djohan Effendi and Ismed Natsir (eds.), Pergolakan Pemikiran Islam: Catatan Harian Ahmad Wahib sixth edition (Jakarta: LP3ES and Freedom Institute, 2003), 144-74. See also A.H. Johns, "An Islamic System or Islamic Values? Nucleus of a Debate in Contemporary Indonesia" in William R. Roff (ed.), Islam and the Political Economy of Meaning (Berkeley: University of California, 1987), 254-80.

13. His papers on the issue are published in Nurcholish Madjid, Islam, Kemodernan dan Keindonesiaan (Bandung: Mizan, 1987), 204-56. For the English translation of the papers, see Appendix A to D in Muhammad Kamal Hassan, Muslim Intellectual Responses, 187233. For Madjid's personal account of the background of, and the controversies around, the Islamic renewal movement see Nurcholish Madjid, "The Issue of Modernisation among Muslims in Indonesia: From a Participant's Point of View" in Gloria Davis (ed.), What is Modern Indonesian Culture? (Athens, Ohio: Ohio Centre for International Studies, Southeast Asia Series No.52, 1979), 143-55.

14. In 1953, Dachlan Ranuwihardjo invited President Soekarno to give a lecture on the concept of the national state in relation to Islam in the hall of the University of Indonesia and the President agreed. Madjid noted that, "the resolution of the discussion was in favour of Sukarno's concept; the HMI, or at least its president, Dachlan Ranuwihardjo, preferred the national state." See Madjid, "The Issue of Modernisation", 147. For Dachlan's invitation letter to Soekarno and the latter's lecture, see Soekarno, Negara Nasional dan Tjita2 Islam (Jakarta: Kementrian Penerangan RI, n.d.).

15. Boland, "Discussion on Islam in Indonesia Today," 43.

16. J.W.M. Bakker, "Sekularisasi dalam Pandangan Ummat Islam" Orientasi Vol. 5 (1973), 4668.

17. The Indonesian translation of the thesis was published in 1982. See Victor I. Tanja, Himpunan Mahasiswa Islam: Sejarah dan Kedudukannya di Tengah Gerakan-Gerakan Muslim Pembaharu di Indonesia (Jakarta: Sinar Harapan, 1982). 
18. Tanja, Himpunan Mahasiswa Islam, 140;146;150;167-70; and Hassan, Muslim Intellectual Responses, 89-115. Greg Barton who wrote some years after Tanja (ironically without mentioning Tanja's thesis) also criticised Hassan on this point. See Barton, Gagasan Islam Liberal, 27-32; 547-97. However, if we look at the political background of Nurcholish Madjid's ideas, Hassan's description is quite fair. Moreover, unlike Hassan, both Barton and Tanja assumed that there was no significant difference between Madjid's view before and after 1970. Again, here Hassan's view was much more congruent with Ahmad Wahib's account that Madjid initially still saw Islam as an ideology by the time when Manshur Hamid, Djohan Effendi and Ahmad Wahib already opposed it. See Effendi and Natsir, Pergolakan Pemikiran Islam, 158-70.

19. Agussalim Sitompul, HMIDalam Pandangan Seorang Pendeta: Antara Impian dan Kenyataan Second Edition (Jakarta: Gunung Agung, 1984). The first edition was published in 1982, the same year of the publication Tanja's book. The last part of the second edition contains more than 20 reprinted review articles most of them of Tanja's book and few of them of Sitompul's.

20. Sitompul, HMI Dalam Pandangan, 84-93.

21. Djohan Effendi, "Catatan Tentang Sebuah Tempat Transit" Tempo (3 April 1982), 77 reprinted in Sitompul, HMI Dalam Pandangan, 159-60.

22. The text of the letter published in Laksmi Pamuntjak and Agus Edy Santoso (eds.), Tidak Ada Negara Islam: Surat-Surat Politik Nurcholish Madjid-Mohamad Roem Second Edition (Jakarta: Djambatan, 2000), 38. The book contains correspondences between Madjid and Roem in 1983 when the former was studying in the University of Chicago. The correspondence can be read as a reconciliation between the young and the old generation of the Muslim reformist leaders.

23. For a short biography of Schumann, see Panitia Penerbitan, Agama Dalam Dialog, Pencerahan, Perdamaian dan Masa Depan: Punjung Tulis 60 Tahun Prof.Dr. Olaf Herbert Schumann (Jakarta: BPK, 1999), 497-503.

24. The $20^{\text {th }}$ Seminar of Religions was held in 2000 , and afterward the new leadership of the PGI did not pay attention to this programme anymore. In my interviews, the proponents of inter-religious dialogue among the Protestants were quite unhappy with this PGl's policy. Interviews with Th. Sumartana, Yogyakarta, 24 September 2002; and Martin Sinaga, Jakarta, 16 August 2002.

25. Among the invited speakers were Djohan Effendi, Harun Nasution, Nurcholish Madjid, Masdar F. Mas'udi and Abdurrahman Wahid.

26. This book was a textbook used in the State Institute of Islamic Studies (IAIN) all over the country. It was strongly opposed by the Muslim reformist leader and polemicist, Muhammad Rasjidi. See Harun Nasution, Islam Ditinjau dari Berbagai Aspeknya Second Edition Vol. I and II (Jakarta: UI Press, 1979) and Muhammad Rasjidi, Koreksi Terhadap Dr.Harun Nasution Tentang Islam Ditinjau dari Berbagai Aspeknya (Jakarta: Bulan Bintang, 1977). Harun Nasution obtained his PhD in Islamic Studies at McGill University and when he came back home, he became the promoter of Islamic rational theology on the lines of Mu'tazila and Muhammad 'Abduh. See Saiful Muzani, “Mu'tazilah Theology and the Modernisation of the Indonesian Muslim Community: Intellectual Portrait of Harun Nasution" Studia Islamika No.1 Vol.1 (1994), 91-131.

27. Deliar Noer, Gerakan Modern Islam di Indonesia 1900-1942 (Jakarta: LP3ES, 1982), the Indonesian translation of his The Modernist Muslim Movement in Indonesia 1900-1942 (Singapore: Oxford University Press, 1973); and Harun Nasution, Pembaharuan Dalam Islam (Jakarta: Bulan Bintang, 1975). See Th. Sumartana's report on the first seminar entitled "Laporan Seminar Malang", and J. Garang's report on the second seminar enti- 
tled "Laporan Seminar Islam II" in Kumpulan Rekaman Hasil Seminar Agama-Agama I-IV (Jakarta: Litbang PGI, 1984).

28. See T.B. Simatupang, "Sumbangan Agama-Agama Dalam Negara Pancasila Yang Membangun" in his Iman Kristen dan Pancasila (Jakarta: BPK, 1984), 168-78.

29. See Effendi and Natsir, Pergolakan Pemikiran Islam. For an analysis of the book see Johns, "An Islamic System or Islamic Values?", 254-80; and Barton, Gagasan Islam Liberal, 251 324. For a press account of the controversy, see "Catatan Harian Ahmad Wahib" Tempo (January 30, 1982), 50-5. For a sympathetic but critical review, see Abdurrahman Wahid, "Bak Tukang Batu Menghantam Tembok" Tempo (19 September 1981), 28-9 and his "Sekali Lagi Ahmad Wahib" Tempo (23 January 1982), 76. For an opposing view, see Muhammad Rasjidi, "Pergolakan Pemikiran Islam: Suatu Tragedi" Panji Masyarakat No. 346 (January, 1982), 42-3. The book became a controversy again in 1995 when Republika, commonly considered a Muslim newspaper, published some articles praising Wahib's ideas and this was in turn triggered strong protest from the Muslim hardliners of the DDII. See Robert W. Hefner, "Print Islam: Mass Media and Ideological Rivalries Among Indonesian Muslims" Indonesia No. 64 (October, 1997), 97-99; and Ahmad Sumargono, "Kontroversi dan Keanehan Pemikiran Ahmad Wahib" Republika, 11 April 1995.

30. The MUI identified 26 unacceptable statements in the book. See "Masalah Buku Pergolakan Pemikiran Islam" Mimbar Ulama No. 73 Vol. 8 (August-September, 1983), 3945.

31. Tempo reported that only in three months, 5000 copies of the first edition were sold out while 10,000 copies of the second edition were sold out in a year. See "Catatan Harian Ahmad Wahib", 50. The sixth and most recent edition appeared in 2003.

32. Effendi and Natsir, Pergolakan Pemikiran Islam, 39-41.

33. Effendi and Natsir, Pergolakan Pemikiran Islam, 139.

34. See Th. Sumartana, "Ahmad Wahib, Profil Seorang Pembaharu"Tempo (10 October 1981), 33 and Th. Sumartana, "Ikhtiar Ahmad Wahib: Sebuah Corak Reformasi dalam Islam" Prisma No.8 Vol. 10 (August, 1981), 82-8. See also the proceedings of the seminars in Kumpulan Rekaman Hasil Seminar Agama-Agama Bidang Islam I-IV (Jakarta: Litbang PGI, 1984).

35. See Ismed Natsir, "Melacak Jejak Ahmad Wahib" in Kumpulan Rekaman Hasil Seminar Agama-Agama Bidang Islam I-IV.

36. Information from Martin van Bruinessen based on his interview with Dawam Rahardjo.

37. Barton, Gagasan Islam Liberal, 388-94. Later, in a speech in front of the Christian leaders in 1996, Wahid explained that he was regularly invited to give the lecture for the GKJW course over a period of more than seven years. See Abdurrahman Wahid, "Membangun Kebersamaan Hidup Beragama" Aula (November, 1996), 54.

38. See J. Garang, "Laporan Seminar Islam II", page 4 in Kumpulan Rekaman Hasil Seminar Agama-Agama Bidang Islam I-IV.

39. Martin van Bruinessen, NU, Tradisi, Relasi-Relasi Kuasa, Pencarian Wacana Baru (Yogyakarta: LKiS, 1994), 108-29.

40. See Chapter 3.

41. Einar Martahan Sitompul, Nahdlatul Ulama dan Pancasila: Sejarah dan Peranan NU dalam Perjuangan Umat Islam di Indonesia dalam Rangka Penerimaan Pancasila sebagai Satusatunya Asas (Jakarta: Sinar Harapan, 1989).

42. For a more detail analysis of Wahid's concept of the relationship between Islam and the state, see Mujiburrahman, "Islam and Politics in Indonesia: the Political Thought of Abdurrahman Wahid" Islam and Christian-Muslim Relations Vol. 10 (October, 1999), 33952. 
43. See Abdurrahman Wahid, "Kata Pengantar" in Sitompul, Nahdlatul Ulama, 16-7.

44. In Indonesian, 'pembangunan' as a deliberate constructed act is sometimes contrasted with 'perkembangan' which renders the growth and flourishing aspect of development.

45. Ali Moertopo, Dasar-Dasar Pemikiran Tentang Akselerasi Modernisasi Pembangunan 25 Tahun (Jakarta: CSIS, 1972).

46. Hassan, Muslim Intellectual Responses, Chapter I and II.

47. The epithet 'Berkeley Mafia' was used by some critics to call Widjojo's group which consists of some graduates of the University of California, Berkeley. For the critics, the Berkeley mafia was prepared by the US to control Indonesian economic policies. See Hamish McDonald, Suharto's Indonesia (Honolulu: The University Press of Hawaii, 1981), 75-77.

48. SeePidato Kenegaraan Pd. Presiden RepublikIndonesiaDjenderalSoehartodiDepan Sidang DPR-GR, 16 Augustus 1967 (Jakarta: Penerbit Doa Restu, 1967), 56.

49. For the text of his speech, see "Djend. Soeharto pada Konpernas Geredja \& Masjarakat" Ragi Buana (July, 1967), 17-20.

50. See S.A.E Nababan, Panggilan Kristen Dalam Pembaharuan Masjarakat: Laporan Konperensi Nasional Geredja dan Masjarakat (Jakarta: BPK, 1968), 103-12.

51. Nababan, Panggilan Kristen, 15-8; 47; 79-80.

52. Dick Hartoko, "Membangun Masjarakat Modern” Basis Vol. 16 (1967), 333-8; 356.

53. See Chapter 3.

54. Hassan, Muslim Intellectual Responses, Chapter I, II and III.

55. In his diary, Ahmad Wahib wrote that since 1966, there was already controversy among the HMI activists whether modernisation was acceptable or not. Madjid's paper on "Modernisation is Rationalisation, not Westernisation" was an important reading material among the HMI activists in the late 1960s. On the other hand, Djohan Effendi and Manshur Hamid disagreed with Madjid's view and said, if modernisation implies westernisation, "What else could we do?" Madjid became more positive to the West after his two-month visit to the USA in 1968. He found that Islamic values were more practiced in the USA than in Indonesia. See Effendi and Natsir, Pergolakan Pemikiran Islam, 149$56 ; 161-70$.

56. Ali Munhanif,"Prof. Dr. Mukti Ali, Modernisasi Politik Keagamaan Order Baru"in Azyumardi Azra \& Saiful Umam (eds.), Menteri-Menteri Agama RI: Biografi Sosial Politik (Jakarta: INIS-PPIM, 1998), 290-2.

57. See Effendi and Natsir, Pergolakan Pemikiran Islam, 146-7.

58. Ahmad Wahib noted: "Mukti Ali's position as the guide of the discussion in the Limited Group was to bridge the gap between various conflicting ideas. He always stimulated our thought, clarified a problem and at the same time softened the formulations of ideas considered too strong." See Effendi and Natsir, Pergolakan Pemikiran Islam, 150.

59. See A. Mukti Ali, "Dialogue Between Muslims and Christians in Indonesia and Its Problems" in his Dialoog Antar Agama (Yogyakarta: Jajasan Nida, 1970), 43.

60. Munhanif, "Prof. Dr. Mukti Ali”, 292.

61. A. Mukti Ali, Religion and Development in Indonesia (Yogyakarta: Yayasan Nida, 1971).

62. See A. Mukti Ali, Agama dan Pembangunan di Indonesia (Jakarta: Dirjen Bimas Islam, Depag, 1971). According to this book, the lecture was delivered to (1) the Congress of the Indonesian Scholars of Economics Association (ISEI) on 15 October 1971; (2) the Orientation Programme of the Parliament members of Golkar and Military on 18 October 1971 ; (4) the week celebration of the Youth Oath in the auditorium of the Faculty 
of Economics, University of Indonesia, 24 October 1971; and (5) the Meeting of the DGI on 28 October 1971.

63. Mukti Ali, Religion and Development, 21.

64. Mukti Ali, "Kehidupan Agama, Kerukunan Hidup Ummat Beragama dan Pembangunan" and "Dialog Antar Pemuka-Pemuka Agama" in his Agama dan Pembangunan di Indonesia (Jakarta: Biro Hukum \& Humas Depag, 1975), 62-72; 118-20.

65. Interview with Mukti Ali, Yogyakarta, 28 September 2002.

66. A. Mukti Ali, "Kehidupan Agama, Kerukunan Hidup Ummat Beragama", 70.

67. Mukti Ali used an awkward English expression "agree in disagreement" that was later quite popular. In an interview with me, Mukti Ali proudly said that it took months for him to find this expression and that he deliberately used the English words to attract people's attention. Interview with Mukti Ali, Yogyakarta, 28 September 2002.

68. Mukti Ali, "Kehidupan Agama, Kerukunan Hidup Ummat Beragama", 71.

69. On the Muslim apologetic discourses, see B.J. Boland, The Struggle of Islam in Modern Indonesia (The Hague: Martinus Nijhoff, 1982), 226-7.

70. On the approach developed by Smith and others like him, see Mujiburrahman, "The Phenomenological Approach in Islamic Studies: An Overview of a Western Attempt to Understand Islam" The Muslim World Vol. 91 (Fall 2001), 425-449.

71. See Mukti Ali's account of the Congress in his Dialoog Antar Agama, 7-23.

72. For a summary of Mukti Ali's comparative religion, see B.J. Boland, The Struggle of Islam, 206-11. For a survey of the development of the study of comparative religion in Indonesia, see Karel A Steenbrink, "The Study of Comparative Religion by Indonesian Muslims: A Survey" Numen No. 2 Vol. 37 (1990), 141-67.

73. Djohan Effendi, “Dialog Antar Agama: Bisakah Melahirkan Teologi Kerukunan?" in Imam Ahmad (ed.), Agama dan Tantangan Zaman (Jakarta: LP3ES, 1985), 172-3. The article is a reprint from Prisma No. 5 (June, 1978), 12-7.

74. Interview with Djohan Effendi, Jakarta, 29 August 2002.

75. In his written account, Djohan mentioned the list of topics of the dialogues that are clearly related to the Government development idea. The topics include religious tolerance and harmony; ethical code on religious preaching and interaction; religious values and development; religious values in modern society; the roles of religious leaders in the development of society; religion and national defence; care for homeless children; religious guidance for the people in the transmigration area; religion and family planning; etc. See Effendi, “Dialog Antar Agama”, 172.

76. Djohan Effendi mentioned the following examples of the topics: (1) comparative study of four villages, each of them dominated by a certain religious group in East Java; (2) the role of religious leaders in social activities in a Muslim and a Christian village in Medan; (3) patterns of inter-religious relations in Toraja; (4) the role of mosques and churches in guiding the lives of their respective congregations in Bandung; (5) Temporary marriages and inter-religious marriages in East Kalimantan. See Effendi, “Dialog Antar Agama", 173-4.

77. Steenbrink, "Patterns of Muslim-Christian Dialogue", 88.

78. Effendi, "Dialog Antar Agama”, 174.

79. Effendi, “Dialog Antar Agama”, 174-5.

80. Interview with Djohan Effendi, Jakarta, 29 August 2002.

81. Steenbrink, "Patterns of Muslim-Christian Dialogue", 87.

82. Steenbrink, "Patterns of Muslim-Christian Dialogue", 89.

83. Interview with Djohan Effendi, Jakarta, 9 July 2002. 
84. Interview with Mukti Ali, Yogyakarta, 28 September 2002. This is in line with Djohan Effendi's remark that in the beginning, the dialogue programme was met with scepticism. See Effendi, “Dialog Antar Agama” 173.

85. In his speeches in 1974 and 1975, President Soeharto began to hint at the importance of holding an Inter-religious Consultation and to create the Body for Inter-religious Consultation. In a meeting of the Council of the Stabilisation of Politics and Security on 14 April 1976, the Minister of Religion received a letter from the Minister of Home Affairs explaining the basic thoughts on the creation of the Body. See Hasbullah Mursyid et.al., Masalah Hubungan Antar Umat Beragama di Indonesia (Jakarta: Proyek Pembinaan Kerukunan Hidup Beragama, 1979), 2-4.

86. Mursyid et.al., Masalah Hubungan , 5.

87. See Almasyah Ratu Perwiranegara, Pembinaan Kerukunan Hidup Beragama (Jakarta: Departemen Agama, 1982), 45-54.

88. See Alamsyah Ratu Perwiranegara, "Wadah Musyawarah Antar Umat Beragama di Dalam Negara Pancasila" Dialog No. 9 Vol. 5 (October, 1980), 3. Dialog is an academic journal published by the Office of Religious Research and Development, Department of Religion. The journal was started in 1976 (during Mukti Ali's period) and still survives up to now.

89. Ratu Perwiranegara, "Wadah Musyawarah", 4.

90. Steenbrink, "Patterns of Muslim-Christian Dialogue", 95-6.

91. Interview with Mukti Ali, Yogyakarta, 28 September 2002.

92. Interview with Djohan Effendi, Jakarta, 29 August 2002.

93. The Forum eventually produced a document, dated 19 December 1983, on basic thoughts concerning Pancasila as the sole basis. In the basic thoughts, we can see some reservations rather than an explicit support to the idea of Pancasila as the sole basis. See the text of document in Weinata Sairin (ed.), Himpunan Peraturan di Bidang Keagamaan (Jakarta: BPK, 1994), 547-9.

94. Bakker, Piagam 'Nostra Aetate', 111-3.

95. Eka Darmaputera, "Setelah Mukti Ali Menjadi Menteri" Tempo (June 2, 1973), 30.

96. Abdurrahman Wahid, "The Regional Context of Religious Cooperation: Implications of an Indonesian Case" Dialog No. 12 Vol. 7 (March, 1982), 42-3. The paper was originally presented to the $5^{\text {th }}$ Seminar on Religion as a Field of Study organised by the Department of Religion in March, 1982.

97. Th. Sumartana, “Lagi: Tempat Agama” Tempo (2 February 1974).

98. Th. Sumartana, "Keadilan Sosial Lewat Agama?" Tempo (24 November 1973).

99. See F. Danuwinata, "Pergumulan Agama dengan Masalah Pembangunan"; S. Wismoady Wahono, "Messianisme dalam Perjuangan Petani: Tinjauan dari Sisi Kekristenan"; Th. Sumartana, "Teologi Pembebasan: Kepalan Tangan Sang Uskup"; and Y.B. Mangunwijaya, "Gereja Antara Yesus dari Nasaret dan Caesar" all are reprinted in Imam Ahmad (ed.), Agama dan Tantangan Zaman, 13-24; 276-330. F. Danuwinata's article was originally published in 1975, S. Wismoady Wahono's in 1977 and both Sumartana's and Manguwijaya's in 1982.

100. See Ismid Hadad, "Pengantar Redaksi” Prisma No.1 Vol. 1 (November, 1971), 2.

101. Steenbrink, "Patterns of Muslim-Christian Dialogue", 107.

102. In this context, Rahardjo asked Daniel Dhakidae, an intellectual (a Catholic) who worked in the LP3ES, to translate Hassan Hanafi's article on 'theology of land' and publish it in Prisma. See Hassan Hanafi, "Pandangan Agama tentang Tanah: Suatu Pendekatan Islam" in Ahmad (ed.), Agama dan Tantangan Zaman, 91-112, a reprint from Prisma (April, 1984). For Rahardjo's appreciation of Shariati, see Dawam Rahardjo, "Ali Syari'ati: 
Mujahid Intelektual" in Ali Syari'ati, Kritik Islam atas Marxisme dan Sesat Pikir Barat Lainnya Trans. Husin Anis Al-Habsyi (Bandung: Mizan, 1983), 7-32.

103. Wahono Nitiprawiro, Teologi Pembebasan: Sejarah, Metode, Praksis dan Isinya (Jakarta: Sinar Harapan, 1987). The book was republished by LKiS in the year 2000 under the same title.

104. Masdar F. Masu'di, "Teologi Rasionalistik dalam Islam: Suatu Telaah Kritis Atas Teologi Mu'tazilah" and Moeslim Abdurrahman, "Wong Cilik dan Kebutuhan Teologi Transformatif" published in the proceeding of the seminar, M. Masyhur Amin (ed.), Teologi Pembangunan: Paradigma Baru Pemikiran Islam (Yogyakarta: LKPSM, 1989), 82-91; 153-61. It is noteworthy that Mas'udi is an NU activist while Abdurrahman is a Muhammadiyah activist.

105. Moeslim Abdurrahman used the term "Islam Transformatif" (Transformative Islam) while Masdar F. Mas'udi used the term "Agama Keadilan" (Religion of Justice). See Masdar F. Mas'udi, Agama Keadilan: Risalah Zakat (Pajak) dalam Islam (Jakarta: Pustaka Firdaus, 1991) and Moeslim Abdurrahman, Islam Transformatif (Jakarta: Pustaka Firdaus, 1995).

106. Mansour Fakih,"MencariTeologi Untuk Kaum Tertindas (khidmat dan kritikuntuk guruku Prof. Harun Nasution)" in Refleksi Pembaharuan Pemikiran Islam: 70 Tahun Harun Nasution (Jakarta: LSAF, 1989), 165-77.

107. Asghar Ali Engineer, Islam dan Pembebasan Trans. Hairussalim HS (Yogyakarta: LKiS \& Pustaka Pelajar, 1993); Kazou Shimogaki, Kiri Islam Antara Modernisme dan Postmodernisme: Telaah Kritis Atas Pemikiran Hassan Hanafi Trans. Imam Aziz (Yogyakarta: LKiS \& Pustaka Pelajar, 1993). The book includes the translation of Hassan Hanafi's article "Mādzā Ya'nī al-Yasār al-Islāmī?" (What is Islamic Left?).

108. Conversation with Farid Wajidi, a former PMIl activist and one of the founders of LKiS.

109. In 1988 to 1993, three economic ministries were controlled by Christians: Radius Prawiro (Protestant) was the Coordinating Minister of Economy, Finance, Industry and Development; J.B. Sumarlin (Catholic) was the Minister of Finance; and Adrianus Mooy (Catholic) was the Governor of the National Bank. Among the Muslims, these three persons were often called 'RMS' (Radius, Mooy and Sumarlin) to remind one of the historical RMS (Republik Maluku Selatan), a secessionist movement led by Christians in South Maluku.

110. Robert W. Hefner, "Islam, State and Civil Society: ICMI and the Struggle for the Indonesian Middle Class" Indonesia No. 56 (1993), 1-37.

111. R. William Liddle, "The Islamic Turn in Indonesia: a Political Explanation" The Journal of Asian Studies Vol. 55 No. 3 (1996), 613-34.

112. Martin van Bruinessen, "Islamic State or State Islam? Fifty Years of State-Islam Relations in Indonesia," in Igrid Wessel (ed.), Indonesien am Ende des 20 Jahshunderts (Hamburg: Abera-Verlaag, 1996), 19-34.

113. See "Setelah 'Kagum 5 Juta' Itu Diumumkan" Tempo (27 October 1990), 28-32; "Setelah Breidel, Perlu Penyejuk?" Tempo (November 3, 1990), 26-30. See also Robert W. Hefner, Civil Islam: Muslims and Democratization in Indonesia (Princeton: Princeton University Press, 2000), 161-2.

114. Hefner, Civil Islam, 112

115. M. Amien Rais, "Mass Media Islam: Save Our Soul" Panji Masyarakat No. 293 (April, 1980), 39-43.

116. See M. Amien Rais, "al-Islām wa al-Nasrāniyya fī Indūnīsiyā," Studia Islamika Vol. 2 No.1 (1995), 75-91. This Arabic article discusses some other typical Muslim resentment to the Christians such as aggressive missionary activities, expansion of Christian education and over-representation of the Christians in the Government and Parliament. 
117. See "Membedah Jantung Monitor" Media Dakwah (December, 1990), 25-30.

118. See "Guncangan Baru Setelah 'Monitor"' Tempo (10 November 1990), 26-9.

119. See "Setelah 'Kagum 5 Juta' Itu Diumumkan" Tempo (27 October 1990), 28.

120. See "Angket, Boikot dan Istigfar" Tempo (27 October 1990), 32.

121. "Angket, Boikot dan Istigfar", 33.

122. See "Dialog Makin Perlu" Tempo (10 November 1990), 29-30.

123. "Dialog Makin Perlu", 30.

124. See "Angket, Boikot dan Istigfar" Tempo (27 October 1990), 33.

125. See "Setelah Breidel, Perlu Penyejuk?" Tempo (3 November 1990), 30.

126. The proceedings of the seminar are published in Soetjipto Wirosardjono et al, Agama dan Pluralitas Bangsa (Jakarta: P3M, 1991).

127. Franz Magnis-Suseno, "Kerendahan Hati Prasyarat Kerukunan Antar Agama" Media Indonesia 30 November 1990, reprinted in Wirosardjono et al, Agama dan Pluralitas, 12831.

128. Franz Magnis-Suseno, "Islam 1990: Renungan Seorang Non-Muslim" Tempo (9 January 1991) reprinted in Wirosardjono, Agama dan Pluralitas, 131-33.

129. For an historical description of DIAN by its founder, see Th. Sumartana, "Sejarah Singkat, Visi dan Misi Institut DIAN/Interfidei" Newsletter Interfidei (Special Edition, 2000), 3-6.

130. Among the intellectuals were Abdurrahman Wahid, Djohan Effendi (both are Muslims), Daniel Dhakidae, Y.B. Mangunwijaya (both are Catholics), Eka Darmaputera (Protestant), Gedung Bagus Oke (a female prominent Hindu intellectual), Elga Sarapung (a female Protestant minister who was to succeed Th. Sumartana as the director of Interfidei) and St. Sunardi (a young prominent Catholic intellectual). Among the student activists who joined the Interfidei were Farid Wajidi, Hairus Salim, Ahmad Suaedy, Ciciek Farcha and Zuly Qadir.

131. Interview with Th. Sumartana, Yogyakarta, 24 September 2002.

132. Quoted in Elga Sarapung, "Narasi Kegiatan 10 Tahun Institut Dialog Antar-Iman di Indonesia (Institut DIAN/Interfidei)" Interfidei Newsletter (Special Edition, 2000), 37.

133. Abdurrahman Wahid, "Agama dan Demokrasi" in Ahmad Suaedy (ed.), Spritualitas Baru: Agama dan Aspirasi Rakyat (Yogyakarta: Interfidei, 1994), 269-75.

134. Th. Sumartana, "Experimentasi Demokratisasi dari Agama-Agama: Sudut Pandang Kekristenan" in M. Imam Aziz, M. Jadul Maula, Ellyasa KH. Dharwis (eds.), Agama, Demokrasi \& Keadilan (Jakarta: Gramedia, 1993), 49-62.

135. For a study of this issue, see Masykuri Abdillah, Responses of Indonesian Muslim Intellectuals to the Concept of Democracy (1966-1993) (Hamburg: Abera Verlag Meyer, 1997).

136. The result was published under the title Anotasi 200 Buku Islam Karya Muslim Indonesia (Yogyakarta: Interfidei, 1997). I thank Farid Wajidi for his explanation of the background of this book.

137. Sarapung, "Narasi Kegiatan 10 Tahun.," 37-50; Sumartana, "Sejarah Singkat" 5.

138. Interview with Th. Sumartana, Yogyakarta, 24 September 2002.

139. Th. Sumartana, "SARA dan Integrasi Nasional ? Ketegangan Yang Tak Pernah Padam" in A.E. Priyono, Stanley Adi Prasetyo and Olle Törnquist (eds.), Gerakan Demokrasi di Indonesia Pasca-Soeharto (Jakarta: Demos, 2003), 31.Th. Sumartana passed away on 24 January 2003 during an activity organised by a new NGO concentrating on democracy and human right issues called 'DEMOS' which published this book.

140. Information from Martin van Bruinessen.

141. The first collection of Madjid's papers presented in the KKA was published under the title: Islam, Doktrin dan Peradaban (Jakarta: Paramadina, 1992). 
142. For the speech, see Nurcholish Madjid, "Beberapa Renungan Tentang Kehidupan Keagamaan untuk Generasi Mendatang" Ulumul Qur'an No. 1 Vol. 4 (1993), 4-24.

143. Franz Magnis-Suseno, "Nurcholish Madjid, Islam dan Modernitas" Ulumul Qur'an No. 1 Vol. 4 (1993), 36-44.

144. J.B. Banawiratma, "Tunduk Kepada Allah"Tempo (19 December 1992), 31. In contrast, the Protestant theologian, Einar M. Sitompul said that he could not accept Madjid's inclusive theology because it still implies Islam's superiority over other religions. Interview in Jakarta, 15 December 2003.

145. See Magnis-Suseno, "Nurcholish Madjid, Islam dan Modernitas", 36-44; and circulated copies of correspondences between Madjid and Magnis-Suseno in April and May 1995.

146. See Budhy Munawar-Rachman, "Kesatuan Transendental dalam Teologi: Perspektif Islam tentang Kesamaan Agama-agama" in Abdurrahman Wahid et al, Dialog: Kritik \& Identitas Agama (Yogyakarta: Interfidei, 1993), 121-50. His articles on the similar topic are later published in Budhy Munawar-Rachman, Islam Pluralis: Wacana Kesetaraan Kaum Beriman (Jakarta: Paramadina, 2001).

147. Komaruddin Hidayat and Muhammad Wahyuni Nafis, Agama Masa Depan: PerspektifFilsafat Perennial (Jakarta: Paramadina, 1995).

148. Kautsar Azhari Noer, Ibnal-'Arabi:Wahdatal-Wujud dalam Perdebatan (Jakarta:Paramadina, 1995). See also his "Memperkaya Pengalaman Keagamaan Melalui Dialog" Ulumul Qur'an Special Edition No. 5 \& 6 Vol. 5 (1994), 104-17.

149. Interviews in Yogyakarta with Amin Abdullah, 8 October 2002 and with Munir Mulkhan, 12 October 2002. In the year 2000, through his position in the Majlis Tarjih, a section of the organisation that mostly dealt with fatwa, Amin Abdullah published a book on Qur'anic exegesis concerning inter-religious relations. The book contains an inclusive theological point of view that in turn made some Muhammadiyah leaders unhappy. Because of this, Amin Abdullah said that he was put on 'trial' in a meeting among the Muhammadiyah leaders. For the book, see Majelis Tarjih dan Pengembangan Pemikiran Islam, Tafsir Tematik al-Qur'an Tentang Hubungan Sosial Antarumat Beragama (Yogyakarta: Pustaka SM, 2000).

150. See his preface to Ulumul Qur'an No. 1 and No. 2 Vol. 1 (1989).

151. See "Sebuah Experimentasi Bernama 'Madia"' in Martin L. Sinaga and Trisno S. Sutanto (eds.), Meretas Horison Dialog: Catatan dari Empat Daerah (Jakarta: MADIA, ISAI, 2001), 133-7. Trisno S. Sutanto (Catholic) and Martin L. Sinaga (Protestant) were activists of MADIA.

152. Wahid apparently had good relations with MADIA activists. He once hosted a meeting of MADIA and when he became President, MADIA activists could have easy access to him. Interviews with Kautsar Azhari Noer, Martin L. Sinaga and Trisno S. Sutanto, Jakarta, July 2002.

153. See Th. Sumartana, "Theologia Religionum" in Tim Litbang PGI (eds.), Meretas Jalan Teologi Agama-Agama di Indonesia: Theologia Religonum (Jakarta: BPK, 1999), 17-39. This book is the proceeding of the Seminar in question.

154. E.G. Singgih, "Hidup Kristiani dalam Masyarakat Keagamaan yang Bersifat Majemuk" in Tim Litbang PGI, Meretas Jalan Teologi", 100-21.

155. J.B.Banawiratma, "Mengembangkan Teologi Agama-agama" in Tim Litbang PGl, Meretas Jalan Teologi," 40-9.

156. Interview in Jakarta, July 2002.

157. C. Groenen, "Keselamatan Tidak Ada dalam Nama Lain (Daripada Nama Yesus) Manapun (Kis. 3:12)" Gema: Jurnal Teologi Duta Wacana No.47 (1994), 100-20. 
158. See Hefner, Civil Islam, 190-2.

159. Hefner, Civil Islam, 193. See also “Semua Sama Susah”;"Wawancara Gus Dur: Umatmu Apa Mas?" in Aula (November 1996), 28-44.

160. Information from Martin van Bruinessen.

161. Tahalele and Santoso, Beginikah Kemerdekaan Kita?, 23-6.

162. Abdurrahman Wahid, "Membangun Kebersamaan Hidup Beragama" in Aula (November 1996), 45-65.

163. The FKKS gradually developed to be FKKJT (JT, Jawa Timur) covering the churches in East Java, and then finally became FKKI (I, Indonesia), covering the whole of Indonesia. Interview with Thomas Santoso, Surabaya, 7 January 2004; and Gerrit E. Singgih, Yogyakarta, 15 October 2002.

164. Before the Situbondo incident, on 9 June 1996, there had already been a similar attack on the churches in Surabaya city. According to Thomas Santoso, the secretary of the FKKS, when the Christians complained about the incident, the Regional Army Commander said to them that they had to keep silent because they were a religious minority. The commander also warned the media not to publish the Surabaya incident. Having become disappointed with the authorities, the Christians then attempted another way to make the incident known, that is, by faxing its information to 'a friend in the USA' who later published it on the internet. This strategy proved to be effective, and so when the Situbondo case happened later, the Government authorities became more cooperative. Interview with Thomas Santoso, Surabaya, 7 January 2004.

165. See Tahalele and Santoso, Beginikah Kemerdekaan Kita?The English version was entitled The Church and Human Rights in Indonesia (Surabaya: ICCF, 1997). Before launching the book to the public Tahalele who was one of Soeharto's family doctors, gave the book to the President, who appeared very surprised by it. The effect was that the Commander of the Armed Forces, Wiranto, invited its authors and some other Christian leaders to Jakarta to talk about the book. (Interview with Thomas Santoso, Surabaya, 7 January 2004). One of the shocking bits of information provided in this book is that the number of churches damaged or burned down in Indonesia sharply increased in the second half of the 1990s. See the following table quoted from Tahalele and Santoso, Beginikah Kemerdekaan Kita?, 39.

\section{Churches Damaged or Burned Down in Indonesia (1945-1997)}

\begin{tabular}{|c|c|c|}
\hline Period & Number & Average per-year \\
\hline $1945-1954$ & 0 & 0 \\
$1955-1964$ & 2 & 0.2 \\
$1965-1974$ & 46 & 4.6 \\
$1975-1984$ & 89 & 8.9 \\
$1985-1994$ & 132 & 13.2 \\
$1995-1997$ & 89 & 44.5 \\
\hline Total & 358 & \\
\hline
\end{tabular}


166. Steenbrink, "Patterns of Muslim-Christian Dialogue"101-2. For a sympathetic but critical account of the Conference in Jakarta, see E.G. Singgih, "Tema Kerukunan Umat Beragama di Dalam Diskusi Pakar Agama" in Panitia Penerbitan, Agama Dalam Dialog, 33-46.

167. Information from Karel A. Steenbrink.

168. Interview with Burhanuddin Daya, Yogyakarta, 9 October 2002.

169. Mohtar Mas'oed, Muchammad Maksum and Moh Soehada (eds.), Kekerasan Kolektif: Kondisi dan Pemicu (Yogyakarta: P3PK UGM, 2000).

170. See Tim Peneliti, Laporan Penelitian Kerukunan Antarumat Beragama (Unpublished Report, 1997). 



\section{Bibliography}

\section{Books and Articles}

Abdillah, Masykuri. (1997) Responses of Indonesian Muslim Intellectuals to the Concept of Democracy (1966-1993) Hamburg: Abera Verlag Meyer. Abdullah, Samudi. (1980) "Mengintip Buku PMP Yang Resmi”, Panji Masyarakat No. 309 (December), 45-7.

- (1981) "Mengintip Buku PMP Lagi” Panji Masyarakat No. 323 (May), 22.

- (1981) "Tentang Perayaan Natal Bersama", Panji Masyarakat No. 325 (June), 54-5.

- (1981) "Tentang Teologi Pancasila: Catatan Untuk T.B. Simatupang”, Panji Masyarakat No. 327 (June), 64-5.

Abdullah, Taufik. (1966) "Adat and Islam: An Examination of Conflict in Minangkabau" Indonesia No. 2, 1-24.

Abdurrahman, Moeslim. (1989). “Wong Cilik dan Kebutuhan Teologi

Transformatif" in M. Masyhur Amin ed., Teologi Pembangunan: Paradigma Baru Pemikiran Islam, Yogyakarta: LKPSM,153-61.

- (1995). Islam Transformatif, Jakarta: Pustaka Firdaus.

Abineno, J.L. Ch. (1994) "Peneguhan dan Pemberkatan Nikah" in Weinata Sairin and J.M. Pattiasina eds., Pelaksanaan Undang-Undang Perkawinan Dalam Perspektif Kristen Jakarta: BPK Gunung Mulia, 20-32.

Ali, Fachry and Bahtiar Effendy. (1986) Merambah Jalan Baru Islam, Bandung: Mizan.

Ali, Muhammad. (2002) "Fatwas on Interfaith Marriage in Indonesia" Studia Islamika Vol.9 No. 3, 11-13.

Alisjahbana, Sutan Takdir. (1975) Perkembangan Sejarah Kebudayaan Indonesia Dilihat dari Jurusan Nilai-Nilai, Jakarta: Idayu.

- (1992) Pemikiran Islam Dalam Menghadapi Globalisasi dan Masa Depan Umat Manusia, Jakarta: Dian Rakyat.

Anderson, Benedict R. and Ruth T. McVey. (1971) A Preliminary Analysis of the October 1, 1965 Coup in Indonesia, Cornell: Modern Indonesia Project, Cornell University.

- (1978) "What Happened in Indonesia," The New York Review of Books Vol. 25 No.9 (June).

Anonymous. (1968) Sel dan Tatakerdjanja Kursus Kader Katolik, Sekretariat Nasional K.M. Gunung Sahari 88, Djakarta V/3. 
Anonymous. (1971) Sedjarah Geredja Katolik di Indonesia Djakarta: Sekretariat Nasional K.M./C.L.C.

Anonymous. (1979) Pendidikan Agama dan Kaitannya dengan Libur Sekolah Bulan Puasa, Jakarta: Mercu Baru.

Anonymous. (1980) Christianization in Indonesia: A Preliminary Study, Jakarta: Lembaga Islam Untuk Penelitian dan Pengembangan Masyarakat. Anshari, Endang Saifuddin. (1997) Piagam Jakarta 22 Juni 1945, Sebuah Konsensus Nasional Tentang Dasar Negara Republik Indonesia (1945-1959), Jakarta: Gema Insani Press.

Anwar, Rosihan. (1985) “Prof. Dr. H.M. Rasyidi Pengungkap Gamblang Hubungan Antaragama di Indonesia" in Endang Basri Ananda ed. 70 Tahun Rasyidi, Jakarta: Harian Umum Pelita.

Arioso, R. Harmani. (1994). “Pelaksanaan Pencatatan Perkawinan 'Antar

Agama' pada Kantor Catatan Sipil Propinsi DKI Jakarta" in Weinata Sairin and J.M. Pattiasina eds, Pelaksanaan Undang-Undang Perkawinan Dalam Perspektif Kristen Jakarta: BPK Gunung Mulia, 96-109.

Aritonang, Jan S. (2004). Perjumpaan Islam dan Kristen di Indonesia, Jakarta: BPK Gunung Mulia.

Asad, Talal. (1986) The Idea of an Anthropology of Islam, Washington: CCAS, Georgetown University.

- (1993) Geneologies of Religion: Discipline and Reasons of Power in Christianity and Islam, Baltimore: John Hopkins University Press. Atmawidjaja, Pransa. (1968)"17 Agustus" Peraba (August II), 3-4. - (1968) "Tuhan Tak Lagi Punja Maaf?" Peraba (December II), 7. Aziz, Abdul. (1998) “K.H. Muhammad Wahib Wahab: Kementrian Agama pada Masa Demokrasi Terpimpin" in Azyumardi Azra and Saiful Umam eds., Menteri-Menteri Agama RI: Biografi Sosial-Politik, Jakarta: INIS, PPIM and Litbang Depag, 177-99.

Aziz, Arnicun ed. (1994) Lima GBHN, Jakarta: Sinar Grafika.

Azra, Azyumardi. (1998) "H.M. Rasjidi BA: Pembentukan Kementrian Agama dalam Revolusi" in Azyumardi Azra and Saiful Umam eds. Menteri-Menteri Agama RI Biografi Sosial-Politik, Jakarta: INIS, PPIM, Litbang Depag, 3-33.

Baan, A.G. (1968) Ichtisar Statistik Tentang Geredja Katolik di Indonesia: 19491967 Lembaga Penelitian dan Pembangunan Sosial.

Baharuddin, Shamsul Amri. (1983) "A Revival in the Study of Islam in Malaysia" Man Vol. 18 No. 2.

Bakker, J.W.M. (1972) Piagam 'Nostra Aetate' Konsili Vatikan II: Tafsiran Zaman Kita, Zaman Dialog Antar-Agama, Yogyakarta: Kanisius. 
- (1973) "Sekularisasi dalam Pandangan Ummat Islam" Orientasi Vol. 5., 46-68.

Bakry, Hasbullah. (1968) “Problim Piagam Djakarta Bagi Umat Islam di Indonesia", Peraba (II June), 7-8.

- (1969) “Kerjasama Islam-Kristen Perlu Ditingkatkan”, Kiblat No.7 (September), 24.

- (1978) Kumpulan Lengkap Undang-Undang dan Peraturan Perkawinan di Indonesia, Jakarta: Djambatan.

Banawiratma, J.B. (1992) “Tunduk Kepada Allah” Tempo (19 December), 31.

- (2000) "Mengembangkan Teologi Agama-agama" in Tim Litbang PGI eds., Meretas Jalan Teologi Agama-Agama di Indonesia Jakarta: BPK Gunung Mulia, 40-51.

Barnes, R.H. (2003) “Fransiskus/Usman Buang Duran: Catholic, Muslim, Communist" Bijdragen Tot de Taal, Land en Volkenkunde Vol. 159, 1-29.

Barton, Greg. (1999) Gagasan Islam Liberal di Indonesia: Pemikiran NeoModernisme Nurcholish Madjid, Djohan Effendi, Ahmad Wahib dan Abdurrahman Wahid Trans. Nanang Tahqiq, Jakarta: Paramadina.

Basri, Hasan. (1978) "Catatan Kenangan Untuk Buya," in Solichin Salam ed., Kenang-Kenangan 70 Tahun Buya HAMKA, Jakarta: Yayasan Nurul Islam, 78-80.

Basyir, Ahmad Azhar. (1984/1985) "Hubungan Agama dan Pancasila”, in Peranan Agama Dalam Pemantapan Ideologi Negara Pancasila, Jakarta: Badan Litbang Agama, 41-44.

Batubara, Cosmas. (2004) "Pemikiran dan Pandangan Harry" in Hadi Soesastro, J. Kristiadi and Arief Priyadi eds, Budi dan Nalar: 70 Tahun Harry Tjan Silalahi, Jakarta: CSIS.

Bazor, Moh. (1969?) Departemen Agama? (no publisher).

Benda, Harry J. (1958) "Christian Snouck Hurgronje and the Foundation of Dutch Islamic Policy in Indonesia" The Journal of Modern History Vol. 30 No. 4., 338-47.

Besar, Abdul Kadir. (1969) Himpunan Ketetapan-Ketetapan M.P.R.S. Jakarta: Pantjuran Tudjuh.

Boelaars, Huub J.W.M. (2005) Indonesianisasi: Dari Gereja Katolik di Indonesia Menjadi Gereja Katolik Indonesia Trans. R. Hardawiyana, Yogyakarta: Kanisius.

Boland, B.J. (1974) "Discussion on Islam in Indonesia Today" in Studies On Islam, Amsterdam: North Holland Publishing Company, 37-50.

- (1982) The Struggle of Islam in Modern Indonesia, The Hague: Martinus Nijhoff. 
Bourchier, David. (no date) “Beek, Father Jopie SJ (Joop)" no publisher. Bowen, John R. (1999) "Legal Reasoning and Public Discourse in Indonesian Islam" in Dale F. Eickelman and John W. Anderson eds, New Media in the Muslim World: the emerging of public sphere. Bloomington: Indiana University Press, 83-97.

- (2003) Islam, Law and Equality in Indonesia: An Anthropology of Public Reasoning Cambridge: Cambridge University Press.

Brown, Stuart. (1989) Meeting in Faith: Twenty Years of WCC Sponsored Dialogues, Geneva: WCC.

Bruinessen, Martin van. (1990) “Indonesia's Ulama and Politics: Caught Between Legitimising the Status Quo and Searching for Alternatives" Prisma, the Indonesian Indicator No. 49, 61-3.

- (1994) NU, Tradisi, Relasi-Relasi Kuasa, Pencarian Wacana Baru Yogyakarta: LKiS.

- (1996) "Islamic State or State Islam? Fifty Years of State-Islam Relations in Indonesia," in Igrid Wessel ed., Indonesien am Ende des 20 Jahshunderts, Hamburg: Abera-Verlaag, 19-34.

- (1999) "Global and Local in Indonesian Islam" Southeast Asian Studies Vol.37 No. 2 (September), 158-175.

Cahyono, Heru. (1998) Pangkopkamtib Jenderal Soemitro dan Peristiwa 15 Januari '74, Jakarta: Sinar Harapan.

Cammack, Mark. (1989) "Islamic Law in Indonesia's New Order" International and Comparative Law Quarterly Vol. 38 (January), 53-73.

- (1997) "Indonesia's 1989 Religious Judicature Act: Islamization of Indonesia or Indonesianization of Islam" Indonesia No. 63, 143-68.

Cammack, Mark, Lawrence A. Young and Tim Heaton (1996) "Legislating Social Change in an Islamic Society - Indonesia's Marriage Law" The American Journal of Comparative Law Vol. 44, 45-73.

Castles, Lance. (1966) "Notes on the Islamic School at Gontor" Indonesia No.1 (April) 36-37.

Chalid, Idham. (1968) “Operasi Dakwah”, Kiblat No. 24 (May), 45.

Chatelier, A. Le. (1350 H.) al-Ghāra 'Ala al-'Ālam al-Islāmī, Cairo: al-Matba'a alSalafiyya.

Cooley, Frank. L. (1981) The Growing Seed, Jakarta: BPK Gunung Mulia.

- (1990) "In Memoriam: T.B. Simatupang, 1920-1990" Indonesia No. 49, 145 52.

Cribb, Robert ed. (1990) The Indonesian Killings, 1965-1966: Studies from Java and Bali, Clayton: Monash University. 
CSIS. (1989) Dokumentasi Klipping Tentang Rancangan Undang-Undang Peradilan Agama Jakarta: CSIS.

- (1989) Dokumentasi Klipping Tentang Undang-Undang Tentang Sistem Pendidikan Nasional Vol.1 and 2 Jakarta: CSIS.

Cusa, Nicholas of. (1991) The Catholic Concordance, Trans. Paul E. Sigmund, Cambridge: Cambridge University Press.

Dachlan, Mohammad. (1968) “Piagam Djakarta Sumber Hukum Mendjiwai UUD 1945" Part 1, Kiblat No.3 (July), 6-7.

- (1968) “Piagam Djakarta Sumber Hukum Mendjiwai UUD 1945," Part 2, Kiblat No. 4 (July), 16.

Damian, Eddy ed. (1968) Prasaran, Pembahasan dan Kesimpulan Seminar HakHak Asasi Manusia di Bandung, The Rule of Law dan Praktek2 Penahanan di Indonesia, Bandung: Alumni.

Danuwinata, F. (1985) "Pergumulan Agama dengan Masalah Pembangunan" in Imam Ahmad ed. Agama dan Tantangan Zaman Jakarta: LP3ES, 13-24.

Darmaputera, Eka. (1985) “Beberapa Catatan Sosio-Kultural Tentang Masalah Sekitar Identitas dan Modernisasi di Indonesia" in Kumpulan Rekaman Hasil Seminar Agama-Agama Bidang Islam V dan VI, Jakarta: Litbang PGI.

- (1986) “Keadilan Dalam Pancasila: Suatu Analisa Budaya” in Kumpulan Rekaman Hasil Seminar Agama-Agama Bidang Islam V dan VI, Jakarta: Litbang PGI.

- (1973) "Setelah Mukti Ali Menjadi Menteri” Tempo (2 June), 30.

- (1974) "Kawin Campur Dalam UUP" (19 January), 38.

- (1988) Pancasila and the Search for Identity and Modernity in Indonesian Society: a Cultural and Ethical Analysis, Leiden: E.J. Brill.

DDII. (1991) Kristenisasi di Indonesia Tahun 1988-1990, Jakarta: DDII.

- (1981) Taktik Baru Dalam Pekabaran Injil, Jakarta: DDII.

Deakin, Christine. (1976) "Langit Makin Mendung: Upheaval in Indonesian Literature" Archipel No.11, 87-105.

Denffer, Ahmad von. (1979) Indonesia: Government's Decrees on Mission and Subsequent Developments Leicester: The Islamic Foundation.

- (1981) Indonesia: a Survey of Christian Churches and Mission Among Muslims Leicester: The Islamic Foundation.

- (1981) Indonesia: How Muslims Are Made Christians Leicester: The Islamic Foundation.

Dewantara, Ki Hadjar. (1967) "Some Aspects of National Education and the Taman Siswa Institute of Jogjakarta" trans. Ruth McVey Indonesia No 4 (October), 150-68. 
Dhakidae, Daniel. (2003) Cendekiawan dan Kekuasaan Dalam Negara Orde Baru, Jakarta: Gramedia.

Dijk, C. van. (1981) Rebellion Under the Banner of Islam: the Darul Islam in Indonesia, The Hague: Martinus Nijhoff.

Djambek, Saadoedin. (1957) “Libur Besar Dalam Bulan Puasa” Dunia Madrasah No. 31/32 (March/April).

Djunaidi, Mahbub. (1979) “Bulan Puasa, Anak-anak Sekolah” Tempo (26 May), 11.

Driyarkara, N. (1980) "Pancasila dan Religi” in Driyarkara Tentang Negara dan Bangsa, Yogyakarta: Kanisius.

Effendi, Djohan. (1978) “Dialog Antar Agama: Bisakah Melahirkan Teologi Kerukunan?" Prisma No. 5, June, 12-7.

- (1982) "Catatan Tentang Sebuah Tempat Transit" Tempo (3 April), 77.

- (1986) "Towards a Theology of Harmony: An Islamic Perspective" Dialog No. 21 (September), 38-41.

Effendi, Djohan and Ismed Natsir eds (2003) Pergolakan Pemikiran Islam: Catatan Harian Ahmad Wahib sixth edition, Jakarta: LP3ES and Freedom Institute.

Effendy, Bahtiar. (2003) Islam and the State in Indonesia, Singapore: ISEAS.

Eickelman, Dale F. and James Piscatori. (1996) Muslim Politics, Princeton: Princeton University Press.

Ely, M. Amien. (1981) "Bahaya 'Natalan Bersama' Bagi Pelajar-Pelajar Islam” Panji Masyarakat No. 327 (June), 53-4.

Emmerson, Donald K. (1969) “Kesan Sebuah Perdjalanan ke Sumatera:

Pelaksanaan Unsur2 Sjariat Islam," Kiblat No. 9 (October), 24-29.

- (1976) Indonesia's Elite: Political Culture and Cultural Politics, Ithaca: Cornell University Press.

End, Th. van den and J. Weitjens. (1989) Ragi Carita 2: Sejarah Gereja di Indonesia 1860an - Sekarang, Jakarta: BPK Gunung Mulia.

Engineer, Asghar Ali. (1993) Islam dan Pembebasan trans. Hairussalim HS, Yogyakarta: LKiS \& Pustaka Pelajar.

Eoh, O.S. (1996) Perkawinan Antar Agama Dalam Teori dan Praktik, Jakarta: Srigunting.

Erny, Robert. (1984) “Variety and Harmony Mark Fast-Changing Indonesia," Pulse Vol. 19 No. 6 (March 23), 3.

Fadely, Soeleiman. (1981) “Kristenisasi Lewat Perpustakaan” Aula (March), 8-9. 
Fakih, Mansour. (1989) "Mencari Teologi Untuk Kaum Tertindas (khidmat dan kritik untuk guruku Prof. Harun Nasution)" in Refleksi Pembaharuan Pemikiran Islam: 70 Tahun Harun Nasution, Jakarta: LSAF, 165-77.

Faruqi, Isma'il R. al-. (1976) "On the Nature of Islamic Da'wa” International Review of Mission Vol. 65 No. 260 (October), 391- 400.

Feillard, Andrée. (1999) NU vis-à-vis Negara: Pencarian Isi, Bentuk dan Makna trans. Lesmana, Yogyakarta: LKiS.

Feith, Herbert. (1968) "Suharto's Search for a Political Format" Indonesia No. 6 (October), 88-105.

Foulcher, Keith. (1986) Social Commitement and the Arts: 'the Indonesian Institute of People's Culture' 1950-1965 Clayton: Southeast Asian Studies, Monash University.

Gandhi, L.M. (1994) "Hukum Perkawinan Antar Agama Dari Masa Ke Masa” in Weinata Sairin and J.M. Pattiasina eds, Pelaksanaan Undang-Undang Perkawinan Dalam Perspektif Kristen Jakarta: BPK Gunung Mulia, 130-43.

Garang, J. (1984) Kumpulan Rekaman Hasil Seminar Agama-Agama Bidang Islam I-IV Jakarta: Litbang PGI.

Gautama, Sudargo. (1996) Segi-Segi Hukum Peraturan Perkawinan Campuran Revised Edition, Bandung: P.T. Aditya Bakti.

Gazalba, Sidi. (1973) “Antara Moral Pancasila dan Agama” No. 127 (May), 1213.

Geertz, Clifford. (1960) The Religion of Java, New York: Free Press.

- (1995) After the Fact: Two Countries, Four Decades, One Anthropologist, Cambridge: Harvard University Press.

George, Kenneth M. (1998) “Designs on Indonesia's Muslim Communities" The Journal of Asian Studies Vol. 57 No. 3 (August), 693-713.

Ghofur, Muhammad Abdul. (1998) "KH Saifuddin Zuhri: Eksistensi Agama dalam Nation Building" in Azyumardi Azra and Saiful Umam eds, MenteriMenteri Agama RI: Biografi Sosial Politik Jakarta: INIS, PPIM and Litbang Depag, 203-41.

Go, Piet. (1987) “Perkawinan Campur Menurut Kitab Hukum Kanonik 1983 dan Statuta Perkawinan Regio Jawa 1983" and "Penyeledikan Kanonik Kawin Campur" in KWI, "Dialog KWI-PGI Tentang Kawin Campur" Hak Kerukunan, Jakarta: KWI, 37-50.

Groenen, C. (1994) "Keselamatan Tidak Ada dalam Nama Lain (Daripada Nama Yesus) Manapun (Kis.3:12)" Gema: Jurnal Teologi Duta Wacana No.47, 100-20. 
Hadad, Ismid. (1971) "Pengantar Redaksi" Prisma No.1 Vol. 1 (November), 2. Hadikusuma, Djarnawi. (1974) “Kristenisasi di Indonesia: Kekuatan dan Kelemahannya" Suara Muhammadiyah No. 13, 14, 15\&16, and 17 (July, August and September).

Hakiem, Lukman ed. (1991) Fakta \& Data Usaha-Usaha Kristenisasi di Indonesia, Jakarta: Media Dakwah.

HAMKA. (1952) Urat Tunggang Pantjasila, Djakarta: Pustaka Keluarga.

- (1966) "Siapa Anti Pantjasila!" Pandji Masjarakat No. 4 (November), 3-4;12.

- (1967) "Peristiwa Makassar" Pandji Masjarakat No. 20 (October), 3-4.

- (1967) "Musyawarah Antar Agama Tidak Gagal”, Pandji Masjarakat No. 21 22 (December), 3-6.

- (1968) "Mengapa Mereka Masih Ribut? Mari Kita Berpahit-Pahit, Kaum Muslim Belum Puas Dengan Kemerdekaan ini" Pandji Masjarakat No. 30, 3-5.

- (1968) "Pantjasila Akan Hampa Tanpa Ketuhanan Yang Maha Esa" Pandji Masjarakat No. 23 (January), 29.

- (1968) "Ketuhanan Yang Maha Esa” Pandji Masjarakat No. 23 (January), 3-5.

- (1970) “Sajang Rangkuti Tidak Hadir" Pandji Masjarakat No. 53 (March), 5-7; 20-22;26.

- (1970) “Imadjinasi” Pandji Masjarakat No. 60 (July), 3-4.

- (1971) Hak2 Azazi Manusia Antara Deklarasi PBB dan Sjari'at Islam, Djakarta: Pandjimas.

- (1971) Perkembangan Kebatinan di Indonesia, Jakarta: Bulan Bintang.

- (1973) "RUU Perkawinan Yang Menggoncangkan”, Panji Masyarakat No. 134 (September), 4-5;33.

- (1974) "Toleransi: Bukan Pengorbanan 'Aqidah" in Panji Masyarakat No. 142 (January), 32-4.

- (1976) "Mengagamakan Orang Yang Belum Beragama, Munafiq?" Panji Masyarakat No. 204 (August), 5-8.

- (1978) "Pembahasan Dari Hal Intisari Undang-Undang Dasar 1945", dalam Solichin Salam ed. Kenang-kenangan 70 Tahun Buya HAMKA, Jakarta: Yayasan Nurul Islam, 279-80.

- (1980) "Panca Agama Bukan Kejutan"Panji Masyarakat No. 287 (January), 6-8.

- (1981) “Pedoman Perpustakaan SLTA" Panji Masyarakat No. 315 (February), 7-8.

- (1981) "Bisakah Suatu Fatwa Dicabut?" Panji Masyarakat No. 324 (May), 7-9. 
- (1981) “Niat Yang Tulus” Panji Masyarakat No. 325 (June), 7.

- (1981) “Ulama Pewaris Nabi-Nabi”, Panji Masyarakat No. 326 (June), 7-8.

- (2002) Dari Hati Ke Hati Tentang Agama, Sosial Budaya dan Politik, Jakarta: Panjimas.

Hamzah, Amir. (1979) "Tanggapan Terhadap Pendirian Menteri P\&K Daoed Joesoef Tentang Liburan Puasa", Panji Masyarakat No. 274 (July),10-11.

- (1980) "Tanggapan Terhadap Keterangan Daoed Joesoef" Panji Masyarakat No. 305 (October), 11-3.

Hamzah, Junus Amir and H.B. Jassin eds (1963) Tenggelamnja Kapal Van der Wijck dalam Polemik, Jakarta: Mega Book Store.

Hanafi, Hassan. (1985) “Pandangan Agama tentang Tanah: Suatu Pendekatan Islam" in Imam Ahmad ed., Agama dan Tantangan Zaman Jakarta: LP3ES, 91-112.

Hanifah, Abu. (1948) Kedudukan Agama dalam Negara2 Modern dan Merdeka, Yogyakarta: Kementrian Agama RI.

Hartoko, Dick. (1967) “Membangun Masjarakat Modern”Basis Vol. 16, 333-8; 356.

Harun, Lukman. (1979) "14 Tahun Yang Lalu: Sekelumit Kenangan Dalam Pengganyangan Gestapu/PKI" Panji Masyarakat No. 280 and 281 (October), 10-15 and 12-17.

- (1990) Muhammadiyah dan Undang-Undang Pendidikan Nasional, Jakarta: Pustaka Panjimas.

Haryono, Anwar. (1973) "RUU Perkawinan, Kesadaran Hukum dan UUD ‘45” Kiblat No. 7 (September), 7-8.

Hasan, Mohammad. (1973) "RUU Perkawinan dan Politik Hukum Pemerintah" Panji Masyarakat No. 138 (November), 24-6.

Hasjim, Wahid. (1957) "Tugas Pemerintah Terhadap Agama” in H. Aboebakar ed., Sedjarah Hidup K.H.A Wahid Hasjim dan Karangan Tersiar, Jakarta: Panitia Buku Peringatan Alm. K.H.A. Wahid Hasjim, 873-77.

- (no date) "Sekitar Pembentukan Kementrian Agama RIS" in Kementrian Agama, Djakarta: Pertjetakan Negara, 3-8.

Hasjmi, Ali. (1996) "Catatan Kecil tentang Daoed Joesoef" in Kadjat Hartojo, Harry Tjan Silalahi and Hadi Soesastro (eds.), Nalar dan Naluri: 70 Tahun Daoed Joesoef Jakarta: CSIS.

Hassan, Muhammad Kamal. (1982) Muslim Intellectual Responses to 'New Order' Modernization in Indonesia, Kuala Lumpur: Dewan Bahasa dan Pustaka.

Hatta, Muhammad. (1969) Sekitar Proklamasi 17 Agustus 1945, Jakarta: Tintamas. 
Hefner, Robert W. (1993) "Islam, State and Civil Society: ICMI and the Struggle for the Indonesian Middle Class" Indonesia No. 56, 1-37.

- (1993) The Political Economy of Mountain Java: An Interpretive History, Berkeley: University of California Press.

- (1996) "Islamizing Capitalism: On the Founding of Indonesia's First Islamic Bank" in Mark R. Woodward ed., Toward a New Paradigm: Recent Developments in Indonesian Islamic Thought, Tempe: Arizona State University Press, 291-322.

- (1997) "Print Islam: Mass Media and Ideological Rivalries Among Indonesian Muslims" Indonesia No. 64., 97-99.

- (2000) Civil Islam, Muslims and Democratization in Indonesia, Princeton: Princeton University Press.

Hering, B.B. and G. A. Willis (1973) The Indonesian General Election of 1971, Bruxelles: Cente d'Etude du Sud-Est Asiatique et de l'Extreme Orient. Heuken, Adolf. (2002) 'Be my Witness to the Ends of the Earth!" The Catholic

Church in Indonesia Before the $19^{\text {th }}$ Century, Jakarta: Cipta Loka Caraka. Hidayat, Komaruddin and Muhammad Wahyuni Nafis. (1995) Agama Masa

Depan: Perspektif Filsafat Perennial, Jakarta: Paramadina.

Hindley, Donald. (1964) "Indonesia's Confrontation with Malaysia: A Search for Motives," Asian Survey, Vol. 4 No. 6 (June), 904-13.

- (1970) "Alirans and the Fall of the Old Order" Indonesia No. 9 (April), 23-66. Hing, Lee Kam (1978) "The Taman Siswa in Postwar Indonesia" Indonesia No.

25 (April), 41-59.

Hitam, Muhammad Husin (1967) "Surat Da'wah dari Atjeh" in Pandji Masjarakat No.19 (October), 9-10.

Hoekema, A.G. (1978) "Indonesian Churches: Moving Towards Maturity"

Exchange No. 21 (December).

Holtzappel, Coen. (1979) “The 30 September Movement: A Political

Movement of the Armed Forces or Intelligence Operation?" Journal of Contemporary Asia, Vol. 9 No. 2., 216-40.

Hooker, M.B. (2003) Indonesian Islam: Social Change Through Contemporary Fatāwa, Honolulu: University of Hawaii. Hosen, Nadirsyah. (2004) "Behind the Scenes: Fatwas of Majelis Ulama in Indonesia (1975-1998)" Journal of Islamic Studies Vol. 15 No. 2., 147-79. Howeel, Barbara. (1973) "Meningkatnya Kristenisasi di Indonesia" Kiblat No.11 (November), 17-8.

Howell, Julia D. (1982) "Indonesia: Searching for Consensus” in Carlo

Caldarola (ed.), Religions and Societies: Asia and the Middle East, Amsterdam: Mouton, 530-4. 
Hughes, John. (1967) Indonesian Upheaval, New York: David Mckay Company. Husaini, Adian. (2000) Gereja-Gereja Dibakar: Membedah Akar Konflik SARA di Indonesia, Jakarta: Dea Press.

Husein, Fatimah. (2005) Muslim-Christian Relations in the New Order Indonesia. The Exclusivist and Inclusivist Muslims' Perspectives, Bandung: Mizan.

I.N., Soebagio. (1982) K.H. Masjkur, Sebuah Biografi, Jakarta: Gunung Agung. - (1985) "Dari Saridi ke Rasjidi" in Endang Basri Ananda ed., 70 Tahun Prof. Dr. H.M. Rasjidi, Jakarta: Pelita.

Ihromi. (1978) "Kewajiban Essensiil” Sinar Harapan (27 September).

- (1985) "Hubungan Antaragama" in Endang Basri Ananda ed. 70 Tahun Prof. Dr. H. M. Rasjidi, Jakarta: Harian Umum Pelita.

- (1973) "Respect for the Integrity of Another's Religion" The South East Asia Journal of Theology Vol. 14 No. 2, 61-3.

- (1976) "Islam-Kristen Bertemu di Jenewa" Berita Oikoumene Vol. 4 (August), 30-1.

Indūnīsy, Abū Hilāl al-. (1984) Ghāra Tabshīriyya Jadīda 'alā Indūnīsiyā Cairo: Dār al-Shurūq.

Ireng, Sum. (1973) "Siapa Konseptor RUU Perkawinan?" Hidup No. 48 (23 December), 759.

Ismail, Faisal. (2001) Islam and Pancasila: Indonesian Politics 1945-1995 Jakarta: Litbang Depag.

Ispandrihari, B. Suryasmoro. (2000) Penampakan Bunda Maria, Counter Discourse Atas Hegemoni Gereja \& Rezim Orde Baru, Yogyakarta: KesAnst. Jasin, H.B. (1970) Heboh Sastra 1968: Suatu Pertanggungan Jawab, Jakarta: Gunung Agung.

- (1972) Polemik: Suatu Pembahasan Sastera dan Kebebasan Mencipta Berhadapan dengan Undang2 dan Agama, Kuala Lumpur: Pustaka Antara. - (1951) Angkatan 45 Jakarta: Jajasan Dharma. Jay, Robert R. (1971) “History and Personal Experience: Religious and Political Conflict in Java" in Robert F. Spencer ed. Religion and Change in Contemporary Asia, Minneapolis: University of Minnesota Press, 143-164.

Jenkins, David. (1984) Suharto and His Generals: Indonesian Military Politics 1975-1983, Ithaca: Cornell Modern Indonesia Project. Joesoef, Daoed. (1979) "Jawaban Menteri P\&K Daoed Joesoef Terhadap Pertanyaan Anggota DPR-RI Drs. Amir Hamzah" Panji Masyarakat No. 274 (July), 12-3. 
- (1987) “Bapak Soedjono Hoemardani dan Metoda Tradisional

Kontemplatif-Integralistik" in Soedjono Hoemardani: Pendiri CSIS, Jakarta:

CSIS, 24-37

- (2003) Emak, Jakarta: Aksara Karunia.

Johns, A. H. (1987) “An Islamic System or Islamic Values? Nucleus of a Debate in Contemporary Indonesia" in William R. Roff ed. Islam and the Political Economy of Meaning, Berkeley: University of California, 254-80. Jones, Gavin W. (1976) "Religion and Education in Indonesia" Indonesia (October), 19-56.

Ka'bah, Rifyal. (1985) Christian Presence in Indonesia: a View of ChristianMuslim Relations, Leicester: The Islamic Foundation.

Kamal, Zainun. (2003) "Kawin Antar Umat Beragama” in Penafsiran Baru Islam Atas Pernikahan Antar Agama Seri KKA Paramadina ke-200 (17 October). Katz, June S. \& Ronald S. Katz. (1978) “Legislating Social Change in a Developing Country: The New Indonesian Marriage Law Revisited" The American Journal of Comparative Law Vol. 26, 309-20.

Kelabora, Lambert. (1976) "Religious Instruction Policy in Indonesia" Asian Survey Vol. 16 No. 3, 230-48.

K.H., Ramadhan. (1994) Soemitro (Mantan Pangkopkamtib) Dari Pangdam Mulawarman Sampai Pangkopkamtib, Jakarta: Sinar Harapan.

Kim, Hyung-Jun. (1998) "The Changing Interpretation of Religious Freedom in Indonesia," Journal of Southeast Asian Studies 29 No. 2, 367.

- (1998) "Unto You Your Religion and Unto Me My Religion: MuslimChristian Relations in a Javanese Village," Sojourn Vol. 13 No. 1., 62-85. Kipandjikusmin, "Langit Makin Mendung" Sastra No.8 (August, 1968), 3-8. Klinken, Gerry van. (2003) Minorities, Modernity and the Emerging Nation:

Christians in Indonesia, a Biographical Approach, Leiden: KITLV.

KPPN. (1979) Pokok-Pokok Pikiran Pembaharuan Pendidikan Nasional, Jakarta:

Departemen Pendidikan dan Kebudayaan.

Kraemer, Hendrik. (1938) Christian Message in a Non-Christian World, London: Edinburgh House Press.

Kratz, E. Ulrich ed. (2000) Sumber Terpilih Sejarah Sastra Indonesia Abad XX Jakarta: Kepustakaan Populer Gramedia.

Krissantono ed. (1976) Pandangan Presiden Soeharto Tentang Pancasila $2^{\text {nd }}$ Edition, Jakarta: Yayasan Proklamasi, CSIS.

Kuntowijoyo. (1992) "Konvergensi dan Politik Baru Islam” preface to Abdul Munir Mulkhan, Runtuhnya Mitos Politik Santri, Yogyakarta: Sipress, ix-x. 
KWI. (1987) “Dialog KWI-PGI Tentang Kawin Campur” Hak Kerukunan Jakarta: KWI.

Legge, J.D. (1972) Soekarno: A Political Biography London: Allen Lane The Penguin Press.

Lev, Daniel S. (1966) The Transition to Guided Democracy: Indonesian Politics, 1957-1959, Ithaca: Modern Indonesia Project, Cornell University.

- (1972) Islamic Courts in Indonesia: A Study in the Political Bases of Legal Institutions, Berkeley: University of California Press.

Liddle, R. William. (1978) “Indonesia 1977: The New Order's Second Parliamentary Election," Asian Survey Vol. 18 No. 2.

- (1996) "The Islamic Turn in Indonesia: a Political Explanation" The Journal of Asian Studies Vol. 55 No. 3., 613-34.

Liku, John. (1969) "Pantja Sila Terhadap Objeksi”Basis No. 11 Vol. 18 (August), 358-67.

Lubis, T. Mulya and Fauzi Abdullah eds (1981) Langit Masih Mendung: Laporan Keadaan Hak-Hak Asasi Manusia di Indonesia 1980 Jakarta: LBH and Sinar Harapan.

Lyon, M. L. (1980) "The Hindu Revival in Java: Politics and Religious Identity" in J.J. Fox, Indonesia: The Making of a Culture, Canberra: Research School of Pacific Studies, 205-220.

Maarif, Ahmad Syafi'i. (1985) Islam dan Masalah Kenegaraan: Studi Tentang Percaturan Dalam Konstituante Jakarta: LP3ES.

Maasen, Henk and Paul Ophey. (1993) "Aad van den Heuvel over the best bewaarde geheimen van Azië: De speler die de Wayang-poppen manipuleerde" Indonesia Magazine (July-August), 12-15.

Mackie, J.A.C. (1967) Problems of the Indonesian Inflation, Ithaca, NY: Cornell University, Department of Asian Studies.

Madjid, Nurcholish. (1968) "Selamatkan Pantjasila Agar Tidak Dipalsukan", Pandji Masjarakat No. 24 (January), 13.

- (1979) "The Issue of Modernisation among Muslims in Indonesia: From a Participant's Point of View" in Gloria Davis ed., What is Modern Indonesian Culture? Athens: Ohio Centre for International Studies, Southeast Asia Series No.52, 143-55.

- (1984/1985) “Pembahasan Atas Makalah K.H. Achmad Siddiq 'Hubungan Agama dan Pancasila"' in Peranan Agama Dalam Pemantapan Ideologi Negara Pancasila, Jakarta: Badan Litbang Agama, 35-8.

- (1987) Islam, Kemodernan dan Keindonesiaan, Bandung: Mizan. 
- (1992) Islam, Doktrin dan Peradaban, Jakarta: Paramadina.

- (1993) “Beberapa Renungan Tentang Kehidupan Keagamaan untuk Generasi Mendatang" Ulumul Qur'an No. 1 Vol. 4, 4-24.

- (1994) "Islamic Roots of Modern Pluralism: Indonesian Experiences" Studia Islamika No. 1 Vol. 1.

Madylao, Ibrahim. (1980) "Tanggapan Terhadap Pokok-Pokok Pikiran Pembaharuan Pendidikan Nasional", Panji Masyarakat No. 286 (January), 11-14.

Magnis-Suseno, Franz. (1989) "Seputar Rencana UU Peradilan Agama" Kompas (16 June).

- (1990) "Kerendahan Hati Prasyarat Kerukunan Antar Agama” Media Indonesia (30 November).

- (1991) "Islam 1990: Renungan Seorang Non-Muslim" Tempo (9 January).

- (1993) "Nurcholish Madjid, Islam dan Modernitas" Ulumul Qur'an No. 1 Vol. 4., 36-44.

Mahasin, Aswab ed. (1995) Ruh Islam dalam Budaya Bangsa 5 Vols. Jakarta: Yayasan Festival Istiqlal.

Mahendra, Yusril. (1989) "Kedaulatan Negara dan Peradilan Agama" Pelita (27 June).

- (1989) "Sekitar RUUPA: Menjawab Mingguan Hidup" Serial Media Dakwah (August), 58-60.

- (1989) "Catatan Buat Majalah Hidup"Panji Masyarakat No. 616 (July), 8-9.

- (1995) "Combining Activism and Intellectualism: The Biography of Mohammad Natsir" Studia Islamika Vol. 2 No. 1.

Majelis Tarjih dan Pengembangan Pemikiran Islam. (2000) Tafsir Tematik al-Qur'an Tentang Hubungan Sosial Antarumat Beragama, Yogyakarta: Pustaka SM.

Mangkusasmito, Prawoto. (1968) "Rumus Pantja Sila dan Sedjarah Singkat Pertumbuhannya", Kiblat No.2 (June), 6-7; 46-48.

- (1969) "Beberapa Saat Yang Menentukan Dalam Sedjarah Kita”, Kiblat No. 3 (July), 6; 48-9.

- (1970) Pertumbuhan Historis Rumus Dasar Negara dan Sebuah Projeksi, Jakarta: Hudaya.

Mangunwijaya, Y.B. (1973) “Menangkap Tanda2 Tempo” Peraba (November I), 6-7.

- (1985) "Gereja Antara Yesus dari Nasaret dan Caesar" in Imam Ahmad ed. Agama dan Tantangan Zaman Jakarta: LP3ES, 276-330.

Mas'oed, Mohtar. Muchammad Maksum \& Moh. Soehada eds. (2000)

Kekerasan Kolektif: Kondisi dan Pemicu, Yogyakarta: P3PK UGM. 
Mas'udi, Masdar F. (1989) "Teologi Rasionalistik dalam Islam: Suatu

Telaah Kritis Atas Teologi Mu'tazilah" in M. Masyhur Amin ed., Teologi

Pembangunan: Paradigma Baru Pemikiran Islam, Yogyakarta: LKPSM, 82-

91.

- (1991) Agama Keadilan: Risalah Zakat (Pajak) dalam Islam, Jakarta: Pustaka Firdaus.

Masyhuri, Abdul Aziz. (1997) Masalah Keagamaan: Hasil Muktamar Dan Munas Ulama Nahdlatul Ulama, Surabaya: PP Rabithah Ma'ahidil Islamiyah.

Matondang, H.M. Victor ed. (1989) Percakapan Dengan Dr. T.B. Simatupang, Jakarta: BPK Gunung Mulia.

May, Brian. (1978) The Indonesian Tragedy, London: Routledge \& Kegan Paul. McDonald, Hamish.(1981) Suharto's Indonesia Honolulu: The University of Hawaii.

McVey, Ruth T. (1967) "Taman Siswa and the Indonesian National Awakening" Indonesia No. 4 (October), 128-49.

- (1970) "Nationalism, Islam and Marxism: the Management of Ideological Conflict in Indonesia" in Soekarno, Nationalism, Islam and Communism, trans. Karel H. Warouw and Peter D. Weldon, Ithaca: Modern Indonesia Project, Cornell University, 1-34.

Melik, Sajuti (1968) “UUD '45 \& Piagam Djakarta”, Peraba (15 May), 5-6. Memon, Muhammad Umar. (1976) Ibn Taimiya's Struggle Against Popular Religion With an Annotated Translation of His Kitāb lquidā al-Sirāt alMustaqìm, Mukhālafat Ashāb al-Jahīm, The Hague: Mouton.

Mihardja, Achdiat K. ed. (1948) Polemik Kebudajaan, Djakarta: Balai Pustaka. Moeljanto, D.S. \& Taufiq Ismail eds. (1995) Prahara Budaya: Kilas Balik Ofensif LEKRA/PKI dkk., Kumpulan Dokumen Pergolakan Sejarah), Bandung: MizanRepublika.

Moertopo, Ali. (1972) Dasar-Dasar Pemikiran Tentang Akselerasi Modernisasi Pembangunan 25 Tahun, Jakarta: CSIS.

- (1978) Strategi Kebudayaan, Jakarta: CSIS.

Mortimer, Rex. (1972) The Indonesian Communist Party and Land Reform: 1959-1965, Monash Papers on Southeast Asia, No. 1.

Muchtar, Kamal. (1998) “K.H. Mohammad Dachlan: Departemen Agama di Masa Awal Orde Baru" in Azyumardi Azra and Saiful Umam eds, MenteriMenteri Agama RI, Biograpi Sosial Politik, Jakarta: INIS, 245-67.

Mudzhar, Muhammad Atho. (1984) "Religious Education and Religious Harmony in Indonesia," Mizan Vol. 1 No. 2, 16-25. 
- (1993) Fatwas of the Council of Indonesia Ulama: A Study of Islamic Legal Thought in Indonesia 1975-1988, Jakarta: INIS.

- (1996) "The Council of Indonesian Ulama on Muslim Attendance at Christmas Celebration" in Muhammad Khalid Masud, Brinkley Messick and David S. Powers eds, Islamic Legal Interpretation: Muftis and their Fatwas. Cambridge: Harvard University Press, 230-41.

Muhadjir ed. (1987) Evaluasi dan Strategi Kebudayaan, Jakarta: Fakultas Sastra UI.

MUI. (1981) Fatwa Majlis Ulama Indonesia Tentang Perayaan Natal Bersama, Jakarta: Dewan Dakwah Islamiyah Indonesia.

- (1986) Tuntunan Perkawinan Bagi Ummat Islam, Jakarta: MUI, 71-73. Mujiburrahman. (1999) "Islam and Politics in Indonesia: the Political Thought of Abdurrahman Wahid" Islam and Christian-Muslim Relations Vol. 10 (October), 339-52.

- (2001) "Religious Conversion in Indonesia: the Karo Batak and the Tengger Javanese" Islam and Christian Muslim Relations No.1 Vol. 12 (January), 23-38.

- (2001) "The Diaspora Church in Indonesia: Mangunwijaya on Nationalism, Humanism and the Catholic Praxis" Journal of Ecumenical Studies Vol. 38 No. 4 (2001), 444-69.

- (2001) "The Phenomenological Approach in Islamic Studies: An Overview of a Western Attempt to Understand Islam" The Muslim World Vol. 91 (Fall), 425-449.

Mukti Ali, A. (1970) Dialog Antar Agama, Yogyakarta: Yayasan Nida.

- (1971) Agama dan Pembangunan di Indonesia, Jakarta: Dirjen Bimas Islam, Depag.

- (1971) Religion and Development in Indonesia, Yogyakarta: Yayasan Nida.

- (1973) Agama dan Pembangunan di Indonesia, Bahagian III, Jakarta: Biro Humas Depag RI.

- (1975) Agama dan Pembangunan di Indonesia Jakarta: Biro Hukum \& Humas Depag RI.

Mulia, Siti Musdah. (2003) "Islam dan Pernikahan Antar Agama" in Penafsiran Baru Islam Atas Pernikahan Antar Agama Seri KKA Paramadina ke-200 (17 October).

Munhanif, Ali. (1998) “Prof. Dr. A. Mukti Ali: Modernisasi Politik Keagamaan Order Baru" in Azyumardi Azra and Saiful Umam eds. Menteri-Menteri Agama RI: Biografi Sosial-Politik, Jakarta: INIS, PPIM and Litbang Depag, 271-319. 
Mursyid, Hasbullah et.al. (1979) Masalah Hubungan Antar Umat Beragama di Indonesia, Jakarta: Proyek Pembinaan Kerukunan Hidup Beragama.

Muzani, Saiful. (1994) "Mu'tazilah Theology and the Modernisation of the Indonesian Muslim Community: Intellectual Portrait of Harun Nasution" Studia Islamika No.1 Vol.1, 91-131.

Nababan, S.A.E. (1968) Panggilan Kristen Dalam Pembaharuan Masjarakat: Laporan Konperensi Nasional Geredja dan Masjarakat, Jakarta: BPK.

Nasution, Adnan Buyung. (1992) The Aspiration for Constitutional Government in Indonesia: A Socio-legal Study of the Indonesian Konstituante 1956-1959, Jakarta: Sinar Harapan.

Nasution, Harun. (1975) Pembaharuan Dalam Islam, Jakarta: Bulan Bintang.

- (1979) Islam Ditinjau dari Berbagai Aspeknya second edition Vol. I and II, Jakarta: UI Press.

Natsir, Ismed. (1982) "Melacak Jejak Ahmad Wahib” in Kumpulan Rekaman Hasil Seminar Agama-Agama Bidang Islam I-IV.

Natsir, Mohammad. (1937) Cultuur Islam, Bandoeng: Pendidikan Islam bg.Penjiaran.

- (1968) "Missi dan Zending Mendjadikan Umat Islam sebagai Sasarannja" Al-Djami'ah No. 3 (May), 44-6.

- (1968) “Fungsi Da'wah Dalam Rangka Perjuangan” Kiblat No. 24 (May), 8.

- (1969) Islam dan Kristen di Indonesia, Jakarta: Bulan Bintang.

- (1973) "Sekali Lagi Kerukunan Hidup Antar Agama: Sumbangsih Untuk Prof. Dr. Verkuyl" Panji Masyarakat No. 129 (June), 16-18.

- (1978) Sekali Lagi: Kerukunan Hidup Umat Beragama di Indonesia, Jakarta: Media Da'wah.

- (1980) Mencari Modus Vivendi Antar Ummat Beragama, Jakarta: Media Dakwah.

- (1989) "Tanpa Toleransi Tak-kan Ada Kerukunan!" Serial Media Dakwah (August), 18-19.

Nieuwenhuijze, C.A.O van. (1951) "Religious Freedom in Indonesia” International Review of Mission Vol. 40.

- (1958) Aspects of Islam in Post-Colonial Indonesia, The Hague: W. van Hoeve Ltd.

Nitiprawiro, Wahono. (1987) Teologi Pembebasan: Sejarah, Metode, Praksis dan Isinya, Jakarta: Sinar Harapan.

Noeh, Zaini Ahmad. (1982), “Perkembangan Setelah Undang-Undang Perkawinan", a supplementary chapter to Daniel S. Lev, Peradilan Agama 
Islam di Indonesia: Suatu Studi Tentang Landasan Politik Lembaga-Lembaga Hukum $2^{\text {nd }}$ Edition, Jakarta: Intermasa, 330-332.

Noeh, Zaini Ahmad and Abdul Basit Adnan. (1983) Sejarah Singkat

Pengadilan Agama Islam di Indonesia, Surabaya: Bina IImu.

Noer, Deliar. (1978) The Administration of Islam in Indonesia, Ithaca: Cornell Modern Indonesia Project.

- (1980) "Sekali Lagi: Masalah Pendidikan Agama di Perguruan Tinggi" Panji Masyarakat No. 293 (April), 10-13.

- (1982) Gerakan Modern Islam di Indonesia 1900-1942, Jakarta: LP3ES.

Noer, Kautsar Azhari (1994) “Memperkaya Pengalaman Keagamaan Melalui

Dialog" Ulumul Qur'an Special Edition No. 5 \& 6 Vol. 5, 104-17.

- (1995) Ibn al-'Arabi: Wahdat al-Wujud dalam Perdebatan, Jakarta:

Paramadina.

Notosusanto, Nugroho and Ismail Saleh. (1968) The Coup Attempt of

"September $30^{\text {th }}$ Movement" in Indonesia, Djakarta: Pembimbing Masa.

Norman, Aminah (1973) “Dua Kepentingan DalamRUU Perkawinan” Indonesia Raya (4 September).

Paget, Roger K. (1967/1968) "The Military in Indonesian Politics: The Burden of Power" Pacific Affairs Vol. 40 No. 3-4.

Pamuntjak, Laksmi and Agus Edy Santoso eds. (2000) Tidak Ada Negara Islam:

Surat-Surat Politik Nurcholish Madjid-Mohamad Roem Second Edition, Jakarta: Djambatan.

Panitia Penerbitan. (1999) Agama Dalam Dialog, Pencerahan, Perdamaian dan Masa Depan: Punjung Tulis 60 Tahun Prof. Dr. Olaf Herbert Schumann Jakarta: BPK Gunung Mulia.

Parera, Viator. (1999) "Membangun Jemaat Yang Rukun dan Memasyarakat" in Ignas da Cunha et. al, Berpastoral di Tengah Badai, Potret Gereja Maumere 1956-1969, Maumere: LPBAJ, 94-97.

Parikesit, Suparwan G. \& Krisna R. Sempurnadjaja eds (1995) H. Alamsyah Ratu Perwiranegara, Perjalanan Hidup Seorang Anak Yatim Piatu, Jakarta: Sinar Harapan.

Pauker, Guy J. (1964) "Indonesia in 1963: The Year of Wasted Opportunities," Asian Survey, Vol. 4 No.2 (February), 687-94.

PB. PGRI (1975) Hari Libur Sekolah Bagian Integral Dari Kalender Pendidikan Jakarta: PB-PGRI.

Peursen, C.A. van. (1976) Strategi Kebudayaan trans. Dick Hartoko Yogyakarta: Kanisius and BPK. 
Poerbakawatja, Soegarda. (1970) Pendidikan dalam Alam Indonesia Merdeka, Jakarta: Gunung Agung.

Pompe, S. (1988) "Mixed Marriages in Indonesia: Some Comments on the Law and the Literature," Bijdragen tot de Taal, Land en Volkenkunde No. 144, 259-275.

- (1991) "A Short Note on Some Recent Development with Regard to Mixed Marriage in Indonesia," Bijdragen tot de Taal, Land en Volkenkunde, 261272.

Porter, Donald J. (2002) Managing Politics and Islam in Indonesia, London: Routledge.

Pour, Julius. (1993) Benny Moerdani: Profil Prajurit Negarawan, Jakarta: Yayasan Kejuangan Panglima Besar Sudirman.

Pranarka, A.M.W. (1985) Sejarah Pemikiran Tentang Pancasila, Jakarta: CSIS.

- (1986) "Relevansi Ajaran-Ajaran Ki Hadjar Dewantara Dewasa ini dan di Masa yang Akan Datang" in Wawasan Kebangsaan, Ketahanan Nasional dan Wawasan Nusantara, Yogyakarta: Lembaga Pengkajian Kebudayaan Sarjana Wiyata Taman Siswa, 1-31.

- (1987) "Kasunyatan, Sangkan Paran, Kasampurnan: Mengangkat Pemikiran Bapak Soedjono Hoemardani dalam Studi Analitikal" in Soedjono Hoemardani: Pendiri CSIS, Jakarta: CSIS, 48-80.

Prawiranegara, Syafruddin. (1967) Islam Sebagai Agama Perdamaian, Persatuan \& Persaudaraan serta Pelindung Pancasila, Djakarta: Ruhul Islam.

- (1973) “Komentar Atas RUU Perkawinan: Contohlah Yang Baik Walaupun Darimana", Panji Masyarakat No. 137 (October), 11-13.

- (1984) "Pancasila as the Sole Foundation" Indonesia No. 38, (October), 74-83.

Prijono, Onny S. \& A.M.W. Pranarka. (1979) Situasi Pendidikan di Indonesia Selama Sepuluh Tahun Terakhir Bagian I (Permasalahan) Jakarta: CSIS Prior, John M. (1987) Church and Marriage in an Indonesian Village: a Study of Customary and Church Marriage among the Ata Lio of Central Flores, Bern: Verlag Peter Lang.

- (1999) "Terobosan Pastoral Di Tengah Badai Zaman” in Ignas da Cunha et. al, Berpastoral di Tengah Badai, Potret Gereja Maumere 1956-1969, Maumere: LPBAJ, 206-212.

Puar, Yusuf A. (1978) "Karir Internasional Natsir Dalam Muktamar dan Rabithah", Panji Masyarakat No. 242 (March), 12-13.

Purwahadiwardoyo, Al. (1990) Perkawinan Menurut Islam dan Katolik: Implikasinya dalam Kawin Campur, Yogyakarta: Kanisius. 
Purwo, A. Hassan. (1974) "Washington Post dan Kristenisasi di Indonesia” Suara Muhammadiyah No. 12 (June), 11;17;24.

Pusposaputro, M. S. (1968) "Pantjasila dan Kebebasan Agama” Basis No. 9 Vol. 17 (June), 261-72.

Pusposupadmo, A.J.M. (1969) “Harus Bagaimana? Panennja Melimpah,

Pekerdja Kurang", Penabur No. 13 (August), 196-7.

PW.PII. (1969) Kristenisasi di Kalimantan Selatan (Peristiwa 'Saloh' Dengan

Rangkaian Sekitarnya) Banjarmasin: P.W. PII.

Rachman, Budhy Munawar. (1993) “Kesatuan Transendental dalam Teologi:

Perspektif Islam tentang Kesamaan Agama-agama" in Abdurrahman

Wahid et al, Dialog: Kritik \& Identitas Agama, Yogyakarta: Interfidei, 12150.

- (2001) Islam Pluralis: Wacana Kesetaraan Kaum Beriman, Jakarta: Paramadina.

Rahardjo, Dawam (1983) "Ali Syari'ati: Mujahid Intelektual” in Ali Syari'ati, Kritik Islam atas Marxisme dan Sesat Pikir Barat Lainnya trans. Husin Anis Al-Habsyi, Bandung: Mizan, 7-32.

Rais, M. Amien. (1980) "Mass Media Islam: Save Our Soul", Panji Masyarakat No. 293 (April), 39-43.

— (1995) "al-Islām wa al-Nasrāniyya fĩ Indūnīsiyā" Studia Islamika Vol. 2 No.1, 75-91.

Ramage, Douglas E. (1995) Politics in Indonesia: Democracy, Islam and the Ideology of Tolerance, London: Routledge.

Rangkuti, Bahrum. (1970) "Imadjinasi, Observasi dan Intuisi pada Tjerpen Langit Makin Mendung" Pandji Masjarakat No. 53 (March), 4-5; 26-7.

Ranuwihardjo, A. Dahlan (1989) “Negara, Agama dan Hukum: Sebuah Pendekatan Falsafi", Pelita (21 June).

Rasjidi, Muhammad. (1967) “Kebebasan Beragama” Kiblat No. 7 (September), 19-21.

- (1968) Islam dan Indonesia di Zaman Modern, Jakarta: Bulan Bintang.

- (1971) Islam dan Kebatinan, Jakarta: Bulan Bintang.

- (1973) "Abangan dan Kebatinan Tidak Perlu Wadah di Dalamnya" Abadi (29 November).

- (1973) "Kristenisasi Dalam Selubung?" Nusantara (18 August) and Abadi (20 August).

- (1973) "Sekitar RUU Perkawinan: Bukankah Aku Telah Memperingatkan?" Abadi (22 and 24 December). 
- (1974) Kasus RUU Perkawinan Dalam Hubungan Islam dan Kristen, Jakarta: Bulan Bintang.

- (1974) Sidang Raya Dewan Gereja Sedunia di Jakarta 1975 Merupakan Tantangan Terhadap Dunia Islam, Jakarta: Dewan Dakwah Islamiyah Indonesia.

- (1976) "The Role of Christian Missions, the Indonesian Experience", International Review of Mission Vol. 65 No. 260 (October), 425-38.

- (1976) “Laporan Prof. Dr. H.M. Rasjidi Tentang Konperensi Meja Bundar Da'wah Islam dan Missi Kristen di Geneva Tgl. 26-30 Juni 1976" Serial Media Dakwah No. 35, 2-18.

- (1977) Koreksi Terhadap Dr. Harun Nasution Tentang Islam Ditinjau dari Berbagai Aspeknya, Jakarta: Bulan Bintang.

- (1978) "Islam dan Kristen di Indonesia" Panji Masyarakat No. 258 (November), 10-14.

- (1979) “Kebebasan Beragama Menurut Islam” Mimbar Ulama Vol. 3 No. 27 (February), 9-26.

- (1979) Kebebasan Beragama Jakarta: Media Da'wah.

- (1980) Strategi Kebudayaan dan Pembaharuan Pendidikan Nasional, Jakarta: Bulan Bintang.

- (1982) "Pergolakan Pemikiran Islam: Suatu Tragedi", Panji Masyarakat No. 346 (January), 42-3.

- (1989) "Seputar Rencana UU Peradilan Agama” Panji Masyarakat No. 616 (July), 27-31.

Ratu Perwiranegara, Alamsyah. (1980) “Wadah Musyawarah Antar Umat Beragama di Dalam Negara Pancasila" Dialog No. 9 Vol. 5, (October).

- (1982) Pembinaan Kerukunan Hidup Umat Beragama edited by Djohan Effendi Jakarta: Departemen Agama.

- (1983) "Islam and Other Religions: a Case of an Inter-religious Life in Indonesia," Dialog Vol. 7 No. 14, (March), 3-10.

- (1996) "Strategi Perjuangan Umat Islam di Bidang Hukum," in Amrullah Ahmad ed., Dimensi-Dimensi Hukum Islam Dalam Sistem Hukum Nasional: mengenang 65 Th. Prof.Dr.Bustanul Arifin SH, Jakarta: Gema Insani Press, 237-47.

Reeve, David. (1985) Golkar of Indonesia: An Alternative to the Party System, Singapore: Oxford University Press.

Robinson, Geoffrey. (1995) The Dark Side of Paradise: Political Violence in Bali, Ithaca: Cornell University Press.

Roem, Mohammad. (1969) "Pentjulikan dan Proklamasi” Part 3 Kiblat No.8 Vol. 17 (September). 
- (1978) "Politik HAMKA" in Solichin Salam ed. Kenang-kenangan 70 Tahun Buya HAMKA, Jakarta: Yayasan Nurul Islam, 8-12.

Ropi, Ismatu. (2000) Fragile Relation: Muslims and Christians in Modern Indonesia, Jakarta: Logos.

Rosin, Helmut. (1951) Pantja-Sila, Djakarta: Badan Penerbit Kristen. Rudvin, Arne. (1976) "The Concept and Practice of Christian Mission," International Review of Mission Vol. 65 No. 260 (October), 374-84.

Rusjdi. (1968) “Nasib Interpelasi Lukman Harun dan Nasib Umat Islam” Pandji Masjarakat No. 33 (September), 3-4.

- (1973) "Siapa Dalangnya?" Panji Masyarakat No. 138 (November), 8-9.

- (1974) "Sidang Raya Dewan Gereja Sedunia di Indonesia dan Pengislaman Massal di Malaysia", Panji Masyarakat No. 155 (July), 10-12.

- (1981) "Mengembangkan dan Melindungi Akidah Ummat", Panji Masyarakat No. 337 (October), 12-13.

- (1989) “RUU-PA, Kerukunan Agama," Panji Masyarakat No. 616 (July), 10-11.

S., Rachmawati. (1973) "Kawin Cerai, Pengadilan dan KB" Tempo (30 June), 47-8.

S., Warsito, Muhammad Rasjidi and Hasbullah Bakry (1973) Di Sekitar Kebatinan Jakarta: Bulan Bintang.

Sabrie, Zuffran ed. (2001) Peradilan Agama dalam Wadah Negara Pancasila, Jakarta: Logos Wacana IImu.

Saimima, Iqbal Abdurrauf. (1981) "Ujung Pangkal Suara Cak Dur", Panji Masyarakat No. 326 (June), 14-15.

Saleh, Ismail. (1989) “Eksistensi Hukum Islam dan Sumbangannya Terhadap Hukum Nasional" Kompas (3 June).

- (1989) "Wawasan Pembangunan Hukum Nasional" Kompas (1-2 June).

Salim, Agus. (n.d.) "Kementrian Agama dalam Republik Indonesia" in Kementrian Agama, Jakarta: Pertjetakan Negara, 10-11; 14.

Samson, Allan A. (1968) "Islam in Indonesian Politics," Asian Survey, Vol. 8 No.

12 (December), 1001-1017.

- (1971-1972) "Army and Islam in Indonesia" Pacific Affairs, Vol. 44 No.4, (Winter), 545-565.

Sani, Asrul. (1997) Surat-Surat Kepercayaan, Jakarta: Pustaka Jaya.

Sanneh, Lamin. "Christian Experience of Islamic Da'wa with Particular Reference to Africa", International Review of Mission Vol. 65 No. 260 (October, 1976), 410-23. 
Santoso, Heru. (1989) "Seputar RUU Peradilan Agama Yang Berputar-putar" Kompas (21 June).

Sanusi, M. (1973) “Demi Keamanan dan Suksesnya Pembangunan: Tarik Kembali RUU Perkawinan" Panji Masyarakat No. 135 (September), 6.

Sarapung, Elga. (2000) “Narasi Kegiatan 10 Tahun Institut Dialog Antar-Iman di Indonesia (Institut DIAN/Interfidei)" Interfidei Newsletter Special Edition.

Sarmudi. (1974) “Perkembangan Pemikiran Baru Dikalangan Gereja Katholik di Indonesia: Usaha Mencapai Modus Vivendi Antara Islam dan Nasrani" Panji Masyarakat No.142 (January), 16-17.

Schumann, Olaf. (1990) "Suatu Pengamatan Tentang Hubungan Antar umat Beragama di Indonesia Dilihat dari Sudut pandang DGI" in J.M.Pattiasina and Weinata Sairin eds. Gerakan Oikomene, Tegar Mekar di Bumi Pancasila, Jakarta: BPK Gunung Mulia, 273-88.

Sekaten, Ki Urip. (1969) “Wahai Ummat Pantjasilais: Waspadalah! Kaum Sekularis Penghalang Lahirnja Undang-Undang Perkawinan Ummat Islam di Indonesia," Kiblat No. 22 (April), 12-14; 26.

Sekretariat Negara RI. (1994) Gerakan 30 September, Pemberontakan Partai Komunis Indonesia, Latar Belakang, Aksi dan Penumpasannya, Jakarta: Sekneg.

Shihab, Alwi. (1998) Membendung Arus: Respons Gerakan Muhammadiyah Terhadap Penetrasi Misi Kristen di Indonesia, Bandung: Mizan.

Shimogaki, Kazou. (1993) Kiri Islam Antara Modernisme dan Postmodernisme: Telaah Kritis Atas Pemikiran Hassan Hanafi trans. Imam Aziz, Yogyakarta: LKiS \& Pustaka Pelajar.

Shiraishi, Saya S. (1997) Young Heroes: the Indonesian Family in Politics, Ithaca: Southeast Asia Program, Cornell University.

Siddiq, Achmad. (1984/1985) "Hubungan Agama dan Pancasila" in Peranan Agama Dalam Pemantapan Ideologi Negara Pancasila Jakarta: Badan Litbang Agama, 21-34.

Sidjabat, W. B. (1965) Religious Tolerance and the Christian Faith: A Study Concerning the Concept of Divine Omnipotence in the Indonesian Constitution in the light of Islam and Christianity. Jakarta: Badan Penerbit Kristen.

Silalahi, Harry Tjan. (1985) "Think Tank" in Sekar Semerbak, Kenangan Untuk Ali Moertopo, Jakarta: Yayasan Proklamasi, CSIS, 334-41.

- (1991) "CENTER Lahir dari Tantangan Jaman" in CSIS 20 Tahun, Jakarta: CSIS.

Simanjuntak, Marsillam. (1994) Pandangan Negara Integralistik: Sumber, Unsur dan Riwayatnya dalam Persiapan UUD 1945, Jakarta: Grafiti. 
Simatupang, T.B. (1967) "Tjatatan Perdjalanan: Mengunjungi 4 Daerah dgn Tjiri jg Chas", Ragi Buana No. 45 (October, 1967).

- (1969) "The Situation and Challenge of the Christian Mission in Indonesia Today" South East Asia Journal of Theology Vol. 10 No. 4.

- (1973) "Catatan Berhubung Dengan Rancangan UU Tentang Perkawinan" (two-pages of notes found in a dossier of Litbang PGI, Jakarta).

- (1974) "This is My Country" International Review of Mission Vol. 63 (July).

- et. al. (1974) Buku Persiapan Sidang Raya Dewan Gereja-Gereja Seduia Tahun 1975, Jakarta: BPK Gunung Mulia.

- (1978) "Catatan Tentang Kedua SK Menag", Berita Oikoumene (October), 3.

- (1981) "Pandangan Umum Terhadap Konsep Garis-Garis Besar Haluan Negara (GBHN) Yang Akan Datang," Sinar Harapan (14-15 May).

- (1981) "Sama-Sama Menolak Teologi Pancasila", Panji Masyarakat No. 329 (July), 6.

- (1984) Iman Kristen dan Pancasila, Jakarta: BPK Gunung Mulia.

- (1986) Kehadiran Kristen dalam Perang, Revolusi dan Pembangunan, Jakarta: BPK Gunung Mulia.

- (1987) Dari Revolusi ke Pembangunan, Jakarta: BPK Gunung Mulia.

- (1989) "Menyempurnakan RUUPA Demi Memantapkan Persatuan \& Kesatuan Bangsa" Suara Pembaruan (29 June).

- (1991) Membuktikan Ketidakbenaran Suatu Mitos, Jakarta: Sinar Harapan. Simorangkir, J.C.T. (1989) Manuscript Sejarah Parkindo Jakarta:Yayasan Proklamasi.

Simorangkir, J.C.T. and B. Mang Reng Say. (1975) Tentang dan Sekitar UndangUndang Dasar 1945, Jakarta: Djambatan.

Sinaga, Martin L. and Trisno S. Sutanto eds. (2001) Meretas Horison Dialog: Catatan dari Empat Daerah Jakarta: MADIA \& ISAI.

Singgih, Gerrit E. (1997) "Contextualisation and Inter-Religious Relationship in Java: Past and Present" The Asian Journal of Theology Vol. 11 No. 2 (October).

- (1999) "Tema Kerukunan Umat Beragama di Dalam Diskusi Pakar Agama" in Panitia Penerbitan, Agama Dalam Dialog Pencerahan, Pendamaian dan Masa Depan: Punjung Tulis 60 Tahun Prof. Dr. Olaf Herbert Schumann, Jakarta: BPK Gunung Mulia, 33-46.

- (2000) "Hidup Kristiani dalam Masyarakat Keagamaan yang Bersifat Majemuk" in Tim Litbang PGI eds. Meretas Jalan Teologi Agama-Agama di Indonesia Jakarta: BPK Gunung Mulia, 100-21.

Singodimedjo, Kasman. (1968) "Mengungkap Problem Hukum: Dekrit 5 Djuli 1959" Kiblat No. 20 (March), 9-10. 
- (1974) “UUD '45 Tidak Boleh Diselewengkan Dalam Pembuatan Perundang-undangan Apapun, Termasuk Pembuatan UUP" Abadi, (10 January).

Sirozi, Muhammad. (2004) Politik Kebijakan Pendidikan di Indonesia: Peran Tokoh-tokoh Islam dalam Penyusunan UU No. 2/ 1989, Jakarta: INIS.

Sitompul, Agussalim. (1984) HMI Dalam Pandangan Seorang Pendeta: Antara Impian dan Kenyataan, Second Edition, Jakarta: Gunung Agung.

Sitompul, Einar Martahan. (1989) Nahdlatul Ulama dan Pancasila: Sejarah dan Peranan NU dalam Perjuangan Umat Islam di Indonesia dalam Rangka Penerimaan Pancasila sebagai Satu-satunya Asas Jakarta: Sinar Harapan. Sjadzali, Munawir (1989) "RUU Peradilan Agama Harap Diterima Dengan Lapang Dada" Pelita (26 June).

Sjahir, Abdullah (1968) "Lagi Tentang: Piagam Jakarta", Peraba (June III), 6-7. Sjahrir, Sutan. (1990) Renungan dan Perjuangan, Jakarta: Dian Rakyat and Djambatan.

Soebijat, L. (1968) “Kristen Katolik Jang Salah!?” Peraba (25 February 1968), 3. Soekarno. (1947) Lahirnja Pantja-Sila Medan: Bin Harun.

- (n.d.) Negara Nasional dan Tjita2 Islam Jakarta: Kementrian Penerangan RI. Soeharto. (1987) Butir-Butir Budaya Jawa (n.p.).

Soewondo, Nani. (1977) “The Indonesian Marriage Law and Its Implementing Regulations" Archipel 13, 283-313.

- (1981) Kedudukan Wanita Indonesia Dalam Hukum dan Masyarakat, Jakarta: Ghalia.

Sosroatmodjo, Arso and Wasit Aulawi. (1978) Hukum Perkawinan di Indonesia, Jakarta: Bulan Bintang.

Sou'yb, Joesoef. (1989) "BW dan RUU PA" Panji Masyarakat No. 618 (July), 267.

Sparringa, Daniel T. (1997) “Discourse, Democracy and Intellectuals in New Order Indonesia: A Qualitative Sociological Study", PhD Thesis, Flinders University of South Australia.

Sperber, Jutta. (2000) Christians and Muslims: The Activities of the World Council of Churches, Berlin: De Gruyter.

Stange, Paul. (1986) "Legitimate Mysticism in Indonesia" Review of Indonesian and Malaysian Affairs Vol. 20 No. 2.

Steenbrink, Karel A. (1973) "Christian Faith in an Indonesian Environment" Exchange, No.5.

- (1984) "Indonesian Churches 1978-1984: Main Trends, Issues and Problems" Exchange Vol. 13 No. 39. 
- (1986) Pesantren, Madrasah, Sekolah: Pendidikan Islam dalam Kurun Modern Jakarta: LP3ES.

- (1990) "The Study of Comparative Religion by Indonesian Muslims: A Survey" Numen No. 2 Vol. 37, 141-67.

- (1993) Dutch Colonialism and Indonesian Islam, Contacts and Conflicts 1596-1950 Amsterdam: Rodopi.

- (2000) "Patterns of Muslim-Christian Dialogue in Indonesia (1965-1998)" in Jacques Waardenburg (ed.), Muslim-Christian Perceptions of Dialogue Today: Experiences and Expectations, Leuven: Peeters, 78-112.

Subagya, Rahmat. (1955) Pantjasila Dasar Negara Indonesia Yogyakarta: Basis.

- (1979) Agama dan Alam Kerohanian Asli di Indonesia Jakarta: Yayasan Cipta Loka Caraka.

Sudiyono, F.X. (1973) "Mungkinkah Unifikasi Undang2 Perkawinan" (I-III) Peraba (December I, II and III), 9, 8-9 and 8 respectively.

Suharto. (1994) “Beberapa Segi Hukum Perkawinan di Indonesia Khususnya Perkawinan Campuran Antar Agama," Weinata Sairin and J.M. Pattiasina eds. Pelaksanaan Undang-Undang Perkawinan Dalam Perspektif Kristen Jakarta: BPK Gunung Mulia., 83-95.

Sulaiman, Muhammad \& Murthado Makmur (1981) "Stemmotivering Fraksi Persatuan Pembangunan: Tinjauan Terhadap Buku Pelajaran PMP" Panji Masyarakat No. 329 (July), 40-3.

Sulistiyo, Hermawan. (2000) Palu Arit di Ladang Tebu: Sejarah Pembantaian Massal Yang Terlupakan (Jombang-Kediri, 1965-1966) Jakarta: Gramedia. Sumargono, Ahmad. (1995) “Kontroversi dan Keanehan Pemikiran Ahmad Wahib", Republika (11 April).

Sumartana, Th. (1973) “Keadilan Sosial Lewat Agama?” Tempo (24 November).

- (1974) "Lagi: Tempat Agama” Tempo (2 February).

- (1981) "Ikhtiar Ahmad Wahib: Sebuah Corak Reformasi dalam Islam" Prisma No.8 Vol. 10 (August), 82-8.

- (1981) "Ahmad Wahib, Profil Seorang Pembaharu" Tempo (10 October), 33.

- (1985) "Teologi Pembebasan: Kepalan Tangan Sang Uskup" in Imam Ahmad (ed.), Agama dan Tantangan Zaman Jakarta: LP3ES, 289-305.

- (1993) “Experimentasi Demokratisasi dari Agama-Agama: Sudut Pandang Kekristenan" in M. Imam Aziz, M. Jadul Maula, Ellyasa KH Dharwis eds, Agama, Demokrasi \& Keadilan Jakarta: Gramedia, 49-62.

- (1994) Mission at the Crossroads: Indigenous Churches, European Missionaries, Islamic Association and Socio-Religious Change in Java 18121936, Jakarta: BPK. 
- (1999) "Theologia Religionum" in Tim Litbang PGI eds. Meretas Jalan Teologi Agama-Agama di Indonesia Jakarta: BPK Gunung Mulia, 17-39.

- (2000) "Sejarah Singkat, Visi dan Misi Institut DIAN/Interfidei" Newsletter Interfidei (Special Edition), 3-6.

- (2003) "SARA dan Integrasi Nasional? Ketegangan Yang Tak Pernah Padam" in A.E. Priyono, Stanley Adi Prasetyo and Olle Törnquist eds. Gerakan Demokrasi di Indonesia Pasca-Soeharto, Jakarta: Demos.

Suryadinata, Leo. (1974) "Confucianism in Indonesia: Past and Present" Southeast Asia, an International Quarterly Vol. 3.

- (1985) Military Ascendancy and Political Culture: A Study of Indonesia's Golkar, Athens: Ohio University Center for International Studies.

- (1995) "Kong Hu Cuisme dan Agama Kong Hu Cu di Indonesia: Sebuah Kajian Awal" in Abdurrahman Wahid et al. Konfusianisme di Indonesia: Pergulatan Mencari Jati Diri, Yogyakarta: Interfidei.

- (1995) Prominent Indonesian Chinese: Biographical Sketches, Singapore: Institute of Southeast Asian Studies.

Suryadinata, Leo. Evi Nurvidya Arifin and Aris Ananta (2003) Indonesia's Population: Ethnicity and Religion in a Changing Political Landscape, Singapore: ISEAS.

Swasono, Sri-Edi. (1995) “Penegasan Pak Alamsyah: Pancasila Hadiah Ummat Islam," in Krisna R. Sempurnadjaja ed., H. Alamsyah Ratu Perwiranegara 70 Tahun Jakarta: Sinar Harapan, 61-4.

Tahalele, Paul and Thomas Santoso eds (1997) The Church and Human Rights in Indonesia, Surabaya: ICCF.

- (1997) Beginikah Kemerdekaan Kita? Surabaya: FKKS.

Tambunan, A.M. (1967) “Dalam Agama Tidak Ada Paksa” Ragi Buana No. 47 (December), 2-7.

Tanja, Victor I. (1982) Himpunan Mahasiswa Islam: Sejarah dan Kedudukannya di Tengah Gerakan-Gerakan Muslim Pembaharu di Indonesia, Jakarta: Sinar Harapan.

- (1989) "RUU PA" Editor No. 48 (5 August)

Tanter, Richard. (1991) "Beek, Father J. van. SJ". Appendix 1 of his "Intelligence, Agencies and Third World Militarization: A Case Study of Indonesia" PhD. Thesis, Monash University.

Taymiyya, Ibn (1907) Kitāb lqtidā al-Sirāt al-Mustaqīm, Mukhālafat Ashāb alJahìm, Cairo: al-Matba'a al-Sharqiyya.

Teeuw, A., (1979) Modern Indonesian Literature Vol.I and II The Hague: Martinus Nijhoff. 
Tim ISAI. (1995) Bayang-Bayang PKI Jakarta: ISAI.

Tim Peneliti (1997) Laporan Penelitian Kerukunan Antarumat Beragama (Unpublished Report).

Tim Penyusun. (1985) Kenang-Kenangan Seabad Peradilan Agama di Indonesia, Jakarta: Departemen Agama.

Tim Penyusun. (1999) Peradilan Agama di Indonesia: Sejarah Perkembangan Lembaga dan Proses Pembentukan Undang-Undangnya, Jakarta: Departemen Agama.

Tim Penulis. (1997) Anotasi 200 Buku Islam Karya Muslim Indonesia Yogyakarta: Interfidei.

Toer, Pramoedya Ananta. (2003) Realisme Sosialis dan Sastra Indonesia, Jakarta: Lentera Dipantara.

Toer, Promoedya Ananta and Stanley Adi Prasetyo eds. (1995) Memoar Oei Tjoe Tat, Jakarta: Hasta Mitra.

Tsuchiya, Kenji. (1987) Democracy and Leadership: The Rise of the Taman Siswa Movement in Indonesia trans. Peter Hawkes Honolulu: University of Hawaii Press.

Tulaar, David H. (1997) You Must Be Born Again: a Preliminary Study of Evangelicalism in Indonesia, Masters Thesis, Faculty of Theology, University of Amsterdam.

Ukur, Fridolin and F.L. Cooley. (1979) Jerih dan Juang: Laporan Nasional Survai Menyeluruh Gereja di Indonesia, Jakarta: Lembaga Penelitian dan Studi DGI.

Ukur, Fridolin. (1994) “Problematik Pelaksanaan Perkawinan di Indonesia Dalam Pengamatan PGI" in Weinata Sairin and J.M. Pattiasina eds. Pelaksanaan Undang-Undang Perkawinan Dalam Perspektif Kristen Jakarta: BPK Gunung Mulia, 11-8.

Vatikiotis, Michael. (1989) "Islamic Courts Law to Test Religious Tolerance" Far Eastern Economic Review (8 June).

Wahid, Abdurrahman. (1981) “Bak Tukang Batu Menghantam Tembok" Tempo (19 September) 28-9.

- (1981) "Fatwa Natal, Ujung dan Pangkal” Tempo (30 May), 17.

- (1981) "Kisah Sebuah Anak Kalimat" Tempo (7 November).

- (1982) "Sekali Lagi Ahmad Wahib" Tempo (23 January).

- (1982) "The Regional Context of Religious Cooperation: Implications of an Indonesian Case" Dialog No. 12 Vol. 7 (March), 42-3. 
- (1983) "Salahkah Jika Dipribumikan?" Tempo (16 July).

- (1989) "Kata Pengantar" in Einar Martahan Sitompul. Nahdlatul Ulama dan Pancasila: Sejarah dan Peranan NU dalam Perjuangan Umat Islam di Indonesia dalam Rangka Penerimaan Pancasila sebagai Satu-satunya Asas, Jakarta: Sinar Harapan.

- (1989) "Pribumisasi Islam" in Muntaha Azhari and Abdul Mun'im Saleh eds, Islam Indonesia Menatap Masa Depan, Jakarta: P3M, 81-96.

- (1994) "Agama dan Demokrasi" in Ahmad Suaedy ed. Spritualitas Baru: Agama dan Aspirasi Rakyat, Yogyakarta: Interfidei, 269-75.

- (1996) "Membangun Kebersamaan Hidup Beragama” Aula (November), 45-65.

- (2000) Melawan Melalui Lelucon: Kumpulan Kolom Abdurrahman Wahid di Tempo Jakarta: Pusat Data \& Analisa Tempo.

Wahono, S. Wismoady. (1985) “Messianisme dalam Perjuangan Petani: Tinjauan dari Sisi Kekristenan" in Imam Ahmad ed. Agama dan Tantangan Zaman Jakarta: LP3ES, 276-88.

Walkin, Jacob. (1969) "The Moslem-Communist Confrontation in East Java 1964-65", Orbis (Fall) 822-47.

Waney, Rufus Alexander. (1990) "Missiological Dimensions in Inter-religious Marriages Between Christians and Muslims in Indonesia" M Th. Thesis, Fuller Theological Seminary.

Ward, Kenneth. (1968) "Some Comments on Islamic Reactions to Recent Developments in Indonesia" Review of Indonesian and Malaysian Affairs Vol.2 No.2, 37-46a.

- (1974) The 1971 Elections in Indonesia: An East Java Case Study, Victoria: Monash University.

Wawer, Wendelin. (1974) Muslime und Christen in der Republik Indonesia Wiesbaden: Franz Steiner Verlag.

Webb, Paul. (1978) Indonesian Christians and Their Political Parties 1923-1966:

The Role of Partai Kristen Indonesia and Partai Katolik, Townsville: James Cook University.

- (1986) "The Sickle and the Cross" Journal of Southeast Asian Studies Vol. 17, 94-112.

Wertheim, W. F. (1969) "Indonesia Before and After the Untung Coup" Pacific Affairs Vol. 39 No.1-2 (Spring-Summer).

- (1970) "Suharto and the Untung Coup - The Missing Link", Journal of Contemporary Asia No. 1., 50-7.

- (1979) "Whose Plot? New Lights on the 1965 Events," Journal of Contemporary Asia Vol.9 No. 2. 
- (1980) Moslems in Indonesia: Majority with Minority Mentality, Townsville: Occasional Paper No.8 of South East Asian Studies, James Cook University.

- (1995) "Indonesia's Hidden History of 1965: When Will the Archives be Declassified?" in Bob Hering ed. Pramoedya Ananta Toer 70 Tahun: essays to honour Pramoedya Ananta Toer's 70 th year Den Haag: Yayasan Kabar Seberang.

Widjojo, S. (1989) “Peradilan Agama: Antara Negara Agama dan Negara Pancasila" Hidup No. 7 (12 February), 28-9; 50.

- (1989) “Kesaktian Pancasila dalam Tantangan” Hidup No. 10 (5 March), 401.

Wijoyo, Alex Soesilo. (1981) "Kehadiran Gereja Minoritas di Tengah Mayoritas Muslim," Ummat Baru, 393.

Willis, Avery T. (1977) The Indonesian Revival: Why Two Millions Came to Christ, South Pasadena: William Carey Library.

Wirosardjono, Soetjipto et al. (1991) Agama dan Pluralitas Bangsa, Jakarta: P3M.

Yamin, Muhammad. (1959) Naskah Persiapan Undang-Undang Dasar 1945 Vol.1 Jakarta: Yayasan Prapantja.

Zaini, Azkarmin. (1974) "Malaysia dan Masa Depan Kerjasama Islam” Suara Muhammadiyah No. 15\&16 (August), 13;28-9.

Zubir, H.M. Goodwill and Sudar Siandes eds. (no date) Potret Gerakan Kristenisasi di Indonesia Versi Da'i LDK Muhammadiyah, Jakarta: LDK PP Muhammadiyah.

Zuhri, Saifuddin. (1979) "Hari Depan Anak-anak Yang Didambakan Melalui Pendidikan Terpadu", Mimbar Ulama No. 31 (June), 20-8.

- (1979) "Pendidikan Nasional dan Pendidikan Agama" Pelita (9 May).

- (1987) Berangkat Dari Pesantren, Jakarta: Gunung Agung.

\section{News, Features and Editorials of Magazines and Newspapers}

Aula. (March 1981) “Lagi-Lagi Terkejut Oleh Olah Daoed”, 6-7.

- (May 1989), "RUU Peradilan Agama Maju, Datang Penghalang", 51-6.

- (August 1989) "RUUPA Lahir Karena Tuntutan Sejarah", 24-8.

- (November 1996), "Semua Sama Susah"\&“Wawancara Gus Dur: Umatmu Apa Mas?", 28-44.

Basis. (November 1967) No. 2 Vol. 17, "Pemberontakan thd Pantjasila”, 62.

- (December 1967) No. 3 Vol. 17, "Seminar Hak Azasi Manusia", 97. 
- (January 1968) No. 4 Vol. 17, "Sekitar Musjawarah Kerukunan Agama”, 123-4.

Berita DGI. (February 1968), "Hasil-Hasil Sidang Lengkap DGI ke IV", 30-1.

Berita Oikoumene. (September 1973) Vol. 1 No. 9, "Rencana Untuk Sidang Raya WCC di Jakarta Ditegaskan Kembali", 4-5.

- (March 1974) Vol.2 No. 3, "Dari Edinburgh ke Jakarta”, 1-5.

— (July 1974) Vol. 2 No. 7, “90 Orang Indonesia Hadir Di Kongres Pekabaran Injil", 2-3.

- (July 1974) Vol.2 No.7 "Pendeta Anglikan Dibunuh di Jakarta", 4-5.

- (August 1974) Vol. 2 No.8 "Rencana Sidang Raya DGD di Jakarta Dibatalkan", 2-3.

- (September 1978) Vol. 6 No.9, “DGI dan MAWI Tolak SK Menteri Agama No, 70 dan No. 77 Tahun 1978", 7.

- (October 1978) Vol. 6 No. 10 "Catatan Tentang Keputusan Menteri Agama No. 70/1978 Tentang Pedoman Penyiaran Agama", 16-17.

- (November 1978) Vol. 6 No. 11, "Seputar Keputusan Menteri Agama No. 70 \& 77 Tahun 1978 dan Prosesnya", 17-21.

- (November 1978) Vol. 6 No. 11 "Pesan Sidang Istimewa BPL-DGI 1978", 4 -7 .

- (November 1978) Vol. 6 No. 11 “BPL-DGI Dukung Sikap Langkah BPH DGl - MAWI Mengenai SK Menteri Agama".

Duta Masjarakat (6 October 1967) "Persitiwa Makassar".

Editor (19 March 1988) No. 30 "Kepercayaan adalah Kepercayaan”, 44.

Forum Keadilan (13 May 1993) No. 2 "Setelah Malari Benny Datang", 15.

Gatra (21 June 2003) "Bukan Ombak Penggoyah Iman", 42.

Gema Islam (1962) Vol.1 No.1. "Musyawarah Seniman dan Budayawan Islam"

- (1963) Vol. 2 No. 45. "Manifes Kebudayaan dan Kesenian Islam"

HAK Kerukunan (September-November 1981, January 1982) “Pesan Natal

Bersama DGI Dan MAWI Tahun 1981"Vol. 3 and 4 No. 16, 17, 18, pp. 69-71.

- (September-November 1981, January 1982) "Tanggapan MAWI-DGI” Vol. 3 and 4 No. 16, 17, 18, pp. 53-62.

Hidup (26 November 1978) No. 44 "Bebas Pilih Atau Pindah Agama Karena Keyakinan Bukan Berdasarkan Bujukan", 1208.

- (26 November 1978) No. 44 "Siaran Pers Sidang MAWI 1978", 1204-5.

Kiblat (August 1967) No. 6"Pantjasila Milik Semua Agama” 11.

- (August 1967) No. 5 "Badan2 Ke-Agamaan di Indonesia," 25.

- (October 1967) No. 10 "Fakta Sebab Musabab Peristiwa Makasar", 47

- (October 1967) No. 10, 48-9.

- (December 1967) No. 14, 46-47. 
- (January 1968), No. 15, 20.

- (April 1968) No. 21 "Tak Ada Pintu Untuk Pemurtadan Agama" 4-5; 50-51.

- (May 1968) No. 23 "Appeal Baru Presiden Suharto", 4-5.

- (June 1968) No. 2 "Issue Menghapuskan Departemen Agama" 24-5;33.

- (July 1968) No. 3 "Lampu Merah Buat Ummat Islam Indonesia”, 41.

- (July 1968) No. 4 "Sesudah Peringatan Piagam Djakarta Mau Apa?", 19.

- (September 1968) No. 8., 19-22,33.

- (October 1968) No.9, 31-2.

- (November 1968) No.11, 46-7;50.

- (January 1969) No.16.

- (April 1969) No. 22 “Katholik Mulai Praktekkan Adjaran Paulus 'Segala Sesuatu Halal Bagiku' (Korintus 6:12)" 4-5.

- (April 1969) No. 22., 12-14;26.

- (June 1969) No. 1 "Untuk Ketertiban Masjarakat: Perlu Segera Dikeluarkan UU Pernikahan" 21-23.

- (June 1969) No. 2., 26.

- (July 1969) No. 4 "Ekor dari Peristiwa Slipi", 31.

- (July 1969) No. 4, 25.

- (October 1969) No.10, 38.

- (November 1969) No.11 “Pantjasila Akan tetap Sakti Djikalau Diridhoi Allah", 55.

- (July 1973) No.3, 18-20; 32.

- (September 1973) No.7 "Presiden Suharto: Perkawinan Sangat Erat Dengan Unsur2 Keagamaan dan Kerohanian", 4.

- (September 1973) No.7 "Rencana Undang-Undang Perkawinan", 8 -10.

- (September 1973) No. 8“RUU Perkawinan", 46.

Kompas (2, 15-19 June 1967).

- (31 July 1967).

- (4, 5, 6 October 1967).

- (9 October 1967) "Itikad Baik Kita Semua”.

- (1 April 1968).

- (17 December 1973) "Para Penyusun UUD '45 Sudah Berikan Jalan Keluar".

- (19 December 1973) "Pokok-Pokok Pemikiran BPH-DGI dan MAWI".

- (22 December 1973) "Hakekat RUU Perkawinan".

- (16 September 1978) "Siaran Pers DGI dan MAWI".

- (8, 10 March 1989).

- (27 June 1989).

- (5 July 1989). 
Media Dakwah (August 1989) “Dimana Toleransi Mereka", 7-11.

- (August 1989) "Menggugat Protes Naif", 12.

- (December 1990) "Membedah Jantung Monitor", 25-30.

Mimbar Ulama (September-October 1978) No. 23 "Majelis Ulama Indonesia Dukung Keputusan Menteri Agama", 55.

- (June 1979) No. 31 "Risalah Kronologis Peranan Dewan Majelis Ulama Indonesia dalam Masalah Pendidikan Nasional dan Libur Ramadhan", 2934.

- (January-February 1980) No. 37, 49-61.

- (August-September 1983) No. 73 "Masalah Buku Pergolakan Pemikiran Islam", 39-45.

Pandji Masjarakat (July 1967) No. 14, 13.

- (September 1967) No.18 "Simorangkir dkk. Mundur", 6.

- (October, 1967) No.19, 25.

- (October, 1967) No. 20, 5-6.

- (December 1967) No. 21-22, “Menteri Agama K.H.M. Dachlan: Ada Jang Mau Ganti Agama Islam dengan Agama Mereka", 12.

- (December 1967) No.21-22, 34.

- (January 1968) No. 24 "Masih Perlukah Dept. Agama?", 19-20.

- (December 1969), No. 49, 16.

- (May 1973) No. 126 "Pendidikan Agama di Sekolah2", 5-6.

- (June 1973) No. 128 "Moral Pancasila", 4-5.

- (July 1973) No. 130 "Tradisi Keraton Sala Pecah", 32.

- (August 1973) No. 133, "Rencana Undang2 Tentang Perkawinan (I)" 4.

- (September 1973) No. 135, 7-8.

- (October 1973) No.136 "Berita dan Komentar", 9.

- (October 1973) No. 136 "Catholic Worker' Apa Kegiatan Orang Katolik di Indonesia", 25.

- (October 1973) No. 137, "Berita dan Komentar", 5-7;34.

- (November 1973) No. 138 "Berita dan Komentar", 7.

- (December 1973) No. 140, "Berita dan Komentar", 8-9.

- (January 1974) No. 142 "Toleransi: Bukan Pengorbanan 'Aqidah"

- (April 1974) No. 149 "Berita dan Komentar", 6-7.

- (June 1974) No. 153, 31.

- (July 1974) No. 155 "Berita dan Komentar", 12-13.

- (September 1974) No. 158 "Pidato Presiden Tentang Agama", 7.

- (November 1977) No. 234 "Majelis Ulama Tolak Aliran Kepercayaan".

- (November 1977) No. 234 “Bung Hatta: Kata 'Kepercayaan' Penguat Kata 'Agama'". 
- (December 1977) No. 237, "Alasan Penolakan Partai Persatuan Tentang Rancangan Pedoman Penghayatan Pancasila", 54-8.

- (April 1978) No. 245 "Tap MPR 1973 dan Tap MPR 1978", 7.

- (June 1978) No. 248 “Da'wah dan Kuliah Subuh Lewat Radio Tak Perlu Izin", 5-6; 9.

- (October 1978) No. 257 “Instruksi Presiden Kepada Menteri Agama, 7.

- (October 1978) No. 257 "Jangan Bertepuk Sebelah Tangan (Wawancara Dengan Menteri Agama H. Alamsyah)", 14-5.

- (October 1978) No. 257 "Simakkan Alamsyah dan Langkahnya", 10-13.

- (December 1979) No. 285 "Saran-Saran Majelis Ulama Terhadap Pembaharuan Pendidikan Nasional", 12-15.

- (January 1980) No. 286 "Penertiban Mata Kuliah Agama”, 14-15.

- (January 1980) No.287 "Beberapa Komentar Tentang Panca Agama", 15.

- (January 1987) No. 287, "Alamsyah: Panca Agama Ide Gila",7.

- (January 1980) No. 287, "Bantahan Menteri P\&K tentang Panca Agama”, 19.

- (September 1980) No. 303, “Pemutusan Subsidi Muhammadiyah: Kebijakan Yang Tidak Bijak",12-6.

- (February 1981) No. 315 "Pedoman itu Tidak Ber-Pancasila", 11-2.

- (February 1981) No. 315 “Persandingan Antara P dan K dan Towa”, 14-5.

- (May 1981) No.324, 9.

- (June 1981) No. 326 "MUI, Jembatan Siapa?", 12-16.

- (July 1981) No. 329, "Libur Puasa: Menggugat Sebuah 'Kebijaksanaan'”, 1315.

- (October 1981) No. 338 "Mereka Menolak SE", 11.

- (March 1989) No. 606 "Guru Agama Kembali Diributkan", 12-3.

- (April 1989) No. 607 "RUU Peradilan Agama Mulai Digugat", 15.

- (June 1989) No. 614 "RUU PA, dari Pak Harto sampai Victor Tanja", 22-4.

- (June 1989) No. 615 "RUU PA, Tiga Fraksi Tanpa Ragu",12-13.

- (July 1989) No. 617 "RUU PA di Mata Victor Tanja”, 12.

- (December 1989) No. 633, "Goool...(R)UUPA", 14.

- (October 1991) No. 698, "PP No.29/1990 Harus Ditinjau Kembali”, 71-4.

- (December 1993) No. 777, “Umat Islam Diharamkan Ikut Natal Bersama”, 68-9.

Pelita (30 April 1979).

- $(9,5,12,17,28,29$ May 1979).

- (14 June 1979).

- (12 September 1988).

- (13 October 1979). 
- (6 March 1989).

- (22 June 1989).

- (6 and 11 July 1989).

Peraba (25 October 1967) No. 30, 5-7.

- (25 March 1968) "Gagal ?? Berhasil ??", 3-4.

- (25 March 1968) "Penjembahan Berhala Diantjam 6 Bulan", 4.

- (April 1968, II) "Pelaksanaan Piagam Djakarta Semakin Meluas" , 5.

- (25 April 1968) “Piagam Hak-hak Azasi Manusia Didjungkir Balikkan!”, $5 ; 12$.

- (15 May 1968) "Natsir di UGM: Piagam Djakarta mendapat tepuk tangan dari mahasiswa jang pakai kudung...," 5.

- (June 1968, I) "Pendapat Partai Katolik Tentang Piagam Djakarta", 3-4; 12.

- (June 1968, II) “Beberapa Kesimpulan", 3-4.

- (July 1968, III) "Ada 'Strategi Bertahap' Kehebohan 'Piagam Djakarta", 6.

- (August 1968, II) “Riwayat Proklamasi: Tidak Diambil dari 'Piagam Djakarta", 6-7; 8.

- (August 1968, IV), "Pegawai Dept. Agama Harus Djadi Pedjuang Islam”, 4.

- (September 1968, I), "Gudang SD. Katolik Dibakar" and "Geredja di Asahan Dibakar", 6.

- (September 1968, I), "Agama Islam Agama Negara?", 5.

- (September 1968, III), 2.

- (October 1968, IV), "Berita dari Madiun: Badan2 Hukum Katolik Tak Punja Hak Hidup?", 6.

- (April 1969, II), “Negara Pantjasila Dirongrong: Pelaksanaan Piagam Djakarta Semakin Meluas", 5.

- (April 1969, IV), "Tjatatan" and "Dirusak", 1-3.

- (October 1973, II), "Menanggapi RUU Perkawinan", 3.

- (October 1973, III), "Mendesaknya: Kesatuan Hukum Perkawinan”, 2;4-5.

Sinar Harapan (2 January 1966).

- $(9,13,14,17,22,27,29$ June 1967).

- (29 July 1967).

- (9 October 1967).

- (14 December 1973).

- (17 December 1973) "Mengapa Surat Kabar Ini Begitu Getol Mengenai RUUP?".

- (19 December 1973) "Demi Perikemanusiaan dan Ketertiban Hukum".

- (19 December 1973) "Pokok-Pokok Pemikiran BPH-DGI dan MAWI".

- (21 December 1973) "Mudah-Mudahan Pengalaman Seperti ini Tidak Terulang". 
- (24 December 1973).

- (1, 2, 5, 13 July 1976).

- (10 October 1978) "Instruksi Presiden: Pelaksanaan SK No. 70 dan 77 Diteruskan".

- (21 October 1978) "Pesan Sidang Istimewa BPL-DGl: Harus Dijaga Agar Kebebasan Tidak Bahayakan Kerukunan".

- (6 November 1978) "Bebas Pilih Atau Pindah Agama Karena Keyakinan Bukan Berdasarkan Bujukan".

Suara Karya (25 August 1988).

- (9 September 1988).

- (10, 11, 14 March 1989).

- (13, 16 June 1989).

- (5 July 1989).

Suara Pembaruan (3 March 1989) "Sekitar Pasal 28 Ayat 2 RUU SPN".

- (8 March 1989) "Langkah Pertama Pelaksanaan UU Sistem Diknas".

- (11, 14 March 1989).

- (17 March 1989) "RUU Peradilan Agama dalam Rangka Wawasan Nusantara".

- (28 March 1989) "Hanya Ada Satu Hukum Nasional”.

- (17 April 1989) “Pendekatan 'Ad Hoc' Dapat Timbulkan Keadaan Semrawut".

- (17, 30 May 1989).

- (5 June 1989) "Pertanyaan Keenam Untuk Fraksi di DPR".

- (14 June 1989) "Dijamin Tidak Menjurus ke Piagam Jakarta”.

- (27 June 1989).

Suara Muhammadiyah (1963) No.25, 5.

- (April 1974) No.7, 1.

- (May 1974) No. 10 “PP Muhammadiyah dan Konferensi Dewan Gereja Sedunia", 3.

- (July 1974)No.13, 13.

- (August 1974) No. 15\&16"SR Dewan Gereja Sedunia Mungkin Tak Jadi di Jakarta", 7.

- (September 1974) No. 17 "Sesudah Batalnya SR DGS Di Jakarta", 3.

Tempo (31 March 1973) "Dari Sidang 13 Hari di Bulan Maret", 5-10.

- (30 June 1973) "Sambil Menanti Undang-Undang Hawa", 50.

- (1 September 1973) "RUU Perkawinan: Sumpah Para Ulama”, 6.

- (8 September 1973) "RUU Perkawinan, Aksi dan Reaksi", 6-8.

- (15 September 1973) "Khotbah Buat Negarawan dan Si Polan", 43.

- (22 September 1973) "RUU Perkawinan: Mencabut \& Merubah", 8-9. 
- (6 October 1973) "Demonstrasi: Ada 'Allahu Akbar' Dari Luar", 6-7.

- (13 October 1973) "RUU Perkawinan: Bumbu-Bumbu Masakan Baru”, 6.

- (20 October 1973) “Fokus Kita”, 1.

- (20 October 1973) "Katolik: Bola Salju Mulai Menggelinding?", 45-8.

- (3 November 1973) “Demonstrasi: 13 Yang Bebas", 13.

- (15 December 1973) "RUU Perkawinan: Yang Didrop \& Dirubah", 6-7.

- (5 January 1974) "Bila Sri Ketemu Martinus (Dan Mau Kawin)”, 5.

- (5 January 1974) "Bagaimana Aidit Kawin?", 6-7.

- (13 July 1974) "Terbunuhnya Sang Pendeta", 48-50.

- (13 July 1974), "Direktur Bersandal Jepit" 48-50.

- (20 July 1974) "Karena Keunikan Saja”, 7.

- (10 July 1976) "Setelah Presiden Ke Salatiga", 5-7.

- (23 September 1978) "Mengapa Mereka Resah?", 55-7.

- (23 September 1978) "Menteri Alamsyah Menjawab", 53-5.

- (2 June 1979) "Libur, Tidak, Libur...", 8-9.

- (7 July 1979) "Memang Bukan Asbur", 48.

- (4 October 1980) "Yang Resmi Datang, Rezeki Hilang (?)", 19.

- (30 May 1981) "Buya, Fatwa dan Kerukunan Beragama”, 12-15.

- (30 May 1981) "MUI, Kisah Sebuah Jembatan”, 15-17.

- (30 January, 1982) "Catatan Harian Ahmad Wahib", 50-5.

- (13 April 1985) "Silakan Memilih Agama", 69.

- (1 November 1986) "Dari Kus Ondowiyah Sampai Camelia Malik", 56-8.

- (1 November 1986) "Menguji Cinta di Depan Hukum", 54.

- (4 February 1989) "Si Bungsu Yang Ditunggu Bukan Hantu”, 81.

- (24 June 1989) "Buka-Tutup Pintu Kawin Campuran”, 36-7.

- (24 June 1989) “Dari Piagam Jakarta ke Wawasan Nusantara”, 27-8.

- (24 June 1989) "Menunggu Lahirnya si Anak Bungsu", 30-1.

- (24 June 1989), "Peradilan Agama: Kebutuhan atau Kecemasan”, 22.

- (24 June 1989) "Sebuah RUU dengan Lapang Dada", 26.

- (23 December 1989) "Telah Lahir si Anak Bungsu".

- (30 December 1989) "Mau Kawin Dipersulit", 15.

- (27 October 1990) "Angket, Boikot dan Istigfar", 32.

- (27 October 1990) "Setelah 'Kagum 5 Juta' Itu Diumumkan", 28-32.

- (3 November 1990) "Setelah Breidel, Perlu Penyejuk?", 26-30.

- (10 November 1990) "Dialog Makin Perlu", 29-30.

- (10 November 1990) "Guncangan Baru Setelah 'Monitor", 26-9.

- (1 January 1994) "Surat Natal Dari Istiqlal", 35.

Ragi Buana (January 1966) No. 24"Menjambut Hari Lahir Jang ke-70 dari Prof.Dr. S.T.G.Mulia", 3-8; 86. 
- (September 1967) No. 44 "Interpelasi JCT. Simorangkir dkk.", 26-27.

- (December 1967) No. 47 "Pesan Sidang Lengkap DGI dari Kota Makassar", 19.

- (September 1967) No. 44, 32.

- (October 1969) No. 69, 38-40.

\section{Official Speeches}

- "Alasan Pemberian Persetujuan oleh Dewan Perwakilan Rakyat Terhadap Undang-Undang Tentang Perkawinan serta Sambutan Pemerintah" in Sekitar Pembentukan Undang-Undang Perkawinan Beserta Peraturan Pelaksanaannya (Jakarta: Dirjen Hukum dan Perundang-Undangan, Departemen Kehakiman, 1974), 190-231.

- "Djend. Soeharto pada Konpernas Geredja \& Masjarakat" Ragi Buana (July 1967), 17-20. (Soeharto's speech to the Conference on Church and Society, 1967).

- "Interpelasi Peristiwa Meulaboh, Kabupaten Atjeh Barat oleh Anggota DPRGR, JCT Simorangkir" Microfilm No. 2145/71, KITLV Library, Leiden.

- "Jawaban Pemerintah Atas Pandangan Umum Para Anggota Dewan Perwakilan Rakyat Terhadap Rancangan Undang-Undang Tentang Perkawinan" in Sekitar Pembentukan Undang-Undang Perkawinan Beserta Peraturan Pelaksanaannya (Jakarta: Dirjen Hukum dan PerundangUndangan, Departemen Kehakiman, 1974), 127-37.

- "Kesulitan Ekonomi Jg Diderita Rakjat Indonesia Dipakai Kristen Untuk Mengekspansi Ummat Islam" Kiblat, No. 15 and 16 (January, 1968) 21-22 and 12-13; 37. (Speech by Lukman Harun to Parliament).

- "Keterangan Pemerintah Mengenai Rancangan Undang-Undang Tentang Perkawinan" in Sekitar Pembentukan Undang-Undang Perkawinan Beserta Peraturan Pelaksanaannya (Jakarta: Dirjen Huku dan PerundangUndangan, Departemen Kehakiman, 1974), 43- 52.

- "Keterangan Pemerintah Sebagai Djawaban Terhadap Interpelasi Drs. Lukman Harun dkk Soal Bantuan Luar Negeri Kepada Agama2 atau Badan2 Keagamaan di Indonesia" Kiblat No.7 (September 1967) 4-5; 9. (Speech by Minister of Religion, Saifuddin Zuhri, to Parliament).

- "Keterangan Pemerintah Tentang Peristiwa Geredja di Atjeh Barat" Kiblat (August, 1967) No. 5 (Speech by Minister of Religion, Saifuddin Zuhri, to Parliament). 
- "Landasan Pemikiran Politik Hukum Nasional" Pelita (24 June 1989) (Speech by Minister of Religion, Munawir Sjadzali, to Parliament).

- "Menteri Agama Djawab: Pemerintah Jakin, Kegiatan Agama adalah Positif" Peraba (September 1968, IV) 6-8. (Speech by Minister of Religion, Moch. Dachlan, to Parliament).

- "Pandangan Umum Para Anggota Dewan Perwakilan Rakyat Atas Rancangan Undang- Undang Tentang Perkawinan": R. Tubagus Hamzah (Fraksi ABRI), Pamudji (Fraksi Partai Demokrasi Indonesia, Ny. Nelly Adam Malik (Fraksi Karya Pembangunan), Ischak Moro (Fraksi Persatuan Pembangunan), H.A. Balya Umar (Fraksi Persatuan Pembangunan, Ny. Asmah Syahroni (Fraksi Persatuan Pembangunan), Teuku H.M. Saleh (Fraksi Persatuan Pembangunan), H.M. Amin Iskandar (Fraksi Persatuan Pembangunan), K.H. Kodratullah (Fraksi Karya Pembangunan) in Sekitar Pembentukan Undang-Undang Perkawinan Beserta Peraturan Pelaksanaannya (Jakarta: Dirjen Hukum dan Perundang-Undangan, Departemen Kehakiman, 1974), 53-126.

- "Pemandangan Umum Fraksi ABRI: Rancangan Undang-Undang Peradilan Agama" Pelita 17 June 1989 (Speech by the ABRI faction to Parliament).

- "Pendapat FKP atas RUU Peradilan Agama" Pelita 20 June 1989. (Speech by Golkar's faction to Parliament).

- Pidato Kenegaraan Pd. Presiden Republik Indonesia Djenderal Soeharto di Depan Sidang DPRGR, 16 Agustus, 1967 (Jakarta: Doa Restu, 1967).

- "Pidato Drs. Lukman Harun di Hadapan Sidang Pleno DPRGR Tanggal 21 Juli 1967 Sebagai Pendjelasan Mengenai Interpelasi Tentang 'Bantuan Luar Negeri Kepada Agama2 Atau Badan2 Keagamaan di Indonesia" Kiblat No. 6 (August 1967), 13-15.

- "Pidato Sambutan Dr. A.M. Tambunan SH" Al-Djami'ah No. 3 (May 1968), 18-22.

- "Pidato Sambutan Dr. H.M. Rasjidi" Al-Djami'ah No. 3 (May, 1968), 35-43.

- "Pidato Sambutan I.J.Kasimo" Al-Djami'ah No. 3 (May 1968), 23-6.

- "Pidato Sambutan K.H.Masjkur" Al-Djami'ah No. 3 (May 1968), 32-4.

- "RUU Peradilan Agama Harap Diterima Dengan Lapang Dada" Pelita 26 June 1989 (Speech by Minister of Religion, Munawir Sjadzali, to Parliament).

- "Sambutan Menteri Negara Kesra" Al-Djami'ah No. 3 (May 1968), 9-10.

- "Sambutan Pedjabat Presiden Republik Indonesia" Al-Djami'ah No. 3 (May 1968), 5-9. 


\section{Decrees and Other Official Documents}

- "Keputusan Bersama Menteri Agama dan Menteri Dalam Negeri No. 1 Tahun 1979 Tentang Tatacara Pelaksanaan Penyiaran Agama dan Bantuan Luar Negeri Kepada Lembaga Keagamaan di Indonesia," in Weinata Sairin ed., Himpunan Peraturan di Bidang Keagamaan (Jakarta: BPK Gunung Mulia, 1994), 63-8.

- "Keputusan Bersama Menteri Agama dan Menteri Dalam Negeri No. 1/ BER/MDN-MAG/1969 Tentang Pelaksanaan Tugas Aparatur Pemerintahan Dalam Menjamin Ketertiban dan Kelancaran Pelaksanaan Pengembangan dan Ibadat Agama oleh Pemeluk-Pemeluknya" in Weinata Sairin ed., Himpunan Peraturan di Bidang Keagamaan (Jakarta: BPK Gunung Mulia 1994), 3-6.

- “Keputusan Jaksa Agung RI No. Kep-058/J.A/194 Tentang Larangan Peredaran Barang-Barang Cetakan Yang Memuat Ajaran Kepercayaan Children of God" and "Press Release Jaksa Agung RI" in Weinata Sairin ed., Himpunan Peraturan di Bidang Keagamaan (Jakarta: BPK Gunung Mulia, 1994), 273-8.

- "Keputusan Menteri Agama No. 44 Tahun 1978 Tentang Pelaksanaan Dakwah Agama dan Kuliah Subuh Melalui Radio" in Weinata Sairin ed., Himpunan Peraturan di Bidang Keagamaan (Jakarta: BPK Gunung Mulia, 1994), 69-70.

- "Keputusan Menteri Agama Republik Indonesia No. 70 Tahun 1978 Tentang Pedoman Penyiaran Agama" in Weinata Sairin (ed.), Himpunan Peraturan di Bidang Keagamaan (Jakarta: BPK Gunung Mulia, 1994), 50-1.

- "Keputusan Menteri Agama Republik Indonesia No.77 Tahun 1978 Tentang Bantuan Luar Negeri Kepada Lembaga Keagamaan di Indonesia," Weinata Sairin ed., Himpunan Peraturan di Bidang Keagamaan (Jakarta: BPK Gunung Mulia, 1994), 56-9.

- “Keputusan Menteri Dalam Negeri Nomor 221a Tahun 1975 Tentang Pencatatan Perkawinan dan Perceraian pada Kantor Catatan Sipil Sehubungan Dengan Berlakunya Undang-Undang Perkawinan Serta Peraturan Pelaksanaannya" Weinata Sairin and J.M. Pattiasina eds, Pelaksanaan Undang-Undang Perkawinan dalam Perspektif Kristen (Jakarta: BPK Gunung Mulia (1994), 308-10.

- "Keputusan Pertemuan Lengkap Wadah Musyawarah Antar Umat Beragama Tentang Peringatan Hari-Hari Besar Keagamaan," in Weinata Sairin ed., Himpunan Peraturan di Bidang Keagamaan (Jakarta: BPK Gunung Mulia, 1994), 518-521. 
- “Keputusan Presiden RI No.12 Tahun 1983 Tentang Penataan dan Peningkatan Pembinaan Penyelenggaraan Catatan Sipil" in Weinata Sairin and J.M. Pattiasina eds, Pelaksanaan Undang-Undang Perkawinan dalam Perspektif Kristen (Jakarta: BPK Gunung Mulia (1994), 342-6.

- “Ketetapan MPRS No. XX/MPRS/1966 Tentang Memorandum DPR-GR Mengenai Sumber Tertib Hukum Republik Indonesia dan Tata Urutan Peraturan Perundangan Republik Indonesia" in Abdul Kadir Besar, Himpunan Ketetapan-Ketetapan MPRS (Jakarta: Pantjuran Tudjuh, 1969), 39-56.

- "Ketetapan Sidang MPL PGI No. 03/MPL-PGI/1989 Tentang Sikap GerejaGereja Terhadap Rancangan Undang-Undang Peradilan Agama (RUUPA)" in Weinata Sairin ed., Himpunan Peraturan di Bidang Keagamaan (Jakarta: BPK Gunung Mulia 1994), 550-3.

- "Ketetapan Sidang MPL-PGI Nomor 01/MPL-PGI/1989" in Weinata Sairin and J.M. Pattiasina eds, Pelaksanaan Undang-Undang Perkawinan dalam Perspektif Kristen (Jakarta: BPK Gunung Mulia (1994), 146-51.

- "Ketetapan Sidang MPL-PGI Nomor 02/MPL-PGI/1989" in Weinata Sairin, Partisipasi Kristen Dalam Pembangunan Pendidikan Indonesia Menyongsong Milenium Ketiga (Jakarta: BPK Gunung Mulia, 1998), 178-81.

- “Penjelasan Atas Keputusan Menteri Agama No. 77 Tahun 1978 Tentang Bantuan Luar Negeri Kepada Lembaga Keagamaan" in Weinata Sairin ed., Himpunan Peraturan di Bidang Keagamaan (Jakarta: BPK Gunung Mulia, 1994), 60-62.

- "Penjelasan Atas Keputusan Menteri Agama RI No. 70 Tahun 1978 Tentang Pedoman Penyiaran Agama" in Weinata Sairin ed., Himpunan Peraturan di Bidang Keagamaan (Jakarta: BPK Gunung Mulia, 1994), 52-55.

- "Penjelasan Atas Penetapan Presiden Republik Indonesia Nomor 1 Tahun 1965 Tentang Pencegahan Penyalahgunaan dan/atau Penodaan Agama" in Weinata Sairin ed., Himpunan Peraturan di Bidang Keagamaan (Jakarta: BPK, 1994), 265-268.

- "Pernjataan Geredja Katolik di Indonesia Mengenai Beberapa Masalah Penting di Tanah Air" (31 March 1969).

- "Pokok2 Pikiran Fraksi Katholik Mengenai Rantjangan Undang2 Perkawinan Umat Islam," Kiblat (May 1969) No. 23, 17-20; Peraba (July 1969, I), 3-6.

- "Pokok-Pokok Pikiran DGI dan MAWI Serta Usul Penyelesaian Atas Masalah Yang Ditimbulkan Oleh Surat Edaran Menteri Agama Nomor MA/325/1981 Tanggal 2 September 1981 Perihal Penyelenggaraan Hari- 
Hari Besar Keagamaan," in Weinata Sairin (ed.), Himpunan Peraturan di Bidang Keagamaan (Jakarta: BPK Gunung Mulia, 1994), 522-7.

- "Rangkuman Hasil Konsultasi Hukum di Wilayah-Wilayah Tentang Undang-Undang Perkawinan" and "Hasil-Hasil dan Kesimpulan Konsultasi Hukum Tentang Pelaksanaan Undang-Undang Perkawinan" in Weinata Sairin and J.M. Pattiasina eds, Pelaksanaan Undang-Undang Perkawinan dalam Perspektif Kristen (Jakarta: BPK Gunung Mulia, 1994) 152-168.

- "Seruan Majelis Ulama Indonesia DKI Jakarta Tentang Perkawinan Antar Agama" and "Keputusan Kepala Kantor Catatan Sipil DKI Jakarta, 1986" in Weinata Sairin and J.M. Pattiasina eds, Pelaksanaan Undang-Undang Perkawinan dalam Perspektif Kristen (Jakarta: BPK Gunung Mulia, 1994), 376-84.

- “Tanggapan Atas Surat Edaran Menteri Agama Nomor MA/325/1981 Tanggal 2 September 1981 Perihal Penyelenggaraan Hari-Hari Besar Keagamaan," in Weinata Sairin ed., Himpunan Peraturan di Bidang Keagamaan (Jakarta: BPK Gunung Mulia, 1994), 528-36.

- "Tanggapan DGI-MAWI Atas Keputusan Bersama Menteri Agama dan Menteri Dalam Negeri No. 1 Tahun 1979 Tentang Tatacara Pelaksanaan Penyiaran Agama dan Bantuan Luar Negeri Kepada Lembaga Keagamaan di Indonesia," in Weinata Sairin ed., Himpunan Peraturan di Bidang Keagamaan (Jakarta: BPK Gunung Mulia, 1994), 488-99.

- "Tanggapan Terhadap Penjelasan Atas Keputusan Menteri Agama No. 70 Tahun 1978 Tentang Pedoman Penyiaran Agama," in Weinata Sairin ed., Himpunan Peraturan di Bidang Keagamaan (Jakarta: BPK Gunung Mulia, 1994), 477-82.

- "Tanggapan Terhadap Penjelasan Atas Keputusan Menteri Agama No.77 Tahun 1978 Tentang Bantuan Luar Negeri Kepada Lembaga Keagamaan di Indonesia," in Weinata Sairin ed., Himpunan Peraturan di Bidang Keagamaan (Jakarta: BPK Gunung Mulia, 1994), 483-487.

- "Tinjauan Mengenai Keputusan Menteri Agama Nomor 70 dan 77 Tahun 1978 dalam Rangka Penyelenggaraan Kebebasan Beragama dan Pemeliharaan Kerukunan Nasional" in Weinata Sairin ed., Himpunan Peraturan di Bidang Keagamaan (Jakarta: BPK Gunung Mulia, 1994), 455-6.

- "Usul-Usul PGI Tentang Perubahan Terhadap RUUPA" in Weinata Sairin ed., Himpunan Peraturan di Bidang Keagamaan (Jakarta: BPK Gunung Mulia, 1994) 554-7. 


\section{Internet Sources}

- Wahid, Abdurrahman "Harlah, Natal dan Maulid" in: www.gusdur.net (accessed 14 January 2004).

- "Apa dan Siapa-Cosmas Batubara" in: www.pdat.co.id/hg/apasiapa/html/C/ads,20030617-02,C.html (accessed 15 March 2005).

- "J.B. Sumarlin Mengabdi di Pusat Kebijakan Ekonomi" in: www.tokohindonesia.com/ensiklopedi/j/jb-sumarlin/index.sthtml (accessed 15 March 2005).

\section{Interviews by the Author}

- Abdullah, Amin in Yogyakarta (8 October 2002).

- Arifin, Busthanul in Jakarta, (19 December 2003).

- Blot, Paul de in Nyenrode (22 July 2003).

- Daja, Burhanuddin in Yogyakarta (9 October 2002).

- Dhakidae, Daniel in Jakarta (12 December 2003).

- Effendi, Djohan in Jakarta (9 July and 29 August 2002).

- Husaini, Adian in Jakarta (23 August 2002).

- Ismartono, in Jakarta (26 July 2002), (15 December 2003); and in Yogyakarta (5 October 2002).

- Ispandrihari, B. Suryasmoro in Yogyakarta (30 September 2002); (14 October 2002) and (12 January 2004).

- Mukti Ali, A. in Yogyakarta (28 September 2002).

- Mulkhan, Munir in Yogyakarta (12 October 2002).

- Murniati, Agustine Prasetyo in Yogyakarta (7 October 2002).

- Noer, Kautsar Azhari in Jakarta (July 2002).

- Pakpahan, Damai in Yogyakarta (4 October 2002).

- Putuhena, Saleh Puhena in Makassar (15 December 2002).

- Sairin, Weinata in Jakarta (19 December 2003).

- Santoso, Thomas in Surabaya (7 January 2004).

- Silalahi, Harry Tjan in Jakarta (22 December 2003).

- Sinaga, Martin L. in Jakarta (July 2002) and (16 August 2002).

- Singgih, Gerrit E. in Yogyakarta (15 October 2002) and (16 January 2004).

- Sitompul, Einar in Jakarta (15 December 2003).

- Sumartana, Th. in Yogyakarta (24 September 2002). 
- Sunardi, St. in Yogyakarta (2 October 2002).

- Sutanto, Trisno S. in Jakarta (July 2002).

- Sutrisno, Andry Kristiawan in Yogyakarta (14 October 2002).

- Umar, Husein in Jakarta (22 October 2003).

- Wahono, Francis in Yogyakarta (14 January 2004).

- Yafie, Ali in Jakarta (14 December 2003).

\section{Special Interview}

- Van Thienen, Mathilda Maria. A tape recording of this interview (in Dutch) is registered as KMM 526 in the Katholiek Documentatie Centrum, Radboud Universiteit Nijmegen. 


\section{Samenvatting}

Indonesië is het grootste moslimland ter wereld. Temidden van die moslim meerderheid vormen de christenen de belangrijkste minderheid. In sommige provincies is het christendom de godsdienst van de meerderheid, en in andere gebieden is het de godsdienst van een grote minderheid. Bovendien was (en is) godsdienst in Indonesië een belangrijke maatschappelijk aangelegenheid, en was het dat in toenemende mate tijdens de Orde Baru (nieuwe orde) van 1966-1998, de periode die centraal staat in dit onderzoek. De relaties tussen moslims en christenen behoren dan ook tot één van de belangrijke politieke onderwerpen in Indonesië.

Deze studie geeft een analyse van teksten en politieke gedragingen van islamitische en christelijke leiders alsmede van nationale politieke figuren ten aanzien van de interreligieuze relaties. Op deze manier wijst deze studie erop, dat er zowel antagonistische als meer neutrale uiteenzettingen waren tussen de moslims en christenen. In antwoord op de felle debatten tussen moslims en christenen, nam de staat vaak een tweeslachtige positie in die uiteindelijk vaak leidde tot verdere controverses tussen de twee godsdienstige groeperingen. Aan de andere kant bepaalde en verplichtte de staat soms een bepaalde opvatting als algemeen geldig. Sommige islamitische en christelijke leiders reageerden positief op dit door de staat opgelegde algemeen geldige standpunt, terwijl anderen hier tegen waren en alternatieve opvattingen voorstelden. Zeker is dat de debatten tussen moslims en christenen de onderlinge inzichten en het optreden van de twee godsdienstige gemeenschappen beïnvloed hebben. De discussies hebben ook de staatspolitiek ten aanzien van religieus-politieke onderwerpen gemodelleerd, als ook de wijze waarop ze in werkelijkheid tot uitvoering werden gebracht.

De relaties tussen moslims en christenen waren gespannen vanwege het wederzijdse wantrouwen. Dit wederzijdse wantrouwen werd weerspiegeld in en verergerd door de vijandige discussies waarin de moslim en christelijke leiders elkaar beschouwden als een bedreiging voor hun respectievelijke religieuze gemeenschappen. Onder de moslims wordt de christelijke bedreiging Kristianisasi (poging tot kerstening) genoemd. Dat betekent volgens hen het gebruik van oneerlijke en agressieve methoden om arme moslims tot christenen te bekeren zoals via het schenken van geld, voedsel, onderwijs en gezondheidszorg, het bouwen van een kerk midden in een typisch moslim omgeving, het aanmoedigen van huwelijken tussen christenen en moslims, waarbij de moslim partner zich dan moet bekeren, 
het uitnodigen van moslims bij christelijke feesten onder het mom van religieuze tolerantie, en tenslotte het onderwijs van het christendom aan moslimstudenten op christelijke scholen. Kerstening kan ook een politieke samenzwering inhouden van christenen met andere vijanden van de Islam, met name met de secularisten, in binnen- en buitenland, om islamitische groeperingen cultureel, politiek en economisch te verzwakken.

De discussie over de bedreiging van kerstening heeft verschillende moslims tot gewelddadige acties gebracht, bijvoorbeeld door christelijke kerkgebouwen en scholen aan te vallen. De moslims vragen ook dat de regering de christelijke missie controleert en beperkingen oplegt door $1^{\circ}$ strikte eisen te stellen voor het verkrijgen van toestemming om een nieuw gebedshuis op te richten; $2^{\circ}$ religieuze propaganda te beperken tot de 5 erkende godsdiensten; $3^{\circ}$ buitenlandse hulp aan religieuze instellingen te controleren; $4^{\circ}$ gemengde huwelijken te verbieden; $5^{\circ}$ te eisen dat de godsdienstlessen op school gegeven zullen worden door een leraar die dezelfde religieuze achtergrond heeft als de leerlingen. De moslimleiders probeerden ook de programma's van islamitische propaganda (da'wah) te intensiveren als tegenwicht tegen the christelijke missie. Bovendien ontwikkelden de moslimleiders exclusieve interpretaties van religieuze leerstellingen, zoals een totale afwijzing van de vrijheid om je te bekeren tot een ander geloof, een verbod om deel te nemen aan christelijke vieringen, en een verbod op een huwelijk tussen een moslim en niet-moslim.

In antwoord op deze discussie onder de moslims over kerstening, benadrukten de christenen stelselmatig de noodzaak van algehele en onbeperkte vrijheid van godsdienst, ondanks de steeds wat weifelachtige reacties van de regering op dit punt. In bepaalde perioden, als de regering een nauwe band met islamitische groeperingen nodig had, zorgde zij ervoor dat bepaalde eisen van moslims in regeringsbesluiten werden verankerd. Omdat de christenen zich echter stelselmatig tegen deze besluiten verzetten, werden ze niet consequent ingevoerd. Dit gebeurde omdat het belang van de regering noch lag in het beperken van de christelijke missie noch in het benadrukken van de godsdienstvrijheid, maar in het behouden van politieke macht en het beheersen van de sociaal-politieke stabiliteit.

Daar waar de moslims zich onzeker en bedreigd voelden door de kerstening, waren de christenen bang voor de gevaar van de Islamitische staat. Te moeten leven in een islamitische staat waar de sharīa als wet zou zijn ingevoerd, zou voor de christenen betekenen dat ze werden beschouwd als tweederangs burgers. Als een religieuze minderheid geven de christenen de voorkeur aan het seculiere politieke idee van scheiding van kerk en staat. 
Om zich zelf te beschermen tegen de dreiging van de ideologische aspiraties van de moslims, besloten de christenen zich aan te sluiten bij de opkomende macht van het leger. Deze politieke keuze was een natuurlijke optie voor de christenen aangezien, evenals de seculier georiënteerde moslims burgers, het leger werd gezien als de sterkste voorstander van de nationalistische ideologische zienswijze, als tegenovergesteld aan de islamitische.

Deze christelijke politieke keuze zou uiteindelijk zekere consequenties hebben. Een daarvan was dat de christenen de verdedigers, of zelfs de aanstichters werden van het ontstaan van de autoritaire 'Nieuwe Orde' regering van Soeharto. Een belangrijke groep katholieken vormde zelfs een sterke coalitie met de regering in enige belangrijke politieke instellingen, namelijk bij de activiteiten van de geheime diensten, in de regeringspartij Golkar, en in de denktank, Centre for Strategic and International Studies (CSIS). Hoewel het CSIS, tenminste tot midden de jaren 1980, in feite veel meer de staat dan de katholieken representeerde, heeft de betrokkenheid van katholieke intellectuelen in deze denktank geholpen om onder de moslims een slecht imago van de katholieken te creëren. Het gebeurde zeer vaak dat de politieke frustraties van de moslims ten opzichte van de regering zich manifesteerden in een sterk negatief beeld van de katholieken. Het wantrouwen van de moslims ten aanzien van de christenen werd ook versterkt in de latere periode, toen de regering zich tot op zekere hoogte schikte naar de ideologische ambities van de moslims. Dit was deels omdat de christenen consequent bleven in hun protest tegen de islamitische ideologie, terwijl de regering niet altijd even consequent was.

Naast de vijandige discussies over de dreigingen van kerstening en de Islamitische staat, waren er ook algemene gesprekken tussen moslims en christenen, door de staat geëntameerd of ontwikkeld door moslims en christenen zelf. De staat eiste economische herstel op als de publieke zaak voor de natie. Daarom ging het publieke debat voor de staat over ontwikkeling of pembangunan. Hoge regeringsambtenaren beklemtoonden vaak dat ontwikkelingsprogramma's alleen effect konden hebben bij politieke stabiliteit en daarvoor spoorden zij religieuze leiders aan conflicten te vermijden en een interreligieuze harmonie te realiseren dat wil zeggen, vreedzame interreligieuze coëxistentie. Staatsambtenaren moedigden eveneens religieuze leiders aan om de religie te gebruiken als een helpende kracht voor ontwikkelingsprogramma's. Het regeringsprogramma van de religieuze dialoog in het bijzonder en religieuze harmonie in het algemeen was primair gericht op deze doeleinden. 
In de beginjaren van de Nieuwe Orde schenen de christelijke leiders de gouvernementele discussie over ontwikkeling redelijk te steunen, terwijl de moslimgroeperingen sceptisch bleven, of zelfs er tegen waren. Rond midden jaren 1970 echter, doken er in intellectuele christelijke en moslim kringen kritische geluiden op tegen de gouvernementele ontwikkelingsprogramma's. Beïnvloed door de katholieke bevrijdingstheologie van ZuidAmerika probeerden deze intellectuelen een kritisch religieus debat over ontwikkeling te ontwerpen, door de universele waarde van sociale gerechtigheid te benadrukken. In de jaren 1990 verwisselde de regering zijn politieke overeenkomst met de abangan (nominale) Moslims en met de christenen voor een alliantie met de santri (praktiserende) reformistische moslims. De regering ondersteunde de elite van de Associatie van Indonesische Moslims Intellectuelen (ICMI, Ikatan Cendekiawan Muslim Indonesia). Veel van de ICMI activisten werden toen vertegenwoordigers van de regeringspartij, Golkar, en sommigen van hen werden tot minister in het kabinet benoemd. De christenen en andere religieuze minderheden waren zeer bevreesd voor deze politieke ontwikkeling. Het was binnen deze context dat enkele prominente moslim- en christenintellectuelen samenwerkten om gezamenlijk te komen tot een discussie over democratie en pluralisme.

(Nederlandse vertaling door Dr. Paule Maas) 


\section{Curriculum Vitae}

Mujiburrahman was born in Amuntai, South Kalimantan, on 9 December 1971. From 1984 to 1989, he was educated at the Islamic Boarding School, Al-Falah, Banjar Baru. He then continued his studies for a year at the Islamic Senior High School, Al-Istiqamah, Banjarmasin. From 1990 to 1994, he undertook his undergraduate work at the Faculty of Ushuluddin of the State Institute of Islamic Studies (IAIN) Antasari, Banjarmasin. In 1995 he was admitted to the Training of Candidates for Lecturers at IAINs which took place at IAIN Syarif Hidayatullah, Jakarta, for nine months. In 1996 he was appointed by the Government as an assistant lecturer at IAIN Antasari, Banjarmasin. In 1998 he continued his studies at the Faculty of Religious Studies, McGill University, Canada, from which he received an M.A in the year 2000. In 2001-2005, he was a PhD fellow at the International Institute for the Study of Islam in the Modern World (ISIM), the Netherlands. 


